\title{
Het Indonesisch nationaliteitsrecht
}

Citation for published version (APA):

de Haas-Engel, R. H. (1993). Het Indonesisch nationaliteitsrecht. [Doctoral Thesis, Maastricht University]. Rijksuniversiteit Limburg. https://doi.org/10.26481/dis.19930630rh

Document status and date:

Published: 01/01/1993

DOI:

10.26481/dis.19930630rh

Document Version:

Publisher's PDF, also known as Version of record

\section{Please check the document version of this publication:}

- A submitted manuscript is the version of the article upon submission and before peer-review. There can be important differences between the submitted version and the official published version of record.

People interested in the research are advised to contact the author for the final version of the publication, or visit the DOI to the publisher's website.

- The final author version and the galley proof are versions of the publication after peer review.

- The final published version features the final layout of the paper including the volume, issue and page numbers.

Link to publication

\footnotetext{
General rights rights.

- You may freely distribute the URL identifying the publication in the public portal. please follow below link for the End User Agreement:

www.umlib.nl/taverne-license

Take down policy

If you believe that this document breaches copyright please contact us at:

repository@maastrichtuniversity.nl

providing details and we will investigate your claim.
}

Copyright and moral rights for the publications made accessible in the public portal are retained by the authors and/or other copyright owners and it is a condition of accessing publications that users recognise and abide by the legal requirements associated with these

- Users may download and print one copy of any publication from the public portal for the purpose of private study or research.

- You may not further distribute the material or use it for any profit-making activity or commercial gain

If the publication is distributed under the terms of Article $25 \mathrm{fa}$ of the Dutch Copyright Act, indicated by the "Taverne" license above, 
HET INDONESISCH NATIONALITEITSRECHT 


\section{HET INDONESISCH NATIONALITEITSRECHT}

\section{PROEFSCHRIFT}

ter verkrijging van de graad van doctor

aan de Rijksuniversiteit Limburg te Maastricht op gezag van de Rector Magnificus, Prof. Mr. M.J. Cohen, volgens het besluit van het College van Dekanen, in het openbaar te verdedigen op woensdag 30 juni 1993 om 16.00 uur

door

RENATA HENRIETTE DE HAAS-ENGEL

geboren te Balige, Indonesië in 1925 


\section{Promotores}

Prof.dr. C. Flinterman LL.M.

Prof.dr. S. Gautama

Prof.dr. G.R. de Groot

\section{Beoordelingsconmissie}

Prof.dr.dr.h.c. Th.C. van Boven M.C.L.

Prof.dr. Ko Swan Sik

Dr. M. Tratnik

Van dit boek is een handelseditie verschenen onder ISBN 9026824610

\section{(C) 1993, R.H. de Haas-Engel, Maastricht}

Alle rechten voorbehouden. Niets uit deze uitgave mag worden verveelvoudigd, opgeslagen in een geautomatiseerd gegevensbestand, of openbaar gemaakl, in enige vorm of op enige wijze, hetzij elektronisch, mechanisch, door fotocopieèn, opnamen, of enige andere manier, zonder voorafgaunde schriftelijke toestemming van de uitgever.

Voor zover het maken van kopicën is toegestaan op grond van artikel $16 \mathrm{~B}$ Auteurswet 1912 jo. het Besluit van 20 juni 1974, Stb. 351, zoals gewijzigd bij het Besluit van 23 augustus 1985, Stb. 47 l en artikel 17 Auteurswet 1912, dient men de daarvoor wettelijk verschuldigde vergoedingen te voldoen aan de Stichting Reprorecht (Postbus 882, 1180 AW Amstelveen). Voor het overnemen van gedeelte(n) uit deze uitgave in bloemlezingen, readers en andere compilatiewerken (artikel 16 Auteurswet 1912) dient men zich tot de uitgever te wenden. 
Aan mijn echtgenoot Henk

en mijn zonen Richard, Henk en Nino 
Turend in een witte muur van mist Zoekend naar wat licht Snakkend naar een zonnestraal...... Maar helaas, alles zit dicht.

Ik doe een stap terug in het verleden..... Het zonlicht doet weldadig aan Ik zie blauwe bergen, groene sawahs Ik zie asembomen staan..... Ik zie mooie, slanke palmen Bonte vogels in hun vlucht Ik zie bougainville, kembang sepatu En daarboven hoge, blauwe lucht....

Maar de werkelijkheid is anders De mist is dik - de wereld klein...... Is het dan een wonder, dat ik wegulucht in mijn dromen Om weer heel even in mijn geboorteland te zijn? (van Gerry Stern-Dossin, uit: Dromen op een mistige morgen) 
Het is altijd een hartewens van mij geweest om in Nederland te promoveren, alhoewel ik in Indonesië afgestudeerd ben. Drukke werkzaamheden in Indonesië en persoonlijke. omstandigheden waarmede ik sedert mijn verblijf in Nederland geconfronteerd werd, hebben ertoe geleid dat ik eerst op gevorderde leeftijd deze wens in vervulling zag gaan. Dat dit mogelijk werd, heb ik te danken aan het College van Dekanen van de Rijksuniversiteit Limburg, dat mij in staat stelde aan genoemde Universiteit te promoveren, waarvoor ik mijn welgemeende dank uitspreek.

Ik had oorspronkelijk de bedoeling, om niet alleen het Indonesisch nationaliteitsrecht. als onderwerp voor mijn proefschrift te kiezen, doch daarop aansluitend in te gaan op het Indonesisch agrarisch recht en de mogelijkheden tot investeren in Indonesië. De reden daartoe was hierin gelegen, dat het op het nationaliteitsrecht gebaseerde onderscheid tussen staatsburgers en buitenlanders ook is te maken in genoemde gebieden van het Indonesische recht. Ik heb dit ambitieuse plan echter moeten laten varen en mij dienen te beperken tot het nationaliteitsrecht. Het Indonesisch agrarisch recht en de investeringsmogelijkheden in Indonesië zijn in afzonderlijke boeken behandeld, die binnenkort zullen verschijnen.

Wat mijn dissertatie betreft, ben ik in de eerste plaats dank verschuldigd aan Prof. Dr. Cees Flinterman LL.M. voor zijn begeleiding gedurende de moeizame tijd van de totstandkoming daarvan en voor zijn gewaardeerde suggesties. Prof. Dr. Gerard-René de Groot ben ik niet alleen zeer erkentelijk voor zijn waardevolle aanwijzingen en opmerkingen, die zeker hebben geleid tot de verhoging van de kwaliteit van mijn proefschrift, maar ook voor de betoonde medewerking en bijstand. Voorts betuig ik Prof. Dr. Cues van Dijk mijn welgemene dank voor het doomemen van mijn manuscript in de origine vorm. Mijn dank gaat voorts in het bijzonder uit naar Prof. Mr. Dr. Sudargo Gautama, die ondanks het feit dat hij in Indonesië verblijft, zich bereid verklaarde mij terzijde te staan. Aangezien mijn proefschrift op Indonesisch recht is gericht, was zijn hulp en medewerking in deze van veel nul.

Om de publicatiekosten van mijn boek enigszins beperkt te houden, was ik genoodzaakt de tekst van mijn proefschrift zélf op een Personal Computer te zetten. Alhoewel ik voor dit doel in de gauwigheid een certificaat heb behaald, kwam ik geregeld "vast" te zitten. Ik ben dan ook dank verschuldigd aan Mr. Réjean Pinckaers, assistent in opleiding aan de Rijksuniversiteit Limburg, die steeds klaar stond mij, indien nodig, bij te staan en het zijne ertoe bijgedragen heeft, genoemde kosten beperkt te houden.

Bij het verzamelen van de voor het schrijven van mijn dissertatie benodigde gegevens, heb ik veel hulp gehad van Mw. Moentiari Bakrie-Sigit B.A.Hons., M.Sc.L.S., voormalig bibliothecaresse van het Nederlands Onderzoekcentrum voor het Recht in Zuid-Oost Azië en het Caraibisch Gebied (NORZOAC) en van de staf van het van Vollenhoven Instituut voor recht en bestuur in niet-westerse landen, zoals eerstgenoemd Onderzoekcentrum thans heet, waarvan ik in het bijzonder Mr. Cora de Waay en Mr. 
Albert Dekker, beiden in de hoedanigheid van coördinator bibliotheek en juridische informatieverzorging wil noemen, die steeds voor mij klaar stonden, indien dit nodig was. Allen hiervoor mijn hartelijke dank.

Een woord van dank wil ik voorts uiten aan het adres van dhr. James Claessen voor de vertaling van de verschillende, in dit boek opgenomen teksten.

Van onschatbare waarde is de hulp en bijstand van mijn echtgenoot Henk de Haas geweest. Dit betreft in de eerste plaats zijn nooit aflatende morele steun, het mij terzijde staan door het verrichten van allerlei administratieve "klusjes" en het corrigeren van de drukproeven, maar vooral voor de gelegenheid mij geboden om het proefschrift te schrijven, door mij zoveel mogelijk werk uit handen te nemen.

Ik spreek het vertrouwen uit, dat dit boek inzake het Indonesisch nationaliteitsrecht tot een betere kennis zal leiden van het Indonesische recht voor personen die daarbij belang hebben, buitenlanders en buitenlandse bedrijven, die in Indonesië activiteiten willen verrichten daaronder begrepen en ik op deze wijze in staat wordt gesteld om de belangstelling voor mijn geboorteland te stimuleren.

Maastricht, 1 maart 1993. 


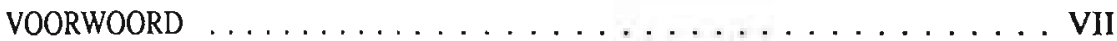

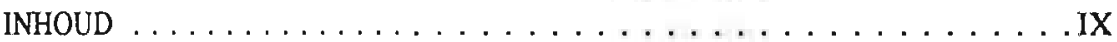

LIJST VAN AFKORTINGEN $\ldots \ldots \ldots \ldots \ldots \ldots \ldots \ldots$ XV

LIJST VAN INDONESISCHE TERMEN $\ldots \ldots \ldots \ldots \ldots$ XVII

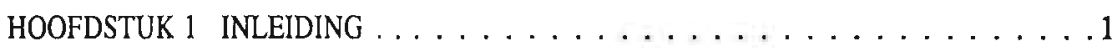

$\S 1$ Probleemstelling en indeling van het boek $\ldots \ldots \ldots \ldots \ldots \ldots$

$\S 2$ Enkele algemene gegevens inzake Indonesië . . . . . . . . . . . 3

2.1 De politieke geschiedenis . . . . . . . . . . . . . 3

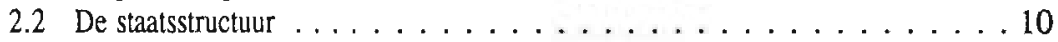

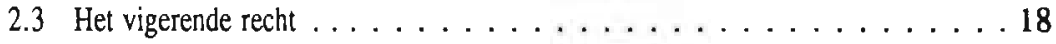

2.4 Betrekkingen tussen Indonesië en derde landen . . . . . . . . . . 19

2.5 Bevolkingsopbouw.......................... 22

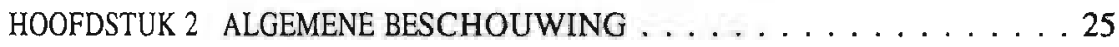

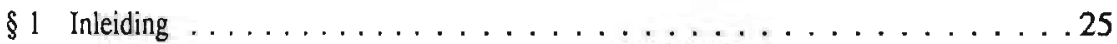

1.1 Enkele betekenissen van het begrip "nationaliteit" ........ . 25

1.2 De functie van de nationaliteit $\ldots \ldots \ldots \ldots \ldots \ldots \ldots \ldots$

1.3 Het recht op een nationaliteit, een mensenrecht? . . . . . . . . 32

1.3.1 De nationaliteit als koppelbegrip . . . . . . . . . . 33

1.3.2 Koppelbegrip of inhoudelijk begrip? . . . . . . . . . . . 34

1.3.3 Het recht op nationaliteit als mensenrecht . . . . . . . . 42

1.3.3.1 Het belang van de nationaliteit als inhoudelijk

begrip voor de typering van het recht op een

nationaliteit als mensenrecht . . . . . . . . . 43

1.3.3.2 Het ter zake doende geschreven recht . . . . . . . 43

1.3.3.3 Ontneming van nationaliteit en het recht op expatriatie .................. 48

1.3.3.4 Gevolgen van het typeren van het recht op een nationaliteit als mensenrecht . . . . . . . . . . 53

1.3.3.5 Conclusie . . . . . . . . . . . . . . . 55

1.4 De nationale autonomie en volkenrechtelijke beperkingen . . . . . . 56

1.4.1 De nationale autonomie van Staten . . . . . . . . . . 56

1.4.2 Beperking van de nationale autonomie van Staten . . . . . 57

1.4.2.1 Beperking door het internationale gewoonterecht en door algemene rechtsbeginselen . . . . . . . . . . 5 57

1.4.3.2 Beperking door verdragsrecht ..........663

1.4.3.3 De "genuine link" theorie . . . . . . . . . 64 64 
1.4.3.4 Waarborging van mensenrechten als mogelijke beperking .................65

1.5 Nationaliteitsrechtelijke gevolgen van gebiedsovergang . . . . . . 66

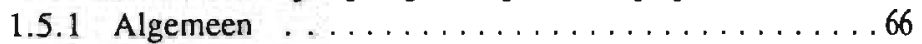

1.5.2 Universele en partiële statenopvolging . . . . . . . 68

1.5.3 Dekolonialisatie . . . . . . . . . . . . . . 69

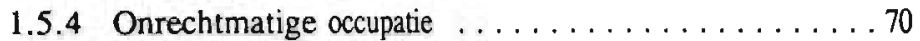

$\S 2$ Inhoud van het Indonesisch staatsburgerschap $\ldots \ldots \ldots \ldots \ldots \ldots 72$

HOOFDSTUK 3 VOORGESCHIEDENIS VAN DE WET NO. 62 VAN HET JAAR 1958 BETREFFENDE HET STAATSBURGERSCHAP VAN DE REPUBLIEK INDONESIE $\ldots \ldots \ldots \ldots \ldots \ldots \ldots \ldots \ldots \ldots$

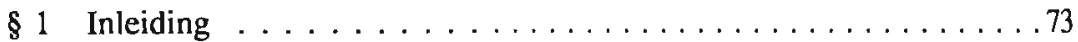

1.1 De situatie in (Nederlandsch-)Indië tot $1926 \ldots \ldots \ldots \ldots \ldots 73$

1.2 De situatie in Nederland vóór de afkondiging van de Wet van 1892 . . 76

1.3 Consequenties van het bestaan van een dubbele nationaliteitsrechtelijke regeling voor Nederlandsch-Indië . . . . . 79

1.4 Effect van de afkondiging van de Wet van 1892 op

Nederlandsch-Indië . . . . . . . . . . . . . . . . . . .81

$\S 2$ Wettelijke onderverdeling van de bevolking van Indonesië . . . . . . 85

2.1 Het voor de bevolkingsgroepen geldende recht . . . . . . . 90

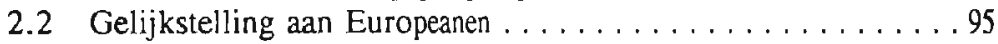

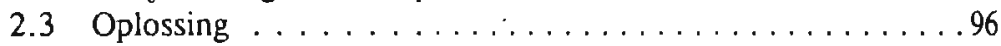

2.4 Het gemengde huwelijk ex Ind. Stb. $1898-158 \ldots \ldots \ldots \ldots \ldots . . \ldots 9$

$\S 3$ Het Nederlands onderdaanschap krachtens de Wet van $1910 \ldots \ldots$. . . . 99

$\S 4$ Het Haagse Verdrag van $1930 \ldots \ldots \ldots \ldots \ldots$

$\$ 5$ De Wet no. 3 van 1946 en de Toescheidingsoverkomst . . . . . . . . . 111

5.1 Algemeen . . . . . . . . . . . . . . . . 112

5.2 De Wet no. 3 van 1946 betreffende het Indonesisch

Staatsburgerschap en Ingezetenschap . . . . . . . . . 113

5.3 De Overeenkomst betreffende de Toescheiding van Staatsburgers . . 118

5.3.1 Enige opmerkingen inzake de gehanteerde terminologie . . 122

5.3.2 Indonesisch staatsburger krachtens de Toescheidingsovereenkomst . . . . . . . . . . . . . 125

5.3.3 Indonesisch staatsburger krachtens de Wet no. 3 van het jaar 1946 en de Toescheidingsovereenkomst . . . . . . . . . 137

$\S 6$ De Verordeningen van het Militaire Gezag . . . . . . . . . . . 138

6.1 Bewijzen van Indonesisch staatsburgerschap . . . . . . . . 138

6.2 Overige bepalingen het Indonesisch staatsburgerschap betreffende . . 139

$\$ 7$ Chinezen met de nationaliteit van het vroegere Nationalistisch China c.q. het huidige Taiwan . . . . . . . . . . . . . . . . 141 7.1 Algemeen ........................ 141

7.2 Politieke verwikkelingen $\ldots \ldots \ldots \ldots \ldots \ldots \ldots \ldots \ldots$ 
$\$ 8$ Problemen rond het Indonesisch staatsburgerschap . . . . . . . . . . . . 144

$\$ 9$ De praktijk . . . . . . . . . . . . . . . . . . . . . 146

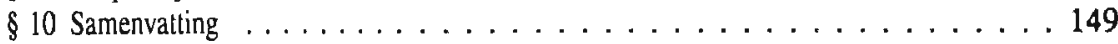

HOOFDSTUK 4 DE WET NO. 62 VAN HET JAAR 1958 BETREFFENDE HET STAATSBURGERSCHAP VAN INDONESIE . . . . 153

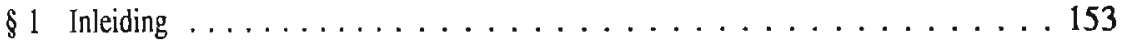

1.1 Verkregen rechten geëerbiedigd $\ldots \ldots \ldots \ldots \ldots$

1.2 Bepalingen ter opheffing van onzekerheid met betrekking tot het bezitten van het Indonesisch staatsburgerschap . . . . . . . . 158

$\S 2$ Algemene aspecten van de Wet no. 62 van het jaar $1958 \ldots \ldots$. . . . . 161

$\S 3$ Het dubbel staatsburgerschap der Chinezen . . . . . . . . . . . . 163

3.1 Het verplicht stellen van het maken van een keuze . . . . . . . . 164

3.2 Sanctie op het niet maken van een keuze . . . . . . . . . . . . . 168

3.3 Voor welke categorieën van personen het maken van een keuze niet verplicht was gesteld . . . . . . . . . . . . . . . . . . 169

3.4 Datum van inwerkingtreding der Overeenkomst en annulering daarvan . . . . . . . . . . . . . . . . 172

$\S 4$ Enige gevallen uit de praktijk $\ldots \ldots \ldots \ldots \ldots \ldots \ldots$

HOOFDSTUK 5 WIJZE VAN VERKRIJGING VAN HET INDONESISCH STAATSBURGERSCHAP VOLGENS DE WET NO. 62 VAN HET JAAR 1958

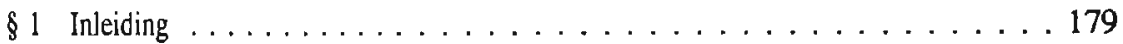

$\S 2$ Verkrijging "iure sanguinis" . . . . . . . . . . . . . . . . . . . . 179

$\$ 3$ Verkrijging krachtens het "ius soli" . . . . . . . . . . . . . . . 185

$\S 4$ Verkrijging door adoptie . . . . . . . . . . . . . . . . 187

4.1 Leeftijdsgrens van vijf jaar . . . . . . . . . . . . . . 187

4.2 Wettelijke vereisten . . . . . . . . . . . . . . . . . 189

$\$ 5$ Verkrjging door geprivilegieerde naturalisatie ... . . . . . . 196

5.1 Op basis van artikel 3 van de Wet . . . . . . . . . . . . 197

5.2 Op basis van artikel 4 van de Wet . . . . . . . . . . . 200

5.3 Artikel $v$ der Overgangsbepalingen van de Wet . . . . . . . . . . 205

$\$ 6$ Verkrijging door gewone naturalisatie . . . . . . . . . . 208

6.1 De leeftijd $\operatorname{van} 21$ jaar . . . . . . . . . . . . . . 211

6.2 Geboorte of woonplaats in Indonesië . . . . . . . . . . 213

6.3 Instemming van de echtgenote(n) . . . . . . . . . . . 214

6.4 Kennis van de Indonesische taal en geschiedenis . . . . . . . 215

6.5 Misdrijf jegens de Staat . . . . . . . . . . . . . . 216

6.6 De eis betreffende gezondheid en voldoende inkomsten . . . . . 217

6.7 Voor de naturalisatie verschuldigde som . . . . . . . . . . . 217

6.8 Vermijding van apatridie en bipatridie . . . . . . . . . . . 219 
6.9 Aflegging van de eed of belofte van trouw . . . . . . . . 222

6.10 Wijze van verlening van het staatsburgerschap middels naturalisatie . 222

6.11 Aanvullende bepalingen betreffende naturalisatie . . . . . . 223

6.12 Vergelijking tussen de artikelen 3 en 4 enerzijds en artikel 5 der

Wet anderzijds . . . . . . . . . . . . . . . . 224

6.13 De uitzonderingsnaturalisatie van artikel 6 van de Wet no. 62 van $1958 \ldots \ldots \ldots \ldots . \ldots \ldots \ldots$

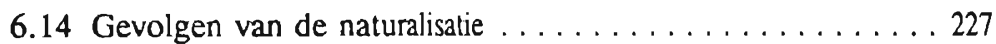

$\S 7$ Verkrijging door of als gevolg van huwelijk . . . . . . . . 228

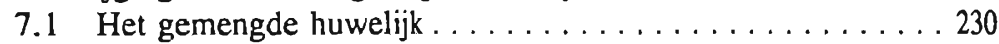

7.1.1 Buitenlandse vrouw met staatsburger getrouwd . . . . . 230

7.1.2 Indonesische vrouw met buitenlander gehuwd . . . . 235

7.1.3 Gemengde huwelijken in de zin van de Huwelijkswet van 1974 . . . . . . . . . . . . . . . . . . . . . . . 238

7.1.4 Verdient het gelijkgerechtigdheidsbeginsel voorkeur boven het "vrouw volgt man" beginsel? . . . . . . . . . . . 244

$\S 8$ Verkrijging door het volgen van de staat van de vader c.q. moeder . . . 248

$\$ 9$ Verkrijging door aflegging van een verklaring (optie) . . . . . . 252

9.1 Gevallen waarin niet van zuivere optie kan worden gesproken . . . 254

9.1.1 Artikel 18 van de Wet no. 62 van 1958, zoals gewijzigd en aangevuld bij de Wet no. 3 van $1976 \ldots \ldots . \ldots . . .254$

9.1.2 Buitenlanders in de Indonesische krijgsmacht . . . . . . . 261

$\S 10$ Regeling van de nationaliteit van de ingezetenen van Irian Jaya . . . . . . 264

10.1 Status van de ingezetenen van Irian Jaya vóor de overdracht van dit gebiedsdeel aan Indonesië . . . . . . . . . . . 265

10.2 Status van de ingezetenen van Irian Jaya ná de overdracht van dit gebiedsdeel aan Indonesië . . . . . . . . . . . . . 267

HOOFDSTUK 6 WIJZE VAN VERLOREN GAAN VAN HET INDONESISCH STAATSBURGERSCHAP VOLGENS DE WET NO. 62 VAN HET JAAR $1958 \ldots \ldots \ldots \ldots . \ldots 273$

$\S 1$ Inleiding . . . . . . . . . . . . . . . . . 273

1.1 Verlies van rechtswege krachtens het "vrouw volgt man" beginsel . . 273

1.2 Verlies van rechtswege door het volgen van de staat van de vader of moeder . . . . . . . . . . . . . . . . . . . . . . 275

1.3 Verlies door negatieve oplie in gevallen van gemengde huwelijken . 275

1.4 Verlies door negatieve optie in gevallen van het volgen van de staat van de vader of moeder . . . . . . . . . . . . . . 278

1.5 Samenvatting . . . . . . . . . . . . . . . 278

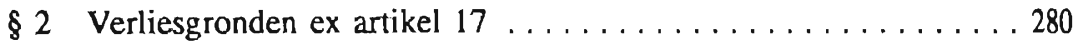

2.1 Het vrijwillig verkrijgen van een andere nationaliteit . . . . . . 280

2.2 Het niet verwerpen c.q. prijsgeven van een andere nationaliteit, terwijl de betrokken persoon daartoe de gelegenheid krijgt . . . . 282

2.3 Erkenning door een buitenlander . . . . . . . . . . . 284 
2.4 Adoptie door een buitenlander . . . . . . . . . . . . . 285

2.5 Verlorenverklaring door de Minister van Justitie . . . . . . . . . 289

2.6 Het verrichten van bepaalde handelingen . . . . . . . . . . . . 290

2.7 Het langdurig in het buitenland gevestigd zijn . . . . . . . . . . . . 294

2.8 Verlies van hel Indonesisch staatsburgerschap door een gehuwde vrouw . . . . . . . . . . . . . . . . . . . . 295

§ 3 Mogelijkheid tot intrekking van het Indonesisch staatsburgerschap . . . . 296

$\$ 4$ De praktijk . . . . . . . . . . . . . . . . . . . . . . . . . 298

HOOFDSTUK 7 HET BEWIJS VAN HET BEZIT VAN HET

INDONESISCH STAATSBURGERSCHAP . . . . . . . . 301

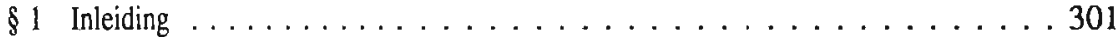

$\$ 2$ De oude en de nieuwe situatie . . . . . . . . . . . . . . . . . 304

2.1 De oude situatie . . . . . . . . . . . . . . . . . 305

2.2 De nieuwe situatie . . . . . . . . . . . . . . . . . . 306

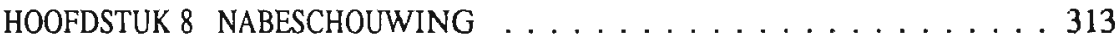

$\$ 1$ Algemeen $\ldots \ldots \ldots \ldots \ldots \ldots \ldots \ldots$

$\S 2$ Het "ius sanguinis" tegenover het "ius soli" . . . . . . . . . . . . . . . 316

$\S 3$ Apatridie en bipatridie . . . . . . . . . . . . . . . . . . . . 317

$\$ 4$ Positie van de gehuwde vrouw . . . . . . . . . . . . . . . . 322

$\$ 5$ Voorstellen tot wijziging van de Wet no. 62 van $1958 \ldots \ldots \ldots 325$

$\$ 6$ Maatregelen door Indonesië buiten de nationaliteitswetgeving om op juridisch gebied te nemen . . . . . . . . . . . . . . . . . . . . . 329

$\S 7$ Een enkel woord tot besluit . . . . . . . . . . . . . . . . . . . . 332

NEDERLANDSE SAMENVATTING . . . . . . . . . . . . . . 335

ENGLISH SUMMARY $\ldots \ldots \ldots \ldots \ldots \ldots \ldots \ldots$

RINGKASAN INDONESIA . . . . . . . . . . . . . . . . . 355

BIJLAGEN . . . . . . . . . . . . . . . . . . . . 367

1. Wet van 1910 op het Nederlandsch Onderdaanschap van niet-Nederlanders . . . . . . . . . . . . . . . . . . . . . . 367

2. Act No. 3 year 1946 concerning Citizens and Residents of the State of the Republic of Indonesia . . . . . . . . . . . . . . . . . . 371

3. Act No. 6 year 1947 regarding Alteration of Act No. 3 year 1946 concerming Citizens and Residents of the State of the Republic of Indonesia . . . . . . . . . . . . . . . . . . . . . . . . . 379 
4. Act No. 8 year 1947 concerning Prolongation of the Period to submit a Statement as to the Indonesian Citizenship . . . . . . . . . . 383

5. Act No. 11 year 1948 concerning the further Prolongation of the Period to submit a Statement as to the Indonesian Citizenship . . . . . . . . . 385

6. Overeenkomst betreffende de Toescheiding van Staatsburgers . . . . . . 387

7. Regulation of the Central War Authority No. Prt./Peperpu/014/1958 concerning Some Matters regarding Citizenship . . . . . . . . . . . . 391

8. Act No. 2 of the year 1958 concerning the Approval of the Agreement between the Republic of Indonesia and the People's Republic of China conceming the problem of Dual Citizenship . . . . . . . . . . . 393

9. Wet no. 62 van het jaar 1958 zoals gewijzigd met Wet no. 3 van het jaar 1976 betreffende het Staatsburgerschap van de Republiek Indonesië . . . 405

LITERATUURLIJST . . . . . . . . . . . . . . . . . . . . . . 421

LUJST VAN AANGEHAALDE JURISPRUDENTIE . . . . . . . . . . . 441

ZAAKREGISTER . . . . . . . . . . . . . . . . . . . 443

CURRICULUM VITAE . . . . . . . . . . . . . . . . . . . 449 


$\begin{array}{ll}\text { AB } & \text { Algemene Bepalingen van Wetgeving voor Indonesië } \\ \text { ASEAN } & \text { Association of Southeast Asian Nations } \\ \text { ATPC } & \text { Association of Tin Producing Countries } \\ \text { BAKIN } & \text { Badan Koordinasi Inteligen Negara (Staatsinlichtingendienst) } \\ \text { BW } & \text { Burgerlijk Wetboek } \\ \text { CGI } & \text { Consultatieve Groep voor Indonesië } \\ \text { DPR } & \text { Dewan Perwakilan Rakyat (Volksvertegenwoordiging) } \\ \text { DPRD } & \text { Dewan Perwakilan Rakyat Daerah (regionale } \\ & \text { Volksvertegenwoordiging) } \\ \text { EEC } & \text { European Economic Community } \\ \text { EEG } & \text { Nu EG, Europese (Economische) Gemeenschap } \\ \text { GBHN } & \text { Garis-Garis Besar Haluan Negara (Grote Lijnen van het door } \\ & \text { de Staat te volgen Beleid) } \\ \text { GOLKAR } & \text { Golongan Karya (Functionele Groep) } \\ \text { IBW } & \text { Indonesisch Burgerlijk Wetboek } \\ \text { IGGI } & \text { Inter-Gouvernementele Groep inzake Indonesië } \\ \text { Ind. Stb. } & \text { Indisch Staatsblad } \\ \text { Indon. } & \text { Indonesisch } \\ \text { IS } & \text { Indische Staatsregeling (de Wet op de Staatsinrichting } \\ & \text { van Nederlandsch-Indië) } \\ \text { IMF } & \text { International Monetary Fund } \\ \text { KB } & \text { Koninklijk Besluit } \\ \text { KNIL } & \text { Koninklijk Nederlandsch-Indisch Leger } \\ \text { KTP } & \text { Kartu Tanda Penduduk (persoonsbewijs) } \\ \text { LMD } & \text { Lembaga Musyawarah Desa (Dorpsraad) } \\ \text { MA } & \text { Mahkamah Agung (Hooggerechtshof) } \\ \text { MPR } & \text { Majelis Permusyawaratan Rakyat (Raad voor Volksoverleg) } \\ \text { Ned. } & \text { Nederlands } \\ \text { N. Stb. } & \text { Nederlands Staatsblad } \\ \text { NGO's } & \text { Niet-gouvernementele organisaties } \\ \text { No. } & \text { Nummer } \\ \text { OM } & \text { Openbaar Ministerie } \\ \text { OPEC } & \text { Organization of Petroleum Exporting Countries } \\ \text { P. } & \text { Pagina } \\ \text { PETA } & \text { Pembela Tanah Air (Verdediging van het Vaderland) } \\ \text { Prp. } & \text { Peraturan Pemerintah Pengganti Undang-Undang } \\ \text { RGH } & \text { (Regeringsverordening die in de plaats van een wet treedt) } \\ \text { RI } & \text { Regeling op de Gemengde Huwelijken } \\ \text { RR } & \text { Republiek Indonesië } \\ \text { RS } & \text { Reglement op het beleid der Regering van Nederlandsch-Indië } \\ \text { RTC } & \text { Risalah Sementara (Voorlopige Verhandeling) } \\ \text { RVSI } & \text { Ronde Tafel Conferentie } \\ & \text { Republiek der Verenigde Staten van Indonesië } \\ & \end{array}$


Stb.

SBKRI

Trb.

Vgl.

$\mathrm{VN}$

VOC

WvS
Staatsblad van Indonesië

Surat Bukti Kewarganegaraan Republik Indonesia (Bewijs van Indonesisch Staatsburgerschap)

Traktaatblad

Vergelijk

Verenigde Naties

Verenigde Oost-Indische Compagnie Wetboek van Strafrecht 


\section{LIJST VAN INDONESISCHE TERMEN}

De onderstaande lijst bevat een selectie van Indonesische termen die in dit boek zijn gebruikt.

Adat

Ahli hukum

Ambil alih

Anak angkat

Asli

Badan Koordinasi

Inteligen Negara

Badan Pemeriksa

Keuangan

Bahasa Indonesia

Berita Negara

Bertempat tinggal

Bukan asli

Bupati

Camat

Desa

Dewan Pertimbangan

Agung

Dewan Perwakilan

Rakyat

Diperlakukan sebagai

Golongan Karya
Gewoonte

Rechtsgeleerde

Overname, confiscatie

Geadopteerd kind

Autochtoon

Coördinerend Lichaam van de Staatsinlichtingendienst

Algemene Rekenkamer

De Indonesische taal

Staatscourant

Het hebben van woonplaats

Niet-autochtoon

Regent, hoofd van een regentschap

Onderdistricthoofd

Territoriale rechtsgemeenschap, dorp, dorpsgemeenschap

Hoge Adviesraad

Volksvertegenwoordiging

Behandeld als

Functionele Groepen 


\begin{tabular}{|c|c|}
\hline Hak milik & Een specifiek Indonesisch eigendomsrecht \\
\hline Himpunan & Verzameling \\
\hline Hukum & Recht \\
\hline Hukum Adat & Ongeschreven recht, gewoonterecht \\
\hline Izin menetap & Vestigingsvergunning \\
\hline Kabupaten & Regentschap \\
\hline Kartu Izin Masuk & Toelatingskaart \\
\hline $\begin{array}{l}\text { Kartu Tanda } \\
\text { Penduduk }\end{array}$ & Persoonsbewijs \\
\hline Keadilan sosial & Sociale rechtvaardigheid \\
\hline Kebangsaan & Nationalisme \\
\hline Kecamatan & Onderdistrict \\
\hline Kedaulatan rakyat & Onafhankelijkheid \\
\hline Kelaskaran & Troep van gewone personen, geen echte soldaten \\
\hline Kelurahan & Ressort van een Lurah, dorpsadministratieve eenheid \\
\hline Keputusan & Rechterlijke uitspraak, vonnis \\
\hline Ketuhanan & Geloof in God \\
\hline Kewarganegaraan & Staatsburgerschap \\
\hline Kotamadya & Middelgrote stad \\
\hline $\begin{array}{l}\text { Lembaga Musyawarah } \\
\text { Desa }\end{array}$ & Dorpsraad \\
\hline Lembaran Negara & Staatsblad \\
\hline Lurah & Dorpshoofd, kamponghoofd \\
\hline Mahkamah Agung & Hooggerechtshof \\
\hline
\end{tabular}


Majelis

Permusyawaratan

Rakyat

Menetap

Musyawarah

Nikah

Non pribumi

Pancasila

Panitia Penyelesaian

Perselisihan

Perburuhan

Partai Demokrasi

Indonesia

Partai Persatuan

Pembangunan

Pegawai pencacat

nikah

Pembela Tanah Air

Pemuda

Pengadilan Agama

Pengadilan Negeri

Pengadilan Negeri

Jakarta-Pusat

Pengadilan Tinggi

Pengangkatan

Penghulu
Raad voor Volksoverleg

zich vestigen, verblijf houden

Overleg, beraadslaging

Huwelijk

Niet-autochtoon

De vijf grondbeginselen van de Republiek Indonesië, de staatsideologie

Commissie ter Beslechting van Arbeidsgeschillen

Indonesische Democratische Partij

Verenigde Ontwikkelingspartij

Beambte voor de registratie van huwelijken

Verdediging van het Vaderland

Jongere

Gerecht voor Godsdienstzaken

Landgerecht

Landgerecht voor Centraal Jakarta

Raad van Justitie

Adoptie

Hoogste moskeebeambte 
Peraturan Pemerintah Pengganti Undang-

Undang

Pergerakan Tionghoa

Perhimpunan

Perhimpunan Ahli-

Hukum Indonesia

Perikemanusiaan

Pribumi

Rangkuman

Risalah Sementara

Rujuk

Sejati

Suku

Surat Bukti

Kewarganegaraan

Republik Indonesia

Surat Jalan Laksana

Paspor

Talak

Tambahan Lembaran

Negara

Undang-undang

Visa berdiam
Regeringsverordening die in de plaats van een wet treedt

Chinese Beweging

Vereniging

Vereniging van Indonesische rechtsgeleerden

Menswaardigheid, humaniteit

Autochtoon

Samenvatting, résumé

Voorlopige Verhandeling

Herroeping van een verstoting

Waar, echt

Etnische groepering

Bewijs van Indonesisch Staatsburgerschap

Reisdocument

Verstoting

Aanvullend Staatsblad, bijblad

Wet

Verblijfsvergunning

XX 
Wali

Walikota

Warganegara

Indonesia
Voogd

Burgemeester

Indonesische staatsburger 



\section{\$1 Probleemstelling en indeling van het boek}

Over het Indonesische nationaliteitsrecht bestaat in Nederland geen enkele monografie. Dit is verbazingwekkend, gezien de langdurige historische banden tussen Indonesië en Nederland. De invloed van deze langdurige banden manifesteert zich op diverse gebieden, waaronder op het economische en culturele vlak, maar met name ook op het gebied van het recht. Voor het nationaliteitsrecht geldt dit in bijzondere mate.

In de vorige eeuw hadden de meeste inwoners van het territorium van het huidige Indonesië - althans voor privaatrechtelijke doeleinden - de Nederlandse nationaliteit, daar dit gebied een Nederlandse kolonie was en de nationaliteitsregeling neergelegd in het Nederlands Burgerlijk Wetboek van 1838 geen onderscheid maakte tussen personen die geboren waren en leefden in het moederland en personen die geboren waren en leefden in de koloniën. De situatie veranderde door het in werking treden van de Wet op het Nederlanderschap en het ingezetenschap van 1892 op 1 juli 1893 . Daarna had slechts een klein gedeelte van de bevolking van het territorium van het huidige Indonesië de Nederlandse nationaliteit. Sinds 1910 hadden de meeste inwoners van dat gebied de status van Nederlands onderdaan-niet-Nederlander. In volkenrechtelijk perspectief waren deze personen Nederlanders: Nederland had het recht hun diplomatieke bescherming te verlenen. Nederlandse onderdanen-niet-Nederlander hadden echter niet de Nederlandse nationaliteit in de zin van de Wet op het Nederlanderschap en het ingezetenschap en hadden derhalve in het moederland geen politieke rechten.

Toen Indonesië zich in 1945 onafhankelijk verklaarde, was het noodzakelijk te bepalen welke personen de nationaliteit van de nieuwe Staat zouden bezitten. De Indonesische regering heeft redelijk snel na de onafhankelijkheidsverklaring ook daadwerkelijk nationaliteitsregelingen afgekondigd, die echter slechts betrekkelijk korte tijd hebben gegolden. De formele overdracht van de soevereiniteit door Nederland aan Indonesië vond echter pas op 27 december 1949 plaats. Ter gelegenheid van de soevereiniteitsoverdracht werd een Overeenkomst op de Toescheiding van Staatsburgers gesloten. Deze overeenkomst was een essentiële schakel in de ontwikkeling van de Indonesische nationaliteit, vooral omdat deze overeenkomst ook het vertrekpunt vormde van de thans geldende Indonesische nationaliteitswet van 1958. Voor het begrip van (de ontwikkeling van) het Indonesische nationaliteitsrecht is van belang, dat de Toescheidingsovereenkomst nauw aansloot bij de Wet op het Nederlanderschap en het ingezetenschap van 1892 alsmede bij de uit 1910 daterende regeling van het Nederlands onderdaanschap van niet-Nederlanders.

Wil men heden ten dage vaststellen welke personen de Indonesische nationaliteit bezitten en welke uit de Indonesische archipel afkomstige personen (of hun afstammelingen) Nederlander zijn, dan is goede kennis nodig van de vroeger voor het territorium van het huidige Indonesië geldende regelingen, van diverse bijzondere regelingen, alsmede van het positieve Indonesische en Nederlandse nationaliteitsrecht. Het onderha- 
vige boek poogt een overzicht van deze voorschriften te geven met uitzondering van het Nederlandse nationaliteitsrecht, waarover reeds voldoende publicaties bestaan.

De ontwikkeling van het nationaliteitsrecht van een bepaald land kan niet goed worden begrepen zonder enige kennis van de politieke geschiedenis van dat land, de staatsstructuur, speciale banden met zekere landen etc. Aan dergelijke Indonesië betreffende algemene onderwerpen is de rest van dit inleidende eerste Hoofdstuk gewijd.

Een kritische beschrijving van het nationaliteitsrecht van een land ondergaat nolens volens invloed van de opvattingen van de auteur over enkele algemene vraagstukken betreffende de nationaliteit. Om die reden zal in Hoofdstuk 2 op de verschillende betekenissen van het begrip "nationaliteit" en op de functie van de nationaliteit worden ingegaan. Voorts komt de vraag aan de orde, of het recht op een nationaliteit al dan niet als een mensenrecht kan worden beschouwd. Aandacht wordt vervolgens besteed aan de volkenrechtelijke beperkingen met betrekking tot de nationale autonomie van Staten tot regeling van hun nationaliteit. Tenslotte wordt ingegaan op enkele algemene problemen betreffende de nationaliteitsrechtelijke gevolgen van gebiedsovergang.

De inhoud van Hoofdstuk 3 is sterk bepaald door de geschiedenis van de ontwikkeling van het nationaliteitsrecht op het territorium van het huidige Indonesië. Achtereenvolgens wordt aandacht besteed aan de voór 1892 geldende bepalingen ter regeling van de status van de inwoners van het territorium van het huidige Indonesië. Ook de reeds genoemde Wet van 1910 op het Nederlands onderdaanschap van niet-Nederlanders en de eerste Indonesische nationaliteitswet van 1946 komen aan de orde. Op basis van de afkondiging van de Staat van Oorlog en Beleg c.q. Staat van Gevaar in het jaar 1957 werden verschillende regelingen van het Militaire/Oorlogsgezag vastgesteld, die ook enkele nationaliteitsaangelegenheden regelden. Voorts zal aandacht worden besteed aan de eveneens reeds genoemde Toescheidingsovereenkomst, tussen Indonesië en Nederland naar aanleiding van de formele soevereiniteitsoverdracht in het jaar 1949 aangegaan.

Het feit, dat Indonesië vóór de afkondiging van de thans vigerende Nationaliteitswel nog niet over een eigen nationaliteitswet beschikte, deed zich in de praktijk echter terdege voelen. Niettegenstaande na de proclamatie van de onafhankelijkheid op 17 augustus 1945 door de Republiek Indonesië van de Yogyaregering de Wet van het jaar 1946 zoals naderhand gewijzigd en aangevuld werd afgekondigd - het betrof hier de eerste nationaliteitswet van Indonesië - heeft deze Wet slechts beperkt en kort gegolden, met het gevolg dat van de daarin opgenomen bepalingen ter regeling van het staatsburgerschap van de ingezetenen van de Republiek Indonesië geen gebruik kon worden gemaakt. ' Met het doel om in het bestaande rechtsvacuüm te voorzien, werd op 1 augustus 1958 de langverwachte Wet no. 62 van het jaar 1958 betreffende het Staatsburgerschap van Indonesië afgekondigd, die in de Hoofdstukken 4 tot en met 6 aan een uitvoerige en kritische beschouwing zal worden onderworpen. Daarbij zullen enkele 
belangrijke algemene aspecten en de wijze van verkrijging en verlies van de nationaliteit volgens deze Nationaliteitswet worden behandeld.

Hoofdstuk 7 behandelt de wijze van verkrijging van een bewijsstuk inzake het bezit van het Indonesisch staatsburgerschap; dit is vooral van belang voor Indonesische staatsburgers van vreemde origine.

Ik acht het voorts van belang om in te gaan op enkele internationale aspecten waardoor het Indonesisch nationaliteitsrecht zich in de loop van zijn ontwikkeling heeft onderscheiden. In dit verband verdient behalve de Toescheidingsovereenkomst ${ }^{2}$, de Overeenkomst ter afwikkeling van het probleem van de Bipatridie tussen de Republiek Indonesië en de Chinese Volksrepubliek ${ }^{3}$ vermelding. Twee andere gebeurtenissen die nationaliteitsrechtelijke vragen hebben opgeroepen, zijn de overdracht van Irian Jaya in 1963 aan Indonesië ${ }^{4}$ en de inlijving van Oost-Timor in 1976 door Indonesië als de 27 ste provincie van dit land. ${ }^{5}$

In Hoofdstuk 8 zullen enkele conclusies uit de behandelde materie worden getrokken. Daarbij zal worden nagegaan, of de huidige Nationaliteitswet van 1958 aan het gestelde doel om te komen tot een nationale regeling inzake het Indonesisch staatsburgerschap beantwoordt en in hoeverre deze Wet zwakke punten vertoont. Hierop aansluitend zullen suggesties worden gedaan tot wijziging van enkele in de onderhavige Wet voorkomende bepalingen.

\section{$\S 2$ Enkele algemene gegevens inzake Indonesië}

\subsection{De politieke geschiedenis}

Een beschrijving van de geschiedenis van Indonesië wordt meestal aangevangen met de behandeling van de vorstendommen die circa het midden van de zestiende eeuw in Indonesië bestonden. In het bestek van deze beschouwing zal hierop echter niet worden ingegaan. Wél dienen de "Centuries of Sorrows under the Europeans", te worden genoemd - zoals door Himawan aangeduid ${ }^{6}$ - dat wil zeggen de jaren 1511-1942, waarin successievelijk de Portugezen (1511-1596), de Nederlanders (1596-1795), de Fransen (1795-1811), de Engelsen (1811-1816), vervolgens wederom de Nederlanders (1816-1942) het voor het zeggen hadden in Indonesië. ${ }^{7}$

De eerste Nederlanders zetten in 1596 voet aan wal in Indonesië. Hun spoedig concurrerende handelsondernemingen werden in 1602 verenigd tot de Verenigde Oost-Indische

2. Zie hiervoor $\$ 5.3$ van Hoofdstuk 3 .

3. Behandeld in $\$ 3$ van Honfdstuk 4.

4. Aan de orde gekomen in $\$ 10$ van Hoofdstuk 5 .

5. Op deze aangelegenheid is ingegaan in $\$ 1.5 .4$ van Hoofdstuk 2.

6. Himawan, Ch., The Foreign Investment Process in Indonesia, Singapore, 1980, p. 79-205.

7. Ibid., voor een uitvoerige beschouwing inzake de ontwikkelingen in Indonesië onder de Portugezen, de Nederlanders, de Fransen, de Engelsen en de terugkeer der Nederlanders. 
Compagnie (VOC). De 18de eeuw deed de bezwaren van het handelssysteem van de Compagnie steeds meer aan het licht komen. Geteisterd door mismanagement en corruptie ging de VOC steeds meer achteruit. De aan dit lichaam door de Nederlandse overheid toegekende concessie liep af op 31 december 1799 en werd niet vernieuwd zodat op deze datum de VOC ophield te bestaan en alle goederen en geldelijke verplichtingen op de Nederlandse staat overgingen. ${ }^{8}$

Vanaf het jaar 1816 tot het jaar 1942 was Indonesië, onder de naam NederlandschIndië, een kolonie van Nederland. De Nederlandse regering heeft in de 20 ste eeuw de kracht van de nationalistische beweging in Indonesië onvoldoende onderkend. In dit verband kan de oprichting in 1927 door Soekarno van de PNI ("Partai Nasionalis Indonesia", de Indonesische Nationalistische Partij) worden genoemd. Deze partij streefde naar volledige onafhankelijkheid voor Indonesië. Na 1926 traden de Nederlanders geleidelijk krachtiger tegen de nationalisten op. Zo werden velen naar het interneringskamp Boven-Digul in het binnenland van (Westelijk) Nieuw-Guinea of naar een andere uithoek van Indonesie verbannen, een lot dat onder meer Soekarno, Hatta en Sjahrir trof. Eerst door de Japanners werden deze nationalistische voormannen op vrije voeten gesteld. 9

Gedurende de Japanse bezetting in de periode 1942-1945, werkten de Japanners samen met de Indonesische nationalisten. ${ }^{10}$ Vooral Soekarno, die in juli 1942 in Batavia terugkeerde, trad hierbij op de voorgrond. Een belangrijke ontwikkeling was de oprichting in 1943 van een Indonesisch vrijwilligersleger, de PETA ("Pembela Tanah Air" = Verdediging van het Vaderland), die samen met Japan Java tegen een geallieerde inval zou moeten verdedigen. " De hierdoor verkregen militaire kennis vormde niet alleen de kern van de latere moderne Indonesische strijdkrachten, maar bleek ook heel effectief te zijn na de Proclamatie van de Indonesische Onafhankelijkheid op 17 augustus 1945. Van belang was het ontstaan van een nieuwe groepering, de "Pemuda's" (jongeren), samengesteld uit studenten, jongere ambtenaren en leden van militaire en paramilitaire hulpformaties zoals de PETA. ${ }^{12}$

Twee dagen na de overgave van Japan aan de geallieerden op 15 augustus 1945 riepen Soekarno en Hatta, onder druk van de "Pemuda's" de Republiek Indonesië uit, waarvan Soekarno president werd. ${ }^{13}$ De eerste Grondwet van de Republiek zag het licht op 18 augustus 1945 , een dag na de onafhankelijksverklaring. ${ }^{14}$

8. Ibid., p. 123, betreffende het opheffen van de VOC.

9. Ibid., p.209.

10. Zie voor de ontwikkelingen tijdens de Japanse bezetting, Ricklefs, M.C., A History of Modem Indonesia; c. 1300 to the present, Monash University, Londen, 1981, p.187-200.

11. Himawan, The Foreign Investment Process, p.209-213, waarin de toestand in Indonesiẽ onder de Japanse bezetting wordt beschreven.

12. Ricklefs, A History, p. 200-225.

13. Ricklefs, A History, p. 246.

14. Departement van Voorlichting RI, Indonesia 1988, an official handhook, Jakarta, p.50. De Grondwet van 1945 is opgenumen in de Himpunan Peraturan Perundang-Undangan Republik 
Na de overgave van Japan was Nederlandsch-Indië gedurende een overgangsperiode door het Amerikaanse leger aan het Britse Zuidoost-Azië-commando overgedragen, dat echter weinig troepen had en het land voorshands niet kon bezetten. Er kwam een interregnum. De eerste Britten en Nederlanders kwamen pas in oktober 1945 op Java aan. In de meeste Buitengewesten werd het Nederlandse gezag snel hersteld. De Republiek bood echter op Java en Sumatra verzet in een guerrilla-oorlog tegen de terugkerende Nederlanders, waaraan onder Britse druk een einde werd gemaakt door de sluiting in november 1946 van het Nederlands-Republikeinse accoord van Linggarjati. ${ }^{15}$ Levensvatbaar was deze overeenkomst echter niet. De militaire strubbelingen tussen Nederland en Indonesië hielden aan. Op 21 juli 1947 begon Nederland zijn eerste politionele actie, die door toedoen van de Verenigde Naties op 5 augustus 1947 werd gestaakt. Op 8 december 1947 onderhandelden partijen opnieuw aan boord van het zeetransportschip van de V.N., de Renville. Met de Renville-overeenkomst kwam voorlopig een einde aan de militaire vijandelijkheden. ${ }^{16}$ Was Indonesië reeds ten tijde van het Renville-accoord een factor in de "koude oorlog" geworden, geleidelijk aan kreeg de Republiek in Washington meer gezag. Dit was de voornaamste reden, waarom een in december 1948 door Nederland ingezette tweede politionele actie ondanks de bezetting van Yogyakarta en de gevangenneming van vrijwel de hele Republikeinse regering, politiek mislukte. ${ }^{17}$

Onder Amerikaanse pressie droeg Nederland op 27 december 1949 de soevereiniteit over Nederlandsch-Indië over aan de jonge Republiek. Hiervan werd Nieuw-Guinea uitgezonderd, waarvan de status binnen een jaar middels onderhandelingen zou moeten worden geregeld. Voor het geval deze onderhandelingen niet tot resultaat zouden leiden. was echter geen oplossing aangegeven.

Tijdens de naar aanleiding van de soevereiniteitsoverdracht gehouden Ronde Tafel Conferentie (RTC) tussen beide landen, werden verschillende overeenkomsten ter regeling van de verhouding tussen deze landen aangegaan. ${ }^{18}$ Voor Indonesië werd op 31 januari 1950 de federale rechtsvorm van de Verenigde Staten van Indonesië (VSI) geïntroduceerd en zag de Constitutie van de Republiek der Verenigde Staten van Indonesië het licht. ${ }^{19}$ Op grond van genoemde overeenkomsten werden Nederland en de VSI in een Unie verenigd; in de ogen van Indonesië was dit een schijnconstructie, omdat de VSI niet levensvatbaar konden worden geacht. Het staatshoofd hiervan,

14. $\rightarrow$

Indonesia, disusun menurut sistem Engelbrecht (Verzameling van de wetten van de Republiek Indonesiē, opgesteld volgens het systeem Engelbrecht), tweede druk, 1989, vitgegeven door P.T. Ichtiar Baru-van Hoeve, in het vervolg aangeduid met "Engelbrecht", p. 1.

15. Himawan, The Foreign lnvestment Process, p. 216-218.

16. Himawan, The Foreign Investment Process, p.218-220.

17. Ricklefs, A History, p.200-225.

18. Zie voor de RTC, Himawan, The Foreign Investment Process, p.220.

19. Zie voor de Wet Souvereiniteitsoverdracht Indonesiẽ van 21 december 1949 en de verschillende overeenkomsten bij de RTC aangegaan, De Wetboeken, Wetten en Verordeningen benevens de Voorlopige Grondwer van de Republiek Indonesië, Leiden, 1954, in het vervolg alangeduid met "Engelbrecht-oude stijl", p.2967-3026. De Constitutie der VSI is opgenomen in Engelbrecht, p.5. 
Soekarno was meer dan wie ook de belichaming van het unitarisme. Dit heeft lot gevolg gehad, dat de VSI op 17 augustus 1950 van het toneel verdwenen. Alleen in de ZuidMolukken - in april 1950 was hier een onafhankelijke republiek uitgeroepen - werd tegen deze ontwikkeling, vooral door voormalige KNIL-militairen (Koninklijk Nederlandsch-Indisch Leger) verzet geboden. In de plaats van de VSI kwam de unitarische Republiek Indonesië tot stand, met een op Nederlandse leest geschoeide voorlopige grondwet, de Voorlopige Grondwet van 1950. ${ }^{20}$ Het leger, de communistische partij (PKI, de "Partai Komunis Indonesia") en de President werden de voornaamste machtscentra. In deze constellatie van groeiend nationalisme en steeds toenemende inflatie zegde Indonesië in 1956 vanwege het Nieuw-Guinea-geschil de Unie met Nederland op, gevolgd door de unilaterale opzegging op 13 februari 1956 van de overeenkomsten bij de RTC aangegaan. Verkiezingen voor een Parlement in 1955, een Constituante in 1955-1956 en voor Gemeenteraden in 1957 leverden successen op voor de PKI. ${ }^{21}$ Mede als reactie op deze PKI-successen werd de situatie gecompliceerd toen conservatieve officieren in de Buitengewesten separatislische neigingen gingen vertonen. Hier kwam nog bij, dat Sumatra en Sulawesi als exportgebieden meenden dat Java als gevolg van de deviezenbepalingen hun inkomsten afroomde. De onstabiele politieke situatie kwam mede tot uiting in het groot aantal, elkaar snel opvolgende kabinetten. ${ }^{22}$ Dit was de achtergrond van de afkondiging van de Staat van Oorlog en Beleg door President Soekarno in het jaar 1957. Deze toestand bleef gehandhaafd tot 15 december 1960. ${ }^{23}$ Ondertussen had Soekarno in 1959 met behulp van het leger de Constituante naar huis gestuurd en de Grondwet van 1945 in juli 1959 wederom van kracht verklaard, die aan de President veel grotere macht gaf. ${ }^{24}$ Het daarop volgende jaar ging de President nog verder met de doorvoering van het nieuwe staatsbestel, betiteld als "geleide democratie". In maart 1960 werd het parlement vervangen door een lichaam, waarin naast afgevaardigden van de politieke partijen - wier macht sterk beknot werd ook vertegenwoordigers van beroepen en maatschappelijke groeperingen, de zogenaamde Functionele Groepen (GOLKAR, de "Golongan Karya") zitting kregen. ${ }^{25}$

De politieke verwikkelingen met Nederland vanwege het Nieuw-Guinea-conflict had de confiscatie ("ambil-alih") van Nederlandse bedrijven door de arbeiders daarvan ten gevolge. Bij besluit van Generaal Nasution van 13 december 1957 werd echter de verdere confiscatie van genoemde bedrijven verboden en de reeds overgenomen

20. Himawan, The Foreign Investment Process, p.224. De Voorlopige Grondwet van 1950 is opgenomen in Engelbrecht, p.31.

21. Ricklefs, A History, p. 247-248.

22. Himawan, The Foreign Investment Process, p.239-240.

23. De in Ind. Stb. 1939-582 opgenomen Regeling op de Staat van Oorlog en Beleg werd vervangen door de Wet no. 23 Prp van het jaar 1959, Stb. 1959-139, dit in verband met het weer van kracht worden van de Grondwet van 1945. Bij deze gelegenheid werd tot de vaststelling van een nieuwe regeling inzake de Staat van Gevaar overgegaan, die corspronkelijk tot 16 juni 1960 van kracht zou blijven, doch krachtens de Wet no. 22 Prp van het jaar 1960, Stb. 1960-66, werd verlengd tot 15 december 1960.

24. Ricklefs, A History, p. 253-254.

25. Ricklefs, A History, p. 247. 
bedrijven op basis van de Staat van Oorlog en Beleg onder militaire controle geplaatst. ${ }^{26}$ Bij Wet no. 86 van 1958, Stb. 1958-162 werden vervolgens de Nederlandse bedrijven genationaliseerd. De diplomatieke betrekkingen tussen Indonesië en Nederland werden op initiatief van eerstgenoemd land verbroken.

In het conflict tussen Indonesië en Nederland inzake Irian Jaya speelden de Verenigde Staten een belangrijke rol door druk op Nederland uit te oefenen om over de Irian Jayakwestie te onderhandelen. ${ }^{n}$ Onder Amerikaanse bemiddeling werd op 15 augustus 1962 een accoord tot stand gebracht. Krachtens dit accoord droeg Nederland Irian Jaya op 1 oktober 1962 aan de Verenigde Naties over, die dit gebied op hun beurt op 1 mei 1963 aan Indonesië overdroegen. ${ }^{28}$ In 1969 werd een volkraadspleging gehouden volgens het "musyawarah"-systeem ("musyawarah" = overleg), waarbij 1025 afgevaardigden voor de Papoea's beslisten dat het gebied bij Indonesië zou blijven. ${ }^{29} \mathrm{Na}$ de overdracht van Irian Jaya aan Indonesië werden de diplomatieke betrekkingen tussen Indonesië en Nederland hersteld. ${ }^{30}$

In 1963 ontstond een controverse inzake de op 16 september 1963 geproclameerde Federatie van Maleisië, waarbij zich ook de voormalige Engelse bezittingen op Kalimantan aansloten. ${ }^{31}$ Genoemde proclamatie vond plaats, nadat op 8 juli 1963 Engeland en de lidstaten van de Federatie in Londen overeenstemming hadden bereikt over de voorwaarden van haar totstandkoming. Dit conflict spitste zich toe in de zogenaamde confrontatiepolitiek van Indonesië tegen de Federatie van Maleisië, die door Indonesië als "neo-koloniaal" werd aangemerkt, vanwege het zich blijven bevinden aldaar van Britse basissen. Voorts werd gevreesd dat de dynamische Chinese samenleving van Singapore de nieuwe natie zou domineren en als zodanig de Chinese invloed in de regio zou bevorderen. ${ }^{32}$ Genoemde confrontatiepolitiek had de confiscatie van Britse en Maleisische eigendommen ten gevolge, in 1965 gevolgd door de confiscatie van Amerikaanse en andere buitenlandse bedrijven. ${ }^{33}$ De confrontatie met de Federatie werd in 1966 beëindigd.

26. Himawan, The Foreign Investment Process, P. 242.

27. Irian Jaya heette van 1962 tot 1973 Irian Barat en tot 1962, Nederlands Nieuw-Guinea. Dit gebiedsdeel is gelegen op de westelijke helft van het eiland Nieuw-Guinea; de ousthelft bestaat uit het in 1975 onathankelijk geworden Papua New Guinea.

28. Zie voor literatuur inzake Nieuw-Guinea, Duynstee, F.J.M., Nieuw-Guinea als schakel tussen Nederland en Indonesië, Amsterdam, 1961 en Röling. B.V.A., Nieuw-Guinea als Wereldprobleem, Assen, 1958, voorts een gecommentarieerde bloemlezing onder redactie van Koch, D.M.G. en Riemers, J.W.E., Het geschilpunt West Nieuw-Guinea eist een oplossing, Amsterdam, 1955.

29. Ricklefs, A History, p. 258-260.

30. De situatie op Irian Jaya kan ook heden ten dage nog niet bevredigend worden genoemd, blijkend uit het nog actief zijn van de bevrijdingsorganisatie "Papua Merdeka"; tegen leden en sympathisanten hiervan wordt door het leger opgetreden.

31. Sabah en Serawak zijn in 1963 bij de Maleise Federatie gevoegd. Brunei heeft zich in helzelfde jaar als autonome staat aangesloten bij de Federatie. Genoemde gebiedsdelen - voormalige Engelse bezittingen - zijn in Noord-Kalimantan gelegen.

32. Ricklefs, A History, p.260-261.

33. Himawan, The Foreign Investment Process, p. 245, 247-248. 
Op 30 september 1965 werd in Indonesiē een communistische staatsgreep verijdeld door het leger. Eerst nadat een golf van geweld het land overspoeld had, slaagde de commandant van de strategische reserve, generaal Soeharto erin, om de orde in Jakarta te herstellen en werd het leger de toestand meester. Bij deze mislukte staatsgreep vonden zes generaals de dood en vielen talloze slachtoffers. De communistische partij werd verboden. ${ }^{34}$ Het parlement beroofde in 1966 Soekamo van zijn presidentschap, waarop Generaal Soeharto hem vervolgens ontsloeg als regeringsleider. Op 22 februari 1967 droeg Soekamo al zijn prerogatieven aan Soeharto over, die in dit jaar president werd. ${ }^{35}$

Melding dient voorts te worden gemaakt van de Oost-Timor kwestie, waarvoor nog steeds niet tot een oplossing is gekomen. Teneinde enig licht te werpen op de houding van Portugal in deze kwestie, kan worden opgemerkt dat in 1974 een staatsgreep in Portugal plaatsvond. De val van de dictatuur in dit land heeft de oprichting van politieke partijen, ook in Oost-Timor mogelijk gemaakt. Deze politieke partijen waren de UDT, de Democratische Unie van Timor, voorstander van een blijvende band met Portugal; het Revolutionaire Front van Oost-Timor, het FRETILIN, voorstander van onmiddellijke onafhankelijkheid en de APODETI, de Democratische Volksvereniging van Timor ${ }^{36}$, die integratie in Indonesië verdedigde, doch inmiddels is opgeheven. De UDT kwam door de ontwikkelingen in links-socialistische zin in het moederland al gauw terug van haar verlangen tot handhaving van de banden met Portugal en ging een, zij het kortstondige, coalitie met het FRETILIN aan, die zich baseerde op de principes van nationale onafhankelijkheid. ${ }^{37}$ Overeengekomen werd om met Portugal te onderhandelen over de formatie van een nieuwe Overgangsregering, onder toezicht van de VN. Tijdens de conferentie van Macau in juli 1975, werd door de Portugese regering het recht tot zelfbeschikking van de bevolking van Timor bevestigd, met alle consequenties van dien, waaronder de aanvaarding van haar onafhankelijkheid. Het feit, dat tijdens de verkiezingen in augustus 1975 het FRETILIN de meerderheid behaalde, direct gevolgd door de UDT, bracht laatstgenoemde partij ertoe een staatsgreep te proberen, waarop het FRETILIN de bevolking tot gewapend verzet opriep. De Portugese regering bleef, tevergeefs, proberen de drie partijen rond de onderhandelingstafel te verenigen. Na het vertrek van de Portugese troepen uit Oost-Timor omdat geen kans werd gezien het toezicht te herstellen, mengde Indonesië zich eind 1975 militair in de gewapende strijd tussen de verschillende politieke groeperingen. ${ }^{38}$ Op 28 november 1975 riep het FRETILIN de Democratische Republiek van Oost-Timor uit. ${ }^{39}$ Portugal heeft de nieuwe Staat niet erkend en heeft verklaard zich als de besturende macht van het gebied te blijven beschouwen. ${ }^{40}$ Inmiddels was van Indonesische zijde verscheide-

34. Ricklefs, A History, p.268-270.

35. Ricklefs, A History, p.275.

36. Zie Leite, P., Oost-Timor, de Westelijke Sahara van Zuidoost-Aziě, Leiden, 1988, p.98.

37. Zie voor meer details, Leite, Oost-Timor.

38. Ricklefs, A History, p. 278.

39. Jolliffe, J., East Timor, Nationalism \& Colonialism, University of Queensland Press, 1978, p.211212.

40. Leite, Oost-Timor, p.134. 
ne malen verklaard, dat een zelfstandig Oost-Timor met het FRETILIN als grootste politieke groepering een bedreiging voor West-Timor zou zijn. Op 17 juli 1976 maakte President Soeharto officieel bekend dat Oost-Timor als 27ste provincie bij Indonesië was ingelijfd. Deze aangelegenheid werd bestreden door Portugal die de kwestie voor de VN bracht. Tot op heden is evenwel nog geen oplossing door de VN voor OostTimor bereikt.

De regering-Soeharto bracht een heroriëntatie teweeg in de buitenlandse politiek. Van de verschillende fasen die Indonesië heeft doorlopen, kan de aflossing van de "geleide economie" van de voormalige President Soekarno door de "open-door policy" van President Soeharto worden genoemd. ${ }^{41}$ Hierbij werd de sterk nationalistisch gekleurde politiek van het voormalige bewind beëindigd, die werd gekenmerkt door tegenzin tot het gebruikmaken van buitenlands kapitaal. ${ }^{42}$

De "Nieuwe Orde" die door President Soeharto werd ingeluid, benadrukt in eerste instantie de principiële openstelling van het land voor buitenlandse investeringen. ${ }^{43}$ Om haar oprechtheid in deze aangelegenheid te tonen en het doen van buitenlandse investeringen in Indonesië te stimuleren, ving de Overheid aan met het onmiddellijk teruggeven van de in de jaren 1957-1965 "overgenomen" buitenlandse bedrijven. Wat betreft Nederland, werd een overeenkomst gesloten om tot afwikkeling te komen van de uitstaande schulden. In het jaar 1967 vond de afkondiging van de Wet no. 1 van het jaar 1967, Stb. 1967-1 betreffende Buitenlandse Investeringen plaats. ${ }^{44}$ Belangrijke resultaten met betrekking tot buitenlandse aangelegenheden, die door het bewind van de "Nieuwe Orde" onder het leiderschap van President Soeharto zijn bereikt, zijn de hertoetreding van Indonesië tot de Verenigde Naties (Indonesië had zich in 1965 uit de VN teruggetrokken ${ }^{45}$ ) en de oprichting tezamen met andere landen uit de zuidoostAziatische regio van een regionale samenwerkingsorganisatie, de ASEAN. ${ }^{46}$ Meldenswaardig zijn voorts de onderhandelingen die Indonesië met verschillende landen voerde om te komen tot een herschikking van de schuldenlast. Een belangrijk succes daarvan was de vorming van een consortium van donoren, de IGGI, de Inter-Gouvernementele Groep inzake Indonesië, waarvan het voorzitterschap bij Nederland berustte. ${ }^{47}$ Recente politieke ontwikkelingen tussen Indonesië en Nederland hebben echter tot wijziging van het tot dusverre gevolgde beleid geleid, waarop nader zal worden tenggekomen.

41. Zie voor meerdere gegevens The Indonesian economy, gepubliceerd door Praeger Publishers, CBS Educational and Professional Publishing, a Division of CBS, inc., New York, 1980.

42. Himawan, The Foreign Investment Process, p. 259-260.

43. Ricklefs, A History, p.272.

44. Opgenomen in Engelbrecht, p. 1209 ,

45. Ricklefs, A History, p.268.

46. Zie voor deze aangelegenheid het Departement van Voorlichting RI, Indonesia, p. 49 .

47. Posthumus, G.A., The Intergouvernemental Group on Indonesia (IGGI), Rotterdam, 1971. 
De Indonesische staat is een rechtsstaat, gebaseerd op een Grondwet. ${ }^{48}$ Indonesië vormt een eenheidsstaat van republikeinse structuur, verdeeld in provincies die onderverdeeld zijn in districten en onderdistricten. Deze structuur is neergelegd in de Grondwet van 1945, die in 1959 bij Presidentieel Besluit opnieuw van kracht werd verklaard.

De staatsideologie, de Pancasila, fungeert als bindmiddel tussen de verschillende politieke, religieuze en etnische stromingen. Het is gebleken dat deze ideologie een nuttig instrument is. De vijf zuilen van de Pancasila, zijn in de Préambule van de Grondwet van 1945 opgenomen. Genoemde vijf zuilen zijn: het Geloof in God de Almachtige, een Rechtvaardige en Geciviliseerde Humaniteit, de Eenheid van Indonesië, een Democratie, geleid door Wijsheid van Beraadslaging/Vertegenwoordiging en Sociale Rechtvaardigheid voor het gehele Indonesische Volk. ${ }^{49}$

Onder het Soeharto-bewind werd aan het Indonesische leger, dat zijn origine had in de Indonesische revolutie en ook in de jaren vijftig als een beslissende machtsfactor was opgetreden, een belangrijke rol toegekend in de politieke en bestuurlijke macht. Na de periode-Soekarno, waarin Indonesië in toenemende mate in economische chaos werd gedompeld ${ }^{50}$, zag de regering-Soeharto economische wederopbouw en ontwikkeling als absolute prioriteit.

Volgens de Grondwet van 1945 zijn er zes staatsorganen, met name de Raad voor Volksoverleg ("Majelis Permusyawaratan Rakyat" of MPR), de President, in de vervulling van zijn taak bijgestaan door een Vice-President, de Hoge Adviesraad ("Dewan Pertimbangan Agung"), de Volksvertegenwoordiging ("Dewan Perwakilan Rakyat" of DPR), de Algemene Rekenkamer ("Badan Pemeriksa Keuangan") en het Hooggerechtshof ("Mahkamah Agung" of MA). De President wordt bijgestaan door Ministers, belast met de leiding van de Departementen van Bestuur, verdeeld over het politieke terrein en dat van de veiligheid, het economische, financiële en industriële terrein en het terrein van het volkswelzijn. ${ }^{51}$ Hiernaast zijn een aantal Coördinerende Ministers, Staatsministers, Onderministers en hoge staatsfunctionarissen met de status van Staatsminister te onderscheiden. De term "staatsminister" betreft ministers zonder

48. Zie voor een nadere vitleg, Rom. Darjanto en Muljadi, D., Kewargaan Negara Indonesia, Yogyakarta, 1968, p. 166-167.

49. De Indonesische terminologie van genoemde vijf zuilen luidt als volgt: "Ketuhanan Yang Maha Esa", "Kemanusiaan yang Adil dan Beradab", "Persatuan Indonesia", "Kerakyatan yang dipimpin oleb Hikmat Kebijaksanaan dalam Permusyawaratan/Perwakilan" en "Keadilan Susial bagi Seluruh Rakyat Indonesia". Zie voor een nadere toelichting op bedoelde vijf zuilen van de Pancasila, het Departement van Voorlichting RI, Indonesia, p. 8-9.

50. Ricklefs, A History, p.268.

51. Zie voor de samenstelling van de departementen, het hierop betrekking hebbende Presidentiële Besluit no. 15 van het jaar 1984, sedertdien herhaaldelijk gewijzigd, laatstelịk met het Presidentiële Besluit no. 67 van het jaar 1992. 
portefeuille. ${ }^{52}$ Van belang is voorts, dat in Indonesië de Ministers alleen verantwoording verschuldigd zijn aan de President, derhalve niet aan de Volksvertegenwoordiging.

De soevereiniteit berust bij het volk en wordt ten volle uitgeoefend door de "Majelis Permusyawaratan Rakyat", die als de hoogste politieke instelling van de Staat is aan te merken. De MPR bekrachtigt de Grondwet en de hoofdlijnen van het door de Staat te voeren beleid. Op basis van de Wet no. 16 van het jaar 1969 zoals herhaaldelijk gewijzigd, laatstelijk met de Wet no. 2 van het jaar 1985, Stb. 1985-2 is het totale aantal leden van de MPR het dubbele aantal leden van de Volksvertegenwoordiging, hetgeen neerkomt op een aantal van 1000 personen. ${ }^{53}$ De MPR is samengesteld uit de 500 leden van de Volksvertegenwoordiging en voorts uit aanvullende leden. Iedere Regio van het eerste Niveau - op dit begrip zal hieronder worden teruggekomen - levert minimaal 4 en maximaal 8 personen, in het totaal neerkomende op 147 personen. De overige aanvullende leden van de MPR bestaan uit vertegenwoordigers van partijen, die aan de algemene verkiezingen deelnemen - bedoeld zijn hier de "Partai Persatuan Pembangunan" en de "Partai Demokrasi Indonesia" - en uit vertegenwoordigers van de tot de Functionele Groepen (de regeringspartij, de Golkar) behorende strijdkrachten, bij elkaar genomen in het totaal 253 personen. ${ }^{54}$ De rest van de aanvullende leden zijn door de President vast te stellen vertegenwoordigers van diverse, andere groeperingen, in het totaal 100 personen. ${ }^{55}$ De President en de Vice-President worden door de MPR bij meerderheid van stemmen gekozen. Genoemde autoriteiten vervullen hun ambt gedurende vijf jaar en kunnen herkozen worden. ${ }^{56}$ De President - bijgestaan door de Vice-President - is tevens als Mandataris van de "Majelis Permusyawaratan Rakyat" aan

52. Als voorbeeld van een staatsminister kan worden genoemd, de Staatsminister voor Bevolkingsaangelegenheden en Milieu en de Statsminister voor de Rol van Vrouwen. Van de Coördinerende Ministers kan worden genoemd, de Coördinerende Minister voor Economische, Financiële en Industriële aangelegenheden. Van de Hoge functionarissen met de status van staatsminister kan voorts worden genoemd, de Gouverneur van de Bank Indonesia. Zie Departement van Voorlichting RI, Indonesia, p.58-59.

53. Zie voor deze Wet Engelbrecht, p.95. In bedoelde Wet zijn bepalingen opgenomen inzake de samenstelling en de positie van de Raad voor Volksoverleg, de Volksvertegenwoordiging en de regionale Volksvertegenwonrdigingen.

54. De Golkar bestaat uit diverse functionele groepen, zoals ambtenaren, leden van de strijdkrachten en van vrouwenorganisaties, studenten, boeren etc. De twee andere partijen die aan de verkiezingen deelnemen zijn de Verenigde Ontwikkelingspartij ("Partai Persatuan Pembangunan"), een fusie van Islamitische partijen en de Indonesische Democratische Partij ("Partai Demokrasi Indonesia"), bestaande uit de Indonesische Nationalistische Partij (PNI) en uit voomamelijk christelijke partijen. Met de Wet no. 3 van 1975, Stb. 1975-32, later gewijzigd met de Wet no. 3 van 1985, Stb. 1985 12 zijn nadere bepalingen getroffen inzake de politieke partijen en de Golkar, Engelbrecht, p. 104. De regeringspartij, de Golkar is de machtigste partij die aan de verkiezingen deelneemt. Volgens de Wet no. 15 van het jaar 1969, Stb. 1969-58 zoals herhaaldelijk gewijzigd, laatstelijk met de Wet no. I van het jaar 1985, Stb. 1985-1 betreffende de Algemene Verkiezingen, Engelbrecht, p.84, maken leden van de strijdkrachten geen gebruik van het stemrecht (artikel 11). Zie ook het Departement van Voorlichting RI, Indonesia, p.51 en p.60.

55. Zie Engelbrecht p.95 voor de samenstelling en positie van de "Majelis Permusyawaratan Rakyat". Voor de Golkar kan worden verwezen naar Ricklefs, A History, p. 276-277.

56. President Soebarto is in 1993 herkozen voor een nieuwe ambtstermijn. 
te merken en voert in die hoedanigheid het beleid uit in overeenstemming met de hoofdlijnen van het staatsbeleid zoals hem door dit lichaam opgedragen, waaraan hij verantwoording verschuldigd is. Het ambt van Voorzitter van de MPR wordt vervuld door een persoon die tevens Voorzitter is van de Volksvertegenwoordiging. De Raad houdt tenminste eenmaal per vijf jaar zitting. Buitengewone ziltingen kunnen worden gehouden, ingeval zich dringende problemen die verband houden met de richtlijnen van het staatsbeleid voordoen. ${ }^{57}$

De President is met de uitvoerende macht volgens de Grondwet bekleed. Hij heeft bovendien krachtens artikel 5 lid 1 van de Grondwet van 1945 de macht om wetten tot stand te brengen met goedkeuring van de Volksvertegenwoordiging. Hieruit vloeit voort, dat de President niet alleen het Hoofd van de uitvoerende macht is, doch samen met de Volksvertegenwoordiging ook de wetgevende macht in de Staat uitoefent. Hij stelt voorts regeringsverordeningen vast tot uitvoering van wetten, indien dit noodzakelijk is. De President stelt de ministers aan en ontslaat deze functionarissen, die alleen aan hem verantwoording verschuldigd zijn. Hieruit kan worden afgeleid, dal het regeringssysteem door de Republiek Indonesië aangehangen het presidentiële systeem is, hetgeen inhoudt dat regeringsgezag in handen ligt van de President en door deze autoriteit wordt uitgevoerd, bijgestaan door de ministers. ${ }^{\text {sh }}$ Als statshoofd bezit de President bepaalde prerogatieven die andere functionarissen niet bezitten:

1. op executief gebied:

a. de President oefent de hoogste macht uit over de strijdkrachten;

b. de President verklaart oorlog aan c.q. sluit vrede met andere landen, onder goedkeuring van de Volksvertegenwoordiging;

c. de President verkJaart het gehele land dan wel een gebiedsdeel in staat van gevaar;

d. de President ontvangt en stelt ambassadeurs en consuls aan.

2. op wetgevend gebied:

a. de President stelt wetten vast onder goedkeuring van de Volksvertegenwoordiging;

b. de President stelt regeringsverordeningen vast ter uitvoering van wetten;

c. de President stelt in urgente gevallen regeringsverordeningen met de kracht van wet vast;

57. Zie voor meer gegevens inzake de MPR, Kansil, C.S.T., Sistem Pemerintahan Indonesia, Jakarta, 1985, p.67-101 en Sri Soemantri, Tentarg Lembaga-Lembaga Negara menurut UUD 1945, Bandung, 1983, p.83-92.

58. Zie hiervoor Rom. Darjanto en Muljadi, Kewargaan Negara, p.125-126. Zie voorts voor een volledige opsomming van de bevoegdheden van de President, Himawan, The Foreign Investment Process, p.63-65. Zie ook Sri Soemantri, Tentang Lembaga-Lembaga, p. 119-138 en Kansil, Sistem Pemerintahan, p. 102-103. 
- de President verleent gratie, amnestie, abolitie en rehabilitatie. ${ }^{59}$

De samenstelling van de Volksvertegenwoordiging ("Dewan Perwakilan Rakyat" of DPR), die tenminste eenmaal per jaar zitting houdt, is bij de reeds genoemde Wet no. 16 van het jaar 1969, zoals laatstelijk gewijzigd met de Wet no. 2 van 1985, vastgesteld. Het aantal leden van de DPR omvat 500 personen, waarvan 400 personen gekozen worden door de partijen die aan de algemene verkiezingen deelnemen en 100 personen uit de fractie van de strijdkrachten van de Golkar worden aangesteld. Voor elke wet en voor de vaststelling van de staatsbegroting is de goedkeuring van de Volksvertegenwoordiging vereist. Uit het voorgaande is gebleken, dat in dringende buitengewone omstandigheden de President het recht heeft om regeringsverordeningen met kracht van wet vast te stellen; dit komt regelmatig voor. Deze regeringsverordeningen hebben echter de goedkeuring van de Volkstegenwoordiging op haar volgende zitting nodig en dienen te worden ingetrokken, ingeval deze goedkeuring niet wordt verleend. ${ }^{60}$ De positie van de Volksvertegenwoordiging is enerzijds krachtig - anders dan in het parlementaire systeem kan dit lichaam niet door de President ontbonden worden - anderzijds beschikt de Volksvertegenwoordiging over geringe bevoegdheden ten aanzien van Regering en President.

Wat betreft de functie en de rechten van de Hoge Adviesraad, ("Dewan Pertimbangan Agung") als advieslichaam van de President c.q. Regering kan worden verwezen naar de Wet no. 3 van hel jaar 1967, Stb. 1967-6, naderhand aangevuld bij Wet no. 4 van het jaar 1978, Stb. 1978-33. ${ }^{61}$ Deze Raad is verplicht om door de President gestelde vragen te beantwoorden en heeft het recht om voorstellen en overwegingen aan de President c.q. Regering voor te leggen die betrekking hebben op aangelegenheden, die rechtstreeks verband houden met het nationaal belang op het politieke, economische en socioculturele vlak en op het gebied van de verdediging en veiligheid. De leden van dit lichaam bestaan uit prominente nationale personen met een uitstekende reputatie op het vlak van het staatsbeleid, personen uil de functionele groeperingen en uit leidende persoonlijkheden op regionaal en nationaal niveau, als zodanig bij Presidentieel besluit aangewezen. ${ }^{62}$

De Algemene Rekenkamer ("Badan Pemeriksa Keuangan"), geregeld bij Wet no. 5 van het jaar 1973, Stb. 1973-39, is belast met het onderzoek van de verantwoording

59. Onder "abolitie" wordt een besluit van de politieke macht - in Indonesië de President - verstaan, waarbij wordt bevolen met een begonnen strafvervolging niet verder voort te gaan. Mel "rehabilitatie" wordt herstel in eer en goede naam bedoeld.

60. Zie ook Sri Soemantri, Tentang Lembaga-Lembaga, p.31-69.

61. Zie voor genoemde Welten, Engelbrecht p.172.

62. Zie voor meer gegevens, Sri Soemantri, Tentang Lembaga-Lembaga, p.139-159. 
betreffende de staatsfinanciën. ${ }^{63}$ Het resultaat van bedoeld onderzoek wordt aan de Volksvertegenwoordiging medegedeeld. ${ }^{64}$

Naast de wetgevende en uitvoerende macht is de rechterlijke macht te onderscheiden. Basisprincipes inzake de Rechterlijke macht zijn vastgesteld bij Wet no. 14 van het jaar 1970, Stb. 1970-74. ${ }^{65}$ Krachtens artikel 31 van deze Wet worden de rechters benoemd en ontslagen door het Staatshoofd. Opmerkelijk is dat deze rechters niet voor het leven worden benoemd. Met het doel om de samenstelling en de competentie van de "Mahkamah Agung" (MA) meer in overeenstemming te brengen met de bepalingen van genoemde Wet no. 14 van het jaar 1970, werd de Wet no. 14 van het jaar 1985, Stb. 1985-73 afgekondigd, die bepalingen bevat inzake de positie, samenstelling, bevoegdheden en het voor de MA geldende procesrecht. ${ }^{66}$ De bevoegdheden van de MA omvatten het onderzoeken en beslissen van verzoeken tot cassatie, geschillen inzake de bevoegdheid tot berechten en verzoeken tot herzien van vonnissen van het Gerecht die reeds in kracht van gewijsde zijn gegaan. ${ }^{67}$

De rechterlijke macht in Indonesië bestaat uit vier onderdelen, te weten de algemene rechtbanken, de religieuze rechtbanken, de militaire rechtbanken en de administratieve rechtbanken.

Met betrekking tot de algemene rechtbanken kan worden opgemerkt, dat deze civiele en strafrechtelijke jurisdictie hebben over alle personen die onder hun territoriaal rechtsgebied vallen. Deze zijn te onderscheiden in de "Pengadilan Negeri" (Landgerecht) de rechtbank in eerste aanleg, de "Pengadilan Tinggi" (Raad van Justitie) waarbij in beroep kan worden gegaan tegen de vonnissen van de "Pengadilan Negeri", voorts de "Mahkamah Agung" (Hooggerechtshof), dat als hoogste gerecht in laatste instantie beslist. ${ }^{68}$

Hiernaast bestaan religieuze rechtbanken die jurisdictie hebben over personen die de Islamitische godsdienst belijden, in geschillen die betrekking hebben op aangelegenheden waarin fundamentele regels van de Islam centraal staan. Deze fundamentele regels betreffen hoofdzakelijk het huwelijksrecht. Ook moeten deze rechtbanken bepalingen inzake vererving toepassen, voornamelijk in regio's buiten Java. De rechters van deze religieuze rechtbanken, worden door de Minister van Godsdienstzaken benoemd. Personen die hiervoor in aanmerking komen, zijn personen die in de Islamitische gedachtengang zijn onderwezen. Voorheen had een vonnis van een religieuze rechtbank

63. Zie voor genoemde Wet, Engelbrecht p. 200.

64. Voor meer gegevens kan worden verwezen naar Sri Soemantri, Tentang Lembaga-Lembaga, p. 160192.

65. Engelbrecht, p. 132.

66. Engelbrecht p.118. Zie voor genoemde staatsorganen tevens Roeder, R.0.G. en Willecke, J., Wirtschaftspartner Indonesien, Hamburg, 1979, p. 42-45.

67. Zie ook Sri Soemantri, Tentang Lembaga-Lembaga, p.193-212.

68. Zie voor de algemene rechtspraak, de Wet no. 2 van het jaar 1986, Stb. 1986-20, Engelbrecht p. 157. 
een fiat van een staatsrechtbank nodig om te kunnen worden uitgevoerd. In deze aangelegenheid is echter wijziging gebracht met het Rondschrijven van de "Mahkamah Agung" no. MA/Kumdil/1973/IV/1990 van 3 april 1990 aan de Voorzitters van de "Pengadilan Negeri", de "Pengadilan Agama", de "Pengadilan Tinggi" en de "Pengadilan Tinggi Agama" no. 2 van het jaar 1990 gericht, waarbij aanwijzingen werden gegeven inzake de uitvoering van de Wet no. 7 van het jaar 1989 betreffende de Godsdienstige Rechtspraak, Stb. 1989-40. Als gevolg hiervan is bedoelde fiat tot executie thans niet meer nodig. Op de Wet no. 7 van het jaar $1989 \mathrm{zal}$ in $\S 7.1 .3 \mathrm{van}$ Hoofdstuk 5 worden teruggekomen.

De militaire rechtbanken spreken recht in strafrechtelijke zaken tegen leden van de strijdkrachten. Ieder van de vier onderdelen van de strijdkrachten - het leger, de zeemacht, de luchtmacht en de politie - heeft zijn eigen rechtbank.

Tenslotte bestaan administratieve rechtbanken, zoals de "Panitia Penyelesaian Perselisihan Perburuhan" (Commissies ter Beslechting van Arbeidsgeschillen). Het betreft hier permanente instituten, die zowel op regionaal als op centraal niveau fungeren en zijn ingesteld krachtens de Wet no. 22 van het jaar 1957, Stb. 1957-42, zoals naderhand gewijzigd en aangevuld met de Wet no. 26 van hetzelfde jaar, Stb. 1957-72. ${ }^{69} \mathrm{Ge}-$ noemde Commissies hebben de afwikkeling van arbeidsgeschillen tussen vakverenigingen of groepen van arbeiders dan wel individuele werknemers en een persoon of bedrijf die deze in dienst heeft, tot taak. Een op centraal niveau ingestelde Commissie, fungeert als beroepscollege ten aanzien van de uitspraken van de regionale Commissies. Soortgelijke administratieve rechtbanken zijn ingesteld voor huisvestings- en belastingsaangelegenheden. Volledigheidshalve dient echter te worden gewezen op de afkondiging van de Wet no. 5 van het jaar 1986 inzake de Administratieve Rechtspraak, Stb. 1986-77, waarmede een algemene regeling is getroffen teneinde te komen tot de instelling van administratieve rechtbanken, in beginsel in iedere middelgrote stad of hoofdstad van een Regentschap. Aangezien het bij de in het kader van de administratieve rechtspraak in te stellen rechtbanken om een nieuw instituut gaat in het Indonesische rechtsbestel en de instelling van deze rechtbanken een zorgvuldige planning en voorbereiding behoeft, zal de uitvoering hiervan bij fasen plaatsvinden. ${ }^{70}$

Bepalingen betreffende het Openbaar Ministerie (OM) zijn vastgesteld met de Wet no. 5 van 1991, Stb. 1991-59. " De Procureur-Generaal wordt door de President benoemd

69. Engelbrecht p. 2096. Zie voor verdere gegevens, de Intemational Encyclopedia of Comparative Law, volume I, National Reports, hoofdredacteur Viktor Knapp. De beschouwing over Indonesie is opgesteld door Gautama, S., p. I-29 tot 1-31.

70. Inmiddels is reeds overgegaan tot de instelling van administratieve rechtbanken in Jakarta, Medan, Palembang, Surabaya, Ujung Pandang, Bandung, Semarang en Padang. Zie hiervoor de Presidentiēle Besluiten no. 52 van het jaar 1990 en no. 16 van het jaar 1992. De instelling van een "Pengadilan Tinggi" (Raad van Justitie) in het kader van de administratieve rechtspraak in Jakarta, Medan en Ujung Pandang heeft plaatsgevonden bij Wet no. 10 van het jaar 1990, Stb. 1990-80.

71. De Wet no. 5 van het jaar 1991 is in de plaats getreden van de eerder geldende Wet no. 15 van het jaar 1961 betreffende Basisbepalingen inzake het Openbaar Ministerie, die niet langer in overeen- 
en is aan deze laatste verantwoording verschuldigd. Het OM houdt zich normaliter slechts bezig met strafzaken. Op grond van een bijzondere volmacht kan het OM op het civiele vlak ${ }^{72}$ en dat van de administratie van de Staat optreden, zowel in als buiten het Gerecht voor en namens de Staat of de Regering. Op het gebied van de algemene orde en veiligheid neemt het $\mathrm{OM}$ deel aan activiteiten, onder meer gericht op verhoging van het rechtsbewustzijn van de samenleving, het veiligstellen van het beleid inzake de instandhouding van het recht, de circulatie van drukwerk en het toezicht op stromingen van overtuigingen die de samenleving en de Staat in gevaar zouden kunnen brengen.

Het Indonesische overheidsapparaat is niet alleen gericht op de bevordering en de ontwikkeling van de hem toegekende taak, die op algemene administratieve verplichtingen betrekking heeft. Hiernaast wordt verwacht, dat het in staat is om administratieve verplichtingen met betrekking tot het ontwikkelingsproces uit te voeren. Dit houdt het voorbereiden van plannen en programma's in, die tot doel hebben om gepast toezicht op ontwikkelingsactiviteiten met betrekking tot de implementatie van vijfjaarlijkse ontwikkelingsplannen of jaarlijkse plannen uit te oefenen. De verbetering van regeringsdiensten is gericht op de ontwikkeling van deze diensten tot effectieve, stabiele, gerespecteerde en van "schone" (van corruptie gezuiverde) instrumenten, loyaal aan de Overheid en aan de Staat.

De verdeling van het gebied van Indonesië in grote en kleine regio's en de inrichling van het bestuur daarvan is bij Wet no. 5 van het jaar 1974, Stb. 1974-38 betreffende Basisbepalingen inzake de Regering in de regio's vastgesteld. ${ }^{73}$ De structuur van de lokale Overheid is zo uniform mogelijk. Hierbij wordt gelet op het beginsel van overleg in het regeringsstelsel en op de traditionele rechten in de regio's van bijzondere aard. Zo functioneren op het autonome niveau van de lokale Regering, de hoofden van de regio's, met name de Gouverneurs, de Regenten ("Bupati") en de Burgermeesters ("Walikota"), die de voomaamste uitvoerders zijn in respectievelijk de Provincies, de Regentschappen ("Kabupaten") en de Middelgrote steden ("Kotamadya") die zij leiden. $\mathrm{Zij}$ worden bijgestaan door functionarissen, die aan het hoofd staan van de verschillende afdelingen van de lokale Regering. Deze functionarissen zijn bevoegd tot het opstellen van lokale regelingen tezamen met de respectieve regionale Vertegenwoordigersraden.

Aangezien de Gouverneurs, Regenten en Burgermeesters over bevoegdheden beschikken, die aan hen zijn gedelegeerd door de nationale Regering c.q. de Minister van Binnenlandse Zaken, hebben zij in feite twee functies: zij zijn vertegenwoordiger van de nationale Regering in hun regio en tevens de voornaamste uitvoerder in die regio.

71. $\rightarrow$

stemming met de ontwikkeling van het recht en de staatsinrichting van de Republiek Indonesië wordt geacht en om die reden is ingetrokken.

72. Volgens Gautama kan het $O M$ zich met hepaalde civiele zaken bezig houden, met name indien het gaat om zaken, waarbij het algemeen belang is betrokken, zoals in zaken betreffende bescherming van buitenlandse handelsmerken en oneerlijke concurrentie. Zie Knapp, International Encyclopedia, Gautama (Indonesiē) p. [-3].

73. Engelbrecht p. 203. 
Uit dien hoofde dragen zij twee titels. Als voorbeeld kan worden genoemd, Gouverneur van de Provincie... /Speciaal District van... en tevens Hoofd van de Regio van het eerste Niveau...; Regent van het Regentschap.../Burgemeester van de Stad... en Hoofd van de Regio van het tweede Niveau... De naam en begrenzing van een Regio van het eerste Niveau komt overeen met de naam en begrenzing van het gebied van een Provincie. Hiernaast bestaat het Speciale District van de Hoofdstad Jakarta en het Speciale District van Yogyakarta. Evenzo komt de naam en begrenzing van een Regio van het tweede Niveau overeen met de naam en begrenzing van het gebied van een Regentschap of van een Middelgrote Stad. De hoofdstad van een Regio van het eerste Niveau is de hoofdstad van een Provincie; de hoofdstad van een Regio van het tweede Niveau is de hoofdstad van een Regentschap. Daarentegen zijn de Onderdistricten ("Kecamatan") en de Dorps-administratieve eenheden ("Kelurahan") niet autonoom en hebben geen vertegenwoordigersraden. Een Onderdistrict is eenvoudigweg een administratief onderdeel van een Regentschap of Middelgrote stad en wordt geleid door een Onderdistrictshoofd ("Camat") en zijn staf. Het Kantoor van een Onderdistrict heeft afdelingen van de Regering, voor het welzijn van het volk en voor economische en administratieve zaken. De situatie in een Dorpsadministratieve eenheid komt vrijwel overeen met die in een Onderdistrict, met dit verschil dat daar geen kantoren zijn van de departementen van de nationale Regering. Een Dorpsadministratieve eenheid wordt geleid door een Dorpshoofd ("Lurah"). Zowel het Onderdistrictshoofd als het Dorpshoofd zijn ambtenaren uit de rijen van lokale regeringsfunctionarissen, aangesteld wegens verdienste. De situatie in de dorpen ("Desa") heeft een afwijkende structuur, te danken aan de aan deze toegekende traditionele rechten. Het Hoofd van een "Desa" wordt gekozen door alle volwassenen van het dorp in kwestie en wordt voorts door de Regent namens de Regering aangesteld. Naast het kantoor van het Desahoofd (meestal ook "Lurah" genoemd) bevindt zich de Dorpsraad ("Lembaga Musyawarah Desa", afgekort LMD), samengesteld uit 9 tot 15 leiders van het desbetreffende dorp. De Dorpsraad is een overlegorgaan en heeft een consultatieve functie. Beslissingen inzake dorpsaangelegenheden die interne, huishoudelijke zaken ${ }^{74}$ betreffen, worden genomen door het Dorpshoofd - die in het desbetreffende Dorp een uitgebreide en concrete taak heeft - na de LMD te hebben geraadpleegd. ${ }^{75}$

Alle functionarissen van de lokale Regering hebben een zekere mate van vrijheid van handeling, passend bij hun positie als leider. Dit geldt voor zaken, die niet uitdrukkelijk volgens de wetgeving zijn toegewezen aan de jurisdictie van een bepaalde regeringsinstelling. Gezegd kan worden, dat het hier een "gap-filling" functie betreft. Dit kan van

74. Als voorbeeld hiervan kan worden genoemd dat een huwelijk binnen de "desa" gesloten, niet alleen een zaak is van de daarbij betrokken familie doch van het gehele dorp. Voorts houdt het Desahoofd toezicht op zaken, die op de binnen de dorpsgemeenschap gelegen grond betrekking hebben. Zo zal een persoon, die van buiten het desbetreffende dorp afkomstig is, normaliter eerst tot het bewerken van die grond worden toegelaten, na betaling van een heffing.

75. Zie voor meer details inzake deze aangelegenheid, het Departement van Voorlichting RI, Indonesia, p.66-68. Zie ook Marsono, Almanak Negara RI van 1987, p.759-765 en Roeder en Willecke, Wirtschaftspartner, p.42-45. Voor meer uitgebreide gegevens inzake het bestuur in de dorpen, zie Taliziduhu Ndraha, Dimensi-dimensi Pemerintahan Desa, Jakarta, 1991, p.23, 66, 77 en 175. 
belang zijn bijvoorbeeld bij het optreden van natuurrampen, waarbij handelend kan worden opgetreden, zonder een order van een hogere functionaris te moeten afwachten en kan voorts van nut zijn voor het verlenen van bepaalde publieke diensten. ${ }^{76}$

\subsection{Het vigerende recht}

Gezien het in Indonesië heersende rechtspluralisme is het Indonesische recht te onderscheiden in een diversiteit van componenten, die zich vooral op het gebied van het civiele recht manifesteert. Naast geschreven recht - wettenrecht - is het ongeschreven recht, het Adatrecht, te onderscheiden, dat bovendien van regio tot regio verschilt. ${ }^{n}$ Hiernaast speelt het Islamitisch recht - al dan niet in het Adatrecht gerecipieerd - een rol. ${ }^{78}$ Genoemde rechtsverscheidenheid heeft tot consequentie dat het intergentiele recht, dat dient vast te stellen, welk recht in voorkomende gevallen geldt, (nog) een belangrijke rol speelt. Daarbij dient echter te worden gewezen op het unificatiestreven van de Indonesische overheid, dat tot uiting komt in het zoveel mogelijk tot stand brengen van nationale wetten. Het is echter niet altijd zo eenvoudig om dit streven te verwezenlijken, met name niet op het vlak van het familierecht. Met het oog hierop rijst de vraag of op dit gebied, in het bijzonder op dat van het huwelijksrecht, unificatie kan worden bereikt c.q. of dit wenselijk is. Ook de afkondiging van de Huwelijkswet no. 1 van het jaar 1974, Stb. 1974-1, gericht op de unificatie van het huwelijksrecht heeft niet geheel tot de verwezenlijking van dit doel geleid. Zo blijkt uit artikel 66 van de Wet no. 1 van 1974 jo. artikel 47 van de ter uitvoering van de Huwelijkswet afgekondigde Regeringsverordening no. 9 van het jaar 1975, dat deze artikelen niet alle bepalingen betreffende het huwelijksrecht zoals die voorkomen in het Indonesisch Burgerlijk Wetboek (IBW), de Huwelijksordonnantie Christen-Indonesiërs, Ind. Stb. 1933-74 en de Regeling op de Gemengde Huwelijken (RGH) van 1898 beogen in te trekken, doch slechts die bepalingen die betrekking hebben op aangelegenheden, die reeds in de Huwelijkswet regeling hebben gevonden. ${ }^{79}$ Van een volledige unificatie van het huwelijksrecht kan derhalve nog niet worden gesproken.

76. Departement van Voorlichting RI, Indonesia, p.68.

77. Zie voor het Adatrecht van Vollenhoven, C., Het Adatrecht van Nederlandsch-Indië, deel I en deel II, Leiden, 1918 en 1926. Zie voorts Ter Haar. B., Beginselen en Stelsel van het Adatrecht, Batavia, 1939.

78. Voor het Islamitische recht kan worden verwezen naar Juynboll, Th.W., Handleiding tot de Kennis van de Mohammedaanse Wet, Leiden, 1930.

79. De Huwelijkswet is opgenomen in Engelbrecht, p.774. Zie voorts Martiman Prodjohamidjojo, Penerapan atas ketentuan Pasal 284 (1) KUHP, Varia Peradilan, jaargang VII, no. 73 van oktober 1991, p.154 die voor de geldigheid van een huwelijk als bedoeld in artikel 2 van de Huwelijkswet, voor autochtone Indonesiērs en Vreemde Oosterlingen andere dan Chinezen en Japanners verwijst naar hun Adatrecht; voor Christen-Indonesiërs naar de Ordonnantie Christen-Indonesièrs van 1933 en voor Europeanen en Chinezen naar bet BW. Wat betreft de RGH dient rekening te worden gehouden met het feit, dat sinds de afkondiging van de Huwelijkswet van 1974, gemengde huwelijken in de zin van verschil in nationaliteit van de huwelijkspartners thans onder laatstgenoemde Wet vallen. Op deze aungelegenheid zal in \$7.1.3 van Hoofdstuk 5 worden teruggekomen. Zie ook Gautama, S., Essays in Indonesian Law, Jakarta, 1991, p.139-160. 
In een land als Indonesië kan grote waarde worden gehecht aan de jurisprudentie, in het bijzonder met betrekking tot het ongeschreven recht - het Adatrecht - en betreffende conflicten tussen verschillende rechtsbronnen. Ook met betrekking tot het geschreven recht is de jurisprudentie van belang, niettegenstaande het feit dat precedenten geen bindende werking hebben in Indonesië. De "Mahkamah Agung" (het Hooggerechtshof) speelt een belangrijke rol in de unificatie van de jurisprudentie. Van belang is dat de lagere rechtbanken zich gebonden achten aan de uitspraken van het Hof en zich niet blootstellen aan nietigverklaring in cassatie.

\subsection{Betrekkingen tussen Indonesië en derde landen}

Zoals in $\$ 2.1$ reeds werd opgemerkt, voerde de Regering van President Soeharto een heroriëntatie in de buitenlandse politiek door. Financiële hulp door landen als de Verenigde Staten en Nederland werd hervat. Deze hulp kreeg een grootscheeps karakter, toen ook andere landen daaraan gingen deelnemen.

Wat betreft de in $\S 2.1$ genoemde IGGI, kan worden opgemerkt dat de IGGI een forum was, waarin de sociaal-economische situatie in Indonesië en de ontwikkelingshulp aan dit land werd besproken. Naast Indonesië en Nederland, waren de volgende landen lid van de groep: Australië, België, Canada, Duitsland, Frankrijk, Groot-Brittannië, Italië, Japan, Nieuw-Zeeland, Oostenrijk, Spanje, de Verenigde Staten en Zwitserland. Lid waren ook vier internationale organisaties: de Wereldbank, het IMF, de Aziatische Ontwikkelingsbank en het Ontwikkelingsprogramma van de Verenigde Naties (UNDP). ${ }^{80}$

Politieke verwikkelingen tussen Indonesië en Nederland, hebben echter inmiddels ertoe geleid dat Indonesië voortaan alle Nederlandse ontwikkelingshulp afwijst, hetgeen tevens heeft geleid tot opheffing van de IGGI. De oorzaak hiervan ligt in het verschil van opvatting inzake de relatie die door Nederland - in feite door de landen van de EG wordt gelegd tussen ontwikkelingsbeleid en het beleid met betrekking tot de mensenrechten. ${ }^{81}$ Van Indonesische zijde is evenwel verklaard dat niet alle hulp aan Indonesië behoeft te worden stopgezet; niet-gouvernementele organisaties (NGO's) in Indonesië, die hulp ontvangen van zusterorganisaties in Nederland, behoeven daarvan geen afstand te doen. ${ }^{82}$ Van officiële Indonesische zijde is voorts benadrukt, dat het afstoten van Nederlandse hulpgelden gericht is op financiering in de vorm van leningen en schenkingen en niet op de deskundigen of de bedrijven die bij de door Nederland betaalde projecten zijn betrokken, die hetzij door Indonesië of andere donorlanden worden overgenomen, hetzij gestaakt. Dit impliceert, dat experts en ondernemers uit Nederland in principe welkom blijven. Ook is ontkend, dat Nederlandse investeringen gevaar lopen; het zakelijk verkeer met Nederland zal eerder opleven na de afsluiting

80. Gegevens ontleend aan lndonesië, Internationale Samenwerking, uitgave Ned. Ministerie van Buitenlandse Zaken, no. 6 van juni 1988.

81. NRC Handelsblad van 26 maart 1992.

82. NRC Handelsblad van 30 maart 1992. 
van het hulphoofdstuk. ${ }^{83}$ Op verzoek van Jakarta coördineert de Wereldbank de hulp aan Indonesië waartoe een nieuwe adviserende groep - Consultatieve Groep voor Indonesië (CGI) - is gevormd die in de plaats is gekomen van de IGGI. ${ }^{84}$

Binnen Zuidoost-Azië speelt Indonesië - gelegen tussen het vasteland van Azië en Australië en tussen de Grote en de Indische Oceaan - een niet onbelangrijke rol in de, eveneens in $\$ 2.1$ genoemde ASEAN, de "Association of Southeast Asian Nations". Het gaat hier om een regionale samenwerkingsorganisatie die werd opgericht, na ondertekening van de "Bangkok Declaration" door de Ministers van Buitenlandse Zaken van de respectieve lidstaten op 8 augustus 1967 . Het betreft hier een samenwerkingsverband op economisch, cultureel en wetenschappelijk terrein, waarbij naast Indonesië zijn aangesloten, Thailand, Maleisië, Singapore, de Filippijnen en sinds 7 januari 1984, Brunei Darussalam terwijl Vietnam als toekomstig partner wordl beschouwd. Het permanente centrale secretariaat van deze organisatie is in Jakarta gevestigd. Verschillende doelstellingen in het kader van de samenwerking op economisch gebied zijn reeds verwezenlijkt, zoals de ondertekening op 24 februari 1977 en op 4 oktober 1979 van respectievelijk de "Preferential Trading Arrangements" (PTA) en de "ASEAN Food Security Reserve (AFSR) Agreement". ${ }^{85}$ Een ander belangrijk resultaat is gelegen in het bereiken van de "Jakarta Consensus on Tropical Forestry" van 13 augustus, 1981. In het kader van het streven naar samenwerking op sociocultureel gebied zijn drie permanente commissies gevormd, respectievelijk inzake sociale ontwikkeling, cultuur en voorlichting, alsmede wetenschap en technologie. Besprekingen tussen de leiders van de respectieve landen hebben geleid tot de opstelling van de Verklaring van Singapore, die betrekking heeft op het instellen van een vrijhandelszone in de regio, die op 1 januari 1993 een aanvang heeft genomen en in 2008 dient te zijn voltooid. ${ }^{86}$ Hiernaast dient de samenwerking van de ASEAN met derde landen, regionale en internationale organisaties worden genoemd. Wat betreft de samenwerking tussen de ASEAN en de

83. Zie NRC Handelsblad van 27 maart 1992. Vermelding verdient dat op 21 september 1992 tussen Nederland en Indonesië een samenwerkingsovereenkomst op wetenschappelijk gebied is ondertekend. Het betreft hier een document betreffende samenwerking bij wetenschappelijk onderzoek op het gebied van luchtvaarttechnologie, biotechnologie en milieu. Het andere document betreft samenwerking in onderwijs en onderzoek. Van belang is, dat hierin de nieuwe grondslag van de samenwerking is verwoord, met name "op voet van gelijkheid" en "tot wederzijds voordeel". Dit houdt in dat de samenwerking geen elementen van eenzjjdige hulp mag bevatten. Aldus het NRC Handelsblad van 22 en 23 september 1992.

84. De nieuwe donorgroep CGI is inmiddels vonr de eerste keer in Parijs bijeengekomen, bij welke gelegenheid aan Indonesië bijna 5 miljard dollar hulp werd toegezegd. Zie Indonesia Business, bijlage van Indonesia Magazine, jaargang 9, no. 105, augustus 1992, p. 29.

85. Departement van Voorlichting RI, Indonesia, p. 109, Zie ook 10 years ASEAN, uitgave van deze organisatie, Jakarta, 1978 en ASEAN, a bibliography, uitgegeven door het Institute of Southeast Asian Studies, Singapore, 1984.

86. Departement van Voorlichting RI, Indonesia, p.110. De instelling van een vrijhandelszone (ASEAN Free Trade Area, afgekort AFTA) is bekendgemaakt door het NRC Handelsblad van 27 januari 1992. 
EG bestrijkt die samenwerking vier sectoren van activiteiten, met name handel, landbouw, industrie en ontwikkeling. ${ }^{87}$

Indonesië is voorts actief lid van verschillende economische organisaties zoals de OPEC, de organisatie van olie-exporterende landen, het ATPC, de organisatie van tinproducerende landen en voorts van internationale samenwerkingsverbanden op het gebied van koffe, rubber en tropisch hout. De rol van de OPEC is gelegen in het stabiliseren van de prijs van olie middels het vaststellen van quota. Wat betreft produkten als rubber en koffie wordt door het aanleggen van buffervoorraden getracht te komen tot stabilisering der prijzen. Dat Indonesië streeft naar het verstevigen van zijn positie als exporteur van tropisch hout blijkt uit de ondertekening van de "International Tropical Timber Agreement" van 1983, goedgekeurd in 1984. ${ }^{88}$ Gelet op het belang van tropisch hout voor de economie van de lidstaten - in het bijzonder voor de exporten van de producerende leden en de bevoorradingsvereisten der consumerende leden wordt het creëren van internationale samenwerking tussen genoemde groeperingen als een noodzaak gezien.

Naast voomoemde samenwerkingsverbanden op economisch gebied, is Indonesië lid van politieke organisaties zoals de Verenigde Naties, de "Non-Aligned Movement", de organisatie van niet-gebonden landen ${ }^{89}$ en van de "Organization of the Islamic Conference", een samenwerkingsverband tussen Islamitische landen.

De relatie met Japan, een andere Aziatische mogendheid heeft geleidelijk aan een bijzonder karakter gekregen, gezien de grote activiteiten die dit land ontplooit op het vlak van de Indonesische economie, vooral op het vlak der mijn- en bosbouw, de visserij en het hotelwezen.

De betrekkingen met de Chinese Volksrepubliek, die op 30 oktober 1967 werden verbroken, zijn sedertdien geleidelijk aan ontdooid. In 1985 heeft een Indonesische handelsmissie de Volksrepubliek bezocht, terwijl later in hetzelfde jaar van Chinese zijde een tegenbezoek aan Indonesië plaatsvond. Ter gelegenheid van de begrafenis van Keizer Hirohito van Japan in 1988, vonden besprekingen plaats tussen de leiders van

87. Zie voor meer gegevens inzake de samenwerking van de ASEAN met derde landen, Departement van Voorlichting RI, Indonesia, p. 108-110. Naar door het NRC. Handelsblad van 30 oktober 1992 is bekendgemaakt, is de kwestie Oost-Timor het grote struikelblok gebleken bij het afsluiten van een samenwerkingsakkoord tussen de EG en de ASEAN. Het overleg, dat op het niveau van de Ministers van Buitenlandse Zaken in Manila zou worden afgerond, is in de voorbereiding vastgelopen door de eis van Portugal dat een veroordeling van Indonesië, wegens zijn opstelling ten aanzien van Oost-Timor, in de slotverklaring zou worden opgenomen. Van Indonesische zijde wordt deze aangelegenheid echter als onbelangrijk aangemerkt; dit onderwerp zal van geen invloed zijn op de doelen die de EG en de ASEAN willen bereiken.

88. Dit geschiedde met Presidentieel Besluit no. 49 van het jaar 1984.

89. Naar bet NRC Handelsblad van 1 september 1992 meldt, is Indonesië met ingang van genoemde datum voor drie jaar voorzitter van deze organisatie. Nu niet-gebondenheid in de zin van een "blokvrije" status geen bindmiddel meer is, geeft de Boodschap van Jakarta het begrip een nieuwe inhoud: vermindering van de afhankelijkheid ten opzichte van het rijke Noorden. 
de twee landen. Dit heeft geleid tot het op 8 augustus 1990 herstellen van de diplomatieke betrekkingen tussen beide landen. ${ }^{90}$

Militair is Indonesië ongebonden; evenwel dient te worden gewezen op de nauwe samenwerking met Maleisië en Singapore ten aanzien van de defensie van de wateren rond het schiereiland Malakka. ${ }^{91}$

\subsection{Bevolkingsopbouw}

Ter oriëntatie moge vooraf worden opgemerkt, dat Indonesië de grootste archipel ter wereld vormt, met een geschatte oppervlakte van $5.193 .250 \mathrm{~km} 2$, bestaande uit $2.027 .087 \mathrm{~km} 2$ aan grondgebied en $3.166 .163 \mathrm{~km} 2$ aan zeegebied. Het land is naar bevolkingsgrootte, het vijfde land ter wereld en wordt in dit opzicht slechts door de Chinese Volksrepubliek, India, de Sovjetunie - thans de $\operatorname{GOS}^{92}$ - en de Verenigde Staten van Amerika overtroffen. ${ }^{93}$

De bevolking van Indonesië kenmerkt zich door een ongekende complexiteit en diversiteit. Dit komt tot uiting in diverse bevolkingsgroepen, elk met hun eigen taal c.q. dialect en hun eigen zeden en gewoonten. Vanuit etnisch oogpunt gezien, kunnen meer dan een dozijn grotere inheemse bevolkingsgroepen en enkele tientallen kleinere worden onderscheiden. Dit wordt weerspiegeld door het bestaan van 18 verschillende taalgroepen en rond 300 dialecten, die van Irian Jaya niet medegerekend. ${ }^{94}$ De "Bahasa Indonesia" (Indonesische taal) is de officiële, nationale taal, terwijl als handelstaal ook het Engels wordt gebruikt. De hierboven genoemde heterogeniteit werd in de loop der tijden nog ingewikkelder door de immigratie van grote groepen niet-Indonesische Aziaten, voornamelijk Chinezen maar ook Arabieren en Indiërs. Ook Europeanen als Nederlanders, Duitsers, Engelsen en Fransen vestigden zich in de loop der tijd in Indonesië.

De bevolking is uitermate onevenwichtig over de eilanden - een aantal van ongeveer 13.600 omvattende - verdeeld; circa $63 \%$ van de bevolking leeft op Java, dat slechts 7\% van het Indonesische grondgebied beslaat. Van de andere eilanden van de Indonesische archipel - de voornaamste zijn naast Java, de eilanden Madura, Sumatra, Kalimantan, Sulawesi en Irian Jaya - zijn uitgestrekte gebieden op Kalimantan en Irian Jaya zeer dun bevolkt. Deze onevenredigheid in de spreiding der bevolking vormt de

90. Bij deze gelegenheid werd een "Memorandum of Understanding" tussen de twee landen ondertekend.

91. Paite, J.G.L. en Tempelman, G.J., Indonesië, Haarlem, 1981, p.204.

92. Volledigheidshalve dient te worden opgemerkt, dat op 23 december 1991 elf van de twaalf voormalige Sovjet-republieken de Sovjet-Unie definitief hebben opgeheven en een nieuwe "Gemenebest van Onafhankelijke Staten"(GOS) hebben opgericht

93. Kähler, K., Wirtschaftsverfassung und Kapitalinvestation in Indonesien, Hamburg, 1974, p. 1. Zie voorts Roeder en Willecke, Wirtschaftspartner, p.31. Dat volgens officiële gegevens in deze situatie voorshands geen wijziging is opgetreden, blijkt uit door het Departement van Voorlichting gepubliceerde gegevens, zie het Departement van Voorlichting RI, Indonesia, p.24.

94. Zie Palte en Tempelman, Indonesië, p.47. 
voornaamste motivatie, gelet op de beschikbaarheid van grond en de natuurlijke bronnen, voor de introductie van het transmigratie-programma. Dit programma dient te worden gezien als een poging om een evenwichtige spreiding van de bevolking over het Indonesisch grondgebied te bereiken, het creëren van werkgelegenheid te intensiveren en de produktie te verhogen. Het op transmigratie gerichte beleid der Indonesische overheid heeft mede ten doel het welzijn van het volk te bevorderen middels verhoging van het inkomen van de transmigranten door gebruik te maken van de natuurlijke hulpbronnen. Laatstgenoemde doelstelling hoopt men te bereiken door het openleggen en ontwikkelen van nieuwe produktiegebieden. Voorts worden programma's opgesteld met als doel, het opnieuw vaststellen van het gebruik, de toewijzing en de eigendom van land, zowel in de transmigratiegebieden als in de gebieden, waaruit de transmigranten afkomstig zijn. De transmigratie is gericht op de verhoging van de doelmatigheid in het gebruik der natuurlijke bronnen, de regionale ontwikkeling, een verbeterde levensstandaard voor de transmigranten en de omringende bevolking. Hierbij wordt aandacht geschonken aan de instandhouding van de natuur en het milieu en aan de socioculturele waarden van de bevolking. In de uitvoering dient het transmigratieprogramma te worden onderscheiden in de van overheidswege gesponsorde, algemene transmigratie en die op eigen initiatief, de vrijwillige of spontane transmigratie. ${ }^{95}$

ledere transmigrant c.q. gezinshoofd heeft het recht om 2.0 ha. landbouwgrond te verkrijgen, waarvan $0.25 \mathrm{ha}$, is bestemd voor woning en tuin, 1.0 ha. voor een bewerking door de Overheid te bepalen, terwijl het overblijvende deel van 0.75 ha. de grond is die door het gezinshoofd naar eigen inzicht wordt gebruikt. De nieuwe vestiging der transmigranten op bepaalde locaties is gebaseerd op het zogenaamde "drievoudige" principe, hetgeen inhoudt dat een deel der locatie is bestemd voor van overheidswege gesponsorde algemene transmigranten, een ander deel voor de lokale ingezetenen en nog een deel wordt toegewezen aan vrijwillige transmigranten.

Vanuit het operationele gezichtspunt gezien omvat de transmigratie twee verschillende regio's, in casu de plaats van oorsprong en de plaats van bestemming der transmigranten. Bij het kiezen van de plaats van oorsprong der transmigranten wordt onder meer afgegaan op overwegingen als een hoge graad van bevolkingsdichtheid, zeer beperkte werkgelegenheid, schaarse landbouwgrond, ongunstige conditie van de grond en het bestaan van ontwikkelingsprojecten. Als zodanig zijn aangewezen het Speciale District van de Hoofdstad Jakarta, West-Java, Midden-Java, het Speciale District van Yogyakarta, Oost-Java, Bali en Nusatenggara. Daarentegen wordt bij de keuze van de plaats van bestemming van de transmigranten afgegaan op de beschikbaarheid van voldoende onbewerkt land en van dunbevolkte streken, waartoe onder meer zijn aangewezen, de Provincies Lampung, Zuid-Sumatra, Bengkulu, Jambi, Riau, West- en Noord-Sumatra, Aceh, West-Kalimantan, Noord-, Midden-, Zuid- en Zuidoost-Sulawesi, Maluku en Irian Jaya.

95. De algemene transmigratie wordt door de Indonesische overheid georganiseerd, waarhij aan de transmigranten onder meer bijstand wordt verleend waaronder het in de eerste jaren ná de transmigratie verstrekken van voedingspakketten en andere hulpmiddelen. Voor vrijwillige transmigranten, die op eigen initiatief transmigreren, gelden deze voorzieningen niet. 
Uitgegaan wordt van het feit, dat ongeveer 750.000 gezinshoofden zullen worden verplaatst en opnieuw gevestigd gedurende het lopende Vijfjarige Ontwikkelingsplan, bestaande uit zowel door de Overheid gesponsorde transmigranten als uit vrijwillige transmigranten. Het succes van het transmigratie-programma is afhankelijk, niet alleen van de ontwikkeling der infrastructuur en van faciliteiten, maar ook van de kennis, het geven van leiding aan en de ontwikkeling van de kundigheden van de transmigranten in de vorm van training en opleiding. ${ }^{\%}$

Het transmigratie-programma komt niettemin moeizaam op gang; in de jaren 1986/1987 nam het aantal gevestigde transmigranten met $3.9 \%$ toe, oplopend tot 172.859 families of $15.2 \%$ van het "target". Van dit aantal waren 126.508 families spontaan getransmigreerd, hetgeen een toename van $46.0 \%$ vergeleken met het voorafgaande jaar, impliceert. ${ }^{97}$ De oorzaken zijn velerlei, waarvan kan worden genoemd: de gehechtheid van de Javaan aan geboortegrond en familieverband; moeilijkheden met de plaatselijk gevestigde bevolking in verband met grondtoewijzingen aan de transmigranten, die door de lokale bevolking onrechtmatig worden geacht; de gebrekkige organisatie met als gevolg, dat de door de Overheid gesponsorde transmigranten op andere bestemmingen dan oorspronkelijk vastgesteld terechtkomen, het vertrek niet overeenkomt met de oorspronkelijke planning hetgeen de transmigranten - die hun hele bezit meestal reeds van de hand hebben gedaan - in de problemen brengt en het feit dat het merendeel der bodemontginningen en irrigatiewerken bij aankomst der immigranten vaak nog niet of summier is uitgevoerd, al wordt van regeringswege ernaar gestreefd om in deze omstandigheid verbetering te brengen. ${ }^{98}$

96. Swasono, S. en Singarimbun, M., Sepuluh Windhu Transmigrasi di Indonesia 1905-1985, Jakarta, 1985.

97. Zie Report of the Bank Indonesia for the Financial Year 1986/87, p. 106.

98. Zie voor kritische literatuur, Otten, M., Transmigrasi: Myths and Realities, Indonesian Resettlement Policy. 1965-1985, Kopenhagen, 1986. Zie ook Transmigration in Indonesia, ACFOA Briefing, mei, 1985. 


\section{HOOFDSTUK 2 ALGEMENE BESCHOUWING}

\section{\$ Inleiding}

Alvorens na te gaan hoe het Indonesische nationaliteitsrecht zich ontwikkeld heeft vanuit het koloniale tijdperk tot op heden, is het van belang om aandacht te besteden aan enige aspecten van het begrip "nationaliteit".

Allereerst zal worden ingegaan op diverse betekenissen van het begrip "nationaliteit".

Vervolgens zal worden nagegaan, warin de functie van de nationaliteit ligt.

Daama zal de vraag aan de orde worden gesteld, of het recht op het bezitten van een nationaliteit al dan niet als een mensenrecht dient te worden gezien.

Ook zal de vraag worden besproken, of zich met betrekking tot de nationale autonomic van Staten om bepalingen vast te stellen ter regeling van de nationaliteit van hun burgers volkenrechtelijke beperkingen kunnen voordoen.

Tenslotte is het van belang te onderzoeken wat in het algemeen de nationaliteitsrechtelijke gevolgen van gebiedsovergang kunnen zijn. Gezien de geschiedenis van Indonesië is dit onderwerp immers uiterst relevant.

\subsection{Enkele betekenissen van het begrip "nationaliteit"}

Het nationaliteitsbegrip wordt in diverse betekenissen gebruikt. Zo onderscheidt men de nationaliteit in etnische, sociologische, morele, juridische, "sachlich beschränkte", functionele en effectieve zin. ${ }^{99}$ Hiernaast kan ook het begrip "Schutz-angehörigkeit" worden genoemd.

Naar de mening van de Groot en Tratnik, heeft het begrip "nationaliteit" enerzijds betrekking op het bestaan van informele, etnische of sociologische banden en anderzijds op het bestaan van een formele, juridische relatie tussen een individu en een Staat. Van de eerste groep maken de etnische, de sociologische en de morele nationaliteit deel uit. Hiertegenover staat de nationaliteit in juridische betekenis, die steeds uitgaat van een formele band tussen een individu en een Staat. ${ }^{100}$ Deze juridische nationaliteit is te onderscheiden in de algemene, "sachlich beschränkte" en de functionele nationaliteit, naargelang de rechtsgevolgen die uit het bezit daarvan voortvloeien. Deze verschillende betekenissen van het begrip "nationaliteit" zullen hierna aan een beschouwing worden onderworpen.

99. De Groot, G.R., Staatsangehōrigkeitsrecht im Wandel, 's-Gravenhage. 1988, p. 10-12. Deze auteur geeft een uitvoerige uiteenzetting inzake de verschillende betekenissen van het begrip "nationaliteit".

100. De Groot, G.R. en Tratnik, M., Nationaliteitsrecht, Zwolle, 1986, p.6-7. 
Van etnische nationaliteit wordt gesproken, wanneer een persoon etnisch tot een bepaald volk behoort, zonder dat dit volk met een bepaalde Staat behoeft te worden geidentificeerd. ${ }^{101}$ Deze etnische nationaliteit speelt onder meer in landen, waarvan de bevolking in verschillende bevolkingsgroepen uiteenvalt, een rol. Dit is bijvoorbeeld het geval in Indonesië, waar verschillende bevolkingsgroepen kunnen worden onderscheiden. Ten dele zijn op de diverse bevolkingsgroepen uiteenlopende regels van toepassing. Zo zijn in het geval van een huwelijk tussen Indonesische staatsburgers die beide van Chinese origine zijn, de huwelijkspartners aan Europees recht (het IBW) onderworpen. Betreft het een huwelijk tussen een Indonesisch staatsburger van Chinese origine met een vrouw, die ook Indonesisch staatsburger is maar deel uitmaakt van de autochtone Indonesische bevolking, dan is de vrouw niet aan het Adatrecht onderworpen, maar aan het Europese recht dat voor de man geldt, aangezien wordt aangenomen dat de vrouw zich in de rechtssfeer van haar man beweegt.

Het begrip "sociologische nationaliteit" houdt in, dat een persoon op grond van objectieve criteria zoals afstamming, historische solidariteit, gemeenschappelijke cultuur tot een bepaalde samenleving of staatsverband behoort. Deze omschrijving sluit aan op die door Paulus gegeven. ${ }^{102}$ Hierop aansluitend kan op de mening van Sanger worden gewezen, die de sociologische nationaliteit typeert als het behoren tot een volk door afstamming, woonplaats, taal etc. ${ }^{103}$ Volgens de Groot kan van sociologische nationaliteit worden gesproken, als iemand - geabstraheerd van juridische formalismen - als behorend tot een zeker staatsband mag worden beschouwd. ${ }^{104}$ Deze mening van de Grool, waarbij de sociologische nationaliteit wordt gekoppeld aan een Staat, is evenwel inconsistent met de in de aanvang van deze paragraaf genoemde mening van deze auteur en Tratnik, waarbij de sociologische nationaliteit - mijns inziens terecht - wordt gekoppeld aan een volk. Volgens Mannoury houdt de nationaliteit in de sociologische betekenis in, het behoren tot een bepaald volk, in casu een groep mensen wier onderscheidende kenmerken zeer moeilijk in een algemene omschrijving zijn vast te leggen. ${ }^{105}$ De sociologische nationaliteit komt wat Indonesië betreft onder meer tot uiting bij de mogelijkheid van een niet-Indonesiër om zich in de autochtone bevolking "op te lossen", waarbij aan verschillende criteria dient te worden voldaan, wil betrokkene Indonesiër worden. ${ }^{106}$

Wordt tegen de vorige begrippen de morele nationaliteit afgezet dan wordt daarmede bedoeld, dat een persoon zichzelf met een bepaalde samenleving of staatsverband verbonden voelt, hij zichzelf tot een bepaald volk rekent en zich daarnaar ge-

101. Zie voor het begrip "etnische nationaliteit" de Groot, G.R., Personen- en familierecht, Nationaliteitswetgeving, Deventer, losbladige uitgave, Inleiding nationaliteitsrecht, p.5.

102. Vgl. Paulus B.P., Kewarganegaraan RI ditinjau dari UUD 1945, khususnya Kewarganegaraan Peranakan Tionghoa, Jakarta, 1983, p.44.

103. Sanger, E., Die indonesische Staatsangehörigkeit, Bonn, 1958, p.2.

104. De Groot, Personen- en familierecht, p.5.

105. Mannoury, J., Het Nederlandse Nationaliteitsracht, tweede druk, Alphen aan den Rijn, 1954, p.1.

106. Op deze aangelegenheid zal in $\$ 2.3$ van Hoofdstuk 3 worden teruggekomen. 
draagt. ${ }^{107}$ Wordt dit wat betreft Indonesië met een voorbeeld toegelicht dan kan ook hier de mogelijkheid tol oplossing in de autochtone bevolking worden genoemd. Een persoon, niet-Indonesiër zal zich door deze oplossing "Indonesiër onder de Indonesiërs" voelen en zich daamaar gedragen.

De algemene juridische nationaliteit is de nationaliteit die een persoon bezit krachtens een algemene nationaliteitsrechtelijke regeling, zoals bijvoorbeeld de Wet no. 62 van 1958 betreffende het Indonesisch staatsburgerschap. Krachtens een dergelijke regeling komen een persoon alle rechten en verplichtingen toe, die normaliter uit het bezit van een nationaliteit voortvloeien. Volgens Mannoury is de nationaliteit in juridische zin een door de wet toegekende en doorgaans nauwkeurig omschreven hoedanigheid, die de strekking heeft het behoren tot een bepaalde Staat nader te bepalen. ${ }^{108}$ Gaat men volgens deze auteur uit van de vraag, in hoeverre de juridische nationaliteit met de sociologische behoort overeen te stemmen, dan komt men op het zogenaamde nationaliteitsbeginsel: elk volk eén Staat. ${ }^{109}$ Onderscheid kan dan worden gemaakt tussen een nationale Staat - in welk geval de Staat één volk omvat - en een nationaliteitenstaat, indien de Staat meerdere volken omvat. ${ }^{110}$ Als voorbeeld van een nationaliteitenstaat kan Indonesië worden genoemd, gezien de heterogeniteit waardoor de bevolking van dit land gekenmerkt wordt. Volgens de Groot, kan beïnvloeding van de algemene nationaliteit door het sociologische begrip optreden; dit blijkt uit discussies inzake eventuele wijzigingen van nationaliteitsregelingen, wanneer benadrukt wordt dat aan bepaalde groepen van personen een nationaliteit toebedeeld dient te worden, omdat zij een reële betrekking met de Staat in kwestie hebben, terwijl aan een andere groep deze nationaliteit niet dient te worden verleend, omdat van een dergelijke betrekking geen sprake is. "Ook volgens van Panhuys, dient "nationaliteit" als politiek-wettelijke term die het lidmaatschap van een Staat aangeeft, te worden onderscheiden van het lidmaatschap van een natie in de etnologische-sociologische betekenis. ${ }^{112}$ Makarov verstaat onder "nationaliteit", de status van het toebehoren aan een Staat, waaraan deze Staat door nationale rechtsvoorschriften en de statengemeenschap door volkenrechtelijke normen bepaalde rechtsgevolgen verbindt, die voor alle leden van die Staat gelijk zijn. "

Geeft de algemene juridische nationaliteit toegang tot alle rechten en verplichtingen, die uit het bezit daarvan voortvloeien, bij de "sachlich beschränkte" nationaliteit - de term is van Makarov afkomstig ${ }^{114}$ - is dit niet het geval. Van een "sachlich beschränkte" nationaliteit is sprake, indien de nationaliteit slechts in een beperkt aantal wetten en

107. De Groot, Personen- en familierecht, p.5.

108. Mannoury, Het Nederlandse Nationaliteitsrecht, p. 1-2.

109. Duidelijk moge zijn dat Mannoury hier het begrip "sociologische nationaliteit" gebruikt in de betekenis van "etnische nationaliteit". Daarop werd reeds gewezen door de Groot, Personen- en fanilierecht, p.6.

110. Mannoury, Het Nederlandse Nationaliteitsrecht, p. 3-4.

111. De Groot, Staatsangehörigkeitsrecht, p.II.

112. Van Panhuys, H.F., The rôle of Nationality in International law, Leiden, 1959, p. 37.

113. Makarov, A.N., Allgemeine Lehren des Staatsangehörigkeitsrecht, Stuttgart, 1962, p. 12.

114. Ibid., p.52. 
verordeningen als nationaliteitscriterium wordt gehanteerd. Als voorbeeld kunnen de twee in Nederland tussen 1850 en 1893 bestaande nationaliteitsrechtelijke regelingen worden genoemd, die respectievelijk betrekking hadden op het Nederlanderschap in privaatrechtelijke zin als geregeld in het Burgerlijk Wetboek van 1838 en het Nederlanderschap in publiekrechtelijke betekenis als geregeld in de Wet van 1850. ${ }^{115}$

De Groot en Tratnik noemen voorts de functionele nationaliteit, waarvan sprake is indien een wet bijvoorbeeld bepaalt, dat "Nederlanders in de zin van deze wet zijn....." en deze omschrijving een engere of ruimere kring personen aangeeft dan krachtens de geldende nationaliteitsrechtelijke regelingen. ${ }^{116}$ Wordt dit wat betreft Indonesië toegelicht met een voorbeeld uit het koloniale tijdperk, dan kan het Gouvernementsbesluit van 19 mei 1877, Bijblad 3190 worden genoemd, waarbij de Nederlandse consul te Bangkok werd uitgenodigd om als Nederlandse onderdanen slechts te beschouwen, die Vreemde Oosterlingen die in Nederlandsch-Indië geboren waren en daar gedurende zes jaar aan de aanvraag van hun buitenlandse pas voorafgaande, gevestigd waren geweest. Doel van het voomoemde Besluit was bepaalde personen af te grenzen, die in aanmerking kwamen voor bepaalde handelsprivileges. ${ }^{117}$

Het voorgaande samenvattend, kan worden opgemerkt, dat de meest ideale toestand zou zijn, indien personen die etnisch-sociologisch tot een bepaald staalsverband behoren, zichzelf ook daartoe rekenen (morele nationaliteit) en bovendien de algemene juridische nationaliteit van die Staat bezitten. Dit is echter niet altijd het geval. Zo zal een Indonesisch staatsburger die deel uitmaakt van de autochtone bevolking van Indonesië indien hij zonder toestemming van de Indonesische overheid in vreemde krijgsdienst treedt zijn nationaliteit in juridische zin verliezen ${ }^{118}$; etnisch blijft hij evenwel Indonesiër. Ook Sanger wijst erop, dat een volledige overeenstemming tussen de juridische en de sociologische nationaliteit heden ten dage nauwelijks mogelijk is, zoals bijvoorbeeld het geval is bij de bevolking in de koloniën, die dezelfde nationaliteit bezitten als de bevolking in het moederland. Ook bij huwelijken met een buitenlandse partner, waarbij de vrouw de nationaliteit van de man verkrijgt, komen de juridische en sociologische nationaliteit niet overeen. ${ }^{119}$

Wat betreft de juridische nationaliteit kunnen drie gradaties worden onderscheiden: Het verst gaat de algemene nationaliteit, die een persoon alle rechten en verplichtingen toekent waartoe het bezit van die nationaliteit aanleiding geeft. Minder ver gaat de "sachlich beschränkte" nationaliteit, die geen toegang geeft tot alle hiervoor bedoelde

115. Op deze aangelegenheid zal worden teruggekomen in $\$ 1.2$ van Hoofdstuk 3 .

116. De Groot en Tratnik, Nationaliteitsrecht, p.7.

117. Zie voor deze aangelegenheid $\$ 1.3$ van Hoofdstuk 3 . Ter toelichting diene, dat het begrip "Nederlands onderdaan" ouder is dan het Nederlands onderdaanschap van niet-Nederlanders als geregeld in de Wet van 1910.

118. De gronden die leiden tot verlies van het Indonesisch slaatsburgerschap zullen worden behandeld in $\$ 2$ van Hoofdstuk 6 .

119. Sanger, Die Indonesische, p.2. Evenals als Mannoury gebruikt deze auteur hier het begrip "sociologische nationaliteit" in de betekenis van "etnische nationaliteit". 
rechten en verplichtingen doch slechts tot een deel hiervan. De functionele nationaliteit is dan nog het meest beperkt, geeft slechts in incidentele gevallen toegang tot een bepaald recht c.q. verplichting.

Vervolgens dient aandacht te worden besteed aan de "Schutzangehörigkeit"; dit begrip heeft hoofdzakelijk een rol gespeeld in koloniale Staten, zoals het voormalige Nederlandsch-Indië en wordt om die reden door Mannoury als "koloniale nationaliteit" aangeduid. ${ }^{120} \mathrm{De}$ "Schutzangehörigkeit" kon variëren tussen een iets betere positie dan vreemdelingen en vrijwel volledige gelijkstelling met de eigen nationalen in Europa. De wens om een onderscheid te maken tussen de bevolking van het moederland en die van de koloniën heeft vroeger in Nederland aanleiding gegeven tot de totstandkoming van de Wet van 1910 inzake het Nederlandsch onderdaanschap van niet-Nederlanders. ${ }^{121}$ Mijns inziens kan in het geval van het Nederlands onderdaanschap van nietNederlanders overigens ook van een "sachlich beschränkte" nationaliteit gesproken worden, omdat de voor dit onderdaanschap in aanmerking komende personen géén aanspraak konden maken op politieke rechten in het moederland. Het gaat hier derhalve zowel om een "Schutzangehörigkeit" - op de status van de bevolking in de koloniën betrekking hebbende - als om een "sachlich beschränkte" nationaliteit; deze personen hadden immers juridisch de Nederlandse nationaliteit, die echter als "sachlich beschränkt" te typeren was. ${ }^{122}$ De Schutzangehorigkeit kon derhalve als een specifieke soort "sachlich beschränkte" nationaliteit worden beschouwd.

Tenslotte kan nog het begrip "effectieve nationaliteit" worden genoemd, dat belangrijk is voor personen met een dubbele nationaliteit, zoals personen die voorheen naast hun Indonesisch staatsburgerschap, ook dat van de Chinese Volksrepubliek bezaten. Ter toelichting diene, dat Chinezen krachtens de in het verleden geldende nationaliteitswetten hun nationaliteit behielden, waar zij zich ook bevonden. Het van toepassing worden van de Wet van 1910 inzake het Nederlands onderdaanschap op bedoelde personen die daardoor tevens de status van Nederlands onderdaan verkregen, veroorzaakte bipatridie bij deze personen. ${ }^{123}$ Ook de tussen Indonesië en Nederland naar aanleiding van de formele soevereiniteitsoverdracht aan Indonesië - in feite was sprake van soevereiniteitserkenning - op 27 december 1949 gesloten Overeenkomst betreffende de Toescheiding van Staatsburgers bracht geen verandering in deze situatie. Chinezen kregen namelijk automatisch het Indonesisch staatsburgerschap toebedeeld en werden derhalve - indien zij niet van het recht van repudiatie gebruik maakten om dit staatsburgerschap te verwerpen - Chinees-Indonesisch bipatride. ${ }^{124}$ Eerst met de totstandkoming van de tussen Indonesië en de Chinese Volksrepubliek op 22 april 1955 gesloten Overeenkomst ter afwikkeling van het Probleem der Bipatridie werden de hierbedoelde bipatriden de verplichting opgelegd een keuze te maken tussen de twee nationaliteiten die zij beza-

\footnotetext{
120. Mannoury, Het Nederlandse Nationaliteitsrecht, p. 42 .

121. Te behandelen in $\$ 3$ van Hoofdstuk 3 .

122. Zie de Groot en Tratnik, Nationaliteitsrecht, p.8.

123. Zie hiervoor $\$ 3$ van Hoofdstuk 3 .

124. Zie voor deze aangelegenheid $\$ 5.3 .2$ van Hoofdstuk 3 .
} 
ten. ${ }^{125}$ Aangezien het merendeel van deze bipatriden reeds geruime tijd in het huidige Indonesië woonachtig is, kan worden aangenomen dat voor deze personen de Indonesische nationaliteit de effectieve nationaliteit was en hun Chinese nationaliteit nog slechts op papier bestond. Deze Overeenkomst werd echter met ingang van 10 april 1969 unilateraal door Indonesië beëindigd, waardoor het maken van bedoelde keuze door bedoelde personen niet langer mogelijk was doch wel voorzieningen werden getroffen ter vaststelling van hun nationaliteit. ${ }^{126}$ Samenvattend kan worden gesteld, dat de effectieve nationaliteit van zo'n "sujet mixte" de nationaliteit is, die hij in feite uitoefent c.q. waarmede hij de engste band heeft; de andere nationaliteit die hij bezit bestaat slechts op papier. De effectieve nationaliteit geeft derhalve de werkelijke relatie tussen een persoon en een bepaalde Staat aan.

Heeft een persoon de algemene juridische nationaliteit van een bepaald land, dan wordt die persoon tot het personensubstraat van dat land gerekend. Aan de hand van de nationaliteit wordt derhalve vastgesteld, wie het staatsvolk van een bepaalde Staat vormen. Dat staatsvolk vormt tezamen dat met het grondgebied en een daadwerkelijk bestuur de traditionele, wezenlijke elementen van een Staat. De nationaliteit is een onmisbaar element in het staatsbegrip, aangezien zonder staatsvolk en zonder grondgebied, moeilijk van een Staat als organisatiestructuur met een zekere autonomie of soevereiniteit kan worden gesproken. Dit heeft tot consequentie dat het bestaan van verschillende, in formeel opzicht gelijkwaardige, zelfstandige Staten de noodzaak met zich brengt om aan te duiden, welke personen bij een Staat c.q. Staten horen. Op deze wijze wordt het mogelijk om aan te geven over welke personen een Staat iets te zeggen heeft, niet alleen tegenover de eigen staatsburgers, maar ook tegenover andere Staten. Het staatsburgerschap is derhalve én der fundamenten voor rechtsmachtverkaveling.

Dient de nationaliteit nu als een relatie tussen een Staat en een individu of als een status te worden aangemerkt? Met andere woorden, is de nationaliteit een rechtsverhouding tussen een Staat en een persoon of is de nationaliteit een status, die een persoon bezit en waar hij recht op heeft? In de literatuur variëren de meningen hieromtrent. In de oudere franstalige literatuur wordt voornamelijk benadrukt, dat de nationaliteit als een band is aan te merken. Zo spreekt Cogordan van "le lien qui unit l'individu à l'Etat, c'est à dire au groupe social suprême et indépendent, est ce que l'on appelle la nationalité". ${ }^{127}$ Makarov omschrijft daarentegen de nationaliteit als volgt: "Die Staatsangehörigkeit ist eine rechtliche Eigenschaft, nämlich die Mitgliedschaft in einer einen Staat bildenden Gebietskörperschaft". ${ }^{128}$ Deze auteur lijkt hier derhalve het accent op het karakter van de nationaliteit als status te leggen.

125. Zie hiervoor $\$ 3$ van Hoofdstuk 4

126. Zie voor meerdere gegevens inzake deze aangelegenheid $\$ 3.4$ van Hoofdstuk 4 .

127. Cogordan, G., La nationalité au point de vue des rapports intemationaux, tweede druk, Parijs, 1890, p.4.

128. Makarov, A.N., Staatsangehōrigkeit in: Strupp, K. en H.J. Schlochauer, Wörterbuch des Völkenrechts, derde deel, Berlijn, 1962, p.323. 
Is genoemd onderscheid nu zo belangrijk? Mijns inziens geeft de nationaliteit zowel een relatie tussen een Staat en een persoon aan, als de status die deze persoon bezit en waar hij recht op heeft. Ook Makarov gaat verder in op de nationaliteit zowel als "Rechtsverhältnis" en als "Status" en tracht beide elementen in een definitie van het juridische karakter van de nationaliteit samen te brengen. Hij zegt hieromtrent onder meer het volgende: "Die Staatsangehörigkeit müßte als ein Rechtsverhältnis zwischen dem Staat und seinen Angehörigen bezeichnet werden, bei dessen Regelung die Eigenschaft der Person als Subjekt dieses Rechtsverhältnisses einen rechtlichen Status dieser Person bildet" ${ }^{129}$, een standpunt door vele anderen waaronder Ko Swan Sik ${ }^{130}$ en de Groot ${ }^{131}$ gedeeld en ook voor mij aanvaardbaar. De Groot maakt ter zake een treffende vergelijking met de familienaam van een persoon die aanduidt dat deze persoon tot een bepaalde familie behoort en derhalve een band manifesteert; tegelijk staat vast dat de betrokken persoon een hoogst persoonlijk recht op zijn naam heeft, dat deel van zijn personeel statuut uitmaakt, ${ }^{132}$

\subsection{De functie van de nationaliteit}

Waarin is de functie van de nationaliteit gelegen? ${ }^{133}$ Is deze functie gelegen in de afbakening van de eigen burgers van andere dan deze, dan kan men zich afvragen of steeds een strikt onderscheid dient te worden gemaakt tussen staatsburgers en buitenlanders.

Vooraf kan worden gesteld, dat de functie van de nationaliteit is gelegen in het afbakenen van de eigen staatsburgers van andere dan deze, met name buitenlanders. Ko Swan Sik typeert nationaliteit als een soort staatkundig lidmaatschap, dat in internationaal opzicht als centraal criterium fungeert voor de opdeling van individuen over de verschillende Staten. ${ }^{134}$ Ook Borchard wijst erop, dat nationaliteit - of staatsburgerschap de status van een individu als onderdaan of burger is in relatie tot een bepaalde Staat en lidmaatschap betekent in een onafhankelijke politieke gemeenschap. ${ }^{1.35}$ Deze functie komt ook in de Indonesische Nationaliteitswet tot uiting, gezien de bepaling dat een ieder die het Indonesisch staatsburgerschap niet bezit, buitenlander is.

Uit het bestaan van zelfstandige Staten als gegevenheid vloeit voort, dat er door Staten onderscheid gemaakt wordt op basis van staatsburgerschap tussen eigen staatsburgers en vreemdelingen. Immers, indien alle mensen tegenover alle Staten dezelfde rechten

129. Makarov, Allgemeine Lehren, p.28.

130. Ko Swan Sik, De Meervoudige Nationaliteit, Leiden, 1957, p. 8.

131. De Groot, Staatsangehōrigkeitsrecht, p. 12.

132. De Groot, Staatsangehōrigkeitsrecht, p. 12-13.

133. Bedoeld is hier de nationaliteit in algemene zin.

134. Ko Swan Sik, preadvies "Nationaliteit en het Volkenrecht", Ned. VVIR, 1981, p.4.

135. Borchard, E.M., The Diplomatic Protection of Citizens abroad or The Law of International Claims, New York, 1915, p.7. 
kunnen claimen, dan zou het onderhouden van territoriale grenzen geen zin hebben, omdat alle personen een recht tot toelating zouden kunnen eisen. ${ }^{136}$

Niet altijd wordt onderscheid tussen de eigen staatsburgers en buitenlanders gemaakt. De personen waarover een Staat soevereiniteit uitoefent, zijn niet alleen de eigen burgers maar ook buitenlanders die in zijn gebied verblijven dan wel anderszins onderworpen aan zijn toezicht. Volgens Van Panhuys merken modeme Staten elkaars burgers niet langer als personen aan, die hoegenaamd geen rechten bezitten. Buitenlanders, staatloze personen daaronder begrepen, hebben evenveel recht op wettelijke bescherming als de staatsburger zelf. De Staat waar deze buitenlander verblijft, dient hem een minimum aan wettelijke bescherming te garanderen en hem als drager van rechten en plichten aan te merken, met uitzondering echter van die rechten en plichten die slechts aan staatsburgers toekomen. ${ }^{137}$ Welke rechten een Staat aan buitenlanders dient te verlenen is volgens Borchard het resultaat van gewoonte en verdrag. Het recht van de nationale Staat dient de rechten van een buitenlander te concretiseren en de buitenlander de rechten, noodzakelijk voor leven, vrijheid en eigendom te waarborgen. Alhoewel ook toezicht op buitenlanders wordt uitgeoefend, dienen de regels van het internationale recht te worden gerespecteerd. ${ }^{138}$ De verplichtingen aan de buitenlander door diens nationale Staat opgelegd en de rechten die voorvloeien uit de nationaliteitsband, vormen de "raison d'être" van het limiet van de handelingen van een Staat ten opzichte van buitenlanders. ${ }^{139}$ Dit geldt ook voor een land als Indonesië.

\subsection{Het recht op een nationaliteit, een mensenrecht?}

De vraag of het recht op een nationaliteit al dan niet als een mensenrecht is aan te merken, is niet zo eenvoudig te beantwoorden. Ik meen er daarom goed aan te doen om deze vraag als volgt op te splitsen en daarbij aan te knopen bij de in de literatuur gehuldigde visies.

Eerst zal worden ingegaan op de visie van de nationaliteit als koppelbegrip, dit naar aanleiding van de ter zake in de literatur gehuldigde opvattingen. Hierop aansluitend zal de vraag aan de orde komen of de nationaliteit méér dan een koppelbegrip is, met name of het ook als een inhoudelijk begrip kan worden gekenmerkt. Nagegaan zal worden wat de consequenties van beide visies zijn. Vervolgens zal de vraag worden

136. Jessurun d'Oliveira, H.U., Onderscheid naar Nationaliteit: Discriminatie, NJCM-bulletin, 1984, p.328 en 330. Zie ook Tratnik, M., Het Nationaliteitsrecht in de Oosteuropese landen, Deventer, 1989 , p. 391, die de functie van de nationaliteit ziet als een soort hekwerk, waardoor een Staat onderscheid tussen zijn eigen onderdanen en vreendelingen kan maken.

137. Bedoeld zijn hier de fundamentele rechten uit het bezit van het staatsburgerschap voortvloeiende als in $\S 1.3 .2$ genoemd en andere dan deze waarbij het staatsburgerschap als aanknopingspunt dient. Zie voorts van Panhuys, The rôle of Nationality, p.44-45.

138. In Indonesiē wordt dit toezicht onder meer vitgeoefend middels de voor buitenlanders bestaande registratieplicht in het kader van de implementatie van de wettelijke bepalingen inzake het toezicht op buitenlanders, een voorziening ook in de nieuwe Immigratiewet no. 9 van het jaar 1992 opgenomen.

139. Borchard, The Diplomatic Protection, p.43. 
behandeld of het recht op een nationaliteit een fundamenteel menselijk recht, een mensenrecht is. Tenslotte zal een conclusie uit het behandelde worden getrokken, waarin mijn mening naar voren zal worden gebracht.

\subsubsection{De nationaliteit als koppelbegrip.}

In de literatuur wordt veelvuldig de mening gehuldigd dat indien de nationaliteit uitsluitend op haar juridisch-technische merites wordt beoordeeld, de nationaliteit een leeg begrip blijkt te zijn. Hierop aansluitend wordt gesteld, dat juridisch-technisch gezien de nationaliteit slechts het karakter van een koppelbegrip heeft, dat op zichzelf geen inhoud heeft. Dit betekent dat de nationaliteit eerst waarde krijgt door de rechtsgevolgen, die nationale of internationale rechtssystemen eraan koppelen. Het gaat er nu maar om, of er weinig c.q. geen belangrijke rechtsgevolgen dan wel veel rechtsgevolgen aan de nationaliteit gekoppeld worden. In het eerste geval is het nationaliteitsbegrip zélf in de letterlijke betekenis van het woord "zinloos". Anders ligt het in het tweede geval, aangezien het bezitten van een nationaliteit op deze wijze belang krijgt c.q. de garantie van het hebben van een nationaliteit betekenis krijgt. ${ }^{140}$

Het lijkt mij van nut, om de meningen van enkele auteurs te noemen. Ko Swan Sik gaat ervan uit, dat de juridische nationaliteitsband inhoudsloos is en in het recht de functie vervult van aanknopingspunt, of voor de bepaling van het personele geldingsbereik van een rechtsregel, of voor de toepasselijkheid van een bepaald nationaal rechtssysteem. ${ }^{141}$ Ook door Koessier wordt de voorstelling van een inhoudsloze nationaliteit gehuldigd, die spreekt van een "formal frame"; volgens deze auteur impliceert de nationaliteit als begrip van het internationale recht geen specifieke rechten en/of plichten, doch is slechts een "purely formal proposition", aangezien het de status van het behoren van een persoon tot een Staat aangeeft, met bijzondere verwijzing naar de internationale betrekkingen tussen Staten betreffende die persoon. ${ }^{142}$ Ook Wengler spreekt van een nationaliteit als een "Bereitschaftsstatus", waaraan bepaalde rechtsgevolgen kunnen doch niet moeten worden vastgeknoopt; de nationaliteit in de zin van het volkenrecht zou dan een, in de eerste plaats "leerlaufender", in casu een niet a priori met rechtsgevolgen uitgeruste "Bereitschaftsstatus" zijn. ${ }^{143}$ Makarov zegt over deze aangelegenheid het volgende: "Welche Rechte und welche Pflichten den Staatsangehörigkeitsstatus zur Voraussetzung haben, ist für den Begriff der Staatsangehörigkeit irrelevant...Es wäre aber verfehit, eines dieser Rechte oder eine dieser Pflichten als zum Wesen der Staatsangehörigkeit gehörend zu betrachten und sie in den Begriff der Staatsangehörigkeit miteinzuschließen". ${ }^{144}$ Hierop aansluitend concludeert de Groot, dat "juristisch-technisch betrachtet, die Staatsangehörigkeit ein Koppelungsbegriff (ist),

140. De Groot en Tratnik, Nationaliteitsrecht, p.2.

141. Ko Swan Sik, preadvies, p.13.

142. Koessler M., Subject, Citizen, National and Permanent Allegiance, Yale Law Joumal, 1946-47, p.70 en 76.

143. Wengler, W., Betrachtungen zum Begriff der Staatsangehörigkeit in internationalrechtliche und staatsrechtliche Abhandelungen, Festschrift für Walter Schătzel (1960), p.550.

144. Makarov, Allgemeine Lehren, p. 30. 
durch den Rechte und Pflichten an Personen gekoppelt werden. Die Staatsangehörigkeit ist damit ein Bereitschaftsstatus, an den Rechtsordnungen Rechtsfolgen knüpfen können". ${ }^{145}$

Ik aarzel echter om het standpunt te onderschrijven, dat de nationaliteit slechts als een koppelbegrip is aan te merken en dat er geen rechten of plichten zijn die voor het individu begripsmatig uit de nationaliteit voortvloeien. De hiervoor genoemde auteurs nemen het standpunt in, dat deze rechten en verplichtingen hun bestaan niet aan de nationaliteit ontlenen doch aan een aparte rechtsbron, die de nationaliteit als aanknopingspunt gebruikt voor de bepaling van het personele geldingsbereik van die rechten en plichten. ${ }^{146} \mathrm{Ik}$ ben van mening, dat de nationaliteit niet slechts de functie van een koppelbegrip kan hebben, maar dat het ook om een inhoudelijk begrip kan gaan. In het hieronder volgende zal worden getracht laatstgenoemde visie aan te tonen.

\subsubsection{Koppelbegrip of inhoudelijk begrip?}

Ter staving van mijn mening, dat de nationaliteit zeker mér dan een koppelbegrip is, met name dat het ook om een inhoudelijk begrip kan gaan, kan worden gewezen op bepaalde fundamentele rechten die nauw met een nationaliteit verweven zijn. Mijns inziens dient de nationaliteit zeker niet als inhoudsloos, als een leeg begrip te worden opgevat. Op deze aangelegenheid zal hieronder worden ingegaan.

De zin van de vraag naar het karakter van de nationaliteit ligt hierin, dat er een groot verschil bestaat tussen het aanmerken van de nationaliteit als "an sich" inhoudsloos dan wel als een status, waarmede bepaalde fundamentele rechten nauw zijn verweven. De aanhangers van de koppelbegriptheorie zien de nationaliteit als "eine leere Hülle", die eerst waarde krijgt door de rechtsgevolgen die nationale of internationale rechtssystemen eraan vastknopen. Wordt daarentegen de nationaliteit als een inhoudelijk begrip aangemerkt, dan wordt er onder meer van uitgegaan dat de inhoud daarvan wordt gevormd door bepaalde rechten die nauw met het nationaliteitsbegrip verweven zijn, zoals nader zal worden aangetoond.

De vraag kan derhalve worden gesteld, of er fundamentele rechten zijn, die begripsmatig uit het bezit van een (bepaalde) nationaliteit voortvloeien, hiermede nauw verweven zijn. Of fungeert de nationaliteit inderdaad slechts als koppelbegrip, als aanknopingspunt voor de toekenning van bepaalde willekeurige rechten (of verplichtingen)?

145. de Groot en Tratnik, Nationaliteitsrecht, p.2 e.v. Zie ook de Groot, Staatsangehōrigkeitsrecht, p.13 e.v. Zie voorts Tratnik, Het Nationaliteitsrecht, p.7.

146. Zie Ko Swan Sik, preadvies, p.12-16. 
Mijns inziens is juist vanwege het feit, dat er belangrijke rechten met het begrip "nationaliteit" zijn verweven, het recht op een nationaliteit als een inhoudelijk recht aan te merken. Deze rechten zijn de navolgende:

- het recht op toelating tot het grondgebied van de Staat waarvan men burger is en op niet-uitwijzing door die Staat;

- het recht op diplomatieke bescherming;

- politieke rechten

die hieronder nader in beschouwing zullen worden genomen, mede aan de hand van de in de literatuur gehuldigde opvattingen.

a. het recht op toelating tot het grondgebied van de Staat waarvan men burger is en het niet kunnen worden uitgewezen door die Staat.

Jessurun d'Oliveira wijst erop, dat wanneer geen rechtsgevolgen verbonden zouden zijn aan het staatsburgerschap - een onmisbaar element in het staatsbegrip - men zich aan het bezit ervan weinig gelegen zou hoeven laten liggen. Deze auteur beschouwt de opvatting dat de juridische nationaliteitsband inhoudsloos is en in het recht de functie vervult van aanknopingspunt, of voor de bepaling van het personele geldingsbereik van een rechtsregel, of voor de toepasselijkheid van een bepaald rechtssysteem als weinig realistisch. ${ }^{147} \mathrm{Hij}$ is van de mening, dat men weliswaar kan waarnemen, dat bepaalde rechten of verplichtingen soms wél, en soms weer niet aan het staatsburgerschap worden vastgeknoopt, en dat dezelfde rechten en plichten nu eens aan staatsburgers, en dan weer aan ingezetenen of natuurlijke personen "tout court" worden verleend, maar wijst het op grond van dergelijke historische variaties beroven van het staatsburgerschapsbegrip van zijn normatieve kanten af. Deze auteur staat zelf een minder neutraal begrip staatsburgerschap voor, een staatsburgerschapsbegrip waar een pakket rechten en plichten op vanzelfsprekende manier mee samenhangt; zo beschouwt hij het als element van het staatsburgerschapsbegrip en daarmee vast verbonden, dat iemand recht heeft op toelating tot het grondgebied van de Staat waarvan hij burger is, dit ondanks het feit dat er Staten zijn die dit recht niet onverbrekelijk aan het staatsburgerschap hebben gekoppeld, vroeger of nu. ${ }^{148}$ Ook Weis is van mening, dat één van de functies die nauw is verweven met het nationaliteitsbegrip, het recht van een persoon is om zich te vestigen in het gebied van de Staat van zijn nationaliteit en dat het de plicht is van deze Staat deze vestiging te verlenen en toe te staan aan zijn burgers. ${ }^{149}$ Hieronder valt mede de verplichting van een Staat om zijn burgers, indien door andere Staten uitgewezen, terug le ontvangen; ook de repatriatie kan als de kem van de nationaliteit worden beschouwd.

147. Jessurun d'Oliveira, Onderscheid naar Nationaliteit, p.328.

148. Jussunun d'Oliveira, Onderscheid naar Nationaliteit, p. 329.

149. Weis, P., Nationality and Statelessness in International Law, Alphen aan den Rijn/Germantown, 1979, p.45. 
Ter staving van het bovenstaande kan worden gewezen op artikel 13 van de Universele Verklaring van de Rechten van de Mens ${ }^{150}$, geproclameerd op 10 december 1948 door de Algemene Vergadering der Verenigde Naties waarvan het tweede lid bepaalt, dat een ieder het recht heeft welk land ook, met inbegrip van het eigen land, te verlaten en naar het eigen land terug te keren. Verder is artikel 12 lid 4 van het Internationaal Verdrag inzake Burgerrechten en Politieke rechten - BUPO-Verdrag ${ }^{\mid 51}$ - van belang dat bepaalt, dat aan niemand willekeurig het recht mag worden ontnomen naar zijn eigen land terug te keren. Voorts verplicht het Internationaal Verdrag inzake de uitbanning van alle vormen van rassendiscriminatie ${ }^{152}$ van 7 maart 1966 - artikel 5 sub d onder II - de Staten partijen daarbij, het recht van een ieder om elk land, waaronder het eigen land, te verlaten en naar het eigen land terug te keren. Artikel 3 van Protocol no. 4 van 16 september 1963 bij het Verdrag tot bescherming van de rechten van de mens en de fundamentele vrijheden bepaalt in het eerste lid dat niemand, bij wege van een maatregel van individuele of van collectieve aard, mag worden verwijderd van het grondgebied van de Staat, waarvan hij een onderdaan is. Het tweede lid bepaalt dat aan niemand het recht mag worden ontnomen het grondgebied te betreden van de Staat, waarvan hij een onderdaan is. ${ }^{153}$

Dat de verplichting tot toelating en van niet-uitwijzing van staatsburgers tot voor kort zelden is opgenomen in het positieve internationale recht, is volgens Weis duidelijk niet bedoeld om het bestaan van deze verplichting onder het internationale recht te ontkennen of betwisten, doch eerder omdat dit algemeen aanvaard is als een inherente verplichting van Staten, die voorvloeit uit het concept van nationaliteit. De plicht tot toelating, als attribuut van nationaliteit eindigt niet gedurende het bestaan van de nationaliteit doch eindigt eerst bij verkrijging van een andere nationaliteit door het individu, in welk geval voor de Staat, wiens nationaliteit wordt verkregen, dezelfde verplichting bestaat. ${ }^{154}$ Ook van Panhuys is de mening toegedaan dat ten aanzien van andere Staten, een Staat verplicht is zijn staatsburgers tot zijn grondgebied toe te laten. De plicht tot toelating van de eigen burgers wordt als zo'n belangrijk gevolg van de nationaliteit aangemerkt, dat het er bijna mee wordt vereenzelvigd. Omgekeerd is een Staat niet verplicht buitenlanders toe te laten en mogen buitenlanders worden uitgewezen, indien daarvoor geldige redenen bestaan. ${ }^{155}$

Van belang is voorts de mening van Heijs, die stelt dat twee van de meest fundamentele rechten die vrijwel elke Staat aan zijn staatsburgers verleent, zijn: het recht op toelating tot het grondgebied en het recht om op dat grondgebied te wonen. Vreemdelingen missen in beginsel deze rechten; het hangt van de vaak zeer complexe regels van het nationale vreemdelingenrecht en van internationale afspraken die Staten hierover hebben gemaakt, af of zij worden toegelaten. Deze auteur stelt zich op het standpunt, dat de

150. Trb. $1969,99$.

151. Opgenomen in Trb. 1978, 177.

152. Trb. 1966, 237.

153. Trb. $1969,241$.

154. Weis, Nationality, p.47 en 53.

155. Van Panhuys, The róle of Nationality, p. 54-56. 
vraag of een Staat een individu tot zijn staatsburgers rekent daarom van groot belang is voor de mogelijkheden van dat individu om zich op het grondgebied van die Staat te vestigen. Deze vraag is ook voor de Staat van belang, omdat de nationaliteitsrechtelijke status van een individu - staatsburger of vreemdeling - bepaalt, of toelating kan worden geweigerd of aan voorwaarden is gebonden. ${ }^{156}$

Wordt ter afsluiling van het hier behandelde onderwerp de situatie in Indonesië aangehaald, dan kan worden gewezen op hetgeen in artikel 2 van de recentelijk afgekondigde Wet no. 9 van het jaar 1992, Stb. 1992-33 betreffende Immigratie is bepaald. ${ }^{157} \mathrm{Dit}$ artikel houdt in, dat iedere Indonesisch staatsburger gerechtigd is om het Indonesisch grondgebied binnen te komen of te verlaten. Hoewel het Indonesische staatsburgers om bepaalde redenen en voor bepaalde tijd kan worden belet Indonesië te verlaten dan wel binnen te komen, dient wat het laatste betreft te worden benadrukt, dat dit zich slechts in zeer uitzonderlijke gevallen kan voordoen; het beletten Indonesië binnen te komen geldt in principe voor buitenlanders. Tot deze maatregel kan onder meer worden overgegaan, indien het om Indonesische staatsburgers gaat die reeds lange tijd Indonesiē hebben verlaten, in een ander land woonplaats hebben dan wel ingezetene daarvan zijn geworden en zich vijandig betonen tegenover de Indonesische staat of overheid. De Wet benadrukt echter in principe het recht van iedere Indonesische staatsburger om Indonesië binnen te komen en te verlaten.

\section{b. het recht op diplomatieke bescherming}

Een ander fundamenteel recht is het recht van een Staat om zijn burgers bescherming te verlenen in relatie tot andere Staten. Deze diplomatieke bescherming verschilt van de interne wettelijke bescherming die iedere staatsburger mag eisen van de Staat van zijn nationaliteit krachtens zijn nationaal recht. Internationale diplomatieke bescherming is een recht van een Staat volgens het internationale gewoonterecht, om te interveniëren namens zijn burgers, indien hun rechten geweld wordt aangedaan door een andere Staat, teneinde herstel van die rechten of vergoeding van geleden schade te verkrijgen. Een Staat is ten volle gerechtigd om dit recht al dan niet uit te oefenen en van ieder diplomatiek middel gebruik te maken, dat hij als passend beschouwt. Weis is van mening, dat het recht om al dan niet gebruik te maken van het recht tot diplomatieke bescherming de geldende situatie krachtens het internationale recht is. Staatsburgers kunnen niettemin krachtens hun nationaal recht een recht op diplomatieke bescherming hebben. ${ }^{158}$ Het recht op diplomatieke bescherming kan bijvoorbeeld in de Grondwet van een land zijn vastgelegd. Naar de mening van Borchard kan diplomatieke bescherming

156. Heijs, E., Nederlanderschap in de Nederlandse Koloniën: Regulering van immigratie vanuit de koloniēn door nationaliteitsbeleid in Nederland, Recht der Werkelijkheid, 1991. p.21. De auteur gaat in dit artikel in op de relatie tussen de nationaliteitsrechtelijke status van de hevolking van de huidige en van de voormalige koloniēn van Nederland enerzijds en de immigratie vanuit de koloniēn naar Nederland anderzijds.

157. Zie voor de tekst van deze Wet, Warta-Cafi jaargang 34, no. 63,64 en 66 respectievelijk van 26 en 27 mei en 2 juni van het jaar 1992.

158. Weis, Nationality, p. 34 . 
worden beschouwd als een buitengewoon middel onder bepaalde omstandigheden aan de burger verleend binnen het beleid van de Staat, in harmonie met de publieke belangen van die Staat, zijn betrekkingen met andere Staten en de rechten van de burger. Volgens deze auteur is staatsburgerschap de voomaamste voorwaarde of titel voor bescherming en bestaat voor de wijze van voorbrenging en uitvoering van internationale claims, geen regel die strikter wordt nagekomen. ${ }^{159}$ Het "Permanent Court of International Justice" heeft de aard van de diplomatieke bescherming beschreven in die zin, dat dit recht noodzakelijk is beperkt tot de interventie ten behoeve van de eigen burgers, omdat bij afwezigheid van een speciale overeenkomst, het alleen de band van de nationaliteit tussen een Staat en een individu is, die de Staat het recht tot diplomatieke bescherming verleent. Onderscheiden van andere gevallen van Staten van uitoefening van bescherming over individuen, is internationale bescherming van staatsburgers permanent en universeel. ${ }^{160}$ Ook Koessler wijst erop, dat het gewoonlijk slechts door de interventie van de Staat van hun nationaliteit is, dat personen in staat worden gesteld vergoeding te verkrijgen van schade, hun aangedaan door een andere Staat in strijd met het internationale recht. ${ }^{161}$ Van Panhuys is van mening, dat diplomatieke bescherming alleen kan worden verleend aan een belanghebbende persoon die de nationaliteit van de Staat in kwestie bezit. Dit betekent in beperkende zin, dat buitenlanders niet hiervoor in aanmerking kunnen komen en in uitgebreide betekenis, dat diplomatieke bescherming zich ook uitstrekt tot staatsburgers, bij verblijf buitenlands. ${ }^{162}$ Een overeenkomstig standpunt wordt ook door Sanger ingenomen ${ }^{163}$, die naar voren brengt dat tegenover andere Staten de nationaliteit de voorwaarde vormt voor de toekenning van diplomatieke bescherming. Wengler merkt voorts op, dat in de volkenrechtelijke status van de nationaliteit veeleer a priori bepaalde rechtsgevolgen worden inbegrepen, die wezenlijke bestanddelen daarvan vormen. Hij zegt vervolgens dat met het begrip van de nationaliteit in deze zin "die Relevanz dieses Begriffs für das völkerrechtliche Schutzrecht und die Personalhoheit von vornherein untrennbar verknüpft" is. ${ }^{164}$

159. Borchard, The Diplomatic Protection, p.353, 457 en 462.

160. Weis, Nationality, p. 35 en 39 . De kwestie van de aard van de diplomatieke bescherming is door het Permanent Court of International Justice in de Panevezys-Saldutiskis Railway Case, P.C.I.J., Series A/B, No.76 omschreven.

161. Koessler, Subject, Citizen, p.71.

162. Van Panhuys, The rôle of Nationality, p.59. Volgens deze auteur kunnen in het geval een persoon zowel burger van de eisende Staat als van de gedaagde Staat is twee stromingen worden onderscheiden. De ene hanteert "the principle of equality", dat inhoudt dat beide nationaliteiten gelijk gewicht hebben en dat derhalve geen der Staten een claim mag uitbrengen tegen de andere ( $V_{g l}$. artikel 4 van het Haagse Verdrag van 1930). De andere banteert "the principe of active of effective nationality", dat hierop neerkomt dat het "sujet mixte" moet worden beschouwd de nationaliteit te hebben die hij in feite uitoefent, t.w. de nationaliteit van de Staat van zijn woonplaats. Verwarring kan ontstaan, indien de eerste opvatting ook betekenis hecht aan woonplaats, d.w.z. dat zolang een als hierbedoelde persoon woont in het gebied van écn van zijn nationale Staten, deze gerechtigd is hem als zijn burger te behandelen en niet verantwoordelijk kan worden gesteld voor deze behandeling door de andere Staat. Tk voeg hieraan nog toe, dat een staatloze persoon geen diplomatieke bescherming kan inroepen van welke Staat dan ook.

163. Sanger, Die indonesische, p. 2.

164. Wengler, Betrachtungen, p.547-548. 
Uit het voorgaande kan de conclusie worden getrokken dat Weis en Wengler het bestaan van rechten en plichten aannemen, die voor de inhoud van de nationaliteit begripsmatig zijn verbonden, echter slechts voor de nationaliteit als volkenrechtelijke status. Weis brengt ter zake een definitie naar voren die hierop neerkomt, dat de nationaliteit een betrekking tussen een bepaalde persoon en een bepaalde Staat vormt, een relatie die deze Staat het recht waarborgt om deze persoon en zijn vermogen tegenover andere Staten te beschermen en hem de plicht oplegt, de persoon in kwestie in zijn staatsgebied op te nemen. Volgens Makarov voert deze definitie tot een niet aanvaardbare uitbreiding van het nationaliteitsbegrip. ${ }^{165} \mathrm{Ik}$ ben dat niet met hem eens, alhoewel dit niet wil zeggen dat ook ik van mening ben dat er een belangrijk verschil bestaat tussen de nationaliteit in volkenrechtelijke zin en in de zin van het nationale recht zoals de hiervoor aangehaalde auteurs doen. De Groot zegt hieromtrent onder meer het volgende: "Von der innerstaatlichen Staatsangehörigkeit haben einige Autoren den internationalen Begriff der Staatsangehörigkeit so stark unterschieden, daß die Ansicht vertreten wurde, es handele sich um zwei unterschiedliche Staatsangehörigkeiten. Bestimmte völkerrechtliche Folgen (wie das Recht diplomatischen Schutz zu verleihen) wären begriffsmäßig mit diesem internationalen Staatsangehörigkeit verbunden. Die Dualität der innerstaatlichen und völkerrechtlichen Staatsangehörigkeit muß jedoch verneint werden". Alhoewel deze auteur toegeeft, dat niet ontkend kan worden dat door de formulering van de nationaliteit in het volkenrecht als een mensenrecht, de verbondenheid van de nationaliteit met de gevolgen die het positieve volkenrecht aan de nationaliteit koppelt, een zeer hechte geworden is, is hij van mening, dat "von einer logisch zwingenden Beziehung der Staatsangehörigkeit und den nach positivem bestehenden Folgen aber dennoch keine Rede sein kann". ${ }^{166}$ Ik ben wat dit laatste punt betreft, echter een andere mening toegedaan, waarop nader zal worden teruggekomen.

Normaliter kan de inhoud van het begrip "nationaliteit" niet aan een nationaliteitswet worden afgelezen; de daarin opgenomen bepalingen geven slechts aan, wie de nationaliteit van het desbetreffende land bezitten en op welke wijze een nationaliteit kan worden verkregen dan wel verloren gaat. De Wet no. 62 van het jaar 1958 betreffende het Indonesisch Staatsburgerschap maakt hierop een uitzondering door in artikel II van de Slotbepalingen te stellen, dat in het begrip "staatsburgerschap" is begrepen, iedere soort bescherming door een Staat te verlenen. ${ }^{167}$

\section{c. Politieke rechten}

Word inzake politieke rechten in eerste instantie de mening van Indonesische auteurs aangehaald, dan kan Gautama worden genoemd, die stelt dat hetgeen de rechten en plichten vormt van een staatsburger op het vlak van het publieke recht, algemeen

165. Makarov, Allgemeine Lehren, p.29.

166. De Groot, Staatsangehörigkeitsrecht, p. 14-15.

167. In de Toelichting op deze Wet staat te lezen, dat de rechtsbetrekking tussen personen en een Staat hoe hecht die ook is - niet door eenzelfde term voor wat betreft de betekenis en de inhoud daarvan door de respectieve Staten wordt aangegeven. Om die reden wordt het nodig geacht, om het begrip "staassburgerschap" nader te omschrijiven. 
bekend is. Zo mag een buitenlander zich niet mengen in de binnenlandse politiek en derhalve geen deel hebben aan de algemene verkiezingen c.q. het passieve en actieve kiesrecht. Buitenlanders kunnen in het algemeen $00 \mathrm{k}$ geen belangrijke overheidsfuncties bekleden. ${ }^{168}$ Ook Syahmin brengt naar voren, dat in verschillende wettelijke regelingen van de Republiek Indonesië is vastgesteld, dat slechts Indonesische staatsburgers over volle rechten beschikken. Zo treedt het onderscheid tussen staatsburgers en buitenlanders onder meer naar voren op het vlak van de politieke en staatkundige rechten, zoals het actief en passief kiesrecht. ${ }^{169}$ Een overeenkomstige mening wordt gehuldigd door Soenario, die naar voren brengt, dat buitenlanders zich niet mogen mengen in de binnenlandse politiek, aangezien dit het recht vormt van de eigen staatsburgers. ${ }^{170}$ Hieruit blijkt dat voor de werking van vele en velerlei normen, de nationaliteit voorwaarde is. Actief en passief kiesrecht zijn daarom voor staatsburgers gereserveerd. Voor de benoembaarheid tot overheidsfuncties is de nationaliteit in principe voorwaarde.

Ook van Panhuys wijst erop, dat buitenlanders zijn uitgezonderd van politieke rechten. ${ }^{171}$ Makarov is van mening, dat naar buiten toe een grens kan worden getrokken tussen staatsburgers en buitenlanders. Naar binnen toe kan de status van de nationaliteit door een reeks juridische eigenschappen worden afgebakend, waarvan kan worden genoemd, het volle genot van burgerrechten, voornamelijk politieke rechten. Deze rechtstoestand heeft de nationaliteit als voorwaarde, maar is volgens Makarov niet hiermede te verwisselen, een mening niet door mij gedeeld. ${ }^{172}$ Borchard neemt het standpunt in, dat krachtens de band die de burger aan zijn nationale Staat bindt, hij wordt voorzien van bepaalde rechten, in het bijzonder politieke rechten en voorts belast is met de uitoefening van bepaalde plichten in ruil voor de voordelen die het staatsburgerschap biedt. Politieke rechten impliceren een aandeel in het toezicht en een actieve deelname aan het leven en de activiteiten van de Staat en worden meestal ontzegd aan buitenlanders. Wat betreft politieke rechten, bestaat de tendens om daaronder te verstaan, het recht tot stemmen en rechten die uit het staatsburgerschap voortvloeien, zoals het bekleden van bepaalde openbare ambten. ${ }^{173}$ Sanger is van mening, dat uit de nationaliteit rechten en plichten voortvloeien, die slechts bij uitzondering buitenlanders toebedeeld worden. Hij noemt als zodanig het kiesrecht en de verplichting de Staat

168. Gautama, S., Warganegara dan Orang Asing, Bandung, 1987, p.3, 5 en 6.

169. Syahmin, A.K., Penyelundupan Hukum lewat lembaga Perkawinan Campuran, tijdschrift Padjadjaran, no. 1 van 1986, p.63-64.

170. Soenario, Masalah-Masalah disekitar soal Warganegara dan Orang Asing, uitgave van de N.V. "Harapan Masa", p.6.

171. Van Panhuys, The rôle of Nationality, p. 46 .

172. Makarov, Allgemeine Lehren, p. 38 en 40.

173. Borchard, The Diplomatic Protection, p.63. Volgens deze auteur omvalten burgerlijke rechten, alle rechten niet als politieke aan te merken; vele auteurs verstaan onder burgerlijke rechten, de rechten van individuen onderling, beschermd door het privaatrecht van de Staat, anders dan politieke rechten die een meer rechtstreekse relatie tussen individu en Staat inhouden en door het publieke recht worden beschermd. 
te verdedigen. Tegenover andere Staten vormt de nationaliteit voorwaarde voor het verlenen van diplomatieke bescherming. ${ }^{174}$

In het bovenstaande werden enkele rechten behandeld, door mij als fundamenteel aangemerkt, nauw met de nationaliteit verweven. Dit zijn respectievelijk het recht tot toelating van een persoon tot het grondgebied van de Staat, waarvan hij de nationaliteit bezit - en in het verlengde daarvan de plicht van een Staat om zijn burger, die door een ander land wordt uitgewezen, terug te ontvangen - het recht op diplomatieke bescherming van zodanige burger en politieke rechten, die zowel het actieve als passieve kiesrecht omvatten.

$1 \mathrm{k}$ heb in het voorgaande auteurs genoemd die de respectieve rechten hebben behandeld. Hierop aansluitend dient Wiessner te worden aangehaald, die onderzoek heeft uitgevoerd met betrekking tot het recht van de Verenigde Staten, Duitsland en de (voormalige) Sovjet-Unie teneinde na te gaan welke rechtsgevolgen begripsmatig uit het bezit van een nationaliteit voortvloeien. Deze auteur komt tot de conclusie, dat transnationaal overeenstemmende consequenties uit het bezit van een nationaliteit kunnen worden geconstateerd, die lange tijd constant gebleven zijn c.q. zich in de loop van deze eeuw hebben gestabiliseerd en de inhoud vormen van een transnationaal concept van nationaliteit. ${ }^{175}$ Deze auteur noemt - kort samengevat - als zodanig:

de verplichting van een Staat om zijn burgers tot zijn gebied toe te laten, indien geen andere Staat zich daartoe bereid verklaart;

- $\quad$ het recht van een staatsburger om naar de Staat van zijn nationaliteit terug te keren;

- staatsburgers mogen niet uit het gebied van de Staat van hun nationaliteit uitgewezen worden;

uitsluitend voor staatsburgers staat het actieve en passieve kiesrecht op het nationale vlak open;

in principe kunnen slechts staatsburgers tot overheidsbetrekkingen worden toegelaten;

een Staat heeft het recht diplomatieke bescherming aan zijn burgers tegenover andere Staten te verlenen.

De door Wiessner genoemde rechten komen overeen met de rechten hiervoor door mij aan de hand van de verschillende auteurs genoemd. Het betreffen hier fundamentele rechten, met de nationaliteit verweven, die inhoud geven aan de nationaliteit. Wiessner heeft ook andere rechtsgevolgen aan een onderzoek onderworpen, die slechts in enkele rechtssystemen overeenkomen dan wel incidenteel met het nationaliteitsbegrip verbonden zijn. ${ }^{176}$ Mijns inziens houdt dit in, dat er ook rechten bestaan waarbij de nationa-

174. Sanger, Die indonesische, p.2.

175. Wiessner S., Die Funktion der Staatsangehörigkeit, Tubingen, 1989, p.396. Het betreft hier een recent werk, anders dan de werken van de meeste hiervoor genoemde auteurs. Blijkbaar gaat Wiessner echter niet zo ver, dat hij de koppelbegriptheorie laat varen.

176. Ibid. 
liteit slechts als aanknopingspunt dient, die hun basis niet vinden in de nationaliteit, maar in een aparte rechtsbron.

Ik concludeer dat het recht op een nationaliteit, gezien bepaalde, hiermede nauw verweven fundamentele rechten, een inhoudelijk recht is, waarvan de inhoud gevormd wordt door de hierboven behandelde fundamentele rechten. Het is zeker geen begrip, dat enkel en alleen de functie van koppelbegrip heeft voor de toekenning van rechten en plichten, die hun bestaan niet aan de nationaliteit maar aan een aparte rechtsbron ontlenen die de nationaliteit als aanknopingspunt gebruikt.

Voor andere, dan de hiervoor genoemde fundamentele rechten, kan de nationaliteit wél als aanknopingspunt fungeren. In dit verband kan de mening van de Groot en Tratnik worden aangehaald, die hierop neerkomt dat indien slechts weinig of geen rechtsgevolgen aan het hebben van een nationaliteit gekoppeld worden, het nationaliteitsbegrip zinloos is doch de zaken anders liggen, indien veel rechtsgevolgen aan de nationaliteit gekoppeld worden. Deze auteurs zijn van mening, dat het hebben van een nationaliteit zo belang krijgt en de garantie van het bezitten van een nationaliteit betekenis krijgt. ${ }^{17}$ Kan dan nog wel van een koppelbegrip in de zuivere betekenis van het woord worden gesproken of is dan niet reeds sprake van een overgang van koppelbegrip naar inhoudelijk begrip? Ko Swan Sik is voorts van mening, dat de rol, functie en betekenis van de Staat als zodanig aan verandering onderhevig en afhankelijk zijn van de politieke ontwikkelingen in de nationale en internationale gemeenschap. Dienovereenkomstig zouden eventuele aan de nationaliteit inherente rechten en plichten ook kunnen ontstaan, veranderen en tenietgaan. ${ }^{178}$ Ik stel mij op het standpunt, dat deze uitspraak niet van toepassing is op de fundamentele rechten die uit de nationaliteit voortvloeien, doch slechts betrekking heeft op niet-fundamentele rechten en plichten die niet aan de nationaliteit inherent zijn, derhalve in de hiervoor genoemde betekenis van de nationaliteit als koppelbegrip, in die zin dat deze aan de nationaliteit gekoppelde rechten en plichten voor verandering vatbaar zijn. Mijns inziens is dit bovendien afhankelijk van het feit, om de nationaliteit van welke landen het hierbij gaat. Daarbij kan bijvoorbeeld verschil worden gemaakt tussen ontwikkelde landen als Europese landen waaronder Nederland en ontwikkelingslanden, waartoe Indonesië behoort en de tijd waarin een en ander zich afspeelt.

\subsubsection{Het recht op nationaliteit als mensenrecht}

Bij het in beschouwing nemen van het recht op nationaliteit als mensenrecht zullen achtereenvolgens de navolgende onderwerpen aan de orde komen:

het belang van het onderscheid tussen de nationaliteit als koppelbegrip of als inhoudelijk begrip voor de typering van het recht op een nationaliteit als mensenrecht;

177. Zit de Groot en Tratnik, Nationaliteitsrecht, p.2.

178. Ko Swan Sik, preadvies, p.13. 
- het ter zake doende geschreven recht, met name artikel 15 van de Universele Verklaring van de Rechten van de Mens en andere documenten ter ondersteuning van de visie dat het recht op een nationaliteit een mensenrecht is;

- willekeurige ontneming van nationaliteit en het recht op expatriatie;

- Gevolgen van het typeren van het recht op een nationaliteit als mensenrecht.

Vervolgens zal een conclusie uit het behandelde worden getrokken.

1.3.3.1. Het belang van de nationaliteit als inhoudelijk begrip voor de typering van het recht op een nationaliteit als mensenrecht

In het bovenstaande werd aangetoond, dat de nationaliteit niet uitsluitend als koppelbegrip dient te worden gezien, aangezien het voor het bezit van bepaalde fundamentele rechten als inhoudelijk begrip dient te worden aangemerkt.

Wordt dit als uitgangspunt genomen, dan kan worden gesteld dat de nationaliteit als inhoudelijk begrip ook van belang is te achten voor de karakterisering van het recht op het bezit van een nationaliteit als mensenrecht.

Het recht op een nationaliteit is als een fundamenteel menselijk recht, als een mensenrecht aan te merken en heeft daardoor niet alleen de functie van koppelbegrip, maar is wat betreft bepaalde fundamentele rechten, een inhoudelijk begrip. Wordt de nationaliteit uitsluitend als koppelbegrip gezien, dan kunnen de daaraan gekoppelde willekeurige, niet fundamentele rechten en plichten aan het individu worden ontnomen. Wordt hiervan uitgegaan, dan zou de nationaliteit "an sich" een leeg begrip, inhoudsloos zijn, enkel en alleen als koppelbegrip, als aanknopingspunt fungeren voor de toekenning van willekeurige rechten en plichten, die hun bestaan niet ontlenen aan de nationaliteit zelf, doch aan een aparte rechtsbron, waarbij de nationaliteit als aanknopingspunt dient. Deze visie zou het recht op een nationaliteit tot een dubieus mensenrecht maken.

Ik stel mij echter op het standpunt, dat het recht op een nationaliteit een mensenrecht is, hetgeen tevens een garantie biedt voor het bezit van bepaalde fundamentele rechten, waaraan, algemeen gesteld, niet kan worden getornd. Het typeren van een recht op een nationaliteit als mensenrecht blijkt ook uit het ter zake doende geschreven recht, waarop in het hieronder volgende nader zal worden ingegaan.

\subsubsection{Het ter zake doende geschreven recht}

Artikel 15 van de Universele Verklaring van de Rechten van de Mens houdt in, dat een ieder recht heeft op een nationaliteit en aan niemand willekeurig zijn nationaliteit mag worden ontnomen, noch het recht ontzegd, van nationaliteit te veranderen. In artikel 24 lid 3 van het BUPO-verdrag is een soortgelijke bepaling opgenomen, die inhoudt dat elk kind het recht heeft een nationaliteit te verwerven. Van meer recente datum is het 
Verdrag inzake de Rechten van het Kind, New York, 20 november 1989. ${ }^{179}$ Dit Verdrag bepaalt in artikel 7 onder meer dat het kind vanaf de geboorte het recht heeft om een naam en een nationaliteit te verwerven. Voorts is in dit artikel bepaald, dat de Staten die partij zijn bij dit verdrag, de verwezenlijking van deze rechten waarborgen, in overeenstemming met hun nationale recht en hun verplichtingen krachtens de desbetreffende internationale akten op dit gebied, in het bijzonder wanneer het kind anders staatloos zou zijn. Artikel 8 bepaalt verder, dat de tot dit Verdrag toegetreden Staten zich verbinden tot eerbiediging van het recht van het kind om zijn of haar identiteit te behouden, met inbegrip van nationaliteit, naam zoals wettelijk erkend, zonder onrechtmatige inmenging. ${ }^{180}$ Ook het Internationaal Verdrag inzake de uitbanning van rassendiscriminatie verlangt, dat Staten zorgen voor gelijkheid voor de wet wat betreft het genot van onder meer het recht op een nationaliteit, zoals bepaald in artikel 5 sub d onder III van dit Verdrag.

Op grond van de Universele Verklaring en genoemde Verdragen zou kunnen worden verwacht dat het onomstreden is, dat het recht op een nationaliteit als een mensenrecht moet worden beschouwd. Uit de literatuur blijkt echter dat dit niet het geval is.

Het is van belang het rechtskarakter van de Universele Verklaring van de Rechten van de Mens in de beschouwing te betrekken. In de literatuur wordt soms gewezen op het feit, dat de Universele Verklaring niet in de vorm van een verdrag is gegoten en als zodanig geen rechtscheppend karakter bezit. De Universele Verklaring houdt "an sich" geen middelen in voor het individu ter handhaving van de daarin opgenomen rechten. Zo wijst Ko Swan Sik erop, dat de Verklaring formeel geen rechtscheppende kracht heeft en dat men kan twisten over de vraag, of de in de Verklaring geformuleerde rechten in 1948 reeds deel uitmaakten van het ongeschreven algemene volkenrecht of sindsdien tot zulk recht, en zelfs van dwingende aard, is uitgegroeid. Hij is echter van mening, dat ook wanneer dit laatste het geval zou zjjn, het rechten betreft waarvoor aan het individa op intemationaal niveau geen handhavingsmiddelen zijn toegekend. ${ }^{181}$ Over het hoofd wordt echter gezien, dat op intemationaal niveau verdragen kunnen worden aangegaan en zijn aangegaan (zoals het BUPO-verdrag), waarin bepalingen worden opgenomen ter handhaving van de in de Universele Verklaring opgenomen rechten. Bovendien kan afgezien van de vraag of de Universele Verklaring van de Rechten van de Mens volkenrechtelijke verplichtingen inhoudt, aan een verklaring van de Algemene Vergadering van de Verenigde Naties hoge morele waarde en een groot internationaal gezag worden gehecht. Ook Weis is van mening, dat de Universele Verklaring van de Rechten van de Mens, alhoewel geen bindend instrument,aanzienlijk gewicht heeft. ${ }^{182}$ Volgens deze auteur kan, gelet op de bepaling in artikel 15 van de

179. Trh. $1990,170$.

180. In de asngehaslde artikelen worden de nasm en de nationaliteit in cén adem genoemd. In dit verband kan worden gewezen op de in $\$ 1.1$ aangehaalde, door de Groot gemaakte vergelijking russen de nationaliteit als band en status en de familienaam, die eveneens een band manifesteert, terwijl tegelijkertijd vaststaat dan betrokkene een hoogst persoonlijk recht op zijn naam heeft.

181. Ko Swan Sik, preadvies, p.27.

182. Weis, Nationality, p. 46. 
Universele Verklaring worden gewezen op een belangrijke tendens om denationalisatie te verbieden of tenminste bij verdrag te beperken. ${ }^{183}$ Hoewel ook Brownlie naar voren brengt dat de Verklaring niet als een "legal instrument" kan worden aangemerkt, is hij aan de andere kant van mening dat "some of its provisions either constitute general principles of law or represent elementary considerations of humanity. Perhaps its greatest significance is that it provides an authoritative guide, produced by the General Assembly, to the interpretation of the provisions in the Charter. No doubt there is a great area of ambiguity, but the indirect legal effect of the Declaration is not to be underestimated, and it is frequently regarded as a part of the "law of the United Nations". ${ }^{184}$ Het standpunt van deze auteur is voor mij alleszins aanvaardbaar. Ik ben van mening, dat de Universele Verklaring een verplichting vormt voor de leden van de internationale gemeenschap, om de doelstellingen zoals opgenomen in het Charter van deze organisatie te verwezenlijken. Dit strookt met het standpunt van Sieghart, die van mening is dat de Universele Verklaring deel uitmaakt van het internationale gewoonterecht. ${ }^{185}$ Mardjono Reksodiputro brengt onder de aandacht dat in het jaar 1968 , tijdens een internationale conferentie inzake de mensenrechten te Teheran door de Verenigde Naties (VN) georganiseerd naar voren is gebracht, dat de Universele Verklaring "constitues an obligation for the members of the international community". Aangenomen kan derhalve worden, dat de Universele Verklaring deel uitmaakt van het internationale recht, tenminste van het internationale gewoonterecht en om die reden als eerste deel onder de "intemational Bill of Human Rights" is te brengen. ${ }^{186}$

Hoe moeten de in de Universele Verklaring opgenomen mensenrechten worden beschouwd? Opgemerkt kan worden, dat deze rechten direct het bestaan van een individu raken, aangezien zij existentiële garanties geven, zoals onder meer het recht op leven, op vrijheid, op onschendbaarheid van de persoon, om als persoon voor de wet te worden erkend, om een gezin te stichten. ${ }^{187}$

183. Ibid., p.124.

184. Brownlie, I, Principles of Public International Law, Oxford, 1990, p.570-571.

185. Sieghart, P., The Lawful Rights of Mankind, Oxford, 1986, p.64.

186. Mardjono Reksodiputro, Pemantauan Pelaksanaan Hukum tentang Hak-Hak Asasi Manusia, tijdschrift Hukum dan Pembangunan, 1991, p.545-559. Deze auteur brengt naar voren, dat met de "International Bill" de navolgende documenten van de VN zijn bedoeld;

a. Universele Verklaring van de rechten van de mens;

b. Internationaul Verdrag inzake economische, sociale en culturele rechten;

c. Internationaal Verdrag inzake burgerrechten en politieke rechten;

d. Facultatief Protocol bij het Internationaal Verdrag inzake burgerrechten en politieke rechten.

187. Teneinde het verschil tussen mensenrechten als inhoudelijke begrippen en koppelbegrippen te doen uitkomen, kan als voorbeeld de naturlijke persoon - gezien de hem toekomende existentiēle garanties - worden geplaatst tegenover de rechtspersoon, die als koppelbegrip kan worden beschouwd doordat deze laatste eerst in het rechtsverkeer functioneert, door de daaraan gekoppelde rechten en verplichtingen. Als ander voorbeeld van het onderscheid tussen koppelbegrip en mensenrecht als inhoudelijk begrip, kan het burgerlijk huwelijk tegenover het kerkelijk huwelijk worden geplaatst. Het eerste, voor de wet gesloten huwelijk is van belang voor de verschillende, daaraan vast te knopen rechtsgevolgen; het kerkelijk huwelijk wordt daarentegen door menige kerk als een sacrament gezien en heeft derhalve zelfstandige betekenis. 
Met betrekking tot het recht op een nationaliteit kunnen verschillende visies worden onderscheiden. Zo zegt de Groot dat het onlogisch is dat de nationaliteit in de Universele Verklaring is opgenomen, aangezien het recht op een nationaliteit op een volledig ander vlak ligt dan de andere daarin geformuleerde mensenrechten, die rechtstreeks het bestaan van het individu raken. Naar de mening van deze auteur is het recht op een nationaliteit minder essenticel; indien de Universele Verklaring beoogt het bezitten van een nationaliteit te garanderen, kan worden geconcludeerd dat die garantie betrekking heeft op een verrassingspakket. Volgens de Groot garandeert artikel 15 van de Universele Verklaring de rechtsgevolgen, die nationale en intermationale rechtssystemen in beginsel geheel naar eigen inzicht aan het bezit van cen nationaliteit vastkoppelen. De inhoud van het verrassingspakket kan door die rechtssystemen in beginsel zelf worden vastgelegd en gewijzigd, hetgeen het recht op een nationaliteit tot een dubieus mensenrecht maakt. ${ }^{188}$ Tratnik neemt het standpunt in, dat het weinig zinvol is, dat het recht op "een nationaliteit" in de gebezigde bewoordingen in de Universele Verklaring is opgenomen, aangezien een zo geformuleerde garantie de justitiabele niets brengt, zolang niet gezegd wordt op welke nationaliteit hij recht zou moeten hebben. ${ }^{189}$ Ook Ko Swan Sik gaat in op artikel 15 van de Universele Verklaring en merkt op dat in de daar omschreven betekenis van fundamentele rechten kan worden gesproken in de nationale of internationale rechtssfeer, welk onderscheid betrekking heeft op bron en op handhavingsmogelijkheden. Volgens deze auteur maakt het verschil in bron voor het individu weinig uit, wanneer hij zich bevindt in de (nationale) rechtssfeer van een Staat, waar internationale rechtsregels in het algemeen slechts van toepassing zijn na te zijn omgezet in nationaal recht. Daarentegen is hij van mening, dat het verschil in handhavingsmogelijkheden belangrijk is, voor zover het intemationale recht daarin voorziet. Deze auteur huldigt de opvatting, dat het alleszins mogelijk is van (onvolmaakte) subjectieve rechten te spreken, zonder dat aan de houder afdoende handhavingsmiddelen ter beschikking worden gesteld. ${ }^{190} \mathrm{Hij}$ wijst voorts erop, dat het begrip "fundamentele menselijke rechten" betrekking heeft op subjectieve rechten van het individu, hem in de hoedanigheid van mens dan wel in een bepaalde kwaliteit toegekend; deze rechten worden geacht het individu in essentie niet te kunnen worden ontnomen. ${ }^{191}$ Naar de mening van Ko Swan Sik ligt de functie van de nationaliteit echter slechts in het zijn van aanknopingspunt voor de toekenning van rechten en plichten. Imam Bardjo voert daartegen bezwaar aan, omdat dit zou betekenen dat de status van nationaliteit los dient te worden gezien van de rechten en plichten als staatsburger. ${ }^{12}$ Op deze wijze zou het kunnen voorkomen, dat een persoon burger is van een bepaalde Staat, terwijl hij (nog) geen rechten en plichten heeft. Imam Bardjo vraagt zich af of dit niet een "contradictio in terminis" is, aangezien een persoon als staatsburger wordt aangemerkt doch niet als een persoon, die rechten en plichten heeft. Volgens deze auteur komen rechten - en plichten - toe aan de mens "an sich", afgezien van het feit of die persoon al dan niet een nationaliteit heeft, waarvoor hij verwijst naar de Universele Verklaring van de Rechten van de

188. De Groot, Staatsangehörigkeitsrecht, p. 15. Zie ook de Groot en Tratrik, Nationaliteitsrecht, p.2.

189. Tratnik, Het Nationaliteitsrecht, p.40.

190. Ko Swan Sik, preadvies, p. 27.

191. Ko Swan Sik, preadvies, p. 27.

192. Imam Bardjo, Masaalah Kewargaan Negara Republik Indonesia, Semarang, 1958, p.26-27. 
Mens. ${ }^{193}$ Tot deze rechten behoort mijns inziens ook het recht op een nationaliteit. Ook van Panhuys wijst erop, dat krachtens artikel 15 van de Universele Verklaring, het recht op een nationaliteit als een mensenrecht is gekwalificeerd en dat dit artikel in de eerste plaats degenen, die geen nationaliteit bexitten, het recht geeft er te verkrijgen; artikel 15 geeft echter niet aan, welke Staat die nationaliteit dient te verlenen. Niettegenstaande zijn bedenkingen tegen de redactie van dit artikel, is zijn uitspraak van belang dat "the provision in its entirety, underlining that the right to a nationality is a fundamental right, gives countenance to the thesis that a contractual waiver of this right would run counter to intemational public order". ${ }^{19}$

Van groot belang is voorts de "Inter-American Convention on Human Rights", van kracht geworden op 18 juli 1978, het enige internationaal bindende instrument dat in artikel 20 een algemeen recht op een nationaliteit inhoudt en veel verder gaat dan de Universele Verklaring doordat het aan de contracterende Staten de verplichting oplegt om hun nationaliteit te verlenen aan iedere staatloze persoon op hun grondgebied geboren. De "Inter-American Court of Human Rights" heeft de belangrijke uitspraak gedaan, dat het recht op een nationaliteit een mensenrecht is, erkend in het intemationale recht, door het volgende te verklaren: "It is generally accepted today that nationality is an inherent right of all human beings. Not only is nationality the basic requirement for the exercise of political rights, it also has an important bearing on the individual's legal capacity. Thus, despite the fact that it is traditionnally accepted that the conferral and regulation of nationality are matters for each State to decide, contemporary developments indicate that international law does impose certain limits on the broad powers enjoyed by the States in that area, and that the manner in which States regulate matters bearing on nationality cannot today be deemed within their sole jurisdiction; those powers of the State are also circumscribed by their obligations to ensure the full protection of human rights. The classical doctrinal position, which viewed nationality as an attribute granted by the State to its subjects, has gradually evolved to the point that nationality is today perceived as involving the jurisdiction of the State as well as human rights issues. ${ }^{195}$ Een belangrijke ontwikkeling valt derhalve te constateren wat betreft de nationale autonomie van Staten, een onderwerp dat in $\$ 1.4$ aan de orde zal komen.

Ook Chan wijst op de uitspraak van de "Inter-American Court of Human Rights" dat "nationality is an inherent right of all human beings; the manners in which States regulate matters bearing on nationality could no longer be deemed within their sole jurisdiction, but are circumscribed by their obligations to ensure the full protection of human rights". 196 Een overeenkomstig standpunt wordt door Weis ingenomen, die opmerkt dat natioliteit nog de voomaamste verbinding tussen het individu en het internationale recht is; het is echter niet de enige verbinding. Er valt een toenemende

193. Bbid., p.27.

194. Van Panhuys, The rôle of Nationality, p.222.

195. Zie Chan, J.M.M., The right to a Nationality as a Human Right, The Current Trend towards Recognition, Human Rights Law Journal, 1991, p. I.

196. Ibid., p.5-6. 
tendens te constateren om de rechten van individuen - los van hun bescherming door de Staat van hun nationaliteit en zelfs in relatie tot deze Staat - te voorzien van waarborgen van internationaal recht door het sluiten van multilaterale verdragen voor de bescherming van de rechten van de mens. ${ }^{197}$ Van belang is ook het standpunt van Borchard, dat het individu in zijn hoedanigheid van menselijk wezen door alle Staten die lid van de internationale gemeenschap zijn, van bepaalde fundamentele rechten wordt voorzien, de "rights of man". ${ }^{198}$

Eén van de meest betekenisvolle veranderingen in de internationale betrekkingen is de toenemende bezorgdheid met betrekking tot mensenrechten, waarvan de snel groeiende omvang van het recht inzake mensenrechten in de internationale arena getuigt. Het op de voorgrond treden van dit recht en de snelle dekolonialisatie sedert de Tweede Wereldoorlog vereist een herwaardering van de positie van de nationaliteit in de nieuwe internationale rechtsorde. Chan geeft een overzicht van de verschillende pogingen om iedere persoon in het bezit van een nationaliteit te stellen en haalt in dit verband de Haagse Codificatie Conferentie van 1930 aan, die onder meer het Verdrag nopens zekere vragen betreffende wetsconflicten inzake nationaliteit en verschillende Protocollen inzake staatloosheid aannam. Alhoewel deze Conferentie op het praktische vlak niet veel bereikt heeft, lag het belang daarvan in de eerste internationale poging om problemen op te lossen die voortvloeien uit een conflict van nationaliteitsrecht, door het vaststellen van gemeenschappelijke standaards en gaf als zodanig de trend in de ontwikkeling van het internationale recht aan. ${ }^{199}$ Chan merkt op dat ondanks de vage formulering van artikel 15 van de Universele Verklaring en het ontbreken van een algemeen recht op nationaliteit daarin, het niettemin "a total innovation in the history of international law" betekent en "that it has since then acquired the status of customary international law" en in vele nationale rechterlijke beslissingen is aangehaald. Deze auteur zegt voorts het volgende: "If the right to a nationality is regarded as a fundamental human right, any deprivation resulting in statelessness could hardly be compatible with the "aims and objectives" of the Universal Declaration". ${ }^{200}$

\subsubsection{Ontneming van nationaliteit en het recht op expatriatie}

In het tweede lid van artikel 15 van de Universele Verklaring van de Rechten van de Mens is bepaald, dat aan niemand willekeurig zijn nationaliteit mag worden ontnomen. Met betrekking tot de term "willekeurig" kan worden opgemerkt dat deze term op verschillende manieren kan worden geïnterpreteerd. Vooraf dient erop te worden gewezen dat genoemd artikellid willekeurige denationalisatie verbiedt, zonder daarop echter een sanctie te stellen. Het is niet altijd zo eenvoudig om vast te stellen, wanneer van een willekeurig ontnemen van de nationaliteit aan een persoon kan worden gesproken. Zo spreekt Verdoodt van een willekeurige ontneming wanneer dit in strijd met de

197. Weis, Nalionality, p. 245 .

198. Borchard, The Diplomatic Protection, p. 12.

199. Chan, The right to a Nationality, p.2. Het Haagse Verdrag van 1930 is opgenomen in Trb. 1967, 73.

200. Chan, The right to a Nationality, p. 3 . 
wet is geschied, een opvatting naar de mening van Tratnik als te beperkt aan te merken. ${ }^{201}$ Laatstgenoemde auteur gaat er in casu vanuit, dat in het geval een nationale wetgeving aan een staatsorgaan onbeperkte discretionaire bevoegdheid verleent en de gronden voor ontneming in het geheel niet of uiterst vaag in de wet zijn geformuleerd, de ontneming zelden of nooit in strijd met de wet zal zijn, aangezien de wet zélf willekeurig is. ${ }^{202}$ Teneinde te voorkomen dat van een willekeurig ontnemen van een nationaliteit aan een persoon zou kunnen worden gesproken, dienen in het nationaliteitsrecht van Staten de daartoe te hanteren criteria niet alleen te worden opgenomen doch ook zorgvuldig te worden omschreven en dient het voorts criteria te betreffen, van voldoende gewicht om als zodanig te kunnen worden gehanteerd. Sprake zal zijn van een willekeurige ontneming van de nationaliteit, indien dezelfde handeling in het ene geval wél en in het ander geval niet tot een als hierbedoelde ontneming leidt. Dit hangt mede af van de in de wet voorkomende omschrijving. Wordt in de wet niet gesteld, dat tot ontneming van de nationaliteit wordt overgegaan in bepaalde daarin nauwkeurig gestipuleerde gevallen, doch daarentegen dat tot ontneming $k a n$ worden overgegaan, dan laat laatstgenoemde omschrijving de mogelijkheid open om in het ene geval wél en in het andere geval niet tot ontneming over te gaan. Hiernaast is het mogelijk dat de gronden voor ontneming - indien niet nauwkeurig omschreven - verschillend kunnen worden geinterpreteerd. Ook dit zou tot willekeurige ontneming van de nationaliteit kunnen leiden.

Bij niet willekeurige ontneming kan een nationaliteit verloren gaan door een handeling van de Staat - ontneming van nationaliteit of denationalisatie - of door een handeling van de staatsburger. Een bepaalde situatie of een bepaald gedrag van de staatsburger zoals het zonder toestemming van de Overheid treden in vreemde krijgsdienst heeft ipso facto verlies van nationaliteit ten gevolge of het kan een individuele handeling van de Staat vereisen, zoals ontneming van nationaliteit als strafmaatregel. Ook langdurig verblijf in het buitenland kan als een daad van "disloyalty" worden opgevat en hetzij tot het van rechtswege verloren gaan van de nationaliteit, hetzij tot ontneming van deze nationaliteit leiden. ${ }^{203}$ In de hierbedoelde gevallen is mijns inziens van een willekeurige ontneming van de nationaliteit - voor zover deze niet van rechtswege verloren gaat - geen sprake, indien de reden van de ontneming nauwkeurig in de wet is omschreven.

Chan merkt voorts op, dat alhoewel algemene eensgezindheid bestaat met betrekking tot de regel dat aan niemand willekeurig zijn nationaliteit kan worden ontnomen, verschillende landen er uiteenlopende visies op na houden met betrekking tot het begrip "willekeurig". Geen enkele Staat zal een willekeurige ontneming van nationaliteit loegeven; ontneming wordt altijd gerechtvaardigd als een gepaste reactie op bepaalde feiten. Aan de andere kant variëren de waarborgen tegen een "willekeurige" beslissing

201. Verdoodt, A., Naissance et Signification de la Déclaration Universelle des Droits de l'Homme, Louvain/Paris, 1964, p. 160.

202. Tratnik, Het Nationaliteitsrecht, p.41-42.

203. Weis, Nationality, p.115-116. 
van land tot land. ${ }^{204}$ De gronden tot ontneming dienen niet alleen nauwkeurig in de wet te zijn omschreven doch ook voldoende gewicht te hebben, wil een ontneming niet als willekeurig worden getypeerd. Voorts dient dit eerst plaats te vinden na inachtneming van de gebruikelijke waarborgen, aan de staatsburger bij wettelijke maatregel geboden. Zo kan ontneming van nationaliteit plaatsvinden indien een handeling van de staatsburger een ernstige bedreiging vormt voor de nationale veiligheid van de Staat. ${ }^{200}$ Ontneming van nationaliteit is voorts aanvaardbaar wanneer verkregen door fraude of bedrog. ${ }^{206}$ In beginsel dient ervoor te worden gewaakt dat ontneming van nationaliteit niet tot staatloosheid leidt, maar uit de statenpraktijk blijkt dat hieraan niet strikt de hand wordt gehouden. ${ }^{201}$

In enkele landen kan vervallenverklaring van de nationaliteit als strafmaatregel plaatsvinden ten aanzien van personen die deze nationaliteit anders dan door geboorte jure sanguinis bezitten. ${ }^{208}$ De achtergrond hiervan ligt in de overweging, dat de verkregen nationaliteit wordt geacht niet voldoende te worden gewardeerd door de betrokken personen. In andere landen bestaat een aparte mogelijkheid van ontneming van de nationaliteit aan genaturaliseerde personen, buiten gevallen van fraude bij de naturalisatieprocedure. ${ }^{209}$ Hieruit kan worden afgeleid, dat aan het gedrag van als hierbedoelde staatsburgers zwaardere eisen worden gesteld, dan aan het gedrag van degenen die de nationaliteit van het land in kwestie van rechtswege verwierven c.q. bij eerstgenoemde personen eerder grove veronachtzaming van staatsburgerrechtelijke verplichtingen wordt verondersteld, dat in feite neerkomt op discriminatie.

204. Chen, The right to a Nationality, p.8.

205. Als voorbeeld kan worden genoemd, dat krachtens de Marokkanse Nationaliteitswet van 1958, vervallenverklaring van de Marokksanse nationaliteit - als strafmastregel - kan plaatsvinden ten anzien van personen die deze nationaliteit niet door geboorte besitten en die zich op enigerlei wijze het bezit van het Marokkannse staatsburgerschap onwardig hebben betoond (artikel 22), bijvoorbeeld door een delict tegen de veiligheid van de Stast, tegen de Koning of een ander lid van het Koninklijk Huis, of door een ernstig commun delict. Adriaanse en van der Weg, Nationaliteitswetgeving.

206. Krachtens de Wet no. 62 van 1958 betreffende het Indonesisch staatsburgerschap kan dit staatsburgerschap worden ingetrokken, indien verkregen op grond van onjuiste gegevens (artikel 19).

207. Ofschoon krachtens de Indonesische nationaliteitswet geen ontneming van het statsburgerschap als strafmaatregel kan plaatsvinden, leidt in enkele gevallen krachtens de daarin opgenomen verliesgronden het verloren gaan van het Indonesische staatsburgerschap tot staatloosheid. Dit is bijvoorbeeld het geval indien stantsburger zonder toestemming van de Overheid in vreemde krijgs- of startsdienst treedt en in enkele andere gevallen, waaronder het zweren van trouw aan een buitenlandse mogendheid.(artikel 17 sub f., g., h., i. en j. van de Wet)

208. Dit is bijvoorbeld het geval ten anzien van de Marokkanse nationaliteit in de in de wet gestipuleerde gevallen.

209. Zie biervoor de Thaise Nationaliteitswet van 1965; de Thaise nationaliteit van personen die deze nationaliteit hebben verkregen door naturalisatie kan worden herroepen onder meer in gevallen de desbetreffende persocon handelt in strijd met de veiligheid of de belangen van de Staat, of de goede nasm van bet volk in diskrediet brengt dan wel in strijd met de openbare orde of goede zeden handelt (artikel 19). Zie Adriaanse en van der Weg, Nationaliteitswetgeving. 
Gezien de status van het recht op nationaliteit als mensenrecht, houdt dit conform artikel 15 lid 2 van de Universele Verklaring in, dat aan niemand (willekeurig) het recht mag worden ontzegd, van nationaliteit te veranderen. Dit expatriatierecht wordt vaak als een fundamenteel menselijk recht voorgesteld. Van Panhuys brengt naar voren dat het hier een recht van het individu betreft om zijn nationaliteit op te geven en zijn nieuw verkregen nationaliteit erkend te krijgen. Hij is van mening dat het recht tot expatriatie wel het meest substantiele recht is, door artikel 15 geboden. ${ }^{210} \mathrm{Er}$ is geen reden om te veronderstellen, dat een persoon onherroepelijk gebonden zou zijn aan een nationaliteit, wanneer hij niet het minste verlangen heeft deze nationaliteit te behouden. Het recht om van nationaliteit te veranderen is dan ook een essentieel aspect van de menselijke waardigheid.

Er schijnt algemene eensgezindheid te bestaan, dat een ieder het recht heeft van nationaliteit te veranderen. ${ }^{211}$ Kan hiermede worden volstaan? Of kan het expatriatierecht van het individu worden beperkt door het stellen van voorwaarden dan wel afhankelijk worden gesteld van het door betrokkene vervuld hebben van bepaalde verplichtingen? Ik onderschrijf het standpunt van de "International Law Association" ${ }^{212}$, dat het expatriatierecht in principe moet worden aanvaard. Alhoewel een "allégeance perpétuelle" in de praktijk niet meer bestaat, wordt het expatriatierecht niet algemeen erkend doch is aan voorwaarden verbonden. Hiervan kan worden genoemd, dat de persoon in kwestie zijn gewoon verblijf buiten de Staat waarvan hij de nationaliteit wil verliezen dient te hebben. ${ }^{213}$ Ook kan het voorkomen dat een persoon eerst van de nationaliteitsband verlost wordt, indien hij binnen een bepaalde termijn een andere nationaliteit verkrijgt. ${ }^{214}$ In andere landen, heeft vrijwillige verkrijging van een andere nationaliteit het verlonen gaan van de oorspronkelijke nationaliteit ten gevolge. ${ }^{215}$ Een algemene voorwarde die in de meeste landen geldt, is hierin

210. Van Panhuys, The róle of Nationality, p.222.

211. In dit verband kunnen de Verenigde Staten worden genoemd, die als immigratieland altijd groot belang hebben gehecht aan het expatriatierecht. De Wet van 27 juli 1868 proclameerde: "Whereas the right of expatriation is a natural and inberent right of all people, indispensable to the enjoyment of the rights of life, liberty and the pursuit of happiness..." Zie Ko Swan Sik, De Meervoudige, p.53 e.v.

212. Zie Report of the 33rd Conference (1924), p.32.

213. Zo wordt in de Indonesische nationaliteitswet onderscheid gemaakt tussen het geval dat de betrokkea persoon zich nog in Indonesiē of dearbuiten bevindt. In het cerste geval gant de nationaliteit van betrokkene - die vrijwillig een andere nationaliteit beeft verkregen - eerst verloren indien deze nationaliteit verloren gegaan wordt verklasd door de daartoe competente autoriteit en hangt het derhalve van de Overheid af, of expatriatie wordt toegestaan.

214. Het betreft hier een voonwaarde gesteld in artikel 7 van bet Hangse Vendrag van 1930 dat onder meer inhoudt, dat het verlof tot uittreden uit het stantsverband - voor zover dit in een wetgeving wordt voorzien - vervalt, indien de houder een nieuwe nationaliteit niet verkrijgt binnen de tenmijn, welke is vastgesteld door de Stant, die het verlof heeft verleend.

215. Dit is onder meer bet geval krachtens de Rijkswet op het Nederlanderschap. In het wetsvoorstel tot aanpassing van deze Rijkswet dat door de bewindslieden van Justitie voor advies naar de Raad van State is gestuurd, is echter de bepaling opgenomen dat Nederlanders die een andere nationaliteit knjgen niet langer automatisch hun Nederlanderschap verliezen. Dit impliceert, da indien de 
gelegen, dat verlies van de oorspronkelijke nationaliteit niet tot staatloosheid mag leiden. ${ }^{216}$ Ook kan het recht op verandering van nationaliteit afhankelijk wordt gesteld van het voldoen aan de verplichtingen tegenover de Staat wiens nationaliteit een persoon wenst te verliezen, bijvoorbeeld het hebben vervuld van zijn militaire dienstplicht. ${ }^{217}$ Verkrijging van een andere nationaliteit door een persoon kan voorts afhankelijk worden gesteld van het niet in strijd zijn met het internationale recht. ${ }^{218}$

Met betrekking tot het recht tot expatriatie zegt Weis: "Such a right can only be said to exist if the State of former nationality is, by international law, under an obligation to discharge a national from its nationality upon his acquisition of another nationality. Such a duty exists within the described limits provided the acquisition of the new nationality is in accordance with international law, and has taken place bona fide. Any national law or administrative practice prohibiting such change of nationality or denying discharge from nationality although the aforementioned conditions have been fulfilled, is irrelevant from the point of view of international law and does not have to be recognised by other States". 219

Alhoewel van een algemeen geldend volkenrechtelijk expatriatierecht nog niet kan worden gesproken, is het idee jure constituendo alleszins te verdedigen. Tot welke paradoxale situaties expatriatie in de ruime zin van het verlaten van het land en doorsnijding van de bestaande banden kan leiden, werd aangetoond door de vluchtelingenstroom uit Vietnam; een land dat expatriatie aanmoedigde, althans toestond en pogingen van andere Staten om die Staat op zijn plicht te wijzen zijn bevolking ervan te weerhouden het land te verlaten.

215. $\rightarrow$

betrokken personen nog een binding met Nederland hebben, zij hun Nederlanderschap kunnen behouden. Hierdoor is de mogelijkheid gecrēerd tot het bezitten van een dubbele nationaliteit. Aldus het NRC Handelsblad van 3 september 1992.

216. Dit geldt ook voor Indonesiè.

217. Dit was bijvoorbeeld het geval krachtens de Belgische nationaliteitswet van 1932, artikel 18 lid 1 , tweede zin jo. de wet van 4 augustus 1926, artikel 16. Zie Ko Swan Sik, De Meervoudige, p.53. Om krachtens de thans vigerende Belgische nationaliteitswet, op 1 januari 1985 van kracht geworden, de staat van Belg te verliezen bij vrijwillige verknijging van een vreemde nationaliteit - waartoe de belanghebbende de leeftijd van 18 jaar dient te hebben bereikt - dient die persoon die nog dienstplichtig is voor het actieve of het reserveleger, daartoe door de Koning te worden gemachtigd. Zie Adriaanse en van der Weg, Nationaliteitswetgeving.

218. Als voorbeeld moge dienen, het geval van onrechtmatige occupatie van een bepaald gebieds(deel), waarbij de occuperende Staat zijn nationaliteit oplegt aan de inwoners van dat gebied - die daardoor mogelijkerwijze de staat van bipatride kunnen krijgen - hetgeen in strijd is met het intemationale recht. Deze aangelegenheid zal in $\$ 1.5 .4$ aan de orde komen.

219. Weis, Nationality, p. 134. Deze auteur brengt naar voren, dat dit het standpunt was van internationale tribunalen in de Salem-zaak en de zaak van Apostolides versus de Turkse overheid, ook ingenomen door nationale gerechtshoven en door auteurs ondersteund. Zie voor de Salem-zaak tussen de Verenigde Staten en Egypte, U.N. Reports, vol.II, p.1161; Annual Digest, 1931-32, Case No.98. Voor de zaak van Apostolides versus de Turkse overheid zie Recueil T.A.M., vol.VIII, p.373; Annual Digest, 1927-28, Case No.207. 
Niettegenstaande ik van mening ben, dat het expatriatierecht in principe dient te worden aanvaard c.q. van het bestaan van een "allégeance perpétuelle" tussen een persoon en het land waarvan de nationaliteit bezit, geen sprake is, betekent dit niet dat een persoon zich ten allen tijde van zijn nationaliteit kan ontdoen, enkel en alleen met de opzet om zich aan zijn verplichtingen tegenover Staat zoals het betalen van belasting dan wel het verrichten van dienstplicht, te onttrekken.

\subsubsection{Gevolgen van het typeren van het recht op een nationaliteit als mensenrecht}

De vraag kan worden gesteld, wat de rechtsgevolgen zijn van het typeren van het recht op een - bepaalde - nationaliteit als mensenrecht. Evenals de andere, in de Universele Verklaring genoemde mensenrechten betreft het hier een existentieel recht, aan het individu verleend in zijn hoedanigheid van mens, dat wordt geacht het individu niet te kunnen worden ontnomen. Dit heeft tot consequentie, dat het ontzetten van een individu uit zijn nationaliteit, de "Ausbürgerung" als een schending van dit recht is aan te merken. Door Tribe wordt ontneming van nationaliteit als een "cruel and unusual punishment" getypeerd ${ }^{220}$, die maar al te vaak terdege wordt gevoeld, hetgeen niet het geval zou zijn als het hier om een "dubieus"mensenrecht zou gaan!

Een andere aangelegenheid betreft de vraag, wanneer onderscheid naar nationaliteit als geoorloofd c.q. wenselijk is te beschouwen en wanneer bedoeld onderscheid als onaanvaardbaar, als discriminatie is aan te merken. Het stellen van deze vraag heeft slechts zin, indien ervan wordt uitgegaan dat het recht op een nationaliteit een mensenrecht is. Met andere woorden: deze vraag komt niet aan de orde, indien de nationaliteit niet als een inhoudelijk begrip - van belang voor het typeren van het recht op een nationaliteit als mensenrecht - maar enkel als een koppelbegrip wordt gezien. Mijns inziens is het billijk te achten, dat aan de eigen staatsburgers rechten - naast verplichtingen - toekomen, die aan buitenlanders worden onthouden, zonder dat daarbij van discriminatie sprake is. Ik sluit mij aan bij de mening van Breukelaar, die met betrekking tot deze aangelegenheid concludeert, dat mensenrechtenverdragen ten principale geen verbod inhouden om in wetgeving onderscheid te maken tussen de eigen staatsburgers en vreemdelingen, alsmede dat van een principiële gelijkstelling van vreemdelingen met de eigen staatsburgers als uitgangspunt voor wet- en regelgeving geen sprake is. ${ }^{221}$

Met betrekking tot deze aangelegenheid kan worden verwezen naar het reeds genoemde VN-verdrag inzake de uitbanning van alle vormen van rassendiscriminatie van 7 maart 1966. Voor het hier behandelde onderwerp is het in genoemd artikel 5 onder d. sub III

220. Tribe, L.H., American Constitutional Law, New York, 1978, p.567-568.

221. Breukelaar, W., Onderscheid naar Nationaliteit, Discriminatie, NCJM-bulletin, 1984, p.341. Deze auteur wijst op het feit, dat voor wat betreft artikel 14 van het Europese Verdrag, de Europese Commissie voor de rechten van de mens zelfs heeft uitgemaakt, dat de status van vreemdeling op zichzelf een objectieve en redelijke rechtvaardigheid kan vormen voor een onderscheid ten opzichte van staatsburgers ter zake van de uitoefening van de verdragsrechten. 
van dit Verdrag bepaalde van belang, dat een uitdrukkelijk vertod van rassendiscriminatie met betrekking tot het recht op nationaliteit inhoudt.

Alhoewel Indonesiē geen partij is bij genoemd verdrag, wordt aan de uitbanning van rassendiscriminatie de nodige aandacht geschonken door de Indonesische overheid. Zo is inmiddels - althans juridisch - afgestapt van het voorheen gemaakt onderscheid tussen autochtone en niet-autochtone Indonesiërs, waarvoor thans het begrip "Indonesisch staatsburger" in de plaats is getreden. Dit is van officièle zijde, met name door de Minister van Justitie met diens Rondschrijven van 28 augustus 1965 benadrukt. ${ }^{2 m}$ Bovendien kan worden gewezen op artikel 1 van het Presidentiële Besluit no. 240 van het jaar 1967, waarin uitdrukkelijk is gesteld dat Indonesische staatsburgers van vreemde origine een gelijkwaardige positie in het staatsrecht innemen als staatsburgers, die deel uitmaken van de autochtone bevolking. In artikel 2 van dit Besluit is in aansluiting hierop bepaald, dat Indonesische staatsburgers van buitenlandse afkomst deel uitmaken van het Indonesische volk en niet in rechten en verplichtingen van andere, hiertoe behorende personen verschillen. Artikel 4 van het onderhavige Presidentiële Besluit bepaalt vervolgens, dat verschil in behandeling tussen Indonesische staatsburgers van vreemde origine en Indonesische staatsburgers die tot de autochtone bevolking behoren, ongedaan wordt gemaakt en niet wordt goedgekeurd. ${ }^{23}$ Het beleid met betrekking tot eerstgenoemde staatsburgers wordt gevoerd middels een assimilatieproces, voornamelijk om het ontstaan van een exclusief raciaal leven te voorkomen. ${ }^{24}$ In dit verband worden in het bijzonder personen, die van deze categorie deel uitmaken en Chinese namen voeren, "aanbevolen" om hun namen te vervangen door Indonesische namen in overeenstemming met de geldende bepalingen (artikel 5). ${ }^{225}$ Een kritische opmerking met betrekking tot deze aangelegenheid is hier zeker op zijn plaats, aangezien aan bedoelde personen het recht op het voeren van hun eigen naam wordt ontnomen. In dit verband kan worden gewezen op het in $\$ 1.3 .3 .2$ reeds aan de orde gekomen Verdrag inzake de Rechten van het Kind van 20 november 1989, ook door Indonesië ondertekend. Zo is in artikel 7 bepaald, dat het kind vanaf de geboorte onder meer het recht heeft op een naam. Artikel 8 van dit Verdrag bepaalt bovendien, dat de

222. Het betreft hier het Rondschrijven no. D.T.C./14/15 van 28 augushus 1965 aan alle voorzitters van de "Pengadilan Negeri's" in gebeel Indonesiê gericht.

223. Krachtens artikel 6 lid 1 van de Grondwet van 1945, Engelbrecht p.1, dient de President aiettemin een autochtone Indonesièr te zijn.

224. Zie in dit verband, Tubagus Pranata Tirtawidjaja, Jus Sanguinis dan Dwi-kewarganegaraan di Indonesii, opgenomen in Mimbar Departemen Kehakiman, Jakarta, 1969, die erop wijst dat Indonesie behoefte heeft an een actieve assimilatiepolitiek teneinde tot een homogene natie te komen en als zodanig de uit het koloniale tijdperk daterende raciale discriminatie teniet te doen. Zie ook de door het Indon. Departement van Binnealandse Zsken uitgegeven Himpunan peraturan perundang-undangan tentang kewarganegaran, ascimilasi dan orang asing, Jakarta, 1978.

225. Met betrekking tot de groep der Chinezen kan worden opgemerk, dat in de loop der tijd verschillende regelingen voor dexe groep zijn afgekondigd, die niet alleen de nationaliteit betreffen, maar ook andere regelingen inzoke onder meer de beperking van hun handelsactiviteiten en hun scholen. De reden dartoe is wellicht hierin gelegen, dat de groep der Chinezen de grootste minderheid in Indonesiê is en bovendien actief is op diverse gebieden van bet bedrijfsleven. Een groot deel van deze personen is inmiddels Indonesisch statsburger geworden. 
tot dit Verdrag toegetreden Staten zich onder meer verbinden tot eerbiediging van het recht van het kind om zijn of haar identiteit te behouden, met inbegrip van naam zoals wettelijk erkend, zonder onrechtmatige inmenging. ${ }^{226}$ Voornoemde "aanbeveling" geldt voorts niet voor andere Indonesische staatsburgers van vreemde origine.

\subsubsection{Conclusie}

In het voorgaande werd in eerste instantie ingegaan op het onderscheid tussen de nationaliteit als koppelbegrip dan wel als inhoudelijk begrip. Laatstgenoemd begrip kan - vanwege het nauw verweven zijn van enkele belangrijke fundamentele rechten met het bezit van een nationaliteit - ook van belang worden geacht voor het karakteriseren van het recht op een nationaliteit als mensenrecht. Het gaat bij het typeren van de nationaliteit als inhoudelijk begrip of als koppelbegrip echter slechts om een gedachtenconstructie; het karakteriseren van het recht op een nationaliteit als mensenrecht ligt daarentegen op een veel hoger niveau, aangezien het dan gaat om een existentieel recht dat rechtstreeks het bestaan van een individu raakt, evenals andere mensenrechten als het recht op leven, op vrijheid.

Dat het recht op een - bepaalde - nationaliteit een mensenrecht is, blijkt bovendien uit hetgeen in artikel 15 van de Universele Verklaring van de Rechten van de Mens en in de andere hierboven geciteerde Verdragen is bepaald. Wat betreft het rechtskarakter van eerstgenoemd document kan worden geconcludeerd, dat de Universele Verklaring deel uitmaakt van het internationale recht, op zijn minst van het internationaal gewoonterecht en de waarborging van de daarin opgenomen rechten - waaronder het recht op nationaliteit - derhalve een verplichting vormt voor de leden van de internationale gemeenschap. Van de verdragen die in mijn betoog aan de orde zijn gekomen, kan vooral de "InterAmerican Convention on Human Rights" - het enige internationaal bindend instrument van belang worden geacht, dat in artikel 20 een algemeen recht op een nationaliteit inhoudt en derhalve veel verder gaat dan de Universele Verklaring.

Het typeren van het recht op een nationaliteit als mensenrecht houdt voorts in, dat het willekeurig ontnemen aan een persoon van diens nationaliteit als een schending van dit recht is aan te merken en dat aan niemand (willekeurig) het recht mag worden ontzegd van nationaliteit te veranderen c.q. dit expatriatierecht vaak als een fundamenteel menselijk recht wordt voorgesteld. Is discriminatie, algemeen gesteld, ontoelaatbaar, ook het kenmerken van het recht op een nationaliteit als mensenrecht houdt in, dat discriminatie op grond van nationaliteit niet geoorloofd is c.q. zou mogen zijn.

226. Zie ook het door de Groot genoemde voorbeeld inzake de familienaam van een persoon; dit geeft niet alleen aan dat een persoon tot een bepaalde familie behoort, maar ook dat die persoon boogst persoonlijk recht op zijn nasm heeft. 


\subsection{De nationale autonomie en volkenrechtelijke beperkingen}

In het hieronder volgende zal de nationale autonomie van Staten om de nationaliteit van hun burgers te regelen aan de orde komen. Het recht van Staten om zelf een regeling te treffen met betrekking tot de nationaliteit van hun burgers kan echter onderhevig zijn aan volkenrechtelijke beperkingen. Deze beperkingen kunnen voortvloeien uit het internationale gewoonterecht; daarnaast kan ook sprake zijn van zelf opgelegde beperkingen middels het sluiten van verdragen. In het kader van de behandeling van de beperkingen van de nationale autonomie als hiervoor bedoeld, zal enige aandacht worden besteed aan de behandeling van de zogenaamde "genuine link" theorie waarbij de vraag aan de orde zal komen, of en in hoeverre met deze theorie rekening dient te worden gehouden bij de vaststelling van de nationaliteit van een bepaalde persoon. Van belang is voorts, dat in de statenpraktijk meer en meer de tendens is waar te nemen tot het waarborgen van de mensenrechten en deze aangelegenheid een steeds belangrijkere rol gaat spelen, waarin een verdere inperking van de nationale autonomie van Staten kan zijn gelegen.

\subsubsection{De nationale autonomie van Staten}

Voor de vaststelling van nationaliteit voor internationale doeleinden, verwijst het internationale recht naar het nationale recht; het laat aan iedere Staat over om in zijn eigen wetten vast te stellen wie zijn burgers zijn, vooropgesteld dat deze wetten vallen binnen de beperkingen die het internationale recht vaststelt. Von Mangoldt is van mening, dat het recht om een nationaliteit te verlenen niet moet worden gezien als een gedelegeerde bevoegdheid van de Staat; verlening van nationaliteit is deel van het "domaine réservé" van de Staat in kwestie. ${ }^{27}$ De verlening van nationaliteit is derhalve één van de onderwerpen die wordt beschouwd binnen de interne legislatieve bevoegdheid van een individuele Staat te vallen. Deze regel is zowel in het internationale gewoonterecht en het conventionele intemationale recht erkend. In dit verband kan worden gewezen op hetgeen in artikel 1 van het Haagse Verdrag nopens zekere vragen betreffende wetsconflicten inzake nationaliteit van 12 april 1930 is bepaald, dat luidt als volgt: "Het behoort tot de bevoegdheid van iedere Staat in zijn wetgeving te bepalen, wie zijn onderdanen zijn. Deze wetgeving moet door de andere Staten worden erkend, voor zover zij in overeenstemming is met de intemationale verdragen, de internationale gewoonte en de algemeen erkende rechtsbeginselen ter zake van de nationaliteit". Artikel 2 voegt hieraan het volgende toe: "ledere vraag of een persoon de nationaliteit van een Staat bezit, moet worden beantwoord overeenkomstig de wetgeving van deze Staat". ${ }^{228}$ Het betreft hier het beginsel van de nationale autonomie dat inhoudt, dat iedere Staat in beginsel uitsluitend bevoegd is te bepalen wie zijn onderdanen zijn. Dit impliceert, dat het een Staat niet toegestaan is om te bepalen, wie er wel of niet de nationaliteit van een andere Staat bezit. Het exclusiviteitsbeginsel houdt voorts in, dat

227. Von Mangoldt, H., Anerkennung der Stratsangebönigkeit und effektive Staatsangehörigkeit natürlicher Personen im Völkerrecht und im Internationalen Privatrecht, Heidelberg, 1988, p.96.

228. Zie voor de Nederlandse tekst van dit verdrag, Brinkman, C.J., de Nederlandse Nationaliteitswetgeving, Zwolle, 1985. 
iedere Staat het recht heeft om personen met een meervoudige nationaliteit die tevens zijn nationaliteit bezitten, uitsluitend als zijn eigen onderdanen te behandelen. Hicruit vloeit voort, dat een Staat bevoegd is om het feit dat Gén van zijn onderdanen tevens een vreemde nationaliteit bezit, te negeren. ${ }^{229}$ De Staat om wiens nationaliteit het gaat, behoeft geen soevereine Staat te zijn; het feit of de Staat al dan niet onbeperkte soevereiniteitsrechten toekomen is van geen belang. ${ }^{230}$

\subsubsection{Beperking van de nationale autonomie van Staten}

De nationale autonomie van Staten om regels te stellen inzake de verkrijging en het verloren gaan van de nationaliteit van zijn burgers kan onderhevig zijn aan diverse beperkingen, die hieronder nader in beschouwing zullen worden genomen.

\subsubsection{Beperking door het internationale gewoonterecht en door algemene rechtsbe- ginselen}

Een hele scala van uiteenlopende meningen is te onderscheiden met betrekking tot het erkennen van het bestaan van volkenrechtelijke beperkingen ten aanzien van de nationale autonomie ter regeling van een nationaliteit.

Zo kan worden verwezen naar het naar aanleiding van de Haagse Codificatie-conferentie uitgewerkte ontwerp van een Nationaliteitsverdrag door de "Harvard Law School" 231, waarin de beperking echter niet precies is gedefinieerd, doch in artikel 2 slechts is gesteld, dat "under international law the power of a State to confer its nationality is not unlimited". ${ }^{232}$ In een commentaar op dit artikel staat onder meer te lezen: "It may be difficult to precise the limitations which exist in international law upon the power of a State to confer its nationality.... Yet it is obvious that some limitations do exist. They are based upon the historical development of intemational law and upon the fact that different States may be interested in the allegiance of the same natural person. If State A should attempt, for instance, to naturalize persons who never had any connection with State A, who have never been within its territory, who have never acted in its territory, who have no relation whatever to any persons who have been its nationals, and who are nationals of other States, it would seem that State A would clearly have gone beyond the limits set by international law...." 233

Uit het bovenstaande kan worden afgeleid, dat het recht van Staten om de nationaliteit van hun burgers te regelen - los gezien van verplichtingen die uit verdragen voortvloei-

229. Tratnik, Het Nationaliteitsrecht, p. 37

230. Makarov, Allgemeine Lehren, p.32.

231. Supplement to the American Joumal of International Law, Vol. 23, Special Number, April 1929. 13. Het betreft hier het voorontwerp van bet Haagse Verdrag van 1930 (Verdrag van 's-Gravenhage van 12 april 1930 nopens zekere vragen betreffende wetsconflicten inzake nationaliteit, Trb. 1967. 73).

232. Makarov, Algemeine Lehren, p.70.

233. Makarov, Allgemeine Lehren, p.70-71. 
en - niet absoluut en onbeperkt is. Het in artikel 1 van het Haagse Verdrag van 1930 bepaalde - in $\$ 1.4 .1$ aangehaald - geeft aan, dat de bevoegdheid van iedere Staat om in zijn wetgeving te bepalen wie zijn onderdanen zijn, door andere Staten dient te worden erkend "voor zover zij in overeenstemming is met internationale verdragen, de internationale gewoonte en de algemeen erkende rechtsbeginselen ter zake van de nationaleit". Gesteld kan derhalve worden dat de nationale autonomie van Staten om bepalingen vast te stellen inzake de nationaliteit van hun burgers onder meer beperkt is door principes en regels van het internationale gewoonterecht. Weis brengt ter zake onder de aandacht, dat overeenstemming van het nationale recht van Staten nog niet het creëren van internationaal gewoonterecht ten gevolge heeft; daartoe is universele eenstemmigheid van opinie van Staten noodzakelijk. Naar de mening van deze auteur is het onjuist te trachten regels van internationaal recht vast te stellen door middel van methodes van rechtsvergelijking, of door te verklaren dat regels van het nationale recht van verschillende Staten, die een zekere mate van uniformiteit aantonen, regels van internationaal recht zijn. ${ }^{234}$ Verkrijging en verlies van nationaliteit wordt bepaald door het nationale recht van de Staat in kwestie. Dit nationale recht moet verenigbaar zijn met het internationale recht. De algemene regels van het intemationale recht, in het bijzonder die regels betreffende soevereiniteit - waarvan onafhankelijkheid, territoriale en persoonlijke suprematie ${ }^{235}$ de elementen vormen - extraterritorialiteit en dergelijke hebben bepaalde effecten op het nationaliteitsrecht van Staten. ${ }^{236} \mathrm{Zo}$ is het essentieel om het recht van iedere Staat om de verkrijging en het verlies van zijn nationaliteit door zijn eigen wetgeving te regelen te erkennen; het regelen van de nationaditeit is echter onderworpen aan het voorbehoud dat de soevereine rechten van andere Staten zoveel mogelijk zullen worden gerespecteerd.

De algemene principes van het recht, erkend door geciviliseerde Staten voorzien, als op elk ander vlak van het internationale recht, in een aanvullende bron van recht, naast intemationale verdragen en gewoonte. Verdragen die door een groot aantal Staten zijn geratificeerd, zijn het bewijs van de statenpraktijk en helpen als zodanig het intemationale gewoonterecht te vormen. De waarde van de resultaten van het Haagse Verdrag overstijgt derhalve de intrinsieke betekenis van de intemationale conventionele documenten die tot stand zijn gekomen. Het is volgens Weis slechts in deze betekenis dat van internationaal recht van de nationaliteit mag worden gesproken. Dit recht omvat naast verdragen - die regels van internationaal recht, die als uitvloeisel van bepaalde principes van het internationale recht van invloed zijn op aangelegenheden van nationaliteit. Deze regels worden zowel afgeleid uit internationale gewoonte als uit algemeen erkende principes van het recht. Aangezien deze regels niet rechtstreeks resulteren in de verkrijging van nationaliteit of verlies daarvan veroorzaken, is het om die reden naar de mening van Weis meer op zijn plaats te spreken van "zogenaamd" intemationaal recht van nationaliteit. ${ }^{237}$

234. Weis, Nationality, p.96.

235. Personele suprematie is het door een Staat over zijn burgers, waar deze zich ook bevinden, uitgeoefende gezag.

236. Weis, Nationality, p.88-89.

237. Weis, Nationality, p. 89 . 
Terwijl het niet voldoende is het principe van automatisch verlies van nationaliteit bij verkrijging van een nieuwe nationaliteit als principe van het internationale recht te stellen, wordt aangenomen dat de praktijk het recht van Staten beperkt om het verloren gaan van hun nationaliteit te weigeren bij de verkrijging van een nieuwe nationaliteit. Naar de mening van Weis gaat deze beperking door het internationaal gewoonterecht verder dan de verplichting aan partijen bij het Haagse Verdrag van 1930 krachtens het tweede lid van artikel 6 daarvan opgelegd. ${ }^{238}$ Deze auteur stelt dat onder het huidige internationale recht, een Staat niet zou mogen nalaten om zijn nationaliteit verloren te doen gaan in de navolgende gevallen:

- de verkrijging van de nieuwe nationaliteit niet onverenigbaar is met het internationaal recht en door de betrokken persoon te goeder trouw wordt nagestreefd;

- de betrokken persoon zijn gewone verblijfplaats in het buitenland heeft;

- hij meerderjarig en niet onbekwaam is;

- het verloren gaan van de nationaliteit niet resulteert in het in gebreke blijven specifieke verplichtingen - zoals militaire dienstplicht - te vervullen ten aanzien van de Staat waaraan de betrokken persoon verantwoording verschuldigd was ten tijde van de verkrijging van een nieuwe nationaliteit;

de Staat niet in oorlog is. ${ }^{239}$

Ook het verbod van gedwongen naturalisatie, dat deel uitmaakt van het geldende internationale gewoonterecht, kan als een algemene uitzondering op de regel van het "domaine réservé" van een Staat in aangelegenheden inzake nationaliteitsrecht worden gezien. Dit verbod betekent, dat het geen Staat toegestaan is zijn nationaliteit op te leggen aan staatsburgers van een andere Staat, tenzij de individu zelf om wijziging van zijn status vraagt of indien het bepaalde categorieën van personen, bijvoorbeeld minderjarigen betreft. ${ }^{240}$

Brownlie merkt op, dat bepaalde principes betreffende de verlening van nationaliteit in de wetgeving van Staten vaak genoeg zijn aangenomen om de status van "algemene principes" te verkrijgen. Deze auteur noemt als de twee voornaamste principes, waarop nationaliteit is gebaseerd het "ius sanguinis" en het "ius soli". ${ }^{241}$ Brownlie wijst op

238. Dit artikellid bepaalt, dat de machtiging tot verwerping van nationaliteit van een Staat niet geweigerd zal worden aan de persoon, die zjn gewoon of hoofdverblijf in het buitenland heeft, mits voldaan zal zijo aan de voorwaarden vereist door de wet van de Staat, wiens nationaliteit hij wenst te verwerpen.

239. Weis, Nationality, p.133.

240. Koessler, Subject, Citizen, p. 74.

241. Brownlie, Principles, p. 385-389. Deze auteur noemt naast het "ius sanguinis" en het "ius soli", de "onvrijwillige" naturalisatie van individuen, waarbij verkrijging van nationaliteit automatisch plaatsvindt als gevolg van bepaalde veranderingen in civiele status, zoals adoptie, erkenning, wettiging, huwelijk en brengt het standpunt van Hudson, de rapporteur van de "International Law Commission" onder de aandacht, dat "while these reasons for the conferment of nationality have been recognized bij the consistent practice of States and may, therefore, be considered as consistent with international law, others have not been so recognized. "Hij noemt voorts de "vrijwillige" 
het belang van specifieke regels die een uitzondering vormen op het "ius soli", waarin toepassing van dit beginsel duidelijk niet te rechtvaardigen zou zijn. Hij verwijst in dit verband naar de bepaling, opgenomen in artikel 12 van het Haagse Verdrag van 1930, die inhoudt dat de wettelijke bepalingen betreffende het toekennen van de nationaliteit van een Staat ingevolge geboorte op het grondgebied van die Staat niet van rechtswege van toepassing zijn op kinderen, wier ouders diplomatieke immuniteit genieten in het land van geboorte. Verondersteld wordt dat dit artikel dient te worden gezien als een "established rule of international law". ${ }^{242}$

De vraag of een bepaalde aangelegenheid al dan niet enkel onder de nationale jurisdictie van een Staat valt is een essentieel relatieve vraag; dit is afhankelijk van de ontwikkeling van de internationale betrekkingen. Alhoewel een aangelegenheid op nationaliteit betrekking hebbende in principe niet door het internationale recht wordt geregeld, is het recht van een Staat tot het uitvoeren van zijn bevoegdheid beperkt door de verplichtingen ten aanzien van andere Staten. Dit impliceert, dat in een als hierbedoeld geval de bevoegdheid van een Staat wordt beperkt door regels van het internationale recht. Het gezag van een Staat om zijn nationaliteit te verlenen of op te leggen is onverbrekelijk verbonden aan c.q. afgeleid uit zijn soevereiniteit. Slechts krachtens zijn territoriale soevereiniteit kan een Staat in de positie zijn door zijn wetgeving de relatie tussen een andere Staat en de burgers daarvan te raken. Weis maakt dit duidelijk door melding te maken van een geschil tussen de Britse en Franse regering inzake een bepaling in twee Franse decreten van 8 november 1921 betreffende de Franse nationaliteit in Marokko respectievelijk Tunesië. Het betrof hier de bepaling, dat iedere persoon, geboren in het Regentschap Tunesië (de Franse zone) uit ouders, waarvan één ouder zélf geboren was in het Regentschap, Fransman is, mits zijn filiatie was vastgesteld vóór de leeftijd van 21 jaar in overeenstemming met de bepalingen van het nationale recht van zijn vader of moeder dan wel het Franse recht. Deze bepaling werd aangevochten door de Britse regering door te betogen dat daardoor de Franse nationaliteit werd opgelegd aan bepaalde Britse onderdanen, namelijk aldaar geboren kinderen van Britse onderdanen, aangezien zowel Tunesië als Marokko naar de mening van de Britse regering, gebieden waren waarover deze Regering jurisdictie uitoefende en dat deze handeling een schending inhield van het internationale recht en het wederzijdse respect. ${ }^{243}$ Op de vraag, of het geschil tussen Frankrijk en Groot-Brittannië inzake de onderhavige nationaliteitsdecreten en de toepassing daarvan op Britse burgers al dan niet enkel een aangelegenheid van nationale jurisidictie volgens internationaal recht was, antwoordde het Permanent Hof van Justitie op 7 februari 1923 dat het geschil volgens internationaal recht niet enkel een aangelegenheid van nationale jurisdictie was. Het Hof beantwoordde om die

241. $\rightarrow$

naturalisatie, algemeen erkend als een wijze van nationaiiteitsverknjging, die gebaseerd dient te zijn op een uitdrukkelijke vrijwillige handeling van het individu of van een persoon, die namens bem handelt, zoals door Hudson naar voren gebracht.

242. Brownlie, Principles, p. 387.

243. Zie hiervoor P.C.I.J., Series C, No. 2, p.24, British Case, Suppl., p.60, 63 en 219. Zie voor meer details, Weis, Nationality, p.71-75. 
reden de voorgelegde vraag in ontkennende zin. ${ }^{244}$ Het Hof baseerde zich echter uitsluitend op de feiten van een bijzonder geval, dat niet kan worden gezien als een beslissing inzake het karakter van het nationaliteitsrecht als zodanig. Belangrijk in dit verband was de door het Hof gegeven omschrijving van aangelegenheden die enkel binnen de nationale jurisdictie van een Staat liggen, als aangelegenheden, die alhoewel deze de belangen van mér dan éen Staat betreffen, in principe niet worden geregeld door internationaal recht. Iedere Staat is met betrekking tot zodanige aangelegenheden de enige rechter. Voor het doel van de hier gegeven beslissing is de volgende uitspraak van belang, namelijk dat "for the purpose of the present decision it is enough to observe that it may well happen that in a matter which, like that of nationality, is not, in principle, regulated bij intemational law, the right of a State to use its discretion is nevertheless restricted by obligations which it may have undertaken towards other States. In such a case, jurisdiction which, in principle, belongs solely to the State, is limited by rules of international law". To hold that a State has not exclusive jurisdiction does not in any way prejudice the final decision as to whether the State has a right to adopt such measures. ${ }^{245}$ Volgens de Britse regering kan oplegging van nationaliteit door een Staat aan onderdanen van een andere Staat eerst worden geacht in overeenstemming met het internationaal wederzijds respect te zijn, indien aan de betrokken personen een recht tot optie voor die nationaliteit te worden gegeven. Hiertegen bracht de Franse regering het argument naar voren, dat het recht tot optie geen principe van het internationale recht was en dat het er in feite om ging, welke nationaliteit nu de effectieve nationaliteit was. ${ }^{246}$ De wijze waarop dit geschil was afgewikkeld toont aan, dat de door Groot-Brittanië aangenomen, door Frankrijk begane schending van het internationale recht door de unilaterale oplegging van haar nationaliteit aan Britse onderdanen was beschouwd als te zijn hersteld door de verlening van een recht tot optie c.q. repudiatie aan de daardoor getroffen personen. Weis merkt naar aanleiding daarvan op, dat genoemd standpunt van betekenis is voor de vraag naar de door het internationale recht opgelegde beperkingen ten aanzien van het recht van Staten om hun nationaliteit te verlenen aan individuen. ${ }^{247}$

Een Staat is niet verplicht de door een andere Staat verleende nationaliteit te erkennen, wanneer deze laatste Staat in de verlening daarvan de soevereiniteit van de eerste Staat aantast. Hiervan kan bijvoorbeeld sprake zijn bij feitelijke occupatie van een bepaald gebiedsdeel, waarbij de occuperende Staat zijn nationaliteit oplegt aan de inwoners van dat gebied, die burgers zijn van een andere Staat. Aantasting van het internationale recht wordt gesanctioneerd door niet-erkenning van de verleende nationaliteit door andere Staten. Buiten de jurisdictie van de Staat, voor internationale tribunalen en autoriteiten van andere Staten dient de kwestie van het verenigbaar zijn met het internationale recht te worden onderzocht. Wordt het nationale recht onverenigbaar bevonden met het internationale recht, dan impliceert dit dat de Staat die het tot stand heeft gebracht, verantwoordelijk is voor de schending van een internationale verplichting en

244. Zie Weis, Nationality, p.71.

245. Weis, Nationality, p.73.

246. Weis, Nationaly, p.74.

247. Zie hiervoor Weis, Nationality, p.75. 
dan door het internationale recht verplicht wordt zijn nationale recht in overeenstemming te brengen met het internationale recht. ${ }^{248}$ Schending van het internationale recht kan ook plaatsvinden bij gebiedsovergang - het onderwerp van $\S 1.5$ - met name indien de daarbij betrokken Staten de verplichting om hun nationaliteit te verlenen of in te trekken niet nakomen. ${ }^{249}$

De analyse van de houding van internationaal recht ten opzichte van nationaal recht betreffende verlies van nationaliteit dient ervan uit te gaan, dat voor doeleinden van intermationaal recht het irrelevant is of het verlies van nationaliteit het gevolg is van een handeling van de Staat of van het individu, door denationalisatie of verwerping. In de praktijk is het onderzoek van de vraag naar de toelaatbaarheid van maatregelen van nationaal recht die verlies van nationaliteit veroorzaken bijna uitsluitend gewijd aan denationalisatie. Immers, denationalisatie door een Staat kan resulteren in staatloosheid en de weigering om vroegere onderdanen terug te nemen en als zodanig leiden tot geschillen tussen Staten. Daarentegen zal het vrijwillig opgeven van een nationaliteit, als regel, slechts plaatsvinden bij verkrijging van een andere nationaliteit; het is onwaarschijnlijk te achten dat dit tot internationale wrijving zal leiden. ${ }^{250}$

Voorts kan het recht op diplomatieke bescherming - in $\S 1.3 .2$ aan de orde gekomen in herinnering worden gebracht, het recht van een Staat, aan deze Staat toegekend door het internationale gewoonterecht, om namens zijn burgers te interveniëren, indien hun rechten geweld worden aangedaan door een andere Staat, teneinde vergoeding te verkrijgen. Of een Staat daartoe gerechtigd is, wordt bepaald door het internationale recht.

Het eveneens in $\S 1.3 .2$ aan de orde gekomen recht van het individu tot toelating en vestiging in het gebied van de Staat van zijn nationaliteit - met daartegenover de plicht van die Staat om toelating en vestiging te verlenen - valt onder de competentie van de afzonderlijke Staten. Wordt echter een persoon door een andere Staat uitgewezen en weigert de Staat, waarvan die persoon de nationaliteit bezit hem tot zijn grondgebied toe te laten, dan kan de onderhavige aangelegenheid een kwestie worden van invloed op de betrekkingen tussen Staten. De plicht van een Staat tegenover zijn burgers onder nationaal recht wordt een plicht tegenover andere Staten; het wordt tot een verplichting van internationaal recht.

Een ander, belangrijk principe is gelegen in het principe van niet-discriminatie dat kan worden beschouwd als een regel van internationaal recht of als een algemeen principe van recht; het verbod tot discriminatoire denationalisatie kan worden aangemerkt als een regel van het huidige algemene internationale recht. Dit geldt zeker voor discriminatie

248. Weis, Nationality, p. 89.

249. Zie hiervoor Weis, Nationality, p.135.

250. $\mathrm{Vgl}$. Weis, Nationality, p.117. 
op grond van ras, dat kan worden beschouwd als in strijd te zijn met een dwingende norm van internationaal recht. ${ }^{251}$

Het is niettemin moeilijk om het internationale recht van de nationaliteit nader vast te stellen, aangezien dit voortdurend verandert. Het is niet doelmatig en, gelet op het primaire nationale karakter van nationaliteitsrecht zelfs onmogelijk, om van te voren regels te ontwikkelen van toepassing op iedere situatie. Regels van het internationale recht kunnen slechts empirisch worden afgeleid uit de uitspraken van internationale tribunalen, uit de houding van Staten en uit internationale gevestigde gewoonte. Er dient naar de geschiedenis van het internationale recht en de internationale betrekkingen te worden gekeken teneinde het internationale recht in zijn huidig stadium van ontwikkeling vast te stellen, zij het dat een dergelijk onderzoek leidt tot de vaststelling van bestaande regels of enkel leidt tot de erkenning dat er geen relevante regels bestaan. ${ }^{252}$

\subsubsection{Beperking door verdragsrecht}

Iedere Staat is beperkt in zijn mogelijkheid om zijn nationaliteit te regelen door verdragsbeperkingen die deze Staat op dit vlak heeft aangegaan. Het betreft hier zelf opgelegde beperkingen. De meeste Staten hebben in feite verdragen aangegaan en daardoor internationale verplichtingen op zich genomen met betrekking tot aangelegenheden, die worden beschouwd binnen hun nationale jurisdictie te liggen. Door deze handeling wordt de specifiek in het verdrag geregelde aangelegenheid, van de nationale sfeer verplaatst naar het gebied van het internationale recht, zonder in principe het essentieel nationale karakter dat het internationale recht toekent aan het onderwerp als een geheel, te wijzigen. Het kunnen hier zowel bilaterale als multilaterale verdragen betreffen. In het eerste geval betreft het specifiek internationaal recht, alleen van kracht voor de betrokken Staten, anders dan in het tweede geval, waarin het internationale recht een meer universeel karakter heeft. Wat Indonesiē betreft, kan als voorbeeld van een bilateraal verdrag op de Overeenkomst tussen de Regering van de Republiek Indonesië en de Regering van de Chinese Volksrepubliek worden gewezen inzake de afwikkeling van het dubbel staatsburgerschap van Chinezen.

Naast verdragen, afgesloten in verband met gebiedsovergang - het onderwerp van $\$ 1.5$ - zijn er ook verdragen die zich meer met nationaliteitsrechtelijke vragen bezig houden, waarvan het reeds genoemde Haagse Verdrag van 1930 een voorbeeld is.

251. Vgl. Weis, Nationality, p.125. Verwezen kan voorts worden naar hetgeen in $\$ 1.4 .3 .4$ ter sprake zal komen aangaande een uitspraak van het "Inter-American Court of Human Rights", waaruit kan worden afgeleid, dat in het geval van "preferential treatment" van buitenlanders in het daarin omschreven geval geen sprake is van discriminatie in strijd met de "Inter-American Convention on Human Rights".

252. Weis, Nationality, p.91. 


\subsubsection{De "genuine link" theorie}

Kan nu het volkenrecht de bevoegdheid van een Staat tot regeling van voorvallen van verkrijging en verlies van zijn nationaliteit inperken? In de bekende Nottebohm-zaak tussen Liechtenstein en Guatemala, stelde het Internationale Hof van Justitie met betrekking tot de kwestie van de nationale jurisdictie, dat het de zaak van Liechtenstein is - zoals voor iedere soevereine Staat - om in de eigen wetgeving bepalingen vast te stellen voor de verkrijging van de nationaliteit en die nationaliteit krachtens naturalisatie door de eigen organen te verlenen in overeenstemming met die wetgeving. Bij het verlenen van diplomatieke bescherming plaats men zich echter op het niveau van het intemationale recht en is het dit recht dat bepaalt, of een Staat gerechtigd is tot het verlenen van diplomatieke bescherming. De naturalisatie van Nottebohm betrof een handeling door Liechtenstein gedaan in de uitoefening van de nationale jurisdictie. De vraag waar het hier om gaat, is om vast te stellen of die handeling het hier bedoelde internationale effect heeft. Een Staat kan echter niet eisen dat de door die Staat vastgestelde regels door een andere Staat worden erkend, tenzij eerstgenoemde Staat heeft gehandeld met het algemene doel om de rechtsband van de nationaliteit te doen overeenstemmen met de "genuine connection" van het individu met de Staat, die de verdediging van zijn burgers op zich neemt middels verlening van bescherming tegenover andere Staten.

Het betreft hier de zogenaamde "genuine link theory" als voorwaarde van het verlenen van diplomatieke bescherming. De beslissing van het Internationale Gerechtshof in de Nottebohm-zaak laat zich zodanig uitleggen, dat Liechtenstein door de "spoednaturalisatie" van Nottebohm de uiterste volkenrechtelijke grenzen voor de verlening van zijn nationaliteit niet geschonden heeft, zodat niet ontkend kan worden dat Nottenbohm staatsburger van Liechtenstein in de zin van het volkenrecht is. In de betekenis van deze beslissing, verlangt echter het algemene volkenrechtelijke gewoonterecht voor de uitoefening van het recht tot diplomatieke bescherming naast het bezit van een nationaliteit, ook nog het effectieve bestaan van "einer engeren sozialen Verbindung des Staatsangehörigen mit dem reklamierenden Heimatstaat". Deze opvatting door Wengler naar voren gebracht, is ook voor mij alleszins aanvaardbaar. ${ }^{253}$ Een soortgelijk standpunt wordt door von Mangoldt ingenomen, met name dat de internationale onaanvechtbaarheid van de verlening van een nationaliteit voor intemationale doeleinden een "genuine link" veronderstelt tussen de persoon en de verlenende Staat, op z'n minst op het tijdstip van de verlening. ${ }^{254}$

253. Wengler, Betrachtungen, p.549-550. Zie voor nadere bijzonderheden van de Nottebohm case, I.C.J. Reports 1955, p.4 en verder. In het arrest van bet Internationaal Gerechtshof betreffende de Nottebohm-zaak kwam het Hof tot de conclusie, dat de vereiste banden tussen Nottebohm en Liechtenstein ontbraken en in elk geval veel zwakker waren dan de banden bestaande tussen genoemde persoon en Guatemala, op grond waarvan Liechtenstein in zijn eis betreffende de uitoefening van diplomatieke bescherming niet ontvankelijk werd verklaard.

254. Von Mangoldt, Anerkennung, p.97. 
Kan in het voorhanden zijn van een "genuine link" tussen een persoon en een Staat nu een volkenrechtelijke beperking met betrekking tot de nationale autonomie van Staten worden gezien? Makarov is van mening, dat het volkenrecht bepaalde grenzen dient te stellen aan de soevereiniteit van de afzonderlijke Staten, die bij regeling van de nationaliteit niet mogen worden overschreden. Hij stelt voorts dat aangezien een nauwkeurige grens niet aan te wijzen is aangenomen moet worden, dat het volkenrechtelijke gebod op het gebied van het nationaliteitsrecht zich tot een bepaalde minimumeis beperkt, die met de volkenrechtelijke afgrenzing van staatsbevoegdheid organisch verbonden is. Als een dergelijke minimumeis moet de grondregel gelden, dat de Staat zijn nationaliteit niet aan die personen kan opleggen, die "keine einzige Anknüpfung" met zijn rechtsordening kan aanwijzen. ${ }^{255}$ Wengler neemt het standpunt in, dat de status van nationaliteit in de zin van het volkenrecht niet kan ontstaan, wanneer niet "eine effektive soziale Verknüpfung" met de Staat in kwestie voorhanden is. ${ }^{256}$

De vraag kan echter worden gesteld of een "genuine link" met de Staat in kwestie voorhanden dient te zijn voor het al dan niet wettig zijn van het verlenen van een nationaliteit, zoals door de hiervoor genoemde auteurs gesteld. Niet alleen is het criterium "genuine link" vaag te noemen, maar het gaat in de praktijk niet altijd op. ${ }^{257} \mathrm{Zo}$ kan men zich afvragen, of in het geval bijvoorbeeld Indonesiërs lange tijd in het buitenland vertoeven en geregeld van hun wens Indonesisch staatsburger te willen blijven blijk geven, nog van een "genuine link" kan worden gesproken. Zo ook of in het geval een persoon door het toevallig van toepassing zijn van het "ius soli" de nationaliteit van een bepaalde Staat verkrijgt, hij geacht kan worden een "effektive soziale Verknüpfung" met die Staat te hebben. Ik heb hier mijn twijfels over; het bestaan van een "genuine link" dient niet als voorwaarde van het bestaan van een nationaliteit te worden gezien, doch is voorwaarde voor de mogelijkheid van het verlenen van diplomatieke bescherming door de respectieve Staat. Ook door de Groot wordt de "genuine link" theorie afgewezen, enerzijds omdat het criterium van de "genuine connection" te vaag is om als duidelijke beperking van de nationale autonomie te gelden, anderzijds omdat de Nottebohmbeslissing zodanig geïnterpreteerd dient te worden, dat de verlening van een nationaliteit aan een persoon, die geen "genuine connection" met de desbetreffende Staat heeft weliswaar geldig is, maar een Staat niet het recht geeft de desbetreffende burger diplomatiek te vertegenwoordigen. ${ }^{258}$

\subsubsection{Waarborging van mensenrechten als mogelijke beperking}

Als manifestatie van soevereiniteit, wordt de nationaliteit angstvallig bewaakt door Staten; als zodanig wordt de ontwikkeling van het internationale recht van de nationaliteit voornamelijk beheerst door de belangen van Staten. De vraag of een bepaalde aangelegenheid al dan niet uitsluitend onder de jurisdictie van een Staat valt, hangt echter af van de ontwikkeling van de internationale betrekkingen. Beperkingen krachtens

255. Makarov, Allgemeine Lehren, p.95.

256. Wengler, Betrachtungen, p. 550 .

257. Zie ook de Groot en Tratnik, Nationaliteitsrecht, p. 17.

258. De Groot, Staatsangebörigkeitsrecht, p.21-22. 
het intemationale recht zijn niet statisch van aard, doch veranderen met gewijzigde internationale betrekkingen. Zo is éćn van de meest belangrijke verandering in de internationale betrekkingen sedert de Tweede Wereldoorlog, de toenemende bezorgdheid met betrekking tot de mensenrechten. De door het internationale recht opgelegde beperkingen ten aanzien van de bevoegdheid van Staten houden verband met de eisen opgelegd door het internationale systeem voor de bescherming van de mensenrechten. Door Chan wordt als voorbeeld een voorgestelde wijziging in de Grondwet van Costa Rica aangehaald, waardoor strengere voorwaarden voor naturalisatie werden opgelegd, bij welke gelegenheid de vraag naar voren kwam of dit verenigbaar was met de "InterAmerican Convention on Human Rights", aan de orde gekomen in $\S 1$ 1.3.3.2. Het "Inter-American Court of Human Rights" spreidde bij die gelegenheid een hoge graad van perfectie ten toon door naar een evenwicht te streven tussen de soevereiniteil van de Staat en de mensenrechten. Om met de woorden van Chan te spreken komt dit neer op het volgende: "It was basically within the sovereignty of a State to give preferential treatment to aliens who, viewed objectively, would more easily and more rapidly assimilate within the national community and identify more readily with the traditional beliefs, values and institutions of Costa Rica, which the State has the right and duty to preserve. International supervision, however, will seek to ensure that the criteria adopted would not have the effect of violating recognized human rights norms..... Accordingly, the Court held, inter alia, that preferential treatment in the acquisition of Costa Rican nationality through naturalization ..... did not constitute discrimination contrary to the Convention, but preferential treatment which favoured only one of the spouses in case of naturalization through marriage was contrary to the principle of sex equality and thus constituted discrimination." 259

Werd in 1923 de nationaliteit beschouwd als onder de exclusieve nationale jurisdictie van een Staat te vallen, de conclusie kan worden getrokken dat een duidelijke trend in het internationale recht is waar te nemen naar een geleidelijke erkenning van het recht van de individu op een nationaliteit, als een inherent recht van alle menselijke wezens, derhalve als mensenrecht.

\subsection{Nationaliteitsrechtelijke gevolgen van gebiedsovergang}

\subsubsection{Algemeen}

Verandering van soevereiniteit over een bepaald gebied kan invloed hebben op de nationaliteit van de daarbij betrokken personen. In dit geval is regeling van de nationaliteit van de inwoners van het gebied aan verandering van soevereiniteit onderworpen, niet alleen een aangelegenheid van een enkele Staat doch zijn er ipso facto tenminste twee Staten bij betrokken. Het wordt een aangelegenheid beheerst door regels van het intemationale recht met betrekking tot de overdracht van gebieden en houdt derhalve op enkel een aangelegenheid van het nationale recht te zijn. ${ }^{200}$

259. Chan, The right to a Nationality, p.6.

260. Weis, Nationality, p. 135. 
Weis gaat er vanuit, dat regeling van de nationaliteit in principe een zaak is van nationale jurisdictie; volgens deze auteur zijn geen positieve regels van het internationale recht aanwezig, die de verlening en intrekking van nationaliteit beheersen, aangezien deze verlening of intrekking van nationaliteit enkel de zaak is van fén Staat. Anders ligt de zaak echter in het geval van territoriale veranderingen, aangezien tenminste twee Staten daarbij zijn betrokken. Onderzocht dient derhalve te worden, of er positieve regels van internationaal recht bestaan die richtlijnen geven inzake collectieve verkrijging en verlies van nationaliteit in het geval van territoriale veranderingen. Uit hetgeen hiervoor door Weis is opgemerkt blijkt, dat deze auteur van mening is dat zelfs indien zulke regels bestaan, deze regels in principe niet rechtstreeks effect hebben op de nationaliteit van de daarbij betrokken personen, aangezien de onderhavige nationaliteit door het nationale recht wordt bepaald. ${ }^{261}$ Dit impliceert, dat eventuele regels van het internationale recht eerst werking hebben na te zijn omgezet in regels van het nationale recht. De regels van het nationaliteitsrecht van Staten leggen alleen een verplichting op aan Staten om hun nationaliteit te verlenen of in te trekken; bij het in gebreke blijven, schenden zij het internationale recht. ${ }^{262}$

De positie van het staatsvolk en de primaire volkenrechtelijke status van de nationaliteit als aanknopingspunt om personen toe te bedelen aan de rechtsmacht van de verschillende Staten, hebben tot consequentie dat verdragen inzake een nationaliteitsrechtelijke afbakeningsregeling zijn te vergelijken met grensverdragen, die het grondgebied van Staten van elkaar afbakenen. De verdragsregeling is maatgevend voor derden. De mogelijkheid dat bedoelde verdragen derden binden wordt in de literatuur niet altijd aanvaard; zo wordt door Schwarzenberger in het algemeen de mogelijkheid van dergelijke derdenverbindende verdragen ontkend; deze auteur stelt de voorwaarde van erkenning van deze verdragen. ${ }^{263}$ Volgens Ko Swan Sik zal de derde Staat waarschijnlijk echter niet tot bezwaren gerechtigd zijn bij gebrek aan een rechtsbelang, waardoor ook in de redenering van Schwarzenberger de bilaterale regeling Staat C bindt. Hij gaat er in casu vanuit, dat zo'n rechtsbelang slechts aanwezig zou zijn, indien de verdragsregeling tussen de staten A en B volkenrechtelijk onrechtmatig is. ${ }^{264}$ De vraag rijst, wat de positie van $S$ taat $C$ is, indien de aangewezen verdragsstaat in strijd met de verdragsregeling de tot de categorie $\mathrm{X}$ behorende personen niet als staatsburgers beschouwt. Ko Swan Sik is van mening dat in dat geval, voornoemde unilaterale opvatting van de verdragsstaat zal prevaleren boven de inmiddels blijkbaar verworpen verdragsregeling. Deze auteur voegt hieraan toe, dat uit de statenpraktijk echter geen geval bekend is waarbij een Staat als partij bij een nationaliteitsverdrag, de hem toegewezen staatsburgers weigert als zodanig te accepteren respectievelijk de personen die volgens het verdrag zijn nationaliteit hebben verloren, blijft beschouwen als zijn

26I. Weis, Nationality, p.135.

262. Weis, Nationality, p.135-136.

263. Schwarzenberger, G., Interational Law, deel 1, 1957, p.458.

264. Ko Swan Sik, preadvies, p.9. 
staatsburgers. ${ }^{265}$ Het is echter niet uitgesloten, dat verschil van mening ontstaat door verschillende interpretatie van de verdragsbepalingen, waardoor toescheiding van oen persoon aan één van de verdragspartners door de andere partner wordt ontkend. ${ }^{266}$

\subsubsection{Universele en partiële statenopvolging}

De vraag kan worden gesteld, of en in hoeverre bij wijziging van het grondgebied van een Staat, ook de kring van zijn staatsburgers zich daardoor wijzigt. Meer in concreto gesteld, gebiedsovergang houdt wisseling van het staatsgezag over een bepaald gebied in. Hierbij komt de vraag aan de orde of, en in het bevestigende geval, op welke wijze bedoelde overgang direct of indirect invloed heeft op de nationaliteit van personen, die op een of andere wijze met dit gebied verbonden zijn. Mijns inziens dient ter beantwoording van deze vraag eerst te worden nagegaan, of de gebiedsovergang al dan niet als wettig dient te worden aangemerkt. Zo kan gebiedswijziging hetzij op een verdrag berusten dan wel het gevolg zijn van - onwettige - occupatie.

Alvorens nader hierop in te gaan kan, algemeen gesteld, onderscheid worden gemaakt tussen universele en partiële statenopvolging. In het eerste geval wordt de opgevolgde Staat opgeheven en houdt zijn nationaliteit eveneens op te bestaan, met als consequentie dat zijn staatsburgers als zodanig ook ophouden te bestaan. In dit geval is sprake van algehele samensmelting van Staten.

Bij partiële opvolging - waarbij het gaat om gedeeltelijke samensmelting van Staten of om opsplitsing van de oorspronkelijke Staat ${ }^{267}$ - zullen nationaliteitsaangelegenheden meestal worden geregeld bij verdrag, aangezien de opgevolgde Staat blijft bestaan, met als gevolg dat bij de gebiedsovergang twee nationaliteiten zijn betrokken, te weten die van de opgevolgde en van de opvolgende Staat. ${ }^{268}$

Is de overdracht gebaseerd op een verdrag, dan regelt het verdrag meestal ook de kwestie van de nationaliteit van de personen, verbonden met het overgedragen gebied of kan de kwestie van hun nationaliteit in een afzonderlijk verdrag geregeld worden.

265. Ko Swan Sik, preadvies, p.10. In deze opvatting schijnt inmiddels wijziging te zijn gekomen; vergelijk de Toescheidingsovereenkomst tussen Suriname en Nederland, Trb. 1975, 132. In Suriname werd de Toescheidingsovereenkomst tegelijk met de Wet op de aationaliteit door het Parlement aangenomen en kregen beide op hetzelfde moment rechtskracht. Zie voor deze materie Haarmans, P.D., de Toescheidingsovereenkomst in de Praktijk, De nationaliteitswetgeving bij de souvereiniteitsoverdracht aan de Republiek Suriname, Paramaribo, 1988. Deze auteur besteedt onder meer aandacht aan de positie van minderjarigen als gevolg van interpretatieverschillen.

266. Op deze aangelegenheid zal in $\$ 8$ van Hoofdstuk 3 betreffende interpretatieproblemen die kunnen ontstaan naar aanleiding van de tussen Indonesië en Nederland gesloten Toescheidingsovereenkomst, nader worden ingegaan.

267. Hiervan is de kolonie een voorbeeld; zie hetgeen in $\$ 1.5 .3$ hieromtrent is opgemerkt. Een meer recent voorbeeld betreft de opsplitsing van de voormalige Sojet-Unie in verschillende Staten. Wat betreft de nationaliteitsrechtelijke gevolgen hiervan kan het voorkomen, dat zich gevallen van apatridie voordoen.

268. Weis, Nationality, p.136 en 144-145. 
Een als hiervoor bedoeld verdrag treft duidelijk slechts regels voor de nationaliteit van de betrokken personen, voor zover het verdrag deel wordt van het nationale recht van de Staat, wiens nationaliteit verloren zal gaan of zal worden verkregen. Weis wijst erop, dat in het geval zodanig nationaal recht van een Staat, partij bij het verdrag, strijdig is met de bepalingen van het verdrag, dit een schending vormt van het internationale recht. ${ }^{269}$ Heeft de overdracht plaatsgevonden in overeenstemming met het internationale recht, dan dient de opgevolgde Staat deze overdracht te erkennen en kan worden aangenomen, dat derde Staten in hun houding met betrekking tot de effecten van een verandering van de soevereiniteit op de nationaliteit, deze nationaliteit ook zullen erkennen.

\subsubsection{Dekolonialisatie}

Gebiedsovergang als gevolg van dekolonisatie - waarbij sprake is van opsplitsing van het gebied van de oorspronkelijke Staat - is als volkenrechtelijk rechtmatig aan te merken. Het gaat hier om het creëren van nieuwe Staten. Etnische overwegingen speelden normaliter een rol in de vaststelling van de criteria voor de verlening c.q. het verlies van de nationaliteit, alhoewel in de wetgeving van slechts enkele Staten uitdrukkelijk genoemd. ${ }^{270}$

Chan brengt naar voren dat territoriale veranderingen nooit op een dergelijke grote schaal hebben plaatsgevonden als na de Tweede Wereldoorlog. Hij zegt hieromtrent dat "nationality is perceived by many new States as a key to the achievement of national unity. It is obvious that territorial residence alone would not be able to fulfil the new political function of nationality. In order to achieve a national unity, the States are looking for, in most cases, a genuine and effective link between population and the State". ${ }^{271}$ Hieruit blijkt, dat Chan bij regeling van de nationaliteit in gevallen van gebiedsovergang, uitgaat van het bestaan van een "genuine and effective link" tussen de daarbij betrokken personen en de desbetreffende Staat.

Vindt de afscheiding niet met instemming van de oorspronkelijke Staat plaats, dan doet zich meestal een discrepantie in tijd voor tussen het tijdstip waarop volgens het afscheidende deel de juridische breuk met het moederland plaatsvindt en het moment waarop genoemd moederland deze afscheiding erkent c.q. de soevereiniteit overdraagt. Personen die de krachtens het verdrag toegescheiden nationaliteit als onaanvaardbaar voelen kunnen dikwijls - onder daartoe vastgestelde voorwaarden - door gebruikmaking van een optie- of repudiatierecht verandering in de toegescheiden nationaliteit brengen. Het hiervoor omschreven geval heeft zich, wat Indonesië betreft, voorgedaan bij de formele

269. Weis, Nationality, p.145.

270. Zo wordt in de Overeenkomst tot toescheiding van staatsburgers tussen Indonesiẽ en Nederland aangegaan - het onderwerp van $\S 5.3$ van Hoofdstuk 3 - enerzijds uitgegaan van Nederlanders en anderzijds van niet-Nederlanders, to weten personen die tot de inheemse bevolking van Indonesië behoren en uitheemse Nederlandse onderdanen niet-Nederlanders als onder meer Vreemde Oosterlingen.

27l. Chan, The right to a Nationality, p. 12 . 
soevereiniteitsoverdracht door Nederland aan de Republiek Indonesiē krachtens de Wet Souvereiniteitsoverdracht Indonesiē van 21 december 1949, N. Stb. 1949-570, Indon. Stb. 1950-2 - Indonesië prefereert de term "soevereiniteitserkenning" - waarbij krachtens de tussen beide Staten gesloten, reeds genoemde Toescheidingsovereenkomst de nationaliteitsrechtelijke gevolgen daarvan geregeld werden. Anders lag het wat betreft Irian Jaya, welk gebiedsdeel eerst in 1963 aan Indonesiē werd overgedragen, aangezien generlei afspraken inzake de nationaliteitsrechtelijke gevolgen van deze overdracht door de hierbij betrokken landen waren gemaakt. Op deze aangelegenheid zal nader worden teruggekomen. ${ }^{272}$

\subsubsection{Onrechtmatige occupatie}

In het algemeen kan voorts worden opgemerkt, dat maatregelen betreffende nationaliteit, getroffen door een Staat die weliswaar een bepaald gebied feitelijk beheerst, doch daartoe geen permanente rechtstitel heeft - het betreft hier derhalve onrechtmatige occupatie - niet kunnen worden gelegitimeerd door de "gebiedsovergang". Om die reden is de occupant niet gerechtigd om de nationaliteit van de inwoners van het gebied in kwestie te veranderen door deze zijn nationaliteit op te leggen. Weis zegt hieromtrent het volgende: "Where, however, the predecessor State does not recognise the transfer because it was inconsistent with international law, no (such) duty to withdraw its nationality exists. Double nationality may be the result. This view is supported by practice of States and by judicial decisions....It is clear, however, that decisions of municipal courts which refer to a particular case of territorial transfer will be determined by the attitude of the State of the forum to the transfer" ${ }^{273}$

Het heeft in dit verband wellicht zin om te wijzen op het Verdrag van Genève betreffende de bescherming van Burgers in Oorlogstijd van 12 augustus 1949. ${ }^{274}$ Dit Verdrag is eveneens van toepassing in alle gevallen van gehele of gedeeltelijke bezetting van het grondgebied van een tot dit Verdrag toegetreden partij, zelfs indien deze bezetting geen gewapende tegenstand ontmoet. Artikel 13 van dit Verdrag bepaalt onder meer dat de in Titel II van dit Verdrag opgenomen bepalingen inzake de algemene bescherming van de bevolking, van toepassing zijn op het geheel der bevolkingen van de bij een conflict betrokken landen, zonder enig voor haar nadelig onderscheid, in het bijzonder gegrond op ras, nationaliteit, godsdienst of politieke overtuiging en tot doel hebben het door de oorlog veroorzaakt lijden te verzachten.

Wat Indonesië betreft, kan met betrekking tot de politieke ontwikkelingen rond OostTimor worden gewezen op artikel 1 lid 1 sub d. van de Nationaliteitswet van 1981 van Portugal, als één van de bij bedoelde aangelegenheid over genoemd gebied betrokken partijen. Krachtens dit artikellid zijn Portugezen door geboorte, zij die binnen het Portugese grondgebied zijn geboren - derhalve krachtens het "ius soli" - en geen andere

272. Op de nationaliteitsrechtelijke gevolgen van de overdracht van Irian Jaya ann Indonesiē, zal in $\$ 10$ van Hoofdstuk 5 worden ingegaan.

273. Weis, Nationality, p. 148.

274. Trb. 1951,75 . 
nationaliteit bezitten. Op grond van artikel 8 van deze Wet, is de enige verliesgrond van de Portugese nationaliteit gelegen in de verklaring van hen, die (mede) de nationaliteit van cen andere Staat bezitten, dat zij geen Portugees wensen te zijn. Men kan zich afvragen of de Wet no. 62 van 1958 inzake het Indonesische staatsburgerschap nu ook van toepassing is in Oost-Timor. In dit verband kan worden gewezen op hetgeen in de Memorie van Toelichting van de Wet no. 7 van het jaar 1976, Stb. 1976-35 betreffende de Bekrachtiging van de Unificatie (in het Indonesisch "penyatuan") van Oost-Timor met de Eenheidsstaat van de Republiek Indonesië en de oprichting van de Provincie/Regio van het eerste Niveau van Oost-Timor is bepaald. In deze Memorie van Toelichting, opgenomen in Aanvullend Staatsblad no. 3084 is met name gesteld, dat "met de unificatie van Oost-Timor met de Eenheidsstaat van de Republiek Indonesiē, het grondgebied van Oost-Timor vanzelfsprekend grondgebied van de Eenheidsstaat van de Republiek Indonesië wordt en het volk van Oost-Timor volk en staatsburger van de Republiek Indonesië wordt en alle wettelijke regelingen van de Republiek Indonesiē tevens voor het grondgebied van Oost-Timor gelden." ${ }^{275}$ Uit de afkondiging van de Regeringsverordening no. 18 van het jaar 1991, Stb. 1991-24 waarbij conversiebepalingen zijn vastgesteld in verband met het door Indonesië van toepassing verklaren aldaar van de Agrarische Basiswet no. 5 van het jaar 1960, Stb. 1960-104 kan voorts indirect worden afgeleid, dat de onderhavige Wet no. 62 van 1958 wordt geacht ook in genoemd gebied van toepassing te zijn. Deze Wet is namelijk in de Considerans van de onderhavige Regeringsverordening no. 18 van het jaar 1991 genoemd. Ter toelichting diene, dat met betrekking tot de mogelijkheid tot het bezitten c.q. verkrijgen van rechten op de grond het nationaliteitscriterium een belangrijke rol speelt. Dit brengt met zich, dat de kwestie van de nationaliteit van de inwoners van Oost-Timor ook op dit vlak van cruciaal belang is. ${ }^{276}$ Voor dit doel wordt door de Indonesische overheid aansluiting gezocht bij genoemde Wet no. 62 van 1958; voor de toepassing van de onderhavige Regeringsverordening zal door de Indonesische overheid aan de hand van deze Wet worden vastgesteld, of een persoon al dan niet Indonesisch staatsburger is, een aangelegenheid die, politiek gezien, gevoelig ligt. Hecker wijst erop, dat andere Staten, die de inlijving van Oost-Timor vanwege schending van het verbod tot het gebruiken van geweld niet erkennen, het nieuwe Indonesisch staatsburgerschap niet behoeven te erkennen. Wordt

275. In het Indonesisch luidt deze passage als volgt: "Dengan penyatuan Timor Timur ke dalam Negara Kesatuan Republik lndonesia, maka dengan sendirinya wilayah Timor Timur menjadi wilayah Negara Kesatuan Republik Indonesia, Rakyat Timor Timur menjadi Rakyat dan Warganegara Republik Indonesia, dan semua peraturan perundang-undangan Republik Indonesia berlaku juga bagi wilayah Timor Timur."

276. Met de Regeringsverordening no. 34 van het jaar 1992, Stb. 1992-63 is de inwerkingtreding van de bepaling, opgenomen in artikel 5 lid 1 van deze Verordening opgeschort. Het betreft hier de opschorting van conversiebepalingen van rechten op de grond in handen van buitenlanders of buitenlandse rechtspersonen, onder aantekening dat deze opschorting zal gelden tot het tijdstip bij Presidentieel Besluit vast to stellen. Volgens het in de Memorie van Toelichting van de onderhavige Regeningsverordening (Aanvullend Staatsblad no. 3483) bepaalde, is deze opschorting bedoeld om de uitvoering van de conversie ordelijk te doen verlopen, waartoe een voldoende lang tijdsbestek nodig is. 
de Wet no. 62 van 1958 in Oost-Timor van toepassing geacht, dan zou dit kunnen betekenen dat de betrokken personen de staat van bipatride bezitten. ${ }^{2 m}$

\section{$\S 2$ Inhoud van het Indonesisch staatsburgerschap}

In $\S 1.3 .2$ werd ingegaan op het karakter van het nationaliteitsbegrip en met betrekking tot de inhoud daarvan aangegeven, welke fundamentele rechten en verplichtingen begripsmatig uit het bezit van een nationaliteit voortvloeien. De inhoud van een nationaliteit kan niet van een nationaliteitswet worden afgelezen; daarvoor dienen andere wettelijke regelingen te worden geraadpleegd. Dit gaat ook op voor de Wet no. 62 van het jaar 1958 betreffende het Indonesisch Staatsburgerschap, op een enkele uitzondering na, in genoemde paragraaf reeds aan de orde gekomen.

Wat Indonesië betreft kan in het kort worden aangegeven dat als fundamentele rechten nauw met het staatsburgerschap verweven kunnen worden aangemerkt, politieke rechten als actief en passief kiesrecht, benoembaarheid in overheidsfuncties, toelating tot het Indonesisch grondgebied - uitwijzing van Indonesische staatsburgers is verboden - en diplomatieke bescherming. 278

Voorts bestaan rechten en plichten, waarbij het Indonesisch staatsburgerschap als aanknopingspunt dient. Ter illustratie diene, dat hieronder het verrichten van handelsactiviteiten - uitzonderingen daargelaten - valt. De uitoefening van sterke en uitgebreide rechten op de grond is voorts aan Indonesische staatsburgers voorbehouden. Bepaalde beperkende - maatregelen zijn bovendien ten aanzien van buitenlanders getroffen, die als zodanig niet voor Indonesische staatsburgers gelden. Bedoeld zijn hier de verplichtingen van buitenlanders die onder het vreemdelingenstatuut vallen, zoals registratieplicht, het betalen van vreemdelingenbelasting en het in het bezit zijn van de voorgeschreven immigratiepapieren. ${ }^{279}$

277. Zie Hecker, H., Das Staatsangehōrigkeitsrecht von Brunei, Indonesien, Malaysia, Singapur und den Philippinen, Frankfurt am Main, 1978, p.47.

278. Zie hiervoor Gautama, Syahmin en Soenario, in $\$ 1.3 .2$ aan de orde gekomen, die deze rechten uitsluitend asn Indonesische staatsburgers voorbehouden.

279. Gautama, Warganegara, p.73-86. Zie voor de bepalingen die voor buitenlanders gelden, tevens de Himpunan undang-undang dan peraturan-peraturan tentang orang asing di Indonesia, samengesteld door het Kantoor ter Regeling van Ingezetenen ("Kantor Urusan Penduduk") van bet Speciale District van de Hoofdstad Jakarta. Zie ook Suntjaja, Himpunan peraturan perundang-undangen tentang masalah orang asing, Jakarta, 1976. In herinnering moge voorts de op 31 maart 1992 afgekondigde nieuwe Immigratiewet no. 9 van het jaar 1992 worden gebracht. Hierin zijn bepalingen opgenomen betreffende het binnenkomen en verlaten van het Indonesische grondgebied, het tijdelijke verbod voor bepaalde personen om wegens bepaalde redenen het Indonesisch grondgebied te verlaten dan wel Indonesiê binnen te komen, de aanwezigheid van buitenlanders in Indonesiē en het toezicht daarop en het nemen van immigratiemaatregelen. 


\section{HOOFDSTUK 3 VOORGESCHIEDENIS VAN DE WET No. 62 VAN HET JAAR 1958 BETREFFENDE HET STAATSBURGERSCHAP VAN DE REPUBLIEK INDONESIE}

\section{§ Inleiding}

Twee wetten die van belang kunnen worden geacht voor de ontwikkeling van het Indonesisch nationaliteitsrecht zijn de Wet van 1892 op het Nederlander- en Ingezetenschap, N. Stb. 1892-268, na de wijziging ingevolge de Wet van 21 december 1936, voor het eerst volledig opgenomen in het Ind. Stb. 1937-514 en de Wet van 1910 betreffende het Nederlandsch Onderdaanschap van Niet-Nederlanders, N. Stb. 1910-55 jo. 1927-175 (Ind. Stb. 1910-296 jo. 1927-418). ${ }^{280}$

Voor een goed begrip van de voorgeschiedenis van de huidige Indonesische nationaliteitswet dient echter verder in de geschiedenis te worden teruggegaan, zowel wat betreft de situatie in het voormalige (Nederlandsch-)Indië, als met betrekking tot de situatie in Nederland.

\subsection{De situatie in (Nederlandsch-)Indië tot 1926}

Wordt eerst de situatie in het voormalige Indië in beschouwing genomen, dan kan de politieke geschiedenis van dit land, zoals in $\$ 2.1$ van Hoofdstuk 1 uiteengezet in herinnering worden gebracht. In dit verband kan de bezetting in 1811 van dit land door de Engelsen van belang worden geacht. Aan deze periode kwam in 1816 een einde toen Indië aan Nederland terugviel en het land een kolonie van Nederland werd onder de naam Nederlandsch-Indië.

In aansluiting op het voorgaande kan de Wet van 18 juni 1824, opgenomen in N. Stb. 1824-39 worden genoemd, waarbij het verdrag van 17 maart 1824 tussen Nederland en Groot-Brittanië aangegaan inzake de wederzijdse belangen en rechten in Indië, werd goedgekeurd. Var belang zijn de in dit verdrag voorkomende bepalingen, op grond waarvan Malakka door Nederland aan Groot-Brittanië werd afgestaan (artikel 10). Daarentegen vielen de bezittingen van Groot-Brittanië op het eiland Sumatra aan Nederland toe (artikel 9). ${ }^{281}$ Krachtens artikel 14 van het Verdrag werd aan de ingezetenen van genoemde gebiedsdelen de vrijheid gegeven om gedurende een periode van zes jaar, gerekend vanaf de datum van ratificatie van dit verdrag naar welgevallen over hun eigendommen te beschikken en zich, zonder hinder of belet, naar eigen goedvinden daarheen te begeven als zij wensten. Volgens Hecker houdt deze bepaling mede in, dat aan bedoelde personen gedurende het tijdsbestek van zes jaar de gelegenheid werd

280. De Wet van 1892 is nadien nog verschillende malen gewijzigd, zie voor een overzicht van de wijzigingen, de Groot en Tratnik, Nationaliteitsrecht, p.49-51. Ook de Wet van 1910 is aan verandering onderhevig geweest, zoals nader $z$ al worden toegelicht in $\$ 3$. Zie voor een overzicht van de in Nederlandsch-Indiê vigerende wettelijke regelingen Hecker, H. , Die Staatsangehörigkeitsregelungen in den vier überseeischen Kontinenten, Hamburg, 1970, p.51-55.

281. Zie ook Hecker, Das Staatsangehönigkeitsrecht, p. 37. 
gegeven om voor de tot dan toe bezeten nationaliteit te opteren. ${ }^{282}$ Dit impliceert, dat dit de eerste keer is, dat een nationaliteitsrechtelijke regeling kwam te gelden voor bepaalde gedeelten van het grondgebied van het huidige Indonesië.

De kolonie Nederlandsch-Indië werd centraal geregeerd. In dit verband kan het Reglement op het beleid der Regering van Nederlandsch-Indië (Regeringsreglement, afgekort RR), Wet van 2 september 1854, N. Stb. 1854-129, Ind. Stb. 1855-2 worden genoemd, in die tijd als de Grondwet van het land te beschouwen. ${ }^{283}$ Dit Regeringsreglement bevatte echter geen bepalingen inzake de nationaliteit van de ingezetenen van Nederlandsch-Indië.

Volgens van de Sande Bakhuysen, zou het inteme Indische recht met betrekking tot de onderhavige aangelegenheid geen oplossing bieden, omdat in Nederlandsch-Indië ten aanzien van de nationaliteit heel andere denkbeelden bestonden dan in het moederland, te wijten aan een drietal omstandigheden:

a. De Indische wetgeving bepaalde niets omtrent nationaliteit;

b. In de meeste gevallen waar de Nederlandse wetten van "Nederlanders" spraken, gebruikten de Indische bepalingen de term "ingezetenen";

c. Het ingezetenschap van Nederlandsch-Indië gaf iets anders aan dan hetgeen hieronder normaliter wordt verstaan ${ }^{284}$; de grens tussen ingezetenschap en onderdaanschap was met name niet duidelijk te trekken.

Ter toelichting van het onder c. gestelde kan worden opgemerkt, dat krachtens artikel 106 jo. 105 RR met ingezetenen van Nederlandsch-Indië werden bedoeld, behalve de "inboorlingen des lands", allen die hun verblijf in dit land gevestigd hadden krachtens de Verordening die de toelating en vestiging regelde. Deze bepaling was evenwel niet duidelijk; zo was niet aangegeven wie onder "inboorlingen des lands" vielen en wanneer het ingezetenschap ex. artikel $106 \mathrm{RR}$ een einde nam. Twee rechtsbetrekkingen, te weten het onderdaanschap en het ingezetenschap die hemelsbreed verschilden, werden in één adem genoemd en gelijksoortig behandeld! Werd afgegaan op de "ingezeteneninboorlingen", dan zou volgens van de Sande Bakhuysen kunnen worden gezegd, dat de Indische wetgeving hun ingezetenschap als een soort onderdaanschap behandelde; werd daarentegen gelet op de ingezetenen krachtens vestiging, dan zou hetzelfde feit als ongerijmd moeten worden aangemerkt. Hij waarschuwt derhalve tegen de opvatting, dat ingezetenschap in Nederlandsch-Indië onderdaanschap zou zijn, aangezien ingezeten-

282. Hecker, Das Staatsangehōrigkeitsrecht, p.47-48.

283. Het Regeringsreglement is verschillende malen gewijzigd, zie Ind. Stb. 1907-205, Ind. Stb. 1919622 en Ind. Stb. 1925-415. Met laatstgenoemd statsblad werd de titel van het Regeringsreglement gewijzigd in "Wet op de Staatsinrichting van Nederlandsch-Indië" (Indische Staatsregeling, afgekort IS) Bij artikel 3 van de wet van 23 juni 1925, Ind. Stb. 1925-415 jo. 577 - in werking getreden 1 januari 1926 - werd besloten de tekst van de Wet op de Staatsinrichting van Nederlandsch-Indië geheel opnieuw af te kondigen, in een doorlopend genummerde reeks van artikelen, waaraan gevolg is gegeven bij KB van 13 juli 1925 (N. Stb. 1925-327, Ind. Stb. 1925-447).

284. Van de Sande Bakhuysen, Nederlandsch Onderdaanschap, Leiden, 1900, p.39-40. 
schap een hoedanigheid is, die ophoudt zodra men zich elders vestigt, terwijl onderdaanschap een hoedanigheid is, die de betrokken persoon juist overal volgt. ${ }^{285}$

Heinsius merkt met betrekking tot de onderhavige aangelegenheid op, dat krachtens genoemde artikelen 105 jo. $106 \mathrm{RR}$ - in de oorspronkelijke redactie - ingezetenen waren, zij die tot de inheemse bevolking behoren; deze hoedanigheid kwam ook toe aan personen die van buiten Nederlandsch-Indië afkomstig waren en zich na verkregen schriftelijke vergunning aldaar gevestigd hadden en van Rijkswege uitgezonden personen, die voor hun vestiging geen vergunning nodig hadden. ${ }^{286} \mathrm{Bij}$ Wet in Ind. Stb. 1918-639 zijn voornoemde artikelen vervangen, in de Indische Staatsregeling (IS) overgenomen als artikel 160 . Ingevolge lid $2 \mathrm{jo}$. lid 1 van dit artikel waren ingezetenen degenen, die mits niet in strijd met de voorschriften der Verordening betreffende toelating en vestiging, in Nederlandsch-Indië gevestigd waren. Alhoewel in het nieuwe artikel niet meer gesproken wordt van "inboorlingen des lands", heeft blijkens de Memorie van Toelichting van genoemde Wet de nieuwe omschrijving naar de bedoeling van de wetgever geheel dezelfde betekenis als de vroegere omschrijving. Heinsius is daarentegen van mening, dat de doorgevoerde wijziging het niet gewilde gevolg heeft gehad, dat de samenhang van de wetgeving verbroken is en dat het - door iedereen erkend - ingezetenschap en onderdaanschap van de inheemse bevolking zijn wettelijke grondslag verloren heeft. Met betrekking tot de mening dat de inhoud van de oude artikelen 105 en $106 \mathrm{RR}$ in de nieuwe lezing zouden zijn samengevat stelt deze auteur zich op het standpunt, dat dit als een dwaling dient te worden aangemerkt, aangezien de uitdrukkelijke toekenning van het ingezetenschap aan personen die deel uitmaken van de inheemse bevolking in de nieuwe bepaling niet terug te vinden is; het hangt van het Toelatingsbesluit (KB van 15 oktober 1915 no. 32, Ind. Stb. 1916-47 jo. 1917-765) af, of bedoelde personen de status van ingezetene hadden c.q. zij slechts als zodanig konden worden aangemerkt indien hun vestiging niet in strijd is met de voorschriften van dat Besluit. ${ }^{2 k 7}$

Beets brengt daarentegen onder de aandacht, dat door de Wet van 1918 de woorden "inboorlingen des lands" weliswaar zijn weggelaten, doch in het nieuwe artikel niet langer van "hun verblijf gevestigd hebben" wordt gesproken doch deze woorden vervangen zijn door "gevestigd zijn". Hij meent hieruit te moeten concluderen, dat door het "gevestigd zijn" een toestand wordt aangeduid, die het gevolg is van het feit der geboorte of van de handeling "zich vestigen"; als ingezetenen van Nederlandsch-Indië krachtens artikel 160 IS konden naar zijn mening worden aangemerkt, personen die aldaar gevestigd waren, hetzij door gegeboorte, hetzij door vestiging. Concluderend

285. Van de Sande Bakhuysen, Nederlandsch Onderdaanschap, p.41-44.

286. Heinsius, A.J.R., Zijn zij, die behooren tot de inheemse bevolking van Nederl. Indië, ingezetenen van Nederl. Indië en Nederlandse onderdanen?, Indisch Tijdschrift van het Recht, 1933, p.9-14.

287. Tbid., p.11. De bedoeling van Heinsius was niet om te betogen, dat de praktijk hen, die behoren tot de inheemse bevolking van Ned. Indiẽ niel meer als ingezetenen en als onderdanen diende te beschouwen. De opzet van deze auteur is aan te tonen, dat naar de wettelijke bepalingen in hun nieuwe redactie niet meer tot het ingezetenschap en onderdaanschap der inheemse bevolking kon worden geconcludeerd. 
stelt Beets, dat artikel 160 lid 2 IS dusdanig dient te worden gelezen, dat als ingezetenen van Nederlandsch-Indië worden aangemerkt, personen aldaar gevestigd, hetzij door geboorte, hetzij door vestiging, mits niet in strijd met de voorschriften betreffende toelating en vestiging. Personen die behoren tot de autochtone bevolking van Nederlandsch-Indië waren krachtens artikel 160 IS ingezetenen, in welk geval niet van het Toelatingsbesluit diende te worden gesproken. ${ }^{288}$ Gezien de status van personen, die van de autochtone bevolking deel uitmaken, lijkt mij dit de enige plausibele uitleg.

Ook Gautama heeft de nodige kritiek op het begrip "ingezetenschap", omdat dit de basis vormde voor het verlenen van rechten en verplichtingen. Volgens deze auteur behoefde het geen verbazing te wekken, dat het Regeringsreglement (RR) - later gewijzigd in de Indische Staatsregeling (IS) - veel bepalingen bevatte betreffende het ingezetenschap. Ook het zijn van buitenlander vormde geen probleem, vooropgesteld dat men de status van "ingezetene" bezat omdat dit toegang gaf tot verschillende rechten en verplichtingen, die in een moderne Staat slechts aan staatsburgers toekomen. De indruk werd gewekt, als zou men zich in die tijd niet veel om het begrip "nationaliteit" bekommeren. Staatsburgerschap en ingezetenschap werden als hetzelfde beschouwd; artikel 5 van de Algemene Bepalingen van Wetgeving (AB) ${ }^{289}$ bepaalde vo6r 1915, dat personen die geen ingezetene waren, buitenlander waren. ${ }^{290}$

\subsection{De situatie in Nederland vóór de afkondiging van de Wet van 1892}

Wat betreft het nationaliteitsrecht in Nederland in de periode vóór 1892, ga ik terug tot het tijdstip dat de Code Civil - als gevolg van het feit dat het Koninkrijk Holland in 1810 een provincie van het Franse keizerrijk was geworden - sedert maart 1811 voor het gehele grondgebied van het huidige Nederland en België kwam te gelden. Genoemde Code Civil werd eerst in 1838 door een eigen Nederlands Burgerlijk Wetboek vervangen, waarvan de tweede titel van Boek 1 - de artikelen 5 tot en met 12 - gewijd was aan het nationaliteitsrecht. Krachtens artikel 5 sub 1 tot en met 4 was de regeling van de verkrijging van het Nederlanderschap gebaseerd op een mengeling van het "ius soli" en het "ius sanguinis." Het "ius soli" had gedeeltelijk zowel op Nederland als op de koloniën - waaronder het voormalige Nederlandsch-Indië - betrekking; geboorte op het grondgebied was echter niet toereikend om het Nederlanderschap te verkrijgen. Als neveneis was gesteld, dat de ouders van de betrokken persoon binnen Nederland of de koloniën gevestigd dienden te zijn (artikel 5 sub 1). ${ }^{291}$ Volgens Adriaanse en van der Weg dient de term "gevestigd" te worden opgevat in die zin dat de desbetreffende

288. Beets, N., Het Ingezetenschap en het Nederlandsch Onderdaanschap der Inheemsche bevolking van Nederlandsch-Indië, Indisch Tijdschrift van het Recht, 1933, p.525-528.

289. Zie voor de Algemeene Bepalingen van Wetgeving voor Indonesië, afgekondigd bij Publicatie van 30 april 1847, Ind. Stb. no. 23, Engelbrecht-oude stijl, p.164.

290. Gautama, Warganegara, p.26-27. Zie voor de tekst van het desbetreffende artikel 5 AB, Schreuder, L.F.G.P., Wet van 12 December 1892 op het Nederlanderschap en het Ingezetenschap, Zutphen, p. 298.

291. De Groot en Tratnik, Nationaliteitsrecht, p.42. 
personen daar woonden. ${ }^{292}$ Het hanteren van genoemde criteria had tot gevolg dat het civiele Nederlanderschap ook toegankelijk was voor autochtone Indonesiërs en daarmede gelijkgestelden. De bepalingen van genoemde artikelen 5 tot en met 12 van het Burgerlijk Wetboek van 1838 bleven van kracht tot de inwerkingtreding van de Wet van 1892 op 1 juli $1893 .{ }^{293}$

Hierbij is het echter niet gebleven; in 1848 werd de Nederlandse Grondwet gewijzigd, een aangelegenheid van belang te achten voor de geschiedenis van het Nederlands nationaliteitsrecht. ${ }^{294}$ Zo bepaalde artikel 5 van de Grondwet, dat om enig burgerschapsrecht te hebben men Nederlander dient te zijn en - krachtens artikel 7 - dat de wet bepaalt wie Nederlander zijn. Kon het nationaliteitsrecht voorheen uitsluitend tot het privaatrecht worden gerekend, ná 1848 ging het belangrijke publiekrechtelijke trekken vertonen. Aangezien de toen geldende nationaliteitsrechtelijke regeling van het Nederlandse Burgerlijk Wetboek - als gevolg van het "ius soli" element van artikel 5 van een zeer ruim begrip "Nederlander" uitging en het kennelijk niet in de bedoeling lag van de Nederlandse wetgever om aan alle Nederlanders in de zin van dit Wetboek politieke rechten te verlenen, werd het noodzakelijk geacht om een nieuwe nationaliteitswet uit te vaardigen. Met het doel gevolg te geven aan het bepaalde in artikel 7 van de Grondwet werd de Wet van 28 juli 1850, N. Stb. 1850-44 afgekondigd. Bedoelde Wet werd traditioneel als een bijzondere Wet beschouwd, die slechts de toekenning van politieke rechten regelde. Opvallend is, dat bij de toepassing van de Wet van 1850, die evenals de regeling van het BW gebaseerd was op een mengeling van het "ius soli" en het "ius sanguinis", het "ius soli" slechts op het Rijk in Europa en niet op de koloniën derhalve ook niet op Nederlandsch-Indië - betrekking had (de artikelen 1 en 2). Adriaanse en van der Weg brengen in dit verband naar voren, dat de term "gevestigd" zoals in deze Wet voorkomende zodanig viel te verstaan, dat de ouders op het tijdstip van de geboorte van hun kind tenminste achttien maanden, of - wanneer de ouders zelf geen Nederlander waren en zij niet aan het bestuur van hun woonplaats het voornemen tot vestiging hadden verklaard - drie jaar in Nederland gewoond moesten hebben. ${ }^{295}$ De Wet van 1850 was bedoeld om de groep van personen aan wie het Nederlanderschap werd verleend, te beperken.

Uit de Memorie van Toelichting van deze Wet kan worden opgemaakt, welke personen van het "politieke" Nederlanderschap dienden te worden uitgesloten; als zodanig kwamen onder meer kinderen van in de koloniên wonende vreemdelingen en "inlanders

292. Adriaanse en van der Weg, Nationaliteitswetgeving, p. 1 A-1.

293. Zie de Groot en Tratnik, Nationaliteitsrecht, p.42-44 en Mannoury, Het Nederlandse Nationaliteitsrecht, p.57-58. Zie voor een uittreksel van het BW, Chalanton. P., La Nationalité Neerlandaise (Pays-Bas et Colonies), 's-Gravenhage, 1928, p 115-118. Voor meer bijzonderheden inzake het BW kan worden verwezen naar Sanger, Die indonesische, p.22-24.

294. Zie voor de tekst van deze Grondwet van Hasselt, Verzameling van Nederlandse Staatsregelingen en Grondwetten, Alphen aan den Rijn, 1964.

295. Adriaanse en van der Weg, Nationaliteitswetgeving, p.1A-2. 
en kleurlingen" niet hiervoor in aanmerking. ${ }^{296}$ Ook Gautama wijst erop, dat het civiele Nederlanderschap geen toegang gaf tot politieke rechten, die normaliter uit het bezit van het staatsburgerschap voortvloeien, met als gevolg dat autochtone Indonesiërs en daarmede gelijkgestelden daarvan verstoken bleven, aangezien zij niet onder de geldingssfeer van de Wet van 1850 vielen. ${ }^{297}$ Zij bleven echter Nederlander in de zin van het BW.

Samenvattend kan worden gesteld, dat Nederland in de periode 28 juli 1850 tot 1 juli 1893 - het tijdstip van de inwerkingtreding van de Wet van 1892 - een dubbele nationaliteitsrechtelijke regeling kende. De regeling van het Burgerlijk Wetboek gold voor civielrechtelijke en de Wet van 1850 voor publiekrechtelijke aangelegenheden, zoals kiesrecht, benoeming tot overheidsfuncties. Volgens Achterberg, was het verschil in Nederlanderschap in politieke en in civiele zin wel te rechtvaardigen - een mening niet door mij gedeeld - aangezien een Nederlands staatsburger, behalve burgerlijke rechten ook politieke rechten diende te bezitten. ${ }^{298}$ Chalanton zegt hierover het volgende: "Ce double règlement de la nationalité, par lequel un individu pouvait en même être, à un point de vue, Néerlandais, et à l'autre point de vue, étranger, avait donné lieu, dans la pratique, à de nombreuses difficultés". 299

Mannoury wijst echter erop, dat tussen 1850 en 1892 voor de toepassing van het verdragenrecht, werd uitgegaan van het $B W$ en niet van de Wet van 1850, die immers slechts op het Rijk in Europa betrekking had. Zo regelde de Consulaire Wet van 25 juli 1871, N. Stb. no. 91 (Ind. Stb. 1872-207) de consulaire rechtsmacht over Nederlanders. Dat daarbij aan het Nederlanderschap volgens het BW werd gedacht bleek uit de artikelen 22a. en 22b. Ook voor het strafrecht waar het Nederlanderschap hoofdzakelijk betekenis had in verband met het uitleveringsrecht, nam de Hoge Raad de toepasselijkheid van het BW aan. De Uitleveringswet van 6 april 1875 N. Stb. 66 stond in artikel 22 op hetzelfde standpunt. ${ }^{300}$ Op grond van deze Wet gold voorheen een algemeen uitleveringsverbod van "Nederlanders", met dien verstande dat ingevolge artikel 22 van deze Wet als Nederlander werden beschouwd, personen die dat waren volgens het Burgerlijk Wetboek. Het Wetboek van Strafrecht van 1886 hield zowel rekening met hen die alleen het staatsrechtelijke, als met hen die uitsluitend het burgerrechtelijke Nederlanderschap bezaten. Artikel 83 van dit Wetboek beschouwde als Nederlanders, degenen die dit ingevolge de Wet van 1850 waren, maar stelde daarmede gelijk "een ieder, wiens uitlevering bij de wet is verboden", dus de Nederlander volgens het BW. ${ }^{301}$ Aangezien deze bepaling eerst wijziging onderging door de Slotbepaling van de Wet van 1892, houdt dit in dat genoemde bepaling van kracht bleef tot 1 juli 1893 . Hieruit kan worden geconcludeerd, dat Nederlanders in de zin van het Burgerlijk

296. De Groot en Tratnik. Nationaliteitsrecht, p.45. Zie voor de tekst van de Wet van 1850, Chalanton, La Nationalité, p.119-124.

297. Gautama, Warganegara, p.23. Zie ook Sanger, Die Indonesische, p.24-26.

298. Achterberg, C.E., Nederlanders, Vreemdelingen en Ingezetenen, Groningen, 1895, p. 11-12.

299. Chalanton, La Nationalité, p.4.

300. Mannoury. Het Nederlandse Nationaliteitsrecht, p. 60

301. Mannoury, Het Nederlandse Nationaliteitsrecht, p.60. 
Wetboek in feite ook ná 1 september 1886 als Nederlanders werden behandeld. Volgens de Groot en Tratnik dient de vraag naar het strafrechtelijk relevante Nederlanderschap in de periode van 1 september 1886 tot 1 juli 1893 als volgt worden beantwoord: "formeel gezien verwees het Wetboek van Strafrecht naar de Wet van 1850 en de Uitleveringswet naar het Burgerlijk Wetboek van 1838 . Feitelijk waren de BW-Nederlanders echter tot 1 juli 1893 met Nederlanders gelijkgesteld". ${ }^{302}$

\subsection{Consequenties van het bestaan van een dubbele nationaliteitsrechtelijke regeling} voor Nederlandsch-Indië

Wat betekent het hierboven uiteengezette nu voor het voormalige Nederlandsch-Indië? Ter beantwoording van deze vraag, dient in eerste instantie te worden teruggegrepen op het hierboven reeds aangehaalde artikel 5 sub 1 van het Ned. Burgerlijk Wetboek van 1838, dat inhield dat Nederlanders zijn, allen die binnen het Koninkrijk of de koloniën daarvan zijn geboren uit ouders, aldaar gevestigd. Dit impliceert dat niet alleen afstammelingen van Nederlanders, doch ook autochtone Indonesiërs, Chinezen en Arabieren in Nederlandsch-Indië geboren, "Nederlander" waren, doch slechts in civielrechtelijke betekenis. Aan deze civiele Nederlanders kwamen derhalve geen politiek-staatkundige rechten en verplichtingen toe, die normaliter aan de status van staatsburger zijn verbonden.

Het was echter wél zo, dat genoemde status niet slechts civiele rechten met zich bracht, doch bedoelde personen ook aanspraak maakten op diplomatieke bescherming. Ten aanzien van de buitenwereld, konden zij zich voordoen als "Nederlands onderdaan". ${ }^{303}$ Door van de Sande Bakhuysen is gewezen op het bij artikel 13 lid 1 van het Consulair Reglement, N. Stb. 1875-21 bepaalde, waarbij was opgedragen Nederlandse onderdanen te beschermen. Voor de uitoefening daarvan diende de desbetreffende Consul te kunnen beoordelen, of een persoon Nederlands onderdaan was. Deze auteur verstaat onder het begrip "onderdanen" allen die tot de Nederlandse staat behoren, afgescheiden van de mate waarin ieder deelneemt aan het staatsbestuur. Zo zullen Nederlandse consuls in de praktijk autochtone: Indonesiërs die: van geslacht: op geslacht op Nederlands gebied hebben gewoond, zeker niet nalaten als Nederlands onderdaan aan te merken c.q. hun bescherming weigeren. Zij konden voorts niet worden uitgeleverd aan derde landen, zoals uit het voorgaande is gebleken. Het positieve recht miste niettemin een aanwijzing wie die onderdanen niet-Nederlanders nu precies waren. ${ }^{3 / 4}$ Ook al was het zo, dat uit de uitleveringstraktaten bleek wie onder Nederlandse onderdanen dienden te worden verstaan; volgens, van de Sande Bakhuysen kon een bewijs dat betrokkenen onderdaan waren, daaruit niet worden geput. Ook het feit dat krachtens artikel 83 van het Wetboek van Strafrecht in verband met artikel 22 van de Uitleveringswet en artikel 22 van de Consulaire Wet, de "niet-uitleverbaren" als

302. De Groot en Tratnik, Nationaliteitsrecht, p.45-46.

303. In internationale verdragen wordt de term "Nederlands onderdaan" reeds Jang vo6r de Wet van 1910 gebruikt, Zie Fromberg, P.H., Verspreide Geschriften, verzameld Joor Chung Hwa Hui, Chineesche Vereeniging in Nederland, Leiden, 1926, p.692 en verder.

304. Van de Sande Bakhuysen, Nederlandsch onderdaanschap, p.28-30. 
Nederlanders werden beschouwd, bracht volgens genoemde auteur hierin geen verandering. 305

Hetgeen betreffende de uitlevering werd opgemerkt gold echter slechts op het vlak van misdrijven. Het zijn van civiele Nederlander kon niet goed worden gehandhaafd ten aarzien van derde landen, die zoveel mogelijk wensten aan de positie van als hierbedoelde beschermde personen afbreuk te doen. De nationaliteit van autochtone Indonesiërs en vooral van vreemde Oosterlingen leverden met name moeilijkheden op met betrekking tot de toepassing van consulaire en handelsverdragen, die - indien met Oosterse mogendheden gesloten - vaak belangrijke voorrechten toekenden aan Nederlandse onderdanen. De regeringen van deze landen maakten bezwaar tegen uitbreiding van deze voorrechten tot personen, wier betrekking tot Nederland grotendeels theoretisch was. Bedoelde personen konden zich in casu op het BW beroepen om hun Nederlanderschap aan te tonen c.q. aanspraak te maken op bescherming van Nederlandse consulaire ambtenaren. Moeilijkheden deden zich vooral voor met betrekking tot de toepassing van het Verdrag met Siam van 17 december 1860, Ind. Stb. 1862, no. 198. Bij Gouvernementsbesluit van 19 mei 1877, Bijblad 3190 werd de Nederlandse Consul te Bangkok uitgenodigd om als Nederlandse onderdanen slechts te beschouwen die Vreemde Oosterlingen, die in Nederlandsch-Indië geboren waren en daar gedurende zes jaar aan de aanvraag van hun buitenlandse pas voorafgaande, waren gevestigd geweest. Deze gedragslijn werd ook door Nederlandse vertegenwoordigers in andere Oosterse landen gevolgd. ${ }^{306}$

Samenvattend kan worden gesteld dat tot de inwerkingtreding van de Wet van 1892, autochtone Indonesiërs en daarmede gelijkgestelden ten aanzien van het burgerlijk recht, het strafrecht en het uitleveringsrecht en in het diplomatieke verkeer als Nederlanders werden beschouwd. Het met de Wet van 1850 geregelde staatsrechtelijke Nederlanderschap - aan bedoelde personen kwamen politieke rechten toe - bracht, zoals reeds opgemerkt, geen wijziging in de status van de civiele Nederlanders, aangezien de geldingssfeer van deze Wet niet werd uitgebreid tot Nederlandsch-Indië.

Het bestaan van twee soorten Nederlanderschap bracht de nodige moeilijkheden met zich mee. Zo moest op de vraag of iemand Nederlander was, onderscheid worden gemaakt tussen een civiele en een politieke Nederlander en moest van dezelfde persoon in het ene geval worden bevestigd en in het andere worden ontkend, dat hij Nederlander was. Gautama wijst erop, dat aan het bezit van het burgerrechtelijk Nederlanderschap geen voordelen waren verbonden, het hier een "lege" nationaliteit betrof, een nationaliteit zonder inhoud. ${ }^{307}$

305. Van de Sande Bakhuysen, Nederlandsch Onderdaanschap, p.29-33.

306. Mannoury, Het Nederlandse Nationaliteitsrecht, p.61.

307. Gautama, Warganegara, p.26. 
Aan de bestaande onzekerheid diende een einde te komen, al was het maar voor de Nederlandse vertegenwoordigers in het buitenland. Dit had tot gevolg, dat met het voorleggen van het ontwerp op het Nederlander- en Ingezetenschap - op een later tijdstip in de vorm van de Wet van 1892 afgekondigd - aan de Staten-Generaal, de leden daarvan zich voldaan betoonden over het feit, dat een einde zou komen aan de moeilijkheden en onzekerheden in verband met het bestaan van twee soorten Nederlanderschap en dat tot eenheid zou worden gekomen in de regeling van het Nederlanderschap.

Met de afkondiging van de Wet van 1892 was het Nederlanderschap voortaan ondeelbaar; wie het verkreeg vielen alle gevolgen, zowel van privaat- als van publiekrechtelijke aard ten deel. Wat betreft personen, die het Nederlanderschap bezaten zowel krachtens het BW als op grond van de Wet van 1850, trad geen verandering in hun positie op. Ten aanzien van degene die zich echter slechts op één van beide Wetten beroepen kon, is door de overgangsbepaling van de Wet van 1892, het recht op de staat van Nederlander niet alleen gehandhaafd, doch uitgebreid met de rechten, welke die staat volgens de andere Wet gaf. ${ }^{308}$ In de Slotbepaling van de Wet van 1892 was in casu vastgesteld, dat met het van kracht worden van deze Wet, de artikelen 5 tot en met 12 van de tweede titel van het eerste boek van het Burgerlijk Wetboek en de Wet van 1850 kwamen te vervallen. In aansluiting daarop was bepaald, dat in de hiervoor genoemde Wetten waarin sprake was van "Nederlanders" diende te worden gelezen, "Nederlanders volgens de Wet op het Nederlanderschap en Ingezetenschap", behalve in artikel 22 van de Wet van 1875, N. Stb. no. 66 - bedoeld is hier de Uitleveringswet waarin de woorden "volgens het Burgerlijk Wetboek" vervangen werden door "volgens de Wet op het Nederlanderschap en Ingezetenschap, alsmede hen, die in de Nederlandse koloniën of bezittingen in andere werelddelen uit aldaar gevestigde ouders zijn geboren".

Van belang was het in de Overgangsbepaling bepaalde, dat met uitzondering van hen, die in Nederlandsch-Indië ingevolge de Wet van 2 september 1854, N. Stb. 129 bedoeld is hier het RR, aan de orde gekomen in $\S 1.1$ - als "Inlanders en met deze gelijkgestelden" werden beschouwd, zij die op het tijdstip waarop deze Wet in werking trad de staat van Nederlander bezitten, Nederlanders waren in de zin van deze Wet, totdat zij het Nederlanderschap volgens genoemde Wet verloren. Dit impliceert, dat volgens de Overgangsbepaling van de Wet van 1892 , Nederlander bleven die dit waren, echter met uitzondering van "Inlanders en met deze gelijkgestelden". In dit verband kan de vraag worden gesteld, of het natuurlijke kind van een autochtone Indonesische of Chinese vrouw die met of zonder de toestemming van de moeder door een Europese vader was erkend, als Europeaan moest worden beschouwd indien dit kind als zodanig was grootgebracht en steeds de staat van Europeaan heeft gehad. Volgens het oordeel van het hoogste rechterlijke college in Nederlandsch-Indië, was de in de Overgangsbe-

308. Achterberg, Nederlanders, p.113-114. 
paling genoemde uitzondering niet van toepassing op buiten echt geboren kinderen van als hierboven bedoelde vrouwen, die door hun Europese vader erkend waren. ${ }^{309}$

Benadrukt dient te worden, dat de hierboven genoemde uitsluiting alleen betrekking had op "Inlanders" en met deze gelijkgestelden, die deel uitmaakten van de bevolking van Nederlandsch-Indië. De koloniale bevolking van Suriname en de Nederlandse Antillen bleef het Nederlanderschap behouden. Volgens Heijs lag de reden daarvan hierin, dat een wettelijk onderscheid tussen Europeanen en "Inlanders" in Suriname en de Nederlandse Antillen niet bestond, waardoor het juridisch onmogelijk was om in de Wel van 1892 dit onderscheid ook voor Suriname en de Nederlandse Antillen te maken. ${ }^{310}$

Het uitsluiten van autochtone Indonesiërs en daarmede gelijkgestelden van het Nederlanderschap zoals in de Wet van 1892 geregeld, was gebaseerd op de overweging, dat indien deze personen het volle Nederlanderschap verkregen - en als gevolg daarvan aanspraak zouden kunnen maken op alle, uit het bezit hiervan voortvloeiende rechten en plichten - daardoor zonder noodzaak een hele verandering teweeg zou worden gebracht in hun positie en dit tot veel moeilijkheden aanleiding zou kunnen geven. ${ }^{331}$ Tot het opnemen van de Overgangsbepaling van de Wet van 1892 in de bewoordingen waarin deze uiteindelijk in de Wet zijn terechtgekomen, heeft de aanvaarding van het amendement van Levyssohn Norman geleid, waardoor een dam werd opgeworpen ten aanzien van groepen van personen die beschouwd werden "als van mindere status" te zijn. ${ }^{312}$ Dit heeft tot gevolg gehad, dat een groot aantal personen die tot op het tijdstip van inwerkingtreding van deze Wet de status van Nederlander hadden, dit bleven behouden, met uitzondering echter van de "inlanders en de met hen gelijkgestelden". ${ }^{313}$ Vanwege dit amendement werden personen die in feite deel vitmaakten van het Nederlands staatsverband, hieruit gestoten! Er zij echter op gewezen, dat - zoals door Mannoury naar voren gebracht - onder deze bepaling niet vielen, de op 1 juli 1893 aanwezige Staatsblad-Europeanen, waarmede de gelijkgestelden zijn bedoeld, die derhalve Nederlanders werden in de zin van de Wet van 1892. Dit gold echter niet voor personen, gelijkgesteld ná de grensdatum 1 juli $1893,{ }^{314}$ Ook Adriaanse en van der Weg merken op dat in voormelde uitsluiting niet waren begrepen, de vóór de inwerkingtreding van de Wet - 1 juli 1893 - krachtens staatsblad met Europeanen gelijkgestel-

309. Schreuder, Wet van 12 december 1892, p.92. Deze auteur verwijst naar een arrest van het Hooggerechtshof van Ned.-Indië van 9 november 1892, overgenomen uit het Ind. W.v.h. R., no. 1536 .

310. Zie Heijs, Nederlanderschap, p.24. Deze auteur voegt hieraan nog toe, dat de Regering ten aanzien van Suriname en de Nederlandse Antillen (nog) minder overtuigd was van de noodzak van uitsluiting dan ten aanzien van Nederlandsch-Indië, aangezien eerstgenoemde gebieden slechts een beperkt aantal inwoners badden, terwijl het aantal inwoners van Nederlandsch-Indieie dat van Nederland vele malen overtrof.

311. Achterberg, Nederlanders, p.114.

312. Zie Schreuder, Wet van 12 december 1892, p. $270-279$ voor de beraadslaging in de Tweede Kamer op 19 en 20 oktober 1892 betreffende de onderhavige Overgangsbepaling.

313. Gautama, Warganegara, p. 31 .

314. Mannoury, Het Nederlandse Nationaliteitsrecht, p.85. Op de kwestie van de gelijkstelling zal in $\S 2.2$ worden teruggekomen. 
den en zij die de staat van Europeaan voerden en dit met officiële bescheiden konden aantonen. ${ }^{315}$ Ook Nederburgh brengt naar voren, dat personen die vóór de inwerkingtreding van de Wet van 1892 reeds met Europeanen waren gelijkgesteld en in Nederlandsch-Indië waren geboren uit aldaar gevestigde ouders, niet onder de in de aanhef van de Overgangsbepaling genoemde vitzondering vielen en derhalve krachtens genoemde Wet Nederlanders waren. Om die reden was het overbodig, iemand te naturaliseren die reeds vóor 1 juli 1893 Nederlander was volgens de Wet van 1892. ${ }^{316}$

Om de moeilijkheden die uit het aanvaarden van het amendement van Levyssohn Norman voortvloeiden te verlichten, ging de Nederlandse regering over tot het aannemen van het amendement van de Beaufort. ${ }^{317}$ Dit amendement had betrekking op personen, die krachtens de Wet van 6 april 1875, N. Stb. no. 66 - hiervoor reeds aan de orde gekomen - niet konden worden uitgeleverd, met name behalve Nederlanders volgens de Wet van 1892 ook zij, die in de Nederlandse koloniën of bezittingen in andere werelddelen uit aldaar gevestigde ouders waren geboren. Volgens Achterberg werd het in casu nodig geacht, om een uitzondering te maken ten aanzien van genoemde personen, ter zake van uitlevering aan vreemde mogendheden wegens begane misdrijven, aangezien zij anders in een slechte positie zouden geraken. ${ }^{318}$ Dit had wijziging van de Slotbepaling van de Wet van 1892 ten gevolge, waardoor Indonesiërs, Chinezen en Arabieren als "Nederlander" konden worden beschouwd, echter enkel voor uitleveringsaangelegenheden. ${ }^{319}$ Uit het Voorlopig Verslag van de Eerste Kamer bleek, dat enige leden niet ongemerkt lieten dat door het amendement de Beaufort een bepaling in de Wet was opgenomen, die in tweeërlei opzicht streed met het stelsel waarop zij steunde. Dit had in de eerste plaats betrekking op het ter zake hanteren van het "ius soli", gezien hier gesproken werd van het land, waar de geboorte plaatsvond; in de tweede plaats werd door de opneming van deze bepaling wederom een tweede soort van Nederlanderschap in het leven geroepen. Deze argumenten werden in de Memorie van Antwoord van de Regering echter van de hand gewezen. ${ }^{320}$

315. Adriaanse en van der Weg, Nationaliteitswetgeving, p.1A-2. De uitsluiting had, zoals reeds opgemerkt, evenmin betrekking op de inwoners van Suriname en Curaçao (de huidige Nederlandse Antillen en Aruba); indien zij Nederlanders waren geweest krachtens het BW, dan behielden zij de Nederlandse nationaliteit.

316. Nederburgh, I.A., Nederlanderschap en Naturalisatie van in Ned.-Indié geborenen, Indisch Tijdschrift van het recht, 1902, p. 69-73. Het betrof hier een persoon, Manupassa genaamd, die van de wens te kennen had gegeven om tot Nederlander te worden genaturaliseerd. De betrokken Minister wees het verzoek af, aangezien betrokkene als gevolg van zijn gelijkstelling met Europeanen reeds het Nederlanderschap deelachtig was geworden in de zin van de Wet van 1892 en om die: reden het verzoek tot naturalisatie als Nederlander niet voor inwilliging vatbaar was.

317. Zie voor de beraadslaging in de Tweede Kamer en Eerste Kamer inzake deze aangelegenheid, Schreuder, Wet van 12 december 1892, p.282-291.

318. Achterberg, Nederlanders, p.126-127.

319. Gautama, Warganegara, p.30-31.

320. Naar voren werd gebracht, dat personen in de koloniën of bezittingen in andere werelddelen uit aldaar gevestigde ouders geboren, niet tot Nederlander werden gemaakt. Slechts met betrekking tot cen onderwerp, en als gevolg daarvan, werden krachtens artikel 83 van hel WvS met betrekking tot het strafrecht de hierbedoelde personen aan dezelfde bepalingen onderworpen als de Nederlan- 
Naar de mening van van de Sande Bakhuysen, heeft de aanneming van het amendement de Beaufort dat heeft geleid tot de wijziging van de Slotbepaling van de Wet van 1892 waardoor ook zij, in de Nederlandse koloniën uit aldaar gevestigde ouders geboren, niet uitleverbaar waren - niettemin geen einde gemaakt aan de bestaande onzekerheid. ${ }^{321}$ Hieraan lag mede ten grondslag, dat krachtens de toenmalige redactie van artikel 12 van de Wet van 1892, een ieder die de staat van Nederlander niet bezat, vreemdeling was. De algemene opvatting in die tijd was, dat veel meer personen tot de Nederlandse onderdanen behoorden dan zij die de staat van Nederlander bezaten, doch het amendement Levyssohn Norman heeft hieraan een einde gemaakt. Chalanton zegt hieromtrent dat "une lacune s'était ainsi formée dans la législation en ce qui conceme la population des Indes néerlandaises". ${ }^{322}$ Ook Nederburgh wijst erop dat de in de Overgangsbepaling van de Wet van 1892 opgenomen uitzondering ten gevolge had, dat de nietEuropese leden van de bevolking van Nederlandsch-Indië vreemdelingen werden volgens de toenmalige bepaling zoals opgenomen in artikel 12 van de Wet. ${ }^{323}$ De behoefte aan een wettelijke regeling van de status van autochtone Indonesiërs en daarmede gelijkgestelden, deed zich dan ook terdege voelen. ${ }^{324}$

Vanuit het Indonesisch nationaliteitsrecht gezien, is de Wet van 1892 "an sich" van geen betekenis, aangezien deze Wet slechts de status van Nederlander volgens deze Wet regelde, en met de inwerkingtreding van deze Wet, autochtone Indonesiërs en daarmede gelijkgesteiden - Vreemde Oosterlingen - van het Nederlanderschap werden uitgesloten. Het lijkt mij wél van belang te wijzen op het feit, dat een kleine groep van autochtone Indonesiërs zich krachtens genoemde Wet tot Nederlander had laten naturaliseren en

320. $\rightarrow$

ders. Aangezien deze personen niet als Nederlanders konden worden aangemerkt, kon er ook geen sprake van zijn dat wat hun nationaliteit betrof, het "ius soli" beginsel zou zijn gehuldigd. Schreuder, Wet van 12 december 1892, p.284-285.

321. Van de Sande Bakhuysen, Nederlandsch Onderdaanschap, p.64, 83-84. Volgens deze auteur zou in het geval de Wet van 1892 uitgestrekt worden tot alle Nederlandse onderdanen, dit niet betekenen, dat de voor een bepaald ambt - naast eisen van bekwaamheid en leeftijd - geen eisen zouden mogen worden gesteld met betrekking tot de landaard van de bekleder van dat ambt. Konden bijvoorbeeld autochtone Indonesiërs geen officier in het Indische leger worden en waren Vreemde Oosterlingen uitgesloten van de benoembaarheid tot administratief ambtenaar in Indië, ook Nederlanders waren in de koloniën van verschillende betrekkingen, die landsbedieningen zijn uitgesloten, zoals het ambt van Regent, Hoofd van de Vreemde Oosterlingen, lid van de Landraad.

322. Chalanton, La Nationalite, p.7.

323. Nederburgh, I. A., Nederlandsch Staatsverband en Koloniën, Rechtsgeleerd magazjjn Themis, 1928, p. 223.

324. Van de Sande Bakhuysen had het voorstel gedaan om de Wet van 1892 in haar oorspronkelijke gedaante te herstellen, derhalve zonder het amendement Levyssohn Norman en het amendement de Beaufort. Voor het gebied in Azië zou dan aanneming van het "ius soli" moeten worden aanbevolen, in verband met het ontbreken van een burgerlijke stand voor het merendeel van de ingezetenen van Nederlandsch-Indiē. Naast de Wet van 1892, zou dan een wet op het onderdaanschap moeten worden opgesteld, waarbij de onderdanen zouden moeten worden gesplitst in Nederlanders volgens de Wet van 1892 en personen, die onderdaan zijn volgens een wet op het onderdaanschap van nietNederlanders, zodat kon worden geconcludeerd, dat vreemdelingen zijn alle niet-onderdanen. Dit heeft in feite plaatsgevonden middels de afkondiging van de Wet van 1910, gebaseerd op het "ius soli". Zie voor het voorstel van van de Sande Bakhuysen, Nederlandsch Onderdaanschap, p.89-90. 
daardoor deze status bezaten vóór 27 december 1949, in casu de datum van de soevereiniteitsoverdracht door Nederland aan Indonesië. Maakten deze personen geen gebruik van de in het kader van de Toescheidingsovereenkomst - het onderwerp van $\$ 5.3$ geboden mogelijkheid om voor het Indonesisch staatsburgerschap te opteren, dan behielden zij genoemde status en bleven derhalve buitenlander. ${ }^{325}$ Ook door Djody Gondokusumo is de aandacht op deze aangelegenheid gevestigd; een soortgelijke beleidslijn werd gevolgd ten aanzien van personen vo6r 1 juli 1893 - de datum van inwerkingtreding van de Wet van 1892 - met Europeanen gelijkgesteld. ${ }^{326}$ Betrof het daarentegen personen, ná 1 juli 1983 gelijkgesteld, dan werden deze personen géén Nederlander doch bleven deel uitmaken van de groep van Nederlandse onderdanen. Deze aangelegenheid zal aan de orde komen in $\S 2.2$.

\section{$\S 2$ Wettelijke onderverdeling van de bevolking van Indonesie}

Voor een goed begrip van de ontwikkelingen die uiteindelijk geleid hebben tot de afkondiging van de Wet van 1910 op het Nederlandsch Onderdaanschap van nietNederlanders, is het noodzakelijk om eerst in te gaan op de wettelijke onderverdeling van de bevolking van Indonesië in bevolkingsgroepen. De achtergrond hiervan is hierin gelegen, dat de bevolking van het Indonesische eilandenrijk zich kenmerkt door een ongekende complexiteit en diversiteit, die in de eerste plaats tot uiting komt in het naast elkaar bestaan van verschillende etnische groeperingen ("suku's"). Deze heterogeniteit werd in de loop der tijden nog ingewikkelder door de immigratie van Europeanen - niet alleen Nederlanders, maar ook Duitsers, Engelsen en andere Europeanen dan deze - en Aziaten, in de Nederlands-Indische wetgeving meestal met de term "Vreemde Oosterlingen" aangeduid, waarvan onder meer deel uitmaken, Chinezen, Arabieren en Indiërs.

De samenstelling van de bevolking van Indonesië maakte het noodzakelijk om te komen tot een onderverdeling daarvan. Bedoelde onderverdeling, zoals uiteindelijk terecht gekomen in artikel 163 IS - de Indische Staatsregeling (IS) was in die tijd als de Grondwet van Nederlandsch-Indië aan te merken - is historisch zo gegroeid, is een erfenis van het koloniale verleden. ${ }^{327}$

Alvorens op genoemd artikel 163 IS in te gaan en aan de hand daarvan vast te stellen, welk recht voor de verschillende bevolkingsgroepen is komen te gelden, moge eerst de verschillende, van regeringswege ondernomen pogingen om tot een onderverdeling van de bevolking van Indonesië te komen, onder de aandacht worden gebracht.

In eerste instantie kan worden gewezen op de artikelen 6,7,8 en 10 van de Algemene Bepalingen van Wetgeving voor Indonesië (AB) Ind. Stb. 1847-23. Krachtens deze

325. Zie het schrijven van de Minister van Justitie aan de Ministerraad no. J.B. 3/70/23 van 28 augustus 1954 , sub ten eerste.

326. Zie de door Djody Gondokusumo - de toenmalige Minister van Justitie - gehouden lezing voor de Baperki met als titel: "Siapa termasuk Warganegara Indonesia?", gepubliceerd door de afdeling Voorlichting van de Centrale Baperki te Jakarta, p.13.

327. Gautama, Warganegara, p. 37. 
artikelen werd onderscheid gemaakt tussen Europeanen enerzijds en Inlanders anderzijds c.q. de met deze categorieën gelijkgestelde personen, waarbij als criterium de godsdienst gehanteerd. Zo werden met Europeanen alle Christenen gelijkgesteld, personen die deel uitmaakten van de Inlandse bevolking daaronder begrepen en voorts alle andere personen, van waar ook afkomstig mits zij de Christelijke godsdienst beleden. Met Inlanders werden vervolgens gelijkgesteld, alle niet-Christenen met name Arabieren, Moren, Chinezen en alle andere personen die Jslamieten of heidenen waren. ${ }^{328} \mathrm{De}$ bevolking van Nederlandsch-Indië werd derhalve verdeeld in twee hoofdklassen: Europeanen en Inlanders en in twee nevenklassen, in casu de met genoemde groepen gelijkgestelden. Onder de met Europeanen gelijkgestelden, vielen onder meer ook personen uit Australië, Amerika en Zuid-Afrika, omdat deze personen in het algemeen Christen zijn. Daarentegen werden Chinezen, Arabieren en Moren beschouwd als met Inlanders gelijkgestelden, vanwege het feit dat deze personen Islamiet waren of geen godsdienst beleden. ${ }^{329}$ Hieraan dient echter te worden toegevoegd, dat de met Inlanders gelijkgestelden van de aanvang af geen afzonderlijke groep vormden en in vele gevallen de regelen die voor hen golden, verschilden van die van de groep van Inlanders. Voor de groep Europeanen en de daarmede gelijkgestelden bestond dit onderscheid vrijwel niet. Dit impliceert dat er in feite drie groepen waren te onderscheiden, met name Europeanen, Inlanders en met Inlanders gelijkgestelden.

De met ingang van 1 januari 1920 gemodemiseerde tekst van artikel $109 \mathrm{RR}^{330}$ - het

328. Zie Schreuder, Wet van 12 December 1892, voor een uittreksel uit de Algemeene Bepalingen van Wetgeving voor Nederlandsch-Indië, vastgesteld bij K.B. 1846, no. 1 (Ind. Stb. 1847 no. 23), p.298, opgenomen in Engelbrecht-oude stijl, p. 164.

329. Ook onder vigeur van het Regeringsreglement (RR), N. Stb. 1854-129, Ind. Stb. 1855-2, waarvan de inhoud van artikel 109 geheel overeenkomt met voomoemde bepalingen van de $A B$ is de hierboven genoemde onderverdeling in twee hoofd-en twee nevenklassen aangehouden.

330. Dit geschiedde met de wetten van 31 december 1906, N. Stb. nos. 346 en 347, Ind. Stb. 1907 nos. 204 en 205 (artikel 1) betreffende wijziging c.q. aanvuling van artikel 109 RR. Uit Ind. Stb. 1919816 is voorts op te maken dat bedoelde wijziging c.q. aanvulling op 1 januri 1920 in werking is getreden. In Ind. Stb. 1907-205 is nog het volgende bepaald:

Art. 2. Wanneer in bestaande algemeene en andere verordeningen, reglementen, keuren van politie en administratieve voorschriften wordt gehandeld over met Inlanders gelijkgestelde personen, zijn daaronder te verstaan zij, die krachtens art. 1 dezer Wet aan de bepalingen voor vreemde Oosterlingen zijn onderworpen.

Wanneer in bestaande algemeene en andere verordeningen, reglementen, keuren van politie en administratieve voorschriften vermeld is, dat zij op Inlanders van toepassing zijn, worden zij ook toepasselijk geacht op hen, die krachtens art. I dezer Wet aan de bepalingen voor Vreemde Oosterlingen zijn onderworpen, ten ware het tegenovergestelde uitdrukkelijk bepaald of blijkbaar de bedoeling is.

Art. 3. Wanneer in bestaande algemeene en andere verordeningen, reglementen, keuren van politie en administratieve voorschriften wordt gebandeld over met Europeanen gelijkgestelde personen, vervalt hunne bijzondere vermelding.

Alle in Ned.-Indiē gevestigcle personen die, vóór de inwerkingtreding dezer Wet (1 jan. 1920), op grond van het vroegere art. 109 van het Reglement op bet beleid der Regeering van Ned.-Indië 
latere artikel 163 IS - bevestigde de bestaande toestand, doordat zij de met Europeanen gelijkgestelden officieel als afzonderlijke groep deed vervallen en aan de met Inlanders gelijkgestelden de naam "Vreemde Oosterlingen" gaf. Het criterium der godsdienst kwam derhalve te vervallen met ingang van 1 januari 1920 . In plaats van de hierboven genoemde artikelen AB kwam artikel 163 IS te gelden - het vroegere artikel $109 \mathrm{RR}$ op genoemde datum in werking getreden. ${ }^{331}$ Op grond van artikel 163 IS werd de bevolking van Indonesië niet langer naar godsdienst maar naar bevolkingsgroep onderverdeeld, als volgt:

- Europeanen

- Inlanders, alsmede

- Vreemde Oosterlingen.

In Artikel 163 IS was bovendien aangegeven, wie voor de toepassing van de daarin genoemde wettelijke regelingen, met de hierboven genoemde categorieën van personen, als gelijkgesteld kon worden beschouwd. Werd gesproken over met Inlanders gelijkgestelde personen, dan waren daaronder te verstaan, degenen die aan de bepalingen voor Vreemde Oosterlingen waren onderworpen. Indien in voornoemde wettelijke bepalingen was vermeld, dat zij op Inlanders van toepassing waren, werden zij ook van toepassing geacht te zijn op personen aan de bepalingen voor Vreemde Oosterlingen onderworpen, tenzij uitdrukkelijk het tegenovergestelde was bepaald of blijkbaar de bedoeling was. ${ }^{332}$ Werd daarentegen in bedoelde wettelijke regelingen gesproken over met Europeanen gelijkgestelde personen, dan verviel hun bijzondere vermelding. ${ }^{333}$

Met betrekking tot deze - raciale - onderverdeling naar bevolkingsgroep lopen in de literatuur de meningen uiteen. Zo oordeelt Blume, dat het gemaakte onderscheid is

330. $\rightarrow$

behoorden tot de met Europeanen gelijkgestelden benevens hunne wettige of wettelijk erkende kinderen en verdere afstammelingen, blijven, zoolang zij zich niet in de inheemsche bevolking hebben opgelost, onderworpen aan de bepalingen voor Europeanen, ook wanneer zij niet vallen in de termen van het hweede lid van het bij art. I dezer Wet gewijzigde art. 109.

Wat betreft de wijziging van de titel "Regeringsreglement" in "Indische Stastsregeling" en het opnieuw afkondigen van de Indische Staatsregeling (IS) moge worden verwezen naar hetgeen hieromtrent reeds naar voren werd gebracht.

331. De Wet op de Staatsinrichting van Ned.-Indiê werd afgekondigd met de Wet van 2 september 1854 , N. Stb. 1854-2, Ind, Stb. 1855-2 jo.1. Zie Engelbrecht II, p. 143.

332. De omschrijving "met Indonesiërs gelijkgestelden" kwam ook in andere vlakken van het recht voor, bijvoorbeeld in het agrarische recht, zoals dat gold vớr de inwerkingtreding van de Agrarische Basiswet no. 5 van 1960. Ter illustratie kan worden verwezen naar het voorheen op gronden, die deel uitmaakten van de voormalige particuliere landerijen gelegen ten westen van de Cimanuk uitgeoefende "hak usaha" (een soort bewerkingsrecht, in feite een afgezwakt "hak milik" dan wel eigendomsrecht) voorbehouden aan de Indonesische bevolking en met deze gelijkgestelden.

333. Het betreft hier het in artikel 2 van Ind. Stb. 1907-205 bepaalde. Zie voor de verschillen tussen de bepalingen $A B$ en die van artikel $109 \mathrm{RR}$, van Mastenbroek, De Historische ontwikkeling van de Staatsrechtelijke Indeeling van de Bevolking van Ned.-Indiē, Amsterdam, 1934, p.62. 
gebaseerd op het verschil tussen de Westerse en Oosterse maatschappij ${ }^{334}$ en spreekt Wertheim van bovenschikking en van onderschikking, doch niet van nevenschikking. ${ }^{335}$ Wordt hiervan uitgegaan, dan is sprake van discriminatie, hetgeen onder meer tot uiting kwam in het voorheen voor Inlanders en daarmede gelijkgestelden geldende strafprocesrecht en in de voor deze personen vastgestelde voorschriften die op kleding en dergelijke betrekking hadden. ${ }^{336}$ Lemaire daarentegen beschouwt bedoelde onderverdeling als historisch interpretatief dispositief. ${ }^{377}$ Gaat men hiervan uit, dan blijft weinig plaats over voor een onderverdeling, in beginsel op discriminatie, op raciale overwegingen gebaseerd. Dan kan zelfs van een gezonde differentiatie en niet van discriminatie worden gesproken, een standpunt door auteurs als Wertheim en Gautama verworpen. ${ }^{338}$ Alhoewel deze onderverdeling naar bevolkingsgroep was gemaakt, kan niet worden ontkend dat dit onderscheid tot op zekere hoogte als een sociaal onderscheid, als een onderscheid naar sferen, die verschillen naar de wijze van leven van de daaronder vallende personen, kon worden gezien. Deze raciale indeling bepaalde in belangrijke mate de rechts- en maatschappelijke positie van de ingezetenen van Nederlandsch-Indië.

Begint in latere tijden de benaming "Inlander" aanstoot te geven, dan komt de term "inheems" naar voren. Sedert 1907 definieen de wet (artikel 109, later artikel 163) "Inlanders" als "allen, die behoren tot de inheemse bevolking van Nederlandsch-Indië en niet tot een andere bevolkingsgroep dan die der Inlanders zijn overgegaan, gelijk mede zij, die behoord hebbende tot een andere bevolkingsgroep dan die der Inlanders, zich in de inheemse bevolking hebben opgelost". Volgens Prins wijst deze definitie op een verschil tussen de begrippen "Inlander" en "tot de inheemse bevolking behorende". ${ }^{339} \mathrm{Na}$ de tweede wereldoorlog heten de Inlanders: "Indonesiërs". ${ }^{340}$ Wordt in de praktijk nog wel van "autochtone Indonesiërs" gesproken, in de Wet no. 62 van het jaar 1958 betreffende het Indonesisch staatsburgerschap wordt niet langer verschil gemaakt tussen autochtone en niet-autochtone Indonesiërs, dit in overeenstemming met het beleid van de Indonesische overheid om niet langer tussen genoemde groepen onderscheid te maken.

334. Blume, H.A., De toekenning van Regt op Verblijf in Nederlandsch-[ndië en de Hoofdonderscheidingen in zijpe Bevolking, naar aanleiding van Art. 105, 106, 107 en 109 van het Regerings-Reglement voor Nederl.-Indië, Leiden, 1858, p.170 e.v.

335. Wertheim, W.F., Herrijzend Azië, Opstellen over de Oosterse samenleving, Arnhem, 1950, p.50 e.v.

336. Gautama, Warganegara, p.42.

337. Lemaire, W.L.G., Het Recht in Indonesië, 's-Gravenhage, 1952, p.230, aantekening onder noot 1. Zie ook Gautama, Warganegara, p. 149.

338. Gautama, Warganegara, p.69. Als voorbeeld van discriminatie verwijst Gautama naar het voorheen geldende strafprocesrecht, waarbij Nederlanders, die van de groep Europeanen deel vitmaakten, veel betere garanties bezaten dan de andere bevolkingsgroepen.

339. Prins, W.F., De gevolgen van de Souvereiniteitsoverdracht ten aanzien van Nederlandse onderdanen, Het Personeel Statuut, 1952, p.52-53.

340. Ook ik geeft er de voorkeur aan van "Indonesiërs" te spreken overeenkomstig de huidig gehanteerde terminologie. 
Naast de hierboven genoemde driedeling kende het Indische recht sedert 1924 nog een andere, echter alleen van belang voor het kiesrecht en als zodanig slechts op Nederlandse onderdanen betrekking hebbende. ${ }^{341}$ In 1924 werden zij ingedeeld in Nederlanders, niet-Nederlanders van inheemse en niet-Nederlanders van vreemde oorsprong, welke terminologie het volgende jaar werd veranderd in: Nederlanders, inheemse onderdanen niet-Nederlanders en uitheemse onderdanen niet-Nederlanders, zoals uit artikel 55 IS blijkt.

Als gevolg van het feit, dat al die verschillende bevolkingsgroepen aan verschillend recht - zowel geschreven als ongeschreven recht - zijn onderworpen, speelt het intergentiele recht in Indonesië nog een rol. ${ }^{342}$ Dit maakt het noodzakelijk om ook in een beschouwing over het Indonesische nationaliteitsrecht enige aandacht te schenken aan het in Indonesië vigerende intergentiele recht. Ook ná het van kracht worden van de Wet no. 62 van 1958 die het Indonesisch staatsburgerschap regelt, kan het voor Indonesische staatsburgers geldende recht onderling verschillen, naargelang het autochtone Indonesische staatsburgers of staatsburgers van vreemde origine betreft. Het zijn van Indonesisch staatsburger biedt derhalve geen garantie dat op Indonesische staatsburgers hetzelfde recht van toepassing is.

Gewezen kan echter worden op het unificatiestreven van de Indonesische overheid gericht op het bereiken van een nationale regeling op de verschillende gebieden van het recht. Ook de Wet no. 62 van het jaar 1958 op het Staatsburgerschap van Indonesië dient als een uiting van dit unificatiestreven te worden gezien, gezien de voorheen op dit vlak heersende rechtsverscheidenheid. Het streven naar unificatie komt voorts tot uiting op het vlak van het huwelijksrecht, ook voor het nationaliteitsrecht van belang, aangezien het van de geldigheid van een huwelijk afhangt, of daaraan nationaliteitsrechtelijke consequenties kunnen worden vastgeknoopt. ${ }^{343}$

34l. Zie voor het begrip "Nederlands onderdaan", de Wet van 1910 betreffende het Nederlands onderdaanschap van niet-Nederlanders, het onderwerp van $\$ 3$. Zoals reeds opgemerkt, werd het begrip "Nederlands onderdaan" reeds vór de afkondiging van de Wet van 1910 gebruikt.

342. Het intergentiele recht speelt cok thans in Indonesië nog een rol. Zie Pompe, S. en de WaayVosters, C., The End of Hukum Antar-golongan?, Bijdragen tot de taal-, land- en volkenkunde, deel 145,2 de en 3 de aflevering, 1989. Een goede omschrijving van "intergentiel recht" is door Gautama gegeven, in casu als "het geheel van rechtsregelingen en beslissingen, die aanwijzen welk rechtsstelsel geldt of wat rechtens is, indien de betrekkingen en gebeurtenissen tussen leden van een Staat in een bepaalde Staat, op een bepaalde plaats of een bepaald tijdstip, aanknopingspunten vertonen met naar personele en zakelijke werking verschillende rechtsstelsels en rechtsnormen". Zie Gouw Giok Siong (Gautama, S.), Hukum Antargolongan, Jakarta, 1956, p. 30.

343. De Huwelijkswet van 1974 beoogt tot een nationale regeling op het vlak van de huwelijken te komen, die de principes van de reads op dit vlak bestaande (wettelijke) regelingen, zoals die gelden voor de verschillende bevolkingsgroepen in Indonesiē opvangt en daaraan een wettelijke basis geeft. Rechtspluralisme op het gebied van het privaatrecht komt, ook ná de afkondiging van de Huwelijkswet van 1974 niettemin nog altijd voor; ook de "Mahkamah Agung" neemt het standpunt in, dat op bet vlak van het privaatrecht nog geen zuiver uniform recht geldt. Zie Gautama, S., Mahkamah Agung dan Keanekaragaman Hukum Perdata, tijdschrift Hukum dan Pembangunan, 1987, p. 163. Zie voorts van dezelfde auteur, Aneka Masalah Hukum Perdata Internasional, Bandung, 1985, p. 309 . 
De grondregel van het Indonesische intergentiele recht gaat ervan uit, dat alle rechtsstelsels in Indonesië gelijkwaardig zijn, een mijns inziens belangrijk beginsel, waaruit voortvloeit dat het ene rechtsstelsel niet boven het andere mag worden gesteld. Bestond in het verleden bij enkele auteurs de neiging, om het Europese recht boven het Adatrecht te laten prevaleren, in het huidige rechtsstelsel doet zich een soortgelijke tendens voor met betrekking tot het naast elkaar bestaan van geschreven recht en Adatrecht, mede als gevolg van het streven van de Indonesische Overheid om nationale wetten in het leven te roepen.

Terugkerend naar mijn uitgangspunt moge voor een goed begrip onder de aandacht worden gebracht, dat artikel 163 IS géén onderscheid naar nationaliteit inhoudt; het betreft hier een onderscheid naar bevolkingsgroep. De termen "Europeanen" en "Vreemde Oosterlingen" slaan uiteraard niet op het hebben van de nationaliteit "Europeaan" dan wel "Vreemde Oosterling"; het gebruik van deze termen is slechts historisch te verklaren, gezien de toenmalige samenstelling van de bevolking van Indonesiè en had tot doel, het voor personen van verschillende nationaliteit - die onder de respectieve groepen vallen - geldende recht vast te stellen.

\subsection{Het voor de bevolkingsgroepen geldende recht}

Ter beantwoording van de vraag, welk recht voor de respectieve bevolkingsgroepen is komen te gelden, kan het volgende naar voren worden gebracht.

\section{Aan de bepalingen voor Europeanen waren onderworpen:}

a. alle Nederlanders;

b. alle personen, niet onder a. vallende, afkomstig uit Europa;

c. alle Japanners en voorts, alle personen van elders afkomstig, niet onder a. en b. vallende, die in hun land onderworpen zouden zijn aan een familierecht, dat in hoofdzaak berust op dezelfde beginselen als het Nederlandse;

d. de in Nederlandsch-Indië geboren wettige of wettelijk erkende kinderen en verdere afstammelingen van de personen als bedoeld onder $b$, en $c$.

2. Aan de bepalingen voor autochtone Indonesiërs waren - uitgezonderd de bij ordonnantie te regelen rechtstoestand der autochtone Christenen - onderworpen allen, die tot de autochtone bevolking van Nederlandsch-Indië behoorden en niet tot een andere bevolkingsgroep dan die der autochtone Indonesiërs waren overgegaan. Van deze groep maakten voorts ook deel uit personen, die tot een andere bevolkingsgroep dan die der autochtone Indonesiërs hebben behoord en zich in de autochtone bevolking hebben opgelost.

3. aan de bepalingen voor Vreemde Oosterlingen waren voorts, behoudens de bij ordonnantie te regelen rechtstoestand van degenen onder hen, die het Christendom beleden, onderworpen allen, die niet vielen in de hierboven onder 1 en 2 genoemde bevolkingsgroepen. 
In het belang van de rechtszekerheid was voorts bepaald, dat personen die vór 1 januari 1920 reeds behoorden tot de met Europeanen gelijkgestelden en hun wettige of wettelijk erkende kinderen en verdere afstammelingen - zolang zij zich niet in de autochtone bevolking hadden opgelost - ook wanneer zij niet voldeden aan het hierboven onder I bepaalde, aan de bepalingen voor Europeanen onderworpen bleven.

Zoals uit het onder 1 gestelde blijkt, vormde de groep van Europeanen géén homogene groep; hieronder vielen niet alleen Nederlanders en andere uit Europa afkomstige personen zoals Duitsers, Fransen, Engelsen doch ook personen krachtens bijzondere wetgeving als de Japannerwet ${ }^{344}$, voorts personen uit landen zoals de Verenigde Staten van Amerika, Australië waarvan het familierecht overeenkomt met het Nederlandse recht, gebaseerd op het beginsel der monogamie. Onder deze groep vielen bovendien personen krachtens gelijkstelling, gemengde huwelijken (waarvan de man Europeaan is) c.q. personen uit dergelijke huwelijken geboren en krachtens erkenning (door een Europeaan). ${ }^{345}$ Onder de groep der Vreemde Oosterlingen vielen Chinezen, Arabieren, Indiërs. Het zijn van Christen had voor personen, die deel uitmaakten van de groepen der autochtone Indonesiërs en Vreemde Oosterlingen niet het vallen onder de groep der Europeanen ten gevolge; zij bleven deel uitmaken van hun oorspronkelijke groep. ${ }^{346}$

In artikel 131 lid 2 IS is voorts het burgerlijk en handelsrecht voor de respectieve groepen als volgt geregeld:

1. voor de groep der Europeanen werden de in Nederland geldende wetten gevolgd. Het betreft hier de toepassing van het concordantiebeginsel, hetgeen wil zeggen,dat het voor deze groep geldende recht in Nederlandsch-Indië diende overeen te stemmen met het recht in Nederland van kracht. Hiervan mocht zowel vanwege bijzondere omstandigheden in Nederlandsch-Indië worden afgeweken als om hen met één of meer der overige bevolkingsgroepen dan wel onderdelen daarvan aan dezelfde voorschriften te kunnen onderwerpen. In het laatste geval gold derhalve gemeenschappelijk recht;

344. Opvallend is dat de gelijkstelling van Japanners aan Europeanen eerst plaatsvond bij Wet van 19 mei 1899, N. Stb. 1899-121, derhalve ná de afkondiging van de Wet van 1892. Aan Japanners werd derhalve een "hogere status" toegekend dan bijvoorbeeld aan de Chinezen, die van de groep van $V_{\text {reemde }}$ Oosterlingen deel uitmaakten. Aangezien het kon voorkomen dat laatstgenoemden door factoren als opvoeding, opleiding e.d. werden geacht te behoren tot de beter gesitueerden, werd dit vaak als een onrecht ervaren. Zie hiervoor Wertheim, W.F., Het Rassenprobleem, De ondergang van een mythe, 's-Gravenhage, 1948, p. 130.

345. Prins, W.F., De bevolkingsgroepen in het Nederlandsch-Indische recht, Kol. Stud., 1923, p.652 en verder. Tussen de jaren 1881 en 1940 is de groep der Europeanen toegenomen middels gelijkstelling: 16.500 personen, gemengde huwelijken: 16.000 personen, geboorten uit gemengde huwelijken: 29.000 personen en erkenningen: 48.000 personen.

346. Utrecht, E. en Moh. Saleh Djindang, Pengantar dalam Hukum Indonesia, Jakarta, 1982, p. 168. 
2. voor autochtone Indonesiërs en Vreemde Oosterlingen geldt hun Adatrecht. Maken de bij hen gebleken maatschappelijke behoeften het nodig, dan kon de wetgever op deze personen:

a. Europees recht;

b. gewijzigd Europees recht;

c. gemeenschappelijk recht, dan wel

d. nieuw recht, met name recht dat een synthese tussen Adatrecht en Europees recht vormt (door van Vollenhoven "fantasierecht" genoemd) toepassen. ${ }^{347}$

Het in artikel 131 IS bepaalde - zie hierboven sub 2. ad a.,b. en c. - vormt de basis van rechtsoplegging door de wetgever, waarbij het voor Europeanen geldende recht van toepassing werd verklaard op niet-Europeanen. Dit had tot doel de geldingssfeer van het Europese recht uit te breiden teneinde mogelijke intergentiele geschillen te vermijden.

Hetzelfde doel werd nagestreefd door het eerst van elkaar verschillende recht om te vormen tot én recht, middels de toepasselijkverklaring daarvan op alle bevolkingsgroepen. Van de staatsbladen in dit kader van belang, kan Ind. Stb. 1924-556 worden genoemd, dat betrekking heeft op de aanwijzing van gedeelten van het voor Europeanen geldende burgerlijk en handelsrecht - al dan niet gewijzigd - van toepassing op Vreemde Oosterlingen andere dan Chinezen. ${ }^{348}$ Hierbij zij opgemerkt, dat het familierecht niet op deze categorie van toepassing is verklaard. Met een soortgelijk doel werd met Ind. Stb. 1917-129, een regeling getroffen voor Chinezen, met dien verstande dat op deze categorie vrijwel het gehele Indonesische Burgerlijk Wetboek (IBW) - behoudens enkele uitzonderingen c.q. aanvullingen, onder meer betreffende de mogelijkheid tot adoptie van toepassing is verklaard. ${ }^{349}$

Van geheel andere aard was de in Ind. Stb. $1917-12$ jo. 528 opgenomen mogelijkheid voor niet-Europeanen, om zich vrijwillig aan het voor Europeanen geldende burgerlijk en handelsrecht te onderwerpen, welke mogelijkheid in artikel 131 lid 4 IS haar rechtsbasis vond. ${ }^{350}$ Het betrof hier in eerste instantie de voor autochtone Indonesiërs en Vreemde Oosterlingen mogelijk gemaakte algehele onderwerping aan genoemd recht. ${ }^{351}$ Een tweede mogelijkheid vormde de mogelijkheid voor autochtone Indonesiers tot gedeeltelijke onderwerping, in casu aan dat gedeelte van het voor Europeanen geldende privaatrecht, dat op grond van Ind. Stb. 1924-556 - hiervoor reeds genoemd -

347. Ibid., p. 168-169. Deze auteur geeft vervolgens aan dat de onderverdeling van het recht in Indonesië reeds lange tijd bestaat en geeft vervolgens de geschiedenis daarvan weer.

348. Engelbrecht p.765.

349. Engelbrecht p.767.

350. Zie voor bedoelde Regeling betreffende de Vrijwillige Onderwerping aan het Europees Privaatrecht, Engelbrecht-II p.766.

351. Deze mogelijkheid stond niet open voor gehuwde vrouwen, mannen die een polygaam huwelijk bebben aangegaan, minderjarigen en onder curatele gestelden. 
op Vreemde Oosterlingen andere dan Chinezen toepasselijk was verklaard. ${ }^{352}$ Onder de aandacht kan worden gebracht, dat gehuwde mannen - zowel ingeval van algehele als voor wat betreft de gedeeltelijke onderwerping - hiervoor toestemming dienden te hebben van hun echtgenote(n). Immers, de hierbedoelde rechtshandeling door de man verricht, had uiteraard gevolgen voor het gehele gezin. Het betreft hier een - vrijwillige - rechtskeuze van betrokkene. Ook hier beoogde de wetgever met het in leven roepen van dit instituut de geldingssfeer van het Europees privaatrecht uit te breiden. Het gevolg van de algehele onderwerping aan het voor Europeanen geldende privaatrecht lag hierin, dat betrokkene privaatrechtelijk "Europeaan" werd, in die zin dat op hem het Europese privaatrecht van toepassing werd. De vrijwillige algehele onderwerping aan het Europees privaatrecht was onherroepelijk, een bepaling opgenomen in het belang van de rechtszekerheid.

Van genoemde algehele dan wel gedeeltelijke onderwerping aan het Europees privaatrecht is in de praktijk weinig gebruik gemaakt, anders dan de onderwerping voor een bepaalde rechtshandeling - slechts beperkt tot het vermogensrecht - ook in het onderhavige Staatsblad geregeld. ${ }^{353}$ Het door de wetgever beoogde doel werd echter door het instituut der vrijwillige onderwerping niet bereikt. Slechts door de toepasselijkverklaring - opgelegd recht - was het mogelijk om geldingssfeer van het Europese privaatrecht uit te breiden. Onder de aandacht kan voorts worden gebracht, dat in de praktijk het instituut van de intergentiele rechtskeuze bekend was, waaruit gevolgen uit de rechtskeuze voor het Europees privaatrecht voortvloeien, zonder dat daarbij een bepaalde formele vorm verplicht was gesteld.

Een vrijwillige rechtskeuze kon nochthans ook vér strekkende gevolgen hebben, met name tot verandering van nationaliteit leiden, anders dan bij de vrijwillige onderwerping als hierboven genoemd. Dit is met name het geval bij instituten als "oplossing in de autachtone bevolking" en het "gemengde huwelijk", hierna te behandelen. ${ }^{354}$

Alvorens op genoemde instituten in te gaan kan de vraag worden gesteld of de artikelen 131 IS en 163 IS thans nog geldig kunnen worden geacht. Deze vraag is met name hierop terug te voeren, dat krachtens artikel II van de Overgangsbepalingen van de Grondwet van 1945, alle aanwezige staatslichamen en regelingen van kracht blijven zolang deze nog niet door nieuwe volgens deze Grondwet zijn vervangen. In dit verband dient ook te worden gewezen op artikel 1 van de Presidentiële Regeling no. 2 van het jaar 1945, dat onder meer inhoudt dat alle staatslichamen en regelingen die bestaan tot de oprichting van de Staat der Republiek Indonesië op 17 augustus 1945, zolang nog

352. De uitzondering betrof in dit geval getrouwde vrouwen, minderjarigen en onder curatele gestelden. Ook mannen die een polygaam huwelijk hadden aangegaan konden van deze gelegenheid gebruik maken, aangezien het op Vreemde Oosterlingen andere dan Chinezen toepasselijk verklaarde Europese privaatrecht niet het familierecht betrof.

353. De achtergrond van deze beperking ligt hierin, dat een handeling van partijen, betrokken bij een vermogensrechtelijke - verbintenis, niet de rechten van derden, die buiten de verbintenis staan, kan beïnvloeden. Zie Gouw Giok Siong (Gautama), Hukum Antargolongan, p. 152.

354. Gouw Giok Siong (Gautama), Hukum Antargolongan, p. 94. 
geen nieuwe bestaan volgens de Grondwet nog van kracht zijn, voor zover zij niet hiermede in strijd zijn. ${ }^{355}$ Gezien het in genoemde Regeling gehanteerde criterium "voor zover niet in strijd met de Grondwet" een rekbaar begrip is, is het niet altijd eenvoudig om vast te stellen of een regeling al dan niet in strijd met de Grondwet kan worden geacht te zijn.

Alhoewel artikel 163 IS in de huidige constellatie van de Republiek Indonesië zeker niet meer op zijn plaats kan geacht te zijn, ligt het belang van dit artikel voor het nationaliteitsrecht in eerste instantie in het feit, dat de daarin opgenomen onderverdeling van de Indonesische samenleving in bevolkingsgroepen doorwerkte in de vóór de afkondiging van de Wet no. 62 van het jaar 1958 geldende nationaliteitswetgeving. Bedoelde onderverdeling is namelijk in de Wet van 1910 betreffende het Nederlands onderdaanschap van niet-Nederlanders en in de Toescheidingsovereenkomst, eveneens op genoemde onderverdeling gebaseerd, ook in de Wet no. 62 van het jaar 1958 - met name in artikel 1 sub a en de toelichting daarop - terug te vinden. Hiernaast geeft bedoeld artikel - hetgeen ook geldt voor artikel 131 IS - een beeld van het vooralsnog in Indonesië heersende rechtspluralisme. Van belang is voorts, dat de status van personen krachtens artikel 163 IS verkregen c.q. het recht dat op deze personen van toepassing is ex. artikel 131 IS gehandhaafd is gebleven, al worden geen nieuwe gevallen op basis van genoemde artikelen aan de reeds bestaande toegevoegd. Toegelicht met een voorbeeld houdt dit in, dat in het geval van een Indonesiër die op basis van artikel 163 IS is gelijkgesteld, hij de hierdoor verkregen status zou blijven behouden, betrokkene derhalve onderworpen zou blijven aan het - voorheen - voor Europeanen geldende privaatrecht, zoals vastgesteld in het IBW, een aangelegenheid waarbij de nodige vraagtekens kunnen worden gesteld!

Genoemde artikelen zijn echter niet meer in overeenstemming te achten met de huidige omstandigheden, nu de Wet no. 62 van het jaar 1958 is komen te gelden en de raciale onderverdeling van de bevolking niet langer noodzakelijk is. Bovendien is met de Instructie van de Voorzitter van het Presidium van het Kabinet van 27 december 1966 verklaard, dat in afwachting van een nationale regeling inzake de Burgerlijke Stand, de onderverdeling van de ingezetenen van Indonesië als gebaseerd op artikel 131 en 163 IS niet langer bij de kantoren van de Burgerlijke Stand in geheel Indonesië wordt gebruikt. ${ }^{356}$ Genoemde kantoren staan open voor alle ingezetenen van Indonesië. Onderscheid zal slechts worden gemaakt tussen Indonesische staatsburgers en buitenlanders. ${ }^{357}$

355. Zie voor deze Presidentiēle Regeling, Engelbrecht p.5.

356. Het betreft hier de Instructie van de Voorzitter van het Presidium van het Kabinet no. 31/U/In/12/1966 van 27 december 1966.

357. Hieraan is echter toegevoegd, dat dit geen afbreuk doet aan de bepalingen inzake huwelijk, erfenis en andere burgerrechtelijke aangelegenheden. Voor het huwelijksrecht is echter reeds een wettelijke regeling getroffen, met name de Huwelijkswet no. I van 1974, die evenwel niet alle aangelegenheden die het huwelijk betreffen, omvat. 


\subsection{Gelijkstelling aan Europeanen}

Aangezien in het voorafgaande verschillende keren het instituut "gelijkstelling aan Europeanen" is genoemd, zal eerst op dit instituut worden ingegaan. Zoals uit hetgeen in $\S 2$ is uiteengezet kan worden afgeleid, werd de status "Europeaan" als van hogere rang, als superieur aangemerkt, in vergelijking met Vreemde Oosterlingen en Indonesiërs. De gelijkstelling aan Europeanen waar artikel 163 lid 5 IS van spreekt, werd dan ook als een "gunst" beschouwd, welke status lang niet aan een ieder werd verleend die daarom verzocht. Werd aanvankelijk in het jaar 1884 de voorwaarde van "volkomen geschikt" om in de Europese samenleving te worden opgenomen gesteld, waaraan in 1894 de voorwaarde van het zijn van christen werd toegevoegd, eerst in 1913 werden de rechtsbehoeften van betrokkene op de voorgrond geplaatst. ${ }^{358} \mathrm{De}$ gelijkstelling gold van rechtswege mede voor de daarna geboren, wettige of wettelijk erkende kinderen van betrokkene en had voor de betrokken personen belangrijke gevolgen, zowel op privaatrechtelijk als op publiekrechtelijk terrein.

Onderscheid kon worden gemaakt tussen de formeel-wettelijke gelijkstelling - gebaseerd op het hierboven aangehaalde artikel 163 lid 5 IS - en de informeel-rechtelijke gelijkstelling, niet gebaseerd op een geschreven regel. In het laatstbedoelde geval diende aan de hand van sociale factoren, levenswijze, naamsverandering, eventueel huwelijk met een Europese vrouw - kortom, maatschappelijke positie en uiterlijke staat - te worden vastgesteld of al dan niet van "gelijkstelling" kon worden gesproken, alvorens daaraan rechtsgevolgen konden worden verbonden. Dat ook de mogelijkheid der informele gelijkstelling voor belanghebbenden openstond, bleek hieruit, dat indien geen staatsblad kon worden overgelegd, genoegen kon worden genomen met een vóór 1 juli 1893 afgegeven verklaring van onder meer de Resident, waaruit bleek dat de betrokken persoon als Europeaan werd beschouwd of zelfs met een verwijzing naar de lijst van Europese inwoners. ${ }^{359}$ Indonesische rechtbanken gingen er traditioneel vanuit, dat personen die aan bepaalde vereisten voldeden ook als gelijkgesteld met Europeanen konden worden aangemerkt, ook al was geen besluit van de Gouvemeur-Generaal, in het staatsblad gepubliceerd - bedoelde personen werden om die reden vaak staatsbladEuropeanen genoemd - voorhanden. In dit verband kan een geval uit de jurisprudentie dat zich in 1855 heeft voorgedaan worden genoemd, waarin het Hooggerechtshof de uitspraak deed dat een man, A.M. van der Z. genaamd, alhoewel geboren uit een nietEuropese vader, Europeaan was omdat hij een Europese naam droeg, als ambtenaar werkzaam was in een toezichthoudende positie, in de samenleving nooit anders dan als Europeaan werd beschouwd en gehuwd was volgens de procedure van het Westers recht. ${ }^{360}$

358. Gautama, Warganegara, p. 41-42. In de wettekst wordt gesproken van de toepasselijkverklaring van het voor Europeanen geldende burgerlijk recht op personen niet daaraan onderworpen. Deze term wekt echter verwarring met de in artikel 131 IS geregelde toepasselijkverklaring, zodat de vóór 1 januari 1920 gehanteerde term "gelijkstelling" wordt gehandhaafd.

359. Prins, De gevolgen, p.59.

360. Gautama, S. en Hornick, R.N., An Introduction to Indonesian law, Unity in diversity, Bandung, 1973, p.15-16. 
Ter voorkoming van misverstand dient niettemin te worden benadrukt, dat de regeling inzake de gelijkstelling niet als een regeling betreffende nationaliteit dient te worden gezien. Bedoelde regeling is slechts beperkt tot de onderverdeling van de bevolking ex artikel 163 IS. ${ }^{361}$ Zoals in $\$ 1.4$ naar voren gebracht, is hierop één uitzondering: personen, die deel uitmaakten van de groep van Indonesiërs die vóor 1 juli 1893, in casu de datum van inwerkingtreding van de Wet van 1892, met Europeanen waren gelijkgesteld, waren Nederlander en bleven die nationaliteit behouden, indien zij niet in het kader van de Toescheidingsovereenkomst voor het Indonesisch staatsburgerschap opteerden. Had bedoelde gelijkstelling echter plaatsgevonden ná de datum 1 juli 1893, dan werden deze personen gén Nederlander, doch bleven deel uitmaken van de categorie van Nederlandse onderdanen. ${ }^{362}$

\subsection{Oplossing}

Aanknopend bij de in artikel 163 lid 3 IS opgenomen omschrijving "zich in de inheemse bevolking hebben opgelost" kan de vraag worden gesteld, wanneer een niet-Indonesiër zich in de Indonesische bevolking heeft "opgelost", een vraag die ook gezien de intergentiele aspecten verbonden aan het "van de ene bevolkingsgroep overgaan naar de andere" van belang kan worden geacht. Waar het in feite om gaat is dat een nietIndonesiër op deze wijze Indonesiër werd.

Wanneer kon worden vastgesteld dat de hierbedoelde "oplossing" zich heeft voltrokken c.q. welke criteria konden ter beoordeling van dit geval worden gehanteerd? Duidelijk is dat deze aangelegenheid met de nodige voorzichtigheid dient te worden benaderd, vanwege de daaraan verbonden juridische consequenties, teneinde mogelijk misbruik te voorkomen, bijvoorbeeld indien het betrokkene erom te doen was "adat milik"-rechten (eigendomsrechten volgens het Adatrecht) op de grond te verkrijgen. Wettelijke criteria ter beoordeling van een als hierbedoeld geval zijn niet voorhanden. Dit impliceert, dat afgegaan diende te worden op de feitelijke omstandigheden en ieder geval "an sich" zal moeten worden beoordeeld. Hierbij konden factoren als onder meer levenswijze in overweging worden genomen, waaruit zou kunnen worden geconcludeerd, dat de persoon in kwestie zich gedroeg als "Indonesiër onder Indonesiërs". Van de andere factoren, die hierbij in aanmerking konden worden genomen kan worden genoemd, het aannemen van de Islamitische godsdienst - een factor zeker als belangrijk aan te merken, alhoewel "an sich" niet doorslaggevend - en voorts, het aannemen van een

361. Dat gemakkelijk misverstand op dit vlak kan optreden moge bljken uit het feit, dat McNair een gelijkgestelde persoon als zijnde genaturaliseerd aanmerkt. Zie MeNair, The Chinese Abroad, Shanghai, 1924, p. 107.

362. Dit is benadrukt in het schrijven van de Minister van Justitie aan de Ministerraad no. J.B. 3/70/23 van 28 augustus 1954 sub ten eerste. Ook door Djody Gondokusumo, Siapa termasuk Warganegara, is een overeenkomstige uitleg gegeven. 
Indonesische naam, het huwen met een autochtone Indonesische vrouw en andere uiterlijke kenmerken. ${ }^{363}$

Volgens Nederburgh had ook de oplossing van een Nederlander in de Inheemse bevolking het verloren gaan van het Nederlanderschap ten gevolge. ${ }^{364}$ In deze wijze van het verloren gaan van het Nederlanderschap was echter niet voorzien in artikel 7 van de Wet van 1892, dat vijf oorzaken van het optreden van het verlies van het Nederlanderschap opsomt. Deze auteur twijfelt eraan of men zich in het algemeen ervan bewust was dat deze zesde oorzaak bestond. Hij acht deze aangelegenheid van des te meer gewicht, omdat de onderhavige oplossing in de Indonesische bevolking - waarvoor de wet geen bepaalde kenmerken aangaf - een vaag begrip was, vatbaar voor een zeer uiteenlopende toepassing. Het al dan niet zijn van Nederlander werd zodoende in dit opzicht iets zeer onzekers. ${ }^{365}$

Speelden de problemen aan de "oplossing" verbonden voorheen een rol, ook thans lijkt het mij niet uitgesloten, dat op deze wijze wordt getracht in het bezit van bepaalde rechten te komen. Dit wordt door de praktijk gestaafd, zoals onder meer uit de in $\S 9$ behandelde jurisprudentie zal blijken.

\subsection{Het gemengde huwelijk ex Ind. Stb. 1898-158}

Aangezien in het hierboven uiteengezette herhaaldelijk sprake was van het maken van een rechtskeuze zal thans aandacht worden besteed aan de Regeling op de Gemengde Huwelijken (afgekort RGH), opgenomen in Ind. Stb. 1898-158. ${ }^{366}$ Het belang van deze Regeling is mede gelegen in de nationaliteitsrechtelijke consequenties van de daarin geregelde gemengde huwelijken en is bovendien ook uit het oogpunt van hel intergentiele recht gezien, als belangrijk aan te merken.

Alhoewel niet met zoveel woorden in de onderhavige Regeling bepaald, kan gezegd worden dat ook hier sprake is van het doen van een rechtskeuze, met name door de vrouw. In artikel 2 is in casu bepaald dat de vrouw die een gemengd huwelijk aangaat, staande huwelijk, publiek- en privaatrechtelijk de staat van haar man volgt. Dit houdt mede in, dat alle door de man verrichte rechtshandelingen óók voor de vrouw komen te gelden. Hierop aansluitend kan worden gewezen op artikel 6 van deze Regeling, dat

363. Als voorbeeld van de aan de "oplossing" verbonden juridische consequenties kan het geval van een Indonesisch staatsburger van Chinese afkomst worden genoemd, die naast het Indonesisch staatsburgerschap ook dat van de Chinese Volksrepubliek bezat. Indien werd vastgesteld dat betrokkene zich in de Indonesische bevolking heef opgelost, werd hij niet langer geacht een dubbele nationaliteit te bezitten en was derhalve niet tot het maken van een keuze verplicht.

364. In herinnering zij het derde lid van artikel 163 IS gebracht, dat onder meer stelt dat "Aan de bepalingen voor Inlanders.....onderworpen (zijn)....zij die behoord hebbende to een andere bevolkingsgroep dan die der Inlanders, zich in de inheemsche bevolking hebben opgelost*. Het gaat hier om iedere andere bevolkingsgroep dan die der Indonesiers, hetgeen derhaive niet is beperkt tot een bepaalde andere bevolkingsgroep.

365. Nederburgh, Nederlandsch Staatsverband, p.223.

366. De Regeling op de Gemengde Huwelijken is opgenomen in Engelbrecht p.820. 
inhoudt dat de voltrekking van een gemengd huwelijk geschiedt volgens het voor de man geldende recht, behoudens de toestemming van de aanstaande echtgenoten, die steeds wordt vereist. Dit betekent dat de vrouw die een gemengd huwelijk aangaat, weet wat de juridische consequenties daarvan zijn, dat haar toestemming in feite een rechtskeuze is voor het recht, dat voor de man geldt.

In genoemd artikel 2 is het beginsel opgenomen, waanit de gelijkwaardigheid van de verschillende, in Indonesië geldende rechtsstelseis kan worden afgeleid. Wordt echter afgegaan op de in artikel 2 neergelegde bewoordingen, dan zou kunnen worden geconcludeerd, dat juist géén sprake is van gelijkwaardigheid van genoemde rechtstelsels. Hierin is immers gesteld, dat de vrouw de staat van haar man volgt. Wordt dit evenwel met een voorbeeld toegelicht, dan verkreeg een niet-Europese vrouw - bijvoorbeeld een Indonesische vrouw - die met een Europeaan - bijvoorbeeld een Nederlander - huwde, door huwelijk de Nederlandse nationaliteit en kan, vanuit juridisch oogpunt bekeken, tot gelijkwaardigheid van alle rechtsstelsels worden geconcludeerd. Het niet-Europese recht wordt dan gelijkgesteld met het Europese recht; dit blijkt nog duidelijker indien een Europese vrouw met een autochtone Indonesiër trouwde, hetgeen statuswijziging voor de Europese vrouw, zowel publiekrechtelijk als privaatrechtelijk ten gevolge had en van een vooropstelling van het Europese recht geen sprake was. ${ }^{367}$

Duidelijkheidshalve dient op het hierboven genoemde begrip "gemengd huwelijk" nader te worden ingegaan; hieronder wordt in de onderhavige Regeling verstaan, een huwelijk tussen personen, die in Indonesië aan verschillend recht zijn onderworpen. Dit kan zich voordoen als gevolg van verschil van godsdienst, van bevolkingsgroep, verschil van regio of plaats dan wel verschil van nationaliteit tussen de huwelijkspartners, welk laatste geval relevant is voor het hier behandelde onderwerp.

Over het feit, of huwelijken tussen personen van verschillende nationaliteit ook onder de geldingssfeer van deze Regeling vallen, bestaat verschil van mening. Auteurs als Gautama en Syahmin nemen het standpunt in, dat dit wél het geval is en vatten derhalve het begrip "gemengd huwelijk" in ruime zin op c.q. zijn van mening, dat huwelijken tussen personen van verschillende nationaliteit - vooropgesteld, dat één der huwelijkspartners Indonesisch staatsburger is - ook onder genoemde Regeling zijn te brengen, een standpunt ook door mij gehuldigd. ${ }^{368}$ Ter staving van dit standpunt kan worden gewezen op artikel 10 van de $\mathrm{RGH}$, dat inhoudt dat gemengde huwelijken buiten het gebied van Indonesië aangegaan geldig zijn, indien deze huwelijken gesloten zijn naar de vorm, gebruikelijk in het land waarin de voltrekking heeft plaatsgevonden. Hierbij is echter het voorbehoud gemaakt, dat géén der partijen gehandeld mag hebben tegen de voorschriften of vereisten van het voor hen geldende recht, wat betreft de hoedanigheden en voorwaarden, gevorderd om een huwelijk te kunnen aangaan. Ter illustratie kan een geval uit de jurisprudentie worden aangehaald, waarbij een huwelijk tussen een

367. Gautama, Aneka Masalah, p.310-324, die deze aangelegenheid vanuit verschillende aspecten belicht.

368. Bedoeld is hier de situatie vóór de inwerkingtreding van de Huwelijkswet van 1974. Zie Syahmin, Penyelundupan Hukum, p.58. 
Egyptische vrouw en een autochtone Indonesiër, die de Islamitische godsdienst belijdt, in Cairo in het jaar 1937 voltrokken - welk huwelijk onder vigeur van genoemde Regeling viel - door de "Pengadilan Negeri" te Jakarta, met het vonnis van 1 september 1954 , no. $269 / 1954 \mathrm{G}$. als geldig werd aangemerkt. ${ }^{369}$

Inmiddels is de Huwelijkswet van 1974 afgekondigd, waarin de term "gemengde huwelijken" in beperktere zin dan in de RGH wordt opgevat, met name is beperkt tot een huwelijk tussen partijen die van nationaliteit verschillen, waarvan één Indonesisch staatsburger is.

\section{\$ 3 Het Nederlands onderdaanschap krachtens de Wet van 1910}

Zoals in het kader van het hiervoor uiteengezette reeds opgemerkt, had de afkondiging van de Wet van 1892 ten gevolge dat de status van autochtone Indonesiërs en met deze gelijkgestelden ongeregeld bleef; deze groeperingen werden in feite "vreemdeling". Regeling van de status van genoemde personen vormde derhalve een noodzaak, onder meer omdat deze aangelegenheid tot internationale moeilijkheden leidde met China, welk land aanspraak wenste te maken op het verlenen van diplomatieke bescherming van de overzee gevestigde Chinezen. Ook het Ottomaanse rijk erkende geen diplomatieke bescherming door Nederland ten aanzien van de Indonesische Mekkagangers. ${ }^{370}$

Om aan genoemde bezwaren tegemoet te komen, werd de Wet van 1910, N. Stb. 1910 55, Ind. Stb. 1910-296 betreffende het Nederlands onderdaanschap van niet-Nederlanders afgekondigd, die verschillende malen wijziging heeft ondergaan. ${ }^{371}$

369. Gautama, S., Tafsiran Undang-Undang Kewarganegaraan Republik Indonesia, Bandung, 1973, p. 150.

370. Hecker, Das Staatsangehörigkeitsrecht, p.42. Zie ook Sanger, Die indonesische, p.29.

371. Met de Wet van 10 juni 1927, Ind. Stb. 1927-418 (N. Stb. no. 175) werd onder meer de toepasselijkheid van de Wet van 1910 uitgebreid tot de bevolking van Suriname en van Curaçao. Met de Wet van 18 mei 1929, Ind. Stb. 1929-294 (N. Stb. no. 258) werd een wijziging doorgevoerd in de Wet van 1910 inzake het verloren gaan van het Nederlandsch onderdaanschap voor zover het personen betreft, die nier behoren tot de inheemse bevolking van Nederlandsch-Indie en nalaten aan de aangifteplicht in geval van verblijf in een vreemd land bij een Nederlandse consulaire ambtenaar in dat land te voldoen. Voorts werd met de Wet van 21 december 1936, Ind. Stb. 1937-389 (N. Stb. 1936-912) onder meer bepaald, dat het verloren gaan van het Nederlandsch onderdaanschap door naturalisatie door een man, zich uitstrekt tot de met de genaturaliseerde gehuwde vrouw, tenzij zij door naturalisatie van haar man een vreemde nationaliteit niet deelachtig wordt noch kan worden en tot de ongebuwde kinderen die nog geen 18 jaar zjjn, indien deze door de naturalisatie van de vader, of is deze onbekend of overleden - van de moeder, in een vreemd land een vreemde nationaliteit deelachtig worden. Met betrekking tot een vrouw was bovendien bepaald, dat door het aangaan van een huwelijk met een vreemdeling zij het Nederlands onderdaanschap verliest, tenzij zij diens vreemde nationaliteit niet deelachtig wordt noch kan worden. Van belang is voorts de wijziging van de Wet van 1910 in verhand met het KB van 20 mei 1937, Ind. Stb. 1937-392 inzake de vaststelling van de dag van inwerkingtreding van onder meer de Wet van 21 december 1936, Ind. Stb. 1937-389. In de bijlage van dit staatshlad is bepaald, dat het Verdrag nopens zekere vragen betreffende wetsconflicten inzake nationaliteit en van het Protocol betreffende een geval van 
Hoe dient de status van deze Nederlandse onderdanen niet-Nederlanders te worden gezien? Chalanton omschrijft deze status als volgt: "Cette loi a créé, à côté des Néerlandais, des "sujets néerlandais" qui ne sont ni Néerlandais ni étrangers. Les Néerlandais, cela va de soi, sont sujets néerlandais également, mais tous les sujets néerlandais ne sont pas Néerlandais. L'on voit par conséquent, que la possession de la qualité de sujet néerlandais ne sous-entend pas toujours celle de nationalité néerlandaise". ${ }^{372}$ Hierop aansluitend kan op de mening van Mannoury worden gewezen, dat zuiver staatsrechtelijk redenerend, kan worden volgehouden dat niet het Nederlanderschap, maar het Nederlands onderdaanschap "de" Nederlandse nationaliteit was. ${ }^{373}$ Alhoewel als Nederlandse onderdanen niet alleen niet-Nederlanders die aan de met de Wet van 1910 vastgestelde criteria beantwoorden, doch ook Nederlanders konden worden aangemerkt, ben ik het met Mannoury eens, dat het Nederlands onderdaanschap een hoedanigheid was, die de betrekking van een bepaald individu tot het toenmalige Nederlandsch-Indië (resp. Suriname of Curaçao) tot uitdrukking bracht; voor Nederlanders miste de hun ook toekomende kwaliteit van Nederlands onderdaan iedere betekenis. Er bestonden in het toenmalige Koninkrijk twee afzonderlijke nationaliteitsregelingen, corresponderende met de twee hoofdgedeelten van het Rijk: Nederland en Nederlandsch-Indië. ${ }^{374}$ Naar de mening van genoemde auteur bestonden er in feite niet één maar twee Nederlandse onderdaanschappen, het ene voor Nederlanders en het andere voor niet-Nederlanders; de rechtsregeling van beide hoedanigheden was geheel onafhankelijk en verschillend. Niet viel te ontkennen, dat de Nederlandse natie haar "nationaliteit" in de eigenlijke zin des woords in het Nederlanderschap en niet in het Nederlands onderdaanschap zag. Het Nederlands onderdaanschap "tout court", heeft het vór de verdeling van het Koninkrijk niet verder kunnen brengen dan tot de bleke abstractie van een juridische grootste gemene deler van de onderdaanschappen van wél en van nietNederlanders, een standpunt waarbij ik mij aansluit. ${ }^{375}$

Het Hooggerechtshof van Nederlandsch-Indië gaf aan de Wet van 1910 dan ook een beperkte strekking, die het Nederlands onderdaanschap van niet-Nederlanders in het geval van bipatridie voor een vreemde nationaliteit deed wijken. Ter illustratie moge op Logemann worden gewezen, die een geval van bipatridie behandelt, dat betrekking heeft op uit een huwelijk tussen een in Nederlandsch-Indië gevestigde Nederlandse vrouw en een Duitser aldaar geboren kinderen, die derhalve zowel Duitser als Nederlands onderdaan waren. Na echtscheiding en conflict over de voogdij, steunde de Raad van Justitie de keuze voor het Nederlands-Indische recht op het feit, dat de kinderen Nederlands onderdaan waren. Door het Hooggerechtshof werd dit standpunt verworpen, vanwege het feit dat de strekking van de Wet van 1910 met zich bracht, dat het

371. $\rightarrow$

staatsloosheid, beide van 12 april 1930, voor Nederland, Nederlandsch-Indie, Suriname en Curaçao met ingang van 1 juli 1937 in werking treden.

372. Chalanton, La nationalité, p.7.

373. Mannoury, Het Nederlandse Nationaliteitsrecht, p.63.

374. Mannoury, Het Nederlandse Nationaliteitsrecht, p.64.

375. Mannoury, J., De Herziening van onze Nationaliteitswetgeving en de Status van Indonesische Staatsburgers in Nederland, Bestuurswetenschappen, 1953, p.139-141. 
Nederlands onderdaanschap van de kinderen week voor hun Duitserschap. Naar de mening van Logemann was echter nergens de kwaliteitsverschil tussen de twee soorten Nederlands onderdaanschap - met name van 1892 en van 1910 - te bespeuren en behoefte de stelling van het Hooggerechtshof een scherpere formulering en nader bewijs. ${ }^{376}$ Ik ben het niet eens met de mening van Logemann; mijns inziens was hier wel degelijk van een kwaliteitsverschil sprake.

Sanger wijst er voorts op dat in de zin van het volkenrecht geen onderscheid bestaat tussen Nederlanders volgens de Wet van 1892 en de Nederlandse onderdanen nietNederlanders volgens de Wet van 1910; binnenlands waren de Nederlanders niet met niet-Nederlanders gelijk te stellen. ${ }^{3 n}$

Blijkens haar Considerans had de Wet van 1910 tot doel "de kenmerken van het Nederlandsch onderdaanschap van de bevolking van Nederlandsch-Indië vast te stellen". Volgens Nederburgh zou een dergelijke regeling een tweeledige strekking kunnen hebben, met name of - zoals de Considerans zou doen denken - het in het leven roepen van een speciaal Indisch onderdaanschap naast het, dan als het algemene te beschouwen, Nederlanderschap, of het creëren van een algemeen Nederlands onderdaanschap naast het Nederlanderschap, dat dan een beperkter karakter zou dragen. Deze auteur is van mening, dat de Wet van 1910, hinkende op beide denkbeelden, noch het ene, noch het andere deed. Een algemeen Nederlandsch onderdaanschap werd niet in het leven geroepen, aangezien de geboorteplaats - het hoofdkenmerk van dit onderdaanschap alleen daarop aanspraak gaf, als deze in Nederlandsch-Indië, niet in het Rijk in Europa of in West-Indië gelegen was. Een speciaal Indisch onderdaanschap bracht de Wet echter evenmin ${ }^{378}$, gelet op de aanhef van artikel 1 , waar in de eerste plaats als Nederlandse onderdanen de Nederlanders zijn genoemd. ${ }^{379}$

De Wet van 1910 vormde een belangrijke schakel in de ontwikkeling van het Indonesische nationaliteitsrecht. Wordt overgegaan op de inhoud van de Wet van 1910, dan rijst de vraag hoe deze Wet dient te worden gezien. Betreft het hier een volwaardige nationaliteitswet? Kon men zich tot Nederlands onderdaan laten naturaliseren? Kon men het Nederlands onderdaanschap door gebruikmaking van het recht van repudiatie verwerpen? Welke rechten konden aan het zijn van Nederlands onderdaan worden ontleend? Ziehier enkele vragen, waartoe het Nederlands onderdaanschap aanleiding geeft.

376. Logemann, J.H.A., Nederlandsch Onderdaanschap en het Hooggerechtshof, Indisch tijdschrift van het Recht, 1932, p.500-501. Ik tekent hierbij aan, dat de Wet van 1892 in feite een regeling inhoudt betreffende bet Nederlanderschap; gelet op de aanhef van artikel 1 van de Wet van 1910, zijn echter in de eerste plaats Nederlanders als Nederlandse onderdanen genoemd.

377. Sanger, Die indonesische, p.34.

378. De aanhef van artikel 1 luidt als volgt "Van degenen, die de statat van Nederlander niet bezitten ingevolge de Wet op het Nederlanderschap en het Ingezetenschap, zijn Nederlandsche onderdaaen....." De tekst van de Wet van 1910 is in dit boek opgenomen.

379. Nederburgh, Nederlandsch Staatsverband, p.224. 
Het ging hier om een "opgelegde" nationaliteit, verwerping van het Nederlands onderdaanschap was niet mogelijk, evenmin als men zich tot Nederlands onderdaan kon laten naturaliseren. Het Nederlands onderdaanschap kon, zoals reeds opgemerkt, worden aangeduid als een zogenaamde "Schutzangehörigkeit", zelfs als een "sachlich beschränkte" nationaliteit, aangezien het geen toegang gaf tot alle, aan Nederlanders toekomende rechten, met name politieke rechten in het moederland. De onderhavige Wet betekende niet een rehabilitatie in die zin dat aan niet-Nederlanders het Nederlanderschap werd teruggegeven doch beoogde slechts te bereiken, dat niet langer van vreemdelingen kon worden gesproken ${ }^{380}$, doch van Nederlandse onderdanen. Om met de woorden van Heijs te spreken: de Wet van 1910 creëerde naast het bestaande Nederlands onderdaanschap voor Nederlanders volgens de Wet van 1892 , een tweederangs onderdaanschap voor niet-Nederlanders. Wél werd met de invoering van de Wet van 1910 het recht op toelating tot Nederland voor alle Nederlandse onderdanen - Nederlanders en nietNederlanders - hersteld. ${ }^{381}$

De Wet van 1910 ging uit van het "ius soli" - het territorialiteitsbeginsel - waarbij de nationaliteit van een persoon, afhankelijk wordt gesteld van de plaats van zijn geboorte, al dan niet in verband met de plaats van vestiging van respectievelijk de vader of de moeder. Zo bepaalde artikel 1 sub 1 van deze Wet dat Nederlands onderdaan zijn, zij die in Nederlandsch-Indië zijn geboren uit ouders aldaar gevestigd. In dit verband kan worden gewezen op de interpretatie van het toenmalige Ministerie van Justitie - door Djody Gondokusumo ${ }^{382}$ naar voren gebracht - van het begrip "gevestigd zijn", waarbij het arrest van het Hooggerechtshof van 10 januari 1935 werd aangehaald. ${ }^{383}$ Naar de mening van het Hof, kwam het begrip "gevestigd zijn" overeen met het begrip "ingezetene". Laatstgenoemde status werd normaliter eerst op basis van een daartoe te verstrekken vergunning tot vestiging aan betrokkene verleend, na 10 jaar in Indonesië gevestigd te zijn. Dit impliceerde dat kinderen binnen die 10 jaar geboren, volgens deze opvatting géén Nederlands onderdaan waren. Volgens Logemann was genoemd arrest van het Hooggerechtshof op grond van historische redenen onjuist, terwijl Kollewijn van mening was dat bedoeld arrest in strijd was met de rechtspraktijk. De term "gevestigd zijn" diende volgens genoemde hoogleraren te worden geïnterpreteerd als "feitelijk gevestigd" en niet als "juridisch gevestigd zijn" - een mening door het Ministerie van Justie gedeeld. Eerstgenoemde interpretatie kwam niet alleen overeen met de geschiedenis of rechtspraktijk c.q. het onderdaanschap kon niet afhankelijk worden gesteld van de afgifte in de praktijk van een vestigingsvergunning, doch deze interpretatie was ook meer in overeenstemming met de Wet no. 3 van 1946 van de toenmalige Republikeinse

380. Op basis van N. Stb. 1910-56 werd artikel 12 van de Wet van 1892 als volgt gewijzigd: "Allen die den staat van Nederlander niet bezitten of niet uit anderen hoofde Nederlandsche onderdanen zijn, zijn vreemdelingen."

381. Heijs, Nederlanderschap, p.25. Volgens deze auteur behoorde volgens de Minister van Justitie Malefijt, het Nederlanderschap vonrbehouden te blijven aan personen van Nederlandse orgine, doch wat de eigenlijke betekenis van het, woord "Nederiander" is, werd door genoemde Minister niet toegelicht. Wel was duidelijk, dat het hier om meer dan een terminologische kwestie ging.

382. Djody Gondokusumo, Siapa termasuk Warganegara, p.14-15.

383. Dit arrest is opgenomen in het Indisch Tijdschrift van het Recht, deel 141, p.351 e.v. 
regering. ${ }^{384}$ Volgens het Ministerie van Justitie kon om te bepalen of een persoon deel uitmaakte van de groep uitheemse Nederlandse onderdanen niet-Nederlander worden afgegaan op het feit, of betrokkene in Indonesië was geboren. Niet nodig was te vragen of de ouders van betrokkene - feitelijk - in Indonesië gevestigd waren ten tijde van de geboorte van de betrokken persoon, aangezien personen die Indonesië slechts bezochten in de hoedanigheid van toerist, "short visitor" en dergelijke en waarvan aldaar een kind werd geboren, praktisch niet voorkwamen. ${ }^{385}$

De regeling van het Nederlands onderdaanschap berustte - in tegenstelling met die van het Nederlanderschap, die het "ius sanguinis" beginsel huldigde - op het "ius soli". Het kiezen van het "ius soli" ais grondslag van de onderhavige Wet van 1910 betreffende het Nederlands Onderdaanschap van niet-Nederlanders dient te worden gezien tegen de achtergrond van het streven van de Overheid om de door zo grote verscheidenheid gekenmerkte bevolking van het voormalige Nederlandsch-Indië onder haar gezagssfeer te brengen en bemoeienis van andere landen zoveel mogelijk buiten te sluiten. Het niet bestaan van een Burgerlijke Stand voor vele, van de autochtone bevolking deel uitmakende groeperingen, die om genoemde reden vaak niet in staat waren hun afstamming te bewijzen, heeft hierbij wellicht ook een rol gespeeld. Ter toelichting diene, dat voor het grootste gedeelte van de autochtone bevolking het ongeschreven recht, het Adatrecht geldt, of indien de personen die daarvan deel uitmaken de Islamitische godsdienst belijden, het Islamitisch recht dat al dan niet in het Adatrecht is gerecipieerd. Het personaliteitsbeginsel - het "ius sanguinis" - waarbij als grondslag wordt beschouwd, de afstamming van de betrokken persoon, werd eerst in laatste instantie toegepast. Hierbij regelt de nationaliteit van het kind zich naar die van respectievelijk de vader of de moeder, die laatstgenoemden bezitten op het tijdstip van de geboorte van het kind in kwestie.

Zoals gezegd leverde de plaats van geboorte de grondslag op voor het Nederlands onderdaanschap der niet-Nederlanders, al werden het huwelijk van de vrouw en in zekere mate ook de afstamming der buiten de koloniën geboren kinderen, als hulpkenmerken aangenomen. Krachtens artikel 1 waren naast Nederlanders, Nederlands onderdaan, personen in de koloniën geboren uit ouders aldaar gevestigd, of indien de vader niet bekend was, uit een aldaar gevestigde moeder. ${ }^{386}$ Voorts bezaten deze hoedanigheid personen in Nederlandsch-Indië (Suriname of Curaçao) geboren, wier ouders niet bekend zijn, de ouders aldaar niet gevestigd en zonder nationaliteit c.q. van onbekende nationaliteit zijn, zolang die onbekendheid voortduurt. Ook waren Nederlands onderdaan als hierbedoelde personen, wier vader of moeder, alhoewel niet in Nederlandsch-Indië (Suriname of in Curaçao) gevestigd, onderdaan was als in dit artikel

384. De Wet no. 3 van 1946, zogls naderhand gewijzigd en aangevuld zal aan de crde komen in \$5.2.

385. Deze aangelegenheid is bekrachtigd met het schrijven van de Minister van Justitie no. J.B. 3/70/23 van 28 augustus 1954, sub ten tweede.

386. Deze bepaling gold niet voor kinderen van beroepsconsuls van vreemde mogendheden of van ambtenaren van vreemde Staten, door hun Regering met sen officiēle opdracht belast, incien die kinderen krachtens geboorte een vreende nationaliteit bezaten. Deze uitzonderingshepaling is in artiel 1 sub ten eerste opgenomen. 
bedoeld. Voor de moeder gold ter zake de voorwaarde, dat de vader zonder nationaliteit, onbekend c.q. van onbekende nationaliteit diende te zijn, in laatstgenoemd geval zolang die onbekendheid voortduurde. Fen in de koloniën te vondeling gelegd kind werd, totdat het bewijs van het tegendeel was geleverd, verondersteld geboren te zijn op het gebied waar het is gevonden. Ook de echtgenote van een Nederlands onderdaan werd als zodanig aangemerkt; betrof het een vrouw, die door of ten gevolge van haar huwelijk haar nationaliteit had verloren en het Nederlands onderdaanschap had verkregen, dan verloor zij laatstgenoemde status ná ontbinding van het huwelijk, indien zij op haar verzoek haar oorspronkelijke nationaliteit terugkreeg. Buiten de koloniën (Nederlandsch-Indië, Suriname of Curaçao) geboren ongehuwde kinderen beneden de leeftijd van 18 jaar van een Nederlands onderdaan, bezaten eveneens die status. Als hierbedoelde kinderen waren Nederlands onderdaan, wanneer zij na hun huwelijk of na het bereiken van de leeftijd van 18 jaar in het Koninkrijk gevestigd waren c.q. zich aldaar vestigden, hetgeen ook gold voor hun vrouw en ongehuwde kinderen van beneden de leeftijd van 18 jaar, indien deze zich mede in het Koninkrijk vestigden.

De in 1927 doorgevoerde wijziging van de Wet van 1910, had onder meer ten gevolge dat de geboorte in elke Nederlandse kolonie uit aldaar gevestigde ouders aanspraak gaf op het onderhavige onderdaanschap en daardoor een uitgebreider karakter verkreeg. Nederburgh brengt in dit verband onder de aandacht, dat hierdoor de eigenaardige situatie werd geschapen dat het Nederlands onderdaanschap alleen verkregen werd door geboorte buiten dat deel van het Rijk, dat bij uitstek Nederlands is. Hij haalt als voorbeeld aan, dat een persoon op Nederlands Nieuw-Guinea onder de Papoea's uit aldaar gevestigde ouders geboren Nederlands onderdaan was - al waren de ouders dat niet - maar de persoon die te Amsterdam uit aldaar gevestigde ouders geboren werd, ontleende hieraan geen recht op enig Nederlands staatsverband. Hij kon slechts Nederlands onderdaan zijn, indien zijn ouders dit zijn of waren of de ouders onbekend zijn. Genoemde auteur is van mening, dat de wetgever een stap verder had moeten gaan en naast het beperktere Nederlanderschap - op het "ius sanguinis" gebaseerd - een algemeen Nederlands onderdaanschap had moeten instellen op basis van geboorte in enig deel van het Koninkrijk, welk dan ook, uit aldaar gevestigde ouders. ${ }^{387}$ Het in dit opzicht tekort schieten van de Wet blijkt uit de hierboven aangehaalde bepalingen.

Verlies van het Nederlands onderdaanschap trad op door naturalisatie van een man of ongehuwde vrouw in een vreemd land. Het verloren gaan van het Nederlands onderdaanschap door naturalisatie door een man strekte zich uit tot zijn vrouw, tenzij zij de door de man verkregen vreemde nationaliteit niet deelachtig werd noch kon worden. Dit gold ook voor een met een vreemdeling getrouwde vrouw. Wél dient nog erop te worden gewezen, dat indien een als hierbedoelde vrouw die het Nederlandsch onderdaanschap heeft behouden, alsnog de - vreemde - nationaliteit van de man verkreeg,

387. Nederburgh, Nederlandsch Staatsverband, p.225. Deze auteur brengt naar voren, dat én van de consequenties van artikel 1 in de huidige redactie is, dat in het geval in de koloniën gevestigde ouders bijvoorbeeld wegens onder meer zaken, studie en verlof in Nederland vertoefden en daar kinderen kregen, deze kinderen vreemdeling konden zijn, terwijl hun in Azië op Nederlands gebied geboren broers of zusters Nederlands onderdaan waren. 
haar onderdaanschap verloren ging. Ongehuwde kinderen die nog geen 18 jaar oud zijn deelden in dit verlies, indien deze door de naturalisatie van de vader, of - is deze onbekend of overleden - van de moeder, in een vreemd land de vreemde nationaliteit deelachtig werden. De vrouw die door of tengevolge van haar huwelijk het Nederlands onderdaanschap verloren had, kreeg dat na ontbinding van het huwelijk echter terug, indien zij binnen een jaar daama, haar wil daartoe aan de daartoe competente autoriteit kenbaar maakte. Het verloren gaan van dit onderdaanschap trad voorts op tengevolge van het zonder verlof van de Koning - of in de koloniën van hem, die aldaar in naam van de Koning het algemeen bestuur uitoefende - zich te begeven in vreemde krijgs- of staatsdienst. Ook verzuim van aangifte bij verblijf buitenlands leidde tot verlies van het onderdaanschap, onder aantekening dat door vestiging in het Koninkrijk het Nederlands onderdaanschap werd herkregen. Hierop aansluitend kan de aandacht worden gevestigd op een praktijkgeval dat betrekking had op twee Indonesiërs, die de status van Nederlands onderdaan-niet-Nederlander bezaten en werden geacht deze status verloren te hebben vanwege verzuim van aangifte bij verblijf buitenlands. Door de in 1929 doorgevoerde wijziging in voomoemde bepaling (Ind. Stb. 1929-294, N. Stb. 1929-258) werden tot de inheemse bevolking behorende personen van voormelde aangifteplicht uitgesioten, waardoor bedoelde Indonesiërs nog steeds Nederlands onderdaan waren. Zijdens de Nederlandse overheid werd echter naar voren gebracht dat de wetswijziging van 1929 niet van toepassing was op genoemde personen, aangezien zij hun Nederlands onderdaanschap reeds vóór 1929 hadden verloren. Ook deze, naar voren gebrachte reden ging echter niet op, omdat de desbetreffende bepaling vóór de wijziging van 1929 reeds wijziging had ondergaan, waarbij herkrijging van het Nederlands onderdaanschap afhankelijk werd gesteld van vestiging in het Koninkrijk. ${ }^{388}$ Dit impliceert, dat de mogelijkheid om het verloren gegane Nederlands onderdaanschap te herkrijgen verruimd was en aan beide personen de gelegenheid en het recht werd gegeven, hun door nalatigheid verloren gegane Nederlandsch onderdaanschap door vestiging in het Koninkrijk en derhalve ook in het Rijk in Europa, alsnog te herkrijgen. Verlies van het Nederlands onderdaanschap kon ook het gevolg zijn van de van regeringswege uitgesproken vervallenverklaring daarvan, op het verzoek van de meerderjarige man of ongehuwde vrouw, die naast genoemd onderdaanschap een vreemde nationaliteit bezat, en beide had verkregen zonder daartoe de wil kenbaar te hebben gemaakt en gedurende de laatste vijf jaar gewoon- en hoofdverblijf buitenlands had.

Opvallend is dat het verloren gaan van het onderdaanschap door naturalisatie in een vreemd land, door de vrouw en minderjarige kinderen werd gedeeld, zoals uitdrukkelijk in de Wet gesteld - zoals opgemerkt trad in het geval de vrouw de vreemde nationaliteit niet deelachtig werd of kon worden, voor haar gén verlies van het onderdaanschap op terwijl dit niet is bepaald, met betrekking tot het verloren gaan wegens vreemde krijgsof staatsdienst en wegens verzuim van aangifte bij verblijf buitenlands. Dit geeft aanleiding tot de vraag of de vrouw en kinderen in de hierbedoelde twee gevallen het Nederlands onderdaanschap bleven behouden. Aangenomen kan worden, dat dit niet in

388. Met de Wet van 10 juni 1927, Ind. Stb. 1927-418 (N. Stb. 1927-175) werd de term NederlandschIndie ${ }^{n}$ in hel desbetreffende derde lid van artikel 2 vervangen door de woorden "het Koninkrijk". 
de bedoeling van de wetgever heeft gelegen, aangezien eenheid van nationaliteit in het gezin in de Wet van 1910 - overeenkomstig de Wet op het Nederlanderschap in die tijd - voorop stond. Dat de Wet op dit punt gebrekkig is geredigeerd blijkt bovendien uit de bepaling, dat de aangifte door de man of vader voor zijn vrouw of kinderen - en door de weduwe voor haar kinderen - gold voor eigen aangifte van deze. Hieruit zou kunnen worden opgemaakt, dat die vrouw en kinderen terwijl de man c.q. vader Nederlands onderdaan bleef, vreemdeling konden worden, indien noch zijzelf, noch de man of vader voor hen de aangifte tijdig deed; omgekeerd kon zich het geval voordoen dat zij Nederlands onderdaan bleven door tijdig aangifte te doen, terwijl hun man of vader door in gebreke te blijven, deze status kwam te verliezen! ${ }^{3 k 9}$

Wat betreft de positie van de gehuwde vrouw kan worden opgemerkt, dat de hierop betrekking hebbende bepalingen de situatie op dit vlak in Nederland hebben gevolgd. Aanvankelijk werd strikt de hand gehouden aan de gezinseenheid in die zin dal de vrouw bij aangaan van het huwelijk de staat van haar man volgde. De hieraan ten grondslag liggende gedachte was, dat de vrouw bij het sluiten van het huwelijk van de nationaliteit van de man op de hoogte was. Anders lag dit echter bij verandering van de nationaliteit van de man tijdens het huwelijk. Werd de vrouw geacht elke verandering in de nationaliteit van de man bijvoorbeeld door naturalisatie van rechtswege te volgen? De op het al dan niet aanhouden van de gezinseenheid betrekking hebbende discussies in de Eerste en Tweede Kamer leidden ertoe, dat de Wet van 1892 bij Wet van 21 december 1936, N. Stb. 1936-209 in zoverre gewijzigd werd dat de vrouw staande huwelijk de staat van haar man volgt, behoudens in het geval dat de vrouw van een Nederlander die in een ander land genaturaliseerd werd en de Nederlandse vrouw die met een niet-Nederlander trouwde, de staat van Nederlander zelfstandig zouden bezitten, indien zij - in het eerste geval door de naturalisatie van de man, in het tweede geval bij het aangaan van het huwelijk - de andere nationaliteit niet deelachtig werden nog konden worden. ${ }^{390} \mathrm{Bij}$ Wet van 21 december 1936, Ind. Stb. 1937-389, werd de Wet van 1910 gewijzigd in die zin dat met het bovenstaande overeenkomende bepalingen in de Wet werden opgenomen. Aanleiding daartoe was de ondertekening te Den Haag op 12 april 1930 van het Verdrag nopens zekere vragen betreffende wetsconflicten inzake nationaliteit, waarvan de geldingssfeer ook werden uitgebreid tot Nederlandsch-Indië, Suriname en Curaçao. Bij de ondertekening had Nederland echter een voorbehoud gemaakt betreffende de artikelen 8 tot en met 10 die op de nationaliteit van de gehuwde vrouw betrekking hadden, terwijl ook voor de koloniën geen enkele verplichting was aangehouden. De oorzaak hiervan was hierin gelegen, dat de Nederlandse regering het beginsel van eenheid van nationaliteit in het huwelijk zoveel mogelijk wenste te handhaven. De artikelen 8 tot en met 10 van het Verdrag kenden de vrouw het recht toe zelfstandig een nationaliteit te handhaven. Deze artikelen moesten

389. Zie Nederhurgh, Nederlandsch Staatsverband, p.227-228 die een gelijksoortig standpunt inneemt.

390. Brouwer, J.. De Nationaliteit van de gehuwde vrouw in België en in Nederland, Assen/Amsterdam, 1955, p. $190-191$. 
derhalve van de bekrachtiging uitgesloten worden. ${ }^{391}$ Op genoemd Verdrag zal nader worden teruggekomen.

Meldenswaardig is voorts het streven van de "Pergerakan Tionghoa" (Chinese Beweging), die mede op het treffen van een nationaliteitsrechtelijke regeling voor de groep van niet-Nederlanders heeft aangestuurd, aangezien de Wet van 1892 autochtone Indonesiërs en daarmede gelijkgestelden van het daarin geregelde Nederlanderschap uitsloot. ${ }^{392}$ Het streven van deze Beweging naar een gelijke behandeling, was tevens van belang voor de groep van autochtone Indonesiërs.

Wie waren nu Nederlands onderdaan? Ter beantwoording van deze vraag dient te worden teruggegrepen op zowel de Wet van 1892 als op de onderhavige Wet van 1910. Met inachtneming van hetgeen hiervoor werd uiteengezet met betrekking tot het karakter van het Nederlands onderdaanschap, kan samenvattend worden gesteld, dat de bevolking van het toenmalige Nederlandsch-Indië kon worden onderverdeeld in de volgende groepen:

1. Nederlandse onderdanen, te onderscheiden in:

a. allen die volgens de Wet van 1892 op het Nederlander- en Ingezetenschap Nederlander waren;

b. zij die vielen onder de toepassing van de Wet van 1910, in casu de niet-Nederlanders, waartoe behoorden:

- Inheemse Nederlandse onderdanen niet-Nederlanders, dat wil zeggen de "Inlanders" (autochtone Indonesiërs);

- Uitheemse Nederlandse onderdanen niet-Nederlanders, te weten de zogenaamde Vreemde Oosterlingen en Europeanen, andere dan Nederlanders.

2. Vreemdelingen, met name allen, die géén Nederlands onderdaan waren.

Zoals uit het voorafgaande is gebleken, kon ten aanzien van de categorie der Nederlandse onderdanen, onderscheid worden gemaakt tussen Nederlanders enerzijds en nietNederlanders anderzijds. Krachtens de Wet van het jaar 1910, kon het Nederlands onderdaanschap, algemeen gesteld, op drieërlei wijze worden verkregen, met name door geboorte in Nederlandsch-Indië, door feitelijke vestiging aldaar - zie hetgeen hieromtrent reeds werd opgemerkt - en voor wat betreft vrouwen, door huwelijk. Zoals uiteengezet, werd als criteria voor het verkrijgen van het Nederlands onderdaanschap, voomamelijk uitgegaan van de plaats van geboorte c.q. van vestiging der ouders, respectievelijk van de vader of moeder. Dit had ten gevolge, dat in eerste instantie personen die van de autochtone bevolking van het voormalige Nederlandsch-Indië deel uitmaakten, Nederlands onderdaan waren. Voorts vielen ook personen van vreemde

391. Zie Brouwer, De Nationaliteit, p.170-171. Zie voor de tekst van dit Verdrag, de Groot, G.R., Personen- en familierecht, p. Nat.29-31.

392. Gautama, Warganegara, p.48-52. 
nationaliteit onder de toepassing van voomoemde criteria, vooropgesteld dat zij aan de in de Wet gestelde voorwaarden voldeden. Als gevolg hiervan ontstond de mogelijkheid, dat een persoon een vreemde nationaliteit bezat, doch daamaast Nederlands onderdaan was op grond van het in de Wet van 1910 bepaalde! Dit was bijvoorbeeld het geval met de in Nederlandsch-Indië geboren Chinezen.

\section{$\S 4$ Het Haagse Verdrag van 1930}

In $\S 3$ werd ingegaan op het Haagse Verdrag nopens zekere vragen betreffende wetsconflicten inzake nationaliteit. Bij die gelegenheid werd naar voren gebracht, dat genoemd Verdrag van 12 april 1930 met ingang van 1 juli 1937 voor Nederland, Nederlandsch-Indië, Suriname en Curaçao (de huidige Nederlandse Antillen en Aruba) in werking is getreden. ${ }^{343}$

Aangezien het Haagse Verdrag van 1930 geheel aan nationaliteitsrechtelijke vraagstukken is gewijd en de toepasselijkheid daarvan ook voor het voormalige NederlandschIndië was komen te gelden - met uitzondering van de artikelen 8 tot en met 10 aangaande de nationaliteit van de gehuwde vrouw - acht ik het van belang om hieraan een enkel woord te wijden.

De vraag kan worden gesteld, hoe het staat met het verbindend zijn van het Haagse Verdrag van 1930 - door Nederland aangegaan en ook van kracht voor NederlandschIndië - voor het huidige Indonesië? Hecker zegt hieromtrent het volgende: "Nach Art. 192 der Verfassung der Vereinigten Staaten v. 1949 (und Art. 142 der Verfassung v. 1950) ${ }^{394}$ blieben alle bestehenden Rechtsvorschriften unverändert in Kraft, soweit sie nicht dieser Verfassung widersprachen. Da Art. 194 nur auf den Vertrag über die Aufteilung der StA'en v. 1949 verwies, der den Haager Verträgen v. 1930 nicht widerspricht, blieben diese für Indonesien danach anwendbar. Anhlich bestimmte Art. 8 I des Vertrages über Ubergansmaßnahmen von 1949, daß alle Rechtsvorschriften, die nicht dem Vertragszweck widersprechen, in Kraft bleiben." ${ }^{995}$

In de literatuur is deze aangelegenheid omstreden; er zijn auteurs die het verbindend zijn van het Haagse Verdrag van 1930 voor Indonesië afwijzen, maar ook auteurs die een tegengesteld standpunt innemen. Naar de mening van Ko Swan Sik en Teuku Moh. Rhadie is het inzake het Haagse Verdrag van 1930 - en twee Protocollen ${ }^{366}$ - twijfelachtig, of Indonesië als atzonderlijke partij moet worden geacht automatisch te zijn

393. Zie voor dit Verdrag eveneens Brinkman, C.J, de Nederlandse Nationaliteitswetgeving, Zwolle, 1985. De Nederlandse, Franse en Engelse tekst zijn opgenomen in Ind. Stb. 1937, 17, zie ook Trb. $1967,73$.

394. Beide Grondwetten zijn in $\$ 2.1$ van Hoofdstuk 1 aan de orde gekomen.

395. Hecker, Das Staatsangehơrigkeitsrecht, p.48.

396. Bedoeld zijn hier het Protocol nopens militaire verplichtingen in bepaalde gevallen van duhbele nationaliteit en het Protocol betreffende een geval van staatloosheid, beide evenals het Haagse verdrag op 14 april 1930 te 's-Gravenhage tot stand gekomen' en resp. opgenomen in Trb. 1976,75 en Trb. 1967,74 . 
opgevolgd met betrekking tot verdragen van voór de onafhankelijkheid als gevolg van de RTC-overeenkomsten, in het bijzonder de Overgangsovereenkomst. Deze auteurs vestigen er de aandacht op, dat het sedert 1949 verschillende keren is voorgekomen, dat Indonesië in strijd met een veronderstelde opvolging heeft gehandeld en stellen vervolgens dat "it appears safer to assume that Indonesia adheres to the clean-slate doctrine, but there seems to be no absolute certainty whether acceptance of a pre-independence treaty, whether a bilateral or mulilateral one, can only be assumed when made explicitly". ${ }^{397}$ Van de Indonesische auteurs kan Sidik Suraputra worden aangehaald, die voor het onderzoeken van de positie van internationale verdragen door de Nederlandse overheid aangegaan en ook voor Nederlandsch-Indië van kracht verklaard en de houding van Indonesië ten aanzien van bedoelde overeenkomsten, als aanknopingspunt neemt het tijdstip, waarop door Indonesië de overeenkomsten bij de Ronde Tafel Conferentie (RTC) werden bekrachtigd. ${ }^{398}$ Deze auteur gaat uit van artikel 5 van de Overgangsovereenkomst in het kader van de overeenkomsten ter gelegenheid van de RTC aangegaan - waarvan de Toescheidingsovereenkomst een bijlage vormt - waarvan het tweede lid onder meer bepaalt, dat de Indonesische regering bevoegd is de toepasselijkheid van internationale verdragen en overeenkomsten in haar rechtsgebied te beëindigen. Deze bepaling wekt de indruk, dat alie internationale verdragen en overeenkomsten rechtstreeks de regering van de RVSI binden tot het beëindigen van de werking daarvan. Lemaire is dan ook van mening, dat de onderhavige overgangsbepaling zodanig dient te worden uitgelegd, dat overeenkomsten tussen Indonesië en Nederland niet alleen partijen binden, doch ook de eenzijdige verklaring van Indonesië aan derde landen inhoudt inzake haar bereidheid gebonden te zijn aan internationale verdragen. ${ }^{399} \mathrm{De}$ Muralt is daarentegen van mening, dat de nadruk niet dient te worden gelegd op de internationale verdragen zelf, doch op de daaruit voortvloeiende rechten en verplichtingen. ${ }^{400}$ Volgens deze auteur kunnen niet alle internationale verdragen verbindend worden geacht voor Indonesië, doch dient ook de inhoud van die verdragen zélf met zorg te worden onderzocht. ${ }^{401}$ Volgens Sidik Suraputra kan de Indonesische regering middels een juiste interpretatie van ieder verdrag, haar houding bepalen inzake het nog gebonden zijn aan internationale verdragen. Deze auteur deelt de visie van de Muralt, dat bij het interpreteren van verdragen de nadruk niet dient te worden gelegd op die verdragen zelf, doch op uit de daaruit voortvloeiende rechten en verplichtingen, zodat de hierbedoelde verdragen niet automatisch van toepassing zijn voor Indonesië. ${ }^{402}$

397. Zie Nationality and International Law in Asian Perspective, Ko Swan Sik en Chang Hyo Sang, redacteuren; de bijdrage over Indonesie is samengesteld door Ko Swan Sik en Teuku Moh. Rhadie, 's-Gravenhage, 1990, p. 137-138.

398. Sidik Suraputra, D., Sikap Indonesia terhadap Perjanjian Intemasional yang dibuat Pemerintah Belanda, tijdschrift Hukum dan Pembangunan, 1980, p. 227-228.

399. Lemaire, Het Recht, p.211.

400. De Muralt, R.W.G., The Problem of State Succession with regard to Treaties, 's-Gravenhage, 1954, p.134.

401. Ibid.

402. Sidik Suraputra, Sikap Indonesia, p.230. 
Hoe is de positie van internationale verdragen ná de unilaterale opzegging door de Indonesische regering van de overeenkomsten bij de RTC aangegaan, waarvoor de Wet no. 13 van het jaar 1956, Stb. 1956-27 werd afgekondigd? In dit verband is van regeringswege naar voren gebracht, dat in een zodanige gewijzigde en dringende situatie die geleid heeft tot het ongeldig verklaren van de overeenkomsten bij de RTC aangegaan, de Indonesische overheid geen andere keuze had om tot opzegging van bedoelde verdragen te komen op basis van de "rebus sic stantibus" clausule, die in het intemationale recht geldt. ${ }^{403}$ Ter illustratie moge voorts dienen, dat Indonesië in een "verbal note" van 16 september 1959 zich heeft uitgesproken met betrekking tot het Protocol te 's-Gravenhage op 12 april 1930 ondertekend met betrekking tot de militaire verplichtingen in gevallen van bipatridie, waarbij het volgende naar voren werd gebracht: "The Republic of Indonesia is of the opinion, that all agreements signed by the Netherlands on behalf of or declared to be valid for the former Netherlands East Indies do not automatically apply to the Republic of Indonesia as a successor of the former Netherlands East Indies. The Republic of Indonesia therefore does not consider itself bound by said Protocol". ${ }^{404}$

Ook Gautama nam het verbindend zijn van enkele, met name genoemde internationale verdragen $^{405}$ - die ook voor Nederlandsch-Indië zijn komen te gelden - voor Indonesië aan, aangezien dit nooit officieel door dit land is afgewezen; Asikin Kusumaatmadja, daarentegen, achtte bedoelde verdragen niet langer van kracht voor Indonesië. ${ }^{406}$ Sidik Suraputra brengt in dit verband naar voren, dat het standpunt van Gautama verwijst naar de theorie van de "Universal Succession", die in de praktijk niet door de Indonesische overheid wordt gevolgd. In aansluiting hierop kan op het standpunt van het Departement van Buitenlandse Zaken worden gewezen, dat de huidige door Indonesië aangehangen praktijk hierop neerkomt, dat de Republiek Indonesië slechts partij wordt bij een verdrag vroeger door Nederland aangegaan en voor Nederlandsch-Indië van toepassing verklaard, voor zover de Republiek Indonesië dit uitdrukkelijk verklaart

403. Deze clausule houdt in, dat wegens het optreden van fundamentele binnenlandse veranderingen van een partij die de desbetreffende overeenkomst heeft ondertekend, de onderhavige partij het recht heeft zich terug te trekken uit de werking van die overeenkomst. Dit houdt met andere woorden in, dat in een zodanige situatie het beginsel "rebus sic stantibus" tot grondslag kan worden gemaakt om het beginsel "pacta sunt servanda" ongedaan te maken.

404. U.N. Document A/L.N. $4 / 149$ and ADD. 1, p.110. Zie Sidik Suraputra, Sikap Indonesia, p.234.

405. Het betreft hier het in het voormalig Nederlandsch-Indië geldende Protocol betreffende Arbitrageclausules, Genève, 24 september 1923 en het Verdrag nopens de Tenuitvoerlegging van in het buitenland gewezen Scheidsrechterlijke Uitspraken, Genève, 26 september 1927. Respectievelijk opgenomen in Trb. 1952,73 en Trb. 1952,74.

406. Gautama, S., Indonesia dan Arbitrase Internasional, Bandung, 1986, p.67-69. In het Verdrag nopens de Erkenning en de Tenuitvoerlegging van in het buitenland gewezen Scheidsrechterlijke Uitspraken, Trb. 1958, 145 door Indonesie in 1981 goedgekeurd met het Presidentiële Besluit no.34 van dat jaar, zijn voornoemde regelingen echter niet meer van kracht verklaard, waardoor het hiervoor genoemde meningsverschil tussen Gautama en Asikin Kusumaatmadja niet langer opportuun is. 
in overeenstemming met het internationale verbintenissenrecht, uitgezonderd indien het grensverdragen betreft. ${ }^{407}$

Uit het bovenstaande kan worden opgemaakt, dat de Indonesische overheid van mening is dat intemationale verdragen, voorheen ook van kracht voor Nederlandsch-Indië, niet automatisch voor Indonesië zijn komen te gelden. Dit geldt derhalve ook voor het al dan niet meer van kracht zijn van het Haagse Verdrag van 1930. De vraag kan worden gesteld of het Indonesische standpunt overeenkomt met het internationale recht. Sidik Suraputra wijst in dit verband op het Verdrag van Wenen van 23 augustus 1978 inzake Statenopvolging met betrekking tot Verdragen ${ }^{408}$; in deel III van dit Verdrag is met betrekking tot "Newly Independent States", in artikel 16 inzake de "Position in respect of the treaties of the predecessor State" het volgende bepaald: "A newly independent State is not bound to maintain in force, or to become a party to any treaty, by reason only of the fact that at the date of the succession of States the treaty was in force in respect of the territory to which the succession of States relates".

Gelet op op de hierboven aangehaalde bepalingen van het Weense Verdrag wordt, vanuit het Indonesische standpunt gezien, het van kracht zijn van het Haagse verdrag van 1930 voor Indonesië niet zonder meer aangenomen, doch dit afhankelijk gesteld van een hierop betrekking hebbende bevestiging van Indonesische zijde. Hiertegenover kan echter worden gesteld, dat het Weense Verdrag ten spijt - van een later tijdstip dan het tijdstip van de soevereiniteitsoverdracht aan Indonesië - dit land niet aan de volkenrechtelijke verplichting tot beëindiging van de geldigheidskracht van het Haagse Verdrag van 1930 voor Indonesië heeft voldaan, noodzakelijk wil dit Verdrag niet voor genoemd land zijn komen te gelden.

\section{$\S 5$ De Wet no. 3 van 1946 en de Toescheidingsovereenkomst}

Ondanks het feit dat de Wet no. 3 van 1946, zoals naderhand gewijzigd en aangevuld, slechts kort en beperkt gegolden heeft, lag het belang van deze Wet onder meer hierin, dat in de Toescheidingsovereenkomst naar deze Wet verwezen werd en de daaronder vallende burgers onder vigeur van de Overeenkomst werden gebracht.

Voorts is van deze Wet op een later tijdstip gebruik gemaakt om de status van de ingezetenen van Irian Jaya vast te stellen, nadat de overdracht van dit gebiedsdeel aan Indonesië had plaatsgevonden.

Gezien het voorgaande, acht ik het van nut om zowel op de Wet no. 3 van 1946 als op de Toescheidingsovereenkomst in te gaan.

407. Schrijven van het Departement van Buitenlandse Zaken van de Republiek Indonesië no. 12727/72/19 van 19 december 1972 aan het Kantoor van rechtsconsultanten Mochtar, Karuwin \& Komar gericht, betreffende de participatie van Indonesiẽ in verdragen door Nederland aangegasan en voor Nederlandsch-Indiẽ van toepassing verklaard.

408. Trb. 1989,51. De volledige tekst van dit Verdrag is ook opgenomen in het American Joumal of Interationale Law, Vol. 72, October 1978, p.971-988. 


\subsection{Algemeen}

Ter inleiding moge voor een goed begrip op de bepalingen inzake de Indonesische nationaliteit, opgenomen in respectievelijk de Grondwet van 1945, de Constitutie van de Republiek der Verenigde Staten van Indonesië (RVSI) ${ }^{409}$ van 1949 en de Voorlopige Grondwet van 1950 worden gewezen. ${ }^{410}$ In artikel 26 , lid 1 van de Grondwet van 1945 - in juli 1959 wederom van kracht verklaard - is bepaald dat staatsburgers autochtone Indonesiërs zijn en anderen die bij de wet als staatsburgers worden erkend. Krachtens het tweede lid van dit artikel worden regels betreffende het staatsburgerschap bij wet vastgesteld. Deze bepaling heeft aanleiding gegeven tot de afkondiging van de Wet no. 3 van 1946, zoals naderhand herhaaldelijk gewijzigd en aangevuld, de eerste Indonesische Nationaliteitswet. Aangezien krachtens deze Wet tot staatsburgers van de Republiek Indonesië werden verklaard, alle tot de autochtone bevolking behorende personen en voorts afstammelingen daarvan en personen die in het gebied van de Republiek geboren zijn, bestond de overgrote meerderheid van de Republikeinse staatsburgers uit personen, die naar Nederlands recht het Nederlands onderdaanschap bezaten. Hieruit zou kunnen worden geconcludeerd, dat de burgers van deze Republiek in zekere zin bipatride waren. ${ }^{411}$

De Constitutie van de RVSI bepaalde in artikel 5 , lid 1 dat de federale wet het staatsburgerschap van de RVSI regelt. ${ }^{412}$ Op grond van het in het tweede lid van dit artikel bepaalde, geschiedt naturalisatie door of krachtens federale wet, terwijl de gevolgen van de naturalisatie ten aanzien van de echtgenote en minderjarige kinderen van de genaturaliseerde door de federale wet worden geregeld. In aansluiting hierop was in artikel 194 bepaald, dat in afwachting van de regeling van het staatsburgerschap bij de in lid 1 van artikel 5 genoemde wet, reeds staatsburgers van de RVSI zijn, zij die het staatsburgerschap hebben ingevolge de overeenkomst betreffende de toescheiding van staatsburgers, gevoegd bij het Charter der Soevereiniteitsoverdracht.

De bepalingen in de Voorlopige Grondwet van 1950 opgenomen, kwamen vrijwel met genoemde bepalingen van de Constitutie van de RVSI overeen. Zo was in artikel 5 , leden 1 en 2 bepaald, dat het staatsburgerschap van de Republiek Indonesië door de Wet wordt geregeld en dat naturalisatie geschiedt door of krachtens de wet, waarbij de

409. In de RVSI wend de Republiek Inconesië van de Yogya-regering als deelstaat opgenomen.

410. Zie voor de Grondwet van 1945, Engelbrecht p.1. Deze Grondwet is bekendgemaakt met de Kennisgeving ("Berita") van de Republiek Indonesiè, jaargang II, no. 7, p.45-48; toelichting op p.51-56. Voor de Constitutie van de RVSI, die krachiens artikel 197 lid 1 op het tijdstip van de overname van de soevereiniteit in werking trad, zie Besluit van de President van de RVSI no. 48 van 31 jan. 1950, Stb. 1950-3, afgekondigd op 6 februari 1950. Voor deze Constitutie kan naar Engelbrecht, p. 5 worden verwezen. De Voorlopige Grondwet van 1950 (Wet van 15 aug. van het jaat 1950 no. 7. Stb. 1950-56) is opgenomen in Engelbrecht, p.31.

411. Onder het grondgebied van de Republiek werd het gehele territoir van Nederlandsch-Indiê verstaan. Zie ook Prins, De gevolgen, p.49.

412. Aangezien de Republiek Indonesiê van de Yogya-regering als deelstaat in de RVSI was opgenomen, is hieruit op te maken dat de Wet no. 3 van 1946 zoals naderhand gewijzigd en aangevuld, niet als nationaliteitswet van de RVSI aangemerkt werd. 
gevolgen van de naturalisatie ten aanzien van de echtgenote en de minderjarige kinderen van de genaturaliseerde bij wet worden geregeld. Van groot belang voor de hier te behandelen Wet no. 3 van 1946 was artikel 144 van deze Grondwet. Dit artikel hield in, dat in afwachting van de regeling van het staatsburgerschap bij wet zoals aangekondigd in artikel 5 lid 1 van de Grondwet, reeds staatsburger van de Republiek Indonesië zijn:

a. zij, die volgens de bij de Overgangsovereenkomst gevoegde Overeenkomst betreffende de Toescheiding van Staatsburgers, de Indonesische nationaliteit hebben verworven, alsmede

b. zij, wier nationaliteit niet door genoemde Overeenkomst werd bepaald, doordat zij op 27 december 1949 reeds Indonesisch staatsburger waren, volgens de op die datum geldende Wet van de Republiek Indonesië, namelijk de Wet no. 3 van het jaar 1946, zoals naderhand gewijzigd en aangevuld.

Het Indonesisch staatsburgerschap, verkregen op grond van de hierboven onder a. en b. genoemde wettelijke regelingen - derhalve verkregen vóor de afkondiging van de Wet no. 62 van het jaar 1958 - werd derhalve door artikel 144 van de Voorlopige Grondwet van 1950 erkend c.q. bekrachtigd. ${ }^{\$ 13}$

Voor de goede orde zij echter nogmaals op het kort en beperkt gegolden hebben van de Wet no. 3 van het jaar 1946, zoals naderhand gewijzigd en aangevuld, gewezen. Dit was hieraan te wijten, dat deze Wet - alhowel voor het gehele grondgebied van Indonesië bedoeld - in feite slechts van kracht is geweest in het gebied dat onder de gezagssfeer van de Yogya-regering viel en de Republiek Indonesië van deze Regering bij het tot standkomen van de RVSI als deelstaat in de RVSI was opgenomen, zodat niet gezegd kan worden dat deze Wet als Nationaliteitswet van de RVSI was komen te gelden. Voorts werd een nieuwe Nationaliteitswet niet alleen in de Constitutie van de RVSI maar ook in de Voorlopige Grondwet van 1950 in het uitzicht gesteld en zijn de burgers van de Republiek Indonesië van de Yogya-regering onder vigeur van de Toescheidingsovereenkomst gebracht. Tenslotte kan niet worden gezegd, dat de Wet no. 62 van het jaar 1958 betreffende het Indonesische Staatsburgerschap in de plaats is getreden van de Wet no. 3 van 1946, aangezien de afkondiging van eerstgenoemde Wet niet gepaard is gegaan mel de intrekking van de Wet no. 3 van 1946. Dit was immers niet nodig, omdat laatstgenoemde Wet reeds op een eerder tijdstip niet langer van kracht was!

5.2. De Wet no. 3 van 1946 betreffende het Indonesisch Staatsburgerschap en Ingezetenschap

De Wet no. 3 van het jaar 1946 op het Staatsburgerschap en Ingezetenschap van Indonesië, als naderhand gewijzigd en aangevuld met de Wetten no. 6 en 8 van het jaar

413. Zie voor de politieke geschiedenis van Indonesië $\$ 2.1$ van Hoofdstuk 1, in het kader waarvan genoemde drie Grondwetten ter sprake kwamen. 
1947 en de Wet no. 11 van 1948, was afgekondigd door de Republikeinse regering, de zogenaamde Yogya-regering. ${ }^{414}$ Deze Wet vormde de eerste Nationaliteitswet, ter regeling van het staatsburgerschap van de ingezetenen van de Republiek Indonesië in het leven geroepen.

Niettegenstaande het feit dat deze Wet niet langer geldt - de Voorlopige Grondwet kondigde in artikel 5 lid 1 aan, dat het Indonesisch staatsburgerschap bij wet zal worden geregeld - acht ik het van nut om, voor zover voor mijn onderwerp relevant, bij deze Wet stil te staan. Ook in de Wet no. 62 van het jaar 1958 wordt naar deze Wet verwezen; zo zijn personen, die middels naturalisatie krachtens de Wet no. 3 van het jaar 1946 het Indonesisch staatsburgerschap hebben verkregen, in deze Wet genoemd.

Wat betreft het in deze Wet bepaalde, kan het volgende worden opgemerkt. Krachtens artikel 1 sub a. waren Indonesisch staatsburger, alle personen die tot de autochtone bevolking behoorden en in de Indonesische staat woonachtig. Het onder b. van dit artikel bepaalde had tot gevolg, dat bovendien Indonesisch staatsburger waren, personen die niet onder artikel 1 sub a. vielen maar van als hierbedoelde personen afstamden personen van gemengde bloede - geboren en gevestigd in het gebied van de Indonesische staat en personen die niet van de onder a. genoemde personen afstamden, voor zover zij in genoemd gebied geboren en tenminste gedurende de laatste 5 jaar ononderbroken aldaar gevestigd waren, de leeftijd van 21 jaar hadden bereikt of reeds gehuwd waren. Laatstgenoemde onder $b$. van artikel 1 vallende Indonesische staatsburgers, die in het bezit zijn van het staatsburgerschap van een ander land, konden echter hun Indonesisch staatshurgerschap prijsgeven door bezwaar aan te tekenen tegen het worden van Indonesisch staatsburger.

De Wet no. 3 van het jaar 1946 - zoals naderhand gewijzigd en aangevuld - ging van het passieve stelsel uit. Dit impliceert, dat personen, die niet afstamden van de onder a. genoemde personen, indien zij aan de hierboven genoemde voorwaarden voldeden, van rechtswege als Indonesisch staatsburger werden aangemerkt, zonder een daartoe strekkende verklaring te behoeven af te leggen.

Met betrekking tot het hiervoor gestelde, brengt Soenario naar voren, dat uit vele, toenmalige politieke kringen de aanbeveling naar voren kwam, om zo gauw mogelijk tot een geheel nieuwe Wet op het Indonesisch staatsburgerschap te komen, mede omdat

414. Zie hiervoor Engelbrecht p.306. Met de Wet no. 6 van 1947 werd onder meer de wijze van prijsgeving van het Indonesisch staatshurgerschap door een persoon reeds in bet bezit van een vreemde nationaliteit middels het afleggen van een daartoe strekkende verklaring - in het geval van overlijden van deze persoon door de respectieve voogd der kinderen dan wel door de weduwe voor haarzelf - meer uitgebreid geregeld. Van belang is voorts dat de Wet no. 3 van 1946 krachtens deze Wet werd geacht met ingang van 17 augusuts 1945 in werking te zijn getreden. Een andere, in de Wet no. 6 van 1947 opgenomen bepaling regelde voorts de nationaliteit van rechtspersonen. Met de Wet no. 8 van 1947 werd de termijn voor het afleggen van een verklaning tot prijsgeving van bet Indonesisch staatsburgerschap verlengd. Met hetzelfde doel, in casu om wederom tot verlenging van bedoelde termijn te komen, werd de Wet no. 11 van 1948 afgekondigd. Een Engelse vertaling van genoemde Wetten is in dit boek opgenomen. 
men geen zekerheid had inzake het nog geldig zijn van deze Wet c.q. in hoeverre deze Wet al dan niet meer van kracht was. Aanbevolen werd zelfs om over te gaan op het actieve stelsel, opdat personen die niet tot de autochtone bevolking behoren, een uitdrukkelijk, op het worden aangemerkt als staatsburger gericht verzoek indienen (niet middels naturalisatie). ${ }^{415}$

Van de zijde van het Ministerie van Voorlichting in het jaar 1946 werd naar voren gebracht, dat het begrijpelijk is, dat Indonesiers krachtens artikel 1 sub a. van rechtswege het Indonesisch staatsburgerschap verkregen. Anders lag het echter bij de andere bevolkingsgroepen, die in het koloniale tijdperk een min of meer bevoorrechte positie hebben gehad; het minst bevoorrecht was de groep der Arabieren, het meest die der Europeanen. Deze bevoorrechting, de zo gehate rasdiscriminatie strekte zich uit over de rechtsbedeling, rechterlijke organisatie, benoembaarheid tot bepaalde ambten, kiesrecht, militieplicht en heeft geleid tot vele dualismen, zoals in het binnenlands bestuur, de rechtspraak, het onderwijs etc. die tot zulke sterke sociale spanningen in het voormalige Nederlandsch-Indië hebben geleid. Dat ontevredenheid heerste over de toen geldende wettelijke rasdiscriminatie lag voor de hand. ${ }^{416}$ Wellicht lag hierin de reden, om in de Wet no. 3 van 1946 het passieve stelsel te hanteren, waardoor niet alleen autochtone Indonesiërs, doch ook van deze personen afstammende personen van gemengde bloede en anderen dan deze, voor zover zij aan de gestelde voorwaarden voldeden, van rechtswege Indonesisch staatsburger werden, al werd aan personen die deel uitmaakten van de laatste groep de gelegenheid gegeven om middels een daartoe strekkende verklaring van bezwaar het verkregen Indonesisch staatsburgerschap prijs te geven. Met deze regeling van het staatsburgerschap werd volledig gebroken met het stelsel van het Nederlandsch onderdaanschap met zijn rassenonderscheiding, die tot zoveel onbillijkheden heeft geleid. ${ }^{417}$

Aangezien in vele gevallen het Indonesisch staatsburgerschap van rechiswege werd verkregen, werd tot de afkondiging van de Regeringsverordening no. 5 van het jaar 1947 overgegaan, op basis waarvan aan een ieder de gelegenheid werd gegeven aan de "Pengadilan Negeri" van zijn woonplaats het verzoek te doen, vast te stellen of hij al dan niet Indonesisch staatsburger is. De vaststelling als gevolg van een als hierbedoeld verzoek kon voorts worden voorgelegd aan de "Pengadilan Tinggi" van de woonplaats van betrokkene binnen 14 dagen na ontvangst van bedoelde vaststelling. Op deze wijze konden belanghebbenden, indien gewenst, in het bezit worden gesteld van een bewijsstuk op hun status betrekking hebbende.

Uit artikel 1 van de Wet blijkt dat in eerste instantie werd uitgegaan van het "ius soli"; slechts in een drietal gevallen was het "ius sanguinis" van toepassing. Zo kreeg het

415. Soenario, Masalah-Masalah.

416. Zie de uitgave van het Ministerie van Voorlichting van mei, 1946, getiteld: Wie zijn de Staatshurgers van de Republiek?

417. Ibid., p.6. Het Nederlandsch onderdaanschap knoopte aan bij de raciale onderverdeling van de bevolking ex artikel 163 I.S., die niet geheel van discriminatoire trekken ontbloot was. Zie hiervoor $\$ 2$ van dit Hoofdstuk. 
wettig, gewettigd of door de vader erkend natuurlijk kind, waarvan de vader tijdens de geboorte de staat van Indonesisch staatsburger bezat, het Indonesisch staatsburgerschap. Dit gold ook voor het kind van een mannelijke Indonesische staatsburger, die overleed binnen driehonderd dagen vór de geboorte van het kind. Evenzo was Indonesisch staatsburger, het alleen door de moeder wettig erkende natuurlijke kind, waarvan de moeder tijdens de geboorte, de staat van Indonesisch staatsburger bezat. Opvallend is, dat de Wet de op het Westerse recht gebaseerde terminologie hanteerde, door te spreken van "wettig, gewettigd of door de vader erkend natuurlijk kind", een omschrijving die wél op personen die onder vigeur van het Indonesisch Burgerlijk Wetboek (IBW) vallen van toepassing is, maar zeker niet op personen die onder vigeur van het Adatrecht of het Islamitische recht vallen, waarin eigen normen worden gehanteerd teneinde te bepalen wanneer een kind als "wettig" kan worden aangemerkt. Wat betreft het Adatrecht komt hierbij nog, dat dit recht van regio tot regio kan verschillen. Wellicht is de op Westerse leest geschoeide terminologie van deze Wet een gevolg van het feit, dat bedoelde Wet tot stand is gebracht door juristen, door Nederlanders opgeleid en bovendien het licht zag in een tijd, waarin de eenheidsstaat c.q. de eenheid van alle Indonesiërs diende te worden benadrukt, als tegenwicht tegen de Nederlandse opvatting, dat Indonesië nooit een eenheidsstaat zou kunnen worden, als gevolg van alle adatverschillen. Wat betreft het criterium "door de moeder wettig erkend natuurijk kind", kan worden opgemerkt dat de Huwelijkswet van 1974 ervan uitgaat, dat tussen een buiten huwelijk geboren kind en de moeder en haar familie een burgerlijke betrekking bestaat (artikel 43 lid 1). Kwam de voorwaarde van erkenning van een natuurlijk kind door de moeder in de oudere - Nederlandse - wetgeving nog voor, wilde dit kind in de nationaliteit van de moeder delen, in de latere wetgeving is deze voorwaarde niet langer verplicht gesteld, doch kreeg het niet-erkende onwettige kind van rechtswege de nationaliteit van de moeder. Ter illustratie kan in dit verband naar de Wet van 1892 op het Nederlander- en Ingezetenschap worden verwezen, waar voorheen de bepaling " het alleen door de moeder erkend natuurlijk kind" voorkwam. Deze bepaling werd ingaande 1 september 1948, op grond van de Wet van 10 juli 1947, N. Stb. 232, vervangen door de omschrijving "het niet-erkend onwettig kind, waarvan tijdens de geboorte, de moeder de staat van Nederlander bezit", wilde een als hierbedoeld kind door geboorte Nederlander zijn.

De verkrijging van het Indonesisch staatsburgerschap middels naturalisatie zoals in de Wet van 1946 geregeld, is van wezenlijk belang, omdat deze bepaling doorwerkte in het huidige Indonesische nationaliteitsrecht, zoals uit $\$ 1.1$ van Hoofdstuk 4 zal blijken. Een verzoek tot naturalisatie kon worden ingediend door personen, die tenminste de leeftijd van 21 jaar hadden bereikt of op een eerder tijdstip waren gehuwd, gedurende de laatste vijf jaar onafgebroken woonplaats in Indonesië hebben gehad en de Indonesische taal goed beheersten. Ook een vrouw, die weduwe was, kon krachtens de Wet no. 3 van het jaar 1946 het Indonesisch staatsburgerschap door middel van naturalisatie verkrijgen; dit kwam van rechtswege mede te gelden voor haar "wettige of gewettigde en op wettige wijze door haar erkende kinderen" - zie de opmerkingen hiervoor in verband met de hier gehanteerde terminologie door mij geplaatst - voor zover deze de leeftijd van 21 jaar nog niet hadden bereikt dan wel niet op een eerder tijdstip in het huwelijk waren getreden. Hierbij zij aangetekend, dat kinderen, die krachtens naturali- 
satie van hun vader of moeder het Indonesisch staatsburgerschap hadden verkregen, bij het bereiken van de leeftijd van 21 jaar c.q. zij op een eerder tijdstip huwden, gerechtigd waren te verklaren hierop geen prijs meer te stellen; genoemde verklaring diende schriftelijk aan de Minister van Justitie te worden gericht, die voor de verdere afwikkeling daarvan zorg droeg. Het middels naturalisatie verkregen staatsburgerschap van Indonesiê, kwam te gelden bij de inwerkingtreding van de wet, waarbij dit werd verleend. ${ }^{418}$

Naar voren kan worden gebracht, dat een op verandering van staatsburgerschap gericht verzoek of een daarop gerichte verklaring, door de gehuwde vrouw niet naar voren kon worden gebracht c.q. afgelegd. Artikel 2 lid 1 van de Wet no. 3 van 1946 ging er voorts vanuit, dat gehuwde vrouwen staande het huwelijk de staat van de man volgden en ook bij ontbinding van het huwelijk het door of als gevolg daarvan verkregen Indonesisch staatsburgerschap bleven behouden. $\mathrm{Zij}$ waren echter gerechtigd om binnen het tijdvak van één jaar nadat het huwelijk ontbonden werd, schriftelijk te verklaren geen prijs meer te stellen op het bezit daarvan, dit krachtens het in artikel 10 bepaalde. Omgekeerd bepaalde artikel 9 van deze Wet, dat een vrouw die door of als gevolg van haar huwelijk het Indonesisch staatsburgerschap verloor, dit terug kon krijgen door binnen één jaar na ontbinding van het huwelijk, haar wil daartoe schriftelijk kenbaar te maken aan de Minister van Justitie.

Volledigheidshalve zij nog vermeld, dat artikel 3 van de onderhavige Wet de rechtsgevolgen regelde van de verkrijging c.q. verlies van het Indonesisch staatsburgerschap door een ouder - vader of moeder - voor de kinderen, voor zolang deze de leeftijd van 21 jaar nog niet hadden bereikt of niet op een eerder tijdstip in het huwelijk waren getreden. In het algemeen kan worden gesteld, dat genoemde kinderen in de verkrijging c.q. verlies van het Indonesisch staatsburgerschap van de ouder deelden, in laatstgenoemd geval evenwel indien zij mede een andere nationaliteit verkregen. Opgemerkt dient te worden, dat bij verlies van het Indonesisch staatsburgerschap door een moeder door of als gevolg van huwelijk - óok indien zij schriftelijk kenbaar maakte, het bezit daarvan niet langer op prijs te stellen - dit zich niet uitstrekte tot haar kinderen.

418. Het aantal op basis van de Wet no. 3 van 1946 bij wet genaturaliseerde personen is gering te noemen. Het gaat hier om de volgende personen:

1. Johana Jordan, bij Wet no. 4 van 1947, van 12 fehruari 1947;

2. Salim Basjir, bij Wet no. 5 van 1947, van dezelfde datum;

3. Frans Matheas Hesse, bij Wet no. 9 van 1947, van 12 mei 1947;

4. Wilhelm Karl Gothfried Mewas, bij Wet no. 24 van 1947, van augustus 1947;

5. George Wilhelm August Friederichs, bij Wet no. 25 van 1947, van dezelfde datum;

6. Herman Oscar Gustav Fischer, bij Wet no. 26 van 1947, idem;

7. Gurt Ulrich Grok, bij Wet no. 27 van 1947, idem;

8. Jean Henry Joseph de Quinze, bij Wet no. 4 van 1947, van 23 maart 1948;

9. Joseph Comelis de Groot, bij Wet no. 31 van 1947, van 31 oktober 1948. 
Krachtens artikel 8 van de Wet ging het Indonesisch staatsburgerschap verloren vanwege de verkrijging van een andere nationaliteit of door het zonder toestemming van de President worden van soldaat of ambtenaar van een ander land.

Met verwijzing naar hetgeen in $\S 3$ inzake het begrip "gevestigd zijn" naar voren werd gebracht, zij gewezen op het feit, dat door de Wet no. 3 van 1946, een termijn van éen jaar werd aangehouden, ter bepaling van het feit, of een persoon kan worden geacht in Indonesië gevestigd te zijn. (artikel 14 lid 1).

Rest mij nog op het bepaalde in de Overgangsbepalingen van deze Wet te wijzen. Krachtens genoemde bepalingen waren personen die op het tijdstip van inwerkingtreding van deze Wet geen vader meer hadden, nog geen 21 jaar en nog niet gehuwd waren Indonesisch staatsburger, indien hun vader op het moment van overlijden voldeed aan de voorwaarden als neergelegd in artikel 1 sub b. der Wet. Voorts was bepaald, dat een vrouw die op het tijdstip van inwerkingtreding van deze Wet geen echtgenoot had, omdat haar laatste echtgenoot was overleden en die echtgenoot op het tijdstip van overlijden aan de voorwaarden voldeed als gesteld in artikel 1 sub a. of artikel 1 sub b. der Wet - en zijzelf niet - Indonesisch staatsburger was. Hierbij was echter een voorbehoud gemaakt voor het geval deze vrouw verklaarde geen prijs te stellen op het bezit van dit staatsburgerschap, omdat zijzelf niet aan bedoelde voorwaarden voldeed.

Opvallend is voorts, dat de onderhavige Wet ook de nationaliteit van rechtspersonen regelde. Zo bezaten rechtspersonen, volgens het in de staat Indonesië geldende recht opgericht en aldaar gevestigd, de Indonesische nationaliteit. Een soortgelijke bepaling komt in de Wet no. 62 van het jaar 1958 op het Indonesisch Staatsburgerschap niet voor, aangezien deze Wet - mijns inziens terecht - alleen een regeling treft voor natuurlijke personen.

\subsection{De Overeenkomst betreffende de Toescheiding van Staatsburgers}

Een voor de ontwikkeling van het nationaliteitsrecht van Indonesië belangrijke overeenkomst, gesloten ter gelegenheid van de Ronde Tafel Conferentie (RTC) tussen het Koninkrijk der Nederlanden en de Republiek der Verenigde Staten van Indonesië, was de aan de Overgangsovereenkomst gehechte Overeenkomst betreffende de Toescheiding van Staatsburgers. ${ }^{419}$ Genoemde Overeenkomst vormde een belangrijke schakel in de ontwikkeling van het Indonesisch nationaliteitsrecht. Deze Overeenkomst greep met name enerzijds terug op de bepalingen die voorheen hebben gegolden, in casu de Wet van 1892 op het Nederlanderschap en Ingezetenschap en de Wet van 1910 op het Nederlands onderdaanschap van niet-Nederlanders en speelt anderzijds ook een rol in de toepassing van de huidige Nationaliteitswet. ${ }^{420}$ De vraag rijst evenwel of de unilaterale opzegging door Indonesië op 13 februari 1956 van de overeenkomsten bij

419. Zie voor de tekst van deze Overeenkomst, Engelbrecht p.314. Deze tekst is in dit boek opgenomen.

420. De Wet van 1892 is inmiddels vervangen door de Rijkswet op het Nederlanderschap van 19 december 1984, N. Stb. 628 jo. N. Stb. 1985 no.660, waarin enkele belangrijke beginselen zijn opgenomen, waarvan het gelijkgerechtigdheidsbeginsel kan worden genoemd. 
de RTC aangegaan ${ }^{421}$, geen effect heeft gehad op het indertijd nog van kracht zijn van de Toescheidingsovereenkomst. Sanger is van mening, dat de status van de Toescheidingsovereenkomst als volkenrechtelijk verdrag van haar status als binnenlandse regeling van Indonesië dient te worden onderscheiden. Laatstgenoemde status is op te maken uit artikel 144 van de Voorlopige Grondwet van 1950. Als binnenlandse regeling kon de Toescheidingsovereenkomst slechts door een wet ter uitvoering van artikel 5 van de Voorlopige Grondwet gewijzigd of worden opgeheven. De Wet ter opheffing van de RTC had wel aan de volkenrechtelijke status van de Overeenkomst een einde gemaakt, doch niets gezegd over de binnenlandse status en derhalve laatstgenoemde status behouden. Deze uitleg is voor mij alleszins aanvaardbaar. ${ }^{422}$

In eerste instantie dient le worden opgemerkt, dat deze Overeenkomst beoogde een regeling te treffen ten aanzien van personen, die op het tijdstip van de soevereiniteitsoverdracht aan Indonesië te weten 27 december 1949, onderdanen waren van het Koninkrijk der Nederlanden. ${ }^{423}$ In bedoelde Overeenkomst zijn met betrekking tot elk der respectieve groepen van Nederlandse onderdanen, namelijk:

\section{- Nederlanders;}

- Inheemse Nederlandse onderdanen niet-Nederlanders, dat wil zeggen "Inlanders" (ik geef er de voorkeur aan van autochtone Indonesiërs te spreken);

Uitheemse Nederlandse onderdanen niet-Nederlanders, dat wil zeggen de zogenaamde Vreemde Oosterlingen en Europeanen, andere dan Nederlanders

regelingen getroffen, krachtens welke bepalingen, personen die van genoemde groepen deel uitmaakten, hetzij de Indonesische, hetzij de Nederlandse nationaliteit verwierven. Niettegenstaande van officiële Nederlandse zijde naar voren is gebracht, dat bij de onderverdeling van personen is uitgegaan van de onderverdeling in artikel 55 IS - van belang voor het kiesrecht - gaat dit, niet geheel op, met name wat betreft de van de autochtone bevolking ("orang yang asli") deel uitmakende personen. ${ }^{424}$ Aangezien in de literatuur aan de op artikel 163 IS gebaseerde onderverdeling van de bevolking van Indonesië veel aandacht is besteed en deze onderverdeling ook in de praktijk (nog) een rol speelt, geef ik er de voorkeur aan van deze onderverdeling van de bevolking van Indonesië uit te gaan. In de hierboven genoemde driedeling is echter getracht om met zowel de onderverdeling ex artikel 55 IS als met die ex. artikel 163 IS rekening te

421. Zie hiervoor \$2.1 van Hoofdstuk 1 .

422. Zie Sanger, Die indonesische, p.67-68. Dat ook thans de Toescheidingsovereenkomst een rol speelt teneinde vast te stellen, of een persoon al dan niet het Indonesisch staatsburgerschap bezit, blijkt uit betgeen in $\$ 4$ van Hoofdstuk 4 en in $\$ !$ van Hoofdstuk 7 is uiteengezel.

423. Van Indonesische zijde wordt de voorkeur gegeven aan de term "soevereiniteitserkenning", aangezien de onafhankelijksverklaring reeds op 17 augustus 1945 werd geproclameerd.

424. In artikel 4 van de Toescheidingsovereenkomst wordt niet gesproken van inheemse Nederlandse onderdanen-niet-Nederlanders, doch van "tot de inheemse bevolking (orang2 jang asli = personen die deel uitmaken van de autochtone bevolking) van Indonesië behorende meerderjarige Nederlandse onderdanen-niet-Nederianders". 
houden. ${ }^{425}$ Niettegenstaande Sanger in beginsel uitgaat van artikel 55 IS noemt hij ook de volgende driedeling:

\section{a. Nederlanders; \\ b. Indonesiërs; \\ c. niet-Indonesiërs}

welke driedeling min of meer overeenkomt met de hierboven door mij gemaakte onderverdeling van de bevolking van Indonesië. ${ }^{426}$ Dat ook een andere driedeling op grond van de bepalingen van de Toescheidingsovereenkomst gevolgd wordt ter verkrijging van het Indonesisch staatsburgerschap, blijkt uit de door Imam Bardjo aangehouden driedeling, als volgt:

a. tot de autochtone bevolking behorende personen;

b. personen die het Indonesisch staatsburgerschap verkrijgen krachtens het recht van optie;

c. personen die Indonesisch staatsburger zijn geworden, door geen gebruik te maken van het recht van repudiatie.

Uit bovenstaande driedelingen blijkt, dat met betrekking tot het Indonesisch staatsburgerschap niet slechts éen homogene groep van personen doch verschillende groepen van personen worden onderscheiden. ${ }^{427}$

De Toescheidingsovereenkomst hield in hoofdzaak slechts een regeling in ter vaststelling van de nationaliteit van personen die Nederlands onderdaan waren, in leven op het tijdstip van de sluiting daarvan. Bij de uitwerking van de in deze Overeenkomst opgenomen bepalingen, werd ook rekening gehouden met de mogelijkheid, dat sommige belanghebbenden. die bovendien nog onderdaan waren van een andere Staat, alleen op deze derde nationaliteit prijs zouden stellen. Bij de behandeling van de uitheemse Nederlandse onderdanen niet-Nederlanders zal deze aangelegenheid nader aan de orde komen. ${ }^{42 x}$ Aangezien de Toescheidingsovereenkomst alleen afging op personen, in leven op het tijdstip van de totstandkoming van deze Overeenkomst, bevatte zij als zodanig geen bepalingen ter regeling van toekomstige gevallen. Ook door Djody Gondokusumo is een overeenkomstig standpunt naar voren gebracht door erop te wijzen dat de status van ná 27 december 1949 geboren personen en ná genoemd tijdstip optredende wijzigingen in de status van personen gén regeling hebben gevonden in de Toescheidingsovereenkomst. Het viel onder de competentie van respectievelijk Indonesië en Nederland om hiervoor een regeling te treffen. ${ }^{429}$ Wat Indonesië betreft, impliceerde dit het optreden van een vacuüm ten aanzien van nationaliteitsrechtelijke

425. Zie voor de onderverdeling op basis van artikel 163 IS en het voor de respectieve groepen geldende recht ex. artikel 131 IS Imam Bardjo, Masaalah Kewargaan, p.44-46.

426. Sanger, Die indonesische, p.40.

427. Imam Bardjo, Masaalah Kewarganegaraan, p.16.

428. Zie ook Prins, De gevolgen, p.51.

429. Djody Gondokusumo, Siapa termasuk Warganegara, p.11. 
aangelegenheden. Immers, de Wet no. 3 van 1946 van de Yogya-regering kon niet langer van kracht worden geacht te zijn, zoals uit het voorgaande is gebleken. Ook in de regelingen vastgesteld door het Militair c.q. Oorlogsgezag - het onderwerp van $\$ 5$ waren nationaliteitsaangelegenheden slechts summier geregeld. Eerst met de afkondiging van de Wet no. 62 van het jaar $1958 \mathrm{kwam}$ aan deze situatie een einde. ${ }^{430}$

Volgens artikel 8 lid I van de Overgangsovereenkomst - waarvan de Toescheidingsovereenkomst een bijlage was - bleven alle wettelijke regelingen en administratieve voorschriften, die golden op het tijdstip van de soevereiniteitsoverdracht tot nader order als eigen regelingen van zowel Nederland als van Indonesië gelden - tenzij zij met de soevereiniteitsoverdracht zelf onverenigbaar waren - zolang zij niet door de bevoegde organen van partijen buiten werking werden gesteld of gewijzigd. Prins merkt in dit verband op, dat in beginsel iedere wet, waarvan de werking niet tot Nederland of tot Indonesië beperkt was, met de soevereiniteitsoverdracht een dubbel leven was gaan leiden: als Nederlandse wet, vatbaar voor wijziging en intrekking door de Nederlandse wetgever en als Indonesische wet, vatbaar voor wijziging en intrekking door de Indonesische wetgever. Hoewel de Toescheidingsovereenkomst kennelijk uitging van de veronderstelling, dat er in de toekomst slechts één soort Nederlanderschap zou bestaan, waren de Wet op het Nederlanderschap van 1892 en de Wet op het onderdaanschap van 1910 ná de soevereiniteitsoverdracht beide in stand gebleven als delen van het Nederlandse recht. Indonesië beschouwde bovendien, in afwachting van de totstandkoming van een eigen nationaliteitswetgeving, voorlopig de Wet van 1910 mutatis mutandis als een deel van het Indonesische recht, omdat men anders in moeilijkheden zou komen met de ná de soevereiniteitsoverdracht geboren kinderen van Indonesische staatsburgers, wier positie immers nergens geregeld was. ${ }^{431}$

Het tweede lid van artikel 8 diende te voorkomen, dat Nederlanders in Indonesië en Indonesiërs in Nederland in moeilijkheden zouden komen, doordat zij niet langer beschouwd werden als Nederlands onderdanen in de zin van de geldende wetgeving. De op het tijdstip van de soevereiniteitsoverdracht bestaande rechten werden voorlopig gehandhaafd door genoemd artikellid, dat bepaalde dat overal waar in de toen geldende wetgeving van Nederlandse onderdanen wordt gesproken, daaronder zowel staatsburgers van het Koninkrijk ais van de RVSI werd verstaan. Eén van de vraagstukken die zich volgens Mannoury op dit vlak voordeed, was de status van degenen, die de nationaliteit van de Republiek Indonesië bezitten. Deze auteur vraagt zich in casu af, of deze personen vreemdeling waren of dat zij te beschouwen waren als personen, in het bezit van een bijzondere hoedanigheid tussen de Nederlandse nationaliteit en het vreemdelingschap in. Afgaande op artikel 12 van de Wet van 1892, dat bepaalde dat allen, die de slaat van Nederlander niet bezitten en niet uit andere hoofde Nederlandse onderdanen zijn, vreemdeling zijn, kan geconcludeerd worden dat dit artikel als een bestaande wettelijke regeling in de zin van artikel 8 van de Overgangsovereenkomst kon worden

430. Zoals reeds opgemerkt, blijkt uit het feit dat de afkondiging van deze Wet niet gepaard is gegaan met de intrekking van de Wet no. 3 van 1946, het reeds op een eerder tijdstip niet meer van kracht zijn van laatstgenoemde Wet.

431. Prins, De gevolgen, p.70. 
aangemerkt. Voor "Nederlandse onderdanen" diende in casu te worden gelezen: "staatsburgers van Nederland of van Indonesië" met als gevolg, dat staatsburgers van Indonesië géén vreemdelingen waren, een standpunt volgens de Nederlandse overheid als onjuist aan te merken, zonder daarbij echter argumenten aan te voeren. ${ }^{432} \mathrm{Man}$ noury is van mening, dat men twee kanten uit kon gaan. Werd ervan uitgegaan dat Indonesië niet meer tot het Rijk behoort, dan zijn Indonesiërs vreemdeling in Nederland. Werd daarentegen afgegaan op artikel 8 van de Overgangsovereenkomst, dan kan worden aangenomen, dat hieraan de gedachtegang ten grondslag lag om de bepalingen der bestaande wetgeving die op respectievelijk Nederlandse onderdanen en vreemdelingen betrekking hebben, niet en bloc af te wijzen doch de bestaande toestand voorlopig te handhaven en het aan latere overwegingen over te laten om elk van deze bepalingen afzonderlijk te bekijken en te beslissen. Volgens deze auteur kan uit technisch-juridisch oogpunt, niet anders dan tot de slotsom worden gekomen, dat Indonesische staatsburgers in Nederland niet als vreemdelingen konden worden beschouwd. ${ }^{43}$. Ik ben van mening, dat ook de politieke kant van het vraagstuk dient te worden onderkend, met name of Indonesië als soevereine Staat zich met het hierboven uiteengezette standpunt zou kunnen verenigen, hetgeen door mij wordt betwijfeld, mede gelet op latere ontwikkelingen. Heijs brengt naar voren, dat van Nederlandse zijde eind 1951 werd besloten om Indonesiërs voortaan als vreemdeling te beschouwen. De Nationaliteitswet werd gewijzigd middels de Wet van 21 december 1951, N. Stb. 593 en zijdens de Nederlandse Regering werd verklaard deze Wet niet langer als een op het moment van de soevereiniteitsoverdracht bestaande regeling in de zin van de Overgangsovereenkomst te beschouwen. ${ }^{434}$ Ook Prins wijst op deze Wet, onder aantekening dat volgens de Considerans daarvan deze Wet tot doel had de nationaliteitswetgeving aan te passen aan de Toescheidingsovereenkomst. Ingevolge artikel 1 van deze Wet waren of werden allen die krachtens de Toescheidingsovereenkomst de Nederlandse nationaliteit bezitten of door optie - zullen bezitten, Nederlanders in de zin van de Wet van 1892. Als gevolg hiervan was artikel 8 lid 2 der Overgangsovereenkomst uitgewerkt! 435

\subsubsection{Enige opmerkingen inzake de gehanteerde terminologie}

In aansluiting op hetgeen in de Toescheidingsovereenkomst inzake de van autochtone bevolking deel uitmakende personen is bepaald kan op Prins worden gewezen, die naar voren brengt dat de terminologie van de Toescheidingsovereenkomst kennelijk is

432. Mannoury, J., De Herziening van onze Nationaliteitswetgeving en de Status van Indonesische Staatsburgers in Nederland, Bestuurswetenschappen, jaargang 1953, p.128-130.

433. Tbid., p.131-134.

434. Heijs, Nederlanderschap, p.30, die ter zake verwijst naar de Memorie van Antwoord, Bijlage Handelingen Eerste Kamer, 1951-1952, 2027, p.5.

435. Prins, De gevolgen, p.71. Zie van dezelfde auteur, Jurisprudentie inzake de Wet op het Nederlandersehap en de Toescheidingsovereenkomst, Het Personeel Statuut, 1953, p.35-36, die naar voren brengt dat tot op de dag van aanneming van de Wet van 21 december 1951 door de Tweede Kamer nog de min of meer vage voorstelling overheerste, dat de Indonesièrs uit hoofde van het Unieverband een positie zouden innemen tussen Nederlanders aan de ene en vreemdelingen aan de andere kant. Eerst tijdens de debatten in de Eerste Kamer kwam aan het licht, dat naar het oordeel van de Overheid met de aanneming van genoemde Wet de Indonesiërs vreemdelingen zouden worden. 
afgestemd op die van artikel 55 IS. Deze auteur wijst erop, dat twee groepen, de Nederlanders en de uitheemse onderdanen niet-Nederlanders geheel in dezelfde bewoordingen zijn omschreven, doch bij de inheemsen op een verschil wordt gestoten, aangezien aldaar niet van inheemse onderdanen wordt gesproken, maar van "tot de inheemse bevolking van Indonesië behorende onderdanen", waarbij tussen haakjes in het Indonesisch de woorden "orang2 jang asli" zijn gevoegd, hetgeen "personen, die deel uitmaken van de autochtone bevolking" betekent. Hij concludeert daaruit dat alle reden bestaat om aan te nemen, dat aan deze afwijking van de gebruikelijke terminominologie gewichtige betekenis dient te worden gehecht. Prins brengt echter onder de aandacht dat van regeringswege uitdrukkelijk is verklaard, dat men nooit iets anders op het oog heeft gehad dan de indeling van artikel 55 IS; de afwijkende formulering van de Toescheidingsovereenkomst (artikel 4) is volgens de Regering waarschijnlijk te wijten aan de "psychologische" reden, dat men speciaal in de Indonesische tekst de autochtone bevolking wilde kunnen vermelden als een omschrijving van het Indonesische bevolking. Volgens genoemde auteur dient in het licht van deze verklaring aan de in artikel 55 IS gebruikte term "inheems" een andere betekenis te worden toegekend, omdat deze meer omvat dan de "orang yang asli". Hij haalt als voorbeeld het kind van een Europese vader en een autochtone moeder aan, dat naar zijn mening bezwaarlijk als "autochtoon" kan worden aangemerkt; is het echter door zijn vader niet erkend, dan behoort dit kind wel tot de "Inlanders" van artikel 163 en tot de "inheemsen" van artikel 55 IS. Hetzelfde geldt voor de in geen enkel opzicht autochtone Europese weduwe van een Indonesiër, die verzuimd heeft gebruik te maken van haar recht om tot haar vroegere staat terug te keren. ${ }^{436}$

Welke opvatting huldigde ter zake de Nederlandse overheid? Enig houvast bood het antwoord van de Regering op in de Eerste Kamer der Staten-Generaal gestelde vragen bij de behandeling van het ontwerp van de wet houdende nadere regelen omtrent nationaliteit en ingezetenschap ${ }^{437}$; het betreft hier de Wet van 21 december 1951 , in $\$ 5.3$ reeds aan de orde gekomen. De vraag werd gesteld, of in de Toescheidingsovereenkomst (artikel 4) opzettelijk geen gebruik is gemaakt van de terminologie van artikel 55 IS "inheemse onderdanen-niet-Nederlanders" en of ten aanzien van dit artikel gezien het verschil in redactie - een volkenkundige of een rechtskundige uitleg dient te worden gevolgd. Behoort bijvoorbeeld een onmiddellijk vóór de soeverejniteitsoverdracht Nederlands onderdaan niet-Nederlander die als natuurlijk kind niet door zijn Europese vader is erkend doch Europees is opgevoed en door administratie en samenleving als Nederlander is behandeld tot de uitheemse Nederlandse onderdanen? Wat is de status van een persoon, die oorspronkelijk volgens de Indische Staatsregeling als behorende tot de inheemse bevolking tot de Inlanders werd gerekend, doch op wie bij gouvernementsbesluit de bepalingen voor Europeanen toepasselijk zijn verklaard;

436. Prins, De gevolgen, p.54. Deze auteur haalt in dit verband de Reggeling Gemengde Huwelijken Ind. Sib. 1898 aan, bet onderwerp van $\$ 2.4$. Ik voeg hieraan nog loe, dal ook in artikel 1 van de Wel no. 3 van 1946 zoals naderhand gewijzigd en aangevuld, onderscheid wordt gemaakt tussen "orang yang asli" - Prins gebruikt de term "inheems" - afstammelingen daarvan en andere dan deze, die aan bepaalde voorwarden dienen te voldoen.

437. Kamerstukken Zitting 1950/195! - 2027, 2a en 2b. 
maakte deze persoon deel uit van de uitheemse onderdanen bedoeld in de Toescheidingsovereenkomst (artikel 5)? Zou het antwoord in één van - of beide - bovenstaande gevallen ontkennend luiden, zou het dan bevestigd luiden, indien in eerstbedoeld geval betrokkene bovendien met Europeanen gelijkgesteld zou zijn en in het tweede geval, betrokkene bovendien geheel in de Europese samenleving zou zijn opgegaan? Zijdens de Regering werd naar voren gebracht dat artikel 4 van de Toescheidingsovereenkomst geacht moet worden dezelfde terminologie te gebruiken als artikel 55 IS, derhalve: "inheemse onderdanen-niet-Nederlanders." Onzekerheid bestaat echter in gevallen van gemengde afstamming. Of met betrekking tot het hierboven aangehaalde natuurlijke, niet door de vader erkende kind gesproken kan worden van uitheems Nederlands onderdaan is volgens de Overheid niet uit te maken, zolang de nationaliteit en landaard van de moeder niet bekend is. De mening wordt gehuldigd, dat een Europese opvoeding geen verandering in de status heeft gebracht; is de persoon door administratie en samenleving als Nederlander behandeld, dan kan die behandeling slechts een maatschappelijke zijn geweest c.q. had deze voor het recht geen betekenis. Van een juridische behandeling kan volgens de Overheid slechts sprake zijn geweest, indien betrokkene door een Nederlandse vader was erkend of uit andere hoofde Nederlander is geworden. Is hij door een Europese vader erkend die zelf geen Nederlander is, dan behoort hij tot de uitheemse Nederlandse onderdanen. Evenzo is een persoon die volgens de Indische Staatsregeling als behorende tot de inheemse bevolking tot de Inlanders werd gerekend, doch op wie ná 1892 bij Gouvernementsbesluit de bepalingen voor Europeanen toepasselijk werden verklaard, tot de inheemse bevolking blijven behoren. In dit antwoord komt volgens de Nederlandse overheid geen verandering indien in het eerste geval betrokkene ná de inwerkingtreding van de Wet van 1892 met Europeanen gelijkgesteld zou zijn, hetgeen ook geldt voor het tweede geval, indien betrokkene geheel in de Europese samenleving zou zijn opgegaan. ${ }^{438}$

Doorgaande op het instituut van de gelijkstelling - het onderwerp van $\S 2.2$ - in het kader van de toepassing van de Toescheidingsovereenkomst, moge de aandacht op het navolgende worden gevestigd. ${ }^{439}$ Naar de mening van Prins kan de in de Toescheidingsovereenkomst (artikel 4) gebezigde ormschrijving "tot de inheemse bevolking (orang2 jang asli) van Indonesië behorende" ook, met een beroep op de terminologie van +1939 , worden opgevat als een synoniem van "Inlander"; gelijkgestelden vallen daardoor niet onder genoemd artikel zodat niets anders overblijft dan deze personen als "uitheemsen" in de zin van de artikelen 5 en 6 van deze Overeenkomst te beschouwen. ${ }^{40}$ Hierop aansluitend kan een uitspraak van de Haagse rechtbank van 2 januari 1952 worden aangehaald, dat een Indonesiër die bij besluit van de Gouverneur-Generaal van Nederlandsch-Indië van 26 september 1914, no. 50 (Ind. Stb. no. 638) gelijkgesteld is, deel uitmaakt van de onmiddellijk vóor de soevereiniteitsoverdracht meerderjarige uitheemse Nederlandse onderdanen niet-Nederlanders, die krachtens de Toescheidingsovereenkomst (artikel 5) de Indonesische nationaliteit verkregen, doch bevoegd waren

438. Adriaanse en van der Weg, Nationaliteitswetgeving, p. 1A-8, 1A-9.

439. Zie Van der Weg, S., Is een met Europeanen gelijkgestelde een inheemse in de zin van de Toescheidingsovereenkomst? Het Personeel Statuut, 1952, p.44-48.

440. Prins, De gevolgen, p.54-55. 
deze te verwerpen. ${ }^{41}$ Betrokkene had van de mogelijkheid tot het verwerpen van de Indonesisch nationaliteit gebruik gemaakt - hetgeen zou betekenen dat hij de Nederlandse nationaliteit "herkreeg" - door de Haagse rechtsbank rechtsgeldig verklaard. Tegen deze uitspraak van de Haagse rechtbank tekende de Staat der Nederlanden evenwel beroep bij het Hof aan, die de Staat in het gelijk stelde, daarbij in overweging nemende dat een inheemse die ná de inwerkingtreding van de Wet van 1892 met Europeanen is gelijkgesteld, onder artikel 4 van de Toescheidingsovereenkomst valt, conform de opvatting van de Nederlandse overheid. ${ }^{442}$

\subsubsection{Indonesisch staatsburger krachtens de Toescheidingsovereenkomst}

De Overeenkomst betreffende de toescheiding van staatsburgers - de Toescheidingsovereenkomst - stelde regels, volgens welke de onderdanen van het Koninkrijk-oude stijl werden verdeeld tussen het Koninkrijk-nieuwe stijl (Nederland, Suriname en de Nederlandse Antillen omvattende) en de RVSI (thans de Republiek Indonesië). Volgens Adriaanse en van der Weg heeft aan de verdeling de mate van verbondenheid tot één van de beide Staten ten grondslag gelegen. Zij, die meer met Nederland, Suriname en de Nederlandse Antillen verbonden waren, zijn aan Nederland toebedeeld; zij die meer met Indonesië verbonden waren, zijn tot de Republiek komen te behoren. ${ }^{443}$ Mijns inziens gaat genoemde grondslag voor de verdeling echter niet altijd op; zo vielen onder de groep uitheemse Nederlandse onderdanen niet-Nederlanders ook Europeanen, andere dan Nederlanders en was van een "meer verbonden zijn met Indonesië" geen sprake. Krachtens het in de onderhavige Overeenkomst bepaalde, werd op grond van de hierboven genoemde onderverdeling van Nederlandse onderdanen, zowel naar geboorteplaats als naar woonplaats toegescheiden, welke twee factoren derhalve beslissend waren voor de toescheiding. Hierbij zij echter aangetekend, dat aan betrokkenen onder daartoe gestelde voorwaarden gelegenheid werd geboden om in de vastgestelde termijn tot verwerping van het toebedeelde Indonesische staatsburgerschap of tot verkiezing daarvan, over te gaan. Aan betrokkenen werd derhalve een zekere ruimte gelaten om te ontkomen aan voornoemde toebedeling, indien dit als onaanvaardbaar werd gevoeld. Ook hierin ligt mijns inziens een motief, om het criterium "mate van verbondenheid tot én der Staten" niet als absoluut geldend aan te merken.

441. Verzoeker bad ter bekrachtiging van zujn status naar voren had gebracht, dat de term "inlanders" gelijk is aan de omschrijving "inheemse bevolking", tot welke bevolkingsgroep hij als gevolg van zijn gelijkstelling met Europeanen niet meer behoort, zodat hij uitheems Nederlands onderdaan is in de zin van de Toescheidingsovereenkomst; dat aan de begrippen "inheems" en "uitheems " in geen geval een uitleg mag worden gegeven, die de onderscheiding zoekt in het zijn van een bepaald ras, van bepaalde bloede of van bepaalde huidskleur, daar krachtens de in artikel 3 van het Unie-statuut ze hiervoor $\$ 2.1$ van Hoofdstuk 1 - vervatte fundamentele menselijke rechten en vrijheden, in de uitoefening van rechten geen onderscheid mag worden gemaakt naar ras, bloed of huiskleur; dat de begrippen "uitheems" en "inheems" geen etnologische of physische begrippen doch rechtsbegrippen zijn en hij tengevolge van zijn gelijkstelling met Europeanen rechtens is overgegaan van de groep "inheemse bevolking" naar de bevolkingsgroep der Europeanen.

442. Het betreft hier de zaak Hehanussa, zie Prins, Jurisprudentie, p. 34-38.

443. Adriaanse en van der Weg, Nationaliteitswetgeving, p. 1A-4. 
De Toescheidingsovereenkomst ging, kort samengevat, uit van het volgende:

1. De artikelen I en 2 waren als interpretatieve bepalingen te beschouwen. Zo was in artikel 1 aangegeven wie als meerderjarig krachtens deze Overeenkomst was aan te merken. Op grond van artikel 2 vielen onder vigeur van de onderhavige Overeenkomst tevens personen, die volgens de nationaliteitswetgeving van de Republiek Indonesië van de Yogya-regering burgers waren van deze Republiek;

2. Artikel 3 bevatte voorzieningen voor Nederlanders die hierop neerkwamen, dat deze het Nederlanderschap bleven behouden, doch het recht hadden in de daartoe gestelde termijn voor de Indonesische nationaliteit te opteren. Hiertoe was de voorwaarde gestelde, dat $z i j$ in Indonesië geboren of aldaar tenminste zes maanden woonachtig dienden te zijn; ${ }^{444}$

3. Artikel 4 trof voorzieningen met betrekking tot inheemse Nederlandse onderdanen niet-Nederlanders. De tot bedoelde categorie van autochtone Indonesiërs behorende personen werden, voor zover in Indonesië geboren en woonachtig, Indonesisch staatsburger. Was dit niet het geval, dan golden de in de Overeenkomst opgenomen bepalingen, waarbij werd afgegaan op geboorteplaats of op woonplaats van betrokkenen; ${ }^{445}$

4. De artikelen 5, 6 en 7 regelden de toescheiding van uitheemse Nederlandse onderdanen niet-Nederlanders; dit kwam in grote ljjnen hierop neer, dat de van deze categorie deel uitmakende Vreemde Oosterlingen als Chinezen en Arabieren alsmede Europeanen andere dan Nederianders, automatisch het Indonesisch staatsburgerschap verwierven, indien zij in Indonesië geboren of aldaar woonachtig waren. $\mathrm{Zij}$ hadden echter hel recht om binnen de gestelde termijn genoemd staatsburgerschap te verwerpen. ${ }^{446}$ Dit had tot gevolg, dat voor degenen die vór de soevereiniteitsoverdracht het Nederlands onderdaanschap bezaten, de Nederlandse nationaliteit werd herkregen. Betrof het echter personen, die naast de Nederlandse, een andere nationaliteit als bijvoorbeeld de Chinese bezaten, dan werd de Nederlandse nationaliteit eerst door deze bipatriden herkregen, indien daartoe een verklaring werd afgelegd, tegelijk met verwerping van het Indonesisch staatsburgerschap. Werd bedoelde verklaring niet afgelegd, dan had de repudiatie tot

444. Naar Lemaire meldt, bedroeg het aantal optanten nog geen 15.000 personen, derhalve nog geen $8 \%$. Zie Lemaire, Het Recht, p. 128.

445. Ter illustratie: indien de hierbedoelde personen buiten Indonesië geboren en in Nederland of buiten de gebieden der deelgenoten van de Unie woonachtig waren, waren zij bevoegd om binnen de gestelde termijn te verklaren, dat zij de Nederlandse nationaliteit verkiezen. Waren zij in Suriname of in de Nederlandse Antillen woonachtig, dan verkregen zij de Indonesische nationaliteit indien zij buiten het Koninkrijk geboren zijn, doch waren bevoegd binnen de gestelde termijn te verklaren dat zij de Nederlandse nationaliteit verkiezen. Waren zij daarentegen in het Koninkrijk geboren, dan behielden zij de Nederlandse nationaliteit, doch waren bevoegd om in de gestelde termijn te verklaren, dat zij de Indonesische nationaliteit verkiezen.

446. Naar schatting heeft $20 \%$, merendeels Chinezen van deze mogelijkheid gebruik gemaakt. Zie Lemaire, Het Recht, p. 128. 
gevolg, dat zij zowel voor Nederland als voor Indonesië vreemdeling werden, doordat zij alleen de vreemde nationaliteit overhielden. Op deze wijze konden bipatriden, die geen prijs stelden op noch de Nederlandse, noch de Indonesische nationaliteit, zich van beide ontdoen. Voorts waren voorzieningen getroffen voor het geval betrokkenen niet in Indonesië geboren of aldaar woonachtig waren, waarbij werd afgegaan op geboorteplaats of woonplaats van bedoelde personen. ${ }^{447}$

Afgaande op het in artikel 3 van de Toescheidingsovereenkomst bepaalde, konden Nederlanders derhalve de Indonesische nationaliteit verkiezen, indien zij in Indonesië geboren waren of aldaar tenminste zes maanden woonachtig. Deze mogelijkheid stond open voor alle Nederlanders in wettelijke zin, de zogenaamde "Indische Nederlanders" zoals personen geboren uit gemengde huwelijken tussen Nederlanders en inheemse vrouwen of buitenechtelijke kinderen die door de vader, een Nederlander zijn erkend en afstammelingen van genoemde personen - daaronder begrepen. ${ }^{448}$ Volgens Heijs heeft een minderheid van deze "Indische Nederlanders" voor de Indonesische nationaliteit geopteerd. Dit was onder meer het gevolg van een toespraak op 8 december 1951 door de Hoge Commissaris Lamping, de hoogste vertegenwoordiger van Nederland in Jakarta, waarbij hij de keuze voor de Indonesische nationaliteit voor deze "Indische Nederlanders" als "de meest natuurlijke oplossing" aanprees. ${ }^{449}$ Mannoury is van mening, dat ook Nederlanders die op Nieuw-Guinea geboren waren van dit optierecht

447. Ter illustratie: waren deze personen buiten Indonesiẽ geboren en in het Koninkrijk woonachtig, dan behielden zj hun Nederlandse nationaliteit. Zij waren echter - met uitzondering van de uit India of Pakistan afkomslige inwoners van Suriname - bevoegd de Nederlandse nationaliteit te repudiēren en als zodanig het Indonesisch staatsburgerschap te verkrijgen. Voor bipatriden stond de mogelijkheid open om zonder meer de toebedeelde Nederlandse nationaliteit te verwerpen.

448. Het bewijs van het Nederlanderschap is niet aan een bepaald middel gebonden. Normaliter wordt het Nederlanderschap van een ná 1 juli 1893 geboren persoon bewezen door overlegging van geboorte-akten, die de filiatie in de mannelijke lijn doen opklimmen tot een stamvader die vóór 1 juli 1893 in Nederland of in de toenmalige koloniën geboren was uit ouders aldaar gevestigd. In berinnering zij gebracht, dat krachtens het toenmalige artikel 5 BW Nederlanders waren, zij die in het Koninkrijk of de koloniën daarvan geboren zijn uit aldaar gevestigde (wonende) ouders en afstammelingen van Nederianders. Een ieder, die op 1 juli 1893 volgens de op die dag vervallen wetgeving Nederlander was, is dit krachtens de overgangshepaling op de Wet van 1892 gebleven, met uitzondering van die personen die in Nederlandsch-Indië naar de Wet van 2 september 1854 als "inlanders en met deze gelijkgestelden" werden beschouwd. Afstammelingen van de in het Nederlanderschap door de overgangsbepaling bevestigde personen zijn Nederlanders. Ook de Toescheidingsovereenkomst heeft een ieder die Nederlander was, in het bezit van die hoedanigheid gelaten. Zie voorts voor het bewijzen van het hezitten van het Nederlanderschap door "Indische Nederlanders", het artikel: Hoe bewijzen "Indische Nederlanders" hun Nederlanderschap?, Van der Weg, S., Het Personeel Statuut, 1950, p.31-32.

449. Heijs, Nederlanderschap, p.30-31. Deze auteur voegt hieraan toe, dat het overbodig is op te merken, dat de Hoge Commissaris zweeg over het feit, dat de keuze voor deze "natuurlijke oplossing" impliceerde dat de optanten vervolgens als Indonesiêr niet langer welkom waren in Nederland. Vele Nederlanders hadden Indonesiẽ echter reeds verlaten en waren naar Nederland vertrokken, een feit dat de Nederlandse Regering niet bepasild verheugde. Nederland stimuleerde na de corlog de emigratie van Nederlanders en had bijgevolg weinig behoefte aan een grootscheepse immigratie vanuit Indonesiê. 
gebruik konden maken, indien zij elders in Indonesië woonachtig waren, aangezien zij in dit geval niet tot de inwoners van Nieuw-Guinea te rekenen waren, die door de aantekening aan het slot van de Overeenkomst aan de werking daarvan onttrokken werden. Al was genoemd gebiedsdeel - op het tijdstip van de soevereiniteitsoverdracht niet aan Indonesië overgedragen, volgens deze auteur maakte Nieuw-Guinea aardrijkskundig deel uit van Indonesië. ${ }^{450}$ Wat betreft de voorwaarde van het tenminste zes maanden in Indonesië woonachtig zijn, kan onder de aandacht worden gebracht, dat nergens de eis was gesteld dat deze zes maanden aan de soevereiniteitsoverdracht dienden te zijn voorafgegaan; voldoende was dat deze periode vóór de gestelde termijn derhalve vóór 27 december 1951 - verstreken was. Mannoury stelt zich op het standpunt, dat indien de betrokken persoon die zes maanden in Nieuw-Guinea heeft doorgebracht, niet kan worden ontkend dat hij gedurende die tijd in Indonesië woonachtig is geweest. Op het ogenblik dat de optie werd verricht, moest betrokkene echter zijn woonplaats naar een andere plaats in Indonesië hebben overgebracht, wilde hij geen deel uitmaken van de "inwoners van Nieuw-Guinea" c.q. geen rechten uit de Toescheidingsovereenkomst affeiden. ${ }^{451}$

Volgens Barentsen - die de opvatting weergeeft zoals van Nederlandse zijde gehuldigd met betrekking tot het hanteren van de Toescheidingsovereenkomst - bestond aanvankelijk tussen de Nederlandse en Indonesische overheid verschil van inzicht omtrent de vraag of opties krachtens artikel 3 van de Overeenkomst uitgebracht al dan niet terugwerkten tot het tijdstip van de soevereiniteitsoverdracht. Van Nederlandse zijde werd het standpunt ingenomen, dat de nationaliteit waarvoor men opteerde geacht moest worden te zijn verkregen vanaf het tijdstip der soevereiniteitsoverdracht, met name 27 december 1949. Van Indonesische zijde was men daarentegen van mening, dat de middels optie plaatsgevonden nationaliteitsverandering eerst werkte vanaf het tijdstip der optie. Het verschil in interpretatie leidde tot de facto staatloosheid van oorspronkelijk Nederlandse kinderen, die op het tijdstip van de optie door de vader c.q. de moeder de leeftijd van 18 jaar reeds hadden bereikt, doch nog geen 18 jaar waren op 27 december 1949. Ook Sanger wijst erop, dat degenen die op 27 december 1949 de Nederlandse nationaliteit behielden en vervolgens een optieverklaring voor het Indonesisch staatsburgerschap afgelegd hadden, naar de Nederlandse visie op genoemde datum eerstgenoemde nationaliteit verloren hadden. Aangezien de Indonesische overheid het standpunt innam, dat de desbetreffende personen eerst met het afleggen van de optieverklaring als Indonesisch staatsburger aangemerkt konden worden, betekende dit voor deze personen dat zij van 27 december 1949 tot de aflegging van de optieverklaring, noch het Indonesische staatsburgerschap, noch de Nederlandse nationaliteit bezaten. ${ }^{452}$ Toen bleek dat terugwerking van opties niet was bedoeld, diende het Nederlandse standpunt te worden herzien. Volgens de nieuwe interpretatie behielden kinderen die krachtens de oorspronkelijke Nederlandse opvatting de facto staatloos werden, ook ná de optie der ouders het Nederlanderschap, doch waren naar de Nederlandse opvatting bevoegd om

450. Mannoury, Het Nederlandse Nationaliteitsrecht, p. 145.

451. Mannoury, Het Nederlandse Nationaliteitsrecht, p.145.

452. Sanger. Die indonesische, p.56. 
na het bereiken van de leeftijd van 18 jaar zelfstandig voor de Indonesische nationaliteit te opteren. ${ }^{453}$ Adriaanse en van der Weg brengen naar voren, dat het zelfstandig recht van verkiezing of verwerping van de toebedeelde nationaliteit in de eerste plaats is toegekend aan personen die meerderjarig waren in de zin van de overeenkomst, op het tijdstip van de soevereiniteitsoverdracht. Van officiële Nederlandse zijde was ten aanzien van Nederlanders echter beslist, dat zij ook een nationaliteitskeuze konden doen wanneer zij in Indonesië geboren waren en zij de leeftijd van 18 jaar bereikten gedurende de optieperiode, derhalve tussen 27 december 1949 en 27 december 1951. 4.54 Zijdens van der Weg wordt echter erop gewezen, dat uit de Toescheidingsovereenkomst niet bleek, op welke datum de verklaring (tot het verkiezen of verwerpen van een bepaalde nationaliteit) effect sorteerde. Ook deze auteur brengt naar voren, dat van officiële Nederlandse zijde het standpunt werd ingenomen dat optie tot verkiezing of verwerping van nationaliteit ingevolge de Toescheidingsovereenkomst terugwerkte tot 27 december 1949, anders dan de Indonesische regering die géén terugwerkende kracht aan een afgelegde optie- c.q. verwerpingsverklaring toekende. ${ }^{455}$ Prins wijst eveneens op het verschil van opvatting met betrekking tot deze aangelegenheid tussen de regeringen van Nederland en van Indonesië, zoals in het voorgaande reeds naar voren gebracht. ${ }^{456}$ Van belang is dat het van Indonesische zijde gehuldigde standpunt, dat de verkiezing of verwerping van de Indonesische nationaliteit in werking trad op de dag, waarop de daartoe strekkende verklaring was ontvangen, in een wettelijke regeling was neergelegd, met name in artikel 8 van de Regeringsverordening van 31 januari 1950 , Stb. 1950-8. ${ }^{457}$ Deze visie had ten gevolge - ondanks de bezwaren die in de literatuur daartegen werden geopperd ${ }^{458}$ - dat het Nederlandse standpunt diende te worden bijgesteld, zoals hiervoor reeds opgemerkt.

453. Barentsen, W.A., Overzicht van de huidige interprelatie van de Overeenkomst betreffende de Toescheiding van Staatshurgers, Het Personeel Statuut, 1961-1962, p.53-54 die verwijst naar de Memorie van Antwoord aan de Eerste Kamer der Staten-Generaal inzake de Justitiehegroting, Kamerzitting 1959-1960-5700, p.4.

454. Adriaanse en van der Weg, Nationaliteitswetgeving, p.1 A-6.

455. Van der Weg, S., Terugwerkende kracht van opties tot verkiezing of verwerping van nationaliteit ingevolge de Souvereiniteitsoverdracht, Het Personeel Statuut, 1952, p.43-44.

456. Prins, De gevolgen, p.69.

457. Opgenomen in Engelbrecbt-oude stijl, p.43.

458. Prins brengt ter zake naar voren, dat het enige argument dat voor de Indonesische opvatting pleitte, gelegen scheen te zijn in artikel 5 van de Toescheidingsovereenkomst, dat sprak van het herkrijgen van de Nederlandse nationaliteit door het verwerpen van de Indonesische. Deze schrijver is echter vал mening dat dit argument niet alleen niet erg sterk leek, maar ook volkomen teniet werd gedaan door artikel 11 van genoemde Overeenkomst. Dit artikel hield in dat de uitoefening van bet recht van verkiezing of venwerping van een nationaliteit, geen tevoren verrichte handeling ongeldig maakt, die geldig zou zijn indien dit recht niet was uitgecefend. Volgens deze auteur zou deze bepaling iedere betekenis missen, indien de optie niet terugwerkte. Ik vraag mij echter af, of aan de omschrijving van een "tevoren verrichte handeling" niet een andere betekenis moet worden gegeven zoals bijvoorbeeld de adoptie of erkenning van een kind en dit artikel derhalve geen betrekking heeft op een handeling in de vorm van het opteren voor een bepaalde nationaliteit. Zie Prins, De gevolgen, p.69. 
Rechtsgeldig waren voorts opties van personen, niet in Indonesië geboren en op het tijdstip van de soevereinitietsoverdracht niet, doch op het tijdstip der optie wél gedurende zes maanden in Indonesië woonachtig. In herinnering kan worden gebracht, dat niet was bepaald dat genoemde termijn van zes maanden aan de soevereiniteitsoverdracht diende te zijn voorafgegaan. ${ }^{459}$ De voor Nederlandse autoriteiten in Nederland, Suriname, de Nederlandse Antillen, in Indonesië en in het buitenland afgelegde optie/verwerpingsverklaringen zijn gepubliceerd in de Nederlandse Staatscourant. Voor het bezit van de staat van Nederlander uit hoofde van een uitgebrachte nationaliteitskeuze kan echter op de Staatscourant geen beroep worden gedaan. Mocht achteraf blijken, dat ten onrechte is geopteerd of verworpen, dan wordt de handeling geacht zonder rechtsgevolg te zijn geweest; wél is het zo dat de tussenkomst van de rechter kan worden ingeroepen door de betrokken persoon. 460

Voor gehuwde vrouwen was in het algemeen het optierecht niet aanwezig; zij volgden de staat van hun man. Was deze man Nederlander, dan hing de verkrijging van de Indonesische nationaliteit c.q. het verlies van het Nederlanderschap voor de vrouw ervan af, of deze man het optierecht bezat en of hij daarvan gebruik maakte. Het kon echter voorkomen dat een vrouw met een vreemdeling gehuwd, het Nederlanderschap zelfstandig bezat. Volgens Mannoury zou zij in dit geval het optierecht zelfstandig hebben bezeten, indien zij aan de gestelde eisen met betrekking tot geboorteplaats of domilicie in Indonesië voldeed, een standpunt ook door mij gedeeld. ${ }^{461}$ Sanger wijst voorts - mijns inziens terecht - op een ander geval waarin een gehuwde vrouw haar optierecht gedurende het huwelijk kon uitoefenen, met name wanneer haar man staatloos was. ${ }^{462}$ Naar de mening van Barentse moest wat betreft vrouwelijke onderdanen, die vớr de soevereiniteitsoverdracht met onderdanen gehuwd zijn geweest, rekening worden gehouden met de Regeling op de Gemengde Huwelijken (RGH) - het onderwerp van $\S 2.4$ - die uitgaat van het "vrouw volgt man" beginsel. Een vrouw van uitheemse origine werd na haar huwelijk met een inheems onderdaan, in juridische zin eveneens geacht tot de groep van inheemse onderdanen te gaan behoren; het omgekeerde gold voor een vrouw/inheems onderdaan na huwelijk met een uitheems onderdaan. De vrouw die het Nederlanderschap bezat en met een Nederlands onderdaan niet-Nederlander huwde, verloor het Nederlanderschap en werd Nederlands onderdaan niet-Nederlandse, inheems of uitheems, naar gelang de staat van de echtgenoot. Omgekeerd verwierf de Nederlands onderdaan-niet Nederlandse door huwelijk met een Nederlander het Nederlanderschap. ${ }^{463}$

Volgde krachtens artikel 10 lid 1 van de Toescheidingsovereenkomst, de op het tijdstip van de soevereiniteitsoverdracht reeds gehuwde vrouw van rechtswege de nationaliteits-

459. Dit was bedoeld om verlofgangers die op het tijdstip der soevereiniteitsoverdracht in het buitenland vertoefden, na terugkeer in Indonesiē alsnog de gelegenheid te geven voor de Indonesische nationaliteit te opteren.

460. Adriaanse en van der Weg, Nationaliteitswetgeving, p.1A-7.

461. Mannoury, Het Nederlandse Nationaliteitsrecht, p. 146.

462. Zie Sanger, Die indonesische, p.50.

463. Zie Barentsen, Overzicht van de huidige interpretatie, p.53. 
keuze van de echtgenoot, het tweede lid van dit artikel bevatte voorzieningen voor het geval ontbinding van het huwelijk plaatsvond. Dit artikellid bood deze vrouw de gelegenheid om binnen een jaar ná ontbinding van haar huwelijk alsnog door het afleggen van een verklaring de nationaliteit te verkrijgen of te verwerpen, die zij, ware zij op genoemd tijdstip niet gehuwd geweest, had verkregen of door aflegging van een verklaring had kunnen verkrijgen of verwerpen. Voor vrouwen, die voór hun huwelijk Nederlandse of uitheems Nederlands onderdaan niet-Nederlandse waren en als gevolg van hun huwelijk Indonesisch staatsburger waren geworden, hetzij door optie, hetzij door toescheiding van hun echtgenoot, bestond derhalve de gelegenheid om binnen een jaar ná ontbinding van het huwelijk, het Nederlanderschap te verkrijgen door aflegging van een verklaring voor de bevoegde autoriteit. ${ }^{464}$ Voorts kon bijvoorbeeld een $\mathrm{Ne}$ derlandse, in Indonesië geboren vrouw die op 27 december 1949 gehuwd was met een Nederlander, die of buiten Indonesië geboren en woonachtig was, of van zijn optierecht geen gebruik wenste te maken, binnen de termijn van een jaar na ontbinding van het huwelijk, alsnog voor de Indonesische nationaliteit opteren. Volgens Mannoury gold dit ook voor de, van oorsprong Nederlandse vrouw, die met een buitenlander gehuwd was en door huwelijk diens nationaliteit had verkregen, aangezien de vrouw in kwestie, ware zij niet gehuwd bij de soevereiniteitsoverdracht, in de termen van artikel 3 van de Toescheidingsovereenkomst zou zijn gevallen, een standpunt dat mij alleszins aanvaardbaar voorkomt. ${ }^{465}$

In aansluiting op hetgeen hierboven reeds wat betreft inheemse Nederlandse onderdanen niet-Nederlanders werd opgemerkt, zij nog gewezen op de in artikel 4 lid 1 van de Toescheidingsovereenkomst voorkomende zinsnede: "de onmiddellijk voor de soevereiniteitsoverdracht tot de inheemse bevolking van Indonesië behorende meerderjarige Nederlandse onderdanen niet-Nederlanders". Zoals door Barentsen naar voren gebracht, was de Nederlandse administratie van mening, dat van de optiegerechtigden slechts zij bevoegd waren, die op het tijdstip van de soevereiniteitsoverdracht reeds de volle leeftijd van 18 jaar hadden bereikt.Dit gold tevens voor de uitheemse Nederlandse onderdanen niet-Nederlanders, gezien de artikelen 5, 6 en 7 der Toescheidingsovereenkomst, waarin eveneens gesproken werd van "de onmiddellijk voor de soevereiniteitsoverdracht meerderjarige uitheemse Nederlandse onderdanen niet-Nederlanders". ${ }^{466}$

464. Barentsen, Overzicht van de huidige interpretatie, p.61.

465. Mannoury, Het Nederlandse Nationaliteitsrecht, p. 147.

466. Aan een aantal uitheemse Nederlandse onderdanen niet-Nederlander, op wie artikel 5 van de Toescheidingsovereenkomst van toepassing was, was op verzoek een Nederlands paspoort uitgereikt, echter zonder de mededeling dat zij de Nederlandse nationaliteit niet meer bezaten c.q. ter herkrijging hiervan een optieverklaring dienden af te leggen. Aangezien het mede aan de administratie te wijten was, dat zij niet binnen de gestelde termijn op formele wijze van hun bedoeling de Nederlandse nationaliteit te willen bezitten hebben doen blijken, werd door de Minister van Buitenlandse Zaken goedgevonden, dat betrokkenen door het aanvragen van een Nederlands paspoort geacht konden worden tevens een verwerpings-loptieverklaring ex artikel 5 te hebben gedaan. Daartoe diende niettemin vast te staan, dat betrokkenen op het tijdstip van de paspoortaanvraag en daama aan de Nederlandse nationaliteit de voorkeur geven boven de Indonesische nationaliteil. Hiervan v' $\therefore$ dan een verklaring opgemaakt, waarin melding werd gemaakt van de paspoortaanvraag en van 
Dit impliceert, dat kinderen, die op genoemd tijdstip nog geen 18 jaar waren, met hun ouders toegescheiden zijn en derhalve geen zelfstandig optierecht hebben gehad; ook indien zij op het tijdstip van de optie van de ouders de 18 -jarige leeftijd hadden bereikt, werden zij geacht in de nationaliteitskeuze van de ouders te hebben gedeeld. Dit standpunt - ook door mij gedeeld - week af van dat ten aanzien van de optiebevoegden krachtens artikel 3 der Toescheidingsovereenkomst, op Nederlanders betrekking hebbende, waarop in het voorgaande reeds werd ingegaan. ${ }^{467}$ Personen, die als minderjarigen in de optie van hun ouders zijn begrepen geweest, hebben niet de gelegenheid gehad om na het bereiken van de meerderjarige leeftijd de optie ongedaan te maken door voor de andere nationaliteit te opteren. Artikel 10 van de Wet van 1892, op grond waarvan aan kinderen van een Nederlander, geboren voor het tijdstip dat deze in een ander land werd genaturaliseerd - waardoor het kind in kwestie mede de staat van Nederlander verloor - de gelegenheid werd geboden om bij het bereiken van de meerderjarige leeftijd het Nederlanderschap terug te krijgen, was niet van toepassing op Nederlandse minderjarigen die krachtens de optie van hun ouders de Indonesische nationaliteit hadden verkregen. ${ }^{468}$

Krachtens de artikelen 8 en 9 van de Toescheidingsovereenkomst, volgden minderjarigen de nationaliteit van respectievelijk de vader of moeder, indien deze onmiddellijk vóór de soevereiniteitsoverdracht - 27 december 1949 - Nederlands onderdaan en in leven was; was dit niet het geval, dan werden de bepalingen van de Toescheidingsovereenkomst rechtstreeks op hen toegepast. In de onderhavige Overeenkomst werd onder "meerderjarig" verstaan, de leeftijd van 18 jaar hebben bereikt of op een eerder tijdstip gehuwd. Ingeval van ontbinding van het huwelijk, bleef betrokkene als meerderjarig aangemerkt. Onderscheid kon wat betreft de toescheiding van minderjarigen derhalve als volgt worden gemaakt tussen:

a. minderjarigen, wier nationaliteit afhankelijk was van het eveneens onderdaan zijn van de vader of moeder, naar de in artikel I van de Wet van 1892 gemaakte onderscheidingen (artikel 8);

b. minderjarigen, van wie de vader of moeder - naar de in artikel 1 van de Wet van 1892 gemaakte onderscheidingen - onmiddeilijk voor de soevereiniteitsoverdracht geen Nederlands onderdaan of niet meer in leven was (artikel 9).

466. $\rightarrow$

het feit dat door een administratief verzuim geen verwerpings- c.q. optieverklaring in de gebruikelijke vorm was opgemaakt. Zie Barentsen, Overzicht van de huidige interpretatie, p.57.

467. Barentsen, Overzicht van de huidige interpretatie, p.56.

468. Aldus de Hoge Raad bij beschikking van 20 oktober 1958 op grond van onder meer de overweging, dat de Toescheidingsovereenkomst geacht moest worden een uitputrende regeling te hevatten met betrekking tot de Nederlandse of de Indonesische nationaliteit van hen, die op het tijdstip van de soevereiniteitsoverdracht onderdanen van het Koninkrijk der Nederlanden waren en dat naast die uitputtende regeling, met betrekking tot de daaronder begrepen gevallen voor een beroep op de Wet van 1892 geen plaats was. Zie Van der Weg, S., Artikel 10 der wet op het Nederlanderschap en het ingezetenschap geldt niet voor kinderen van spijtoptanten, Het Personeel Statuut, 1959, p.36-37 en Adriaanse en van der Weg, Nationaliteitswetgeving, p.1A 6-7. 
Volgens van der Weg, bleek uit de praktijk bij herhaling, dat het bepalen van de nationaliteit van minderjarigen in hel kader van de Toescheidingsovereenkomst tot moeilijkheden aanleiding gaf. Zo zijn in vele gevallen minderjarigen gerangschikt onder de in artikel 9 genoemde categorie, terwijl artikel 8 toepassing had moeten vinden. Dit vond zijn oorzaak in een verkeerde interpretatie van de in deze artikelen voorkomende woorden "vader of moeder naar de in artikel I van de Wet van 1892 gemaakte onderscheidingen", hetgeen echter niet anders op te vatten was, dan dat de moeder de nationaliteit bepaalde, als er geen vader of de vader er niet meer was, derhalve vader respectievelijk moeder. Het kon nooit betekenen, onverschillig wie van beiden, een uitleg die mijns inziens voor de hand ligt. ${ }^{469}$ Barentsen voegt hieraan nog toe, dat de bedoeling van de wetgever was, dat in het geval de vader was overleden, de moederweduwe als nationaliteitsrechtelijke vertegenwoordiger in zijn plaats zou treden. Minderjarigen volgden derhalve de vader in diens nationaliteitskeuze; was het huwelijk door echtscheiding ontbonden en de kinderen mogelijk aan de moeder toegewezen, dan was dit feit van geen invloed. Anders lag het indien het huwelijk van de ouders vóor de scevereiniteitsoverdracht door overlijden van de vader ontbonden was; in dit geval volgden de wettige en gewettigde kinderen de nationaliteit van hun moeder-weduwe. ${ }^{470}$ Was de moeder vóor de soevereiniteitsoverdracht hertrouwd met een man, die tot een andere categorie behoorde dan haar eerste man en zij eveneens tot die andere categorie overgegaan, dan kon dit inhouden dat de kinderen een andere nationaliteit verkregen dan zij zouden hebben bezeten, indien hun vader nog zou hebben geleefd. Was echter het huwelijk van de ouders ontbonden door echtscheiding en de vader daarna, doch vóor de soevereiniteitsoverdracht overleden, dan was op de minderjarige kinderen niet artikel 8 doch artikel 9 van toepassing, aangezien de moeder niet als moeder-weduwe kon worden aangemerkt c.q. niet in de plaats kon treden van de overleden vader. Natuurlijke, niet door de vader erkende kinderen, volgden de nationaliteit van de moeder. Ook in dit geval bestond de mogelijkheid, dat het kind een andere nationaliteit verkreeg dan het eventueel bij zelfstandige toescheiding zou hebben bezeten. Als voorbeeld noemt Barentsen het geval van een niet-erkend kind van een vrouw van inheemse origine, waarvan de moeder vóór de soevereiniteitsoverdracht in het huwelijk trad met een Nederlander en dit kind met de moeder aan Nederland werd toegescheiden. Naar de opvatting van de Nederlandse administratie, deelden kinderen krachtens artikel 8 met hun moeder toegescheiden en waarvan de moeder tijdens de optieperiode door een niet-zelfstandig gedane nationaliteitskeuze, met name door optie van haar echtgenoot van nationaliteit veranderde, echter niet in de nationaliteitswijziging. ${ }^{471}$

469. Van der Weg, S., De artikelen 8 en 9 van de Overeenkomst betreffende de toescheiding van Staatsburgers, Het Personeel Statuut, 1955/1956, p.63-64.

470. Barentsen, Overzicht van de huidige interpretatie, p.57-58.

471. Barentsen, Overzicht van de huidige interpretatie, p. 58-59. Voor deze kinderen kon echter artikel 9 van toepassing geacht worden, hetgeen betekent dat de rechtmatige vertegenwoordiger - met name de moeder - voor de kinderen de nationaliteit kon verkiezen. die zij staande huwelijk door optie van haar echtgenoot verkregen had. 
Artikel 9 regelt de zelfstandige toescheiding van minderjarigen, waarbij de volgende uitsplitsing kan worden gemaakt, te weten:

a. voor wettige en gewettigde kinderen, indien beide ouders vóor de soevereiniteitsoverdracht zijn overleden of wanneer het huwelijk der ouders door echtscheiding is ontbonden en de vader is overleden;

b. voor door de vader erkende kinderen, indien zowel de erkenner als de moeder zijn overleden;

c. voor niet-erkende kinderen, indien de moeder is overleden;

d. voor minderjarigen, wier vader respectievelijk moeder onmiddellijk vóór de soevereiniteitsoverdracht geen Nederlands onderdaan was.

In de hierboven genoemde gevallen, had het kind - ook al was het nog minderjarig wel degelijk een optierecht, door zijn rechtmatige voogd uit te oefenen binnen de gestelde termijn van twee jaar na het tijdstip der soevereiniteitsoverdracht, namelijk 27 december 1949. ${ }^{472} \mathrm{Bij}$ ontstentenis van een rechtmatige voogd of vertegenwoordiger, begon de gestelde termijn eerst te lopen vanaf het tijdstip dal deze was benoemd. Het moest hier een rechtmatige vertegenwoordiger betreffen; was de vertegenwoordiger niet rechtmatig, dan kon aan de door deze gedane optie voor het kind in kwestie, geen rechtsgevolgen worden verbonden. Voor de hierboven genoemde minderjarigen zijn de artikele 3 tot en met 7 rechtstreeks van toepassing; anders dan in het geval van artikel 8 was voor hen wél van belang tot welke categorie Nederlandse onderdanen zij op het tijdstip der soevereiniteitsoverdracht behoorden. Betrof het bijvoorbeeld een kind dat onder de categorie van uitheemse Nederlandse onderdanen niet-Nederlander viel, bijvoorbeeld een uit ouders afkomstig uit Hongarije in Indonesië geboren kind, dan had dat kind ingevolge artikel 5 van de Toescheidingsovereenkomst de Indonesische nationaliteit verkregen. ${ }^{473}$ Was de vader c.q. moeder van deze minderjarigen overleden, dan gold als hun woonplaats de feitelijke plaats van vestiging. ${ }^{474}$

In aansluiting op het hierboven uiteengezette moge melding worden gemaakt van het wetsontwerp tot nadere vaststelling van artikel 2 van de Wet op het Nederlanderschap, dit in samenhang met de Toescheidingsovereenkomst. Volgens dit wetsontwerp zou een kind van een tijdens de geboorte in Suriname wonende vader of moeder - naar de in artikel 1 van de Wet van 1892 gemaakte onderscheidingen - die zelf geboren is uit een in Suriname wonende moeder, Nederlander zijn. Waar het in feite om ging is, dat dit kind het Nederlanderschap ook deelachtig zou worden, onverschillig het soms ook door afstamming de nationaliteit van een andere Staat bezat. Krachtens artikel 4 van de Toescheidingsovereenkomst had de hierbedoelde vader of moeder (in Suriname wonende), indien tot de autochtone bevolking van Indonesië behorende, de bevoegdheid voor

472. Mannoury, Het Nederlandse Nationaliteitsrecht, p. 146. Deze auteur wijst erop, dat ook in het geval de desbetreffende persoon tijdens de optietermijn de meerderjarige leeftijd hereikt had, hij niet gerechtigd was om zélf de verklaring af te leggen. Ook in dit geval is het de rechtmatige voogd die dat recht voor hem dient uit te oefenen.

473. Zie Adriaanse en van der Weg, Nationaliteitswetgeving, p. IA-6:

474. Barentsen, Overzicht van de huidige interpretatie, p.60. 
het Indonesisch staatsburgerschap te opteren. Werd hiertoe overgegaan, dan had dit tot gevolg, dat daardoor zijn/haar minderjarig kind krachtens artikel 8 van de Toescheidingsovereenkomst eveneens het Indonesisch staatsburgerschap deelachtig werd. Van Nederlandse kant werd krachtens de voorgestelde wet (met terugwerkende kracht tot 1 juli 1893) het kind tot Nederlander verklaard.

Het hierdoor ontstane conflict kon niet worden goedgepraat door de redenering, dat de onderhavige wet niet beoogde aan het kind in kwestie zijn Indonesisch staatsburgerschap te ontnemen, doch het als tweede, dubbele nationaliteit het Nederlanderschap werd toegekend, een mijns inziens onhoudbare situatie! Ik sluit me dan ook aan bij het standpunt van Kollewijn, die hiertegen het argument naar voren brengt, dat de Toescheidingsovereenkomst beoogde om personen die daaronder vielen hetzij in hun Nederlanderschap te bevestigen, hetzij hun de Indonesische nationaliteit toe te kennen. Ook is in flagrante strijd met de Overeenkomst om achteraf ten aanzien van personen, aan Indonesië toegewezen door een wijziging in de Nederlandse nationaliteitswetgeving te verklaren, dat zij op het tijdstip dat zij krachtens genoemde Overeenkomst de Indonesische nationaliteit verwierven, ó6k Nederlander waren. ${ }^{475}$ Kollewijn neemt het standpunt in, dat bij het optreden van een conflict als hierboven omschreven, de Toescheidingsovereenkomst voorrang zou hebben boven artikel 2 van de Nederlandse nationaliteitswet. Dit neemt echter niet weg, dat de wetgever dit conflict niet in het leven had mogen roepen. ${ }^{476}$ Het hierbedoelde ontwerp is niettemin tot Wet van 15 mei 1953, N. Stb. 1953-24, houdende nadere vaststelling van artikel 2 van de Wet op het Nederlanderschap en Ingezetenschap geworden.

Samenvattend kan in grote lijnen worden gesteld, dat Nederlandse onderdanen, of automatisch Indonesisch staatsburger werden, met het recht dit te verwerpen middels gebruikmaking van het recht van repudiatie, of Nederlander bleven, met het recht voor het Indonesisch staatsburgerschap te opteren. Volledigheidshalve dient in dit verband nog melding worden gemaakt van de zogenaamde "spijtoptanten", met name Nederlanders die voor het Indonesisch staatsburgerschap hadden geopteerd, doch deze beslissing achteraf betreurden. In dit verband kan melding worden gemaakt van de gelegenheid door de Nederlandse regering aan deze categorie van personen geboden, om op eenvoudige wijze het Nederlanderschap terug te krijgen, zoals geregeld bij de Wet Donker van 3 november 1954 . Het Parlement was van mening, dat Nederland ten aanzien van velen van deze personen speciale verplichtingen had, aangezien de Nederlandse regering hen zelf had aangeraden om voor de Indonesische nationaliteit te opteren. Het duurde echter nog tot het begin van de jaren zestig voordat de Regering bereid was de spijtoptanten

475. Kollewijn, R.D., Het wetsontwerp tot nadere vaststelling van artikel 2 der Wet op het Nederlander* schap en de Toescheidingsregeling met Indonesië, Nederlands Juristenblad, 1952, p.378-379.

476. Volgens Kollewijn bepaalde artikel 18 van het Uniestatuut dit uitdrukkelijk; hij is voorts van mening dat ook zonder dit artikel deze voorrang van de internationale overeenkomst boven de staatswet zou gelden. 
daadwerkelijk tegemoet te komen. ${ }^{477}$ Uiteindelijk werden circa 7.000 van de 12.500 toelatingsverzoeken ingewilligd, ongeveer 25.000 personen betreffende. Op 1 april 1964 $\mathrm{kwam}$ een einde aan dit speciale toelatingsbeleid; de verzoeken die vanaf die dag waren ingediend, werden volgens het reguliere vreemdelingenbeleid beoordeeld. ${ }^{478}$

Met de omschrijving "de gestelde termijn" is krachtens artikel 13 van de Toescheidingsovereenkomst bedoeld, een tijdvak van twee jaar na de overdracht der soevereiniteit. Uitvoeringsbepalingen met betrekking tot de onderhavige Overeenkomst, zijn vastgesteld met de reeds genoemde Regeringsverordening no. I van het jaar 1950, met terugwerkende kracht in werking getreden tot het tijdstip der soevereiniteitsoverdracht. Met deze Regeringsverordening werden bepalingen vastgesteld betreffende de wijze van gebruikmaking van het recht tot verkiezing en het recht tot verwerping van de Indonesische nationaliteit voor personen, die vóór de soevereiniteitsoverdracht Nederlands onderdaan waren.

Van belang hierbij was, dat de daartoe benodigde verklaringen door betrokkene zelf of indien deze persoon nog minderjarig was door zijn wettige vertegenwoordiger, vrij van zegel en kosten konden worden afgelegd - mondeling dan wel schriftelijk - ten overstaan van c.q. gericht tot de daartoe aangewezen instanties. De ondertekening of vingerafdruk van een schriftelijke verklaring moest gelegaliseerd worden. Aan degene, die een verklaring aflegt of indient, werd terstond een daarop betrekking hebbende officiële schrittelijke verklaring c.q. ontvangstbewijs overhandigd of toegezonden. ${ }^{479}$ Rest mij nog op artikel 14 van de Toescheidingsovereenkomst te wijzen. Dit artikel bepaalde, dat beslissingen over de uitoefening of verhindering van uitoefening van het optierecht konden worden gevraagd aan de gewone dagelijkse rechter van de woonplaats van de betrokken persoon. Woonde deze in het buitenland - derhalve buiten Indonesië en Nederland - dan waren de rechtbank in Amsterdam en de gewone dagelijkse rechter in Jakarta ter zake bevoegd. Van belang is voorts, dat hoger beroep en andere rechtsmiddelen daartegen openstonden als in burgerlijke zaken. De in kracht van gewijsde gegane beslissing werd door de Regering van de partij, in wier rechtsgebied de beslissing

477. Gautams. Tafsiran, p.203. De afwikkeling van de toelating van spijtoptanten tot Nederland is echter niet altijd moeiteloos verlopen. Ter gelegenheid van de openbare beraadslaging in de Eerste Kamer der Statengeneraal betreffende Hoofdstuk IV der Rijksbegroting voor hel dienstjaar 1957, zegde de toenmalige Minister van Justitie toe de toelating van spijtoptanten tot Nederland te zullen vergemakkelijken. Zijn deze personen reeds in Nederland gevestigd, dan zouden zij voor naturalisatie in aanmerking kunnen komen. Van de zijde van de aan het woord zijnde leden werd geopperd van een soepele regeling niets te hebben bemerkt. In verschillende gevallen was toelating geweigerd en ook indien toelating werd verleend, nam de behandeling van een ter zake gedaan verzoek uitermate lange tijd in beslag. Dit was ook het geval met spijtoptanten, die naar het oordeel van de Minister voor een en ander in aanmerking kwamen.

478. Heijs, Nederlanderschap, p. 31.

479. Vgl. Sanger, Die indonesische, p.52-53. 
gevallen was, aan de Regering van de andere partij medegedeeld en door deze als zodanig erkend. ${ }^{480}$

5.3.3. Indonesisch staatsburger krachtens de Wet no. 3 van het jaar 1946 en de Toescheidingsovereenkomst

Wordt verband gelegd tussen de Wet no. 3 van 1946, zoals naderhand gewijzigd en aangevuld, en de Toescheidingsovereenkomst, dan rijst de vraag hoe onder de geldingssfeer van eerstgenoemde Wet vallende personen, onder vigeur van de Toescheidingsovereenkomst zijn gebracht.

Ter beantwoording van deze vraag kan worden verwezen naar de aanhef van de Toescheidingsovereenkomst, waarin was neergelegd, dat onder Nederlandse onderdanen - voor welke categorie van personen genoemde Overeenkomst beoogde een regeling ter vaststelling van hun nationaliteit te treffen - mede zijn begrepen, personen die volgens de wetgeving der Republiek burgers waren van deze Republiek.

Als uitvloeisel hiervan was in de Toescheidingsovereenkomst bepaald, dat voor de toepassing van deze Overeenkomst op personen die krachtens de nationaliteitswetgeving van de Republiek Indonesië, burgers waren van deze Republiek, waar in de Overeenkomst werd gesproken van het "verkrijgen" of "verkiezen" van de Indonesische nationaliteit, de Republikeinse nationaliteit werd omgezet in de Indonesische en waar gesproken werd van het "behouden" van de Nederlandse of het "verwerpen" van de Indonesische nationaliteit, de Republikeinse nationaliteit verloren ging.

Hoe dient het hierboven geciteerde nu worden opgevat? Uit het bovenstaande zou kunnen worden afgeleid, dat onder vigeur van de Wet no. 3 van het jaar 1946 vallende burgers - ook deze Wet ging in eerste instantie van het "ius soli" uit - die tevens konden worden geacht aan de criteria voor het Nederlands onderdaanschap vastgesteld te voldoen, onder de geldingssfeer van de Toescheidingsovereenkomst waren gebracht, met inachtneming van de hierboven genoemde aanpassingen. Evenwel vielen vreemdelingen - in casu alle niet-Nederlandse onderdanen - niet onder de Toescheidingsovereen-

480. Door Heijs wordt een vergelijking gemaakt tussen de Toescheidingsovereenkomst van 1949 tussen Nederland en Indonesië en de Toescheidingovereenkomst van 1975 tussen Nederland en Suriname. aangegaan. In het erste geval werden aan de raciale indeling - de indeling naar bevolkingsgroep van de Nederlands-Indische bevolking belangrijke criteria ontleend voor de toescheiding van staatsburgers. Voor Suriname kon in 1975 van een dergelijk juridisch instrumentarium geen gebruik worden gemakkt, aangezien een dergelijke indeling aldaar niet voorhanden was. Deze auteur is voorts van mening, dat het onderwerp immigratie in 1975 een veel grotere rol in de discussies innam dan in 1949; in laatstgenoemd jaar ging het vooral om de wenselijkheid van de onafhankelijkheid "an sich". Immigratie werd pas na 1949 een issue toen de verhouding tussen Nederland en Indonesiē verslechterde en vrijwel alle Nederlanders van bun Nederlanderschap gebruik maakten om naar Nederland te vertrekken. Hetzelfde vond plaats bij de overdracht van Irian Jaya aan Indonesiê. Degenen die de Indonesische nationaliteit hadden verkregen, waren alsi vreemdeling niet langer in Nederland welkom, waarbij een uitzondering werd gemaakt voor de zogenaamde "spijtoptanten". Hejjs, Nederlanderschap, p.40-41. 
komst. Dit impliceert, dat het krachtens de Wet no. 3 van het jaar 1946 verkregen Indonesisch staatsburgerschap van deze niet-Nederlandse onderdanen afzonderlijk diende te worden geregeld c.q. bekrachtigd, om welke reden deze categorie van personen afzonderlijk is genoemd in de Memorie van Toelichting van de Wet no. 62 van 1958.

\section{$\S 6$ De Verordeningen van het Militaire Gezag}

Welke instantie beslist in het geval van twijfel of geschil met betrekking tot de vraag, of een bepaalde persoon al dan niet Indonesisch staatsburger is?

In eerste instantie dient onder de aandacht te worden gebracht, dat Indonesië vóor 1 augustus 1958 nog geen nationaliteitswel bezat, hetgeen het vaststellen of een persoon al dan niet het staatsburgerschap bezat, bemoeilijkte. Was dit staatsburgerschap automatisch verkregen, bijvoorbeeld in het kader van de in $\$ 5.3$ behandelde Toescheidingsovereenkomst, dan verkeerden personen, die op deze wijze Indonesisch staalsburger waren geworden, niet in de mogelijkheid om, indien zich de noodzaak daartoe voordoet, een bewijsstuk dat op het bezit daarvan betrekking heeft, te overleggen.

Deze aangelegenheid had voorheen in diverse verordeningen van het Militaire Gezag, als gebaseerd op de in Ind. Stb. 1939-582 opgenomen Regeling betreffende de Staat van Oorlog en Beleg, regeling gevonden. ${ }^{481}$

\section{1. Bewijzen van Indonesisch staatsburgerschap}

Een persoon die door een officiële instantie werd verplicht te bewijzen, dat hij het Indonesisch staatsburgerschap bezit, diende volgens de normale burgerrechtelijke procedure een verzoekschrift in te dienen bij het Landgerecht (de "Pengadilan Negeri"), teneinde in deze aangelegenheid een uitspraak te verkrijgen. Dit was gebaseerd op de Verordening van het Militaire Gezag no. Prt/PM/09/1957 van 4 juni 1957. Het bij genoemde Verordening van het Militaire Gezag bepaalde, werd naderhand opnieuw vastgesteld met de Regeling van het Centraal Oorlogsgezag no. Prt./Peperpu/014/1958, van dezelfde inhoud. ${ }^{482}$

Het met genoemde bepalingen vastgestelde kwam hierop neer, dat een persoon zich niet op eigen initiatief tot het Gerecht kon wenden ter verkrijging van een bewijs op het bezit van het Indonesisch staatsburgerschap betrekking hebbende, doch voor dit doel een

48I. In 1957 werd door de President om veiligheidsredenen de staat van oorlog en beleg afgekondigd, op genoemde Regeling gebaseerd. In verband met het weer van kracht worden van de Grondwet van 1945, werd vervolgens de Wet no. 23 Prp van het jaar 1959, Stb. 1959-139 afgekondigd, bij welke gelegenheid tot de vaststelling van een nieuwe regeling inzake de staat van gevaar werd overgegaan, die corspronkelijk tot 16 juni 1960 van kracht zou blijven, doch krachtens de Wet no. 22 Prp van het jaar 1960, Stb. 1960-66, werd verlengd tot 15 december 1960.Zie voor de Wet no. 23 Prp van 1959, Engelbrecht p.253. De achtergrond van de afkondiging van de staat van oorlog en beleg - op een later tijdstip, de staat van gevaar - werd belicht in $\$ 2.1$ van Hoofdstuk 1 .

482. Een Engelse vertaling hiervan is in dit boek opgenomen. 
urgentiebewijs van een daartoe competente instantie benodigd was. De noodzaak daartoe deed zich in de praktijk maar al te vaak voor, waarbij nog kwam dat verzoekschriften ter verkrijging van een bewijs van staatsburgerschap aan, voor die tijd, hoge zegelrechten waren onderworpen. ${ }^{483}$ De genoemde Militaire regelingen zijn niet van kritiek verschoond gebleven. Zo is Imam Bardjo de mening toegedaan dat de desbetreffende regelingen in principe neerkwamen op een "verkapte" naturalisatie. ${ }^{484}$

Tot het vorderen van de overlegging van bewijzen van staatsburgerschap waren bevoegd instanties, die bij de uitoefening van hun taak, op grond van een wettige regeling met betrekking tot hun werkkring, zich zekerheid dienden te verschaffen betreffende de vraag, of een persoon al dan niet Indonesisch staatsburger is. Dit hield verband met het bij de zaak in kwestie betrokken belang, waarbij onderscheid werd gemaakt tussen staatsburgers en niet-staatsburgers. Dit geval kon zich bijvoorbeeld voordoen, indien het ging om zaken als het betalen van vreemdelingenbelasting en de voor buitenlanders geldende registratieplicht. Overlegging van de hierbedoelde bewijzen van staatsburgerschap kon slechts worden vereist, indien zowel naar uiterlijke kentekenen als uit bescheiden of uit andere hoofde, niet voldoende van het staatsburgerschap van de persoon in kwestie bleek. Een soortgelijke procedure was vastgesteld voor personen die in het buitenland verbleven, in welk geval de Diplomatieke Vertegenwoordigingen van de Republiek Indonesië werden ingeschakeld.

In de praktijk kwam het hierboven uiteengezette hierop neer, dat een bewijs van staatsburgerschap niet zo eenvoudig was te verkrijgen. De behoefte hieraan deed zich, naast de hiervoor genoemde redenen, ook voor in verband met de voor buitenlanders geldende verplichting tot het bezitten van een werkvergunning c.q. een bedrijfsvergunning voor het ontplooien van bepaalde activiteiten op economisch gebied en met het oog op de mogelijkheid tot het uitoefenen van bepaalde rechten op de grond.

\subsection{Overige bepalingen het Indonesisch staatsburgerschap betreffende}

Een andere aangelegenheid die in de Verordening van het Militaire Gezarg no. Prt/PM/ 09/1957 jo. de Regeling van het Centraal Oorlogsgezag no. Prt./Peperpu/014/1958 regeling vond, betrof de status van buitenlandse vrouwen, ná 27 december 1949 met Indonesische staatsburgers gehuwd. Genoemde vrouwen werden eerst als Indonesisch staatsburger "behandeld" - de Indonesische term luidt "diperlakukan sebagai" - zodra zij een hierop betrekking hebbende bevestiging van de Minister van Justitie hadden verkregen. Bedoeld besluit van bevestiging - geldig zolang het huwelijk van betrokkene niet werd ontbonden of zich geen andere feiten voordeden, waardoor de vrouw in kwestie haar staalsburgerschap verloor - had dezelfde rechtskracht als een door het

483. Zie voor deze aangelegenheid de Verordeningen van bet Militaire Gezag no. 756/PMT/1957 jo. no. 875/PMT/1957 van respectievelijk 14 augustus 1957 en 10 oktoher 1957, die beoogden een aanvulling van de indertijd geldende Zegelverordening 1921 te geven. Nadere voorschriften betreffende deze aangelegenheid werden gegeven met de Instructie van de Minister van Defensie no. III/7/PMT/1957.

484. Zie Imam Bardjo, Masaalah, p.32-33. 
Gerecht afgegeven bewijs van staatsburgerschap. Als uitvloeisel van het op deze aangelegenheid betrekking hebbende beleid, diende een als hierbedoelde, in het buitenland verblijvende buitenlandse vrouw die zich naar Indonesië wilde begeven, in het bezit van een visum te zijn.

In de Toelichting op de Verordening van het Militaire Gezag no. Prt/PM/09/1957 was gesteld, dat tot vaststelling van deze bepaling was overgegaan ter voorkoming van de opvatting, dat een ná 27 december 1949 met een Indonesisch staatsburger gehuwde buitenlandse vrouw, het staatsburgerschap van rechtswege zou verkrijgen. Om die reden was bepaald, dat de vrouw in kwestie slechts als Indonesisch staatsburger werd behandeld - een nogal merkwaardige "rechtsconstructie" - waarbij in het midden werd gelaten of de vrouw juridisch Indonesisch staatsburger was of niet. Hoe was de status van een als hierbedoelde vrouw voordat zij in het bezit werd gesteld van een besluit van de Minister van Justitie op haar "status" betrekking hebbende. Was een als hierbedoelde vrouw dan buitenlandse? Hoe indien het nationaliteitsrecht van haar echtgenoot het beginsel huldigt, dat de vrouw staande huwelijk de staat van de man volgde, zoals vastgelegd in de Regeling Gemengde Huwelijken, opgenomen in Ind. Stb. 1898-158, het onderwerp van $\$ 2.4$ ? Werd dit beginsel doorbroken door hetgeen in de Militaire regelingen was bepaald, was zij dan apatride? ${ }^{\text {?85 }}$

Zoals bovendien uit de Toelichting op de Verordening valt op te maken, werd bij de regeling van de daarin genoemde aangelegenheden ervan uitgegaan, dat een - alomvattende - regeling betreffende het Indonesisch staatsburgerschap nog niet voorhanden was. Zo werd - voorheen - ter bepaling van het feit, wie Indonesisch staatsburger is afgegaan op regelingen, die ten tijde van het afkomen van bedoelde Militaire regelingen niet meer van kracht waren dan wel geen regeling bevatten voor gevallen, die zich ná 27 december 1949 zouden voordoen. Het standpunt werd voorts ingenomen, dat ook bij het voorhanden zijn van op deze aangelegenheid betrekking hebbende juridische bepalingen, het in de praktijk vaak moeilijk is om na te gaan of een persoon al dan niet het Indonesische staatsburgerschap bezit. Ook was geen regeling aanwezig, die aangaf welke instantie in het algemeen bevoegd is om het staatsburgerschap van een persoon vast te stellen.

Aan de aanwijzing van de "Pengadilan Negeri" als de instantie die bepaalde of een persoon al dan niet Indonesisch staatsburger is, lag de overweging ten grondsiag, dat deze aanwijzing geschiedde op juridische gronden. Mocht niettemin een bijzondere regeling, een hogere rechter - bijvoorbeeld in het kader van de Wet betreffende het Toezicht op Buitenlanders, de "Pengadilan Tinggi" (Raad van Justitie) - aanwijzen, dan bleef deze bijzondere regeling van kracht. ${ }^{486}$

485. Zie Imam Bardjo, Masaalah, p.36.

486. Dit was tot voor kort het geval krachtens de Noodwet no. 9 van het jagr 1953 betreffende het Toezicht op Buitenlanders, Stb. 1953-64. De afkondiging van een nieuwe Immigratiewet, met name de Wet no. 9 van het jaar 1992 - hiervoor reeds aan de orde gekomen - heeft bet niet langer van kracht zijn van onder meer deze Wet ten gevolge gehad. Krachtens deze nieuwe Wet zullen 
Met betrekking tot een persoon, die middels zijn handelingen deed blijken, het Indonesische staatsburgerschap minder op prijs te stellen, werd het standpunt ingenomen, dat een als hierbedoelde persoon niet langer als Indonesisch staatsburger diende te worden aangemerkt. Met het oog hierop, was in de onderhavige Militaire regelingen vastgesteld, dat een Indonesich staatsburger, die in het bezit is van een buitenlands paspoort c.q. een document dat als zodanig dienst doet, dat op zijn naam luidt en nog van kracht is, niet langer als Indonesisch staatsburger werd beschouwd. Deze bepaling strekte mede tot doel om het optreden van bipatridie te voorkomen.

De desbetreffende Regeling van het Oorlogsgezag was echter geen lang leven beschoren; de inmiddels plaatsgevonden afkondiging van de Wet no. 62 van het jaar 1958 betreffende het Indonesich staatsburgerschap en de ter uitvoering daarvan afgekondigde regelingen, had de intrekking van de desbetreffende Regeling ten gevolge, omdat handhaving daarvan niet langer noodzakelijk werd geacht. ${ }^{487}$

\section{$\$ 7$ Chinezen met de nationaliteit van het vroegere Nationalistisch China c.q. het huidige Taiwan}

\subsection{Algemeen}

Gelet op de geschiedenis, dient rekening te worden gehouden met het feit, dat met betrekking tot de in Indonesië verblijvende Chinezen onderscheid kan worden gemaakt tussen personen die de nationaliteit van Taiwan bezitten en personen die statsburger zijn van de Chinese Volksrepubliek. Voor een goed begrip dient naar voren te worden gebracht, dat voór het ontstaan van genoemde Volksrepubliek slechts sprake was van het voormalige Nationalistisch China. De politieke verwikkelingen die aan het ontstaan in 1949 van de Chinese Volksrepubliek zijn voorafgegaan hebben ertoe geleid dat sedert genoemd jaar onderscheid kan worden gemaakt tussen enerzijds de Chinese Volksrepubliek en anderzijds Taiwan, ${ }^{488}$

Het bovenstaande had ook voor de Chinezen in Indonesië bepaalde consequenties. Zo is Taiwan tot op heden niet door de Republiek Indonesië erkend en worden personen met de nationaliteit daarvan als "de facto-apatriden" beschouwd, hetgeen bepaalde

486. $\rightarrow$

bepalingen inzake het toezicht op buitenlanders en immigratiemaatregelen bij Regeringsverordening worden vastgesteld. Zie voor de Wet no. 9 van het jaar 1992, Warta-Cafi no.63, 64 en 66, jaargang 34. respectievelijk gedateerd 26 mei, 27 mei en 2 juni 1992.

487. Dit geschiedde met de Regeling van het Hoogste Oorlogsgezag no. 1 van het jaar 1960 betreffende de Intrekking van de Regeling van het Centraal Oorlogsgezag betreffende. Enkele aangelegenheden inzake het Staatsburgerschap.

488. De samenwerking tussen de nationale Regering en de communisten werd in casu steeds slechter en tenslotte brak een burgeroorlog uit. Dit had als gevolg dat de nationale Regering in 1949 naar Taiwan uitweek en door de communisten de Chinese Volksrepubliek werd uitgeroepein. 
nationaliteitsrechtelijke consequenties voor hen kan hebben. ${ }^{489}$ Hierop zal bij de behandeling van de verkrijging van het Indonesisch staatsburgerschap krachtens het "ius soli" en door naturalisatie in respectievelijk $\S 3$ en $\$ 6$ van Hoofdstuk 5 worden ingegaan. Op personen met de nationaliteit van de Chinese Volksrepubliek zal in $\$ 3$ van Hoofdstuk 4 worden teruggekomen.

Wordt in mijn beschouwing van "Chinezen" gesproken, dan zijn hiermede vóor 1949 personen met de nationaliteit van het voormalige Nationalistisch China bedoeld. Ná genoemd jaar kan onderscheid worden gemaakt tussen Chinezen met de nationaliteit van enerzijds de Chinese Volksrepubliek en anderzijds van Taiwan.

Interessant is de vraag hoe de status van de Chinezen in het algemeen is op te vatten, daarbij rekening houdend met de politieke ontwikkelingen, waarop in het voorgaande reeds werd ingegaan. Ook door het toenmalige Nationalistisch China werden Chinezen waar zij zich ook ophielden - als Chinees onderdaan aangemerkt, dit op basis van het "ius sanguinis" beginsel. Bij het tot stand komen van de Chinese Volksrepubliek, bleven Chinezen die onder de gezagssfeer van Taiwan vallen, aangemerkt als Chinees onderdaan van de Chinese Volksrepubliek, met als gevolg dat deze Chinezen mijns inziens in zekere zin de status van bipatride hebben. Uit het oogpunt van de Volksrepubliek bekeken, zou kunnen worden gezegd, dat in het geval Chinezen weigerden het staatsburgerschap van de Chinese Volksrepubliek te aanvaarden, zij hierdoor staatloos werden. ${ }^{490}$

\subsection{Politieke verwikkelingen}

Ter illustratie dat de positie van de Chinezen reeds in het verleden een bron van moeilijkheden vormde, kan worden gewezen op de Wet van 1892 - in $\$ 1.4$ ter sprake gekomen - welke Wet de mogelijkheid tot naturalisatie bood. Hierbij was de voorwaarcle gesteld, dat de betrokken persoon diende aan te tonen, dat de nationaliteitswetgeving van het land van oorsprong, geen beletsel vormde voor het verkrijgen van de staat van Nederlander door naturalisatie. Zo kon een verzoek tot naturalisatie niet worden ingewilligd indien de aanvrager naast zijn nieuw verworven, zijn oorspronkelijke nationaliteit bleef behouden.

Uit de praktijk bleek niettemin dat van deze voorwaarde werd afgeweken indien het Chinezen betrof, die reeds lange tijd in Indonesië gevestigd waren en sedert 1910 het Nederlands onderdaanschap hadden verkregen. Aan deze personen werd de gelegenheid geboden Nederlander te worden middels naturalisatie, niettegenstaande het feit dat zij

489. Ondanks het feit, dat Taiwan officieel niet door Indonesiē is erkend, bestaan er wel handelsbetrekkingen tussen beide landen en heeft uitwisseling van handelsmissies plaats. Recentelijk is van officiēle zijde naar voren gebracht, dat herstel van de diplomatieke betrekkingen met de Chinese Volksrepubliek met ingang van 8 augustus 1990, gén afbreuk zal doen aan de bestaunde economische en handelsbetrekkingen met. Taiwan.

490. Zie het artikel Chinese Dual Nationality, p.15, tijdschrift The Indonesian Spectator van 1 januari, 1958. 
hun op grond van het "ius sanguinis" verkregen Chinese nationaliteit bleven behouden. Deze aangelegenheid speelde derhalve ook reeds in het verleden, vór het ontstaan van de Chinese Volksrepubliek een rol! Ter toelichting diene, dat toestemming van de Chinese overheid moest worden verkregen voor het verloren gaan van de Chinese nationaliteit, wegens het verkrijgen van een andere nationaliteit door naturalisatie. Uit de praktijk bleek echter, dat deze toestemming praktisch nooit werd verleend. ${ }^{491}$

Aan het door de Nederlandse overheid gevolgde beleid lag de overweging ten grondslag, dat het blijven bestaan van een band tussen bedoelde personen die reeds lange tijd in het voormalige Nederlandsch-Indië verbleven en een vreemde mogendheid, niet aanvaardbaar werd geacht. Immers, zou een aanvraag tot naturalisatie door deze personen ingediend worden geweigerd, dan zou dit een erkenning van het bestaan van een "allégeance perpétuelle" met het land van oorsprong inhouden, hetgeen in strijd zou zijn met de soevereiniteit van Nederland. ${ }^{492}$

Onder de aandacht kan worden gebracht dat de emigratie van Chinezen niet weinig heeft bijgedragen aan de ontwikkeling van het Chinese nationaliteitsrecht. Ter staving hiervan zij opgemerkt, dat in het verleden op herhaald verzoek van de Chinese overheid om consulaten in Indonesië te mogen vestigen, de Nederlandse regering onder meer te kennen gaf dat China niet over een nationaliteitswet beschikte, waarop het zijn aanspraken met betrekking tot de bescherming van de Chinezen in Indonesië zou kunnen baseren. Dit leidde tot de opstelling van de eerste Chinese nationaliteitswet van 28 maart 1909. In deze Wet werd het - tot dusverre ongeschreven - "ius sanguinis" beginsel uitdrukkelijk opgenomen. Latere nationaliteitswetten van 18 november 1912 , van 30 december 1914 en van 5 februari 1929, hebben geen afbreuk gedaan aan de in de praktijk gehuldigde opvatting, dat de overzee-geboren Chinezen de Chinese nationaliteit bezaten. ${ }^{403}$ Dit had tot consequentie, dat afstammelingen in vaderlijke linie krachtens het "ius sanguinis" eveneens de Chinese nationaliteit hadden.

Het absoluut geldende patrilineale "ius sanguinis" der Chinezen heeft in de loop der tijden bipatridie doen ontstaan bij de overzee-geboren Chinezen. Wat Indonesië betreft, was de oorzaak hiervan gelegen in het van kracht worden van de Wet van 1910, zoals reeds opgemerkt, op het "ius soli" gebaseerd, in $\$ 3$ aan de orde gekomen. Bipatridie kan ook het gevolg zijn vanwege het samenvallen met andere wijzen van nationaliteitsverkrijging, waarbij de Chinese nationaliteit niet verloren ging. Dit is aangetoond in $\S 5.3$ in het kader van de implementatie van de Toescheidingsovereenkomst, waarbij aan Chinezen in Indonesiê automatisch het Indonesisch staatsburgerschap werd toebedeeld, uiteraard voor zover betrokkenen niet van het recht van repudiatie gebruik hadden gemaakt. In $\S 3$ van Hoofdstuk 4 zal worden nagegaan welke maatregelen de

491. Zie voor verdere details inzake het niet verlenen wan bedorlde toestemming, Ko Swan Sik, De Meervoudige, p. 124.

492. Mannoury, Het Nederlandse Nationaliteitsrecht, p. 108.

493. Ko Swan Sik, De Meervoudige, p.122-124. Zie voor een overzicht van genoemde nationaliteitswetten en uitwoeringsregelingen daarvan onder vermelding van de vindplaatsen, Hecker, H., Die Staatsangehörigkeitsregelungen, p.47-49. 
Indonesische overheid en die van de Chinese Volksrepubliek hebben getroffen om aan bedoelde bipatridie een einde te maken.

\section{$\S 8$ Problemen rond het Indonesisch staatsburgerschap}

In het kader van de in $\$ 6$ gegeven uiteenzetting werd reeds naar voren gebracht, dat het ontbreken van een alomvattende regeling inzake het Indonesisch staatsburgerschap in de praktijk tot veel problemen aanleiding heeft gegeven. Reden daartoe was dat vaak niet met zekerheid was vast te stellen, of een persoon nu al dan niet als Indonesisch staatsburger aan te merken is, mede in aanmerking genomen dat een daarop betrekking hebbend bewijs lang niet altijd eenvoudig te verkrijgen was.

De Toescheidingsovereenkomst beoogde slechts een regeling te treffen ter vaststelling van de nationaliteit van personen - de Nederlandse of de Indonesische nationaliteit - die vóór de soevereiniteitsoverdracht Nederlands onderdaan waren. Hierbij zij aangetekend, dat onder de geldingssfeer van deze Overeenkomst tevens personen waren gebracht, die volgens de Wet no. 3 van 1946 burgers waren van de Republiek Indonesië ten tijde van de Yogya-regering. Dit heeft mede tot gevolg gehad, dal deze Wet maar kort gegolden heeft en het ná 27 december 1949 niet mogelijk was om het staatsburgerschap van personen aan de hand van het in deze Wet bepaalde vast te stellen, hetgeen ook uit de in $\$ 6$ aangehaalde Militaire regelingen is gebleken. In dit verband kan in herinnering worden gebracht, dat zowel de Constitutie van de RVSI van 1949 als de Voorlopige Grondwet van 1950 een nieuwe nationaliteitswet in het vooruitzicht hadden gesteld.

Aanknopend bij het feit dat de Toescheidingsovereenkomst slechts betrekking had op personen, die tot 27 december 1949 Nederlands onderdaan waren, kan worden gesteld dat dit ertoe heeft geleid dat naar de letter der Overeenkomst, de hierin opgenomen bepaling dat minderjarige personen de nationaliteit van respectievelijk hun vader of moeder volgen - indien deze ouder vlak vóór de soevereiniteitsoverdracht Nederlands onderdaan en in leven was - wél van toepassing was op kinderen vóór 27 december 1949 , doch niet op kinderen ná genoemd tijdstip geboren. Dit was een gevolg van het feit, dat met de overdracht van de soevereiniteit aan Indonesië, niet langer van "Nederlands onderdanen" kon worden gesproken. In verband hiermede rees de vraag of die kinderen nu al dan niet als Indonesisch staatsburger dienen te worden aangemerkt. Zoals uit $\S 1.2$ van Hoofdstuk 4 zal blijken, heeft deze aangelegenheid in de Wet no. 62 van 1958 regeling gevonden.

Ook aan het beginsel, dat buitenlandse vrouwen, die ná 27 december 1949 met een Indonesisch staatsburger huwden, niet zonder meer het Indonesisch staatsburgerschap verwierven - zoals in de in $\$ 6$ geciteerde Militaire regelingen bepaald - lag de opvatting ten grondslag, dat een als hierbedoelde buitenlandse vrouw niet onder de Toescheidingsovereenkomst viel, aangezien zij niet als Nederlands onderdaan kon worden aangemerkt. Hiertegen kan echter worden ingebracht, dat in het geval wordt uitgegaan van het "vrouw volgt man" beginsel - hiermede is bedoeld, dat de vrouw staande huwelijk de staat van haar echtgenoot volgt - kan worden aangenomen dat dit beginsel van toepassing kan worden geacht te zijn in het hierbedoelde geval. Dit beginsel komt 
met name voor in de Regeling op de Gemengde Huwelijken, Ind. Stb. 1898-158, in $\$ 2.4$ behandeld, toendertijd óók van kracht op als hierbedoelde gemengde huwelijken. Volgens Bakker werd ook van Nederlandse zijde de vraag gesteld, welke nationaliteit een Nederlandse vrouw heeft, ná de soevereiniteitsoverdracht met een Indonesisch staatsburger gehuwd. Door het vooralsnog ontbreken van een Indonesische nationaliteitswet, achtte men het niet mogelijk met zekerheid vast te stellen, dat de Nederlandse vrouw door huwelijk met een Indonesisch staatsburger, diens nationaliteit deelachtig werd. Naar de mening van deze auteur leverde het huwelijk met een Indonesisch staatsburger voorshands geen verliesgrond voor de Nederlandse nationaliteit op; hij neemt voorts het standpunt in, dat het eventueel verkrijgen van een dubbele nationaliteit van een als hierbedoelde vrouw aanvaard diende te worden. Al zou dit standpunt juridisch aanvechtbaar zijn, het zou de Nederlandse vrouw bescherming kunnen bieden tot Indonesië met een eigen nationaliteitswet komt. ${ }^{44}$

De aandacht dient echter te worden gevestigd op de opvatting van de Nederlandse administratie - door Adriaanse en van der Weg weergegeven - die aanvankelijk hierop neerkwam, dat Nederlandse vrouwen, die ná de soevereiniteitsoverdracht met Indonesische staatsburgers waren gehuwd, geacht moesten worden door het huwelijk het Indonesisch staatsburgerschap deelachtig te zijn geworden. ${ }^{495}$ Vervolgens berichtte de Minister van Binnenlandse Zaken bij het Rondschrijven van 29 februari 1956, Directie B.B., Afdeling Bestuurszaken, no. 16306 de gemeentebesturen, dat Nederlandse vrouwen die na de soevereiniteitsoverdracht met Indonesische staatsburgers waren gehuwd, door de Indonesische regering werden behandeld als vrouwen die de Indonesische nationaliteit hebben, zodat deze vrouwen geacht moesten worden de Nederlandse nationaliteit te hebben verloren. Er werd voorts op gewezen, dat ná 27 december 1949 met Indonesische staatsburgers gehuwde vrouwen van vreemde nationaliteit eerst op genoemde behandeling aanspraak konden maken, indien door de Minister van Justitie ter zake een beslissing was genomen. ${ }^{496} \mathrm{Ik}$ meen in dit verband te mogen opmerken, dat de status van "als Indonesisch staatsburger behandeld" ("diperlakukan sebagai warganegara Indonesia") - uiteraard indien een hierop betrekking hebbend besluit van de Minister van Justitie was verkregen - nog niet betekent, dat deze vrouwen daadwerkelijk het Indonesisch staatsburgerschap verkregen, zoals in $\$ 6.2$ reeds naar voren gebracht. Eerst in het kader van de Wet no. 62 van het jaar 1958 betreffende het Indonesisch staatsburgerschap is de "scheve positie" van bedoelde vrouwen met ingang van 1 augustus 1958 rechtgetrokken, zoals in $\S 1.2$ van Hoofdstuk 4 zal worden aangetoond.

Met betrekking tot personen, die vielen onder de categorie der Nederlanders kan de vraag worden gesteld, of deze personen voor zover zij in Indonesië geboren of aldaar tenminste zes maanden woonachtig waren, gedurende de gestelde termijn van 27 december 1949 tot 27 december 1951 voor het Indonesisch staatsburgerschap konden

494. Bakker, P., De Nationaliteit van de Nederlandse vrouw na huwelijk met een Indonesiër, Het Personeel Statuut, 1954, p.67.

495. Adriaanse en van der Weg, Nationaliteitswetgeving, Indonesië, p.lb-20.

496. Zie hiervoor eveneens Adriaanse en van der Weg, Nationaliteitswetgeving, Indonesiē, p.Ib-20. 
opteren, onafhankelijk van het feit, wanneer zij de meerderjarige leeftijd hadden bereikt. Uit het in $\$ 5.3 .2$ uiteengezette is reeds gebleken dat deze vraag bevestigend kan worden beantwoord. Immers, naar de letter van de Toescheidingsovereenkomst was voor deze groep het bereiken van de meerderjarige leeftijd niet aan een tijdsbepaling gebonden, aangezien in artikel 3 van de Overeenkomst niet gesproken werd van "onmiddellijk vóor de soevereiniteitsoverdracht meerderjarige Nederlanders". ${ }^{497}$ Een andere aangelegenheid die hierin een rol heeft gespeeld, betreft het meningsverschil tussen de Indonesische en Nederlandse autoriteiten inzake het al dan niet terugwerken van optieverklaringen tot 27 december 1949 , waarop reeds uitvoerig werd ingegaan in $\$ 5.3 .2$. Het hiervoor uiteengezette heeft ertoe geleid, dat in het bijzonder met betrekking tot de nationaliteit van in de jaren 1932/1933 geboren personen, die onder bedoelde categorie van Nederlanders vielen en ná de soevereiniteitsoverdracht de meerderjarige leeftijd van 18 jaar hadden bereikt, tussen de Indonesische en Nederlandse overheid interpretatieproblemen ontstonden. De bepaling, dat minderjarige personen de staat van de vader of van de moeder volgen, kon niet op genoemde personen van toepassing worden verklaard, aangezien zij op het tijdstip waarop de ouder - vader of moeder voor het Indonesisch staatsburgerschap opteerde, reeds de meerderjarige leeftijd hadden bereikt.

Wat betreft personen, die deel uitmaakten van de categorie der uitheemse Nederlandse onderdanen niet-Nederlanders, was zoals in \$5.3.2 reeds opgemerkt, daarentegen het bereiken van de meerderjarige leeftijd naar de letter van het in de Toescheidingsovereenkomst bepaalde, wél aan een tijdsbepaling gebonden. In de artikelen 4 tot en met 7 van de Overeenkomst is uitdrukkelijk gesproken van de "onmiddellijk vóór de soevereiniteitsoverdracht meerderjarige uitheemse Nederlandse onderdanen niet-Nederlanders". Zo verwierven de in Indonesië geboren of aldaar woonachtige personen die van deze categorie deel uitmaakten, het Indonesisch staatsburgerschap automatisch, echter met het recht tot verwerping hiervan binnen de gestelde termijn. Van dit recht tot verwerping kon niettemin eerst gebruik worden gemaakt, indien aan voornoemd criterium met betrekking tot de meerderjarigheid gesteld, was voldaan. Dit had tot consequentie, dat gebruikmaking van dit recht door een persoon, minderjarig krachtens het in de Overeenkomst bepaalde, in de zin van het nog niet bereikt hebben van de leeftijd van 18 jaar of niet op een eerder tijdstip gehuwd, als onwettig werd aangemerkt.

De hierboven geschetste problemen leiden vaak tot onzekerheid met betrekking tot de status van de betrokken persoon.

\section{$\$ 9$ De praktijk}

Het feit dat het Indonesisch staatsburgerschap vaak automatisch werd verkregen, kan in de praktijk tot moeilijkheden leiden, vanwege het niet beschikken over een bewijsstuk

497. Artikel 3 van de Overeenkomst luidt als volgt: "Meerderjarige Nederlanders behouden de Nederlandse nationaliteit, doch zijn bevoegd, indien zij in Indonesie geboren of aldaar tenminste zes maanden woonachtig zijn, binnen de gestelde termijn te verklaren, dat zij de Indonesische nationaliteit verkiezen". 
hierop betrekking hebbende. Hierbij komt nog, dat bedoeld bewijsstuk niet altijd gemakkelijk was te verkrijgen. In afwachting van de door artikel 5 lid 1 van de Voorlopige Grondwet van 1950 in het uitzicht gestelde wettelijke regeling inzake het Indonesisch staatsburgerschap, was met de Regeling van het Centraal Oorlogsgezag no. Prt/Peperpu/014/1958 van 16 april 1958 bepaald, dat de rechter in gevallen van twijfel een uitspraak zou doen c.q. in voorkomende gevallen zou beslissen of een persoon al dan niet het Indonesisch staatsburgerschap bezit. ${ }^{498}$

Aansluitend op het bovenstaande, kan de vraag worden gesteld, welke criteria ter zake door de rechter zullen worden gehanteerd. Aangezien het hier gevallen betreft, die betrekking hebben op de situatie zoals die was vórdat de Wet no. 62 van 1958 was afgekondigd, kunnen onder meer als zodanig gelden, het in Indonesië geboren zijn of het op 27 december 1949 aldaar gevestigd zijn. Voor uitheemse Nederlandse onderdanen niet-Nederlanders geldt voorts, het zijn van meerderjarig vó́r de datum 27 december 1949. Ook het feit van het zijn "opgelost" in de autochtone bevolking, kan als criterium worden gehanteerd.

Helaas staan mij slechts enkele rechterlijke vonnissen betreffende de hierboven geschetste aangelegenheid ter beschikking.

In eerste instantie kan de aandacht worden gevestigd op het arrest van de "Mahkamah Agung" (MA) Reg. no. $2 \mathrm{~K} /$ Rup/1956 van 10 oktober 1956. In dit arrest is gesteld, dat krachtens artikel 8 lid 2 van de Regeringsverordening no. 1 van het jaar 1950 tot Uitvoering van de Toescheiding van Staatsburgers, de rechter slechts de bevoegdheid tot het wijzen van vonnis met betrekking tot de uitvoering van bedoelde toescheiding van staatsburgers wordt verleend, indien de verklaring van een persoon inzake de verkiezing of verwerping van het Indonesisch staatsburgerschap niet door de competente functionaris is aanvaard. Met verwijzing naar artikel 17 van de voorheen geldende Wet op de "Mahkamah Agung" no. 1 van het jaar 1950, Stb. 1950-30 is voorts gesteld, dat de bepaling dat nietigverklaring van een vordering tot cassatie in het belang van het recht reeds door de betrokken partij verkregen rechten niet kan verminderen slechts geldt, indien het vonnis van de rechter is gewezen binnen het gebied van zijn attributie. ${ }^{499}$

Uit dit arrest kan de conclusie worden getrokken, dat het aanvaarden van een verklaring van een persoon - in het kader van de uitvoering van de Toescheidingsovereenkomst op verkiezing c.q.verwerping van het Indonesisch staatsburgerschap betrekking hebbende, in principe buiten de competentie van de rechter valt; dit vormt de taak van de krachtens de Regeringsverordening no. 1 van 1950 aangewezen functionaris. In het kort gaat het hier om een vonnis van de "Pengadilan Negeri" te Tandjungkarang van 16

498. Genoemde Regeling werd overbodig in verband met de afkondiging van de Wet no. 62 van het jaar 1958 op het Statsburgerschap van Indonesië en derhalve met de Regeling van het Hoogste Oorlogsgezag no. 1 van het jaar 1960 ingetrokken.

499. Zie voor dit arrest het tijdschrift Hukum van de Vereniging van Indonesische rechtsgeleerden ("Perhimpunan Ahli-Hukum Indonesia"), no. 1-2, jaar 1957. 
oktober 1954. Hierbij werd het verzoek van Tjiong Tjoen Bwee ingewilligd, door de op verwerping van het Indonesisch staatsburgerschap gerichte verklaring ten name van genoemde persoon van 25 december 1951 - als ontvangen en geregistreerd ter griffie van de "Pengadilan Negeri" te Tandjungkarang van 25 december 1951 no. 1007/1951 nietig te verklaren en als zodanig vast te stellen dat Tjiong Tjoen Bwee Indonesisch staatsburger is. Met genoemd arrest van de "Mahkamah Agung" werd het vonnis van de "Pengadilan Negeri Lampung" te Tandjungkarang van 16 october 1954 no. 145/1954 echter nietig verklaard in het belang van het recht. Door de Procureur-Generaal was in casu geëist om bedoeld vonnis nietig te verklaren, die daarbij het bezwaar naar voren had gebracht, dat de "Pengadilan Negeri" een vonnis had gewezen inzake een aangelegenheid die niet onder de attributie van dit Gerecht viel. Dit bezwaar werd door de "Mahkamah Agung" aanvaard. Nietigverklaring van een vordering tot cassatie in het belang van het recht, kan reeds verkregen rechten door de belanghebbende partij niet verminderen. Van "het niet verminderen van verkregen rechten" kan echter eerst sprake zijn, indien het vonnis van de onderhavige rechter is gewezen binnen het gebied van zijn attributie. Dit was hier niet het geval, aangezien bij het wijzen van vonnis de desbetreffende "Pengadilan Negeri" de grenzen van de rechtsbedelingssfeer had overschreden; om die reden kon de betrokken persoon geen rechten middels het vonnis a quo verkregen, naar voren brengen.

Het tweede geval heeft betrekking op het vonnis van de "Pengadilan Negeri" te Semarang no. 308/1957/Pdt.R. van 15 november 1957. Het betreft hier een buiten huwelijk geboren kind, dat krachtens artikel 1 sub c. van de Wet van 1892 op het Nederlanderen Ingezetenschap Nederlander zou zijn, indien zijn moeder op het tijdstip van zijn geboorte de staat van Nederlandse zou bezitten. Aangezien dit niet het geval is, is het kind geen Nederlander doch is - er had geen verwerping of verkiezing van nationaliteit plaatsgevonden - Indonesisch staatsburger. Deze status kan niet worden gewijzigd door het naderhand erkennen van het kind door de moeder, die ten tijde van het verrichten van deze rechtshandeling de Nederlandse nationaliteit bezat, doch Indonesisch staatsburger was ten tijde van de geboorte van het kind. ${ }^{500}$

Voor een beter begrip van de uitspraak bij dit vonnis gedaan zij opgemerkt, dat in deze zaak het instituut der gelijkstelling aan Europeanen, de Wet van 1910 en de Toescheidingsovereenkomst een rol spelen. De moeder van het kind zélf is een door de vader, Kam Thay Soei - die de status van aan Europeanen gelijkgesteld had - erkend kind. De status van aan Europeanen gelijkgesteld had echter niet ten gevolge, dat Kam Thay Soei als Nederlander krachtens de Wet van 1892 kon worden aangemerkt. Hij bezat daarentegen wél de status van (uitheems) Nederlands onderdaan niet-Nederlander, welke status op zijn dochter was overgegaan. Aangezien in het kader van de Toescheidingsovereenkomst géén verwerping door de moeder - voor haarzelf en haar kind - van het Indonesisch staatsburgerschap had plaatsgevonden, waren beide Indonesisch staatsburger. De moeder trouwde op 21 oktober 1953 met een Nederlander, R.L. van Braam genaamd

500. Zie voor dit vonnis, het tijdschrift Hukum van de Perhimpunan Ahli-Hukum Indonesia, no. 9-10, jaar 1958. 
en kreeg op grond van het "vrouw volgt man" beginsel, de status van Nederlandse krachtens de Wet van 1892 (artikel 5). Op 21 maart 1956 - derhalve na voltrekking van het huwelijk - erkende zij het kind in kwestie; deze erkenning had evenwel gén verandering van de nationaliteit van het kind ten gevolge, aangezien ter zake de nationaliteit van de moeder ten tijde van de geboorte van het kind op 2 mei 1946 doorslaggevend is en het kind derhalve Indonesisch staatsburger is. Ik heb dit vonnis aangehaald, omdat hierin aspecten voorkomen, die in het voorafgaande reeds ter sprake zijn gekomen.

Het arrest van de "Mahkamah Agung" van 5 december 1975 no. $261 \mathrm{~K} / \mathrm{Sip} / 1973$ heeft betrekking op de zaak van John Mahdi tegen Mw. Dee Zubaida Thamrin en betreft de "oplossing" van een persoon in de autochtone bevolking. In dit arrest is gesteld, dat het instituut der gelijkstelling in het koloniale tijdperk was bedoeld om het Europese recht op een persoon van toepassing te verklaren. Het betreft hier een gelijkgestelde autochtone Indonesiër, wiens huwelijk met een autochtone Indonesische vrouw op Islamitische wijze voor de "Pengulu"( Hoofd van moskeebeambten onder meer met de huwelijkssluiting belast) van de stad Sukabumi was voltrokken, op bedevaart naar Mekka was gegaan en Voorzitter van de Regionale Volksvertegenwoordiging van de stad Bogor was geweest. Ook de huwelijken van zijn dochters had betrokkene op Islamitische wijze doen voltrekken. Op grond van deze feiten, nam de MA het standpunt in, dat de uit de koloniale tijd stammende rechtsorde van geen invloed is geweest op betrokkene, die in het leven van alle dag, nooit zijn oorspronkelijk leefmilieu als autochtone Indonesiër heeft verlaten. Derhalve kan de conclusie worden getrokken dat betrokkene als gelijkgestelde autochtone Indonesiër zich opnieuw heeft "opgelost" in de groep van autochtone Indonesiërs zodat het Adatrecht op hem van toepassing is. ${ }^{501}$

Zoals in $\S 2.3$ naar voren gebracht, kan het instituut van "oplossing" tot gevolg hebben, dat een niet-Indonesiër daardoor tot Indonesiër wordt en vindt derhalve verandering van nationaliteit plaats. Aangezien sprake is van een autochtone Indonesiër, gaat dit hier niet op. Alhoewel de gelijkstelling algemeen gesteld - hierop zijn, zoals in $\$ 2.2$ aangetoond, uitzonderingen mogelijk - geen verandering van nationaliteit teweegbracht, was wél het gevolg hiervan dat betrokkene onder het Europese recht kwam te vallen. Om dit ongedaan te maken c.q. weer onder het Adatrecht te vallen, diende betrokkene zich "opnieuw" op te lossen in de autochtone bevolking.

\section{$\$ 10$ Samenvatting}

In het voorgaande werd de voorgeschiedenis van de huidige Nationaliteitswet no. 62 van het jaar 1958 zeer gedetailleerd weergegeven.

501. Zie Rangkuman Yurisprudensi Mahkamah Agung Indonesia, II, Hukum Perdata dan Acara Perdata, Proyek Yurisprudensi Mahkamah Agung, p.1. Deze "Rangkuman" bevat slechts uittreksels van arresten van de "Mahkamah Agung". 
Uit de behandelde materie kan worden geconcludeerd, dat wat de ontwikkeling van het nationaliteitsrecht betreft, verschillende perioden zijn te onderscheiden, met name:

a. de periode aan de afkondiging van de Wet van 1892 voorafgaande;

b. de periode sedert de afkondiging van de Wet van 1892 tot de inwerkingtreding van de Wet van 1910;

c. de periode vanaf de inwerkingtreding van de Wet van 1910 tot de Toescheidingsovereenkomst van 1949, alsmede

d. de periode sedent de Toescheidingsovereenkomst van 1949 en de inwerkingtreding van de Wet no. 62 van het jaar 1958.

In de onder a. genoemde periode, waren autochtone Indonesiërs en daarmede gelijkgestelden "Nederlander", alhoewel slechts voor privaatrechtelijke doeleinden. Dit betekent, dat aan deze personen géen politieke rechten toekwamen. Wél was het zo, dat deze personen aanspraak konden maken op diplomatieke bescherming en niet konden worden uitgeleverd aan derde landen. Gesteld kan worden, dat tot de inwerkingtreding van de Wet van 1892, autochtone Indonesiërs en daarmede gelijkgestelden ten aanzien van het burgerlijk recht, het strafrecht en het uitleveringsrecht en in het diplomatieke verkeer als Nederlanders werden aangemerkt. ${ }^{502}$

De afkondiging van de Wet van 1892 zoals onder b. gesteld, had tot consequentie dat krachtens de Overgangsbepaling van deze Wet genoemde categorieên van personen van hun "Nederlanderschap" werden beroofd. Ingevolge de toenmalige redactie van artikel 12 van genoemde Wet verkregen autochtone Indonesiërs en daarmede gelijkgestelden de status van "vreemdeling". Een uitzondering hierop vormden de op 1 juli 1893 - de datum van inwerkingtreding van de Wet van 1892 - reeds aanwezige, met Europeanen gelijkgestelden, die derhalve Nederlanders werden in de zin van deze Wet. ${ }^{513} \mathrm{Ter}$ verlichting van het in de Overgangsbepaling van de Wet van 1892 bepaalde, werd in de Slotbepaling van de onderhavige Wet bepaald, dat autochtone Indonesiërs en daarmede gelijkgestelden wat betreft uitleveringsaangelegenheden als "Nederlander" konden worden beschouwd, zonder dat zij daardoor de status van Nederlander verkregen. Ten aanzien van genoemde categorieën van personen trad in feite een vacuüm op, doordat hun status ongeregeld bleef? Met het doel in genoemd vacuüm te voorzien werd de Wet van 1910 afgekondigd. ${ }^{504}$

Met de afkondiging van de Wet van 1910 als onder c. genoemd, werden autochtone Indonesiërs en daarmede gelijkgestelden echter niet in hun "Nederlanderschap" hersteld, doch moesten genoegen nemen met de tweederangse status van "Nederlands onderdaanniet Nederlander". Aan deze personen kwamen met name geen politieke rechten in het moederland toe, al konden zij wél aanspraak maken op diplomatieke bescherming.

502. Zie hiervoor het in $\$ 1.3$ van dit Hoofdstuk uiteengezette.

503. Zie hiervoor $\$ 1.4$ van dit Hoofdstuk. Volledigheidshalve dient voorts melding worden gernaakt van de, van de hierbedoelde categorieën deel uitmakende personen die tot Nederlander waren genaturalisoerd.

504. Zie voor de Wet van $1910, \$ 3$ van dit Hoofdstuk. 
Aangezien in deze Wet voomamelijk op de plaats van geboorte werd afgegaan ter verkrijging van het Nederlands onderdaanschap, had dit ten gevolge dat niet alleen autochtone Indonesiërs doch ook personen, die reeds in het bezit van een nationaliteit waren Nederlands onderdaan werden. Dit had tot consequentie, dat in het voormalige Nederlandsch-Indië geboren Chinezen de status van bipatride verkregen. De onafhankelijksproclamatie van 1945 had de afkondiging van de Wet no. 3 van het jaar 1946, zoals naderhand gewijzigd en aangevuld, ten gevolge; het betrof hier de eerste Nationaliteitswet van Indonesië. Dat aan dit feit geen bijzonder gewicht dient te worden gehecht vindt zijn reden hierin, dat deze Wet slechts kort en beperkt gegolden heeft. Zo is de Republiek Indonesië van de zogenaamde Yogya-regering als deelstaat van de RVSI opgenomen en is niet alleen in de Constitutie van de RVSI maar ook in de Voorlopige Grondwet van 1950 een Nationaliteitswet in het vooruitzicht gesteld. ${ }^{505}$ De soevereiniteitsoverdracht op 27 december 1949 door Nederland aan Indonesië heeft voorts aanleiding gegeven tot de totstandkoming van de Overeenkomst betreffende de Toescheiding van Staatsburgers.

De onder $d$. genoemde Toescheidingsovereenkomst vormde een belangrijke schakel in de ontwikkeling van het Indonesisch nationaliteitsrecht. Deze Overeenkomst greep met name enerzijds terug op de bepalingen, die voorheen hebben gegolden, in casu de Wet van 1892 en de Wet van 1910 en speelt anderzijds ook een rol in de toepassing van de huidige Nationaliteitswet no. 62 van 1958. Zo is in artikel 1 sub a. van laatstbedoelde Wet bevestigd, dat personen die reeds Indonesisch staatsburger waren krachtens overeenkomsten/wetten/regelingen van kracht sedert de onafhankelijkheidsproclamatie, Indonesisch staatsburger zijn op grond van de Wet no. 62 van 1958. Krachtens het in de Toescheidingsovereenkomst bepaalde, werden de onderdanen van het Koninkrijkoude stijl verdeeld tussen het Koninkrijk-nieuwe stijl en de RVSI (thans de Republiek Indonesië). Aan betrokkenen werd onder daartoe gestelde voorwaarden echter gelegenheid geboden on in de vastgestelde termijn tot verwerping van het toebedeelde Indonesische staatsburgerschap of tot verkiezing daarvan over te gaan. ${ }^{5 n}$

Voor een goed begrip dient echter te worden opgemerkt, dat zowel de Wet van 1910 als de Toescheidingsovereenkomst niet los kan worden gezien van de - raciale onderverdeling van de bevolking van Indonesië ex artikel 163 IS, aangezien daarin van deze onderverdeling in bevolkingsgroepen is uitgegaan. ${ }^{507}$ Zowel in de Wet no. 3 van 1946 als in de huidige Wet no. 62 van 1958 is ernaar gestreefd, van deze raciale onderverdeling af te stappen door thans slechts één begrip, met name het begrip "Indonesisch staatsburger" te handhaven. Is, algemeen gesteld, de nationaliteit voor-

505. De korte en beperkte geldingsduur van de Wet no. 3 van 1946 blijkt ook hieruit, dat de afkondiging van de Wet no. 62 van 1958 niet gepaard is gegaan met de intrekking van eerstgenoernde Wet, waartoe immers geen reden bestond. Wel is het zo, dat personen die krachtens de Wet no. 3 van 1946 door naturalisatie Indonesisch staatsburger zijn geworden, ook Indonesisch staatsburger zijo krachtens de Wet no. 62 van 1958 (artikel 1 sub a). Ook is van de Wet no. 3 van 1946 op een later tijdstip gebruik gemaakt ter vaststelling van de nationaliteit van de ingezetenen van Irian-Jaya.

506. Zie voor de Toescheidingsovereenkomst $\$ 5.3$ van dit Hoofdstuk.

507. Zie hiervoor $\$ 2$ van dit Hoofdstuk. 
waarde voor het toe te passen recht, in Indonesië is dit niettemin (nog) niet het geval. Het zijn van Indonesisch staatsburger betekent niet dat op Indonesische staatsburgers hetzelfde recht van toepassing is. Voor de vaststelling van het van toepassing zijnde recht, dient in casu te worden afgegaan op de oorspronkelijke afkomst van deze personen, hetgeen impliceert dat Indonesië - uitzonderingen daargelaten - (nog) geen eenheid van recht kent. De onderverdeling in bevolkingsgroepen ex artikel 163 IS vormt de basis van de vaststelling van het voor de diverse bevolkingsgroepen geldende recht; het optreden van rechtsverscheidenheid is hiervan het gevolg. ${ }^{503}$ Voor hen, die niet onderworpen zijn aan het Europeanenrecht van het IBW, zijn regels van geschreven en vooral van ongeschreven (Adat-)recht van toepassing, die zowel personeel als territoriaal beperkt zijn in hun gelding. ${ }^{509}$ Herkomst, godsdienst en milieu kunnen van beslissende betekenis zijn voor de vraag, welk recht in een concreet geval van toepassing is. 510

508. Zie hiervoor artikel 131 I.S., aan de orde gekomen in $\$ 2.1$.

509. Zo geldt de Huwelijksordonnantie Christen-Indonesiêrs, Stb. 1933-74 jo. 1936-607, opgenomen in Engelbrecht-oude stijl, p.511 alleen voor (autochtone) Indonesiërs, die Christen zijn en uitsluitend voor Java, Madoera, de Minahassa en een gedeelte van de Molukken.

510. Prins brengt onder de aandacht, dat deze vraag er niet gemakkelijker op wordt, wanneer het gast om personen, die zich - blijkens hun vertrek naar Nederland - min of meer hebben losgemaakt van de groep, waartoe zij corspronkelijk behoren. Zo kan het moeilijk zijn te beslissen, indien een als hierbedoelde persoon in Nederland komt te overlijden, welk erfrecht van toepassing is. Zie Prins, Jurisprudentie, p.38. 


\section{$\S 1$ Inleiding}

Het is van belang om in eerste instantie na te gaan welke invloed de afkondiging van de Wet no. 62 van 1958 op het reeds vóór de inwerkingtreding daarvan verkregen Indonesisch staatsburgerschap heeft gehad.

In aansluiting daarop zal worden onderzocht, of met de afkondiging van deze Wet een einde is gekomen aan bestaande onzekerheden inzake het al dan niet bezitten van het Indonesisch staatsburgerschap zoals omschreven in $\$ 8$ van Hoofdstuk 3 .

\subsection{Verkregen rechten geëerbiedigd}

Dat met de inwerkingtreding van de Wet no. 62 van het jaar 1958 niet aan het reeds vóor de inwerkingtreding daarvan verkregen Indonesisch staatsburgerschap is getornd, blijkt in eerste instantie uit artikel 1 sub a. van deze Wet, dat bepaalt dat Indonesisch staatsburger zijn:

- personen, die op grond van wetten en/of overeenkomsten en/of regelingen, van kracht sedert de proclamatie van 17 augustus 1945, reeds staatsburger van de Republiek Indonesië waren.

Met de hierboven gegeven omschrijving zijn personen bedoeld, die krachtens de Wet no. 3 van 1946 zoals naderhand gewijzigd en aangevuld of de Toescheidingsovereenkomst - het onderwerp van $\S 5$ van Hoofdstuk 3 - Indonesisch staatsburger zijn geworden, hetzij van rechtswege, hetzij door optie of anderszins. In de Memorie van Toelichting van de Wet no. 62 van het jaar 1958 als opgenomen in het Aanvullend Staatsblad ${ }^{511}$ no. 1647 is, onder verwijzing naar artikel 144 van de Voorlopige Grondwet van 1950, uitdrukkelijk aangegeven, wie sedert de proclamatie reeds Indonesisch staatsburger waren, dit met het doel alle onzekerheid hieromtrent weg te nemen. ${ }^{512}$ Voor een beter begrip van de hierboven genoemde categorieën van personen die Indonesisch staatsburger zijn krachtens de Toescheidingsovereenkomst of de Wet no. 3 van 1946 meen ik er goed aan te doen om de desbetreffende bepalingen van genoem-

511. De Indonesische benaming van "Aanvullend Staatsblad" luidt "Tambahan Lembaran Negara". In bet Nederlands wordt de term "Bijblad" gebezigd.

512. In aansluiting op hetgeen reeds naar voren werd gebracht, zij vermeld, dat de Voorlopige Grondwet van 1950 werd afgelost door de Grondwet van 1945, krachtens het Presidentiële Decreet van 5 juli 1959 - op dezelfde datum van kracht geworden - waarbij deze Grondwet wederom van kracht werd verklaard. Dit Decreet is opgenomen in Engelbrecht p.48. Dit geschiedde onder meer om de effectuering van het principe der "geleide democratie" en een stabiele Regering beter te kunnen waarborgen. Van officiële Indonesische zijde is te kennen gegeven, dat de rechtsgrond van het Decreet was gelegen in staatsnoodrecht en ideologische gronden. Zie speciale editie no. 56 van het Ministerie van Voorliching, Republiek Indonesiè. 
de wettelijke regelingen telkens aan te halen. Krachtens deze regelingen zijn derhalve Indonesisch staatsburger:

1. personen die deel uitmaken van de autochtone bevolking en in Indonesië woonachtig zijn;

2. meerderjarige personen als bedoeld onder 1, buiten Indonesië geboren en in Nederland of buiten de gebieden van het Koninkrijk der Nederlanden en de Republiek Indonesiē woonachtig, die in de periode van twee jaar ná 27 december 1949 niet de Nederlandse nationaliteit hebben verkozen;

Ingevolge artikel 4 lid 1 van de Toescheidingsovereenkomst zijn de hierboven onder 1 en 2 genoemde personen Indonesisch staatsburger. Het desbetreffende artikellid luidt als volgt:"(1) Behoudens het tweede lid van dit artikel verkrijgen de onmiddellijk vóor de soevereiniteitsoverdracht tot de inheemse bevolking (orang2 jang asli) van Indonesië behorende meerderjarige Nederlandse onderdanen-niet-Nederlanders de Indonesische nationaliteit, doch zijn, indien zij buiten Indonesië geboren en in Nederland of buiten de gebieden der deelgenoten van de Unie woonachtig zijn, bevoegd binnen de gestelde termijn te verklaren, dat zij de Nederlandse nationaliteit verkiezen". In het hierboven onder 2 bepaalde, zijn de woorden "buiten de gebieden der deelgenoten van de Unie" vervangen door de woorden "buiten de gebieden van het Koninkrijk der Nederlanden en de Republiek Indonesië", dit conform de politieke ontwikkelingen, die zich op dit vlak hebben voorgedaan. ${ }^{513}$ De ter zake geldende criteria, zoals die voorkomen in het onder 2 gestelde, hebben betrekking op het "buiten Indonesië geboren zijn" en het "in Nederland of buiten de gebieden van het Koninkrijk der Nederlanden en de Republiek Indonesië woonachtig zijn".

3. meerderjarige personen als bedoeld onder 1, buiten het Koninkrijk der Nederlanden geboren en in Suriname of de Nederlandse Antillen woonachtig, die in de periode van twee jaar ná 27 december 1949 niet de Nederlandse nationaliteit hebben verkozen;

4. meerderjarige personen als bedoeld onder 1, in het Koninkrijk der Nederlanden geboren en in Suriname of de Nederlandse Antillen woonachlig, die in de periode van twee jaar ná 27 december 1949 hebben verklaard, de Indonesische nationaliteit te verkiezen;

De hierbedoelde personen zijn Indonesisch staatsburger krachtens het tweede lid van artikel 4 van de Toescheidingsovereenkomst, dat als volgt luidt:"(2) De in de aanhef van het vorige lid omschreven Nederlandse onderdanen die in Suriname of in de Nederlandse Antillen woonachtig zijn:

a. verkrijgen, indien zij buiten het Koninkrijk geboren zijn, de Indonesische nationaliteit, doch zijn bevoegd binnen de gestelde termijn te verklaren, dat zij de Nederlandse nationaliteit verkiezen;

513. Zie voor deze aangelegenheid, \$2.1 van Hoofdstuk 1. 
b. behouden, indien zij in het Koninkrijk geboren zijn, de Nederlandse nationaliteit, doch zijn bevoegd binnen de gestelde termijn te verklaren, dat zij de Indonesische nationaliteit verkiezen".

Zoals uit deze omschrijvingen blijkt, speelt het feit of de desbetreffende personen buiten of in het Koninkrijk geboren zijn ter zake een rol. In het onder b. bedoelde geval, wordt het Indonesisch staatsburgerschap verkregen middels optie.

5. meerderjarige afstammelingen van Nederlanders in Indonesië geboren of aldaar tenminste zes maanden vóor 27 december 1949 woonachtig, die in de periode van twee jaar ná 27 december 1949 hebben verklaard, de Indonesische nationaliteit te verkiezen;

Het betreft hier personen die voor het Indonesisch staatsburgerschap geopteerd hebben op grond van artikel 3 van de Toescheidingsovereenkomst, dat het volgende bepaalt: "Meerderjarige Nederlanders behouden de Nederlandse nationaliteit, doch zijn bevoegd, indien zij in Indonesië geboren of aldaar tenminste zes maanden woonachtig zijn, binnen de gestelde termijn te verklaren, dat zij de Indonesische nationaliteit verkiezen". ${ }^{514}$ Opvallend is, dat in de onder 5 gegeven omschrijving gesproken wordt van "afstammelingen van Nederlanders", anders dan in de Toescheidingsovereenkomst waar sprake is van "Nederlanders". Wordt hiermede beoogd de hierbedoelde categorie te beperken tot de zogenaamde "Indische Nederlanders", dan kan onder de aandacht worden gebracht, dat dit niet overeenkomt met de praktijk, aangezien de mogelijkheid om zich voor het Indonesisch staatsburgerschap uit te spreken voor Nederlanders in het algemeen gold. Een andere beperking is hierin gelegen, dat krachtens het onder 5 bepaalde, de termijn van zes maanden van het in Indonesië woonachtig zijn aan de datum van 27 december 1949 dient te zijn voorafgegaan, dit in afwijking van het in artikel 3 van de Toescheidingsovereenkomst bepaalde.

6. vreemdelingen, die geen Nederlands onderdaan waren, vóor 27 december 1949 reeds meerderjarig, die staatsburger van de Republiek Indonesiè op grond van de Wet no. 3 van het jaar 1946 zijn geworden;

Het betreft hier de door naturalisatie geworden Indonesische staatsburgers, als bedoeld in de Wet no. 3 van het jaar 1946. Zoals in $\S 5.2$ van Hoofdstuk 3 naar voren gebracht, betrof het hier geén Nederlandse onderdanen, maar personen met een buitenlandse nationaliteit - hoofdzakelijk Duitsers - die zich tot Indonesisch staatsburger hebben laten naturaliseren.

514. Volgens het Regeringsantwoord ten tijde van de Algemene Beschouwingen, Hoofdstuk I van 13-61958, Voorlopige Verhandeling, afgekort RS ("Risalah Sementara") p.14, inzake het ontwerp dat geleid heeft tot de Wet no. 62 van 1958, hebben 12.871 personen door optie het Indonesisch staatsburgerschap verkregen. 
7. vreemdelingen, Nederlandse onderdanen niet-Nederlanders, op 27 december 1949 reeds meerderjarig en in Indonesië geboren, die in de periode van twee jaar ná 27 december 1949, niet hebben verklaard de Indonesische nationaliteit te verwerpen;

De hierbedoelde personen werden van rechtswege Indonesisch staatsburger c.q. bleven in het bezit van dit staatsburgerschap voor zover zij geen gebruik maakten van de mogelijkheid bedoeld staatsburgerschap te verwerpen middels gebruikmaking van het recht van repudiatie. Bedoeld zijn hier personen als Chinezen en Arabieren krachtens artikel 163 IS met de term "Vreemde Oosterlingen" of ingevolge artikel 55 IS als "uitheemse Nederlandse onderdanen niet-Nederlanders" aangeduid. Ook Europeanen andere dan Nederlanders vielen onder deze categorie. Het desbetreffende artikel 5 van de Toescheidingsovereenkomst luidt als volgt:"De onmiddellijk vóór de soevereiniteitsoverdracht meerderjarige uitheemse Nederlandse onderdanen-niet-Nederlanders, die in Indonesië geboren of in de RVSI (Republiek der Verenigde Staten van Indonesië) woonachtig zijn, verkrijgen de Indonesische nationaliteit, doch zijn bevoegd deze binnen de gestelde termijn te verwerpen; bezaten zij in dit geval onmiddellijk voór de soevereiniteitsoverdracht geen andere dan de Nederlandse nationaliteit, dan zullen zij deze herkrijgen; bezaten zij op gemeld tijdstip mede een vreemde nationaliteit, dan zullen zij, bij verwerping van de Indonesische nationaliteit, de Nederlandse slechts dan herkrijgen, indien zij tegelijkertijd een daartoe strekkende verklaring afleggen". ${ }^{515}$ In de onder 7 opgenomen omschrijving zijn de woorden "of in de RVSI woonachtig zijn" niet opgenomen, die in het onderhavige artikel 5 van de Toescheidingsovereenkomst wél voorkomen. Dit zou een beperking kunnen inhouden van hetgeen ter zake is overeengekomen en in genoemde Overeenkomst is opgenomen.

8. personen als bedoeld onder 7 , die op 27 december 1949 reeds meerderjarig waren, buiten Indonesië geboren zijn en in het Koninkrijk der Nederlanden woonachtig, die in de periode van twee jaar ná 27 december 1949, de Nederlandse nationaliteit hebben verworpen en hebben verklaard de Indonesische nationaliteit te verkiezen;

De hierbedoelde personen zijn Indonesisch staatsburger geworden krachtens artikel 6 van de Toescheidingsovereenkomst, dat als volgt luidt: "De onmiddellijk vóór de soevereiniteitsoverdracht meerderjarige uitheemse Nederlandse onderdanen-niet-Nederlanders, die niet in Indonesië geboren zijn en in het Koninkrijk woonachtig, behouden de Nederlandse nationaliteit, doch zijn bevoegd binnen de gestelde termijn met verwerping van deze, de Indonesische nationaliteit te verkiezen; bezaten zij op gemeld tijdstip mede een vreemde nationaliteit, dan zijn zij bevoegd de Nederlandse zonder meer te verwerpen. Deze bevoegdheid tot verwerping van de Nederlandse nationaliteit al dan niet verbonden met die tot verkiezing van de Indonesische nationaliteit komt niet toe aan

515. De twee laatste alinea"s - voor het hier behandelde onderwerp van geen belang - die betrekking hebben op het geval, een als hierbedoelde persoon het Indonesisch staatsburgerschap verwerpt en de daaraan voortvloeiende consequenties met betrekking tot de mogelijkheid tot herkrijging van de Nederlandse nationaliteit zjjn reeds aan de orde gekomen in $\$ 5.3 .2$ van Hoofdstuk 3 . 
de uit India of Pakistan afkomstige bewoners van Suriname". ${ }^{516}$ Van de in het onderhavige artikel van de Toescheidingsovereenkomst opgenomen bepalingen als voorkomende in de eerste alinea, zijn de criteria "die niet in Indonesië geboren zijn" en "in het Koninkrijk woonachtig" ter zake relevant. Het betreft hier personen, die middels gebruikmaking van het recht van optie Indonesisch staatsburger zijn geworden.

9. personen als bedoeld onder 7 , die op 27 december 1949 reeds meerderjarig waren, woonachtig buiten de gebieden van het Koninkrijk der Nederlanden en de Republiek Indonesië en geboren in Nederland, Suriname of de Nederlandse Antillen, maar waarvan de ouders Nederlands onderdaan waren door geboorte in Indonesië en binnen de periode van twee jaar ná 27 december 1949, de Indonesische nationaliteit hebben verkozen met verwerping van de Nederlandse nationaliteit;

De hierbedoelde personen zijn Indonesisch staatsburger geworden krachtens het in artikel 7 van de Toescheidingsovereenkomst bepaalde, als volgt: "De onmiddellijk vóór de soevereiniteitsoverdracht meerderjarige uitheemse Nederlandse onderdanen-nietNederlanders, die buiten de gebieden der deelgenoten van de Unie woonachtig en in Nederland, Suriname of de Nederlandse Antillen geboren zijn, behouden de Nederlandse nationaliteit, doch zijn, indien zij geboren zijn uit ouders, die door geboorte in Indonesië Nederlands onderdaan waren, bevoegd binnen de gestelde termijn met verwerping van deze de Indonesische nationaliteit te verkiezen; bezaten zij op gemeld tijdstip mede een vreemde nationaliteit, dan zijn zij bevoegd de Nederlandse zonder meer te verwerpen". ${ }^{517}$ De ter zake geldende criteria waarop in het hierbedoelde geval dient te worden afgegaan, zijn het "buiten de gebieden der deelgenoten van de Unie - in de tekst van de Memorie van Toelichting op de Wet no. 62 van 1958 vervangen door de woorden "de gebieden van het Koninkrijk der Nederlanden en de Republiek Indonesië" - woonachtig zijn" en het "in Nederland, Suriname of de Nederlandse Antillen geboren zijn" alsmede "het uit ouders, die door geboorte in Indonesië Nederlands onderdaan waren geboren zijn". Was aan deze voorwaarden voldaan, dan was een als hierbedoelde persoon gerechtigd om voor het Indonesisch staatsburgerschap te opteren, met verwerping van de Nederlandse nationaliteit.

10. personen als bedoeld onder 7 , indien zij geboren zijn buiten de gebieden van het Koninkrijk der Nederlanden en de Republiek Indonesië en op 27 december 1949 reeds meerderjarig waren, waarvan de ouders in Indonesië geboren zijn, die binnen de periode van twee jaar ná 27 december 1949, de Indonesische nationaliteit hebben verkozen of niet hebben verklaard deze nationaliteit te verwerpen.

516. Zie voor de laatste twee bepalingen van het onderhavige artikel, eveneens hetgeen in \$ 5.3 .2 van Hoofdstuk 3 naar voren werd gebracht. Op de status van de uit India of Pakistan afkomstige bewoners van Suriname is niet nader ingegaan, als zjnde voor het hierbehandelde onderwerp niet relevant.

517. Zie voor de laatste zinsnede, hetgeen naar voren werd gebracht in \$ 5.3.2 van Hoofdstuk 3. 
De hierbedoelde personen hadden het Indonesisch staatsburgerschap verkregen krachtens artikel 7, laatste alinea van de Toescheidingsovereenkomst dat het volgende bepaalt: "Zijn zij buiten de gebieden der deelgenoten van de Unie geboren dan is naar gelang van de geboorteplaats van hun vader of van hun moeder, naar de in artikel I van de Wet van 1892 op het Nederlanderschap en het Ingezetenschap gemaakte onderscheidingen, dit artikel of artikel 5 toepasselijk; indien deze ouder ook buiten de gebieden der deelgenoten van de Unie geboren is, zal de geboorteplaats van diens vader of moeder beslissend zijn". Ook in deze bepaling, als opgenomen in het onder 10 gestelde, zijn de woorden "de gebieden der deelgenoten van de Unie" vervangen door de woorden "de gebieden van het Koninkrijk der Nederlanden en de Republiek Indonesië". ${ }^{518}$ Voorts is in bedoelde omschrijving de bepaling, dat indien ook deze ouders - respectievelijk de vader of moeder - buiten het Koninkrijk der Nederlanden en de Republiek Indonesië geboren waren, de geboorteplaats van diens vader of moeder beslissend is, niet opgenomen. Ook dit impliceert een beperking van hetgeen bij de Toescheidingsovereenkomst werd overeengekomen.

Bij de behandeling van het ontwerp, dat leidde tot de Wet no. 62 van 1958 op het Indonesisch staatsburgerschap, werd door enkele leden van de Volksvertegenwoordiging voorgesteld om een slotbepaling op te nemen, die inhoudt dat op het tijdstip van inwerkingtreding van de Wet, personen die Indonesisch staatsburger zijn op grond van de hierboven gestipuleerde bepalingen dit ook zijn in de zin van deze Wet tot zij het staatsburgerschap volgens bedoelde Wet verliezen. Van regeringswege werd het echter niet nodig geacht dit mel zowel woorden te benadrukken, aangezien dit reeds uit de Wet is af te leiden. ${ }^{519}$ Zo zijn krachtens artikel 1 sub a. van de Wet no. 62 van 1958 personen, die op grond van wetten en/of overeenkomsten en/of regelingen die golden sedert de proclamatie van 17 augustus 1945 reeds staatsburger van de Republiek Indonesië waren, door het opnemen van de desbetreffende bepaling in de Wet uitdrukkelijk onder de geldingssfeer van deze Wet gebracht. In de Memorie van Toelichting van de Wet is ter bevestiging hiervan, niet alleen naar artikel 144 van de Voorlopige Grondwet van 1950 verwezen - waarin benadrukt is, dat reeds Indonesisch staatsburger zijn, die personen die de Indonesische nationaliteit hebben verworven krachtens de Toescheidingsovereenkomst of de Wet no. 3 van 1946 - maar is voorts nog een verdere uitsplitsing gegeven van de hierbedoelde personen, zoals in het voorgaande behandeld.

1.2. Bepalingen ter opheffing van onzekerheid met betrekking tot het bezitten van het Indonesisch staatsburgerschap

Teneinde de onzekerheid met betrekking tot de status van ná de soevereiniteitsoverdracht, derhalve ná 27 december 1949 geboren kinderen weg te nemen, zijn de bepalin-

518. Zie voor deze aangelegenheid $\$ 2.1$ van Hoofdstuk 1 .

519. Zie de Algemene Beschouwingen. Hoofdstuk I, vervolgens opnieuw aan de orde gekomen in de Algemene Beschouwingen Hoofdstuk II van 16-6-1958, RS p.19, p.24, p.26 en p.36 inzake de behandeling van het ontwerp op het Staatsburgerschap van Indonesië en het Regeringsantwoord op voorstellen van verschillende leden van de Volksvertegenwoordiging, waaronder R. Abulhajat, J.R. Koot, R.P.R. Situmeang en Mw. Umi Sardjono. 
gen die deze materie regelen, krachtens artikel VIII van de Slotbepalingen van de Wet. no. 62 van 1958 met terugwerkende kracht tot 27 december 1949 in werking getreden. Dit had tot doel om het optreden van een vacuüm in de bepalingen inzake het Indonesisch staatsburgerschap met betrekking tot de status van bedoelde kinderen, te voorkomen. In herinnering zij gebracht, dat van officiële Indonesische zijde het standpunt werd ingenomen, dat ná 27 december 1949 niet langer van "Nederlands onderdanen" kon worden gesproken. Aangezien de Toescheidingsovereenkomst enkel voor Nederlandse onderdanen bedoeld was, werden niet-Nederlandse onderdanen niet door de bepalingen daarvan getroffen. Dit heeft mede tot gevolg gehad, dat de status van bedoelde kinderen ongeregeld is gebleven. De bepalingen die met terugwerkende kracht tot 27 december 1949 in werking zijn getreden, zijn de in artikel 1 sub b. tot en met sub i. van de Wet opgenomen bepalingen, op grond waarvan Indonesisch staatsburger is:

a. de persoon, die op het moment van geboorte een familierechtelijke betrekking heeft met zijn vader, een Indonesisch staatsburger; dit Indonesisch staatsburgerschap neemt een aanvang bij het ontstaan van bedoelde familierechtelijke betrekking, die dient te zijn ontstaan voordat die persoon de leeftijd van achttien jaar heeft bereikt dan wel op een eerder tijdstip in het huwelijk is getreden;

b. het kind, dat geboren wordt binnen 300 dagen nadat zijn vader overleed, indien die vader op het moment van overlijden Indonesisch staatsburger was;

c. de persoon, waarvan de moeder op het moment van zijn geboorte Indonesisch staatsburger is, indien hij op dat moment geen familierechtelijke betrekking met zijn vader heeft;

d. de persoon, waarvan de moeder op het moment van zijn geboorte Indonesisch staatsburger is, indien zijn vader geen staatsburgerschap bezit of zolang het staatsburgerschap van zijn vader onbekend is;

e. de persoon, geboren in het gebied van de Republiek Indonesië, zolang beide ouders onbekend zijn;

f. het kind, ten vondeling gelegd in het gebied van de Republiek Indonesië, zolang beide ouders onbekend zijn;

g. de persoon, geboren in het gebied van de Republiek Indonesië, indien beide ouders geen staatsburgerschap bezitten of zolang het staatsburgerschap van beide ouders onbekend is;

h. de persoon, geboren in het gebied van de Republiek Indonesië. die op het moment van zijn geboorte het staatsburgerschap van zijn vader of moeder niet verkrijgt en zolang hij dat staatsburgerschap niet verkrijgt.

Ook in het bijzonder ten aanzien van personen, in de jaren 1932/33 geboren, die mogelijkerwijze de meerderjarige leeftijd hadden bereikt op het tijdstip dat de vader respectievelijk de moeder voor het Indonesisch staatsburgerschap opteerde, heeft de onderhavige Wet voorzien. In artikel IV van de Overgangsbepalingen is in casu bepaald, dat een persoon die niet met zijn vader of moeder het Indonesisch staatsburgerschap, middels het afleggen door deze van een daartoe strekkende verklaring volgens de wetten die golden vóor de inwerkingtreding van deze Wet heeft verkregen, ook Indonesisch staatsburger is. Hieraan lag de overweging ten grondslag, dat een dergelijke bepaling noodzakelijk was, omdat die persoon op het tijdstip van aflegging van bedoelde 
verklaring door de ouder - vader of moeder - reeds meerderjarig was, terwij] het hemzelf naar de Indonesische opvatting niet was toegestaan om de verklaring tot verkiezing van het Indonesisch staatsburgerschap af te leggen, aangezien hij op het tijdstip van de soevereiniteitsoverdracht nog minderjarig was. ${ }^{520}$ In herinnering zij gebracht, dat krachtens de Toescheidingsovereenkomst de meerderjarige leeftijd op 18 jaar was gesteld en het zijn van meerderjarig voorwaarde was om voor het Indonesisch staatsburgerschap in de gestelde periode van twee jaar gerekend vanaf 27 december 1949 te kunnen opteren. Het onderhavige artikel IV houdt echter het voorbehoud in, dat betrokkene bij de toepassing van deze bepaling of op een eerder tijdstip niet reeds in het bezit van een andere nationaliteit mag zijn, dit om het optreden van bipatridie te voorkomen. De mogelijkheid was namelijk niet uitgesloten, dat de hierbedoelde persoon reeds de Nederlandse nationaliteit bezat. Het door deze persoon verkregen Indonesisch staatsburgerschap werkt terug tot het tijdstip, dat de vader of moeder dit staatsburgerschap verkreeg. De behoefte aan een dergelijke bepaling was gebleken, omdat deze aangelegenheid een geschilpunt opleverde tussen de Indonesische en Nederlandse autoriteiten. Laatstgenoemden stelden zich met name op het standpunt, dat een als hierbedoelde persoon de nationaliteit van de vader c.q. moeder volgt, hetgeen aanvankelijk van Indonesische zijde werd ontkend, met de consequentie dat een als hierbedoelde persoon het gevaar liep als staatloos te worden aangemerkt. In herinnering zij gebracht, dat verschil van mening bestond tussen de Indonesische en Nederlandse autoriteiten inzake het al dan niet terugwerken van optieverklaringen tot 27 december 1949; zo werd van Nederlandse zijde het standpunt ingenomen dat optieverklaringen terugwerken tot genoemde datum, hetgeen van Indonesische zijde werd ontkend. In deze aangelegenheid heeft mede een rol gespeeld, dat krachtens de letter van de Toescheidingsovereenkomst het bereiken van de meerderjarige leeftijd voor personen, die vallen onder de categorie der Nederlanders niet aan een tijdsbepaling was gebonden. In het desbetreffende artikel 3 van de onderhavige Overeenkomst werd in casu niet gesproken van de "onmiddellijk vóór de soevereiniteitsoverdracht meerderjarige Nederlanders". Voor de vaststelling van de nationaliteit van bedoelde personen in de jaren 1932/1933 geboren, die ná de soevereiniteitsoverdracht de meerderjarige leeftijd van 18 jaar hadden bereikt leverde de hierboven geschetste aangelegenheid interpretatieproblemen op. De bepaling dat minderjarigen de staat van de vader of moeder volgen, kon op hen niet van toepassing worden verklaard, aangezien zij op het tijdstip waarop de ouder - vader of moeder - opteerden, mogelijkerwijze reeds de meerderjarige leeftijd bereikt hadden. Hun werd van Indonesische zijde ook niet toegestaan, om zélf te opteren voor het Indonesisch staatsburgerschap, omdat zij op het tijdstip van de soevereiniteitsoverdracht nog minderjarig waren. Bovendien konden de in de Toescheidingsovereenkomst opgenomen bepalingen ook niet rechtstreeks op hen toegepast worden, aangezien de daarvoor in de Overeenkomst gestelde voorwaarden dienden te zijn vervuld. ${ }^{521}$

Ook ten aanzien van de status van een buitenlandse vrouw, ná 27 december 1949 met een Indonesisch staatsburger gehuwd, die op basis van de voorheen geldende bepalingen

520. Gautama, Tafsiran, p.224-225.

521. Zie hetgeen omtrent deze aangelegenheid in $\S 8$ van Hoofdstuk 3 werd opgemerkt. 
van het Centraal Oorlogsgezag werd "behandeld" als Indonesisch staatsburger, zijn in de Wet no. 62 van het jaar 1958 voorzieningen getroffen. ${ }^{522}$ In artikel I van de Overgangsbepalingen is gesteld, dat een als hierbedoelde vrouw met ingang van 1 augustus 1958 - de datum van inwerkingtreding der Wet - automatisch Indonesisch staatsburger wordt, indien zij geen andere nationaliteit bezit; door deze bepaling werd de in het verleden geldende "scheve positie" van de vrouw in kwestie rechtgetrokken. Hierbij is echter het voorbehoud gemaakt, dat het de echtgenoot van deze vrouw niet is toegestaan, zijn staatsburgerschap alsnog prijs te geven. Het betreft hier een - algemeen - in de Wet opgenomen voorziening voor Indonesische staatsburgers met buitenlandse vrouwen gehuwd, in casu op grond van artikel 7 lid 2 van de Wet, waarop bij de behandeling van de verkrijging van het Indonesisch staatsburgerschap door of als gevolg van huwelijk in § 7.1.1 van Hoofdstuk $5 \mathrm{zal}$ worden teruggekomen.

\section{$\S 2$ Algemene aspecten van de Wet no. 62 van het jaar 1958}

Wordt thans nagegaan, welke beginselen aan de Wet no. 62 van het jaar 1958 ten grondslag liggen, dan valt uit de daarin opgenomen bepalingen op te maken, dat niet langer - zoals in de Wet no. 3 van 1946 van de Yogya-regering - wordt uitgegaan van het "ius soli", doch in eerste instantie van het "ius sanguinis", teneinde vast te stellen, wie Indonesisch staatsburger is. Ook in de Wet van 1910 werd ter regeling van het Nederlands onderdaanschap van niet-Nederlanders uitgegaan van het "ius soli". ${ }^{523}$ Zoals met betrekking tot de onderhavige Wet van 1910 reeds opgemerkt, ging de koloniale Overheid uit van het "ius soli" om de door diversiteit gekenmerkte bevolking van Indonesië mede als gevolg van het grote aantal immigranten onder haar gezagssfeer te brengen. Hierbij werd bovendien rekening gehouden met het niet voorhanden zijn van een Burgerlijke Stand voor een groot gedeelte van de bevolking. Dat in de Wet van 1946 ook de Republikeinse overheid van het "ius soli" uitging, is mijns inziens deels een gevolg van het grotendeels door Nederlanders in de toen geldende gedachtensfeer opgeleid zijn van Indonesische juristen, doch ook een gevolg van het streven, om zoveel mogelijk personen die van de bevolking van Indonesië deel uitmaken, in haar nationale aspiraties te betrekken. De huidige Indonesische overheid geeft evenwel de voorkeur aan het in eerste instantie hanteren van het "ius sanguinis", een beginsel door de meeste jonge naties gehanteerd.

Zoals uitdrukkelijk in de Toelichting op de onderhavige Wet staat omschreven, wordt het "ius soli" eerst toegepast om apatridie te voorkomen, en wel zolang dit nodig is ter vermijding van deze ongewenste situatie.

Een ander belangrijk beginsel, dat aan de Wet no. 62 van het jaar 1958 ten grondslag ligt, is het zoveel mogelijk vermijden van het optreden van apatridie en multipatridie c.q. bipatridie. ${ }^{524}$

522. Zie voor deze aangelegenheid, $\$ 6.2$ van Hoofdstuk 3 .

523. Zie hiervoor $\$ 3$ van Hoofdstuk 3.

524. Jessurun d'Oliveira spreekt niet van "multipatridie", doch van "polypatridie". Ik geef echter de voorkeur aan eerstgenoemde term. 
Wat betreft apatridie, blijkt dit uit diverse in de Wet opgenomen bepalingen als het toepassen van het "ius soli" ter voorkoming van staatloosheid, zoals omschreven in artikel 1 sub $\mathrm{f}, \mathrm{g}$, h, en i. der Wet. ${ }^{525}$ Staatloosheid vormt voorts ook éćn van de voorwaarden om voor naturalisatie in aanmerking te komen en wel krachtens artikel 5 lid 2 sub $h$. van de onderhavige Wet, zonder dat daarbij aan staatlozen bepaalde faciliteiten worden verstrekt in de vorm van een verlichte of snellere naturalisatie. Het Indonesisch staatsburgerschap kan bovendien niet verloren gaan, indien dit staatloosheid ten gevolge heeft, zoals omschreven in de artikelen 7 lid 2, 8 lid 1, 9 lid 2, 10 lid 2, 12 lid 2, 13 lid 1 en 2, 14 lid 2, 15 lid 1 en 2, 17 sub c, d, en e. der Wet. Alhoewel Indonesië in zijn nationaliteitswetgeving, het beginsel van vermijding van het optreden van apatridie hanteert, is dit land niettemin geen partij geworden van multilaterale verdragen, die hoofdzakelijk of gedeeltelijk zijn gericht op het verminderen van het optreden van staatloosheid. Ook Ko Swan Sik en Teuku Moh. Rhadie spreken hun verwondering uit over het feit, dat Indonesië niet is toegetreden tot het Verdrag tot beperking van staatloosheid van 1961, hetgeen ook geldt voor het Verdrag betreffende de status van vluchtelingen van 1951 en het Verdrag betreffende de status van staatlozen van 1954. ${ }^{526}$ Deze auteurs zeggen hierover dat Indonesië "has, therefore, not committed itself to providing facilitated naturalization to refugees and stateless persons". ${ }^{527}$ Dit neemt evenwel niet weg dat Indonesië in het beleid om het optreden van apatridie te voorkomen, vrijwel even ver gaat als in haar streven bipatridie te vermijden.

Dat ook het optreden van bipatridie door de Indonesische overheid als een ongewenste situatie wordt beschouwd, blijkt uit de in de onderhavige Wet opgenomen artikelen om dit te voorkomen. Zo is het ontstaan van bipatridie een beletsel voor de verkrijging van het Indonesisch staatsburgerschap, zoals blijkt uit de artikelen 3 lid 1, 4 lid 1, 7 lid 1, 9 lid 1,11 lid 2, 16 lid 2, 18 lid 5 en 6 en de artikelen I en IV van de Overgangsbepalingen der Wet. Voorts is als één der voorwaarden om voor naturalisatie tot Indonesisch staatsburger in aanmerking te komen bepaald - met name in artikel 5 lid 2 sub h. der Wet - dat de desbetreffende personen met het verkrijgen van het Indonesisch staatsburgerschap, de eigen nationaliteit dienen te verliezen of zij het verzoek tot naturalisatie vergezeld dienen te laten gaan door de verklaring van de eigen nationaliteit afstand te doen. De hierbedoelde verklaring van de eigen nationaliteit afstand te doen, dient te worden gericht aan de bevoegde autoriteit van het land van oorsprong. Hierbij dienen de bepalingen van het recht van dit land - of de bepalingen van de overeenkomst ter afwikkeling van het dubbel staatsburgerschap tussen de Republiek Indonesië en het desbetreffende land gesloten - in acht te worden genomen. Maken de bepalingen van het recht van het land van oorsprong het niet mogelijk van de eigen nationaliteit afstand te doen, dan kan de betrokken persoon geen verzoek tot naturalisatie tot Indonesisch staatsburger indienen.

525. Het betreft hier een nadere uitsplitsing van de in $\$ 1.2$ gegeven specificatie van personen, die Indonesisch staatsburger zijn.

526. Genoemde verdragen zijn respectievelijk opgenomen in Trb. 1967, 124, Trb. 1951, 131 en Trb. $1967,22$.

527. Zie Ko Swan Sik en Teuku Moh. Rhadie, Nationality, p. 138-139. 
Voor de goede orde zij erop gewezen, dat het aanwezig zijn c.q. ontstaan van bipatridie, uiteraard niet eenzijdig, in dit geval van Indonesische zijde kan worden voorkomen. Hiervoor is de medewerking van het andere, daarbij betrokken land noodzakelijk. Het gaat erom, wat de wettelijke bepalingen van het land in kwestie hieromtrent bepalen, waarbij vaak demografische en politieke overwegingen een rol spelen.

Bipatridie kan ook ontstaan indien het nationaliteitsrecht van het ene land is gebaseerd op het "ius sanguinis" terwijl dat van het andere land op het "ius soli". Dit was bijvoorbeeld het geval met de in Indonesië geboren afstammelingen van Chinezen, aangezien volgens het nationaliteitsrecht van hun land - op het "ius sanguinis" gebaseerd - uit Chinese staatsburgers geboren personen, hun Chinese nationaliteit behouden, ongeacht waar zij zich bevinden c.q. reeds lange tijd hun land van oorsprong verlaten hebben. Aangezien deze personen, krachtens de Wet van 1910 - gebaseerd op het "ius soli" - het Nederlands onderdaanschap automatisch verwierven en ingevolge de Toescheidingsovereenkomst, eveneens automatisch Indonesisch staatsburger werden - voor zover niet van het recht van repudiatie gebruik werd gemaakt - hadden zij een dubbele nationaliteit.

Deze situatie heeft aanleiding gegeven tot het sluiten van een overeenkomst tussen de Indonesische overheid en die der Chinese Volksrepubliek ter afwikkeling van het probleem van de bipatridie, in $\S 3$ te behandelen. In dit verband kan nog op het in artikel I van de Slotbepalingen der Wet no. 62 van het jaar 1958 bepaalde worden gewezen, krachtens welk artikel een Indonesisch staatsburger, die zich in het gebied van de Republiek Indonesië bevindt wordt geacht geen ander staatsburgerschap te bezitten. ${ }^{528}$ Deze bepaling is onder meer in de Wet opgenomen teneinde bemoeienis met Indonesische aangelegenheden door andere landen, wier staatsburgerschap de desbetreffende personen mede bezitten, bijvoorbeeld met betrekking tot dienstplicht en het betalen van belasting te voorkomen. ${ }^{529}$

\section{$\S 3$ Het dubbel staatsburgerschap der Chinezen}

Met het oogmerk tot een oplossing te komen ten aanzien van het probleem van de bipatridie, werd op 22 april 1955 tussen de Indonesische regering en die der Chinese Volksrepubliek een Overeenkomst gesloten inzake het Probleem van de Bipatridie. Deze Overeenkomst is met de op 27 januari 1958 afgekondigde Wet no. 2 van het jaar 1958,

528. Uit deze bepaling blijkt niet of het hier al dan niet een onweerlegbaar vermoeden betreft. Dat aan deze bepaling niet strikt de hand is gehouden, blijkt echter uit de in de Agrarische Basiswet no. 5 van het jaar 1960, Stb. 1960-104 opgenomen bepaling, op grond waarvan Indonesische staatsburgers van Chinese origine met de status van bipatride van het bezit van het "hak milik" - een eigensoortig Indonesisch eigendomsrecht op de grond - zijn uitgesloten.

529. Ook in het Haagse Verdrag nopens zekere vragen betreffende wetsconflicten inzake nationaliteit van 1930, Trb. 1967, 73 is de bepaling opgenomen, dat onder voorhehoud van de bepalingen van dit Verdrag een persoon, die twee of meer nationaliteiten bezit, door ieder van de Staten, waarvan hij de nationaliteit heeft, als zijn onderdaan kan worden beschouwd (artikel 3 ). 
Stb. 1958-5 inclusief de uitgewisselde nota's goedgekeurd. ${ }^{530}$ De onderhavige Overeenkomst is op de datum van uitwisseling van de ratificatiedocumenten in werking getreden. ${ }^{531}$

Gezien het belang van deze Overeenkomst zal nader daarop worden ingegaan. Afgezien van de Overeenkomst betreffende de Toescheiding van Staatsburgers, tussen Indonesië en Nederland naar aanleiding van de soevereiniteitsoverdracht aan Indonesië gesloten, is deze overeenkomst de enige overeenkomst van deze soort door de Indonesische Regering met een ander land aangegaan. De noodzaak om tot het sluiten van de onderhavige Overeenkomst te komen, was hierin gelegen, dat van de minderheden in Indonesië de Chinezen verreweg de grootste groep vormen. Bovendien vormde het aangaan van een overeenkomst ter afwikkeling van het probleem van de bipatridie gezien het voorheen door de Chinese Volksrepubliek gevoerde nationaliteitsbeleid - een noodzaak, die zich niet voordeed met betrekking tot andere bevolkingsgroepen van vreemde origine, die deel uitmaken van de Indonesische samenleving. Laatstbedoelde groeperingen zoals onder meer Arabieren, Indiërs vormen slechts kleine minderheden. Bovendien is de afwikkeling van de onderhavige aangelegenheid in de praktijk op de nodige moeilijkheden gestoten.

\subsection{Het verplicht stellen van het maken van een keuze}

De onderhavige Wet no. 2 van het jaar 1958 en de ter uitvoering daarvan vastgestelde Regeringsverordening no. 20 van het jaar 1959 - krachtens de Regeringsverordening no. 11 van het jaar 1960 in werking getreden op 20 januari 1960 - legde krachtens artikel

530. In dit verband moge de aandacht worden gevestigd op artikel 120 lid 1 van de Voorlopige Grondwet van 1950 - in die tijd nog van kracht - dat bepaalde dat de President alle verdragen en andere overeenkomsten met andere mogendheden sluit en bekrachtigt. Tenzij bij de wet anders is bepaald, wordt een verdrag of andere overeenkomst niet bekrachtigd dan na goedkeuring bij de wet. Krachtens het in lid 2 van dit artikel bepaalde, geschiedt toetreding tot en opzegging van verdragen en andere overeenkomsten door de President alleen krachtens de wet.

531. Bij de Wet no, 2 van het jaar 1958 waarbij de Overeenkomst tussen de Republiek Indonesië en de Chinese Volksrepubliek inzake de afwikkeling van het Probleem van het Dubbel Staatsburgerschap is goedgekeurd, zijn de tekst van de onderhavige Overeenkomst en de uitgewisselde nota's van 3 juni 1955 aangehecht. Aangezien van genoemde documenten slechts een lndonesische en Chinese tekst voorhanden is, is hiervan in dit boek een Engelse vertaling opgenomen. Ter uitvoering van deze Overeenkomst werd de Regeringsverordening no. 20 van het jaar 1959, Stb. 32 van 1959 afgekondigd, die werd gewijzigd en aangevuld met de Regeringsverordening no. 5 van het jaar 1961, Stb. 23 van 1961. Met de Regeringsverordening no. 11 van het jaar 1960, Stb. 26 van 1960 werd in verband met de inwerkingtreding van de onderhavige Overeenkomst tussen Indonesië en de Chinese Volksrepubliek op 20 januari 1960 - de datum van uitwisseling van de ratificatiedocumenten te Peking - bevestigd dat ook de Regeringsverordening no. 20 van het jaar 1959 op genoemde datum van kracht is geworden. Op 15 december 1960 werd de wijze van uitvoering van de onderhavige Overeenkomst tussen beide regeringen overeengekomen. Met de Wet no. 4 van het jaar 1969, Stb. 17 van 1969 werd de hierboven genoemde Wet no. 2 van het jasr 1958 niet meer van kracht verklaard. Zie ook de door de Yayasan Lima uitgegeven Himpunan undang-undang \& peraturan mengenai masalah Cina di Indonesia, Jakarta, 1976 en Sasmojo, Menjelesaikan masalah dwikewarganegaraan R.I.-R.R.T., Jakarta, 1959. 
I der Overeenkomst aan personen die een als hierbedoeld dubbel staatsburgerschap bezaten, de verplichting op om naar eigen inzicht een keuze tussen de desbetreffende nationaliteiten te maken. ${ }^{532}$ Ook voor gehuwde vrouwen gold onafhankelijk van hun man bedoelde optieplicht (artikel I lid 2).

Bedoelde keuze diende te worden gemaakt in de daartoe vastgestelde termijnen, als volgt:

a. voor meerderjarige personen - naar het criterium van de leeftijd van 18 jaar te hebben bereikt of op een eerder tijdstip gehuwd - binnen twee jaar vanaf de inwerkingtreding der Overeenkomst (artikel In);

b. voor minderjarigen - daaronder begrepen geadopteerde kinderen, mits op wettige wijze vór het vijfde levensjaar geadopteerd - gold een gelijksoortige verplichting, in welk geval de keuze diende te worden gemaakt binnen een jaar ná het bereikt hebben van de meerderjarige leeftijd. Zolang deze personen nog minderjarig waren, volgden zij de staat van respectievelijk de ouders of van de vader (artikel VI lid 1);

Gezien het hierboven uiteengezette, had het maken van een keuze - naar de eigen wil van betrokkene - middels aflegging van een daartoe strekkende verklaring (optie in ruime $z$ zin $^{533}$ ) tot consequentie, dal de andere nationaliteit verloren ging. In dit verband kan worden gewezen op artikel IV van de Overeenkomst, waarin uitdrukkelijk was gesteld dat het zich uitspreken voor de nationaliteit van de ene Staat volgens de bepalingen van de onderhavige Overeenkomst door een als hierbedoelde bipatride, het automatisch verloren gaan van de nationaliteit van de andere Staat ten gevolge heeft. Wat minderjarige kinderen betreft zij erop gewezen, dat hun optieplicht verschilde van die voor meerderjarigen. Niet alleen was de voor hen geldende termijn korter, van groot belang is dat zij tijdens hun minderjarigheid de staat van de ouders of van de vader indien de ouders een verschillende keuze hadden gedaan - volgden c.q. de door deze gekozen nationaliteit; zij waren hierdoor derhalve geen bipatride meer. Had het kind geen familierechtelijke betrekking met zijn vader of was de vader overleden alvorens de keuze te hebben gedaan in de daartoe vastgestelde termijn of was het staatsburgerschap van de vader niet bekend, dan werd het geacht slechts het door de moeder gekozen staatsburgerschap te bezitten (artikel VI lid 2 en 3). Dit nam echter niet weg, dat zij bij het bereiken van de meerderjarige leeftijd ook tot het maken van de keuze verplicht waren, hetgeen in feite neerkwam op de mogelijkheid hun nationaliteit -

532. De onderhavige Regeringsverordening no. 20 van het jaar 1959 is vastgesteld op 26 mei 1959 - niet op 13 maart 1959 zoals Hecker stelt - en op 1 juni 1959 afgekondigd; van belang is, zoals reeds opgemerkt, de inwerkingtreding daarvan op 20 januari 1960 . Hecker geeft de gegevens niet altijd correct weer; zo is de Uitvoeringsovereenkomst tussen de deshetreffende landen gesloten van 15 december 1960 en niet van 16 december 1960 . Vgl. Hecker, H., Die Staatsangehörigkeitsregelungen, p.49 en 53.

533. Ik spreek hier van optie in ruime zin, omdat hier sprake is van een verplicht gestelde keuze tussen de twee nationaliteiten die de betrokken persoon bezit, naar zijn/haar eigen wil door het afleggen van een verklaring te maken. 
verkregen door het volgen van de staat van de ouders c.q. vader - indien gewenst, door de andere te vervangen. ${ }^{534}$ Sanger wijst erop, dat in de desbetreffende Overeenkomst geen voorzieningen waren getroffen voor het geval dat slechts minderjarigen de status van een als hierbedoelde bipatride hadden, doch dit niet het geval was met de vader c.q. moeder. ${ }^{535}$ Aan te nemen is, dat in dit geval de minderjarige aan zijn status van bipatride een einde kon maken door binnen het tijdsbestek van 1 jaar na het bereiken van de meerderjarige leeftijd een keuze te maken tussen de nationaliteiten die hij bezat. In de Overeenkomst is echter geen op dit geval betrekking hebbende bepaling opgenomen.

Dat in deze Overeenkomst tevens werd uitgegaan van het "ius sanguinis", blijkt uit de bepaling dat in het gebied van de Chinese Volksrepubliek geboren kinderen sedert het tijdstip van hun geboorte het Indonesisch staatsburgerschap bezitten, indien de ouders of de vader dit staatsburgerschap bezitten. Voor in Indonesië geboren kinderen, waarvan de ouders of de vader de Chinese nationaliteit bezitten, gold een overeenkomstige bepaling (artikel VIII). De Overeenkomst bevatte echter géén bepaling voor het geval de kinderen in een derde land geboren waren, waarvan de vader de Indonesische respectievelijk Chinese nationaliteit heeft en de moeder de Chinese respectievelijk de Indonesische nationaliteit bezit. ${ }^{536}$ Voornoemde bepaling dient tevens te worden gezien in het licht om het ontstaan van bipatridie in de toekomst te voorkomen. In hetzelfde licht dient het in artikel IX van de Overeenkomst bepaalde te worden gezien, op grond waarvan door Indonesische staatsburgers geadopteerde kinderen van beneden de vijf jaar met het staatsburgerschap van de Chinese Volksrepubliek door de onderhavige adoptie het Indonesische staatsburgerschap verwierven en dat van laatstgenoemd land verloren ging. Evenzo verkregen door Chinese staatsburgers geadopteerde Indonesische kinderen - waarbij dezelfde leeftijdsgrens gold - door bedoelde rechtshandeling het staatsburgerschap van de Chinese Volksrepubliek en ging dat van de Republiek Indonesië verloren. ${ }^{537}$

In het geval van een huwelijk tussen een Indonesisch staatsburger en een staatsburger van de Chinese Volksrepubliek, bleven partijen het staatsburgerschap van vór het huwelijk behouden - het huwelijk was derhalve niet van invloed op de nationaliteit tenzij een verzoek werd gedaan ter verkrijging van het staatsburgerschap van de andere partij. Werd in dit geval het staatsburgerschap van de andere partij verkregen, dan ging het oorspronkelijk staatsburgerschap verloren (artikel X). Mijns inziens impliceert dit dat elke nationaliteitsverkrijging en elk nationaliteitsverlies voor de vrouw, met het huwelijk verband houdende, slechts plaats kon vinden krachtens de wil van de vrouw. Ook deze bepaling strekte ten doel het ontstaan van bipatridie in de toekomst te vermijden.

534. Ko Swan Sik, De Meervoudige, p.303.

535. Sanger, Die indonesische, p.78, aantekening onder noot 2.

536. Hierop is ook door Ko Swan Sik gewezen, De Meervoudige; p. 305.

537. De leeftijdsgrens van vijf jaar bij adoptie van kinderen gehanteerd, komt ook in de Wet no.62 van 1958 voor. 
Hoe dient de voorgeschreven keuze tussen het staatsburgerschap van de Republiek Indonesiê en dat van de Chinese Volksrepubliek te worden opgevat? In de onderhavige Overeenkomst is niet volstaan met een bepaling, die stipuleerde dat bepaalde categorieën van personen de ene nationaliteit behouden, tenzij zij de andere kiezen. De verplichting tot het maken van een keuze voor de ene of de andere nationaliteit was integendeel uitdrukkelijk gesteld. Volgens Ko Swan Sik - wiens mening ik deel - heeft men met deze constructie het navolgende willen bereiken; ik citeer:

1. "de gelijkheid der verdragspartners wordt er nadrukkelijk door bevestigd;

2. de verdragspartijen hebben een grote zekerheid slechts die personen als staatsburger te krijgen, die daadwerkelijk op dit staatsburgerschap prijs stellen;

3. de vergemakkelijking van het bewijs der nationaliteit, omdat bij een uitdrukkelijke optie een bewijsstuk hiervan zal worden afgegeven." 538

Wat het derde punt betreft, is dit door de praktijk gestaafd, zoals uit het hieronder volgende zal blijken. Krachtens het in artikel IV van de Overeenkomst bepaalde, ging door de keuze de andere nationaliteit daadwerkelijk verloren. Hieruit kan worden geconcludeerd, dat geen sprake was van een overeenkomst, die enkel de voorrang van cén der nationaliteiten regelde.

De op de keuze voor het Indonesisch staatsburgerschap betrekking hebbende verklaring, geldt als rechtstreeks bewijs voor betrokkene en de eventuele minderjarige kinderen ${ }^{539}$, hetgeen echter nog niet wil zeggen dat aan de geldigheid daarvan niet kon worden getornd. Bleek achteraf bijvoorbeeld, dat een persoon als "niet gerechtigd" diende te worden aangemerkt, bijvoorbeeld doordat betrokkene geen Indonesisch staatsburger was c.q. hij niet de staat van bipatride bezat dan werd de onderhavige verklaring verworpen c.q. ongeldig verklaard. De betrokken persoon werd in dit geval wél in de gelegenheid gesteld, om gedurende een termijn van vier maanden alsnog zijn recht te bewijzen en kon op basis van de later afgekondigde Regeringsverordening no. 5 van het jaar 1961 - met terugwerkende kracht in werking getreden op 24 december 1960, waarbij voornoemde Regeringsverordening no. 20 van het jaar 1959 werd aangevuld en gewijzigd - een verzoek indienen bij de daartoe aangewezen Commissie. Deze Commissie legde, indien de bezwaren gemotiveerd werden geacht, het verzoek aan de Minister van Justitie voor, met het voorstel de onderhavige aangelegenheid opnieuw in overweging te nemen. Werd hierop gunstig beschikt, dan werd de verklaring alsnog geldig verklaard, ingaande de datum waarop deze eerder was afgelegd.

Van belang is voorts de bepaling in artikel VII van de Overeenkomst opgenomen, die inhoudt dat een persoon die zich voor het Indonesisch staatsburgerschap had uitgesproken, dit staatsburgerschap van rechtswege kwijt zou raken, indien hij na verlating van het grondgebied van Indonesië, zich blijvend buitenlands vestigde en vrijwillig het

538. Ko Swan Sik, De Meervoudige, p.302.

539. Voor dit doel waren bepaalde formulieren vastgesteld; de gehanteerde vorm daarvan was afgestemd op de gezinssamenstelling van betrokkenen. 
staatsburgerschap van de Volksrepubliek terugkreeg. Omgekeerd gold, dat een persoon die het staatsburgerschap van de Chinese Volksrepubliek had verkozen, dit staatsburgerschap van rechtswege zou verliezen, indien hij zich blijvend buiten het grondgebied der Volksrepubliek vestigde en vrijwillig het Indonesisch staatsburgerschap terugkreeg. Gezien de redactie van deze bepaling, ging de nationaliteit van de Volksrepubliek in genoemd geval, zoals gezegd, automatisch verloren. Hierdoor ging eén van de voorwaarden in vervulling om door naturalisatie wederom Indonesisch staatsburger te worden, gezien het vereiste dat hierbij géen bipatridie mag ontstaan. ${ }^{540}$ Bij vestiging in Indonesië - gedurende de daartoe gestelde termijn - voldeed betrokkene bovendien aan één van de andere voorwaarden, in het kader van het indienen van een verzoek voor naturalisatie tot Indonesisch staatsburger gesteld. Wordt bedoelde bepaling op deze wijze geïnterpreteerd, dan zouden ook personen die eerder het Indonesisch staatsburgerschap hadden verworpen, op deze wijze dit staatsburgerschap kunnen terugkrijgen. ${ }^{5+1}$

Niettegenstaande de onderhavige Overeenkomst in feite bedoeld was voor personen, die én het Indonesisch staatsburgerschap én dat der Chinese Volksrepubliek bezaten, werd met de reeds genoemde Regeringsverordening no. 5 van het jaar 1961, de geldingssfeer daarvan uitgebreid tot personen, nog minderjarig in de periode 27 december 1949 tol 27 december 1951, die deelden in de verwerping van het Indonesisch staatsburgerschap der ouders, of voor wie de ouders het Indonesisch staatsburgerschap hadden verworpen. Het betrof hier in feite personen, die geén dubbel staatsburgerschap bezaten! Deze gelegenheid werd geboden, voor zover betrokkenen het grondgebied van de Republiek Indonesië nooit zonder "re-entry permit" hadden verlaten dan wel bij verlating van het Indonesisch grondgebied, de duur van hun "re-entry" permit nooit hadden overschreden, sedert het tijdstip van verwerping van het Indonesisch staatsburgerschap van of door de ouders.

\subsection{Sanctie op het niet maken van een keuze}

Als sanctie op het niet maken van de keuze door meerderjarigen, werden deze geacht het Indonesisch staatsburgerschap te hebben verkozen, als zij van vaderszijde van Indonesische afkomst zijn. dan wel het staatsburgerschap van de Chinese Volksrepubliek, indien van Chinese afkomst van vaderszijde. Had betrokkene geen familiebetrekking met zijn vader of was het staatsburgerschap van deze niet bekend, dan werd hij geacht het Indonesisch staatsburgerschap te hebben verkozen, indien zijn moeder van vaderszijde van Indonesische afkomst was en het Chinese staatsburgerschap, indien die moeder van vaderszijde van Chinese origine was (artikel V). ${ }^{542}$

540. Het betreft hier éćn van de voorwaarden die zijn gesteld om een verzoek tot naturalisatie te kunnen indienen. Het al dan niet inwilligen van een als hierbedoeld verzoek hangt echter van het beleid van de Indonesische overheid af. Op deze aangelegenheid zal in $\$ 6$ van Hoofdstuk 5 worden teruggekomen.

541. Zie voor meer detsuls, Gautama, Tafsiran, p.133-134.

542. Niet geheel duidelijk is hoe de term "geacht" - in het Indonesișch "dianggap" - het Indonesisch dan wel het staatsburgerschap van de Chinese Volksrepubliek te hebben verkozen moet worden opgevat, 
Hoe dient deze bepaling te worden opgevat? Toegegeven dient te worden, dat de redactie daarvan nu niet bepaald door helderheid uitblonk. In dit verband kan worden opgemerkt, dat het bewijs van afkomst van betrokkenen in de praktijk vaak moeilijk te leveren is. Dit had ten gevolge dat het in feite hierop neerkwam, dat de personen in kwestie door de Republiek Indonesië tot vreemdeling werden bestempeld, met alle consequenties van dien. Immers, aangezien een groot gedeelte van de Chinese-Indonesische bipatriden van gemengd Chinees/Indonesisch bloed is - hetgeen ook geldt voor de vaders, wier afkomst beslissend was voor de toepassing van artikel V - zal het niet zo eenvoudig zijn uit te maken op welke afkomst diende te worden afgegaan. Werd afgegaan op de rechte vaderlijke linie dan zou dit normaliter leiden tot de toekenning van het Chinese staatsburgerschap, gezien de toepassing van het "ius sanguinis" beginsel. Moeilijker ligt dit nog, indien diende te worden afgegaan op het bezit van een (etnische) Indonesische voorouder, niet in rechte vaderlijke linie. Het lijkt mij onwaarschijnlijk, dat dit voldoende zou kunnen zijn voor de toekenning van het Indonesisch staatsburgerschap.

Ook voor minderjarigen gold een sanctie op het niet maken van de keuze in de daartoe vastgestelde termijn. Na het bereiken van de meerderjarige leeftijd werden zij geacht het staatsburgerschap te bezitten, dat zij gedurende hun minderjarigheid bezaten door het volgen van de staat van hun ouders of van hun vader.

De sanctie op het niet maken van een keuze lag derhalve in de - onvrijwillige - toekenning van eén der beide nationaliteiten. De achtergrond hiervan lag in het feit, dat het maken van bedoelde keuze niet kon worden afgedwongen.

\subsection{Voor welke categorieën van personen het maken van een keuze niet verplicht was gesteld}

De verplichting tot het maken van een keuze gold krachtens artikel 12 van de Regeringsverordening no. 20 van het jaar 1959 echter niet voor bepaalde categorieën van Indonesische staatsburgers van Chinese afkomst. Het betrof hier personen, die van hun loyaliteit ten opzichte van de Republiek Indonesië hadden blijk gegeven. Ko Swan Sik en Teuku Moh. Rhadie noemen in dit verband de pogingen van overzeese Chinese politici in Indonesië "to include as many persons as possible in the category, the reason being mainly threefold. First, there was the fear that many "first glance dual nationals" would fail to fulfil their obligation to repudiate expressly Chinese nationality in order to retain Indonesian nationality, out of pure ignorance or inertia. Second, it was held to be in the persons' interests to retain Indonesian nationality since they were living in Indonesia and intended to stay there for the rest of their and their children's lives. Third, it was considered politically inappropriate to require yet another explicit act of

542. $\rightarrow$

met name of het hier een al dan niet weerlegbaar vermoeden betreft. Gegevens uit de praktijk inzake de onderhavige aangelegenheid zijn mij helaas niet bekend. Wél is het zo dat in voorkomende gevallen de rechter een uitspraak dient te doen. 
choice from persons who had allegedly given more than enough evidence of their adherence to Indonesian citizenship by their behaviour". ${ }^{543}$

Bedoeld zijn hier personen, die ooit trouw hadden gezworen c.q. beloofd aan de Indonesische staat, in de hoedanigheid van lid van een officieel lichaam als de Volksvertegenwoordiging, die Minister waren en dergelijke, leden der Indonesische strijdkrachten en van de politie, veteranen - laatstgenoemden dienden onder meer als candidaat-veteraan vóor 20 januari 1960 geregistreerd te zijn en in het bezit te zijn van een besluit op hun status als veteraan betrekking hebbende ${ }^{544}$ - bepaalde categorieën van landsdienaren en personen, die mér dan eens de Indonesische overheid hadden vertegenwoordigd op politiek, economisch, cultureel gebied of het gebied der sport.

Een soortgelijk beleid werd gevolgd ten aanzien van staatsburgers, die in hun levenswijze en omgang hadden getoond, zich "kinderen van het land" te voelen, zoals onder meer landbouwers, dit ter beoordeling van de daartoe bevoegde autoriteiten. Het betreft hier de kwestie van het zich in de autochtone bevolking te hebben opgelost, in $\$ 2.3$ van Hoofdstuk 3 aan de orde gekomen! Nadere bepalingen inzake de voor als hierbedoelde landbouwers geldende voorwaarden werden gesteld met het Gezamenlijk Besluit van de Ministers van Binnenlandse Zaken en Regionale Autonomie, van Justitie, van Landbouw en van Agraria van 20 april 1961. ${ }^{545}$ Bedoelde voorwaarden kwamen hierop neer, dat deze personen het bewerken van de grond als voomaamste bron van inkomsten hebben, in Indonesië zijn geboren en grootgebracht, de Indonesische taal of regionale taal beheersen, zich dagelijks onder de autochtone Indonesische bevolking bewegen en hun verplichtingen ten aanzien van de rechtsgemeenschap van hun woonplaats nakomen.

Krachtens een met de Chinese Volksrepubliek gesloten Uitvoeringsovereenkomst van 15 december 1960 werden de hierboven genoemde categorieën van personen nog aanzienlijk uitgebreid, namelijk met die Indonesische staatsburgers van Chinese origine die deel hadden genomen aan de algemene verkiezingen van 1955, ten behoeve van de Volksvertegenwoordiging en de lokale vertegenwoordigingsraden. De hierbedoelde Uitvoeringsovereenkomst is van kracht geworden op 24 december 1960, zoals vastgesteld in de uitwisseling van Nota's tussen de Minister van Buitenlandse Zaken van de Republiek Indonesië en de Buitengewone Ambassadeur en Gevolmachtigde van de Chinese Volksrepubliek voor de Republiek Indonesië op 21 december 1960. Dit betekent echter niet dat verklaringen, afgelegd vóór het van kracht worden van de onderhavige Uitvoeringsovereenkomst, waarvan de wijze van aflegging niet in strijd is met deze Uitvoeringsovereenkomst, niet wettig zijn. Met het voorhanden zijn van de

543. Ko Swan Sik en Teuku Moh. Rhadie, Nationality, p. 170-171.

544. Voor de verplichting om als candidaat-veteraan vóór 20 januar 1960 geregistreard te zjin en reeds in het bezit te zijn van een besluit inzake de status van veteraan, kan worden verwezen naar de Gezamenlijke Verklaring van de Ministers van Transmigratie, Veteranen en Demobilisatie en van Justitie no. 46/Pnj.B/Mentransved/1968 en no. D.T.B./17/13 van 14 mei 1968.

545. Het betreft hier het Gezamenlijk Besluit van genoemde Ministers no. BPGK 2/2/31-1, no. JB 3/102/7, no. 42/KMP/1961 en no. Sk.212/Ka van 20 april 1961. 
onderhavige Uitvoeringsovereenkomst is de Regeringsverordening no. 20 van het jaar 1959 nog van kracht, met dien verstande dat de bepalingen van deze Uitvoeringsovereenkomst die nog niet in genoemde Regeringsverordening zijn opgenomen, daaraan worden toegevoegd. ${ }^{546}$

Ten aanzien van de hierbedoelde staatsburgers werd het beleid gevolgd dat zij werden geacht slechts één staatsburgerschap te bezitten, omdat naar de mening van de Indonesische overheid de sociale en politieke positie van deze personen bewijst, dat zij van rechtswege - op impliciete wijze - hun staatsburgerschap van de Chinese Volksrepubliek hebben prijsgegeven. ${ }^{547}$ Dit impliceert, dat het deze personen niet werd toegestaan, alsnog de onderhavige keuze te maken! Hierbij werd ervan uitgegaan, dat deze personen enkel en alleen onder de verantwoording van de Indonesische regering vielen.

Uit het bovenstaande kan worden afgeleid, dat de Indonesische overheid de bevoegdheid verkseeg, om middels een eenzijdige beslissing de Chinese nationaliteit van genoemde categorieën van personen - die formeel bipatride waren doch waarvan de Indonesische nationaliteit de effectieve was, die tot uiting kwam in de politieke en sociale status van betrokkenen - verloren te laten gaan! Was dit niet het geval, dan zouden genoemde personen toch verplicht zijn te kiezen, niettegenstaande het feit dat hun Chinese nationaliteit nog slechts in naam bestond. Konden de criteria "sociale en politieke status" wel als zodanig worden gehanteerd? Mijns inziens betrof het hier een rekbare omschrijving, die wellicht tot rechtsonzekerheid aanleiding zou kunnen geven. ${ }^{5.18}$

Door de Indonesische overheid waren nadere bepalingen met betrekking tot deze aangelegenheid vastgesteld. $Z_{0}$ was in de artikelen 13 en 14 van de Regeringsverorde-

546. Deze gegevens werden ontleend aan de Toelichting op de onderhavige Uitvoeringsovereenkomst inzake het Probleem van de Bipatridie tussen de regeringen van de Republiek Indonesiē en van de Chinese Volksrepubliek gesloten. Genoemde Uitvoeringsovereenkomst is opgenomen in de Himpunan Peraturan-Peraturan Kewarganegaraan R.I., samengesteld door het Directoraat-Generaal voor Recht en Wetgeving van her Departement van Justitie. Zie voorts Susanto Tirtoprodjo, Hasil kerdja panitya-bersama tjara pelaksanaan perdjandjian dwikewarganegaraan Republik Indonesia-Republik Rakjat Tiongkok, Jakarta, 1961.

547. De onderhavige aangelegenheid is vastgesteld in de Nota's van 3 juni 1955, uitgewisseld tussen de Premiers van respectievelijk de Republiek Indonesie en de Chinese Volksrepubliek.

548. Gevallen uit de praktijk zjjn mij helaas niet bekend. Er dient echter op te worden gewezen, dat alle personen die vielen onder vigeur van de Overeenkomst van 22 april 1955 zoals goedgekeurd met de Wet no. 2 van het jaar 1958 en het Indonesisch staatsburgerschap hebben verkregen op grond van deze Wet en de uitvoeringsregelingen daarvan, in het bezit werden gesteld van bewijsstukken op de verkrijging van genoemd staatsburgerschap betrekking hebbende. Dit gold mede voor personen die werden geacht enkel het Indonesisch staatsburgerschap te bezitten. Het (nog) niet bezitten van een als hierbecoeld bewijsstuk (in de vorm van de formulieren I/IA-VI/VIA afgestemd op de gezinssamenstelling van betrokkenen en de formulieren $C$ of D) had ingevolge het sehrijven van de Minister van Justitie no. DTB/14/21 van 15 mei 1972 ten gevolge, dat deze personen als buitenlander werden aangemerkt en niet konden worden verklaard Indonesisch staatsburger te zijn middels artikel IV van de Slotbepalingen van de Wet no. 62 van het jaar 1958. Dat in deze kwestie water bij de wijn is gedaan, zal blijken uit hetgeen met betrekking tot bewijzen inzake het bezit van het Indonesisch staatsburgerschap in Hoofdstuk 7 naar voren is gebracht. 
ning no. 20 van het jaar 1959 bepaald, dat in het geval gehuwde vrouwen en op het moment van inwerkingtreding van de Overeenkomst van 22 april 1955 nog minderjarige kinderen van voornoemde categorieën deel uitmaakten, zij in het belang van de gezinseenheid, niet konden worden beschouwd het staatsburgerschap van de Chinese Volksrepubliek te hebben prijsgegeven, los van respectievelijk hun echtgenoot c.q. ouders. Daarentegen was, eveneens in het belang van de gezinseenheid bepaald, dat de vrouw c.q. minderjarige kinderen de staat van de echtgenoot c.q. van de ouder - vader dan wel moeder - volgden, die deel uitmaakte van een als hiervoor bedoelde categorie c.q. op basis daarvan werd beschouwd het staatsburgerschap van de Volksrepubliek te hebben prijsgegeven. De aan deze categorie verstrekte verklaring inzake het enkel bezitten van het Indonesisch staatsburgerschap, geldt als bewijs hiervan.

Het hiervoor uiteengezette deed krachtens artikel 18 van de onderhavige Regeringsverordening no. 20 van het jaar 1959 niettemin geen afbreuk aan de mogelijkheid voor personen, die werden beschouwd enkel het Indonesisch staatsburgerschap te bezitten, om een verklaring af te leggen teneinde wederom staatsburger van de Chinese Volksrepubliek te worden. Met het afleggen van bedoelde verklaring - die mede gold voor de echtgenote en minderjarige kinderen - verkreeg betrokkene het staatsburgerschap van de Volksrepubliek en ging dat van de Republiek Indonesië verloren.

Volledigheidshalve dient nog te worden gewezen op het in de Memorie van Toelichting van de Regeringsverordening no. 20 van 1959 - opgenomen in het Aanvullend Staatsblad no. 1765 - bepaalde. Hierin is uiteengezet, dat ten aanzien van het verkrijgen van het staatsburgerschap van de Volksrepubliek China op andere wijze dan bepaald in de basis-Overeenkomst en de uitgewisselde Nota's en het daardoor verloren gaan van het Indonesisch staatsburgerschap, niet de artikelen van de onderhavige Overeenkomst gelden, doch de gebruikelijke nationaliteitswetgeving. Dit impliceert, dat ter zake dient te worden afgegaan op hetgeen in artikel 17 sub a. van de Wet no. 62 van het jaar 1958 betreffende het Indonesisch staatsburgerschap is bepaald. ${ }^{\text {sa }}$

\subsection{Datum van inwerkingtreding der Overeenkomst en annulering daarvan}

De datum van de inwerkingtreding van de Overeenkomst ter afwikkeling van het dubbel staatsburgerschap van personen die daaronder vielen, heeft lang op zich laten wachten en heeft daardoor de tenuitvoerlegging van deze Overeenkomst in de weg gestaan. Ko Swan Sik en Teuku Moh. Rhadie noemen als twee van de oorzaken daarvan, het feit dat een nieuwe nationaliteitswet inmiddels op de politieke agenda was geplaatst en sterke stromingen bestonden die een synchronisatie voorstonden van de wijze van uitvoering van de Overeenkumst met de principes, te aanvaarden in de toekomstige nationaliteitswet (de huidige Wet no. 62 van 1958). In de tweede plaats werd gesuggereerd, dat het voortdurend gewikkeld zijn van Indonesië in interne moeilijkheden, een andere betekenisvolle factor vormde van het gebrek aan aandacht. Het land was

549. Op deze aangelegenheid zal worden teruggekomen bij de behandeling van de gronden die leiden tot het verluren gaan van het Indonesisch staatshurgerschap in $\$ 2$ van Hoofdstuk 6 . 
bovendien in een extern politieke conflict met Nederland gewikkeld. ${ }^{550}$ Deze gebeurtenissen vonden plaats in de eerste periode van tien jaar van de onafhankelijkheid in de jaren vijftig. ${ }^{51}$ Wat betreft de interne verwikkelingen, kan hier het met de Presidentiële Regeling no. 10 van 1959 aan buitenlanders opgelegde verbod om activiteiten die betrekking hebben op de klein- en detailhandel te verrichten, buiten de hoofdsteden van de Autonome Regio's van het eerste en tweede Niveau en de Residenties. ${ }^{552} \mathrm{Ge}-$ noemd verbod veroorzaakte grote onrust in kringen van personen met de Chinese nationaliteit, die van oudsher in genoemde branches van de handel actief zijn, aangezien deze zich in hun bestaansmogelijkheden bedreigd zagen. ${ }^{553}$ De vertraagde inwerkingtreding van de Overeenkomst had tevens als consequentie, dat de tenuitvoerlegging van bepaalde, in de Wet no. 62 van het jaar 1958 opgenomen bepalingen - in Hoofdstuk 5 toe te lichten - vaak daardoor werden bemoeilijkt. De uitwisseling van de op deze Overeenkomst betrekking hebbende ratificatiedocumenten vond, zoals reeds opgemerkt, eerst op 20 januari 1960 in Peking plaats.

Krachtens artikel XIV van de Overeenkomst van 22 april 1955 zou de onderhavige Overeenkomst gelden voor een termijn van 20 jaar en zou ná genoemde periode van kracht blijven, tenzij één der partijen bedoelde Overeenkomst wenste te verbreken, van welk feit de andere partij schriftelijk op de hoogte diende te worden gesteld. In laatstbedoeld geval zou de Overeenkomst een jaar nadat deze kennisgeving was verstrekt, aflopen.

Verbreking van de onderhavige Overeenkomst vond echter plaats bij Wet no. 4 van het jaar 1969, waarbij de Wet no.2 van het jaar 1958 en alle, ter uitvoering daarvan vastgestelde bepalingen met ingang van 10 april 1969 niet langer van kracht werden verklaard. Hierbij werd bepaald, dat personen die op genoemde datum reeds het Indonesisch staatsburgerschap bezaten krachtens de Wet no. 2 van het jaar 1958, dit blijven behouden. Als hierbedoelde personen op 10 april 1969 nog minderjarig, blijven na het bereiken van de meerderjarige leeftijd Indonesisch staatsburger; op deze personen zijn voorts de bepalingen van de Wet no. 62 van het jaar 1958 betreffende het Staatsburgerschap van Indonesië van toepassing. Uit de Memorie van Toelichting van de Wet no. 4 van het jaar 1969 valt voorts op te maken, dat personen die reeds een keuze hebben gemaakt volgens de bepalingen van de onderhavige Overeenkomst, in het bezit blijven van het door hen gekozen staalsburgerschap. Aan kinderen op 10 april 1969 nog niet meerderjarig, wordt het echter niet langer toegestaan om ná het bereiken van de meerderjarigheid zélf een keuze te maken; hun staatsburgerschap volgt dat van de ouders. In dit verband dient echter te worden opgemerkt, dat dit beleid niet de moge-

550. Op deze inteme en externe moeilijkheden is ingegaan in $\$ 2.1$ van Hoofdstuk 1.

551. Ko Swan Sik en Teuku Mob. Rhadie, Nationality, p. 168.

552. Zie voor de staatsstructuur op lokasl niveau, hetgeen in $\$ 2.2$ van Hoofdstuk 1 werd uiteengezet.

553. Zie voor meerdere details inzake deze aangelegenbeid c.q. welk - vertraagde - effect dit heeft gehad op de inwerkingtreding van de onderhavige Overeenkomst, Mackie, J.A.C., The Chinese in Indonesia, The University Press of Hawai, Honolulu in association with The Australian Institute of International Alfairs, 1976, p.82 e.v. 
lijkheid uitsluit voor de persoon in kwestie om van staatsburgerschap te veranderen volgens de geldende nationaliteitsrechtelijke bepalingen.

De overwegingen die ten grondslag liggen aan de afkondiging van de Wet no. 4 van het jaar 1969, zijn onder meer hierin gelegen, dat niettegenstaande het feit de onderhavige Overeenkomst beoogde een oplossing te bieden voor het probleem van de bipatridie, in de Overeenkomst bepalingen voorkwamen, die een bijzondere behandeling verlenen aan een bepaalde groep personen. De hierbedoelde bijzondere behandeling, die voordelen zou kunnen afwerpen in verband met de toekenning van exceptionele rechten en mogelijkheden, die niet aan een andere groep van de samenleving worden toegekend, werd in strijd geacht met het principe van gelijkheid voor het recht, als gewaarborgd door de Grondwet. Door het niet meer van kracht verklaren van de Wet no. 2 van het jaar 1958 en alle uitvoeringsregelingen daarvan, kon niet langer gebruik worden gemaakt van de door deze bepalingen geboden mogelijkheden.

Met betrekking tot deze aangelegenheid zou enerzijds naar voren kunnen worden gebracht, dat de hiervoor genoemde unilaterale verbreking van de met de Chinese Volksrepubliek gesloten Overeenkomst is geschied binnen de grenzen van het Indonesisch constitutioneel recht. De hierachter liggende "raison d'être" is, dat een overeenkomst in Indonesië eerst van kracht kan worden, ná in een wet van de Volksvertegenwoordiging te zijn omgezet en dat Indonesië als soevereine staat bevoegd is elke door de Volksvertegenwoordiging goedgekeurde wet in te trekken. Anderzijds kan echter worden opgemerkt, dat niettegenstaande de naar voren gebrachte "raison d'être", een als hierbedoelde wet voortspruit uit een overeenkomst; aan internationale normen, bij het sluiten van een overeenkomst in acht te nemen, kan unilateraal geen afbreuk worden gedaan. ${ }^{554} \mathrm{Ik}$ ben dan ook de mening toegedaan, dat aan het beginsel "pacta sunt servanda" in principe de hand dient te worden gehouden c.q. een overeenkomst niet unilateraal kan worden beëindigd door één van de verdragspartners. Hierop aansluitend kan de mening van Hecker worden aangehaald, die hieromtrent het volgende opmerkt: "Durch Gesetz Nr.4 v. 1969 erklärte Indonesien den Vertrag ex nunc für unwirksam, obwohl er für 20 Jahre geschlossen und eine Kündigung erst danach möglich war, wobei genaue Vorschriften über das Wirksamwerden einer schriflichen Kündigung getroffen wurden (Art. 14). Die innerstaatl. Aufhebung berührt daher die völkerrechtl. Gültigkeit nicht, ist vielmehr ein Vertragsbruch". 555

Met de afkondiging van de Wet no. 4 van het jaar 1969, waarbij de Wet no. 2 van het jaar 1958 inzake de Overeenkomst tussen Indonesië en de Chinese Volksrepubliek betreffende het Probleem van de Bipatridie niet langer van kracht werd verklaard, is met ingang van 10 april 1969 de Wet no. 62 van het jaar 1958 de enige wettelijke

554. Himawan, The Foreign Investment Process, p.236. Zie in een geheel andere context met betrekking tot het principe "Pacta Sunt Servanda", Wehberg, H., Pacta Sunt Servanda, 1959, 53 A.J.I.L. 775, p. 786 .

555. Hecker, Das Staatsangehörigkeitsrecht, p.50. 
regeling dat voorzieningen treft ter vaststelling van het Indonesische staatsburgerschap. ${ }^{556}$

Ter afsluiting van dit onderwerp kan nog naar voren worden gebracht, dat met de Instructie van het Presidium van het Kabinet vastgesteld op 7 juni 1967 en op deze datum in werking getreden, het basisbeleid met betrekking tot het Chinezenprobleem verder werd uitgestippeld. ${ }^{557}$ Het door de Indonesische overheid gevolgde beleid kwam hierop neer, dat in principe geen vestigingsvergunning aan "newcomers" c.q. buitenlanders met de nationaliteit van de Chinese Volksrepubliek zal worden verstrekt om in Indonesië te werken of een onderneming te voeren. Iedere buitenlandse ingezetene kan niettemin een verzoek tot verkrijging van het Indonesisch staatsburgerschap middels naturalisatie indienen met inachtneming van de daartoe gestelde voorwaarden. ${ }^{558}$

Met het herstellen van de diplomatieke betrekkingen tussen de Republiek Indonesië en de Chinese Volksrepubliek op 8 augustus 1990 is het getij inmiddels gekeerd. Krachtens het bij deze gelegenheid ondertekende "Memorandum of Understanding" wordt door beide regeringen, het standpunt van het niet erkennen van een dubbel staatsburgerschap voor hun onderdanen, ingenomen. ${ }^{559} \mathrm{Dit}$ vormt een bevestiging van het feit, dat personen van Chinese afkomst in Indonesië gevestigd en tot Indonesisch staatsburger genaturaliseerd of die het Indonesisch staatsburgerschap op andere wijze hebben verkregen, niet langer daamaast de Chinese nationaliteit bezitten. Een soortgelijk beginsel wordt aangehangen met betrekking tot personen van Indonesische afkomst in de Volksrepubliek gevestigd, die tot Chinees staatsburger zijn genaturaliseerd of de Chinese nationaliteit op andere wijze hebben verkregen.

\section{$\S 4$ Enige gevallen uit de praktijk}

Het lijkt mij van nut om na te gaan, hoe hetgeen hierboven werd uiteengezet in de praktijk werkt. Het gaat hier om de vraag, wie op grond van artikel 1 sub a. van de Wet no. 62 van 1958 kunnen worden aangemerkt als personen die het Indonesisch staatsburgerschap bezitten.

Teneinde te bepalen wie krachtens dit artikellid reeds Indonesisch staatsburger waren, dient te worden afgegaan op de bepalingen die in Hoofdstuk 3 aan de orde zijn geko-

556. Zie hiervoor Bujung Datuk Intan Sati, Beberapa Hal mengenai cara memperoleh Kewarganegaraan R.I., Himpunan Peraturan-Peraturan Kewarganegaraan R.I., samengesteld door het DirectoraatGeneraal Recht en Wetgeving van het Departement van Justitie, in het vervolg aangeduid met "Himpunan", Jakarta, 1984, p.351. Zie voorts Gouw Giok Siong (Gautama), Soal-Soal Aktuil tentang Kewarganegaraan, Jakarta, 1959.

557. Het betreft hier de Instructie no. 37/U/N/1967 van 7 juni 1967, opgenomen in Engelbrecht, p. 318.

558. Zie voor deze aangelegenheid, Gunn, G.C., The Garuda and the Dragon: Indonesia-Chinese Relations, University of New Soutb Wales.

559. Genoemd "Memorandum of Understanding" is gepubliceerd door het Indonesische Departement van Buitenlandse Zaken. 
men, waarvan vooral de Wet van 1910 en de Toescheidingsovereenkomst van groot belang zijn te noemen, het onderwerp van $\$ 3$ en $\$ 5.3 .2$ van dit Hoofdstuk. Hiemaast speelt ook de Overeenkomst tussen Indonesië en de Chinese Volksrepubliek betreffende de afwikkeling van de bipatridie een rol, niettegenstaande het feit, dat deze Overeenkomst met ingang van 10 april 1969 eenzijdig door Indonesië werd beëindigd.

Welk effect hebben de in het voorgaande aangehaalde regelingen nu op de status van een persoon gehad? Het lijkt mij van belang, dit aan de hand van enkele voorbeelden toe te lichten.

In eerste instantie dient onder de aandacht te worden gebracht, dat de Wet van 1910 slechts tot 27 december 1949 van kracht is geweest. Enkele gevolgen hiervan zijn:

a. ná 27 december 1949 waren de ingezetenen van Indonesië reeds verdeeld in Indonesische staatsburgers en buitenlanders;

b. kinderen in Indonesië geboren ná 27 december 1949 waren geen Nederlands onderdaan meer; hun staatsburgerschap volgde dat van hun ouders

zoals door Bujung Datuk Intan Sati - mijns inziens terecht - opgemerkt. ${ }^{560} \mathrm{Ik}$ acht het van nut om het voorgaande te illustreren aan de hand van een paar voorbeelden, als volgt:

- $\quad$ een persoon van Indiase afkomst A is in het jaar 1920 te Medan geboren en heeft in de periode van 27 december 1949 tot 27 december 1951 het Indonesisch staatsburgerschap niet verworpen. Zijn kind B is in Medan geboren op 25 september 1950 ;

- $\quad$ in hetzelfde geval als hierboven omschreven geval, heeft A echter zijn Indonesisch staatsburgerschap op 20 augustus 1950 verworpen.

Wordt nu nagegaan welke nationaliteit A en B hebben in eerstgenoemd geval, dan kan naar voren worden gebracht, dat in het eerste geval A Nederlands onderdaan was en als uitheems onderdaan niet-Nederlander het Indonesisch staatsburgerschap automatisch heeft verkregen. Ook B is Indonesisch staatsburger. In het tweede geval heeft A zijn Indonesisch staatsburgerschap verworpen, is derhalve buitenlander. Alhoewel B niet in de verwerping van zijn vader is betrokken, is hij geboren op een tijdstip dat zijn vader buitenlander is en is derhalve ook buitenlander. ${ }^{561}$

Wordt voorts rekening gehouden met de Overeenkomst tussen Indonesië en de Chinese Volksrepubliek gesloten ter afwikkeling van de bipatridie - op grond waarvan het maken van een keuze tussen het Indonesisch staatsburgerschap en dat van de Volksrepubliek verplicht werd gesteld - dan kan worden opgemerkt dat het in deze Overeenkomst

560. Bujung Datuk Intan Sati, Beberapa pokok-pokok dalam memecahkan masalah Kewarganegaraan R.I., Himpunan, p.332.

561. Ibid., p.334-335. 
bepaalde van invloed kan zijn geweest op de status van een persoon, zoals aan de hand van de volgende voorbeelden zal worden aangeduid:

- een persoon van Chinese afkomst A - hij bezit de nationaliteit van de Chinese Volksrepubliek - is in Medan in 1920 geboren en heeft in de optie-verwerpingstermijn tussen 27 december 1949 en 27 december 1951 zijn Indonesisch staatsburgerschap niet verworpen. Zijn kind B is eveneens in Medan op 25 september 1950 geboren;

- In hetzelfde geval als hierboven omschreven, verwerpt A zijn Indonesisch staatsburgerschap op 20 augusulus 1950 .

Aangezien in eerstgenoemd geval, A zijn Indonesisch staatsburgerschap niet heeft verworpen - dus Indonesisch staatsburger is - heeft hij tevens de nationaliteit van de Chinese Volksrepubliek en heeft derhalve de status van bipatride. Hetzelfde geldt voor $\mathrm{B}$; beiden dienden derhalve een keuze te maken tussen de twee nationaliteiten die zij bezitten op grond van de - toen nog geldende - Overeenkomst tussen Indonesië en de Chinese Volksrepubliek aangegaan. ${ }^{562}$ In het tweede geval, verwerpt A zijn Indonesisch staatsburgerschap en wordt daardoor buitenlander, heeft niet meer de status van bipatride. Niettegenstaande de verwerping niet voor B geldt, volgt hij de status van zijn vader, wordt derhalve ook buitenlander. ${ }^{563}$

Wat de Toescheidingsovereenkomst betreft, moge in herinnering worden gebracht, dat slechts Nederlandse onderdanen onder vigeur van deze Overeenkomst vielen. Aangezien dit betekent dat niet-Nederlandse onderdanen niet door de bepalingen van deze Overeenkomst werden getroffen, gold dit ook voor kinderen, ná de grensdatum 27 december 1949 geboren, die derhalve eveneens geen Nederlands onderdaan waren. Wordt hierop verder doorgegaan - het betreft hier uitheemse Nederlandse onderdanen niet-Nederlander - dan houdt dit het volgende in:

a. Is het kind geboren voordat zijn ouders het Indonesisch staatsburgerschap verwierpen, dan is het kind op het tijdstip van zijn geboorte Indonesisch staatsburger. Gaan de ouders vervolgens over tot het verwerpen van hun Indonesisch staatsburgerschap, dan is het kind niet in de verwerping betrokken en blijft derhalve Indonesisch staatsburger;

b. Wordt het kind geboren nadat de ouders het Indonesisch staatsburgerschap verwerpen, dan is hij op het tijdstip van geboorte het kind van buitenlanders en heeft derhalve ook een buitenlandse nationaliteit. 
Het bovenstaande kan met het volgende voorbeeld worden toegelicht:

- A is in Surabaya in het jaar 1920 geboren. Zijn kind B is in Surabaya geboren in het jaar 1942. In het jaar 1950 gaat A over tot het verwerpen van zijn Indonesisch staatsburgerschap;

- $\quad$ A is in Surabaya in het jaar 1910 geboren. Zijn kind B wordt geboren te Surabaya op 20 maart 1933. Vervolgens verwerpt A zijn Indonesisch staatsburgerschap op 20 augustus 1951.

Gezien het jaar van geboorte in het eerste geval, zijn zowel A als B Nederlands onderdaan. Door de verwerping van zijn staatsburgerschap, krijgt A de status van buitenlander. B deelt in de verwerping van het staatsburgerschap en krijgt eveneens een buitenlandse status. Was het kind nog minderjarig op het tijdstip van de soevereiniteitsoverdracht, doch had het de meerderjarige leeftijd bereikt op het tijdstip van verwerping door zijn ouders, dan gold deze verwerping niet voor hem. In het tweede geval zijn zowel A als B Nederlands onderdaan. Door de verwerping op 20 augustus 1951 wordt A buitenlander. B was minderjarig op het tijdstip van de soevereiniteitsoverdracht, doch had op het moment dat $A$ tot verwerping van zijn Indonesisch staatsburgerschap overging, reeds de meerderjarige leeftijd bereikt c.q. was niet betrokken bij de verwerping van zijn vader en blijft derhalve het Indonesisch staatsburgerschap behouden. Bezit B tevens de nationaliteit van de Chinese Volksrepubliek, dan diende hij een keuze te maken krachtens de Overeenkomst tussen Indonesië en de Volksrepubliek aangegaan, vooropgesteld dat deze Overeenkomst nog niet door Indonesië was opgezegd. ${ }^{564}$

Uit de hierboven gegeven voorbeelden kan worden geconcludeerd, dat om vast te stellen of een persoon het Indonesisch staatsburgerschap bezit, vaak op oudere regelingen dan de thans vigerende Wet no. 62 van het jaar 1958 dient te worden afgegaan, een aangelegenheid die ook in Hoofdstuk 7 aan de orde zal komen.

564. Jbid., p.338. 

STAATSBURGERSCHAP VOLGENS DE WET No. 62 VAN HET JAAR 1958

\section{$\S 1$ Inleiding}

Ingevolge het in de Wet no. 62 van het jaar 1958 bepaalde, wordt het Indohesisch staatsburgerschap verkregen:

1 door afstamming krachtens het "ius sanguinis";

2. door geboorte in Indonesië krachtens het "ius soli";

3. door adoptie;

4. door geprivilegieerde naturalisatie;

5. door gewone naturalisatie en door de uitzonderingsnaturalisatie;

6. door of als gevolg van huwelijk;

7. door het volgen van de staat van respectievelijk de vader of moeder;

8. door aflegging van een daartoe strekkende verklaring (optie).

Bovengenoemde wijzen van de verkrijging van het Indonesisch staatsburgerschap zullen hieronder successievelijk aan de orde komen.

\section{§ 2 Verkrijging "iure sanguinis"}

Krachtens artikel 1 sub b., c., d. en e. is op grond van hel "ius sanguinis" - ongeacht de plaats van geboorte - van rechtswege Indonesisch staatsburger:

a. de persoon die op het moment van zijn geboorte een familierechtelijke betrekking heeft met zijn vader, een Indonesisch staatsburger; dit Indonesisch staatsburgerschap neemt een aanvang bij het ontstaan van bedoelde familierechtelijke betrekking, die dient te zijn ontstaan voordat die persoon de leeftijd van achttien jaar heeft bereikt dan wel op een eerder tijdstip in het huwelijk is getreden;

b. het kind dat geboren wordt binnen 300 dagen nadat zijn vader overleed, indien die vader op het moment van overlijden Indonesisch staatsburger was;

c. de persoon waarvan de moeder op het moment van zijn geboorte Indonesisch staatsburger is, indien hij op dat moment geen familierechtelijke betrekking heeft met zijn vader;

d. de persoon, waarvan de moeder op het moment van zijn geboorte Indonesisch staatsburger is, indien zijn vader geen staatsburgerschap bezit of zolang het staatsburgerschap van zijn vader onbekend is.

Met betrekking tot het "ius sanguinis" is in de Memorie van Toelichting van de Wet ${ }^{365}$ naar de letter van de wet bepaald, dat "een Staat vanzelfsprekend een kind 
als zijn staatsburger aanmerkt, waar hij ook geboren is, als de ouders van het kind in kwestie, staatsburgers van die Staat zijn". ${ }^{566}$

Het is echter niet altijd zo, dat beide ouders hetzelfde staatsburgerschap bezitten. Bovendien heeft het kind niet altijd een familierechtelijke betrekking met beide ouders. Door de wetgever wordt het standpunt ingenomen, dat tussen moeder en kind altijd een familierechtelijke betrekking bestaat; het betreft hier het beginsel van "moeder maakt geen bastaard". ${ }^{567}$ Ter staving hiervan kan naar artikel 43 van de Huwelijkswet no. 1 van het jaar 1974, Stb. 1974-1 worden verwezen dat bepaalt, dat een buiten huwelijk geboren kind slechts een burgerlijke betrekking met zijn moeder en haar familie heeft. ${ }^{568}$ Ter illustratie dat genoemd beginsel niet altijd toepassing heeft gevonden in Indonesië, kan op de Wet no. 3 van 1946 worden gewezen, waarin erkenning van het kind door de moeder uitdrukkelijk was voorgeschreven, wilde het kind in de nationaliteit van de moeder delen. ${ }^{569}$ Een familierechtelijke betrekking tussen vader en kind ontstaat, indien dat kind geboren is in of uit een wettig huwelijk dan wel het kind door zijn vader op wettige wijze is erkend c.q. gewettigd. ${ }^{570}$

Zoals uit het hiervoor onder a. bepaalde blijkt, is van belang voor het nationaliteitsrecht, dat in het geval van erkenning - zo ook in het geval van wettiging - de familierechtelijke betrekking eerst aanwezig is vanaf het moment van erkenning c.g. wettiging en derhalve niet terugwerkt tot het tijdstip van de geboorte van het kind,

De hiervoor onder b. genoemde voorwaarde dat een kind binnen 300 dagen nadat zijn vader overleed dient te zijn geboren, wil dat kind Indonesisch staatsburger zijn vooropgesteld uiteraard dat deze vader Indonesisch staatsburger was - dient om "confusio sanguinis" te voorkomen. Het kan hier slechts kinderen betreffen, die staande huwelijk zijn verwekt. Tijdens de behandeling van het ontwerp dat heeft geleid tot de

566. In het Indonesisch luidt deze zin: "Sudah sewajamya suatu negara menganggap seorang anak sebagai warganegaranya di manapun ia dilahirkan, apabila orang tua anak warganegara dari negara itu".

567. Zie ook Gautama, S., Hukum Perdata Internasional Indonesia, vol. III, deel 1, Bandung, 1981, p.58.

568. In het tweede lid van dit artikel is gesteld, dat de positie van het kind hij Regeringsverordening zal worden geregeld. In de Regeringsverordening no. 9 van het jaar 1975 betreffende de uitvoering van de Wet no. 1 van het jaar 1974 inzake het Huwelijk, Stb. 1975-12 komen echter geen als hierbedoelde bepalingen inzake de positie van het kind voor.

569. Zie hiervoor $\$ 5.2$ van Hoofdstuk 3 .

570. Krachtens artikel 274 IBW is het mogelijk voor ouders, die vór of bij het aangaan van het huwelijk hadden verzuimd hun natuurlijke kinderen te erkennen, dit verzuim te herstellen door brieven van wettiging, door de executieve macht te verlenen. Op dezelfde wijze als in artikel 274 IBW bepaald, kunnen krachtens artikel 275 IBW ook worden gewettigd, natuurlijke en wettig erkende kinderen, geboren uit ouders, die uit hoofde van het overlijden van één van hen, hun voorgenomen huwelijk niet hebben kunnen tot stand brengen dan wel die geboren zijn uit een moeder, die hehoort tot de Indonesische of daarmede gelijkgestelde bevolking, indien deze moeder is overleden dan wel er gewichtige bezwaren - ter beoordeling van de Gouverneur-Generaal - tegen het huwelijk der ouders bestaan. Naar Gautama - mijns inziens terecht - stelt, is duidelijk dat laatstgenoemde bepaling, een "koloniaal artikel" is dat dient te worden aangemerkt als niet meer van kracht te zjjn. Zie Gautama, Hukum Perdata, p.77. 
Wet no. 62 van 1958 in de Volksvertegenwoordiging, maakten enkele leden daarvan bezwaar tegen de termijn van 300 dagen. Voorgesteld werd om deze termijn te verlengen, hetgeen van overheidswege werd afgewezen, aangezien de gestelde termijn in overeenstemming is met de termijn in de geneeskunde gehanteerd. ${ }^{571}$

Bestaat een familierechtelijke betrekking tussen vader en kind, dan zal de staat van de vader bepalend zijn voor de vaststelling van het staatsburgerschap van het kind in kwestie. Is dit echter niet het geval, is het staatsburgerschap van de vader niet bekend of is de vader staatloos, dan is de staat van de moeder doorslaggevend; in het geval van onbekendheid van de nationaliteit der vader, zolang deze onbekendheid voortduurt. Dit blijkt uit de bepalingen als hiervoor onder $c$. en d. genoemd. Naar de mening van Adriaanse en van der Weg, mag worden aangenomen - alhoewel de Wet ter zake geen bepaling bevat - dat ook in het geval de vader wél een bekende nationaliteit bezit, doch deze ingevolge zijn nationale wet niet op het kind overdraagt, het kind de Indonesische nationaliteit aan de - Indonesische - moeder zal ontlenen. ${ }^{572}$ Alhoewel deze, van Nederlandse zijde gehuldigde opvatting, mij alleszins aanvaardbaar voorkomt, zou het toch beter geweest zijn, indien deze bepaling in de Wet was opgenomen. Of dit ook het geval is, wanneer het kind door geboorte in een vreemd land de nationaliteit van dat land bezit, is volgens genoemde auteurs onzeker; zij zijn van mening dat dit niet waarschijnlijk lijkt, omdat de bepaling van artikel 1 sub e. is opgenomen om te voorkomen, dat het kind door geboorte staatloos zal zijn. Voor zover ik heb kunnen nagaan, is in de Indonesische literatuur niet op deze aangelegenheid ingegaan. Het betreft hier echter een Nederlands standpunt!

Rekening houdende met de in Indonesië heersende rechtsverscheidenheid ${ }^{573}$ wordt in de Wet no. 62 van 1958 gesproken van een "familierechtelijke betrekking". Dat hier de gebruikelijke begrippen "wettig", "gewettigd" dan wel "erkend" niet zijn gebruikt, houdt verband met het feit, dat deze op Westerse beginselen geschoeide begrippen in een land als Indonesië, waar de bevolking, vanwege verschil in bevolkingsgroep, godsdienst dan wel plaats of regio aan verschillend recht is onderworpen, genoemde begrippen alleen van toepassing zijn op personen die onder het IBW vallen. Dit geldt met name voor Europeanen dan wel afstammelingen daarvan en voor personen die onder genoemd Wetboek vallen, zoals Chinezen. Hieronder vallen tevens personen die tot de autochtone bevolking behoren en bij besluit aan Europeanen zijn gelijkgesteld of gebruik hebben gemaakt van de mogelijkheid tot vrijwillige algehele onderwerping aan het voor Europeanen geldende privaatrecht. ${ }^{574}$ Ook in het geval van een huwelijk tussen een autochtone Indonesische vrouw met een persoon die onder de categorie der Europeanen valt, is niet alleen op de echtgenoot het voor Europeanen geldende recht

571. Zie hiervoor de Algemene Beschouwingen, Hoofdstuk I van 4-6-1958, RS p.24 ten tijde van de behandeling van het onderhavige ontwerp in de Volksvertegenwoordiging. De termijn van 300 dagen is ook genoemd in artikel 255 IBW.

572. Adriaanse en van der Weg, Nationaliteitswetgeving, Indonesiē, p.Ib-11.

573. Zie hiervoor $\$ 2.1$ van Hoofdstuk 3 .

574. Zie hieromtrent hetgeen in $\$ 2.1$ van Hoofdstuk 3 werd opgemerkt. Zie voorts Adriaanse en van der Weg, Nationaliteitswetgeving, Indonesiē, p.Ib-10. 
van toepassing, maar geldt dit bovendien voor de echtgenote - ó́k indien zij haar orspronkelijke status behoudt - aangezien ook zij valt onder de geldingssfeer van het recht, dat geldt voor haar echtgenoot. ${ }^{575}$ Het grootste gedeelte van de autochtone bevolking valt niettemin onder het Adatrecht, dat deze begrippen niet kent, zodat een begrip als "familierechtelijke betrekking" en "erkenning door de vader" naar de in het Adatrecht geldende begrippen - die van rechtskring tot rechtskring kunnen verschillen dienen te worden uitgelegd. ${ }^{576}$ In dit geval gelden heel andere maatstaven dan die, gehanteerd in het voor Europeanen geldende burgerlijk recht. Alhoewel het in dit verband te ver zou voeren, om diepgaand op het Adatrecht in te gaan, kan ter illustratie worden vermeld, dat bijvoorbeeld in de Minahassa, de betrekking van een kind met de man, die het buiten huwelijk heeft verwekt gelijk is aan de betrekking van een kind met zijn (wettige) vader. Indien deze man iedere twijfel omtrent de bestaande betrekking met het kind in kwestie weg wil nemen, kan hij aan de moeder daarvan - indien de man niet samenleeft met bedoelde vrouw - een geschenk geven "lilikur" genaamd. Op andere plaatsen wordt een buiten huwelijk geboren kind, volgens het Adatrecht als een vaderloos kind beschouwd. Voorts wordt een ná het tijdstip van echtscheiding van de ouders geboren kind beschouwd, als vader de ex-echtgenoot van zijn moeder te hebben. ${ }^{57}$ Ook het systeem van het Adatrecht kent geen verplichting tot erkenning van een buiten huwelijk geboren kind door zijn moeder, voor het doen ontstaan van een burgerlijke betrekking tussen haar en het kind. ${ }^{578}$ Dat toch met de begrippen "wettig", "gewettigd" en "erkend" rekening dient te worden gehouden, heeft hiermede te maken dat de Wet no. 62 van 1958 niet alleen betrekking heeft op personen die onder het Adatrecht vallen, doch evenzeer op personen, onderworpen aan het voor Europeanen geldende burgerlijk recht.

In aansluiting op het voorgaande kan worden opgemerkt, dat in de Indonesische Huwelijkswet van 1974 is bepaald, dat een kind wettig is, indien geboren in of uit een wettig huwelijk. Nog daargelaten, wanneer van een "wettig huwelijk" kan worden gesproken - ter bepaling hiervan worden in het Adatrecht andere maatstaven gehanteerd dan in het Westers recht - kan onder de aandacht worden gebracht, dat de hier gehanteerde begripsomschrijving beperkter is dan die, gehanteerd in de Wet no. 62 van het jaar 1958. In laatstgenoemde Wet wordt namelijk van "familierechtelijke betrekking" gesproken, terwijl in eerstgenoende Wet sprake is van "wettig huwelijk". Aangezien naar de letter van de Huwelijkswet een huwelijk wettig is, indien gesloten volgens de godsdienst dan wel geloofsovertuiging van beide partijen, dient de wettigheid van een kind in die zin te worden vastgesteld.

575. Dit blịkt uit de jurisprudentie, zie het arrest van de "Mahkamah Agung" (MA) no. $556 \mathrm{~K} / \mathrm{Sip} / 1971$ van 8 januari 1972, dat aan de orde zal komen in \$ 4 van Hoofdstuk 6.

576. lk spreek hier van "rechtskring", omdat het Adatrecht van plaats tot plaats en van regio tot regio kan verschillen.

577. Zie Soerjono Soekanto, Hukum Adat Indonesia, Jakarta, 1983, p. 277 en 278. Deze auteur maakt onderscheid tussen eigen kinderen ("anak kandung"), geadopteerde kinderen ("anak angkat"), stiefkinderen ("anak tiri"), pleegkinderen ("anak piara") en kinderen buiten huwelijk geboren.

578. Zie ook Gautama, Hukun Perdata, p.78. 
Terugkomend op de in Indonesiē heersende rechtsverscheidenheid, moge ter toelichting worden opgemerkt, dal voor autochtone Indonesiërs die de Islamitische godsdienst belijden, het Islamitisch recht zoals dat in het Adatrecht is gerecipieerd geldt en voor andere dan deze het Adatrecht. Voor Christen-Indonesiërs geldt de Huwelijksordonnantie Christen-Indonesiërs, Ind. Stb. 1933-74 jo. 1936-607 in de daartoe aangewezen gebieden. ${ }^{579}$ Voor Chinezen die deel uitmaken van de categorie van de Aziaten en voor Indonesische staatsburgers van Chinese afkomst, geldt het IBW met enige, speciaal voor deze groep aangebrachte wijzigingen en aanvullingen. Op Europeanen en Indonesische staatsburgers van Europese afkomst, is eveneens het IBW van toepassing. Voor Aziaten andere dan Chinezen en voor Indonesische staatsburgers die van deze groep afstammen, geldt het voor deze groep geldende Adatrecht en indien zij de Islamitische godsdienst belijden, het Islamitisch recht. ${ }^{580} \mathrm{Zo}$ zijn volgens de Islamitische wet, kinderen wettig indien geboren of gedurende het huwelijk - mits tenminste zes maanden ná de voltrekking daarvan - óf gedurende de "iddah"-periode, dat wil zeggen drie menstruatieperioden of honderd dagen na ontbinding van het huwelijk door de "talak" 581, waaronder dient te worden verstaan, de verstoting van de vrouw door de man. ${ }^{582}$ In Indonesië wordt getracht onwettige geboorten in de inheemse samenleving zoveel mogelijk te voorkomen door het instituut van noodhuwelijken - het huwen van een willekeurige man met een zwangere vrouw, teneinde de geboorte tijdens het huwelijk te doen plaatsvinden - of middels dwanghuwelijken, het volgens de "adat" dwingen van de blijkbare verwekker van het kind te trouwen met de betrokken vrouw ${ }^{583}$. Ook al komt het kind binnen zes maanden ná de huwelijksvoltrekking ter wereld, volgens de "adat" wordt het meestal in alle opzichten met wettige kinderen gelijkgesteld. Met andere woorden, naar het Adatrecht schijnt het niet relevant, hoeveel tijd na sluiting van het huwelijk het kind wordt geboren. Het recht van de Islam dat eist, dat het kind tenminste zes maanden ná de huwelijkssluiting dient te worden geboren, wil het als wettig worden aangemerkt, heeft wellicht hier en daar - doch zelden - invloed op het Adatrecht en heeft zeker niet het instituut van nood- en dwanghuwelijken aangetast. ${ }^{584}$ Het instituut van dwanghuwelijken komt voor op ZuidSumatra en Bali; noodhuwelijken, die op Java "nikah tambalan" worden genoemd kunnen, indien dit wordt gewenst, nadat het huwelijk enige tijd heeft voortgeduurd door echtscheiding worden ontbonden. ${ }^{585}$ Wat het recht van de Islam betreft, wordt met betrekking tot onwettige kinderen geen onderscheid gemaakt tussen erkende en niet-

579. Zie Engelbrecht-oude stijl, p.511.

580. Genoemde groeperingen zijn, voor zover aangelegenheden in de Huwelijkswet van 1974 geregeld, aan deze Wet onderworpen. Overigens gelden voor niet daarin geregelde onderwerpen, bedoelde (wettelijke) regelingen. Zie hiervoor artikel 66 van de Huwelijkswet no. 1 van 1974 jo. artikel 47 van de Regeringsverordening no. 9 van 1975

581. In de artikelen 14 tot en met 18 van de Regeringsverordening no. 9 van 1975 zijn voorwaarden opgenomen, waaraan dient te worden voldaan, wil een man gebruik kunnen maken van de "talak."

582. Zie Nani Soewondo, Kedudukan Wanita Indonesia dalam Hukum dan Masyarakat, Jakarta, 1984, p. 134.

583. Juynbol, Th. W., Handleiding tot de Kennis van de Mohammedaanse Wet volgens de leer van de Sjafi'itische school, Leiden, 1930, p.219.

584. Ter Haar, B., Beginselen en stelsel van het Adatrecht, Groningen, 1939, p. 142-143.

585. Nani Soewondo, Kedudukan Wanita, p. 133-134. 
erkende onwettige kinderen. Aan de erkening van onwettige kinderen wordt door de wet geen rechtsgevolg hoegenaamd verbonden. Daarentegen is de rechtsbetrekking tussen de moeder en haar buiten huwelijk geboren kinderen van rechtswege geheel dezelfde als die tussen haar en haar wettige kinderen. ${ }^{586}$

Van belang is de in artikel 55 van de Huwelijkswet van 1974 opgenomen bepaling, dat de afkomst van een kind slechts kan worden bewezen met een authentieke geboorteakte, uitgegeven door de daartoe bevoegde registratiebeambte. Is een als hierbedoelde akte niet voorhanden, dan kan het Gerecht een beslissing nemen inzake de afkomst van het desbetreffende kind, na een zorgvuldig onderzoek te hebben uitgevoerd met betrekking tot bewijsstukken die aan de voorwaarden voldoen. Op basis hiervan geeft de competente registratiebeambte een geboorte-akte uit voor het kind in kwestie.

Adriaanse en van der Weg brengen onder de aandacht, dat de Wet erop is gericht om niet alleen staatloosheid te voorkomen, doch evenzo ernaar streeft om het optreden van bipatridie zoveel mogelijk te vermijden. ${ }^{587}$ Ko Swan Sik en Teuku Moh. Rhadie zijn niettemin van mening, dat het voorkomen van bipatridie in de Wet niet als absoluut is aan te merken, aangezien in een aantal gevallen de Wet voorziet in de verkrijging c.q. behoud van het Indonesisch staatsburgerschap ondanks het optreden van bipatridie. Deze auteurs noemen als zodanig onder meer de verkrijging van het Indonesisch staatsburgerschap krachtens het "ius sanguinis", als omschreven in artikel 1 sub b., c., en d. ${ }^{588}$ Toegegeven moet worden dat de Wet niet dermate nauwgezet is geredigeerd, dat het optreden van bipatridie geheel is uitgesloten. Ook in genoemde bepalingen is bijvoorbeeld niet met zoveel woorden gesteld, dat de persoon in kwestie geen andere nationaliteit mag bezitten. Houdt dit nu in, dat het optreden van bipatridie in genoemde gevallen aanvaardbaar wordt geacht? Ik kan mij voorstellen, dat bijvoorbeeld in het in artikel 1 sub b. omschreven geval, waarin het kind het Indonesisch staatsburgerschap verkrijgt vanwege het bestaan van een familierechtelijke betrekking met zijn vader, een Indonesisch staatsburger, de mogelijkheid niet uitgesloten is, dat het kind aan zijn moeder een buitenlandse nationaliteit ontleent; het zijn van bipatride van het kind in kwestie dient in dit geval mijns inziens te worden aanvaard. Immers, zou dit niet het geval zijn, dan zullen vele kinderen uit gemengde huwelijken geboren - een in Indonesië veel voorkomend verschijnsel - van de verkrijging van het Indonesisch statsburgerschap zijn uitgesloten. Het beleid van de Indonesische overheid is er niettemin op gericht bipatridie tegen te gaan, hetgeen blijkt uit de vele, in de Wet opgenomen bepalingen die dit dienen te voorkomen. ${ }^{599}$ In aansluiting hierop dient bovendien op de in artikel 17 sub b. en sub j. van de Wet opgenomen bepalingen te worden gewezen. Krachtens eerstgenoemde bepaling treedt verlies van het Indonesisch staatsburgerschap op, in het geval van bezit van een andere nationaliteit naast het Indonesische staatsburgerschap en niet tot verwer-

586. Juynboll, Handleiding, p. 218.

587. Vergelijk hetgeen in $\$ 2$ van Hoofdstuk 4 inzake de algemene aspecten van de Wet no. 62 van 1958 werd naar voren gebracht. Zie voorts Adriaanse en van der Weg, Nationaliteilswetgeving, Indonesie, p.lb-10.

588. Ko Swan Sik en Teuku Mob. Rhadie, Nationality, p.167.

589. Zie ook hiervoor $\$ 2$ van Hoofdstuk 4. 
ping of prijsgeving van die andere nationaliteit wordt overgegaan, terwijl de betrokken persoon daartoe de gelegenheid krijgt. Evenzo gaat het Indonesisch staatsburgerschap verloren indien de betrokken persoon een op zijn naam staand en nog geldig buitenlands paspoort bezit. Deze bepalingen fungeren als "stok achter de deur" mochten zich onverhoopt toch gevallen van bipatridie voordoen. Van Nederlandse zijde - Adriaanse en van der Weg - is echter niets gezegd over de mogelijkheid van het optreden van bipatridie in de hiervoor genoemde gevallen.

\section{§ 3 Verkrijging krachtens het "ius soli"}

Krachtens artikel 1 sub f., g., h. en $i$, is op grond van het "ius soli" van rechtswege Indonesisch staatsburger:

a. de persoon geboren in het gebied van de Republiek Indonesië, zolang beide ouders onbekend zijn;

b. het kind ten vondeling gelegd in het gebied van de Republiek Indonesië, zolang beide ouders onbekend zijn;

c. de persoon geboren in het gebied van de Republiek Indonesië, indien beide ouders geen statsburgerschap bezitten of zolang het staatsburgerschap van beide ouders onbekend is;

d. de persoon geboren in het gebied van de Republiek Indonesië, die op het moment van zijn geboorte het staatsburgerschap van zijn vader of moeder niet verkrijgt en zolang hij dat staatsburgerschap niet verkrijgt.

Blijkens de Memorie van Toelichting van de onderhavige Wet, ligt het in de bedoeling van de Indonesische wetgever, het "ius soli" eerst toe te passen, in gevallen mogelijkerwijze apatridie zou kunnen ontstaan.

Wordt de vraag gesteld, wanneer een persoon als apatride kan worden aangemerkt, dan kan op het in $\$ 1.4 .1$ van Hoofdstuk 2 aangehaalde beginsel van de nationale autonomie worden gewezen. Iedere Staat is in beginsel bevoegd is om te bepalen, wie zijn onderdanen zijn; a contrario betekent dit, dat een Staat niet bevoegd is om te bepalen wie er staatsburgers van een andere Staat zijn. Evenzo kan een Staat niet verklaren, wie volgens het recht van een andere Staat staatloos is. Dit kan slechts aan de hand van het recht van de desbetreffende Staat worden beslist. ${ }^{590}$ Bij de behandeling van het ontwerp betreffende het Indonesisch staatsburgerschap in de Volksvertegenwoordiging is een hiermede overeenkomend standpunt naar voren gebracht. ${ }^{591}$

Het hierboven uiteengezette doet niettemin geen afbreuk aan de bevoegdheid van een Staat om bepaalde regels vast te stellen voor staatlozen. In aansluiting hierop kan de

590. Ter illustratie diene, dat in artikel I sub f. van de Rijkswet van 1985 op het Nederlanderschap een definitie is gegeven van het begrip "staatloze", met name: hij die geen nationaliteit heeft of wiens nationaliteit niet kan worden vastgesteld. Hiermede zijn eventuele moeilijkheden met betrekking tot het feit, welke Staat bevoegd is vast te stellen of een persoon staatloos is, omzeild.

591. Ter gelegenheid van het Regeringsantwoord van 13-6-1958, RS p.8, op vragen van Ibnu Parna. 
aandacht worden gevestigd op het Rondschrijven van de Minister van Justitie van 1 juli 1969, waarin is gesteld dat met apatriden zijn bedoeld, personen die geen staatsburger zijn van welk land dan ook - pure apatriden - en personen die de nationaliteit bezitten van een land, dat (nog) niet door de Republiek Indonesië is erkend (de facto apatriden). Van belang is dat kinderen van ouders, die als pure apatride worden aangemerkt, Indonesisch staatsburger zijn, terwijl kinderen van de facto apatriden, de nationaliteit van hun ouders volgen, derhalve ook staatloos zijn vanuit het standpunt van Indonesië gezien. ${ }^{592}$ Hieruit blijkt, dat kinderen van pure apatriden in een betere positie verkeren dan kinderen van de facto apatriden. Ook Bujung Datuk Intan Sati gaat in op deze aangelegenheid en noemt Taiwan als een land, (nog) niet door Indonesië erkend. ${ }^{993}$ Het optreden van pure staatloosheid kan volgens deze auteur bij voorbeeld het gevolg zijn van de toepassing van beginselen, die van elkaar verschillen. Indien Staat A slechts het "ius soli" hanteert, zijn allen die aldaar geboren worden, burgers van deze Staat. Hangt daarentegen Staat B slechts het "ius sanguinis" aan, dan zijn afstammelingen van burgers van Staat B., waar ook geboren, staatsburgers van B. Wanneer in dit geval een burger van Staat A een kind ter wereld brengt in Staat B, dan is hij geen burger van Staat A en ook geen burger van Staat B; hij is derhalve staatloos. Om dit te voorkomen, hanteren landen, algemeen gesteld, beide beginselen, hetgeen ook het geval is wat betreft Indonesië. Staatloosheid kan echter ook optreden als gevolg van de eigen nationaliteitswetgeving. Als voorbeeld kan de krachtens artikel 17 sub $\mathrm{k}$. van de Wet no. 62 van 1958 bij langdurig verblijf in het buitenland voorgeschreven aanmeldingsplicht bij de lokaal gevestigde Diplomatieke Vertegenwoordiging van Indonesië worden genoemd, wil de betrokken persoon in het bezit van het Indonesisch staatsburgerschap blijven. Wie niet aan deze verplichting voldoet en niet de nationaliteit van het land van vestiging bezit wordt staatloos, aangezien de Indonesische nationaliteit verloren gaat. ${ }^{54}$

Terugkerend naar de hierboven gegeven specificatie van personen kan worden opgemerkt, dat het onder a. gestelde niet bepaald door duidelijkheid uitblinkt; volgens Adraanse en van der Weg mag worden aangenomen, dat hier een in Indonesië verlaten kind is bedoeld, dat wordt geacht in Indonesië te zijn geboren, zolang niet van het tegengestelde blijkt. ${ }^{595}$

Wat betreft het onder d. gestelde, rijst de vraag wanneer hiervan sprake is. Volgens Bujung Datuk Intan Sati kan dit geval zich voordoen, indien het land van oorsprong van de vader enkel het "ius soli" aanhangt en als zijn burgers alleen personen aldaar geboren erkent. ${ }^{596}$

Met betrekking tot het ter voorkoming van apatridie gehanteerde "ius soli" zoals in de Wet no. 62 van het jaar 1958 geregeld kan worden opgemerkt, dat in de bepalingen als

592. Bedoeld is hier het Ministeriele Rondschrijven no. DTC/9/11 van 1 juli 1969.

593. Bujung Datuk Intan Sati, Beberapa hal, Himpunan p. 364.

594. Zie Bujung Datuk Intan Sati, Beberapa hal, Himpunan p. 364.

595. Adriaanse en van der Weg, Nationaliteitswetgeving, Indonesië, p.Jh-12.

596. Bujung Datuk Intan Sati, Beberapa hal, Himpunan p. 366. 
hiervoor onder a. tot en met d. genoemd, gén termijn is gesteld; de in de onderhavige bepalingen genoemde personen zijn op basis van het "ius soli" Indonesisch staatsburger, zolang de daarin genoemde voorwaarden gelden. Met andere woorden: aan een als hierbedoelde Indonesisch staatsburger wordt in feite géén garantie geboden met betrekking tot het behouden van zijn staatsburgerschap, dat hem elk moment - ook na lange tijd - ontnomen kan worden en derhalve als het zwaard van Damocles boven zijn hoofd blijft hangen!

Alhoewel mij geen gevallen uit de praktijk bekend zijn die op de hierbedoelde aangelegenheid betrekking hebben, kan naar voren worden gebracht, dat in enkele andere nationaliteitswetten de hierbedoelde aangelegenheid wel aan een termijn is gebonden. ${ }^{597}$ Mijns inziens zou het aan te bevelen zijn, ook de hierbedoelde bepalingen om rechtvaardigheidsredenen aan een termijn te binden.

\section{$\$ 4$ Verkrijging door adoptie}

Krachtens artikel 2 lid 1 van de Wet no. 62 van het jaar 1958 kan het Indonesisch staatsburgerschap door adoptie worden verkregen. De Wet opent deze mogelijkheid voor buitenlandse kinderen door een Indonesisch staatsburger geadopteerd, voor zover het kind in kwestie:

a. nog geen vijf jaar is, en

b. de adoptie wettig wordt verklaard door de "Pengadilan Negeri" van de woonplaats van de adoptant; bedoelde wettigverklaring dient door de adoptant te worden aangevraagd binnen de termijn van één jaar, nadat de adoptie heeft plaatsgevonden of binnen één jaar ná inwerkingtreding van deze Wet (1 augustus 1958).

\subsection{Leeftijdsgrens van vijf jaar}

Met betrekking tot de hierboven onder a. genoemde voorwaarde, is in de Memorie van Toelichting van de Wet gesteld, dat aan de vaststelling van deze leeftijdsgrens de veronderstelling ten grondslag ligt, dat een kind op zo'n jonge leeftijd werkelijk als eigen kind kan worden behandeld. ${ }^{598}$ Hierdoor wordt de buitenlandse afkomst van het kind niet langer gekend of gevoeld en is het derhalve wenselijk om het kind in kwestie de staat van de adoptief-ouders te geven. Hienuit blijkt, dat het begrip "nationaliteit" niet alleen in juridische zin dient te worden opgevat, doch aan de sociologische

597. De Wet van 1892 kende reeds het "voorwaardelijke" Nederlanderschap van vondelingen. Kon echter onder vigeur van deze Wet de vondeling het Nederlanderschap zijn hele leven lang verliezen indien zijn afstamming van vreemdelingen vastgesteld kon worden, krachtens de Rijkswet op het Nederschap van 1985 is dit nu slechts binnen vijf jaar mogelijk. Zie de Groot en Tratnik, Nationaliteitsrecht, p. 71-72.

598. Ook in de Overeenkomst tussen Indonesië en de Chinese Volksrepubliek ter afwikkeling van de Bipatridie werd ten aanzien van geadopteerde kinderen dezelfde leeftijdsgrens gehanteerd. 
betekenis daarvan eveneens grote waarde kan worden toegekend. ${ }^{599}$ Oorspronkelijk was in het ontwerp dat geleid heeft tot de totstandkoming van de Wet no. 62 van 1958 de leeftijd op 18 jaar gesteld, op één lijn met de leeftijd die voor erkenning geldt. Door enkele leden van de Volksvertegenwoordiging werd hiertegen bezwaar gemaakt, omdat bij erkenning van kinderen sprake is van bloedverwantschap, hetgeen bij adoptie niet het geval is. Dit bezwaar kon van regeringswege worden aanvaard; dit heeft geleid tot het opnemen van de leeftijdsgrens van vijf jaar in de Wet. ${ }^{600}$ In herinnering moge worden gebracht, dat onder het begrip "familierechtelijke betrekking" ook vallen, erkenning c.q. wettiging voor personen die onder het IBW vallen. Bovendien levert krachtens artikel 17 sub c. van de Wet de erkenning van een Indonesisch kind door een buitenlander grond tot verlies van het Indonesisch staatsburgerschap op, vooropgesteld dat het kind niet staatloos wordt.

Voor het kind in kwestie blijft niettemin de mogelijkheid open om bij het bereiken van de leeftijd van 21 jaar, indien het dit wenst, afstand te doen van zijn Indonesisch staatsburgerschap. Op deze aangelegenheid zal bij de behandeling van de mogelijkheden die kunnen leiden tot het verloren gaan van het Indonesisch staatsburgerschap, in Hoofdstuk 6 worden teruggekomen.

Volgens Ko Swan Sik en Teuku Moh. Rhadie, maakt de verkrijging van het Indonesisch staatsburgerschap door adoptie deel uit van de gevallen, waarin bipatridie kan optreden; zij concluderen ook hier dat de preventie ten aanzien van het ontstaan hiervan in de Wet niet absoluut is. ${ }^{601}$ Ook Adriaanse en van der Weg wijzen erop, dat artikel 2 niet als voorwaarde stelt, dat het kind door de verkrijging van de Indonesische nationaliteit de vreemde nationaliteit, die het mogelijk bezit, moet verliezen. ${ }^{602}$ Toegegeven dient te worden, dat artikel 2 niet dermate nauwgezet is geformuleerd, dat het optreden van bipatridie is uitgesloten. Heeft het niet met zoveel woorden stellen van de hierop gerichte voorwaarde - waardoor de verkrijging van het Indonesisch staatsburgerschap middels adoptie afhankelijk wordt gesteld van het niet bezitten van een andere nationaliteit - nu tot gevolg, dat van Indonesische zijde het mogelijk optreden van bipatridie wordt toegestaan? Ook hier dient in eerste instantie te worden gewezen op het beleid van de Indonesische overheid om bipatridie te voorkomen, zoals uit de vele, in de Wet opgenomen bepalingen blijkt. ${ }^{003}$ In dit licht gezien, is het op z'n minst merkwaardig te noemen, dat de Indonesische overheid in enkele bepalingen van dit beleid afwijkt, door de mogelijkheid van het optreden van bipatridie in bepaalde gevallen open te laten! Het niet opnemen van het voorwaarde, dat de desbetreffende persoon geen andere nationaliteit mag bezitten, is wellicht aan een verzuim van Indonesische zijde te wijten.

599. Zie hiervoor betgeen inzake de verschillende betekenissen van het begrip nationaliteit in \$ 1. I van Hoofdstuk 2 werd opgemerkt.

600. Naar voren gebracht door het lid van de Volksvertegenwoordiging Situmeang, ten tijde van de Algemene Beschouwingen Hoofdstuk II van 16-6-1956, RS p.35 inzake de behandeling van het ontwerp betreffende het Indonesisch staatsburgerschap.

601. Ko Swan Sik en Teuku Moh. Rhadie, Nationality, p. 167.

602. Adriaanse en van der Weg, Nationaliteitswetgeving, Indonesie, $\mathrm{p} . \mathrm{Ib}-13$.

603. Ook in dit verband kan naar hetgeen in $\$ 2$ van Hoofdstuk 4 werd uiteengezet, worden verwezen. 
Alhoewel artikel 2 niet uitdrukkelijk als voorwaarde stelt, dat het kind in kwestie - wil het de Indonesische nationaliteit verkrijgen - de vreemde nationaliteit die het mogelijkerwijze nog bezit, dient te verliezen, dient hier rekening te worden gehouden met het feit, dat het hier om van oorsprong buitenlandse kinderen gaat, anders dan in de gevallen als omschreven in artikel 1 sub b., c. en $d$. Voorts dient ook in dit verband te worden gewezen op de "stok achter deur" waarvan in artikel 17 sub b. en j. wordt gesproken, wil het kind in kwestie - bij het bereiken van de meerderjarigheid ${ }^{604}$ - zijn Indonesisch staatsburgerschap niet verliezen, waardoor een einde wordt gemaakt aan zijn mogelijke status van bipatride. ${ }^{605}$ Toegegeven dient echter te worden dat de Wet op dit punt geen duidelijkheid biedt; wil de Indonesische overheid in het hierbedoelde geval aan het niet optreden van bipatridie de hand houden, dan dient een hierop betrekking hebbende bepaling in de Wet te worden opgenomen.

\subsection{Wettelijke vereisten}

Wat betreft de hierboven onder $b$. genoemde voorwaarde, dat de adoptie wettig dient te worden verklaard door de "Pengadilan Negeri" van de woonplaats van de adoptant kan worden opgemerkt, dat deze voorwaarde wijziging heeft ondergaan door hel Rondschrijven van de "Mahkamah Agung" no.6 van 1983, waarin onder meer de "intercountry adoption" is geregeld. ${ }^{606}$ Met dit Rondschrijven is in afwijking van het bepaalde in artikel 2 van de Wet no. 62 van 1958 gesteld, dat bij adoptie van buitenlandse kinderen door Indonesische staatsburgers, het verzoek tot wettigverklaring van de adoptie dient te worden gericht aan de Voorzitter van de "Pengadilan Negeri" wiens ressort de woonplaats van het te adopteren buttenlandse kind ornvat. ${ }^{\text {m }}$ In aansluiting herop is uidrukkelik bepald dat dit betekent, dat de bepalingen inzake het verzoek tot wettigverklaring/adoptie van kinderen wat betreft de relatieve competentie van de "Pengadian Neger" als geregeld in artikel 2 lid 1 en artikel 17 sub d van de Wet no. 62 van het jaar 1958 - laatstgenoemd artikel hoef betrekking op de adoptie van kinderen die Indonesisch staatsburger zijn door butenlazders - niet langer worden ge-

604. Bij de verliesgronden ex artikel 17 wan de Wet, word het vereiste van het zijn wan meerderiarig de leetiju van 18 jaar bereikt hebhen dan wel op een eerder tijdstip gehwwd zjon - niel met zoveel woorden zesteld, matar is er wel wit af te leiden. $Z_{0}$ is in het geval yan werlies van het indonesisch staxtshurgerschap werens erkenning door sen butenlander, het vereiste wan het zijn van minderjarig in de zin wan de leeftiju wan 18 jar nog wiet hebben bereilat en nog ongefuwid zija, met zoveel woorden genomd. An de in atikel 17 sab k. genomde verliesgrond wegens langdurig verblijf in het butenland, kan woonts worden ontkomen door binnen de daartoe bepalde termijnen het verkangen kenbaat te muken Indonesisch staatsburget te willen blijven. Voor minderjarigen uitgezonderi indien zij gehuwd of gehwwd zjn geweest - beginnen bedoelde termijnen te lopen bij het bereiken wan de leeftijd van 18 jarar.

605, Op deze gronden die leiden tot het verloren gaan van het Indonesisch stantshurgerschap zal is Hwotdstuk 6 worden tenggekomen.

6\%, Met dit Rondschrijven is het eerder uitgegeven Rondschrijwerk wan de "Mabkamah Agung" no. 2 van bet jaar 1979 inzake de adoptie van landeren yervolmakik, hetgeen bet komen te vervallen van latstgenwend Rondschrijven ter gewolge heet gehad.

607. Budiato, M., Pengangkatan anak ditinjau dari segi Hukum, Jakarts, 1984, p.54. 
bruikt. ${ }^{608}$ Het betreft hier een "lex posterior"-regel! Ik ben niettemin van mening, dat wijziging van een bepaling van de Wet no. 62 van 1958 niet met een rondschrijven van de "Mahkamah Agung" kan geschieden, doch daartoe een wet dient te worden afgekondigd. Rekening houdend met de omstandigheid dat een Indonesisch staatsburger bij verblijf buitenlands van de mogelijkheid om een buitenlands kind te adopteren gebruik wilt maken, is de te Jakarta gevestigde Centrale "Pengadilan Negeri" aangewezen om in dit geval de adoptie wettig te verklaren. ${ }^{609}$ De adoptie van het kind in kwestie dient voorts te geschieden met inschakeling van een sociale stichting, die een vergunning dient te bezitten van het Departement van Sociale Zaken, die inhoudt dat het de onderhavige stichting is toegestaan activiteiten te ontplooien op het vlak van de adoptie van kinderen. Dit betekent dat een "private adoption" - een adoptie die rechtstreeks tussen de natuurlijke ouders van het kind in kwestie en de adoptief-ouders wordt afgewikkeld - niet toegestaan is. Ook een adoptie door een niet wettig gehuwde/ongehuwde persoon - één ouder adoptie - is niet toegestaan.

Aangezien de mogelijkheid tot adoptie krachtens het bepaalde in artikel VIII der Slotbepalingen van de Wet no. 62 van 1958 met terugwerkende kracht tot 27 december 1949 in werking is getreden houdt dit in, dat als hierbedoelde adopties sedert genoemde datum verricht binnen de termijn van één jaar gerekend vanaf 1 augustus 1958, konden worden gelegaliseerd op de wijze als hier vastgesteld.

Het adopteren van kinderen is in Indonesië een gebruikelijk verschijnsel. Ook hier dient rekening te worden gehouden met de verscheidenheid van het recht in dit land. In het Adatrecht is deze handeling - in het Indonesisch "pengangkatan" geheten - een normale zaak, waardoor een niet tot de familie behorend kind zodanig in de familie wordt opgenomen, dat daardoor een met bloedverwantschap gelijkstaande betrekking wordt geschapen. Hierbij dient echter te worden opgemerkt, dat deze "pengangkatan" van rechtskring tot rechtskring kan verschillen, aangezien het Adatrecht van plaats tot plaats en van regio tot regio verschilt. Deze handeling vindt vaak plaats, indien de desbetreffende personen geen kinderen hebben, met het doel het nageslacht voort te zetten. Een als hierbedoelde "pengangkatan" dient niettemin met de nodige reserve te worden bekeken, aangezien in de praktijk de zaak vaak gecompliceerd ligt. Zo worden de banden met de oorspronkelijke familie nagenoeg niet geheel verbroken; de mate waarin hangt af van de mate waarin wordt "geadopteerd" en de mogelijkheden die het Adatrecht biedt. ${ }^{610}$

608. Ibid., p.76. In de Bijlage van het Rondschrijven van de "Mahkamah Agung" no. 6 van 1983, is een nadere toelichting gegeven inzake het begrip "domicilie".

609. Zie hiervoor Soedarman Ganda Soebrata, Pengadilan Negeri dalam penyelenggaraan UndangUndang Kewarganegaraan Republik Indonesia, bijlage van het schrijven van de Minister van Justitie no. J.B. $3 / 2 / 25$ van 5 januari 1959, gericht aan alle Voorzitters van de "Pengadilan Negeri's" in Indonesie..

610. De term "adoptie" is wat verwarrend, omdat dan gauw wordt gedacht aan de inhoud, die het Westers recht daaraan toekent. 
Het Islamitisch recht erkent daarentegen het instituut der "pengangkatan" niet c.q. verbindt daaraan generlei rechtsgevolgen. Onder de aandacht kan evenwel worden gebracht, dat in het oorspronkelijk ontwerp van de Indonesische Huwelijkswet, in het jaar 1973 aan de Volksvertegenwoordiging voorgelegd, enkele artikelen inzake de adoptie van kinderen voorkwamen, die de voorwaarden, de wijze, en de gevolgen daarvan regelden. Als gevolg van een compromis tussen de verschillende fracties van de Volksvertegenwoordiging bereikt, werd echter besloten de desbetreffende artikelen te laten vervallen, omdat het Islamitisch recht dit instituut niet erkent. Aangezien adoptie van kinderen een gebruikelijk verschijnsel is, waarvan geregeld door autochtone Indonesische staatsburgers gebruik wordt gemaakt en deze personen, over het algemeen de Islamitische godsdienst belijden, kan de vraag worden gesteld, hoe dit nu rijmt met het niet erkennen van adoptie door het Islamitisch recht. Of is deze aangelegenheid afhankelijk van het feit, in hoeverre het Islamitisch recht in het Adatrecht is gerecipieerd? Naar de mening van Gautama, is het verbod tot adoptie op het Islamitische recht gebaseerd, niet in het Adatrecht gerecipieerd. ${ }^{611}$

Aangezien nog geen speciale wet inzake de adoptie van kinderen bestaat, terwijl de behoefte aan dit instituut zich in de samenleving steeds meer doet gevoelen, werden met het reeds genoemde Rondschrijven van de "Mahkamah Agung" no. 6 van het jaar 1983 inzake de vervolmaking van het eerder uitgegeven Rondschrijven no. 2 van het jaar 1979 nadere richtlijnen met betrekking tot de onderhavige aangelegenheid gegeven. Binnenlandse adopties van kinderen dienen te geschieden bij besluit van de "Pengadilan Negeri", wil een zodanige adoptie rechtsgeldig zijn. Dit geldt ook voor internationale adopties.

Aan de uitgifte van dit Rondschrijven ligt onder meer de overweging ten grondslag, dat de "Pengadilan Negeri" niet altijd het ter zake van een adoptie voorgeschreven nauwkeurig onderzoek instelt. Zo vindt adoptie ook plaats bij notariële akte, die vervolgens door de "Pengadilan Negeri" wordt gelegaliseerd, hetgeen in strijd met de Wet is. Hiemaast komt het vaak voor, dat tot adoptie van kinderen met de nationaliteit van de Chinese Volksrepubliek door Indonesische staatsburgers wordt overgegaan, met het oogmerk dit staatsburgerschap op eenvoudige wijze te verkrijgen. Dit strookt echter niet met het van regeringswege vastgestelde beleid, waarbij adoptie niet dient te geschieden enkel en alleen als middel om het Indonesisch staatsburgerschap te verkrijgen; het gaat hier in eerste instantie om het welzijn van het kind in kwestie. Het ter zake instellen van een nauwkeurig onderzoek door het Gerecht is derhalve vereist, teneinde als zodanig achter de motieven, niet alleen van de natuurlijke ouders maar ook van de adoptief-ouders te komen.

Het Gerecht dient een onderzoek uit te voeren naar de candidaat-adoptiefouders en hun motieven, de eigen ouders van het kind - of naar de sociale lichamen en stichtingen, die

611. Gautama, Hukum Perdata, p.110. 
zich over kinderen hebben ontfermd - en het te adopteren kind zelf. ${ }^{612}$ Bij het nemen van een beslissing, dient het belang van het kind in kwestie voorop te staan.

In aansluiting op het voorgaande kan nog worden opgemerkt, dat in artikel 12 van de Wet no. 4 van het jaar 1979, Stb. 1979-32 betreffende het Welzijn van Kinderen is bepaald, dat de adoptie van kinderen volgens de "adat" en het gebruik geschiedt met vooropstelling van het belang van het welzijn van het kind, welk belang nader bij Regeringsverordening zal worden geregeld. ${ }^{613}$ Vindt adoptie van kinderen plaats buiten de "adat" en het gebruik om, dan dient dit te geschieden krachtens een wettelijke regeling. Alhoewel reeds een ontwerp met betrekking tot deze aangelegenheid is opgesteld, is de behandeling hiervan nog steeds niet voltooid. ${ }^{614}$ De mogelijkheid om een kind te kunnen adopteren is zeker van belang voor het welzijn van families, die geen kinderen hebben. Ook het belang van het kind zélf speelt echter een grote rol, aangezien het kind in kwestie gewoonlijk komt uit minvermogen gezinnen of gezinnen die minder in staat zijn het kind zélf groot te brengen. ${ }^{615}$ Ook ik ben van mening, dat in de hierbedoelde gevallen, adoptie uitkomst kan bieden.

Hierop aansluitend dient echter te worden opgemerkt, dat hier in feite sprake is van doorkruising van twee rechtssferen, met name die van het Adatrecht wanneer de "pengangkatan" van een kind volgens dit recht plaatsvindt en die van het geschreven recht, indien het gaat om de adoptie van kinderen bij wettelijke bepalingen geregeld. Hierbij is de mogelijkheid van frictie tussen bedoelde rechtssferen zeker niet uitgesloten, omdat een "pengangkatan" geldig volgens het Adatrecht, nog niet geldig behoeft te zijn volgens het geschreven recht. Hier speelt het intergentiele recht een rol en gaat het erom, welk recht van toepassing kan worden geacht. Als voorbeeld kan worden genoemd, de adoptie van een kind met de Chinese nationaliteit - dat als zodanig onder het IBW valt - dat wordt geadopteerd door Indonesische staatsburgers die tot de autochtone bevolking behoren, waarop het Adatrecht van toepassing is. In het geval van een geschil met betrekking tot het feit, welk recht van toepassing is, heeft het Gerecht een beslissende stem. Ook Gautama wijst erop, dat in het geval adoptie in de eigen bevolkingsgroep - derhalve intern - plaatsvindt, niet op moeilijkheden wordt gestoten. Anders is het echter indien het gaat om adoptie tussen verschillende bevolkingsgroepen, waarbij het intergentiele recht een rol gaat spelen. ${ }^{616}$

Ook in de Huwelijksordonnantie Christen-Indonesiërs komen adoptief-kinderen ter sprake. Zo is een huwelijk onder meer verboden tussen personen die aan elkaar verwant zijn door adoptie en heeft een onvolwassen persoon die een huwelijk wil aangaan -

612. Als voorbeeld van een als hierbedoelde sociale stichting, kan de te Jakarta gevestigde "Yayasan Sayap Ibu" worden genoemd.

613. Zie voor de tekst van genoemde Wet, Engelbrecht p.2401.

614. Zie Nani Soewondo, Kedudukan Wanita, p.138. Bedoeld ontwerp dat op de adoptie van kinderen betrekking heeft, was reeds in 1984 voorhanden doch de behandeling daarvan is tot op heden nog niet voltooid.

615. Ibid., p.138-139.

616. Gautama, Hukum Perdata, p.110. 
indien hij geadopteerd is - naast toestemming van zijn eigen ouders, die van zijn adoptief-ouders nodig. ${ }^{617}$

Wat betreft Indonesische staatsburgers van Chinese afkomst, kan worden verwezen naar het in $\$ 2.1$ van Hoofdstuk 3 aangehaalde Ind. Stb. 1917-129. Hierin is de toepasselijkverklaring van het voor Europeanen geldende burgerlijk recht en handelsrecht op Chinezen opgenomen, dat ook adoptiemogelijkheden betreft waarvoor een speciale regeling is getroffen. ${ }^{618}$ Voor de hierbedoelde categorie is bepaald dat in het geval een man, die gehuwd of gehuwd geweest is, geen wettige mannelijke nakomelingen eigen of adoptieve - in de mannelijke linie heeft, hij iemand als zijn zoon kan adopteren. Ook de weduwe, indien niet hertrouwd kan, indien geen als hiervoor bedoelde nakomelingen door haar overleden man zijn nagelaten - tenzij laatstgenoemde bij testament te kennen heeft gegeven dit niet te wensen - een persoon als haar zoon adopteren. Van de voor deze adoptie geldende voorwaarden kan worden genoemd, dat dit alleen bij notariële akte kan plaatsvinden. Voorts is uitdrukkelijk gesteld, dat adoptie van meisjes en een als hierbedoelde rechtshandeling die anders dan bij notariële akte plaatsvindt, van rechtswege nietig is. Volgens Budiarto wordt niettemin thans ook de adoptie van meisjes wettig geacht. ${ }^{619}$ Ook Bujung Datuk Intan Sati stelt zich op hetzelfde standpunt; deze auteur wijst erop dat een als hierbedoeld geval door de "Pengadilan Negeri" te Jakarta is beslist en door de "Mahkamah Agung" is bevestigd. ${ }^{620}$ Volgens Gautama, die dezelfde mening huldigt, is de uitbreiding van de adoptiemogelijkheden tot meisjes op een vrije interpretatie gebaseerd, doordat men zich niet langer gebonden acht aan wettelijke regelingen die door de koloniale Overheid zijn achtergelaten. ${ }^{021}$

Voor Indonesische staatsburgers van Europese afkomst, bestaat geen wettelijke regeling inzake adoptie; het IBW bevat - anders dan het Nederlands BW - geen bepalingen betreffende deze aangelegenheid. Aangezien in de praktijk ook in deze kringen de behoefte aan dit instituut zich doet gevoelen, is een regeling afgekomen om adoptie door deze categorie mogelijk te maken. ${ }^{622}$ Tot de uitgifte van het desbetreffende Rondschrijven van de "Mahkamah Agung" no. 6 van het jaar 1983 is in casu overgegaan om in een rechtsvacuüm te voorzien, en tevens om als leidraad te dienen voor de "Pengadilan Negeri" bij de behandeling van verzoeken tot adoptie.

Welk recht dient nu te worden toegepast bij adopties? Volgens Gautama zijn met betrekking tot het recht, van toepassing bij adoptie diverse systemen te onderscheiden,

617. Zie de artikelen 5 lid 1 en 12 lid 1 van de Huwelijksordonnantie Christen-Indonesiërs Java, Minahassa en Amboina, Ind. Stb. 1933-74 jo. 1936-607.

618. In het JBW ź́lf zjjn geen bepalingen opgenomen, die op adoptie betrekking hebben.

619. Zie Budiarto, Pengangkatan anak, p.15.

620. Bujung Datuk Intan Sati, Beberapa hal, Himpunan p.367.

621. Zie Gautama, S., De rechtsontwikkeling in Indonesiê na de souvereiniteitsoverdracht, WPNR 49824984, februari 1968.

622. Gautama, Tafsiran, p.58-59. 
die hier niet nader in beschouwing zullen worden genomen. ${ }^{623}$ Deze auteur geeft er echter de voorkeur aan, om af te gaan op de gewone verblijfplaats van het kind, doorslaggevend voor de uitvoering van een internationale adoptie. Dit komt overeen met hetgeen hieromtrent in het Rondschrijven van de "Mahkamah Agung" no. 6 van het jaar 1983 is bepaald, zoals hierboven uiteengezet. ${ }^{24}$

In een land als Indonesië ligt de hier behandelde aangelegenheid niet zo eenvoudig; zo werd in het voorgaande reeds naar voren gebracht, dat in de sfeer van het Adatrecht de banden met de oorspronkelijke familie nagenoeg niet geheel verbroken worden, doch dit afhangt van de mate waarin wordt geadopteerd en de mogelijkheden die het Adatrecht biedt. Het betreft hier het onderscheid tussen de "adoptio plena" - waarin alle biologische banden worden verbroken - en de "adoptio minus plena", in welk geval dit minder volledig geschiedt. Of volgens het Adatrecht een persoon al dan niet als een "anak angkat" (geadopteerd kind) is aan te merken, is niet altijd eenvoudig vast te stellen. Ook wat betreft de rechtsgevolgen van een adoptie zijn in de praktijk variaties waar te nemen bijvoorbeeld wat betreft de erfgerechtigheid van een geadopteerd kind.Ter illustratie zullen hieronder enkele arresten van de "Mahkamah Agung" (MA) volgen.

Het arrest van de MA no. $281 \mathrm{~K} / \mathrm{Sip} / 1973$ van 29 december 1975 heeft betrekking op het wettig verklaren van een adoptie van een kind op Bali door Tj., aan de hand van het gehele proces aan de adoptie ("pengangkatan") voorafgaande, vanaf het zoeken naar een te adopteren kind, het desbetreffende adatceremonieel, het verblijven van het kind ten huize van $\mathrm{Tj}$. en het beheren van de boedel van $\mathrm{Tj}$. door de geadopteerde persoon in kwestie. ${ }^{625}$

Een tweede geval betreft een pleegkind ("anak piara") in Zuid-Sulawesi. In dit geval werd eiser door de MA niet als een geadopteerd kind, doch slechts als pleegkind aangemerkt. Om deze reden kan de desbetreffende persoon niet als erfgenaam van de overledene worden aangemerkt. Deze aangelegenheid werd door de MA beslist met het arrest no. 942/Sip/1972 van 14 december $1975 .{ }^{626}$

Met het arrest van de MA no. $1002 \mathrm{~K} / \mathrm{Sip} / 1976$ van 13 april 1978 werd de uitspraak gedaan, dat de tijdens huwelijk verworven goederen ("harta gono-gini") tussen Pak en Bok Katodirjo nadat zij hertrouwden werden verdeeld, doch dit geen afbreuk deed aan het feit dat het hier nog steeds om "harta gono-gini" gaat en niet om bij huwelijk ingebrachte goederen ("harta gawan"), die meestal aan de familie van de respectieve partners terugvallen. Om deze reden, werd na het overlijden van Pak Kartidirjo beslist

623. Zie voor de verschillende aspecten die in het algemeen aan het instituut "adoptie" zijn te onderscheiden, Gautama, Hukum Perdata, p. 84-114.

624. Gautama, Hukum Perdata, p. 102-103.

625. Hamid, A.T., Kamus Jurisprudensi dan beberapa Pengertian tentang Hukum (acara) Perdata, vitgegeven door A.T. Hamid, Surabaya, 1984, p.22.

626. Hamid, Kamus Yurisprudensi, p.22. 
dat zijn vrouw Bok Kartidirjo als weduwe en Sugeng als geadopteerd kind gerechtigd zijn als erfgenaam van bedoelde "harta gono-gini" op te treden. ${ }^{627}$

Het arrest van de MA no. $849 \mathrm{~K} / \mathrm{Sip} / 1977$ van 3 juli 1980 betreft de vaststelling van een persoon als geadopteerd kind. Het betreft hier een zaak, waarbij de natuurlijke moeder van wijlen Moestirah gelijktijdig met Moestirah zélf het leven schonk aan een kind, doch het kind van laatstgenoemde kwam te overlijden. Het kind van de moeder van Moestirah (eiseres I) werd vervolgens aan Moestirah afgestaan. Aangezien eiseres I vanaf baby door wijlen Moestirah is verzorgd totdat zij trouwde, werd het billijk geacht om eiseres I als geadopteerd kind aan te merken. ${ }^{628}$

Terugkerend naar de Wet no. 62 van het jaar 1958 kan nog worden opgemerkt, dat met betrekking tot de wettigverklaring van de adoptie door de Pengadilan Negeri, in de ter uitvoering van deze Wet afgekondigde Regeringsverordening no. 67 van het jaar 1958, Stb. 1958-157 de ter zake bevoegde instanties zijn genoemd en de aan een als hierbedoelde adoptie verbonden gerechts- en administratiekosten. ${ }^{629}$

Ter afsluiting van het hier behandelde onderwerp, acht ik het van belang de aandacht te vestigen op een geval van internationale adoptie, dat zich in Indonesië heeft afgespeeld, waarop door Gautama is gewezen. Het betreft hier de uitspraak van de "Pengadilan Negeri" te Tanjung Pinang no. 205/Pdt.P/1989/PN.TPI van 20 mei 1989. ${ }^{630}$ In dit verband rees de vraag, welk recht in dit geval van internationale adoptie dient te worden toegepast. Hierbij werd in overweging genomen, dat de adoptanten de Canadese nationaliteit hebben en het te adopteren kind Vietnamees is en de leeftijd van 12 jaar heeft bereikt. Het Verdrag inzake adoptie van 's-Gravenhage, 1965 werd in dit geval als leidraad genomen, niettegenstaande Indonesië niet tot dit Verdrag is toegetreden, dit met het doel om op het gangbare recht aan te sluiten. ${ }^{631}$ De "Pengadilan Negeri" te Tanjung Pinang achtte zich ter zake bevoegd, omdat de adoptanten hun gewone verblijfplaats aldaar hebben. Wat het toe te passen recht betreft, was de "Pengadilan Negeri" van mening, dat voor de gestelde voorwaarden en de rechtsgevolgen van de onderhavige adoptie op de status van de adoptanten dient te worden afgegaan en om die reden het Canadese recht dient te worden gebruikt, een standpunt door Gautama terecht bevonden. Dit heeft tot gevolg dat de leeftijdsgrens van vijf jaar, zoals in de Wet no. 62 van 1958 gesteld, in dit geval niet geldt, aangezien het Canadese recht deze leeftijdsgrens niet kent. Zijdens de Canadese ambassade werd naar voren gebracht, dat aan een als hierbedoeld kind woonplaats in Canada kan worden verleend als "permanent residence", indien de leeftijd van dit kind beneden de 13 jaar ligt op het tijdstip van de adoptie en daama niet boven 21 jaar komt te liggen en hij nog ongehuwd is. Aangezien de

627. Yurispndensi Indonesia, uitgegeven door de Mahkamah Agung R.I., 1980-II, p. 160-169.

628. Opgenomen in Yurisprudensi Indonesia, uitgegeven door de Mahkamah Agung, 1980-I, p. 179-189.

629. Zie voor deze Regeringsverordening, Engelbrecht p.293. De hierin genoemde bedragen hebben inmiddels wijziging ondergaan.

630. Gautama, S., Adopsi Internasional dalam praktek Peradilan di Indonesia, tijdschrift Hukum dan Pembangunan, 1991, p.83-90.

631. Zie voor meer gevens inzake dit Verdrag, Gautama, Hukum Perdata, p. 102-109. 
"Pengadilan Negeri" ervan uitging, dat de adoptie van het kind in kwestie niet in strijd is met het nationale recht der adoptanten, werd het gepast geacht om het verzoek tot adoptie in te willigen.

\section{$\S 5$ Verkrijging door geprivilegieerde naturalisatie}

Krachtens de artikelen 3 en 4 van de Wet no. 62 van het jaar 1958, kan het Indonesisch staatsburgerschap worden verkregen door inwilliging van een daartoe strekkend verzoek. De hierbedoeide, krachtens de artikelen 3 en 4 te onderscheiden mogelijkheden zullen hieronder aan de orde komen.

Alvorens hierop in te gaan, dient voor een goed begrip te worden aangegeven, hoe de hierbedoelde mogelijkheid tot nationaliteitsverkrijging kan worden getypeerd. In eerste instantie moge het Nederlandse standpunt onder de aandacht worden gebracht, zoals door Adriaanse en van der Weg vertolkt. Genoemde auteurs maken ter zake verschil tussen opties, waarbij de nationaliteit eerst wordt verkregen, nadat op het desbetreffende verzoek door de Minister van Justitie goedgunstig is beschikt en opties, die niet aan het oordeel van genoemde autoriteit zijn onderworpen. ${ }^{632}$ Mijns inziens kan in het eerste geval als hiervoor genoemd, moeilijk van "optie" in de zuivere betekenis daarvan worden gesproken, aangezien hier sprake is van een verzoek ter verkrijging van het Indonesisch staatsburgerschap. Het heeft in dit verband wellicht zin om de mening van de Groot aan te halen, die onderscheid tussen "reine" en "kontrollierte" optierechten maakt. Van "reine" optierechten is sprake "wobei die Behörden auf die Kontrollmöglichkeit beschränkt sind, ob der Optierende die Voraussetzungen für das Abgeben der Optionserklärung erfüllt" terwijl van "kontrollierte" optierechten sprake is "bei denen Behörden die Möglichkeit haben, sich der Optionserklärung aus andere Gründen zu widersetzen". ${ }^{633}$ Deze auteur zegt verder dat het bij een gecontroleerde optie om een geval van verlichte naturalisatie gaat en wijst als een onderscheid tussen bedoelde vormen van optie aan, dat in het eerste geval de nationaliteit op het tijdstip van het afleggen van de desbetreffende verklaring verkregen wordt, terwijl in het tweede geval - in de door hem onderzochte Staten - de nationaliteitsverkrijging steeds constitutief is. Volgens de Groot zijn echter ook gevallen van gecontroleerde opties te constateren, waarin verkrijging van de nationaliteit eerst intreedt, indien in een bepaalde termijn geen bezwaar is gerezen en zelfs eerst, wanneer de desbetreffende optieverklaring door de autoriteiten is goedgekeurd. ${ }^{634}$ Kan bij gecontroleerde optie, nog wel van "optie" worden gesproken, aangezien de Overheid in de hier bedoelde gevallen het voor het zeggen heeft? Of dient de term "optie" voorbehouden te blijven voor die gevallen, waarin de nationaliteitsverkrijging enkel en alleen afhankelijk is gesteld van de wil van de betrokken persoon? Tratnik zegt hieromtrent dat deze wil dient te worden geuit door een uitdrukkelijke, uitsluitend op de verwerving van de nationaliteit gerichte verklaring van de betrokken persoon zelf, die door de Overheid niet mag worden

632. Adriaanse en van der Weg, Nationaliteitswetgeving, Indonesiê, p.Ib-16.

633. De Groot, Staatsangehörigkeitsrecht, p.211. Het gaat hier om gronden van openbare orde, staatsbelang of onvoldoende assimilatie van de betrokken persoon.

634. Zie eveneens De Groot, Staatsangehörigkeitsrecht, p.211. 
geweigerd, indien aan de objektieve optievereisten is voldaan. Hij is van mening, dat in alle andere gevallen de nationaliteit door de Overheid wordt verleend en derhalve gesproken kan worden van naturalisatie ${ }^{635}$, een standpunt ook door mij gedeeld. Wat betreft naturalisatie kan onderscheid worden gemaakt tussen de gewone, uitzonderings-, verlichte c.q. vereenvoudigde en geprivilegieerde naturalisatie, naargelang voor bepaalde groepen naturalisandi hetzij vrijstelling van bepaalde vereisten wordt verleend, hetzij voor hen - tevens - andere lichtere of zwaardere eisen gelden dan bij gewone naturalisatie het geval is.

Hoe kan het hiervoor uiteengezette nu worden toegepast op een land als Indonesië? Zowel in artikel 3 als in artikel 4 van de Wet no. 62 van 1958 wordt het accent gelegd op het indienen van een verzoek ter verkrijging van het Indonesisch staatsburgerschap, waarbij het van de Overheid afhangt of het verzoek al dan niet wordt ingewilligd, los van het feit of de ter zake geldende voorwaarden zijn vervuld door betrokkene. Ko Swan Sik en Moh. Rhadie typeren de hierbedoelde mogelijkheid tot nationaliteitsverkrijging eenvoudigweg als een mogelijkheid tot verlening van het Indonesisch staatsburgerschap op verzoek ${ }^{636}$, in feite conform de typering van de Indonesische overheid als in de onderhavige Wet gevolgd.

Aansluitend bij het standpunt van Tratnik, dat hier geen sprake is van een wijze van verkrijging van de nationaliteit waarbij de beslissing omtrent de verwerving uitsluitend afhankelijk is van de wil van betrokkene, kan worden gezegd dat het hier om een wijze van naturalisatie gaat, aangezien verlening van het Indonesisch staatsburgerschap door de Overheid geschiedt, uiteraard indien goedgunstig op het desbetreffende verzoek wordt beschikt. Op deze wijze kan de Overheid zélf uitmaken, wie al dan niet tot de kring van Indonesische staatsburgers wordt toegelaten. Gaat het nu om een verlichte c.q. vereenvoudige naturalisatie dan wel om een geprivilegieerde naturalisatie? Op deze vraag zal na de behandeling van de artikelen 3 en 4 worden teruggekomen.

\subsection{Op basis van artikel 3 van de Wet}

Met artikel 3 der Wet is de mogelijkheid geopend voor kinderen, zowel buiten huwelijk als uit een wettig huwelijk geboren, wier nationaliteit dat van de vader, een buitenlander volgt, om het Indonesische staatsburgerschap van de moeder te verkrijgen.

Oorspronkelijk was in het ontwerp inzake het Indonesisch staatsburgerschap, deze mogelijkheid beperkt tot kinderen buiten huwelijk geboren, hetgeen door enkele leden van de Volksvertegenwoordiging als in strijd met de gelijkgerechtigdheid van mannen en vrouwen werd aangemerkt, aangezien deze beperking ertoe leidt dat slechts met de status van de man rekening werd gehouden. Het standpunt werd ingenomen, dat deze mogelijkheid ook aan kinderen, uit een gemengd huwelijk geboren dient te worden gegeven, waarbij de status van de moeder doorslaggevend is. Dit leidde tot het indienen

635. Tratnik, Het Nationaliteitsrecht, p.29.

636. Ko Swan Sik en Teuku Moh. Rhadie, Nationality, p. 147. 
van een hierop betrekking hebbend amendement, dat uiteindelijk door de Regering werd aanvaard. ${ }^{637}$ Wat betreft bedoelde, uit een wettig huwelijk geboren kinderen, is de voorwaarde gesteld, dat zij bij de scheiding door de rechter aan de zorg van de moeder zijn toevertrouwd.

In de Memorie van Toelichting van de Wet no. 62 van 1958 is naar voren gebracht, dat aan het opnemen van deze bepaling de overweging ten grondslag ligt, dat het hier kinderen betreft die vanwege het bestaan van een bepaalde regeling, delen in de nationaliteit van hun vader - een buitenlander - terwijl zij zich in werkelijkheid meer bij hun moeder betrokken voelen. Om die reden wordt het billijk geacht om deze kinderen in de gelegenheid te stellen om het staatsburgerschap van de moeder te verkrijgen op het moment $\mathrm{zij}$ in staat worden geacht, zélf over hun nationaliteit te beslissen, waartoe de leeftijd van 18 jaar is vastgesteld.

Het daartoe strekkend verzoek dient binnen de termijn van één jaar na het bereikt hebben van genoemde leeftijd van 18 jaar aan de Minister van Justitie, door bemiddeling van de "Pengadilan Negeri" of de Diplomatieke Vertegenwoordiging van de Republiek Indonesië van de woonplaats van betrokkene in het buitenland te worden gericht. Betreft het een buiten huwelijk geboren kind dat door zijn vader, een buitenlander is erkend, dan dienen op deze situatie betrekking hebbende bewijsstukken te worden ingesloten; dit geldt uiteraard ook voor kinderen uit een gemengd huwelijk geboren. ${ }^{628}$ Genoemde autoriteit kan het verzoek inwilligen dan wel afwijzen; in het eerstgenoemde geval, neemt het aldus verkregen Indonesisch staatsburgerschap een aanvang op de datum van het daarop gerichte besluit van de Minister van Justitie. Benadrukt dient te worden, dat het onderhavige verzoek kan worden afgewezen, ook al is aan alle voorwaarden voldaan. Een overweging, die hierin mede een rol speelt, is hierin gelegen dat het hier om kinderen van buitenlandse nationaliteit gaat, die deze status reeds geruime tijd bezitten. Evenals in het geval van gewone naturalisatie krachtens artikel 5 , hierna te behandelen - gaat het hier om een gunst, om een beleidskwestie en hangt het van de daartoe competente autoriteit af - in dit geval de Minister van Justitie - of het verzoek in kwestie al dan niet wordt ingewilligd. Hierin ligt een belangrijk verschil met een optieverklaring in de betekenis van een wijze van nationali-

637. Dit amendement van 25-6-1958 werd ingediend door de leden van de Volksvertegenwoordiging Dirk Hage, J.R. Koot, Z.A. Tanamas, H. Siradjuddin Abbas.

638. Betreft het hier een buiten huwelijk geboren kind dat door een buitenlander is erkend, dan dient dit uit zijn geboorte-akte te blijken of uit een afzonderlijke erkenningsakte. De nationaliteit van de vader dient te worden bewezen door overlegging van een daarop betrekking hebbend bewijsstuk, zoals bijvoorbeeld een verklaring van de Diplomatieke Vertegenwoordiging van het land van oorsprong. Ook het bewijs dat de moeder Indonesisch staatsburger is, dient door overlegging van een bewijsstuk te worden aangetoond. Overige bewijsstukken dienen betrekking te hebben op het feit, dat betrokkene met het verkrijgen van het Indonesisch staatsburgerschap geen andere nationaliteit zal bezitten en het desbetreffende verzoek is ingediend binnen de daartoe gestelde termijn. Dit geldt ook voor een persoon uit een gemengd huwelijk geboren, met dit verschil dat de huwelijks-en scheidingsakte van de ouders dient te worden overgelegd en het vonnis van de rechter waarbij betrokkene aan de zorg van de moeder is toevertrouwd. Zie Bujung Datuk Intan Sati, Beberapa hal, Himpunan, p.357. 
teitsverkrijging, waarbij de beslissing omtrent de verkrijging uitsluitend afhankelijk is van de wil van betrokkene, een aangelegenheid die in de Wet no. 62 van 1958 slechts summier is geregeld. ${ }^{639}$ Hieraan ligt wellicht de gedachte ten grondslag dat de Overheid zelf wenst te bepalen, wie tot de kring van haar staatsburgers wordt toegelaten.

Een belangrijke voorwaarde, die in deze aangelegenheid een rol speelt, is uiteraard gezien het streven van de Indonesische overheid om zoveel mogelijk het ontstaan van een dubbel staatsburgerschap te voorkomen - dat betrokkene geen andere nationaliteit dient te bezitten dan wel hij zijn verzoek vergezeld laat gaan van een verklaring, van zijn oorspronkelijke nationaliteit afstand te doen, op de wijze daartoe vastgesteld door de wettelijke bepalingen van het land van oorsprong of van de overeenkomst tussen Indonesië en het betrokken land ter regeling van het dubbel staatsburgerschap gesloten. ${ }^{640}$ Dat een officiële verklaring van de Diplomatieke Vertegenwoordiging van het land van oorsprong, die inhoudt dat de verzoeker volgens de wetgeving van het land van oorsprong zijn oorspronkelijke nationaliteit zal verliezen, indien hij het Indonesisch staatsburgerschap verkrijgt van groot belang wordt geacht, blijkt ook uit een Rondschrijven van de Minister van Justitie van 21 juli 1959. ${ }^{641}$

Wordt het in artikel 3 bepaalde aan een nadere beschouwing onderworpen, dan zou kunnen worden geconcludeerd, dat het hier, indien een vergelijking wordt getrokken met het verkrijgen van het Indonesisch staatsburgerschap middels gewone naturalisatie om geprivilegieerde naturalisatie gaat. Alhoewel uit een Rondschrijven van de Minister van Justitie van 27 augustus 1970 blijkt $^{642}$ dat enkele voorwaarden, in het kader van de gewone naturalisatieprocedure gesteld naderhand ook in het hier behandelde geval zijn komen te gelden, die met name op kennis van de Indonesische taal en geschiedenis betrekking hebben terwijl ook een verklaring van goed gedrag van het Hoofd van de plaatselijke Politie dient te worden overgelegd, wordt betrokkenen vrijstelling van de andere, bij de gewone naturalisatieprocedure geldende voorwaarden verleend. ${ }^{* 3} \mathrm{De}$ hierbedoelde nationaliteitsverkrijging wordt in de literatuur niet altijd op dezelfde wijze getypeerd. Zo spreekt Hecker van "Einbürgerung in befristeten Sonderfällen", waaron-

639. Op de verknjging van het Indonesisch staatsburgerschap middels optie, waarbij verschillende variaties zijn te onderscheiden, zal nader worden teruggekomen.

640. Ter illustratie: Het kan hier een buiten echt geboren kind van een autochtone vrouw, die het Indonesisch staatsburgerschap bezit betreffen, dat door de vader, een Nederlander, is erkend, zodat het kind de Nederlandse nationaliteit bezit. In het tweede geval, betreft het een uit een wettig buwelijk - in casu een gemengd huwelijk in de zin van de Huwelijkswet van 1974 - geboren kind, dat derbalve $6 \delta \mathrm{k}$ Nederlander is. Wordt het verzoek in kwestie ingewilligd, dan gaat het Nederlanderschap voor bet kind verloren vanwege het vrijwillig verkrijgen van een andere nationaliteit en wordt bet kind derhalve géćn bipatride.

641. Het betreft hier het Ministeriēle Rondschrijven van $2 J$ juli 1959 no. J.B.3/138/4 aan de Voorzitters van de "Pengadilan Negeri's" in Indonesië gericht.

642. Bedoeld is hier het Rondschrijven van de Minister van Justitie no. D.T.A./152/7 van 27 augustus 1970 aan de Voorzitters van de "Pengadilan Negeri's" in geheel Indonesië gericht.

643. Voorheen diende ook een verklaring inzake de politieke betrouwbaarheid van betrokkenen te worden bijgesloten; deze voonwaarde, die nergens in de onderhavige Wet no. 62 van 1958 voorkomt, is inmiddels komen te vervallen. 
der hij onder meer zowel de in artikel 3 en in artikel 4 jo. artikel $V$ van de Overgangsbepalingen van de onderhavige Wet omschreven gevallen brengt. ${ }^{6+4}$ Bujung Datuk Intan Sati brengt daarentegen onder de aandacht, dat indien de nadruk wordt gelegd op het karakter van het desbetreffende verzoek tot nationaliteitsverkrijging, in casu dat dit verzoek niet verplicht dient te worden ingewilligd, de in artikel 3 opgenomen mogelijkheid kan worden omschreven als een vereenvoudige naturalisatie. ${ }^{645} \mathrm{Ik}$ geeft er echter de voorkeur aan om hier van een geprivilegieerde naturalisatie te spreken.

Ook in dit geval zijn administratiekosten, zowel voor de "Pengadilan Negeri" als voor de Diplomatieke Vertegenwoordiging van de Republiek Indonesië - bij verblijf van betrokkene buitenlands - voor de bemiddelende rol van deze instanties verschuldigd, doch géén gerechtskosten, zoals bij de adoptie van buitenlandse kinderen.

\subsection{Op basis van artikel 4 van de Wet}

Krachtens artikel 4 van de Wet no. 62 van het jaar 1958, worden buitenlanders in de gelegenheid gesteld, om het Indonesisch staatsburgerschap middels een daartoe strekkend verzoek te verkrijgen. Op basis van het eerste lid van dit artikel, dienen betrokkenen aan de navolgende vereisten te voldoen:

1. zij dienen in het gebied van de Republiek Indonesië geboren te zijn en aldaar woonplaats te hebben;

2. hun vader of moeder - indien bedoelde buitenlander geen familierechtelijke betrekking met zijn vader heeft - dient óok in het gebied van de Republiek Indonesië geboren en ingezetene van de Republiek te zijn.

Wat betreft het ingezetenschap van de ouders wijst Bujung Datuk Intan Sati erop, dat deze ouders nog geen ingezetene behoeven te zijn op het tijdstip van geboorte van de betrokken persoon, doch dit wél vereist is, op het tijdstip dat het desbetreffende verzoek wordt ingediend. ${ }^{646}$ Voorts is de voorwaarde gesteld, dat die buitenlander, nadat hij het Indonesisch staatsburgerschap verkregen heeft:

3. gến andere nationaliteit dient te bezitten of het verzoek vergezeld dient te laten gaan van een verklaring van afstand van de andere nationaliteit die hij mogelijkerwijze bezit, in overeenstemming met de geldende wettelijke bepalingen van het land van oorsprong of van de overeenkomst tussen de Republiek Indonesië en het land in kwestie, ter afwikkeling van het dubbel staatsburgerschap gesloten. ${ }^{(4)}$

644. Hecker, Das Staatsangebōrigkeitsrecht, p.57-58.

645. Bujung Datuk Intan Sati, Beberapa hal, Himpunan, p. 356.

646. Bujung Datuk Intan Sati, Beberapa hal, Himpunan, p. 356.

647. De onder 1 tot en met 3 gestelde vereisten dienen te worden bewezen door overlegging van een geboorte-akte van de verzoeker, een persoonsbewijs ("kartu penduduk") of een andere verklaring, die aangeeft dat de verzoeker in Indonesië woonplaats heeft, de geboorte-akte van zijn ouders, een verklaring dat de ouders ingezetene zijn van Indonesië en het bewijs, dat de verzoeker geen andere 
Vervolgens is in het tweede lid van bedoeld artikel 4 van de Wet bepaald dat:

4. het verzoek binnen de termijn van één jaar nadat betrokkene de leeftijd van achttien jaar heeft bereikt dient te worden gericht aan de Minister van Justitie, door bemiddeling van de "Pengadilan Negeri" van zijn woonplaats.

Ingevolge het in het derde en vierde lid van artikel 4 bepaalde, kan de Minister van Justitie het onderhavige verzoek inwilligen of afwijzen. Wordt het verzoek ingewilligd, dan neemt het aldus verkregen Indonesisch staatsburgerschap een aanvang op de datum van het daarop betrekking hebbende besluit van de Minister van Justitie. ${ }^{648}$

De in artikel 4 opgenomen bepaling, heeft bij de behandeling van het ontwerp betreffende het Indonesisch staatsburgerschap in de Volksvertegenwoordiging, de gemoederen danig in beroering gebracht. ${ }^{649}$ Door enkele leden daarvan werd voorgesteld om het onderhavige artikel 4 te doen vervallen, gezien de reeds in artikel 5 van de Wet opgenomen mogelijkheid tot - gewone - naturalisatie. Ook Bujung Datuk Intan Sati stelt de nodige vraagtekens bij dit artikel; hij wijst op de mogelijkheid dat van dit artikel veel gebruik zal worden gemaakt, nadat de geldingskracht van de Overeenkomst inzake het Probleem van de Bipatridie tussen Indonesië en de Chinese Volksrepubliek ${ }^{650}$ door eerstgenoemd land unilateraal is beëindigd. Dit heeft volgens deze auteur ertoe geleid, dat enkele voorwaarden van artikel 5 ook bij de toepassing van artikel 4 - eveneens in het geval van artikel 3 - zijn komen te gelden. Hij wijst voorts op de mogelijkheid, dat dit artikel zal komen te vervallen, overeenkomstig het voorstel van enkele leden van de Volksvertegenwoordiging bij de behandeling van het desbetreffende ontwerp ${ }^{651}$, hetgeen echter tot op heden niet is geschied. Door andere leden van de Volksvertegenwoordiging werd gevreesd dat artikel 4 maar tot onnodige administratieve rompslomp zou leiden; om die reden werd voorgesteld om het in dit artikel 4 bepaalde in artikel 5 van de Wet op te nemen. Door weer andere leden van de Volksvertegenwoordiging werd gewezen op de beduidend zwaardere vereisten inzake geboorte, woonplaats en ingezetenschap zoals in artikel 4 opgenomen, in vergelijking met het op gewone naturalisatie betrekking hebbende artikel 5 . Ook werd de bezorgdheid geuit, dat het onderhavige artikel 4 aanleiding zou geven tot het wederom ter discussie stellen van het binnen het kader van de Toescheidingsovereenkomst - automatisch - verkregen Indone-

647. $\rightarrow$

nationaliteit zal bezitten, na in het bezit te zijn gesteld van het Indonesisch staatsburgerschap. Zie Bujung Datuk Intan Sati, Beberapa hal, Himpunan, p.356.

648. De met de afwikkeling van bedoelde verzoeken belaste autoriteit heeft wijziging ondergaan, aangezien voorheen de Minister van Justitie de goedkeuring nodig had van de Ministerraad. Dit lichaam is echter niet meer in overeenstemming met de Grondwet van 1945, sedert juli 1959 wederom van kracht verklaard.

649. Zie hiervoor de Algemene Beschouwingen Hoofdstuk I van 4-6-1958, RS p.41 inzake de behandeling van dit ontwerp in de Volksvertegenwoordiging.

650. Zie hiervoor $\S 3$ van Hoofdstuk 4.

651. Bujung Datuk Intan Sati, Beberapa hal, Himpunan, p. 356. 
sisch staatsburgerschap door de groep der voormalige uitheemse Nederlandse onderdanen niet-Nederlanders. ${ }^{652}$

Van regeringszijde werden genoemde bezwaren echter niet onderschreven. Naar voren werd gebracht, dat er verschil bestaat tussen de artikelen 4 en 5 en dat artikel 4 zeker niet was opgenomen om louter administratieve redenen. Zo verschillen de gevolgen van het verkrijgen van het Indonesisch staatsburgerschap ex artikel 4 van die van artikel 5 . In het laatste geval bijvoorbeeld, strekt het Indonesisch staatsburgerschap door een weduwe verkregen zich ook uit tot haar kinderen, voor zover deze aan de gestelde voorwaarden voldoen, een mogelijkheid niet door artikel 4 geboden. Ook werd naar voren gebracht, dat aan reeds verkregen rechten niet zou worden getomd en dat artikel 4 slechts voor "newcomers" is bestemd; dit wil zeggen dat van de door artikel 4 geboden gelegenheid slechts gebruik kan worden gemaakt door daarvoor in aanmerking komende personen, ná de inwerkingtreding van de Wet no. 62 van het jaar 1958 op 1 augustus $1958 .^{653}$

Bij nadere beschouwing van het in artikel 4 lid 1 van de Wet bepaalde, kan in eerste instantie worden gewezen op hetgeen hieromtrent in de Memorie van Toelichting van de onderhavige Wet naar de letter is bepaald. Hierin is gesteld, dat een Staat die personen die van buiten komen toestaat zich in zijn gebied te vestigen, "vanzelfsprekend" op een gegeven ogenblik afstammelingen van die personen tot de kring van zijn staatsburgers zal toelaten. In hoeverre en op welke wijze het "ius soli" op personen, die niet staatloos zijn zal worden toegepast, hangt af van de in de desbetreffende landen heersende situatie en de geldende wettelijke regelingen, hetgeen ook voor Indonesië opgaat. Voorts is aangegeven, aan welke personen deze mogelijkheid krachtens deze Wet wordt verleend, met name aan hen, geboren uit een ingezetene van het land of aan personen, die later ingezetene worden, onder voorbehoud dat deze personen geen bipatride mogen worden.

In aansluiting op het bovenstaande kan de vraag worden gesteld, hoe artikel 4 lid 1 , vide de in de aanvang van deze paragraaf onder 1 en 2 opgenomen criteria dient te worden geïnterpreteerd. Naar de letter van de wet, komen voor deze mogelijkheid in aanmerking "in Indonesië geboren en woonplaats hebbende buitenlanders, wier vader of moeder $66 \mathrm{k}$ in Indonesië is geboren en ingezetene van genoemd land is". Uit deze omschrijving kan worden geconcludeerd, dat het hier om de derde generatie van in Indonesië gevestigde buitenlanders gaat, zoals uit de Memorie van Toelichting van de Regeringsverordening no. 67 van het jaar 1958 - ter uitvoering van de Wet no. 62 van het jaar 1958 afgekondigd - blijkt. ${ }^{654}$ Hierin wordt met name aangeknoopt bij het in artikel $\mathrm{V}$ van de Overgangsbepalingen van de Wet no. 62 van het jaar 1958 bepaalde.

652. Zie hiervoor \$ 5.3.2 van Hoofdstuk 3 .

653. Algemene Beschouwingen. Hoofdstuk I van 4-6-1958, RS p.41 inzake de behandeling van het ontwerp betreffende het Indonesisch staatsburgerschap in de Volksvertegenwoordiging.

654. De Memorie van Toelichting op de onderhavige Regeringsverordening is opgenomen in Aanvultend Staatsblad no. 1685. 
Ter toelichting diene, dat artikel 4 - met enige wijzigingen - door middel van voornoemd artikel $\mathrm{V}$ van toepassing is verklaard op kinderen, waarvan de ouders in het kader van de Toescheidingsovereenkomst in de periode van 27 december 1949 tot 27 december 1951 het automatisch verkregen Indonesisch staatsburgerschap hebben verworpen. ${ }^{655}$ Het gaat hier voomamelijk om de groep van de, onder de voormalige categorie van Vreemde Oosterlingen vallende Chinezen. ${ }^{656}$ In de Memorie van Toelichting van de Regeringsverordening no. 67 van het jaar 1958 is met name naar voren gebracht, dat artikel $V$ van de Overgangsbepalingen, dient te worden aangemerkt als een "versoepeling" van het in artikel 4 van de Wet bepaalde, zonder daarbij de principes als vervat, in zowel dit artikel als in de Wet in haar algemeenheid, te veronachtzamen. Hiermede wordt beoogd te zeggen, dat deze versoepeling voomamelijk terecht wordt geacht, voor wat betreft de in artikel 4 gestelde eis van afstamming in tweede graad (kleinkind); deze eis is met name in de toepassing van artikel $\mathbf{V}$ van de Overgangsbepalingen afgezwakt tot afstamming in de eerste graad (kind) van een vader c.q. moeder die het staatsburgerschap van het kind in kwestie destijds verworpen heeft.

Van de door artikel 4 van de Wet geboden gelegenheid kan eerst door kleinkinderen van buitenlanders gebruik worden gemaakt, voor zover zij aan de gestelde voorwaarden, als hiervoor onder 1 tot en met 4 genoemd, voldoen. Met betrekking tot de vraag, waarom eerst kleinkinderen van de door artikel 4 geboden gelegenheid gebruik kunnen maken, werd van regeringswege naar voren gebracht, dat afstammelingen in de eerste graad (kinderen) niet "rijp" genoeg worden geacht om voor verkrijging van het Indonesisch staatsburgerschap in aanmerking te komen.

Ook aan de eis als genoemd onder 3 van deze paragraaf zal niet altijd zonder problemen kunnen worden voldaan. Dit is met name het geval als volgens het recht van het land van oorsprong, de staatsburgers van het land in kwestie de nationaliteit daarvan blijven behouden waar zij zich ook bevinden en derhalve sprake is van een "allégeance perpétuelle" tussen bedoeld land en zijn burgers. ${ }^{657}$ Maken de wettelijke bepalingen van het land van oorsprong het voor een als hierbedoelde persoon niet mogelijk om zijn oorspronkelijke nationaliteit prijs te geven en wordt tussen Indonesië en het desbetreffende land géén overeenkomst ter afwikkeling van het dubbel staatsburgerschap gesloten, dan loopt de persoon in kwestie kans bipatride te worden met als consequentie, dat hij van de door artikel 4 geboden gelegenheid géén gebruik zal kunnen maken.

Het hierbedoelde verzoek dient binnen de termijn van één jaar na het bereiken van de leeftijd van 18 jaar, te worden gericht aan de Minister van Justitie, door tussenkomst van de "Pengadilan Negeri" van de woonplaats van betrokkene.

655. Zie hiervoor \$ 5.3.2 van Hoofdstuk 3.

656. De kwestie van de onderverdeling van de ingezetenen van Indonesie is aan de orde gekomen in 82 van Hoofdstuk 3.

657. Wat betreft Chinezen, heeft dit indertijd aanleiding gegeven tot het sluiten van de Overeenkomst inzake het Probleem van de Bipatridie tussen de Regering van de Republiek Indonesiē en de Chinese Volksrepubliek, het onderwerp van $\$ 3$ van Hoofdstuk 4. 
Met betrekking tot de hierboven genoemde mogelijkheden om het Indonesisch staatsburgerschap door geprivilegieerde naturalisatie middels een daartoe strekkend verzoek, zoals opgenomen in de artikelen 3 en 4 van de Wet te verkrijgen, zij er volledigheidshalve op gewezen, dat dit verzoek niet door een gehuwde vrouw mag worden ingediend, dit krachtens artikel 10 lid 1 van de Wet. Aan deze bepaling ligt het principe ten grondslag, dat beide echtgenoten zoveel mogelijk hetzelfde staatsburgerschap dienen te bezitten. De Wet no. 62 van het jaar 1958 handhaaft in principe het beginsel der eenheid van nationaliteit.

Met het Rondschrijven van de Minister van Justitie van 12 augustus 1970, zijn aanvullende voorwaarden gesteld, waaraan voor het gebruikmaken van de door dit artikel geboden mogelijkheid dient te worden voldaan. ${ }^{658}$ Zoals reeds opgemerkt, dient de persoon in kwestie middels een akte te bewijzen dat hij in Indonesië geboren en aldaar woonplaats heeft, de desbetreffende ouder - vader of moeder - ingezetene van Indonesië is en dat hij buitenlander is. Wordt in de Wet van het "hebben van woonplaats" (in het Indonesisch "bertempat tinggal") in Indonesië gesproken, blijkens het Rondschrijven van de Minister van Justitie van 19 februari 1972 dient deze omschrijving te worden opgevat in de zin van de immigratiebepalingen, te bewijzen middels een vestigingsvergunning of een bewijs van registratie uitgegeven door het Directoraat-Generaal c.q. Kantoor van de Immigratiedienst. Ook het ingezetenschap van de vader c.q. moeder dient te worden bewezen aan de hand van de immigratiebepalingen en eveneens middels een als hiervoor genoemd bewijsstuk te worden gestaafd. ${ }^{659}$ Is de desbetreffende ouder reeds Indonesisch staatsburger, dan kan het bewijs van het bezit van dit staatsburgerschap als zodanig dienst doen. ${ }^{660}$ Hierbij dient in gedachten te worden gehouden, dat het hier meerderjarige personen betreft - die derhalve niet de staat van de betrokken ouder volgen - die van de door artikel 4 geopende mogelijkheid tot verkrijging van het Indonesisch staatsburgerschap gebruik wensen te maken. Hiernaast zijn nog voorwaarden gesteld inzake de kennis van de Indonesische taal en geschiedenis en overlegging van een bewijs van goed gedrag. ${ }^{601}$

Het feit, dat de hierbedoelde personen door verschillende factoren zoals het niet beschikken over de nodige papieren, en de zwaardere, voorheen niet gestelde vereisten, niet altijd op eenvoudige wijze aan de gestelde voorwaarden kunnen voldoen, heeft tot consequentie dat gebruikmaking van de door artikel 4 geboden mogelijkheid op de nodige moeilijkheden kan stuiten! ${ }^{662}$

658. Het betreft hier het Ministeriële Rondschrijven no. D.T.A./152/7 van 12 augustus 1970.

659. In herinnering moge worden gebracht, dat inmiddels tot de afkondiging van een nieuwe Immigratiewet, te weten de Wet no. 9 van het jaar 1992 is overgegaan.

660. Het betreft hier het Rondschrijven van de Minister van Justitie no. JHB.3/4/71 van 19 februari 1972. Bij deze gelegenheid is verklaard dat een persconsbewijs ("kartu penduduk") niet als zodanig dienst kan doen.

661. Ook hier was voorheen een verklaring op de politieke hetrouwbarheid van betrokkene betrekking hebbende verplicht gesteld.

662. De voorwasurden van het hebben van kennis van de Indonesische taal en geschiedenis zjjn eerst op een later tijdstip - hetgeen ook geldt voor artikel 3 - komen te gelden. 
Hoe nu dient de nationaliteitsverkrijging ex artikel 4 te worden opgevat? Ook hier geldt de regel, dat het daartoe ingediende verzoek door de daartoe competente autoriteit kan worden ingewilligd of kan worden afgewezen! In het eerste geval heeft verlening van het staatsburgerschap van overheidswege plaats. Met verwijzing naar hetgeen in het kader van de behandeling van artikel 3 reeds werd opgemerkt, ben ik van mening, dat ook hier van een geprivilegieerde naturalisatie kan worden gesproken. Alhoewel toegegeven dient te worden, dat de krachtens artikel 4 gestelde geboorte- en vestigingseisen aanmerkelijk zwaarder zijn dan de op deze aangelegenheid betrekking hebbende voorwaarden in het kader van de gewone naturalisatieprocedure ex artikel 5 vastgesteld - hierop zal nader worden teruggekomen - kan ook deze nationaliteitsverkrijging worden getypeerd als geprivilegieerde naturalisatie. Dit vindt hierin zijn reden dat betrokkenen van de overige, in artikel 5 gestelde vereisten zijn vrijgesteld en bovendien krachtens artikel 4 een lagere leeftijdsgrens is aangelegd dan in artikel 5 het geval is. Voor de goede orde zij voorts opgemerkt, dat Bujung Datuk Intan Sati ook in dit geval het standpunt huldigt - evenals met betrekking tot de in artikel 3 omschreven mogelijkheid tot nationaliteitsverkrijging - dat indien het accent wordt gelegd op de aard van het desbetreffende verzoek, dat niet verplicht dient te worden ingewilligd, hier van vereenvoudigde naturalisatie kan worden gesproken. ${ }^{663} \mathrm{Hecker}$ spreekt daarentegen ook in dit geval van "Einbürgerung in befristeten Sonderfällen". ${ }^{664} \mathrm{Ik}$ ben niettemin van mening, dat de omschrijving "geprivilegieerde naturalisatie" hier beter op zijn plaats is.

\subsection{Artikel V der Overgangsbepalingen van de Wet}

In het bovenstaande werd reeds opgemerkt, dat de bepalingen, als opgenomen in artikel 4 van de Wet no. 62 van het jaar 1958 - met enige wijzigingen - krachtens artikel V van de Overgangsbepalingen van deze Wet, van toepassing zijn verklaard op kinderen, waarvan de ouders in het kader van de Toescheidingsovereenkomst, het automatisch verkregen Indonesisch staatsburgerschap hebben verworpen.

Bedoelde kinderen deelden in deze verwerping, vanwege het feit dat zij op het beslissende tijdstip - in casu 27 december 1949 - nog niet meerderjarig waren en derhalve niet in de gelegenheid waren, zélf hun staatsburgerschap te bepalen, met als gevolg dat zij de status van buitenlander verkregen. ${ }^{665}$

Het hierboven aangehaalde artikel beoogt bedoelde kinderen alsnog in de gelegenheid te stellen om het Indonesisch staatsburgerschap te verkrijgen op de in artikel 4 omschreven wijze, waarbij door de wetgever met betrekking tot de in genoemd artikel 4 lid 1 en 2 gestelde voorwaarden, een "versoepeling" is doorgevoerd. Zoals reeds opgemerkt, is van regeringswege naar voren gebracht dat het in artikel 4 gestelde beoogt een

663. Bujung Datuk Intan Sati, Beberapa hal, Himpunan, p.356.

664. Hecker, Das Staatsangehörigkeitsrecht, p.57.

665. Zie voor de Toescheidingsovereenkomst \$ 5.3.2 van Hoofdstuk 3. Naar Soedarman Ganda Soebrata naar voren brengt, dient de status van de betrokken persoon aan de hand van bewijzen te worden gestaafd, in casu dat verwerping van het Indonesisch staatsburgerschap van de betrokken persoon heeft plaatsgevonden. Zie Soedarman Ganda Soebrata, Pengadilan Negeri, p. 129. 
regeling te treffen voor "newcomers" en dit artikel zeker niet is bedoeld om aan reeds in het kader van de Toescheidingsovereenkomst - verkregen rechten te tomen. Dit is ook door de Regering bij de behandeling van het desbetreffende ontwerp in de Volksvertegenwoordiging benadrukt.

Anders is het daarentegen gesteld met het in artikel $\mathrm{V}$ van de Overgangsbepalingen bepaalde, aangezien dit artikel in het leven is geroepen met het doel een voorziening te treffen voor personen als hiervoor genoemd.

Ter beantwoording van de vraag, wat de hiervoor genoemde "versoepeling" van de bij artikel 4 der Wet gestelde voorwaarden nu eigenlijk inhoudt, moge voor een goed begrip hieronder het onderhavige artikel $\mathrm{V}$ van de Overgangsbepalingen worden geciteerd:

"Onder afwijking van de bepalingen van artikel 4 lid 1 en 2, worden kinderen, waarvan het Indonesisch staatsburgerschap door de ouders lussen 27 december 1949 en 27 december 1951 is verworpen, in de gelegenheid gesteld om gedurende de termijn van Gén jaar na inwerkingtreding van deze Wet, een verzoek aan de Minister van Justitie, door tussenkomst van de "Pengadilan Negeri" van hun woonplaats te richten, ter verkrijging van het Indonesisch staatsburgerschap, indien zij de leeftijd van 28 jaar nog niet hebben bereikt, onder aantekening dat voor het overige, artikel 4 lid 3 en 4 geldt". ${ }^{666}$

In hoeverre kan nu van het in artikel 4 lid 1 en 2 bepaalde worden afgeweken? Zoals in het voorafgaande medegedeeld, zijn in het eerste lid van dit artikel de voorwaarden als in de aanvang van $\$ 4.2$ onder 1 tot en met 3 genoemd, opgenomen. In het kader van de behandeling van artikel 4 werd reeds gewezen op de "versoepeling" van de eisen, zoals vastgesteld in artikel 4 voornoemd, die hierop neerkomt dat de voor de toepassing van artikel 4 gestelde eis van afstamming in de tweede graad (kleinkind), in het kader van de implementatie van artikel $\mathrm{V}$ is afgezwakt tot afstamming in de eerste graad (kind).

Houdt nu het feit, dat de ter vermijding van het optreden van een eventueel dubbel staatsburgerschap opgenomen bepaling - als hiervoor onder 3 vermeld - onder artikel 4 lid 1 valt in, dat voor de toepassing van artikel $\mathrm{V}$ ook van déze eis kan worden afgeweken? Dit blijkt niet in de bedoeling van de Indonesische wetgever te hebben gelegen, gezien het streven van de Overheid om het ontstaan van een dubbel staatsburgerschap zoveel mogelijk te voorkomen! ${ }^{\text {(57 }}$

Het hierop gericht beleid vormde voor de zogenaamde Vreemde Oosterlingen van Chinese afkomst een moeilijk te boven te komen hinderpaal, omdat een verklaring van

666. De tekst van het onderhavige artikel $V$ der Overgangsbepalingen, is uiteraard in het Indonesisch gesteld.

667. Ook door Soedarman Ganda Soebrata, Pengadilan Negeri, p. 129 wordt uitdrukkelijk erop gewezen, dat geen mogelijkheid tot het ontstaan van bipatridie aanwezig dient te zjnn. 
afstand van deze nationaliteit zeer moeilijk te verkrijgen was. Ook het feit, dat tussen de Indonesische regering en die der Chinese Volksrepubliek indertijd een Overeenkomst ter afwikkeling van de bepatridie was gesloten bood ter zake geen uitkomst, aangezien genoemde Overeenkomst eerst op 20 januari 1960 in werking is getreden, terwijl de Wet no. 62 van het jaar 1958 daarentegen op 1 augustus 1958 van kracht is geworden. Hierbij komt nog, dat de Wet no. 2 van 1958 waarbij de Overeenkomst met de Volksrepubliek werd goedgekeurd en alle uitvoeringsregelingen daarvan, met ingang van 10 april 1969 niet langer door Indonesië van kracht zijn verklaard. ${ }^{668}$

Door de Chinese Volksrepubliek is in het jaar 1980 echter een nieuwe nationaliteitswet aangenomen, die aan de hierboven geschetste moeilijkheden tegemoet kan komen. Dit zal in $\S 6.8$ ter sprake komen, bij de behandeling van de mogelijkheid tot het verkrijgen van het Indonesisch staatsburgerschap middels - gewone - naturalisatie.

Ook de gestelde eis die op de termijn van eén jaar gerekend vanaf 1 augustus 1958 betrekking heeft - die een afwijking vormt van het in artikel 4 lid 2 bepaalde - stuitte in de implementatie van artikel $V$ op moeilijkheden. Dit vond zijn oorzaak hierin, dat van de door dit artikel geboden gelegenheid om middels een verzoek aan de Minister van Justitie gericht - door tussenkomst van de "Pengadilan Negeri" - het Indonesisch staatsburgerschap te verkrijgen, slechts mogelijk was voor personen beneden de 28 jaar. In dit verband kan worden verwezen naar hetgeen in de Memorie van Toelichting van de Regeringsverordening no. 67 van het jaar 1958 omtrent deze aangelegenheid is uiteengezet. In casu konden slechts de navolgende personen van de hierbedoelde mogelijkheid gebruik maken, met name:

1. zij waarvan het Indonesisch staatsburgerschap door de ouders was verworpen omdat de kinderen in kwestie op 27 december 1949 nog geen achttien jaar waren of met andere woorden, kinderen die geboren zijn op 17 december 1931 of daarna. Dit houdt in, dat zij op 1 augustus 1959, niet ouder mochten zijn dan zevenentwintig jaar en vier maanden of op I augustus 1958, zesentwintig jaar en vier maanden;

2. zij die tussen 1 augustus 1958 en 1 augustus 1959 - het tijdstip dat bedoelde gelegenheid afliep - de leeftijd van achttien jaar bereikten, met andere woorden, zij die geboren zijn voór 1 augustus 1941. Deze leeftijd werd benadrukt, omdat eerst met het bereikt hebben van deze leeftijd, de belanghebbende persoon volgens het in de Wet neergelegde principe werd geacht voldoende inzicht te bezitten om zélf zijn staatsburgerschap te kunnen bepalen. ${ }^{609}$

Men kan zich afvragen, welke zin het opnemen van voomoemd artikel $\mathrm{V}$ van de Overgangsbepalingen in feite had, gezien de hiervoor genoemde beperkingen met betrekking tot de gestelde leeftijdsgrens. Dit had tot gevolg, dat slechts weinig personen

668. Zie hiervoor $\$ 3.4$ van Hoofdstuk 4.

669. Ook Soedarman Ganda Soebrata, Pengadilan Negeri, p.130 wijst op de in de Memorie van Toelichting van de Regeringsverordening no. 67 van 1958 opgenomen interpretatie inzake de aangelegde leeftijdsgrens. Hiernaast dienen betrokkenen te bewijzen dat zij in Indonesië woonplaats bebben. 
van de door artikel $\mathrm{V}$ geboden gelegenheid om het Indonesisch staatsburgerschap te verkrijgen, gebruik konden maken. Helaas beschik ik niet over gegevens omtrent deze aangelegenheid uit de praktijk.

Ook het feit, dat de hierbedoelde mogelijkheid tot het verkrijgen van het Indonesisch staatsburgerschap door geprivilegieerde naturalisatie in de vorm van een daarop gericht verzoek diende te worden gedaan - waardoor het van de desbetreffende autoriteit afhing of al dan niet tot inwilliging daarvan werd overgegaan - en niet middels een optieverklaring kon plaatsvinden, werd niet altijd als een billijkheid ervaren. De hier behandelde aangelegenheid is thans uiteraard niet meer opportuun.

\section{$\$ 6$ verkrijging door gewone naturalisatie}

De Wet no. 62 van het jaar 1958 opent de mogelijkheid om het Indonesisch staatsburgerschap door - gewone - naturalisatie te verkrijgen, krachtens een daarop betrekking hebbend besluit van de Minister van Justitie. Het betreft hier een wijze van nationaliteitsverkrijging, waarbij aan personen die aan de gestelde eisen voldoen, door een overheidsorgaan op eigen verzoek - vooropgesteld dat daarop goedgunstig wordt beschikt - de nationaliteit wordt verleend. Anders dan in het geval van - zuivere - optie, werkt de desbetreffende beschikking van het overheidsorgaan constitutief. ${ }^{670}$ Ik spreekt hier van "gewone" naturalisatie, omdat - zoals reeds opgemerkt - onderscheid kan worden gemaakt tussen de gewone, uitzonderings-, vereenvoudigde (of verlichte) en geprivilegieerde naturalisatie. Ook in de Wet no. 62 van 1958 kan dit onderscheid worden gemaakt. Zo is bij de behandeling van de artikelen 3 en 4 de geprivilegieerde naturalisatie reeds aan de orde gekomen. Naast de gewone naturalisatie onderscheidt de Wet de uitzonderingsnaturalisatie, waarover artikel 6 van de Wet - hierna te behandelen - gaat. Dat in de onderhavige Wet ook vereenvoudigde naturalisatie wordt onderscheiden, zal blijken uit de in $\S 9$ gegeven uiteenzetting.

Zoals in $\$ 1$ 1.3.3.3 van Hoofdstuk 2 naar voren gebracht, wordt het expatriatierecht vaak als een fundamenteel menselijk recht voorgesteld. Ook in artikel 15 lid 2 van de Universele Verklaring van de Rechten van de Mens is gesteld, dat aan niemand het recht mag worden ontzegd van nationaliteit te veranderen. Van een "allégeance perpétuelle" is immers geen sprake meer, al kan het recht van expatriatie aan bepaalde voorwaarden zijn verbonden. ${ }^{671}$

Artikel 5 van de Wet geeft aan, aan welke voorwarden dient te worden voldaan om een hierop gericht verzoek te kunnen indienen, als volgt:

a. betrokkene dient de leeftijd van eenentwintig jaar te hebben bereikt;

670. Zie Tratnik, Het Nationaliteitsrecht, p.27.

671. Zie hiervoor het in $\$ 1.3 .3 .3$ van Hoofdstuk 2 uiteengezette, warin uitvoerig op de onderhavige aangelegenheid is ingegaan. 
b. hij dient in het gebied van de Republiek Indonesië te zijn geboren of op het moment van indiening van het verzoek in genoemd gebied tenminste gedurende een periode van de laatste vijf jaar ononderbroken of gedurende een periode van, over het geheel genomen, tien jaar onderbroken woonplaats te hebben;

c. indien hij gehuwd is, toestemming te hebben verkregen van zijn echtgenote c.q. echtgenoten;

d. hij dient de Indonesische taal voldoende te beheersen, enige kennis te bezitten van de Indonesische geschiedenis, en nooit te zijn veroordeeld vanwege een misdrijf dat de Republiek Indonesië nadeel heeft berokkend;

e. betrokkene dient zich in gezonde, geestelijke en lichamelijke conditie te bevinden;

f. hij dient aan 's landskas een som te hebben betaald, waarvan de grootte zal worden bepaald door de Belastingdienst van zijn woonplaats, op basis van zijn reëel maandelijks inkomen; dit bedrag mag genoemd inkomen niet te boven gaan;

g. betrokkene dient over een vaste bron van inkomen te beschikken;

h. hij dient geen nationaliteit te bezitten of zijn nationaliteil te verliezen indien hij het Indonesisch staatsburgerschap verkrijgt of een verklaring in te sluiten, afstand te doen van die andere nationaliteit volgens de wettelijke bepalingen van het land van oorsprong dan wel volgens de overeenkomst ter afwikkeling van het dubbel staatsburgerschap tussen de Republiek Indonesië en het desbetreffende land gesloten.

Het betreft hier de voorwaarden, waaraan dient te worden voldaan om een verzoek tot naturalisatie als in artikel 5 van de onderhavige Wet no. 62 van 1958 geregeld, te kunnen indienen.

Wordt op het verzoek goedgunstig beschikt, dan dient de betrokken persoon een eed c.q. belofte van trouw binnen de daartoe gestelde termijn af te leggen c.q. uit te spreken. Het Indonesisch staatsburgerschap gaat in met terugwerkende kracht tot de datum van het ministerieel besluit dat op de verkrijging daarvan betrekking heeft. Wordt bedoelde eed c.q. belofte van trouw niet afgelegd/uitgesproken, dan komt het ministerieel besluit van rechtswege te vervallen. Aan het vereiste van het afleggen van de eed c.q. uitspreken van de belofte van trouw ligt de overweging ten grondslag, dat het hier om buitenlanders gaat, die op deze wijze het Indonesisch staatsburgerschap verkrijgen.

Verlening van het staatsburgerschap middels naturalisatie is een gebruikelijk beginsel dat in het nationaliteitsrecht voorkomt. De daartoe gestelde voorwaarden verschillen van land tot land, afhankelijk van het ten aanzien van vreemdelingen gevoerde beleid. Een land dat tracht zoveel mogelijk emigranten aan te trekken - met name landen met een bevolkingstekort - zal in het vaststellen van de voorwaarden met betrekking tot naturalisatiemogelijkheden flexibeler zijn dan een land dat hierin een meer restrictief beleid voert. Ko Swan Sik en Teuku Moh. Rhadie zeggen met betrekking tot Indonesië hieromtrent onder meer het volgende: "The institution of naturalization is of particular importance in Indonesia because of the large alien population in the country, the constant need for family reunions of both alien residents and nationals of alien ("non- 
indigenous") origin, the continous trickle of new immigrants...." ${ }^{672}$ Gautama wijst erop, dat krachtens de Wet van 1910 het Nederlands onderdaanschap aan alle personen die aan de gestelde vereisten voldeden - waarvan geboorte op Nederlands-Indisch grondgebied wel én van de voornaamste was - werd opgelegd en in feite van een "collectieve naturalisatie" kon worden gesproken. De Wet no. 62 van 1958 gaat daarentegen van een geheel ander systeem uit, waarbij van "dwang" geen sprake is, deze Wet beoogt zeker niet om een persoon te dwingen het Indonesisch staatsburgerschap te aanvaarden. Volgens deze auteur loopt de vrijheid tot het maken van een keuze als een rode draad door de nationaliteitswetgeving heen. ${ }^{673}$ Mijns inziens gaal deze visie wél op in het geval van verkrijging van het Indonesisch staatsburgerschap middels het afleggen van een optieverkJaring; gaat het echter om de verkrijging van dit staatsburgerschap middels (gewone, geprivilegieerde of vereenvoudige) naturalisatie, dan hangt het van de Overheid af of een verzoek tot naturalisatie al dan niet wordt ingewilligd.

In de Memorie van Toelichting van Wet no. 62 van 1958 is naar voren gebracht, dat in het geval een buitenlander werkelijk van de wens doet blijken om Indonesisch staatsburger te worden, het billijk wordt geacht hem in de gelegenheid te stellen om deze wens te doen verwezenlijken. Hierbij is het voorbehoud gemaakt, dat de verlening van dit staatsburgerschap niet tegen de belangen van de Republiek Indonesië mag indruisen. Om die reden zijn objectieve voorwaarden gesteld, waaraan dient te worden voldaan, teneinde een verzoek tot naturalisatie te kunnen indienen.

Hierop aansluitend moge de mening van Paulus worden weergegeven, een auteur die aan de nationaliteit in sociologische betekenis de voorkeur geeft boven de juridische betekenis daarvan. ${ }^{674}$ Volgens deze auteur moet om Indonesisch staatsburger te kunnen zijn, de persoon in kwestie zich met het Indonesische volk kunnen vereenzelvigen. $\mathrm{Hij}$ is om die reden van mening, dat ook de adatrechtsgemeenschappen bij de naturalisatieprocedure dienen te worden ingeschakeld. In dit verband worden vereisten als "enige kennis" van de Indonesische geschiedenis en "voldoende beheersing" van de Indonesische taal - hierboven genoemd - door Paulus als te licht aangemerkt. Hij gaat uit van het Indonesische volk, de autochtone Indonesiërs die tezamen het Indonesische volk vormen, waarin andere dan deze zich dienen op te lossen. ${ }^{675}$ Paulus vindt dat de Wet no. 62 van 1958 om die reden niet aan deze aspiraties voldoet en stelt voor om deze Wet af te schaffen c.q. te vervangen door een nieuwe Wel. ${ }^{676} \mathrm{Ik}$ ben het echter niet met deze auteur eens, al wil dit niet zeggen dat de onderhavige Wet niet voor wijziging c.q. aanvulling vatbaar is. Het door Paulus voorgestelde strookt niet met het beleid van de Indonesische Overheid om buitenlanders de gelegenheid te geven Indonesisch staatsburger te worden, waarbij niet zulke extreme voorwaarden gelden om een verzoek

672. Ko Swan Sik en Teuku Moh. Rhadie, Nationality, p.147. Deze auteurs brengen naar voren, dat in de periode tussen 1965 en 1985 ongeveer 80.000 naturalisatieverzoeken zjjn ingewilligd.

673. Gautama, Tafsiran, p.96-97.

674. Zie voor deze betekenissen van het begrip "nationaliteit", $\$ 1.1$ van Hooldstuk 2.

675. De oplossing in de autochtone bevolking werd behandeld in $\$ 2.3$ van Hoofdstuk 3 .

676. Zie Paulus, Kewarganegaraan R.I., p.489-495. 
tot naturalisatie te kunnen indienen, als door Paulus voorgesteld. Bovendien wordt althans juridisch - geen onderscheid meer gemaakt tussen autochtone en niet-autochtone staatsburgers, zoals van bevoegde zijde - met name door de Minister van Justitie - is medegedeeld en met Presidentieel Besluit no. 240 van het jaar 1967 is benadrukt; volgens dit Besluit maken Indonesische staatsburgers van buitenlandse afkomst deel uit van het Indonesische volk en verschillen niet in rechten en verplichtingen van andere, daartoe behorende personen. ${ }^{6 n}$ Het lijkt mij derhalve niet op zijn plaats, om te veel het accent te leggen op het deel uitmaken van de autochtone bevolking, aangezien de Overheid juist van dit onderscheid wenst af te stappen. ${ }^{678}$ Niettegenstaande in artikel 5 van de Wet no. 62 van 1958 enkele voorwaarden zijn opgenomen, waaruit kan worden afgeleid dat de persoon die een verzoek tot naturalisatie indient zich nauw bij Indonesië betrokken voelt - zoals het langdurig aldaar gevestigd zijn en het hebben van enige kennis van de Indonesische taal en geschiedenis - is een volkomen oplossing in de Indonesische bevolking, waarbij afstand dient te worden gedaan van de eigen culturele identiteit zoals door Paulus voorgestaan, niet voorgeschreven.

In het onderstaande zullen de verschillende voorwaarden worden behandeld, voor het indienen van een verzoek tot naturalisatie vastgesteld.

\subsection{De leeftijd van 21 jaar}

Met betrekking tot de vastgestelde leeftijdsgrens van 21 jaar - een op een eerder tijdstip gesloten huwelijk, is in dit geval niet van invloed - kan worden gewezen op het feit, dat hier een hogere leeftijdsgrens is aangelegd, dan over het algemeen in de Wet aangehouden. ${ }^{679}$

677. Zie hiervoor § 1.3.3.4 van Hoofdstuk 2 .

678. Ter illustratie: Als voorbeeld van een door te voeren versoepeling ter zake van het naturalisatiebeleid kan de gezamenlijke motie van de fractiespecialisten van CDA en PvdA worden genoemd, waarin voor het Nederlandse kabinet de nodige ruimte is gecreēerd om het naturalisatiebeleid in de Nederlandse nationaliteitswetgeving daadwerkelijk te versoepelen. Naar de Volkskrant van 11 oktober 1991 meldt, hoeven migranten die Nederlander willen worden, niet langer afstand te doen van bun eigen nationaliteit, zoals de wet nu nog voorschrijft. Volgens het NRC Handelsblad van 9 november 1991 heeft het kabinet inmiddels tot wijziging van de Wet op het Nederlanderschap van 1985 besloten, nadat daarvoor onlangs in de Tweede Kamer steun bleek te bestaan van de fracties van CDA en PvdA. Dit betekent dat als hierbedoelde buitenlanders eventueel de staat van bipatride kunnen bezitten.

679. Ter staving dient een geboorte-akte van de Burgelijke Stand of een akte van bekendheid - opgemaakt ten overstaan van de Regent ("Bupati") van de woonplaats van betrokkene, in tegenwoordigheid van twee getuigen - te worden overgelegd. Voor een persoon buiten Indonesië geboren, kan een uittreksel van de geboorte-akte van de Burgelijke Stand, opgemaakt door de registratiebeambte van de plaats van zijn geboorte of een verklaring van de Diplomatieke Vertegenwoordiging van het land van oorsprong van de verzoeker als bewijs dienen. Voor personen, in Indonesië geboren, dient ook een bewijs te worden overgelegd, dat betrokkene buitenlander is. Dit kan onder meer worden aangetoood door overlegging van een buitenlands paspoort of eeen verklaring het Indonesisch staatsburgerschap verworpen te hebben. Zie Bujung Datuk Intan Sati, Beberapa pokok-pokok, Himpunan p. 340 . 
Wordt eerst ingegaan op de bepaling, dat een op een eerder tijdstip gesloten huwelijk niet van invloed is, dan kan worden opgemerkt dat dit in feite neerkomt op een beperking van de hier gestelde voorwaarde. Immers, een persoon die op een eerder tijdstip in het onderhavige geval vór het bereiken van de leeftijd van 21 jaar - in het huwelijk is getreden, wordt in de regel als meerderjarig aangemerkt en blijft deze status behouden, indien het huwelijk wordt ontbonden. In artikel 5 van de onderhavige Wet wordt met deze aangelegenheid echter geen rekening gehouden, zodat ook vóor het bereiken van de leeftijd van 21 jaar gehuwde personen, om een verzoek tot naturalisatie te kunnen indienen, dienen te wachten tot zij genoemde leeftijd hebben bereikt.

Met betrekking tot het aanhouden van een hogere leeftijdsgrens dan normaliter in de Wet aangehouden, kan als voorbeeld worden aangehaald, dat in de toepassing van de in de artikelen 3 en 4 omschreven mogelijkheden tot verkrijging van het Indonesisch staatsburgerschap middels geprivilegieerde naturalisatie, de leeftijdsgrens op 18 jaar is gesteld. Genoemde leeftijd van 18 jaar is ook als maatstaf genomen, teneinde te bepalen in hoeverre kinderen delen in de verkrijging dan wel het verlies van het Indonesisch staatsburgerschap van respectievelijk hun vader of moeder.

Waarom hier een hogere leeftijdsgrens is aangehouden? In de Memorie van Toelichting van de Wet is slechts de wenselijkheid tot het hanteren van een hogere leetijdsgrens tot uitdrukking gebracht zonder enige nadere argumentatie. Gewezen kan echter worden op de hiermede overeenkomende leeftijd die op de meerderjarigheid betrekking heeft, als vastgesteld in het IBW. ${ }^{680}$ Een andere overweging die mijns inziens in deze aangelegenheid een rol heeft gespeeld, ligt hierin dat een persoon die de hierbedoelde leeftijd heeft bereikt meer in staat wordt geacht, om de ernst van zijn beslissing onder ogen te zien, een overweging die ook elders in de onderhavige Wet voorkomt.

De gestelde leeftijdsgrens om voor naturalisatie in aanmerking te komen, kan van land tot land verschillen. Is géén bepaalde leeftijd genoemd, doch volstaan met de bepaling "die meerderjarig zijn" dan kan men zich afvragen, het recht van welk land dient te bepalen of aan de gestelde voorwaarde van "meerderjarig zijn" is voldaan. Wordt ervan uitgegaan, dat het zijn van meerderjarig aan de hand van het personeel statuut van

680. Ook in de Wet no. 3 van 1946 van de Yogya-regering werd de leeftijd van 21 jaar aangehouden. In het rechtsverkeer buiten de geldingssfeer van het Adatrecht om, kan de noodzaak njzen om vast te stellen of een persoon al dan niet als handelingsbekwaam dient te worden aangemerkt, waarbij de leeftijd een rol gast spelen. Teneinde onzekerheid hieromtrent weg te nemen, is bij Ordonnantie van 31 januari 1931, Ind. Stb. 1931-54 bepaald, dat voor zover de autochtone bevolking betreffende, met de term "minderjarig" zijn bedoeld, personen die de leeftijd van 21 jaat nog niet hebben bereikt en niet op een eerder tijdstip in het huwelijk zijn getreden. De noodzaak hiertoe deed zich voor, omdat in het Adatrecht andere maatstaven worden gehanteerd teneinde te bepalen of een perscon al dan niet als volwassen wordt aangemerkt, waaronder het tijdstip waarop betrokkene gehuwd uit de ouderlijke- of schoonouderlijke gezinswoning wegtrekt en het paar zich zelfstandig vestigt. Ook het Islamitisch recht hanteert andere maststaven, met name het tijdstip dat betrokkene geacht wordt in staat te zijn zelfstandig op te treden dan wel "rasjid" geworden is, dit ter beoordeling van zjjn voogd("wali"), zie Juynboll, Handleiding p.229-230. Zie voorts Gautama, Hukum Perdata, p.38. 
betrokkene dient te worden vastgesteld, dan houdt dit in, dat het eigen - nationaal recht van betrokkene ter zake geldt, voor zover betrokkene een nationaliteit bezit. ${ }^{681}$

\subsection{Geboorte of woonplaats in Indonesië}

Met betrekking tot de voorwaarde, dat betrokkene in het gebied van de Republiek Indonesië dient te zijn geboren of tenminste gedurende de in het onderhavige artikel aangegeven periode - zoals hiervoor onder b. genoemd - aldaar woonplaats heeft gehad, kan worden opgemerkt, dat aan de hand van de in het kader van de immigratiewetgeving aan betrokkene verstrekte toelatingskaart of verblijfsvergunning, kan worden beoordeeld of aan deze voorwaarde is voldaan. ${ }^{682}$

Een bepaling van soortgelijke strekking wordt normaliter onder de voorwaarden om voor naturalisatie in aanmerking te komen in het nationaliteitsrecht opgenomen, aangezien uit het langdurige verblijf van een persoon in een bepaald land blijkt - anders dan in dienst van de Overheid van zijn land, in welk geval het verblijf buitenlands noodzakelijk is - dat hij zich bij het land in kwestie betrokken voelt. Uit de gestelde voorwaarde blijkt dat - anders dan in artikel 4 - betrokkene niet in Indonesie behoeft te zijn geboren, doch kan worden volstaan met het aldaar woonplaats te hebben gedurende de daartoe vastgestelde termijn. ${ }^{683}$ Uit artikel 5 lid 3 van de Wet no. 62 van 1958 blijkt voorts, dat ook personen die niet in Indonesië woonachtig zijn kunnen worden genaturaliseerd. Dit houdt in, dat ook een persoon die in Indonesië geboren is of aldaar gedurende een ononderbroken periode van vijf jaar c.q. een onderbroken periode van in het totaal tien jaar woonachtig is geweest en thans in het buitenland vertoeft kan worden genaturaliseerd. ${ }^{684}$ In het hierbedoelde geval dienen de Diplomatieke Vertegenwoordigingen in het buitenland te worden ingeschakeld, om eventuele

681. Zie voor het personeel stanut, Gautama, Hukum Perdata, p.2-3. In Indonesiē geldt ter zake artikel $16 \mathrm{AB}$. Krachtens dit artikel geldt voor Indonesische staatsburgers die zich buitenlands ophouden eveaals voor buitenlanders die zich in Indonesiē bevinden - hun eigen nationale recht.

682. Voor degenen, buiten Indonesiē geboren, dient een verklaring van de Immigratiedienst te worden bijgeslotea, die inhoudt dat de verzoeker op het tijdstip van indiening van het desbetreffende verzoek tenminste de laatste 5 jasr ononderbroken of in het geheel gedurende 10 , niet achtereenvolgende jaren, woonplaats heeft gehad in Indonesiê. Zie Bujung Datuk Intan Sati, Beberapa pokok-pokok, Himpunan p. 340. Zie voorts de nieuwe Immigratiewet no. 9 van 1992.

683. In de Rijkswet op het Nederlanderschap van 1985 is ter zake van naturalisatie het vereiste gesteld, dat tegen het verblijf van naturalisandi voor onbepaalde tijd in Nederland, geen bezwaar dient te bestaan. In enkele gevallen bestaat een uitzondering, waaronder ten aanzien van oud-Nederlanders en oud-Nederlandse onderdanen, mits zjj reeds voor hun komst naar Nederland een bijzondere band met dit land hadden op grond van opvoeding, dienstbetrekking, maatschappelijke positie of anderszins. Het enkele feit, dat betrokkene te eniger tijd de Nederlandse nationaliteit heeft bezeten, schept nog geen bijzondere band. Behalve de Nederlandse afstamming moeten er andere feiten zijn, die aannemelijk maken dat de betrokkene nauwe banden met Nederland heeft. Zie van der Avoort, A.S. en de Groot, G.R., De Rijkswet op het Nederlanderschap, De jurisprudentie naar aanleiding van art. 8,9 en 10 van de Rijkswet op het Nederlanderschap nader onderzocht, Migrantenrecht, 1992, p. 28.

684. Zo ook de mening van Adriaanse en van der Weg, Nationaliteitswetgeving, Indonesië, p.Ib- 13 en 14. 
bewijsstukken op de juistheid daarvan te onderzoeken en betrokkene op het beheersen van de Indonesische taal en het bezitten van enige kennis van de Indonesische geschiedenis te testen.

\subsection{Instemming van de echtgenote(n)}

Dat betrokkene, indien hij gehuwd is, de instemming van zijn echtgenote c.q. echtgenoten - in laatstbedoeld geval, indien het een polygaam huwelijk betreft - nodig heeft ligt voor de hand, aangezien de verandering van nationaliteit rechtsgevolgen heeft voor het gehele gezin. Ook de echtgenote zal immers - indien ook zij een buitenlandse status heeft - het door haar echtgenoot verkregen Indonesisch staatsburgerschap komen te bezitten, voor zover het voor haar geldende nationaliteitsrecht dit mogelijk maakt. In dit verband dient op het bepaalde in artikel 9 lid 1 van de Wet worden gewezen, dat nader zal worden toegelicht. Belangrijk in dit opzicht is de voorwaarde dat zij hierdoor niet de staat van bipatride mag verkrijgen. Bujung Datuk Intan Sati wijst erop, dat het hierbedoelde bewijs van instermming niet als bewijs van prijsgeving van de nationaliteil door de vrouw dienst kan doen. Wil de vrouw tegelijk met haar man het Indonesisch staatsburgerschap verkrijgen, dan dient zij een bewijs van prijsgeving van haar oorspronkelijke nationaliteit naast het bewijs van instemming bij te sluiten. ${ }^{685}$ Dat hier rekening is gehouden met de mogelijkheid van het voorkomen van polygame huwelijken, dient te worden gezien tegen de achtergrond van de Indonesië heersende rechtsverscheidenheid. ${ }^{686}$

De Wet no. 62 van het jaar 1958 gaat niet uit van het gelijkgerechtigdheidbeginsel. Zoals uit artikel 5 lid 2 sub h tweede alinea van de Wet blijkt, is het gehuwde vrouwen niet toegestaan om een verzoek tot naturalisatie in te dienen, aangezien gevreesd wordt dat het door de Wet gehuldigde beginsel van eenheid van nationaliteit der echtgenoten hierdoor in gevaar zou worden gebracht. De echtgenoot kan echter niet handelen, zonder daartoe bijstand van zijn echtgenote(n) te hebben verkregen. Van het hierboven uiteengezette kan echter in zoverre worden afgeweken, dat krachtens artikel 13 lid 2 tweede alinea der Wet een vrouw, moeder van kinderen met de status van weduwe, wél een verzoek tot naturalisatie kan indienen. In dit geval delen haar kinderen, die een familierechtelijke betrekking met de - overleden - vader hadden, in het door haar verkregen Indonesisch staatsburgerschap, waartoe aan bepaalde voorwaarden dient te zijn voldaan. Hieronder valt uiteraard niet het geval van een moeder, wiens huwelijk door echtscheiding is ontbonden en waarvan de vader nog in leven is.

685. Het is ook mogelijk, dat de vrouw reeds Indonesisch staatsburger of staatloos is. Zie Bujung Datuk Intan Sati, Beberapa hal, Himpunan, p. 355.

686. Voor dit doel dient een afsehrift/uittreksel van de huwelijksakte te worden overgelegd; in het geval van een huwelijk buiten Indonesie voltrokken kan eventueel worden volstaan met een verklaring van de Diplomatieke Vertegenwoordiging van het land van herkomst. Ook een geschreven verklaring van instemming van de echtgenote dient te worden overgelegd. Bujung Datuk Intan Sati, Beberapa pokok-pokok, Himpunan, p.341. 
Bedoelde kinderen dienen namelijk de leeftijd van 18 jaar nog niet hebben bereikt c.q. niet gehuwd te zijn. Bovendien gaat een en ander eerst op, nadat deze kinderen in Indonesië woonplaats hebben en aldaar de facto verblijven. Hierbij zij echter opgemerkt, dat laatstgenoemde voorwaarde niet geldt voor kinderen, die vanwege het verkrijgen van het Indonesisch staatsburgerschap door de moeder, staatloos zouden worden. Dit impliceert, dat ook buitenlands verblijvende kinderen, waarvan hun buitenlandse - nationaliteit verloren gaat vanwege het worden van Indonesisch staatsburger door hun moeder, Indonesisch staatsburger worden.

Aan de mogelijkheid tot het indienen van een verzoek door een weduwe ligt de overweging ten grondslag, dat in het hierbedoelde geval de vrouw in kwestie de staat van weduwe heeft. Volgens het in de Toelichting op de Wet gestelde is deze mogelijkheid opengesteld voor een weduwe, omdat de verandering van staat veroorzaakt wordt door een handeling die "zorgvuldige afweging" noodzakelijk maakt, met name door naturalisatie. Mijns inziens behoeft iedere verandering van nationaliteit echter zorgvuldige afweging! Meer op zijn plaats lijkt mij het motief, dat het huwelijk reeds ontbonden is door het overlijden van de echtgenoot en het derhalve billijk wordt geacht, dat de weduwe zelfstandig kan optreden c.q. dat haar kinderen - voor zover aan de gestelde voorwaarden is voldaan - in de verkrijging van het Indonesisch staatsburgerschap van de moeder delen.

Als tegenpool van het in artikel 13 lid 2 tweede alinea van de Wet bepaalde, is in artikel 15 lid 3 een bepaling opgenomen inzake het verlies van het Indonesisch staatsburgerschap van een moeder met de status van weduwe door naturalisatie in het buitenland en de consequenties hiervan voor haar kinderen. Op deze aangelegenheid zal in Hoofdstuk 6 worden teruggekomen.

\subsection{Kennis van de Indonesische taal en geschiedenis}

De voorwaarde op het beschikken van een redelijke kennis van de Indonesische taal en geschiedenis betrekking hebbende, duidt erop, dat het begrip "nationaliteit" niet alleen in juridische zin, doch ook in sociologische betekenis kan worden opgevat.

De persoon, die van de mogelijkheid om zich tot de nationaliteit van een bepaald land te laten naturaliseren gebruik wenst te maken, dient blijk te geven van zijn betrokkenheid bij het land in kwestie. In dit licht dient de voorwaarde "een redelijke kennis van de Indonesische taal bezitten" te worden gezien, een voorwaarde - van soortgelijke strekking - die ook in de nationaliteitswetgeving van andere landen vaak voorkomt. ${ }^{687}$ Wat betreft de eis van "enige kennis van de Indonesische geschiedenis bezitten" kan

687. Een soortgelijke voorwaarde is ook gesteld in de Rijkswet op het Nederlanderschap van 1985 (artikel 8 sub d.), teneinde als "ingeburgerd" te kunnen worden beschouwd, naast het "zich in de samenleving te doen opnemen". Van der Avoort en de Groot wijzen echter erop, dat het begrip "inburgering" dient om ontwikkelingsproces aan te duiden, dat leidt tot daadwerkelijke participatie in de samenleving en niet wil zeggen dat de vreemdeling zijn culturele identiteit dient op te geven. Zie van gencemde auteurs, De Rijkswet, p.29. 
men zich afvragen of deze eis niet te "zwaar" kan worden geacht in verband met het in Indonesie nog voorkomende analfabetisme. Het gaat hier echter om een "redelijke" beheersing van de Indonesische taal en "enige" kennis van de Indonesische geschiedenis.

Met betrekking tot de vraag, wie over het voldoen aan de hierbedoelde voorwaarden dient te oordelen, kan worden opgemerkt dat voor deze aangelegenheid de "Pengadilan Negeri" van de woonplaats van betrokkene - of de Diplomatieke Vertegenwoordiging van de Republiek Indonesië in het buitenland gevestigd - is aangewezen. Het hierin te volgen beleid is niet aan vastliggende normen gebonden, doch zal worden uitgevoerd met inachtneming van de positie van de persoon in kwestie c.q. de plaatselijke omstandigheden. De hierbedoelde test zal onder meer aangelegenheden omvatten, als de Indonesische vrijheidsstrijd, de betekenis van het begrip "Pancasila", terwijl het beheersen van de Indonesische taal, de spreektaal - niel de geschreven taal - betreft. De onderhavige personen kunnen aan een hernieuwde test worden onderworpen, indien hun kennis (nog) niet voldoende wordt geacht. ${ }^{888}$

\subsection{Misdrijf jegens de Staat}

Het behoeft geen nadere uitleg, dat een persoon, die zich schuldig heeft gemaakt aan een misdrijf jegens de Staat, niet van de hier geboden gelegenheid om zich tot Indonesisch staatsburger te laten naturaliseren, gebruik kan maken.

Ook deze voorwaarde dient te worden gezien tegen de achtergrond, dat het Indonesisch staatsburgerschap slechts wordt verleend aan buitenlanders die werkelijk van de wens om Indonesisch staatsburger te worden hebben blijk gegeven en zeker niet een misdrijf hebben gepleegd, dat de Indonesische Staat benadeeld zou kunnen hebben. Niet aangegeven is echter, wanneer van een "misdrijf jegens de Staat" kan worden gesproken. Is hier een misdrijf bedoeld dat het staatsbelang heeft benadeeld, of dat indnist tegen de openbare orde of goede zeden? Ik ben van mening dat kan worden aangenomen, dat het hier niet om een misdrijf gaat, waarvoor betrokkene door het Gerecht is veroordeeld, doch waar de Staat als zodanig buiten staat.

Voor dit doel dient een verklaring van goed gedrag van het Hoofd van de Politie van de woonplaats van betrokkene te worden overgelegd. ${ }^{689}$ Een soortgelijke bepaling komt ook in het nationaliteitsrecht van andere landen voor. ${ }^{690}$

688. Zie voor deze aangelegenheid de Instructies van de Minister van Justitie aan de Voorzilters van de "Pengadilan Negeri's" in geheel Indonesië gevestigd, no.DTA/25/18 en no. DTA/152/7 van resp. 17 november 1965 en 27 auguslus 1970.

689. Zie Bujung Datuk Intan Sati, Beberapa pokok-pokok, Himpunan, p.34l.

690. Zo noemt de Wet op het Nederlanderschap van 1985 als sén der afwijzingsgronden, bet binnen de periode van 10 jaar aan het verzoek voorafgaande zijn veroordeeld wegen een strafbaar feit tegen de veiligheid van het Koninkrijk of het veroordeeld zijn tot gevangenisstraf van min. 5 jaar wegens een ander strafbaar feit. 
De voorwaarde betreffende het bezitten van een goede gezondheid, zowel in lichamelijke als in geestelijke betekenis, dient te worden gezien tegen de achtergrond, dat het zeker niet in de bedoeling ligt dat de betrokken persoon ten laste van de Indonesische staat komt. Voor dit doel kan overlegging van een medische verklaring worden verplicht gesteld. De Indonesische wetgever gaat hierbij uit van de gedachtengang, dat slechts die personen tot de kring van de Indonesische staatsburgers worden toegelaten, die van nut voor de Staat kunnen zijn en zeker niet degenen, die als "afgeschreven" kunnen worden aangemerkt.

In hetzelfde licht dient de voorwaarde te worden gezien, dat de verzoeker over een vaste bron van inkomsten dient te beschikken, derhalve niet armlastig mag zijn en als zodanig een belasting voor de Staat kan vormen. Het voldoen aan deze voorwaarde dient, indien dit nodig wordt geoordeeld, aan de hand van een werkgeversverklaring dan wel een verklaring van de Belastingdienst betreffende de inkomstenbelasting door de betrokken persoon verschuldigd, te worden gestaafd.

Het zijn van student of het nog ten laste van de ouders komen, kan normaliter niet worden beschouwd als aan de hierbedoelde voorwaarde te voldoen. Hierbij zij echter opgemerkt, dat in het geval de kosten van levensonderhoud van de betrokken personen volledig gedragen worden door de ouders die over vaste inkomsten beschikken, het studenten betreft met een dienstverband c.q. andere vormen van hulpverlening of die naast hun studie werkzaam zijn, aangenomen wordt dat deze personen aan de hierbedoelde voorwaarden voldoen. Dit geldt ook voor ouderen, wier levensonderhoud volledig voor rekening komt van hun familieleden, die over een vaste bron van inkomsten beschikken. ${ }^{691}$

\subsection{Voor de naturalisatie verschuldigde som}

Met betrekking tot het voor de naturalisatie verschuldigde bedrag door de Belastingdienst van de woonplaats vast te stellen en door betrokkene in 's lands kas te storten, is bepaald dat bedoeld bedrag het reëel maandelijks inkomen van betrokkene niet te boven mag gaan. Deze bedragen hebben inmiddels wijziging ondergaan.

Bij niet-inwilliging van het verzoek tot naturalisatie, vindt terugstorting van het onderhavige bedrag aan de betrokken persoon plaats.

De eis tot betaling van een naturalisatiesom, komt ook in andere nationaliteitswetten voor. In de literatuur wordt ook wel het standpunt verdedigd, dat aan naturalisaties geen kosten dienen te zijn verbonden, aangezien het verlenen van een bepaalde nationaliteit

691. Zie hiervoor het Rondschrijven van de Minister van Justitie no. JHB.3/93/19 van 18 november 1981 aan de Voorzitters van alle, in Indonesiē gevestigde 'Pengadilan Negeri's en de Hoofden van de Diplomatieke Vertegenwoordigingen in bet buitenland gericht. 
middels naturalisatie geen materiële voordelen voor de Staat dient op te leveren. Zo neemt de Groot het standpunt in, dat naturalisaties gratis dienen te zijn. ${ }^{692}$ Ook Mannoury is van mening, dat betaling voor naturalisatie niet kan worden geëist. Zelfs indien men zich op de kosten aan de naturalisatieprocedure verbonden baseert, kan de heffing daarvan niet worden gerechtvaardigd. Deze auteur stelt zich op het standpunt, dat een juiste opvatting van de betekenis van de nationaliteit met zich brengt, dat geen naturalisatie behoort te geschieden dan in het belang van de gehele nationale gemeenschap en rechten en plichten, materiële en geestelijke voor- en nadelen met zich brengen, voor het grootste deel niet in geld waardeerbaar. Mannoury huldigl het standpunt, dat indien aan de behartiging van dat belang kosten zijn verbonden, deze kosten behoren te komen ten laste van de nationale geldmiddelen. Naar zijn mening zou eigenlijk het gestorte bedrag dienen te worden teruggegeven, niet wanneer de naturalisatie niet verleend wordt, maar juist indien dit wél plaatsvindt, een zienswijze die mijns inziens te ver gaat. ${ }^{693}$

Gautama huldigt daarentegen de opvatting, dat de huidige naturalisatiewetgeving niet uit het oogpunt van het verkrijgen van de geldmiddelen van een Staat dient te worden gezien, doch als een wijze van toelating van de persoon in kwestie tot het lidmaatschap van een nationale samenleving. Alhoewel dit lidmaatschap rechten en verplichtingen, voordelen en nadelen voor betrokkene met zich brengt, dienen deze voor- of nadelen grotendeels niet in geld te worden gewaardeerd, een standpunt ook voor mij aanvaardbaar. Deze auteur trekt een vergelijking met het toelaten van een buitenstaander tot een adatrechtsgemeenschap, hetgeen vaak gepaard gaat met bepaalde ceremonieen, waarbij ook betalingen aan de adathoofden in hun hoedanigheid van vertegenwoordiger van de plaatselijke rechtsgemeenschap, plaatsvinden. Wordt hier een parallel getrokken met de verplicht te storten naturalisatiesom, dan zou betaling hiervan uit een soortgelijk gezichtspunt dienen te worden gezien. ${ }^{694}$

692. De Groot, Staatsangehörigkeitsrecht, p.339.

693. Mannoury, Het Nederlandse Nationaliteitsrecht, p.115.

694. Gautama, Tafsiran, p.120-121. De meest recente bepalingen inzake de wijze van vaststelling, betaling, storting en teruggave van de naturalisatiesom zijn vastgesteld met het Gezamenlijke Besluit van de Directeur-Generaal voor Belastingen, de Directeur-Generaal voor de Begroting van het Departement van Financiēn en de Directeur-Generaal voor Recht en Wetgeving van het Departement van Justitie no. Kep-428/PJ/92, Kep-37/A/1092, C-UM.01.10.46 van 22 oktober 1992. De groolte van de naturalisatiesom als gebaseerd op het reëel maandelijks inkomen van de desbetreffende verzoeker ligt thans tussen $\mathrm{Rp} 120.000$,- en $\mathrm{Rp} 1.000 .000$,- en dient, indien hij in Indonesiē woonplaats heeft, te worden betaald aan de penningmeester van de "Pengadilan Negeri" van zijn woonplaats. Verblijft betrokkene in het buitenland, dan dient de betaling te geschieden aan de penningmeester van de Diplomatieke Vertegenwoording van het land van zijn woonplaats. In eerstgenoemd geval vindt vervolgens storting van de naturalisatiesom in 's landskas plaats; in laatstgenoemd geval op rekening van de Minister van Financiēn als buitenlandse routine-ontvangsten. 
Deze voorwaarde dient te worden gezien in het licht van het door de Indonesische overheid gevolgde beleid, om apatridie en bipatridie zoveel mogelijk te voorkomen.

Ter bereiking van eerstgenoemd doel, wordt aan staatlozen de gelegenheid gegeven Indonesisch staatsburger te worden. In § 3 werd reeds naar voren gebracht, dat ter zake onderscheid kan worden gemaakt tussen pure apatriden en de facto apatriden. Met betrekking tot de facto apatriden kan worden opgemerkt, dat deze personen hun rechten en verplichtingen als staatsburger niet kunnen uitoefenen. Zo bezitten zij geen paspoort van hun land, terwijl hun geen diplomatieke bescherming kan worden verleend door het land in kwestie.

In dit verband kan teruggegrepen op de positie van de Taiwanezen, in $\S 7$ van Hoofdstuk 3 aan de orde gekomen. Wordt het begrip "staatloos" door de Indonesische overheid in ruime zin opgevat, zodat ook de facto apatriden daaronder vallen, dan zouden Taiwanezen van de door artikel 5 geboden mogelijkheid tot naturalisatie gebruik kunnen maken. ${ }^{695}$ Dat dit beleid naderhand door de Regering is gevolgd, kan worden afgeleid uit het Besluit van de Minister van Justitie van 4 november 1969, waarmede een gedragslijn werd uitgestippeld voor Indonesische staatsburgers van Taiwanese afkomst, die het indertijd geldende verbod om naar Taiwan te gaan c.q. aldaar te verblijven, hadden overtreden. ${ }^{696}$ Tijdens hun verblijf in Taiwan, hadden deze personen niet aan de voorgeschreven aanmeldingsplicht ex artikel 17 sub $\mathrm{k}$ - dit artikellid zal bij de behandeling van de verliesgronden in Hoofdstuk 6 aan de orde komen - kunnen voldoen, hetgeen geleid heeft tot het verloren gaan van hun Indonesisch staatsburgerschap. Op grond van voomoemd Ministerieel Besluit werd aan deze personen de gelegenheid geboden om een verzoek in te dienen ter verkrijging van een verblijfsvisum om in Indonesië woonplaats te hebben, waarop zij vervolgens in het bezit van een toelatingskaart - vergezeld van een "clearance"-verklaring - werden gesteld, die kon worden gebruikt om het Indonesisch staatsburgerschap krachtens artikel 18 van de Wet

695. Een bewijs dat het hier om Taiwanezen, derhalve voor Indonesiē om de facto apatriden gaat, kan slechts worden verwacht van het Immigratiekantoor in de vorm van een verklaring dat deze personen niet staan geregistreerd als burgers van de Chinese Volksrepubliek of van andere landen zoals Vietnam en Korea warvan de namen van hun burgers gelijkenis vertonen met die van deze Taiwanezen. Wensen deze Taiwanezen zich te naturaliseren tot Indonesisch staatsburger, dan kunnen zij geen verklaring van de Diplomatieke Vertegenwoordiging van hun land van oorsprong krijgen, omdat een dergelijke vertegenwoordiging niet aanwezig is in Indonesië. Ook al zou een dergelijke verklaring worden verkregen, dan zou deze verklaring niet kunnen worden gebruikt, aangezien Indonesiẽ Taiwan niet erkent. Dit impliceert, dat met een verklaring van het Immigratiekantoor als biervoor genoemd zal dienen te worden volstaan. Zie Bujung Datuk Intan Sati, Beberapa hal, Himpunan, p. 354.

696. Het betreft bier het Ministeriële Besluit no. J.M./4/6 van 4 november 1969. 
terug te krijgen. ${ }^{67}$ Dit beleid hield in feite een versoepeling in met betrekking tot het herkrijgen van het Indonesisch staatsburgerschap door genoemde personen. ${ }^{698}$

Dat ook het optreden van een dubbel staatsburgerschap door de Indonesische overheid als een ongewenste situatie wordt beschouwd, blijkt uit de bepaling, dat betrokkene met het verkrijgen van het Indonesisch staatsburgerschap, of zijn oorspronkelijke nationaliteit dient te verliezen, of zijn verzoek vergezeld dient te laten gaan van een verklaring, afstand te doen van zijn oorspronkelijke nationaliteit met inachtneming van de daartoe door land van oorsprong vastgestelde bepalingen. ${ }^{699}$

Zoals reeds opgemerkt, is het afstand doen - evenzo het verloren gaan - van de oorspronkelijke nationaliteit slechts mogelijk, indien het nationaliteitsrecht van het land van oorsprong van de betrokken persoon daartoe de mogelijkheid biedt. Dit impliceert, dat in het geval het nationaliteitsrecht van betrokkene generlei voorzieningen voor het hierbedoelde geval inhoudt - waardoor deze persoon niet in de gelegenheid is een verklaring van het verloren gaan c.q. van het doen van afstand van zijn oorspronkelijke nationaliteit van de Diplomatieke Vertegenwoordiging van zijn land te overleggen betrokkene niet aan deze voorwaarde kan voldoen en hij derhalve geen verzoek tot naturalisatie kan indienen.

Het stereotiepe voorbeeld was gelegen in de positie van personen met de nationaliteit van de Chinese Volksrepubliek, het onderwerp van $\$ 3$ van Hoofdstuk 4. Wat betreft de voorwaarde van overlegging van een document of bewijsstuk van de Diplomatieke Vertegenwoordiging van het land van herkomst, dat inhoudt dat betrokkene na het verkrijgen van het Indonesisch staatsburgerschap, geen andere nationaliteit bezit, kan echter onder de aandacht worden gebracht dat in het bijzonder voor staatsburgers van de Chinese Volksrepubliek kan worden volstaan met een door de verzoeker ondertekende verklaring, afstand te doen van zijn oorspronkelijke nationaliteit. Ter nadere toelichting diene, dat in verband met de voorheen heersende politieke verwikkelingen met de Chinese Volksrepubliek, de Instructie was uitgevaardigd om tijdelijk geen nieuwe verzoeken tot naturalisatie van de hierbedoelde categorie van personen in ontvangst te nemen c.q. de afwikkeling van de reeds bij de "Pengadilan Negeri" of de Diplomatieke Vertegenwoording van de Republiek Indonesië aanwezige verzoeken voorlopig op te schorten. Dezelfde beleidslijn was vastgesteld met betrekking tot verklaringen, waarbij personen met een dubbele nationaliteit zich voor het Indonesisch staatsburgerschap

697. Ook in de nieuwe Immigratiewet no. 9 van 1992 zijn bepalingen inzake het binnenkomen en verlaten van het Indonesische grondgebied opgenomen.

698. Het in artikel 18 bepaalde zal aan de orde komen in $\$ 9.1 .1$ van dit Hoofdstuk.

699. Ter illustratie: Is in de Wet no. 62 van het jaar 1958 de voorwaarde gesteld, dat de verkrijging van het Indonesisch staatsburgerschap niet tot bipatridie mag leiden, in de Wet op het Nederlanderschap van 1985 is bepaald, dat het reeds door naturalisatie verleende Nederlanderschap verloren kan gaan, indien betrokkerie niet al het mogelijke heeft gedaan, om de - eventuele - andere nationaliteit die hij bezit, te verliezen en betreft het hier derhalve een maatregel achteraf. Komt de voorgestelde wijziging van de Wet op het Nederlanderschap van 1985 erdoor, dan kunnen buitenlandse migranten die tot Nederlander worden genaturaliseerd, hun oorspronkelijke nationaliteit behouden, zodat zij de staat van bipatride kunnen bezitten. 
wensten uit te spreken en betreffende verklaringen van vrouwen met de Chinese nationaliteit, gehuwd met Indonesische staatsburgers. De basis van het hierbedoelde beleid werd gevormd door de Instructie van de Minister van Justitie van 9 november 1966. ${ }^{700}$ In dit beleid is echter met de Instructie van genoemde Minister van 16 juni 1968 wijziging gebracht. ${ }^{701}$ Met laatstgenoemde Instructie werd de desbetreffende instanties opgedragen om verzoeken tot naturalisatie wederom in ontvangst te nemen c.q. af te wikkelen. Dezelfde beleidslijn wordt gevolgd met betrekking tot vrouwen, staatsburgers van de Volksrepubliek China, gehuwd met Indonesisch staatsburgers. Ook in dit geval is overlegging van een verklaring van de Diplomatieke Vertegenwoordiging van het land van oorsprong inzake het niet bezitten van een andere nationaliteit bij het verkrijgen van het Indonesisch staatsburgerschap niet verplicht gesteld. ${ }^{702}$

Samenvattend kan derhalve worden gesteld, dat ten aanzien van de hierbedoelde categorie van personen, de Indonesische Overheid uiteindelijk de nodige soepelheid in aanmerking heeft genomen, wellicht om deze personen niet het slachtoffer te doen worden van de politieke verwikkelingen tussen de betrokken landen.

Hierop aansluitend verdient vermelding, dat in het jaar 1980 een nieuwe wet op het Chinees staatsburgerschap door het Chinese Volkscongres is aangenomen, waarbij geen dubbele nationaliteit voor een staatsburger van de Chinese Volksrepubliek zal worden erkend. ${ }^{703}$ Hierin komt de bepaling voor, dat iedere Chinees die zich in het buitenland vestigt en middels naturalisatie staatsburger van het land in kwestie is geworden of vrijwillig een buitenlandse nationaliteit heeft verkregen, het staatsburgerschap van de Volksrepubliek verliest. Aangenomen kan worden, dat met het afkomen van bedoelde Wet van 1980, geen sprake meer zal zijn van een dubbel staatsburgerschap van als hierbedoelde personen. In dit verband zij de in $\$ 3.4$ van Hoofdstuk 4 genoemde "Memorandum of Understanding" in herinnering gebracht, door de Overheid van Indonesië en die van de Chinese Volksrepubliek ondertekend naar aanleiding van het herstel van de diplomatieke betrekkingen tussen beide landen in augustus 1990 . Ook hierin komt tot uitdrukking, dat genoemde partijen het ontstaan van een dubbel staatsburgerschap van hun onderdanen wensen te voorkomen.

700. Het betreft hier de Instructie van genoemde Minister no. D.T./1/2 van 9 november 1966.

701. Bedoeld is hier de Instructie van de Minister van Justitie no. D.T./1/25 van 16 juni 1968.

702. Het bewijs dat een verzoeker geen dubbel staatsburgerschap zal bezitten indien hij het Indonesisch staatsburgerschap verkrijgt kan worden gevormd:

a. een verklaring van de verzoeker, dat hij staatloos is, bevestigd door een verklaring van het Immigratiekantoor, dat volgens de aldaar beschikbare gegevens, hij niet staat geregistreerd als burger van welk land dan ook;

b. een schrijven van de Diplomatieke Vertegenwoordiging van het land van oorsprong, dat inhoudt dat volgens het recht van dat land, verzoeker zijn oorspronkelijke nationaliteit zal verliezen, indien bij het Indonesisch staatsburgerschap verkrijgt;

c. voor staatsburgers van de Chinese Volksrepubliek, kon het schrijven als onder b. bedoeld worden vervangen door een verklaring van de verzoeker zelf, inhoudende dat hij zijn oorspronkelijke nationaliteit prijsgeeft, indien hij het Indonesisch staatsburgerschap verkrijgt.

Zie Bujung Datuk Intan Sati, Beberapa pokok-pokok, Himpunan, p.341.

703. Zie Gunn, The Garuda and the Dragon. 


\subsection{Aflegging van de eed of belofte van trouw}

In aansluiting op hetgeen met betrekking tot deze aangelegenheid reeds naar voren werd gebracht, kan nog worden opgemerkt, dat in het kader van de aflegging van de hierbedoelde eed c.q. het uitspreken van de belofte van trouw aan de Indonesische staat, betrokkene onder meer dient te verklaren alle trouw aan een buitenlandse mogendheid prijs te geven. De eedsaflegging c.q. het uitspreken van de belofte van trouw houdt mede het feit in, het hoogste gezag van de Republiek Indonesië te erkennen en te aanvaarden en daaraan trouw te zijn. Het betreft hier, zoals gezegd, een symbolische handeling, waardoor de persoon in kwestie niet alleen blijkt geeft, het nieuw verworven staatsburgerschap in juridische zin te waarderen, maar ook in sociologische zin.

Heeft de afzwering, die op de buitenlandse mogendheid betrekking heeft ook rechtsgevolgen? Kan men, met andere woorden, door deze afzwering de banden met het land van oorsprong verbreken? Het behoeft geen nadere uitleg, dat dit slechts mogelijk is, indien de nationaliteitswetgeving van het land in kwestie hierin voorziet. Ter illustratie diene, dat indien het Indonesië betreft, het afleggen van een eed of het uitspreken van een belofte van trouw aan een vreemde mogendheid tot het verloren gaan van het Indonesisch staatsburgerschap leidt. ${ }^{704}$

\subsection{Wijze van verlening van het staatsburgerschap middels naturalisatie}

In het voorafgaande werd naar voren gebracht, dat de verlening van het Indonesisch staatsburgerschap door middel van naturalisatie - het verzoek daartoe dient van zegel te worden voorzien en vergezeld te gaan van alle bewijsstukken - bij besluit van de Minister van Justitie plaatsvindt.

Aangezien het hier een verzoek tot nationaliteitsverkrijging - niet optie - betreft, houdt dit in, dat het verzoek tot naturalisatie door genoemde Minister of kan worden ingewilligd, óf kan worden afgewezen. In laatstbedoelde geval, vindt restitutie van de naturalisatiesom plaats. De vraag rijst, gelet op het feit dat de "Pengadilan Negeri" c.q. de Diplomatieke Vertegenwoordiging van de Republiek Indonesië in het buitenland in de naturalisatieprocedure een bemiddelende rol spelen, of in het geval van afwijzing van het verzoek, teruggave van administratiekosten plaatsvindt. Alhoewel dit nergens uitdrukkelijk gesteld is, kan aangenomen worden, dat dit niet het geval is, aangezien de onderhavige kosten immers reeds zijn gemaakt.

Met betrekking tot de autoriteit met de verlening van het Indonesisch staatsburgerschap door middel van naturalisatie belast, kan worden opgemerkt dat deze bevoegdheid niet altijd bij de Minister van Justitie heeft berust. Ter illustratie kan in dit verband worden verwezen naar de Wet no. 3 van het jaar 1946, waarbij was gesteld dat het Indonesisch staatsburgerschap middels naturalisatie werd verkregen met de inwerkingtreding van de

704. Krachtens het in artikel 17 sub h. van de Wet bepaalde, dat aan de orde zal komen in Hoofdstuk 6. 
wet waarbij bedoelde naturalisatie werd verleend. ${ }^{705}$ Een soortgelijke bepaling kwam voor in de Voorlopige Grondwet van 1950. Een hiermede overeenkomende bepaling is in de Grondwet van 1945 daarentegen niet opgenomen. Ter toelichting kan nog worden opgemerkt, dat in het geval naturalisatie bij wet aan een persoon wordt verleend, de daartoe te volgen procedure meer voeten in de aarde heeft dan indien dit plaatsvindt bij ministerieel besluit, aangezien in eerstgenoemd geval behandeling van het daarop gerichte verzoek door de Volksvertegenwoordiging plaatsvindt. Met de hierbij te volgen procedure zal voorts meer tijd gemoeid gaan dan het geval is bij vaststelling van een ministerieel besluit, waarbij ook nog de kwestie van het dragen van de verantwoording hiervoor een rol speelt. In het eerste geval is immers sprake van een wetgevend produkt, waarvoor Regering en Volksvertegenwoordiging de verantwoording dragen, welke verantwoording in laatstgenoemd geval alleen bij de Minister van Justitie berust. Aangenomen kan voorts worden, dat bij verlening van het staatsburgerschap door naturalisatie bij wet, de positie van betrokkene meer is gewaarborgd dan wanneer dit plaatsvindt bij besluit van de Minister van Justitie.

De vraag kan voorts worden gesteld, welke status naturalisatie heeft, of dit als een gunst of als een recht dient te worden opgevat. In dit verband zij opgemerkt, dat de Wet no. 62 van het jaar 1958 in artikel 5 lid 2 wél de voorwaarden aangeeft, in acht te nemen bij indiening van een verzoek tot naturalisatie, doch uitdrukkelijk in artikel 5 lid 4 van de Wet stelt, dat de Minister van Justitie het verzoek kan inwilligen of afwijzen. Met andere woorden: het voldoen aan de gestelde voorwaarden - vastgesteld om het indienen van een verzoek tot naturalisatie mogelijk te maken - houdt nog niet in, dat op het verzoek goedgunstig wordt beschikt. Het al dan niet inwilligen van het desbetreffende verzoek dient dan ook als een beleidskwestie te worden aangemerkt c.q. het goedgunstig beschikken op een als hierbedoeld verzoek, als een "gunst", niet als een recht van de betrokken persoon. Ook Ko Swan Sik en Teuku Moh. Rhadie huldigen dit standpunt, door te stellen, dat "Indonesia does not belong to the group of States under whose laws naturalization carnot be denied if the applicant has fulfilled all the legal requirements. On the contrary, under Indonesian law, naturalization remains essentially a discretionary act of the Government". ${ }^{7 / 6}$

\subsection{Aaanvullende bepalingen betreffende naturalisatie}

De hierboven uiteengezette procedure is in meer recente jaren enigszins gewijzigd middels het Presidentieel Besluit no. 13 van het jaar 1980, uitgevaardigd met het doel om de afwikkeling van verzoeken tot naturalisatie, ingediend door in Indonesië gevestigde buitenlanders, te bespoedigen. Uit de praktijk was namelijk gebleken, dat deze procedure op stagnatie stuitte.

705. Zie hiervoor $\$ 5.2$ van Hoofdstuk 3, waarin de namen zijn genoemd van de personen, die krachtens de Wet no. 3 van 1946 bij wet zijn genaturaliseerd.

706. Ko Swan Sik en Teuku Moh. Rhadie, Nationality, p. 147. 
Krachtens het in dit Besluit bepaalde, dient de "Pengadilan Negeri" in eerste instantie de desbetreffende verzoeken op het voldoen aan de gestelde voorwaarden te onderzoeken. Van belang is in dit verband, dat genoemd Gerecht aan de daartoe aangewezen instanties een verklaring van trouw aan de Indonesische staat, die op de verzoeker betrekking heeft dient aan te vragen, welke verklaring in de plaats is getreden van de voorheen voorgeschreven verklaring inzake de politieke betrouwbaarheid van de verzoeker in kwestie. Het behoeft geen betoog, dat laatstgenoemde, niet in de Wet zelf gestipuleerde verklaring, de rechtens gestelde voorwaarden aanmerkelijk verzwaarde. Het vervangen daarvan door een verklaring van trouw aan de Indonesische staat houdt dan ook een beduidende verlichting in, mede in aanmerking genomen dat deze verklaring in feite reeds is ingesloten in het afleggen van de eed c.q. het uitspreken van de belofte van trouw aan de Indonesische staat, zoals bij de naturalisatieprocedure voorgeschreven.

Van belang is, dat van de instanties c.q. autoriteiten die in de afwikkeling van naturalisatieverzoeken een rol spelen, naast de "Pengadilan Negeri" en de Minister van Justitie, ook het advies wordt ingewonnen van het Hoofd van het Coördinerend Lichaam van de Staatsinlichtingendienst (naar de Indonesische afkorting, de Bakin). Deze functionaris doet, na het verzoek aan een onderzoek c.q. evaluatie te hebben onderworpen, zijn bevindingen met betrekking tot het al dan niet inwilligen van het onderhavige naturalisatieverzoek aan de President toekomen, die tenslotte zijn beslissing met betrekking tot het ingediende verzoek tot naturalisatie neemt.

Gesteld kan derhalve worden, dat wat betreft de bij naturalisatie betrokken autoriteiten, de uiteindelijke beslissing met betrekking tot verzoeken tot naturalisatie op een hoger niveau is getrokken c.q. thans in de handen van de President ligt.

\subsection{Vergelijking tussen de artikelen 3 en 4 enerzijds en artikel 5 der Wet anderzijds}

Ter afsluiting van het hier behandelde onderwerp acht ik het van nut de artikelen 3 en 4 te plaatsen tegenover artikel 5 dan wel de geprivilegieerde naturalisatie te plaatsen tegenover de gewone naturalisatie. Opgemerkt werd reeds, dat in de twee eerste artikelen sprake is van geprivilegieerde naturalisatie aangezien betrokkenen zijn vrijgesteld van bepaalde vereisten die in het kader van de gewone naturalisatie zijn gesteld. Dit geldt ook voor de geprivilegieerde naturalisatie ex artikel 4 van de Wet, al zijn de geboorte- en woonplaats-eisen krachtens dit artikel gesteld als zwaarder aan te merken dan die krachtens artikel 5 gelden. In herinnering dient te worden gebracht, dat eerst de derde generatie van vreemdelingen voor deze mogelijkheid in aanmerking komt, met name kleinkinderen van buitenlandse emigranten. Immers, krachtens artikel 4 van de Wet, dient het kleinkind van een buitenlander in het gebied van de Republiek Indonesië geboren te zijn en aldaar woonplaats te hebben. Deze eis geldt niet alleen voor het kleinkind zélf, maar óók voor zijn vader of moeder, die derhalve ook in Indonesië geboren en ingezetene van het land dient te zijn. Hiertegenover staat, dat op grond van artikel 5 sub b., betrokkene óf in het gebied van de Republiek Indonesiè geboren, of op het moment van indiening van het verzoek tot naturalisatie in Indonesië woonplaats 
dient te hebben gedurende een periode van tenminste de laatste vijf jaar ononderbroken of, over het geheel genomen, tien jaar onderbroken.

Bij de behandeling van het desbetreffende ontwerp in de Volksvertegenwoordiging, heeft de krachtens artikel 4 voorgeschreven geboorte- c.q. woonplaatseis dan ook op de nodige bezwaren bij leden van de Volksvertegenwoordiging gestuit. Om deze reden werd de zogenaamde "verlichte" naturalisatie - door mij geprivilegieerde naturalisatie genoemd - waarvan in artikel 4 sprake zou zijn, als een "paradox" aangemerkt. ${ }^{707}$ Gewezen dient echter te worden op de lagere leeftijdsgrens in artikel 4 opgenomen, in vergelijking met de leeftijd in artikel 5 sub a. gesteld en het niet voorschrijven van een te betalen som in het geval als bedoeld in artikel 4. Ook al zijn enkele voorwaarden in artikel 5 gesteld, achteraf ook komen te gelden in het kader van de toepassing van artikelen 3 en 4, zoals de voorwaarde die op enige kennis van de Indonesische taal en geschiedenis betrekking heeft, dit geldt niet voor de andere vereisten die krachtens artikel 5 gelden. Wél dient ervoor te worden gewaakt, dat door toepassing van alle drie artikelen gé́n bipatridie ontstaat. Dit strookt met het beleid van de Indonesische overheid om bipatridie te voorkomen.

Een overeenkomst tussen de mogelijkheid van verkrijging van het Indonesisch staatsburgerschap op grond van de artikelen 3 en 4 enerzijds en artikel 5 van de Wet anderzijds ligt hierin, dat in alle drie gevallen een daartoe strekkend verzoek dient te worden ingediend. Het voldoen aan de gestelde voorwaarden biedt in genoemde gevallen géén garantie, dat het verzoek wordt ingewilligd.

Ook tegen deze procedure werd door leden van de Volksvertegenwoordiging bij de behandeling van het desbetreffende ontwerp bezwaar gemaakt. Voorgesteld werd om in het geval van artikel 4, instede van het indienen van een ter zake strekkend verzoek, te volstaan met het afleggen van een verklaring (optie). Ter staving hiervan werd naar voren gebracht, dat de betrokken personen kunnen worden beschouwd te voldoen aan objectieve voorwaarden om ware Indonesische staatsburgers te zijn ("warganegara Indonesia jang sejati"). Een vergelijking werd voorts gemaakt met de, als veel beter aan te merken positie van een buitenlandse vrouw met een Indonesisch staatsburger gehuwd, aangezien in het laatste geval met het opteren voor het staatsburgerschap kan worden volstaan. Van overheidswege werden deze bezwaren echter niet aanvaard. ${ }^{708}$

Het gaat in de in de artikelen 3 en 4 omschreven nationaliteitsverkrijging om geprivilegieerde naturalisatie, waarvan het belangrijkste kenmerk ligt in het indienen van een verzoek ter verkrijging van het Indonesisch staatsburgerschap. Het indienen van een daartoe strekkend verzoek maakt een belangrijk onderdeel uit van de te volgen proce-

707. Zoals blijkt uit de Algemene Beschouwingen Hoofdstuk I van 4-6-1958, RS p.41, ter zake van de behandeling van het ontwerp betreffende het Indonesisch staatsburgerschap in de Volksvertegenwoordiging.

708. Zie de Algemene Beschouwingen Hoofdstuk II van 16-6-1958, RS p. 29-30, het Regeringsantwoord aangaande deze aangelegenheid bij de behandeling van het desbetreffende ontwerp in de Volksvertegenwoordiging. 
dure, anders dan bij optie middels het afleggen van een op verkrijging van de nationaliteit gerichte verklaring van betrokkene, die indien aan de objectieve optievereisten is voldaan, niet door de Overheid mag worden geweigerd, een belangrijk onderscheid tussen optie en naturalisatie. ${ }^{709}$ In alle drie van de hier genoemde artikelen hangt de inwilliging hiervan enkel en alleen van de Overheid af; het vervullen van het daartoe gestelde voorwaarden biedt géén garantie voor de inwilliging van het desbetreffende verzoek. Hier is geen sprake van een recht van de onderhavige verzoeker, doch van een gunst door de Overheid verleend. ${ }^{710}$

\subsection{De uitzonderingsnaturalisatie van artikel 6 van de Wet no. 62 van 1958}

Naast de hiervoor behandelde "gewone" manier, om door middel van naturalisatie het Indonesisch staatsburgerschap te verkrijgen, bestaat er nog een "bijzondere" wijze om tot Indonesisch staatsburger genaturaliseerd te worden, met name krachtens artikel 6 van de Wet no. 62 van het jaar 1958. Het betreft hier de naturalisatie tot staatsburger, om redenen van 's lands belang of vanwege het zich verdienstelijk te hebben gemaakt tegenover de Indonesische staat.

Voor de hierbedoelde naturalisatie, komen de voorwaarden waaraan in het geval van een gewone naturalisatie dient te worden voldaan, uiteraard te vervallen. Hierop aansluiting kan het van Nederlandse zijde gehuldigde standpunt - naar voren gebracht door Adriaanse en van der Weg - worden aangehaald, dat in het geval van de uitzonderingsnaturalisatie, waarvan in artikel 6 sprake is, als hierbedoelde personen die in het buitenland vertoeven, eveneens hiervoor in aanmerking komen. Anders dan in artikel 5 , is dit in artikel 6 echter niet uitdrukkelijk gesteld. Bepaald is slechts welke bepalingen van artikel 5 in dit geval gelden, met name artikel 5 lid 1, 5, 6 en 7. Hetgeen in artikel 5 lid 3 is bepaald, is daarentegen niet genoemd. Om deze reden kan mijns inziens worden betwijfeld of in het buitenland vertoevende personen voor deze uitzonderingsnaturalisatie in aanmerking kunnen komen.

Krachtens het in artikel 6 van de Wet bepaalde, wordt deze uitzonderingsnaturalisatie door de Regering met goedvinden van de Volksvertegenwoordiging verleend en heeft de Minister van Justitie tot taak om - iedere keer dat tot naturalisatie van een persoon vanwege redenen als hierboven uiteengezet, zal worden overgegaan - voor de afwikke-

709. In de Wet wordt de hierbedoelde verkrijging van het Indonesisch staatsburgerschap als "verkrijging middels inwilliging van een verzoek" aangeduid - ook door Ko Swan Sik en Moh. Rhadie als zodanig getypeerd - een typering mijns inziens niet als terecht aan te merken, vanwege de reeds aangegeven reden.

710. Ter illustratie diene, dat met de invoering van de Rijkswet op het Nederlanderschap in 1985 onder meer werd beoogd door vaststelling van de naturalisatievereisten in de artikelen 8 en 9 van deze Rijkswet, de naturalisatie van een gunst tot een recht te maken. De vraag is echter, of de Nederlandse overheid in deze opzet is geslaagd, gelet op enkele uitermate flexibele criteria. Zie hiervoor van der Avoort, A.S. en de Groot, G.R., De Rijkswet, p.33. 
ling hiervan zorg te dragen. Gezien het hier een bijzondere wijze van naturalisatie betreft, is hier rechtstreeks bemoeienis van de Volksvertegenwoordiging. ${ }^{71}$

Het voorstel tot het verlenen van het Indonesisch staatsburgerschap aan een persoon op de hierbedoelde wijze, zal uiteraard eerst aan een nauwkeurig onderzoek worden onderworpen, alvorens aan de Volksvertegenwoordiging te worden voorgelegd, teneinde in deze een beslissing te nemen. Dit dient te worden gezien tegen de achtergrond, dat het hier om buitenlanders gaat, aan wie op de hierbedoelde bijzondere wijze het Indonesisch staatsburgerschap zal worden verleend. In dit licht dient de door betrokkene - ook in dit geval verplicht - af te leggen eed c.q. uit te spreken belofte van trouw aan de Indonesische staal te worden gezien. ${ }^{712}$

\subsection{Gevolgen van de naturalisatie}

Volledigheidshalve zij nog naar voren gebracht, dat het door naturalisatie krachtens de artikelen 5 en 6 der Wet verkregen Indonesisch staatsburgerschap, zich ook uitstrekt tot de echtgenote van de betrokken persoon - tenzij deze nog een andere nationaliteit bezit en tot de kinderen, die de leeftijd van 18 jaar nog niet hebben bereikt of niet op een eerder tijdstip zijn gehuwd.

Komt een als hierbedoelde persoon te overlijden alvorens hij de eed heeft afgelegd c.q. belofte van trouw heeft uitgesproken, dan verkrijgt de door hem achtergelaten weduwe, voor zover zij geen andere nationaliteit bezit, het Indonesisch staatsburgerschap. Het betreft hier de verkrijging van het Indonesisch staatsburgerschap krachtens artikel 9 lid 1 van de Wet, dat nader aan de orde zal komen. Dit geldt ook voor de kinderen, die op de datum van het presidentieel besluit, waarbij genoemd staatsburgerschap werd verleend, aan de gestelde criteria krachtens artikel 13 van de Wet - hierop zal nader worden teruggekomen - voldoen. Dit is benadrukt met het schrijven van de Minister van Justitie van 18 september $1969 .{ }^{713}$ In dit verband kan naar voren worden gebracht dat de Wet de eenheid van nationaliteit hanteent, in beginsel door de echtgenoot bepaald.

Ik acht het van belang in dit verband onder de aandacht te brengen, dat met betrekking tot de vraag, of in het geval de onderhavige verzoeker komt te overlijden alvorens hij

711. In het hierbedoelde geval wordt de desbetreffende persoon door de Minister, in wiens ambtsgebied deze persoon zich verdienstelijk heefi gemaakt, voorgedragen. Het voorstel wordt door de betrokken Minister aan de Minister van Justitie voorgelegd; laatstgenoemde autoriteit stuurt het voorstel door naar de President (in feite het kabinet van de President), die ter zake de goedkeuring vraagt van de Volksvertegenwoordiging. Wordt het verzoek door de President ingewilligd, dan wordt een afschrift van het desbetreffende Presidentiēle Besluit aan de "Pengadilan Negeri" doorgestuurd om betrokkeze de eed af te nemen. Zie Bujung Datuk Intan Sati, Beberapa Hal, Himpunan, p.355.

712. Een als hierbedoelde bijzondere naturalisatie heeft, voor zover bekend, slechts in enkele gevallen plaatsgevonden. Naar uit de Indonesische pers kan worden opgemaakt, gaat het hier om personen die Indonesië op het gebied van de sport hehhin vertegenwoordigd.

713. Het betreft bier het Ministeriēle schrijven no. DTC//4//7 van 18 september 1969 aan de Voorzitter van de te Jakarta gevestigde Centrale "Pengadilan Negeri" gericht. 
de eed c.q. belofte van trouw heeft afgelegd c.q. uitgesproken - ook al is een op de inwilliging van het desbetreffende verzoek gericht presidentieel besluit reeds voorhanden - de weduwe en minderjarige kinderen Indonesisch staatsburger zijn geworden, verschil van mening bestond. Aanvankelijk werd het standpunt gehuldigd, dat gezien het feit de verzoeker de eed c.q. belofte nog niet heeft afgelegd c.q. uitgesproken, hij nog geen Indonesisch staatsburger is geworden en derhalve ook zijn vrouw en minderjarige kinderen deze status nog niet hebben verkregen. Dit impliceert, dat de weduwe een verzoek tot naturalisatie dient in te dienen, aangezien zij niet in de plaats van wijlen haar echtgenoot kan treden voor het afleggen c.q. uitspreken van de eed/belofte. Wat de kinderen betreft, nog minderjarig op het tijdstip van verkrijging van het Indonesisch staatsburgerschap - niet die minderjarig waren op het tijdstip van indiening van het onderhavige verzoek - deze verkrijgen eerst bij het aanwezig zijn van bedoeld presidenticel besluit en ná aflegging van de desbetreffende eed/belofte mede het Indonesisch staatsburgerschap. ${ }^{714}$

Met het hiervoor reeds aangehaalde schrijven van de Minister van Justitie van 18 september 1969, is echter benadrukt dat in het geval het verzoek van een persoon om Indonesisch staatsburger te worden is ingewilligd nadat hij komt te overlijden, zijn vrouw het Indonesisch staatsburgerschap verkrijgt, tenzij zij nog een andere nationaliteit bezit. De vrouw behoeft derhalve géén eed meer af te leggen of een belofte van trouw uit te spreken!

Wat betreft de reeds meerderjarige kinderen van de verzoeker, deze volgen uiteraard niet de staat van hun vader, doch dienen het tijdstip, waarop zij de leeftijd van 21 jaar bereiken, af te wachten om zélf een verzoek ter verkrijging van het Indonesisch staatsburgerschap te kunnen indienen. In herinnering zij gebracht, dat krachtens de onderhavige Wet no. 62 van 1958 de meerderjarige leeftijd is gesteld op 18 jaar.

\section{$\S 7$ verkrijging door of als gevolg van huwelijk}

Alvorens op de verkrijging van het Indonesisch staatsburgerschap door of als gevolg van huwelijk in te gaan, dienen eerst enkele opmerkingen te worden gemaakt omtrent het begrip "optie", aangezien de hier te behandelen nationaliteitsverkrijging plaatsvindt door optie. Ik bracht reeds naar voren, onder "optie" te verstaan, een wijze van nationaliteitsverkrijging, waarbij de beslissing omtrent de verkrijging uitsluitend afhankelijk is gesteld van de wil van betrokkene, die een daartoe strekkende verklaring aflegt. Dit impliceert, dat indien aan de ter zake gestelde voorwaarden is voldaan, de Overheid de optie niet kan weigeren.

In het kader van de toepassing van de onderhavige Wet no. 62 van 1958 heeft een als hierbedoelde verklaring echter niet alleen betrekking op de verkrijging van het Indonesisch staatsburgerschap, doch ook op het prijsgeven daarvan, om die reden door mij als "negatieve optie" getypeerd. Dit komt zowel bij de behandeling van hierbedoelde

714. Bujung Datuk Intan Sati, Beberapa pokok-pokok, Himpunan p.343. 
aangelegenheid ter sprake als in Hoofdstuk 6, waarin de wijze van verloren gaan van het Indodonesisch staatsburgerschap zal worden behandeld. Bovendien is nog een derde soort optie te onderscheiden, in $\S 9$ te behandelen, alhoewel het in genoemde paragraaf in feite om "oneigenlijke optie" gaat. De reden hiervan ligt hierin, dat mijns inziens niet meer van "optie" kan worden gesproken, tenzij aan de door de Groot gebezigde term "gecontroleerde optie" 715 de voorkeur wordt gegeven of de door Adriaanse en van der Weg gegeven omschrijving van optie, waarbij de nationaliteit eerst wordt verkregen, nadat op het desbetreffende verzoek goedgunstig door de Minister van Justitie is beschikt ${ }^{716}$, wordl gevolgd. Ik spreek hier van "oneigenlijke optie", aangezien het hier gaat om een nationaliteitsverkrijging op verzoek, waarbij het evenals in het geval van gewone en geprivilegieerde naturalisatie gaat om een beleidskwestie, om een gunst van overheidswege, om die reden eerder als "vereenvoudigde naturalisatie" aan te merken, zoals in $\$ 9$ zal worden aangetoond.

In het kader van de behandeling van de verkrijging van het Indonesisch staatsburgerschap door middel van - gewone - naturalisatie, werd met betrekking tot gehuwde vrouwen opgemerkt, dat het deze personen niet is toegestaan om een verzoek tot naturalisatie in te dienen. Gevreesd wordt dat het door de Wet -in principe - gehuldigd beginsel van "eenheid van nationaliteit der echtgenoten" hierdoor in gevaar zou worden gebracht. Om dezelfde reden is het gehuwde vrouwen niet mogelijk om een verzoek zoals bedoeld in de artikelen 3 en 4 ter verkrijging van het Indonesisch staatsburgerschap in te dienen. ${ }^{717}$

Het - in principe - uitgaan van genoemd beginsel, komt bovendien tot uiting in artikel 9 lid 1 van de Wet no. 62 van het jaar 1958, dat inhoudt dat het door de man verkregen Indonesisch staatsburgerschap, van rechtswege ook voor diens echtgenote geldt, tenzij laatstgenoemde nog een andere nationaliteit bezit. Het hierbedoelde voorbehoud strekt ten doel, het ontstaan van bipatridie te vermijden. Op genoend "vrouw volgt man" principe, maakt de Wet niettemin in bepaalde gevallen een uitzondering, waarop in $\$ 7.1 \mathrm{zal}$ worden teruggekomen.

In het algemeen kan worden gesteld, dat het staatsburgerschap van de man in principe bepalend is ter vaststelling van het staatsburgerschap van beide huwelijkspartners. De Wet no. 62 van het jaar 1958 geeft echter aan mannelijke staatsburgers de gelegenheid om hun staatsburgerschap middels negatieve optie prijs te geven, indien slechts op deze wijze, het principe van eenheid in de nationaliteit van beide partijen gehandhaafd kan worden. Op deze aangelegenheid zal in Hoofdstuk 6 worden teruggekomen.

715. De Groot, Staatsangehörigkeitsrecht, p.211.

716. Zie Adriaanse en van der Weg, Nationaliteitswelgeving, Indonesiē, p.lb-16.

717. Zie artikel 10 lid 1 van de Wet no.62 van 1958. 
Het principe der "eenheid van nationaliteit" wordt door de Wet vooropgesteld, en het is, in het algemeen, de status van de man, die doorslaggevend is. Dit beginsel wordt echter losgelaten, indien:

verkrijging van het Indonesisch staatsburgerschap, bipatridie ten gevolge heeft.

Hieruit blijkt dat aan het streven bipatridie te voorkomen voorrang wordt verleend boven het hanteren van het beginsel van de "eenheid van nationaliteit".

\subsection{Het gemengde huwelijk}

De vraag kan worden gesteld wat rechtens is, in het geval van een gemengd huwelijk, in de zin van een huwelijk van een buitenlandse vrouw met een Indonesisch staatsburger. Aangezien ik hier melding maak van het instituut "gemengd huwelijk" dient ook het omgekeerde geval, met name indien een vrouw die het Indonesisch staatsburgerschap bezit, met een buitenlander trouwt te worden genoemd.

\subsubsection{Buitenlandse vrouw met staatsburger getrouwd}

In het hierbedoelde geval wordt het beginsel van "eenheid van nationaliteit" in zoverre losgelaten, dat de buitenlandse vrouw niet automatisch het Indonesisch staatsburgerschap van haar man verkrijgt. De Wet bepaalt met name in artikel 7, dat een met een Indonesisch staatsburger gehuwde buitenlandse vrouw het Indonesisch staatsburgerschap verkrijgt, indien zij:

a. binnen de termijn van één jaar na voltrekking van het huwelijk, een daartoe strekkende verklaring aflegt - derhalve door optie - dan wel

b. in afwijking van het onder a. bepaalde, zij het Indonesisch staatsburgerschap óók verkrijgt vooropgesteld, dat zij geen verklaring ter verkrijging van het Indonesisch staatsburgerschap aflegt, derhalve passief blijft en binnen de gestelde termijn van een jaar haar echtgenoot géén op het prijsgeven van zijn Indonesisch staatsburgerschap gerichte verklaring aflegt (negatieve optie). Het op deze wijze verkregen Indonesisch staatsburgerschap door de buitenlandse vrouw in kwestie gaat in een jaar ná voltrekking van het huwelijk. ${ }^{718}$

Het hierboven onder a. bepaalde houdt derhalve in, dat een buitenlandse vrouw het Indonesisch staatsburgerschap eerst verkrijgt, door een handeling te verrichten met name door voor het Indonesisch staatsburgerschap binnen de daartoe gestelde termijn te opteren. Met het Rondschrijven van de Minister van Justitie van 1 juli 1969 is echter onder de aandacht gebracht, dat de gestelde termijn waarin de optieverklaring dient te

718. Syahmin, Penyelundupan Hukum, p.65. Deze suteur wijst op de mogelijkheid tot rechtsontduiking door buitenlandse vrouwen, die op de hier omschreven wijze het Indonesisch statsburgerschap verkrijgen met het vooropgezette doel om de als zodanig verkregen status te gebruiken voor bepaalde doeleinden, bijvoorbeeld om onroerend goed in Indonesiê te verkrijgen of aldaar handelsactiviteiten te verrichten. 
worden afgelegd, niet altijd een absolute voorwaarde vormt. Dit houdt in, dat ná de gestelde termijn afgelegde optieverklaringen aan de Minister van Justie dienen te worden doorgestuurd, die een beslissing neemt inzake het feit, of de desbetreffende verklaringen al dan niet nog kunnen worden aanvaard. ${ }^{719}$

De hierboven genoemde mogelijkheid is echter onderworpen aan de in het eerste lid van genoemd artikel 7 der Wet opgenomen voorwaarde, dat zij in het geval van verkrijging van het Indonesisch staatsburgerschap, géen andere nationaliteit mag bezitten. Deze voorwaarde strekt ten doel, bipatridie te voorkomen. Wil een buitenlandse vrouw van de door artikel 7 lid 1 der Wet bedoelde mogelijkheid gebruik maken, dan dient zij het bewijs te overleggen, dat zij ná verkrijging van het Indonesisch staatsburgerschap, geen andere nationaliteit zal bezitten. Voor dit doel dient een verklaring van de Diplomatieke Vertegenwoordiging van haar land van oorsprong te worden overgelegd.Ook Soedarman Ganda Soebrata wijst erop, dat de aflegging van de desbetreffende optieverklaring, gepaard dient te gaan met de overlegging van bewijsstukken. Het gaat hier om bewijzen betreffende een wettig huwelijk, het zijn van Indonesisch staatsburger van de echtgenoot, het nog niet verstreken zijn van een jaar na voltrekking van het huwelijk, de oorspronkelijke nationaliteit van de vrouw en het niet bezitten van een andere nationaliteit bij verkrijging van het Indonesisch staatsburgerschap. ${ }^{720}$ De twee laatstgenoemde voorwaarden staan nauw met elkaar in verband, aangezien het voldoen aan genoemde voorwaarden niet alleen door de vrouw in kwestie dient te worden bewezen, doch dit vergezeld dient te gaan van een verklaring van de Diplomatieke Vertegenwoordiging van het land van oorsprong, die inhoudt dat de betrokken vrouw de nationaliteit van dit land bezit en deze nationaliteit verloren zal gaan, bij verkrijging van het Indonesisch staatsburgerschap. Eerst dan kan worden aangenomen, dat het in het eerste lid van artikel 7 bepaalde - dat inhoudt dat indien bij verkrijging van het Indonesisch staatsburgerschap de vrouw nog een andere nationaliteit bezit, de verklaring niet mag worden afgelegd - geen toepassing vindt. ${ }^{221}$

Maakt het nationaliteitsrecht van de vrouw het niet mogelijk, dat de Diplomatieke Vertegenwoordiging van het land van oorsprong haar in het bezit van een verklaring stelt, die inhoudt dat zij met het verkrijgen van het Indonesisch staatsburgerschap haar

719. Bujung Datuk Intan Sati, Beberapa hal, Himpunan p. 358.

720. Soedarman Ganda Soebrata, Pengadilan Negeri, Himpunan, p.121.

721. Soedarman Ganda Soebrata illustreert de onderhavige aangelegenheid middels het geval een Japanse vrouw met een Indonesisch staatsburger in het huwelijk is getreden en voomemens is de optieverklaring af te leggen. Zijdens de Japanse Diplomatieke Vertegenwoordiging was men aanvankelijk van mening, dat het afgeven van een verklaring inzake het verloren gaan van de Japanse nationaliteit niet nodig was, aangezien krachtens artikel 8 van de Japanse nationaliteitswet een Japanse burger zijn/haar nationaliteit verliest, indien hij/zij vrijwillig de nationaliteit van een ander land verwerft. Van Indonesische zijde werd echter verklaard, dat de desbetreffende "Pengadilan Negeri" dan wel Diplomatieke Vertegenwoordiging van de Republiek Indonesië niet competent is de desbetreffende optieverklaring to anvaarden, indien men niet over een als hierbedoelde verkiaring van het land van oorsprong de beschikking hreft. Zie Soedarman Ganda Soebrata, Pengadilan Negeri, Himpunan, p.121-122. 
oorspronkelijke nationaliteit verliest, dan kan de vrouw van de door artikel 7 lid 1 der Wet geboden gelegenheid geen gebruik maken.

Het verkrijgen van de hierbedoelde verklaring zal op moeilijkheden stuiten, indien het landen betreft, die het recht van expatriatie van hun burgers niet erkennen c.q. de nationaliteitswetgeving van deze landen géen hierop gerichte mogeiijkheid bevat. In herinnering zij echter gebracht, dat vrouwen met de nationaliteit van de Chinese Volksrepubliek, die het bezit van deze nationaliteit middels hun paspoort kunnen bewijzen, géén verklaring van de Diplomatieke Vertegenwoordiging van het land van oorsprong behoeven te overleggen, dat zij met het verkrijgen van het Indonesisch staatsburgerschap hun oorspronkelijke nationaliteit zullen verliezen, zoals in $\S 6.8$ reeds toegelicht. ${ }^{72}$ Gezien de Chinese Volksrepubliek in 1980 een nieuwe nationaliteitswet heeft aangenomen, waarbij het ontstaan van bipatridie niet langer wordt getolereerd, zal aan voomoemd beleid niet langer de hand behoeven te worden gehouden. Ook in het ter gelegenheid van het herstel van de diplomatieke betrekkingen op 8 augustus 1990 tussen Indonesië en de Chinese Volksrepubliek opgestelde "Memorandum of Understanding" is tot uitdrukking gebracht, dat geen dubbel staatsburgerschap meer zal worden erkend. ${ }^{723}$

Betreft het daarentegen het hiervoor onder b. genoemde geval, dan verkrijgt de buitenlandse vrouw dit staatsburgerschap krachtens het in artikel 7 lid 2 der Wet bepaalde van rechtswege. Hiertoe zijn echter twee voorwaarde gesteld, waarvan in de eerste plaats kan worden genoemd dat haar echtgenoot passief dient te blijven c.q. binnen de periode van één jaar na voltrekking van het huwelijk, géen verklaring op het prijsgeven van zijn Indonesisch staatsburgerschap mag afleggen (negatieve optie). De tweede hierbij in acht te nemen voorwaarde is van wezenlijk belang; ook in dit geval mag de buitenlandse vrouw in kwestie, krachtens het in het eerste lid van artikel 7 gemaakte voorbehoud, met het verkrijgen van het Indonesisch staatsburgerschap, niet nog een andere nationaliteit bezitten. De aanhef van artikel 7 lid 2 luidt namelijk als volgt: "met behoud van de in het eerste lid gemaakte uitzondering...." ${ }^{724}$ Op deze aangelegenheid is ook gewezen in het schrijven van de Minister van Justitie van 18 september 1969 - in het voorgaande reeds aan de orde gekomen ${ }^{25}$ - met name dat de echtgenoot van de vrouw in kwestie niet alleen in de daartoe gestelde periode van een jaar na voltrekking van het huwelijk zijn Indonesisch staatsburgerschap niet mag hebben prijsgegeven, maar

722. Zie hiervoor de Instructie van de Minister van Justitie no. D.T./1/5 van 1 februari 1968.

723. Dit memorandum is reeds genoemd in $\$ 3.4$ van Hoofdstuk 4 .

724. Zie ook Gautama, Tafsiran, p. 172. Het hierbedoelde voorbehoud luidt in het Indonesisch: "Dengan kekecualian tersebut dalam ayat 1" (in het Nederlands "met behoud van de uitzondering bedoeld in het eerste lid") en is erop gericht bipatridie te voorkomen.

725. Het schrijven van de Minister van Justitie aan de Voorzitter van de te Jakarta gevestigde Centrale "Pengadilan Negeri" no. DTC/14/17 van 18 september 1969. 
ook de vrouw een jaar ná de huwelijksvoltrekking geen andere nationaliteit mag bezitten. Dit niet bezitten van een andere nationaliteit kan worden veroorzaakt door:

het doen van afstand van de oorspronkelijk nationaliteit volgens de wettelijke bepalingen van het land in kwestie;

- de wettelijke bepalingen van het land van oorsprong bepalen dat de vrouw van rechtswege haar oorspronkelijke nationaliteit verliest door haar huwelijk met een Indonesisch staatsburger;

- de vrouw in kwestie apatride is.

Hieruit kan de conclusie worden getrokken, dat krachtens artikel 7 lid 2 van de Wet het worden van een met een Indonesisch staatsburger gehuwde buitenlandse vrouw tot Indonesisch staatsburger eerst mogelijk is, indien zij niet langer de nationaliteit van het land van oorsprong bezit. Ook artikel 7 lid 2 is aan de termijn van een jaar gebonden, aangezien daarin uitdrukkelijk is gesteld, dat het Indonesisch staatsburgerschap verkregen wordt een jaar nadat de huwelijksvoltrekking heeft plaatsgevonden. Toegelicht met een voorbeeld houdt dit het volgende in: een buitenlandse vrouw huwt met een Indonesisch staatsburger op 15 juni 1959. In de periode tot 15 juni 1960 legt zij geen optieverklaring als bedoeld in artikel 7 lid 1 af. Volgens het recht van het land van oorsprong verliest zij haar oorspronkelijke nationaliteit niet als gevolg van haar huwelijk en geeft deze nationaliteit niet prijs. Krachtens het nationaliteitsrecht van het land van oorsprong bezit de vrouw nog een buitenlandse nationaliteit. Deze situatie wordt ook door artikel 7 lid 1 mogelijk gemaakt, aangezien de vrouw in kwestie immers niet wordt verplicht om voor het Indonesisch staatsburgerschap van haar man te opteren. Het voorgaande impliceert, dat de vrouw een jaar na het tijdstip van de huwelijksvoltrekking nog een buitenlandse status bezit. Geeft deze vrouw op een later tijdstip, bijvoorbeeld in het jaar 1968 haar oorspronkelijke nationaliteit prijs, dan wordt zij staatloos en geen Indonesisch staatsburger. ${ }^{726}$

Wat is nu het verschil tussen het eerste en het tweede lid van artikel 7 van de Wet? Krachtens lid 1 is een positieve handeling nodig, met name het afleggen van een optieverklaring. In lid 2 is geen optieverklaring nodig, mits de vrouw in kwestie over een bewijs beschikt, dat zij niet langer haar oorspronkelijke nationaliteit bezit, met dien verstande dat zij reeds in het bezit van dit bewijs dient te zijn binnen een jaar nadat het huwelijk heeft plaatsgevonden. Voldoet de vrouw niet aan de krachtens artikel 7 leden 1 en 2 gestelde voorwaarde, dan betekent dit dat zij haar buitenlandse status blijft behouden en het principe van eenheid van nationaliteit in het gezin doorbroken wordt. ${ }^{27}$ Voor de goede orde dient hieraan te worden toegevoegd, dat niettegenstaande de Wet no. 62 van 1958 in principe het beginsel van eenheid van nationaliteit in het gezin huldigt, ook aan de wensen van vrouwen aandacht wordt geschonken, conform de emancipatie der vrouwen. Wenst derhalve een buitenlandse vrouw met een

726. Bujung Datuk Intan Sati, Beberapa pokok-pokok, Himpunan p. 343.

727. Zie Bujung Datuk Intan Sati, Beberapa pokok-pokok, Himpunan p.344. 
Indonesisch staatsburger gehuwd haar eigen nationaliteit te behouden, dan wordt dit mogelijk gemaakt door de onderhavige Wet. ${ }^{78}$

Bij de behandeling van het ontwerp betreffende het Indonesisch staatsburgerschap in de Volksvertegenwoordiging, werd door diverse leden daarvan bezwaar gemaakt tegen de voor een buitenlandse vrouw opengestelde mogelijkheid tot verkrijging van het Indonesisch staatsburgerschap door optie. Voorgesteld werd dit te vervangen door een daartoe strekkend verzoek. Door de Overheid werd dit van de hand gewezen, omdat het beginsel van "eenheid van nationaliteit" in het huwelijk zoveel mogelijk dient te worden nagestreefd. Ook werd voorgesteld, om de gestelde termijn van een jaar in te korten tot een maand, hetgeen eveneens van regeringswege werd afgewezen. ${ }^{729}$

Ingevolge het in artikel 7 lid 3 van de Wet bepaalde, mag indien eén van de in artikel 7 lid 1 en 2 bedoelde verklaringen is afgelegd, niet meer tot aflegging van de andere verklaring worden overgegaan. Dit houdt in, dat in het geval de buitenlandse vrouw in kwestie reeds een verklaring heeft afgelegd ter verkrijging van het Indonesisch staatsburgerschap, het haar echtgenoot niet is toegestaan, zijn Indonesisch staatsburgerschap middels het afleggen van een verklaring prijs te geven. Omgekeerd geldt, dat indien de echtgenoot middels een afgelegde verklaring zijn staatsburgerschap heeft prijsgegeven, het zijn echtgenote niet is toegestaan, een verklaring op verkrijging van het Indonesisch staatsburgerschap gericht, af te leggen. Het opnemen van deze bepaling werd noodzakelijk geacht, ter waarborging van de rechtszekerheid.

Volledigheidshalve dient in aansluiting op het bovenstaande nog te worden gewezen op het in artikel II van de Overgangsbepalingen van de Wet bepaalde. Bij dit artikel werd aan buitenlandse vrouwen, die op 1 augustus 1958 - de datum van inwerkingtreding van de Wet - reeds met Indonesische staatsburgers waren gehuwd, alsnog de gelegenheid geboden om een verklaring ter verkrijging van het Indonesisch staatsburgerschap af te leggen, gedurende de termijn van én jaar, ingaande 1 augustus 1958 . Ter toelichting diene, dat een buitenlandse vrouw ná 27 december 1949 met een Indonesisch staatsburger gehuwd niet automatisch het Indonesisch staatsburgerschap verkrijgt. Heeft het huwelijk plaatsgevonden ná 27 december 1949 doch vóór 1 augustus 1958, dan kon de vrouw gebruik maken van de met artikel II van de Overgangsbepalingen geboden gelegenheid. Heeft het huwelijk daarentegen plaatsgevonden ná 1 augustus 1958, dan kan zij gebruikmaken van artikel 7 van de onderhavige Wet. Maakt zij echter geen gebruik hiervan, dan blijft de vrouw haar buitenlandse nationaliteil behouden. ${ }^{730}$

Alhoewel wellicht ten overvloede, zij in herinnering gebracht, dat buitenlandse vrouwen, die krachtens de bepalingen van het Militair Gezag c.q. Oorlogsgezag vóór 1 augustus 1958 geldende, werden "behandeld als" Indonesisch staatsburger, op basis van

728. Bujung Datuk Intan Sati, Beberapa hal, Himpunan p. 358.

729. Zie hiervoor de Algemene Beschouwingen Honfdstuk II van 16-6-1958, RS p. 20-21 bij de behandeling van het onderhavige ontwerp in de Volksvertegenwoordiging.

730. Zie Bujung Datuk Intan Sati, Beberapa pokok-pokok, Himpunan p.337. 
artikel I van de Overgangsbepalingen van de Wet, Indonesisch staatsburger zijn geworden. ${ }^{731}$ Zoals reeds opgemerkt, dienden deze vrouwen om als Indonesisch staatsburger te worden behandeld, in het bezit van een daarop gericht besluit van de Minister van Justitie te zijn. Deze vrouwen verkregen krachtens genoemd artikel I van de Overgangsbepalingen ingaande 1 augustus 1958 het Indonesisch staatsburgerschap. Buitenlandse vrouwen, niet in het bezit van een als hierbedoeld besluit, verloren derhalve hun buitenlandse nationaliteit niet; zij konden echter krachtens artikel II van de Overgangsbepalingen vóor 1 augustus 1959 een op de verkrijging van het Indonesisch staatsburgerschap gerichte verklaring afleggen. ${ }^{732} \mathrm{Het}$ was de echtgenoten van deze vrouwen - uiteraard - niet toegestaan, een verklaring tot prijsgeving van hun staatsburgerschap, als bedoeld in artikel 7 lid 2 van de Wet, af te leggen.

\subsubsection{Indonesische vrouw met buitenlander gehuwd}

Betreft het daarentegen een gemengd huwelijk tussen een vrouw die het Indonesisch staatsburgerschap bezit en een buitenlander, dan dient te worden afgegaan op het in artikel 8 van de Wet no. 62 van het jaar 1958 bepaalde. Ingevolge dit artikel verliest de vrouw in kwestie haar staatsburgerschap eerst, indien zij binnen de gestelde termijn dit middels negatieve optie prijsgeeft, met het doel de nationaliteit van haar man te verkrijgen. Op deze aangelegenheid zal in Hoofdstuk 6 worden teruggekomen.

Of een vrouwelijke Indonesisch staatsburger door of als gevolg van huwelijk de nationaliteit van haar echtgenoot kan verkrijgen, hangt uiteraard van de nationaliteitswetgeving van het land van haar echtgenoot af. Huldigt het land in kwestie het beginsel, dat "de vrouw staande huwelijk de staat van haar man volgt" en geeft de vrouw haar Indonesisch staatsburgerschap niet prijs, dan wordt zij bipatride. In het hierbedoelde geval zijn naar de letter van de Wet generlei voorzieningen getroffen om het ontstaan van bipatridie te voorkomen. De mogelijkheid daartoe kan worden geacht reeds ingecalculeerd te zijn in het feit, dat een vrouw die met een buitenlander trouwt in principe haar staatsburgerschap blijft behouden. Ko Swan Sik en Teuku Moh. Rhadie zeggen hiervan dat "retention of Indonesian nationality in spite of resulting dual nationality is provided in case of marriage of an Indonesian woman to an alien where no express renunciation has taken place". ${ }^{733}$ Ook Gautama is van mening, dat hier het principe wordt losgelaten om het ontstaan van bipatridie te voorkomen; met het bestaan van de mogelijkheid om het Indonesisch staatsburgerschap te behouden, kan een vrouw die Indonesisch staatsburger is en met een buitenlander trouwt, bipatride worden.

731. Zie ook Adriaanse en van der Weg, Nationaliteitswetgeving, Indonesiē, p.Ib-21.

732. Met de Circulaire van de Ned. Minister van Binnenlandse Zaken van 23 juli 1968, afdeling B.B. no. B68/1890 aan de gemeentebesturen gericht is een nadere toelichting gegeven met betrekking tot Nederlandse vrouwen met Indonesische staatsburgers gehuwd krachtens de hier omschreven bepalingen. Hierbij speelt de datum 1 mart 1964 een rol, in die zin dat de Nederlandse vrouw die op of na deze datum met een Indonesisch staatsburger is gehuwd, de Nederlandse nationaliteit niet heeft verloren, tenzij zij binnen een jaar na het huwelijk voor het Indonesische staatsburgerschap heeft geopteerd; in dit geval ging de Nederlandse nationaliteit verloren op de datum van de optie.

733. Ko Swan Sik en Teuku Moh. Rhadie, Nationality, p.167. 
Deze auteur voegt hieraan toe, dat met het bestaan van deze mogelijkheid, de wetgever is afgeweken van één van de hoofdprincipes door de Wet no. 62 van 1958 aanvaard, met name om het ontstaan van bipatridie zoveel mogelijk te vermijden. ${ }^{734}$ Ook Adriaanse en van der Weg brengen naar voren dat een vrouw die Indonesisch staatsburger is en op of ná 1 augustus 1958 met een vreemdeling huwt, ingevolge artikel 8 van de Indonesische wet door dit huwelijk niet automatisch de Indonesische nationaliteit verliest, ook niet wanneer zij krachtens de wet van het land van haar echtgenoot diens nationaliteit verkrijgt. ${ }^{735}$

Verkrijgt de hierbedoelde vrouw de staat van bipatride, is zij dan verplicht om aan deze status een einde te maken door haar Indonesisch staatsburgerschap prijs te geven? De Wet bepaalt niets hieromtrent en ik ben dan ook geneigd te zeggen, dat de vrouw niet daartoe verplicht is. Dit betekent echter niet dat zij de status van bipatridie blijft behouden, gezien de "stok achter de deur" in artikel 17 lid b. van de Wet opgenomen reeds aan de orde gekomen - terwijl ook het bezitten van een geldig, op naam staand buitenlands paspoort tot het verloren gaan van het Indonesisch staatsburgerschap leidt. Op genoemde twee verliesgronden zal in Hoofdstuk 6 worden teruggekomen.

Het is echter niet altijd zo, dat een als hierbedoelde vrouw automatisch de nationaliteit van haar - buitenlandse - echtgenoot verkrijgt. Trouwt zij bijvoorbeeld met een buitenlander, wiens nationaliteitsrecht, het "vrouw volgt man" beginsel niet huldigt, zodat het huwelijk van generlei invloed is op de status van de vrouw, dan blijft zij haar eigen nationaliteit behouden en wordt geen bipatride. ${ }^{736}$

Is het nu zo, dat bipatridie altijd als ongewenst dient te worden beschouwd? Alhoewel ik van mening ben, dat deze situatie zoveel mogelijk dient te worden voorkomen, gezien de moeilijkheden die uit deze status zouden kunnen voortvloeien, kan ik mij voorstellen dat in bepaalde gevallen het optreden van bipatridie als minder bezwaarlijk kan worden aangemerkt. In de literatuur is dit standpunt wel eens naar voren gebracht. Zo kan de mening van Ko Swan Sik worden aangehaald, die met betrekking tot een gehuwde vrouw met de status van bipatridie heeft opgemerkt, dat het slechts zelden zal voorkomen dat betrokkene door een zodanig huwelijk het land van oorsprong geheel zal verloochenen of vergeten. Aan de andere kant zal de vrouw in kwestie in de regel haar verdere leven in het land van haar man doorbrengen c.q. zal in deze maatschappij moeten - leven, zich dienen aan te passen en dit land leren te waarderen. Daardoor krijgt zij een dualistische instelling en wordt - zoals Ko Swan Sik het omschrijft - een "marginal man". Om deze reden kan volgens deze auteur een dubbele nationaliteit de beste weerspiegeling zijn van de sociale positie en het gevoelsleven van vrouwen, die een gemengd huwelijk hebben aangegaan. ${ }^{737}$ Ook ik ben van mening, dat in het

734. Gautama, Tafsiran, p.175-176.

735. Adriaanse en van der Weg, Nationaliteitswetgeving, Indonesiê, p.lb-22 en 23.

736. Trouwt een vrouw die Indonesisch staatsburger is met een Nederlander, dan kan zij van een "verlichte" naturalisatie-procedure gebruik maken, indien het huwelijk tenminste reeds drie jaar voortduurt.

737. Ko Swan Sik, De Meervoudige, p.319. 
hierbedoelde geval, het bezit van een dubbele nationaliteit niet als ongewenst behoeft te worden beschouwd.

De aandacht kan voorts worden gevestigd op artikel III der Overgangsbepalingen van de Wet. Op grond van dit artikel wordt aan een vrouw die krachtens de vóór 1 augustus 1958 geldende wettelijke bepalingen van rechtswege Indonesisch staatsburger zou zijn indien zij niet gehuwd ware, de gelegenheid geboden het Indonesisch staatsburgerschap te verkrijgen. Ter verduidelijking diene dat het hier vrouwen betreft, die door of als gevolg van huwelijk een buitenlandse nationaliteit hebben verkregen. De vrouw dient daartoe een op verkrijging van het Indonesisch staatsburgerschap gerichte verklaring optie - af te leggen bij de "Pengadilan Negeri" of de Diplomatieke Vertegenwoordiging van de Republiek Indonesië, binnen de termijn van één jaar na ontbinding van haar huwelijk dan wel binnen éen jaar gerekend vanaf 1 augustus 1958, het tijdstip van de inwerkingtreding der Wet. De in artikel III der Overgangsbepalingen opgenomen mogelijkheid beoogt in een vacuüm te voorzien door deze vrouwen alsnog de gelegenheid te geven, om de oorspronkelijk staatsburgerschap te verkrijgen. Ook artikel III maakt naar de letter géén uitzondering voor vrouwen, die door het verkrijgen van het Indonesisch staatsburgerschap bipatride worden, doordat zij door of als gevolg van hun huwelijk mogelijkerwijze - afhankelijk van de nationaliteitswetgeving van het land van hun (gewezen) echtgenoot - een buitenlandse nationaliteit hebben verkregen en deze niet verliezen door verkrijging van de Indonesische nationaliteit. Ook Gautama wijst erop, dat genoemd artikel III niet de voorwaarde bevat, dat slechts vrouwen die geen bipatride worden van de gelegenheid om het Indonesisch staatsburgerschap te verkrijgen gebruik kunnen maken. Naar de mening van deze auteur is het mogelijk dat de hierbedoelde vrouw, die haar andere - door huwelijk verkregen - nationaliteit niet verliest, het Indonesisch staatsburgerschap volgens deze bepaling kan verkrijgen. ${ }^{738}$ Ook in dit verband dient echter te worden gewezen op de verliesgronden ex. artikel 17 sub b. en sub j. van de Wet, waarmede terdege rekening te worden gehouden, wil het verkregen Indonesische staatsburgerschap niet verloren gaan.

Artikel 11 van de Wet stelt een persoon, die door of als gevolg van huwelijk het Indonesisch staatsburgerschap verloren heeft in de gelegenheid, dit staatsburgerschap terug te krijgen door binnen een termijn van een jaar na ontbinding van het huwelijk een daartoe strekkende verklaring af te leggen bij de "Pengadilan Negeri" of de Diplomatieke Vertegenwoordiging van de Republiek Indonesië (optie). Deze mogelijkheid staat echter niet open voor een persoon, die na het terugkrijgen van het Indonesisch staatsburgerschap nog een andere nationaliteit bezit. Bij nadere beschouwing van artikel 11 valt op, dat hierin niet wordt gesproken van "vrouwen" die door of als gevolg van hun huwelijk het staatsburgerschap hebben verloren, doch van "personen". Hieruit kan worden afgeleid, dat onder de geldingssfeer van artikel 11 een ruimere categorie valt dan vrouwen alleen en ook mannen onder de hierin opgenomen omschrijving kunnen vallen en als zodanig ook zij op de door artikel 11 der Wet voorgeschreven wijze, hun staatsburgerschap terug kunnen krijgen.

738. Gautama, Tafsiran, p.224. 
De Wet gaat uit van het principe, dat aan een persoon, die van nationaliteit verandert vanwege het door een andere persoon te worden "meegenomen" of door het volgen van de staat van een andere persoon, in beginsel de gelegenheid dient te worden gegeven, om de oorspronkelijke nationaliteit te herkrijgen, indien zij/hij die andere persoon niet meer volgt. Gezien dit principe dient een persoon, die het Indonesisch staatsburgerschap heeft verloren "vanwege het volgen van haar echtgenoot c.q. zijn echtgenote", zoals in de Memorie van Toelichting van de Wet gesteld, te worden toegestaan om het Indonesisch staatsburgerschap terug te krijgen. Aanknopend bij het voorgaande, kan terigkomend op artikel 11 der Wet worden gesteld, dat in eerste instantie vrouwen, die door of als gevolg van huwelijk het staatsburgerschap hebben verloren, van de door dit artikel geboden gelegenheid om het Indonesisch staatsburgerschap terug te krijgen, gebruik kunnen maken. De omschrijving "door of als gevolg van huwelijk" dient in ruime zin te worden opgevat. Dit beperkt zich niet tot verlies van het Indonesisch staatsburgerschap als gevolg van de huwelijkssiuiting, maar zou zich ook kunnen voordoen indien de echtgenoot van de vrouw, van oorsprong Indonesisch staatsburger, zich tot een vreemde nationaliteit heeft laten naturaliseren; het als zodanig verloren gaan van zijn Indonesisch staatsburgerschap, geldt van rechtswege mede voor zijn echtgenote. ${ }^{739}$ Wat betreft mannen, kan als voorbeeld een Indonesisch staatsburger met een buitenlandse vrouw gehuwd worden genoemd, die middels een daartoe strekkende verklaring - negative optie - zijn staatsburgerschap heeft prijsgegeven en vervolgens de nationaliteit van zijn echtgenote heeft verkregen. Bij ontbinding van het huwelijk kan hij van de door artikel 11 geboden gelegenheid om het Indonesisch staatsburgerschap terug te krijgen, gebruik maken.

\subsubsection{Gemengde huwelijken in de zin van de Huwelijkswet van 1974}

Ik acht het van nut, om in aansluiting op het bovenstaande enige aandacht te besteden aan de hiervoor reeds aangehaalde Huwelijkswet no. I van het jaar 1974, Stb. 1974-1, mede vanwege het feit, dat zich hierbij ook nationaliteitsrechtelijke aspecten kunnen voordoen. ${ }^{740}$

De onderhavige Huwelijkswet bevat ook voorzieningen, in het bijzonder betrekking hebbende op gemengde huwelijken, waaronder krachtens artikel 57 van deze Wet dient te worden verstaan, een huwelijk tussen personen, die in Indonesië aan verschillend recht zijn onderworpen, vanwege verschil in nationaliteit, waarvan één der partijen hel Indonesisch staatsburgerschap bezit. ${ }^{741} \mathrm{Het}$ in de Huwelijkswet bepaalde heeft tot

739. De basis hiervan wordt gevormd door artikel 9 lid 2 van do Wet, waarop in Hoofdstuk 6 zal worden teruggekomen.

740. Zie voor de tekst van de Huwelijkswet, Engelbrecht p.774.

741. Ichtiyanto, H., Perkawinan Campuran menurut Undang-Undang Perkawinan, tijdschrift Hukum dan Pembangunan, 1989, p.123-148. Deze auteur interpreteert artikel 57 op zodanige wijze - mijns inziens ten onrechte - dat gemengde huwelijken wegens verschil van godsdienst ook hieronder vallen, door nadruk te leggen op huwelijken in Indonesiē gesloten, "agn verschillend recht onderworpen " ("runduk pada hukum yang berlainan") gezien hel feit, dat achter deze zinsnede cen komma voorkomt. 
gevolg, dat sedert de inwerkingtreding daarvan huwelijken tussen personen van verschillende nationaliteit thans onder vigeur van deze Wet vallen. Het belang van dit feit is hierin gelegen, dat de Huwelijkswet van andere principes uitgaat dan de in \$2.4 van Hoofdstuk 3 behandelde RGH, aangezien deze Wet aansluit op de Wet no. 62 van het jaar 1958 betreffende het Indonesisch Staatsburgerschap.

De Huwelijkswet bepaalt dat in het geval de voltrekking van een als hierbedoeld huwelijk in Indonesië plaatsvindt, dit geschiedt volgens het in deze Wet bepaalde. Vindt de voltrekking daarentegen in het buitenland plaats - hetgeen niet alleen geldt indien het een huwelijk tussen een Indonesisch staatsburger en een buitenlander betreft, maar ook in het geval van een huwelijk tussen twee Indonesische staatsburgers - dan is het huwelijk wettig, indien voltrokken volgens het recht dat geldt in het desbetreffende land, en wat betreft Indonesische staatsburgers, de bepalingen van de Huwelijkswet niet zijn overtreden. ${ }^{742}$ De hierbedoelde gemengde huwelijken kunnen echter niet worden voltrokken, alvorens bewezen is dat aan de ter zake van het huwelijk geldende voorwaarden, zoals vastgesteld door het voor elk der partijen geldende recht, is voldaan. In dit verband kan de aandacht worden gevestigd op het arrest van de "Mahkamah Agung" no. $349 \mathrm{~K} / \mathrm{Sip} / 1967$ dat betrekking heeft op de zaak tussen Lie Kwei Sin tegen Woen Chie Kie. Hierin werd de uitspraak gedaan, dat het Gerecht bevoegd is om te beoordelen, of een huwelijk in het buitenland gesloten al dan niet wettig is. Met dit arrest werd het vonnis van de "Pengadilan Negeri" bekrachtigd, dat inhield dat het tussen partijen op 13 september 1973 in de Chinese Volksrepubliek gesloten huweiijk, niet wettig is volgens de in Indonesië geldende Wet. ${ }^{743}$

Wordt afgegaan op hetgeen naar de letter van de Wet in artikel 2 lid 1 van deze Wet is bepaald, dan kan worden gesteld dat een huwelijk wettig is, indien gesloten volgens het recht van de godsdienst c.q. de geloofsovertuiging van de beide partners. Genoemd criterium geldt ook voor de wijze van voltrekking van het huwelijk. In lid 2 van genoemd artikel 2 is voorts bepaald, dat ieder huwelijk dient te worden geregistreerd volgens de geldende wettelijke bepalingen, waarbij onderscheid wordt gemaakt tussen Moslims en niet-Moslims. De eis van registratie van het huwelijk, vormt een belangrijk onderdeel van de procedure die bij voltrekking dient te worden gevolgd, zoals vastgelegd in de artikelen 3 tot en met 9 van de Regeringsverordening no. 9 van het jaar 1975, Stb. 1975-12 ter uitvoering van de Huwelijkswet afgekondigd. ${ }^{744}$ Dit strekt mede ten doel, na te gaan of geen beletsel voorhanden is ten aanzien van de voltrekking

742. Dit heeft tot gevolg, dat Indonesische staatsburgers die de Islamitische godsdienst belijden en in het buitenland bijvoorbeeld in Duitsland wensen te trouwen, voor de wettigheid van hun huwelijk zowel voor de Duitse Burgerlijke Stand als volgens de bepalingen van het Islamitisch recht dienen te trouwen. Gautama noemt een geval, warin een Indonesisch staatsburger met een Duitse vrouw was getrouwd voor de Duitse Burgerlijke Stand. Bij terugkomst in Indonesiẽ wenste de vrouw opnieuw in het huwelijk te treden met een derde partij; van de kant van het Departement voor Godsdienstzaken werd verklaard dat het in Duitsland gesloten huwelijk niet wettig is omdat dit niet is gesloten volgens de bepalingen van het Islamitische recht. Zie Gautama, Hukum Perdata, p.121.

743. Zie Rangkuman Yurisprudensi Mahkamah Agung Indonesia, II., Hukum Perdata dan Acara Perdata, Proyek Yurisprudensi Mahkamah Agung, p.7.

744. Opgenomen in Engelbrecht p.782. 
van het beoogde huwelijk. ${ }^{74 s}$ In de praktijk is het voorgekomen dat de opvatting wordt gehuldigd, dat een huwelijk dat niet is geregistreerd onwettig zou zijn en kinderen geboren uit een als hierbedoeld huwelijk, slechts een burgerlijke betrekking hebben met hun moeder. Gezien het hierboven uiteengezette, is dit standpunt onjuist. Registratie is geen voorwaarde voor de wettigheid van een huwelijk, doch dient te worden gezien in het licht van het registreren van alle belangrijke gebeurtenissen uit het menselijk leven, zoals geboorte, overlijden, ter verkrijging van een officiële akte, die ook wordt opgenomen in het registratieregister. ${ }^{746}$

Onderscheid dient te worden gemaakt tussen de voor Moslims aangewezen "Pengadilan Agama" (Gerecht voor Godsdienstzaken) en de "Pengadilan Negeri" (Landgerecht), als het voor andere dan Moslims aangewezen Gerecht. Wat betreft de bevoegdheidsafbakening tussen de "Pengadilan Negeri" en de "Pengadilan Agama" kan worden gesteld, dat eerstgenoemd Gerecht als de algemene rechtbank bevoegd is om zaken te onderzoeken van personen die geen Moslim zijn en van godsdienst en van nationaliteit verschillen en met betrekking tot aangelegenheden, niet in Regeringsverordening no. 9 van 1975 geregeld, ook al heeft een en ander op Moslims betrekking. Hieraan ligt de overweging ten grondslag, dat volgens de Wet no.1 van 1974 het de "Pengadilan Negeri" in het kader van de algemene rechtspraak is, die alle burgerrechtelijke geschillen onderzoekt en voorts tot taak heeft recht te spreken in geschillen, waarin volgens het geldende recht verschillend burgerlijk recht wordt toegepast, zoals het Adatrecht, het IBW, het Intergentiel of het Internationaal privaatrecht. De "Pengadilan Agama" is voorts bevoegd tot het onderzoeken van zaken als bedoeld in Regeringsverordening no.9 van 1975 ten aanzien van Moslims, ongeacht de bevolkingsgroep, waarvan deze deel uitmaken. Het behoort tot de competentie van "Pengadilan Negeri" om onder meer een formeel onderzoek in te stellen of de "Pengadilan Agama" de haar door de Wet toegekende bevoegdheden niet heeft overschreden, bijvoorbeeld met betrekking tot aangelegenheden, die niet in de Regeringsverordening no. 9 van 1975 zijn geregeld. Treedt ter zake een jurisdictiegeschil op, omdat zowel de "Pengadilan Negeri" en de "Pengadilan Agama" zich al dan niet bevoegd achten om een bepaalde zaak te onderzoeken, dan is het de "Mahkamah Agung" die in eerste en laatste aanleg beslist.

Het met betrekking tot de geldigheid van een huwelijk hierboven uiteengezette is ook van belang in het geval van huwelijken in de zin van de Huwelijkswet van 1974 tussen personen van verschillende nationaliteit, die bovendien ook van godsdienst kunnen verschilien. Ter illustratie kan een man, die buitenlander is worden genoemd, die "simuleert" tot de Islam over te gaan, ter wille van de vrouw die Indonesisch staatsbur-

745. De voorgeschreven registratie van een huwelijk geschiedt voor de groep der Moslims door de Registratiebeambte als bedoeld in de Wet no. 32 van het jaar 1954, Stb. 1954-98 betreffende Registratie van Huwelijken ("Nikah"), Verstotingen ("Talak") en berroeping van Verstotingen ("Rujuk"), opgenomen in Engelbrecht p.782. De registratie van huwelijken van anderen dan Moslims, geschiedt door de Registratiebeambte van de Burgerlijke Stand.

746. Marbun, D.C., Fungsi dan Makna Pencatan dalam Undang-Undang Perkawinan, tijdschrift Varia Peradilan, januari 1992, p.144-150. Deze auteur beveelt in dit verband aan, om een nationale wet inzake de Burgerlijke Stand vast te stellen. 
ger is en de Islamitische godsdienst belijdt, dit mede in het belang van haar familie. ${ }^{747}$ Soortgelijke gevallen komen in de praktijk vaak voor. Zo kan een geval worden genoemd, waarbij een toerist met de Zwitserse nationaliteit in Indonesië trouwde met een Indonesische Islamitische vrouw. De Zwitserse ambassade, evenals de Zwitserse regering weigerden dit op Islamitische wijze gesloten huwelijk te erkennen; de daarbij betrokken personen werden aanbevolen opnieuw voor de "Standesamt" te trouwen, door Gautama en ook door mij terecht bevonden. ${ }^{748}$

In dergelijke gevallen vindt in Indonesië nog steeds artikel $16 \mathrm{AB}$ betreffende het personeel statuut - dat alleen op familierecht betrekking heeft - toepassing, dat inhoudt dat de wetten betreffende de rechten, de staat en de bevoegdheid van personen, deze personen volgen bij verblijf buitenlands. ${ }^{749}$ Met de woorden "de rechten, de staat en de bevoegdheid" is de "staat" van een persoon bedoeld, in de zin van de rechtspositie die men inneemt, die zowel de handelingsbekwaamheid en handelingsbevoegdheid bepaalt. ${ }^{750}$ Dit houdt in, dat volgens artikel $16 \mathrm{AB}$ de buitenlander zijn personeel statuut naar Indonesië meeneemt en de rechter aldaar de staat van deze buitenlander voor zijn in Indonesië verrichte rechtshandelingen moet beoordelen naar het voor hem geldende (buitenlandse) recht.

Voorts kan op de, in artikel 16 van de Regeling van de Minister van Godsdienstzaken no. 3 van 1975 opgenomen bepaling worden gewezen, die inhoudt dat indien eén der huwelijkspartners Moslim en Indonesisch staatsburger is die een gemengd huwelijk wenst aan te gaan, een verklaring van de Registratiebeambte voor Huwelijken ("Pegawai Pencacat Nikah") als bedoeld in artikel 60 nodig is. Deze verklaring is ook nodig voor een persoon die Moslim is en een huwelijk, anders dan volgens het Islamitische recht, wenst te sluiten. Ingaande op de in artikel 60 van de Huwelijkswet opgenomen bepaling, dat een gemengd huwelijk niet kan worden voltrokken, voordat bewezen is dat de voorwaarden door het voor iedere partij geldende recht voorgeschreven zijn vervuld, kan worden opgemerkt dat in het geval de registratiebeambte weigert bedoelde verklaring af te geven, de "Pengadilan Negeri" ter zake een beslissing neemt, waartegen niet in beroep kan worden gegaan. ${ }^{751}$

747. Djoko Basuki, Z., Perkawinan Antar Agama dewasa ini di Indonesia, ditinjau dari segi Hukum Antar Tata Hukum, tijdschrift Hukum dan Pembangunan, 1987, p.235-243, die een soortgelijk geval naar voren brengt.

748. Zie ook Bismar Siregar, Hubungan Kitab Undang-Undang Hukum Perdata dengan Undang-Undang No. 1 tahun 1974 tentang Perkawinan dan Penerapannya dalam Praktek Notaris, tijdschrift Varia Peradialan, augustus 1988, p.127-139.

749. Zie inzake het personeel statuut, Gautama, Hukum Perdata, p.2-9, die onder meer aangeeft welk recht wordt gebruikt voor het personeel statuut.

750. Pitlo, A. en Meijling, G., Het Personenrecht naar het Nederlands Burgerlijk Wetboek, Haarlem, 1953, p.48.

751. Huwelijken tussen personen die van godsdienst verschillen, met name buwelijken tussen Moslims en niet-Moslims zijn in de literatuur niet ongemoeid gelaten. Aangezien de "Pengadilan Agama" dergelijke buwelijken niet wenst te erkennen, zijn de betrokken personen krachtens een van de "Pengadilan Negeri" verkregen verklaring genoodzaakt voor de Ambtenaar van de Burgerlijke Stand 
Wat betreft de nationaliteitsrechtelijke gevolgen van een gemengd huwelijk is in artikel 58 van de Huwelijkswet bepaald, dat personen van verschillende nationaliteit die een huwelijk aangaan, het staatsburgerschap van de man respectievelijk de vrouw kunnen verkrijgen of verliezen, op de wijze als vastgesteld in de geldende wet op het staatsburgerschap van Indonesië, te weten de Wet no. 62 van het jaar 1958. ${ }^{732}$ Het staatsburgerschap, dat wordt verkregen als gevolg van het huwelijk, bepaalt het voor partijen geldende recht, zowel publiekrechtelijk als privaatrechtelijk. Dit geldt mede voor de positie der kinderen, uit een als hierbedoeld gemengd huwelijk geboren. Met betrekking tot de vraag hoe dit nu uitwerkt in het nationaliteitsrecht, kan naar voren worden gebracht, dat dit afhangt van hetgeen het nationaliteitsrecht van de desbetreffende ouder hieromtrent bepaalt. ${ }^{753}$

Aangezien in de Huwelijkswet verwezen wordt naar de Wet no. 62 van het jaar 1958 betreffende het Indonesisch staatsburgerschap, houdt dit in dat de bepalingen zoals hiervoor reeds uitgebreid toegelicht op een als hierbedoeld gemengd huwelijk van toepassing zijn. Ook indien het een internationaal huwelijk betreft tussen een Indonesisch staatsburger die tevens bijvoorbeeld Moslim is en een persoon van een andere nationaliteit en godsdienst, is voor wat betreft de nationaliteitsrechtelijke gevolgen, de nationaliteit en niet de godsdienst doorslaggevend.

Wordt de in $\S 2.4$ van Hoofdstuk 3 aan de orde gekomen Regeling op de Gemengde Huwelijken (RGH) van 1898 in herinnering gebracht, die het beginsel hanteert dat de vrouw staande huwelijk de staat van haar echtgenoot volgt, dan kan worden gesteld dat dit beginsel voorheen ó́k opging voor huwelijken tussen personen van verschillende

751. $\rightarrow$

to trouwen. Het schijnt dat deze procedure in de praktijk op moeilijkheden stuit, in die zin dat het sluiten van gemengde huwelijken wegens verschil van godsdienst voor de Burgerlijke Stand niet langer op zijn plaats wordt geacht. Zie hiervoor Bismar Siregar, Kawin Campur antar Agama, bagaimana Penyelesaiannya, tijdschrift Varia Peradilan, december 1991, p. 145-147. Nogveel verder gaat Daud Ali, die van mening is dat huwelijken tussen personen die van godsdienst verschillen niet wettig zijn volgens de godsdienst, waarvan het bestaan in de Republiek Indonesiê wordt erkend. Volgens deze auteur houdt dit in, dat huwelijken die niet wettig zijn volgens de godsdienst, ook niet wettig zijn volgens de Huwelijkswet. Zie Daud Ali, H.M., Sikap Negara dalam mewujudkan Perlindungan Hukum bagi Warganegara dan pelaksanaan Undang-Undang Perkawinan yang berlaku, tijdschrift Hukum dan Pembangunan, 1992, p. 128-138.

752. Of de man de nationaliteit van de vrouw kan krijgen, is uiteraard afhankelijk van het recht dat geldt in het land van laatstgenoemde. Als voorbeeld kan worden genoemd, de Indonesisch staatsburger die zijn nationaliteit prijsgeeft en zich vervolgens tot staatsburger van het land van zijn vrouw laat naturaliseren, vooropgesteld dat het nationaliteitsrecht van de vrouw dit mogelijk maakt.

753. Ter illustratie: Een Nederlandse vrouw trouwt met een Italiaan. De Rijkswet van 1985 huldigt, zoals bekend, het beginsel van gelijkheid van de geslachten. Dit brengt met zich, dat de nationaliteit van de vrouw, evengoed bepalend is voor de vaststelling van de nationaliteit van het kind, als die der vader. Het huwelijk van de Nederlandse vrouw is van generlei invloed op haar nationaliteit, zij blijft derhalve Nederlandse. Dit heeft tot consequentie, dat het kind, indien ná 1 januari 1985 geboren, zowel de Nederlandse als de Italiaanse nationaliteit bezit en derbalve bipatride wordt. 
nationaliteit. ${ }^{744}$ Met het van kracht worden van de Huwelijkswet is, zoals gezegd, in deze situatie verandering gekomen, aangezien als hierbedoelde huwelijken thans niet langer onder de RGH vallen.

Betreft het daarentegen gemengde huwelijken in de betekenis van huwelijken tussen personen die verschillen van godsdienst, van bevolkingsgroep dan wel van plaats of regio, dan heeft genoemde RGH haar geldingskracht behouden. ${ }^{755}$ Dit impliceert, dat voor deze gemengde huwelijken het beginsel, dat de vrouw staande huwelijk de staat van haar echtgenoot volgt van kracht is, een beginsel, dat - in principe - ook door de Wet no. 62 van het jaar 1958 wordt gehanteerd. In dit verband kan worden gewezen op artikel 9 van deze Wet - in $\$ 7$ aan de orde gekomen - waarin het "vrouw volgt man" beginsel tot uiting komt. Hierbij is echter het voorbehoud gemaakt, dat de toepassing van genoemd beginsel gén bipatridie voor de vrouw teweeg mag brengen. Hieruit kan worden geconcludeerd, dat in dit geval het "vrouw volgt man" beginsel dient terug te wijken voor het beginsel, bipatridie zoveel mogelijk te vermijden. ${ }^{756}$

Ook in het Rondschrijven no. MA/Pemb/0807/75 van de "Mahkamah Agung", gericht aan de voorzitters en rechters van de "Pengadilan Tinggi" en de "Pengadilan Negeri" is uitdrukkelijk gesteld, dat de Huwelijkswet is bedoeld om unificatie op het gebied van de huwelijkswetgeving door te voeren, zonder daarbij de nuances teniet te doen, die nog dienen te worden gehandhaafd in verband met het nog van kracht zijn van positief verschillend recht in de samenleving. Aanknopend bij voormelde artikelen 66 van de Wet no. 1 van 1974 jo. 47 van de Regeringsverordening no. 9 van 1975 is gesteld, dat deze artikelen niet alle bepalingen betreffende het huwelijksrecht die voorkomen in het IBW, de Huwelijksordonnantie Christen-Indonesiërs, Ind. Stb. 1933-74 en de RGH beogen in te trekken, doch slechts die bepalingen inzake huwelijksaangelegenheden, die reeds in de Huwelijkswet zijn geregeld.

Dat de factoren "godsdienst en "nationaliteit" niet altijd gescheiden van elkaar kunnen worden gezien, komt naar voren bij de toepassing van de in 1989 afgekondigde Wet no. 7 van het jaar 1989 betreffende de Godsdienstige Rechtspraak, Stb. 1989-49. In artikel 49 van deze Wet is bepaald, dat de "Pengadilan Agama" (Gerecht voor Godsdienstzaken) tot taak en bevoegdheid heeft, zaken in eerste aanleg te onderzoeken, te beslissen en af te wikkelen onder meer op het vlak van huwelijken tussen "personen die de Islamitische godsdienst belijden". 757

754. Zie wat betreft de inzake deze aangelegenheid in de literatuur voorkomende verschillen van mening, hetgeen in $\$ 2.4$ van Hoofdstuk 3 werd opgemerkt.

755. Zo ook de mening van Gautama, Mahkamah Agung, p.163-169.

756. Het "vrouw volgt man" beginsel dient bij het verloren gaan van het Indonesisch staatsburgerschap door de man, eveneens te wijken voor het beginsel, het optreden van apatridie zoveel mogelijk te vermijden. Zie hiervoor artikel 9 lid 2 van de Wet.

757. De bevoegdheid van de "Pengadilan Agama" omvat meer dan het vlak der huwelijken, strekt zich onder meer ook uit tot erfenissen en schenkingen, waarop in deze paragraaf niet nader is ingegaan. 
Hoe ligt deze aangelegenheid, indien zich het geval voordoet dat de huwelijkspartners wel beiden de Islamitische godsdienst belijden, doch van nationaliteit verschillen? Met betrekking tot het verschil van nationaliteit is geen bepaling in de Wet opgenomen. De factor "verschil in nationaliteit" kan echter een belangrijke rol spelen in het vaststellen van het recht, dat voor de desbetreffende personen geldt. Krachtens het in de Wet no. 7 van 1989 bepaalde, wordt slechts afgegaan op het feit, of de personen in kwestie de Islamitische godsdienst belijden en speelt de nationaliteit van betrokkenen in de uitvoering van deze Wet geen rol.

Wordt het hiervoor aangehaalde voorbeeld van een Zwitser/Moslim op Islamitische wijze gehuwd met een Moslims meisje, dat Indonesisch staatsburger is - de beide partners derhalve in godsdienst overeenkomen, doch van nationaliteit verschillen - als illustratie genomen, dan rijst de vraag, hoe eventuele geschillen die met het huwelijk verband houden of die hieruit voortvloeien, dienen te worden afgewikkeld. ${ }^{758}$ Welke rechtbank is dan ter zake bevoegd, de "Pengadilan Agama" of de "Pengadilan Negeri" als de algemene rechtbank? Wordt afgegaan op het in artikel 49 van de onderhavige Wet opgenomen criterium van "personen die de Islamitische godsdienst belijden" dan is de "Pengadilan Agama" ter zake bevoegd. Zouden zich hierbij geen onplezierige consequenties kunnen voordoen als gevolg van een jurisdictie-geschil tussen de "Pengadilan Agama" met gebruikmaking van Islamitisch recht en de bepalingen van het Zwitsers Burgerlijk recht?

Aangenomen kan worden, dat het laatste woord hierover nog niet is gezegd. Onder de aandacht dient te worden gebracht, dat in Islamitische landen, het Islamitisch recht ter zake doorslaggevend is. Wat Indonesië betreft, ligt deze aangelegenheid anders, aangezien het hier een rechtsstaat betreft, gebaseerd op de Pancasila. Dit neemt echter niet weg, dat het treffen van de nodige voorzieningen door de Indonesische wetgever om als hierboven geschetste moeilijkheden op te vangen, een eerste vereiste is.

7.1.4. Verdient het gelijkgerechtigdheidsbeginsel voorkeur boven het "vrouw volgt man" beginsel?

Met betrekking tot het Verdrag van New York inzake de Uitbanning van alle vormen van Discriminatie van Vrouwen van 10 december 1979, door Indonesië in 1984 geratificeerd ${ }^{759}$, kan worden gesteld, dat de in artikel 9 daarvan opgenomen verplichting, dat noch huwelijk met een buitenlander, noch verandering van nationaliteit door de echtgenoot gedurende huwelijk, automatisch de nationaliteit van de vrouw zal wijzigen, haar staatloos zal maken of haar de nationaliteit van de echtgenoot zal opleggen, niet geheel door Indonesië wordt nageleefd.

758. Hier kan worden gedacht aan zangelegenheden als het al dan niet wettig zijn van het huwelijk, echtscheiding, erfeniskwesties, de kinderen die uit dit Islamitisch huwelijk worden geboren e.d.

759. Dit Verdrag is opgenomen in Trb. $1980,146$. 
Dit geldt met name voor verandering van nationaliteit door de echtgenoot gedurende het huwelijk, aangezien krachtens artikel 9 lid 1 van de Wet no. 62 van het jaar 1958, het door de echtgenoot verkregen Indonesisch staatsburgerschap van rechtswege ook voor diens echtgenote geldt. Dit vloeit voort uit het "vrouw volgt man" principe, waar de Wet in beginsel van uitgaat. Wél is hierbij het voorbehoud gemaakt, dat de vrouw hierdoor niet de staat van bipatride mag verkrijgen. ${ }^{760}$ Doet dit zich voor, dan vindt het "vrouw volgt man" beginsel geen toepassing. Volledigheidshalve zij erop gewezen, dat indien de man een verzoek tot naturalisatie tot Indonesisch staatsburger indient, hij de toestemming van zijn echtgenote(n) nodig heeft, zoals in artikel 5 lid 2 sub c gesteld.

Een als hiervoor genoemd voorbehoud is daarentegen niet uitdrukkelijk gesteld in het kader van de geprivilegieerde naturalisatie met betrekking tot het indienen van een verzoek ter verkrijging van het Indonesisch staatsburgerschap als omschreven in de artikelen 3 en 4 der Wet. Hierdoor rijst de vraag, of ook in de hierbedoelde gevallen toestemming van de echtgenote - indien de aanvrager gehuwd is - dient te zijn verkregen. Ik neig ertoe om deze vraag bevestigend te beantwoorden. Wel dient acht te worden geslagen op het feit, dat op de in de artikelen 3 en 4 gehanteerde leeftijd van 18 jaar, betrokkenen normaliter nog te jong zijn on gehuwd te zijn. Immers, krachtens het in artikel 7 van de Huwelijkswet bepaalde, is een huwelijk eerst toegestaan, indien de man de leeftijd van 19 jaar en de vrouw die van 16 jaar heeft bereikt. Hiervan kan echter bij het Gerecht dispensatie worden aangevraagd.

Ook de eveneens in artikel 9 van het Verdrag opgenomen verplichting, dat aan vrouwen gelijke rechten als aan mannen zullen worden verleend, ter verkrijging, verandering of lot behoud van hun nationaliteit wordt niet geheel door Indonesië nageleefd. Zo wordt de gehuwde vrouw het recht onthouden om een verzoek tot naturalisatie of een verzoek als bedoeld in genoemde artikelen 3 en 4 der Wet in te dienen. Het beginsel "eenheid van nationaliteit der beide huwelijkspartners" wordt in principe in de toepassing van deze Wel vooropgesteld, al zijn op dit beginsel uitzonderingen mogelijk. Hel "vrouw volgt man" beginsel wordt met name losgelaten, in het geval van een gemengd huwelijk, doordat de buitenlandse vrouw die met een Indonesisch staatsburger huwt, eerst het Indonesisch staatsburgerschap verkrijgt, door hiervoor te opteren. Automatische verkrijging van het Indonesisch staatsburgerschap in het hierbedoelde geval is voorts afhankelijk gesteld van het voldoen aan bepaalde voorwaarden. ${ }^{761}$ Hetzelfde beginsel gaat op in het geval een vrouwelijke Indonesisch staatsburger met een buitenlander trouwt, in welk geval de vrouw haar staatsburgerschap blijft behouden, tenzij zij zélf dit wenst prijs te geven. In het algemeen geldt voorts, dat het "vrouw volgt man" beginsel dient te wijken voor het beginsel, het optreden van apatridie en bipatridie te voorkomen, zoals uit artikel 9 van de Wet blijkt.

760. Dit geldt krachtens artikel 9 lid 2 van de Wet ook bij het verloren gaan van dit staatsburgerschap door de echigenoot, onder voorbehoud dat de vrouw niet de staat van apatride mag verkrijgen.

761. Hierop aansluitend kan worden gewezen op het feit, dat in een als hierbedoeld geval, de man zelfs zijn Indonesisch staatsburgerschap kan prijsgeven, teneinde de nationaliteit van zijn vrouw te verkrijgen. 
Hierop aansluitend kan worden teruggegrepen op het in artikel 3 van de Wet bepaalde, waarbij aan buiten huwelijk geboren kinderen die door exn buitenlander zijn erkend, de gelegenheid wordt geboden om het Indonesisch staatsburgerschap van de moder te verkrijgen. Deze mogelijkheid staat ook open voor bideren gekoren uit ren gemengd huwelik tussen een yrouw, die Indonesisch staatsburger is an ben bittenlander, die bif scheiding aan de moeder worden toegewezen. ${ }^{72}$ Geonduderd kan wonden, dat wh in deze gevallen het Indonesisch statshurgerschap van de vrow c.q. moeder ext belangrike, zo niet doorslaggevende rol speelt.

Gezien genoende uitzonderingen op de hiervoor genowde algemene regel, rijs de wraag of het niet aan te bevelen is, het "krouw wolgt man" beginuel te laten varen $c, 4$. dit te wervangen door het gelijkgerechtigdheidsbeginsel, wok al gezien hetgeen in genoemd, door Indonesie geratificeerd Verdrag is bepaald.

Uit de praktijk blijkt, dat Indonesische vrouwen van het "vrouw volgt man" beginsel wensen af te stappen, aangezien dit riet in overeenstemming wordt geacht met de emancipatiestreven van de vrouw. In dit verband kan op de mening wan Gautama worden gewezen, dat thans op alle vlakken van het bestaan ${ }^{75}$ de vrow niet wenst te worden achtergesteld bij de man, ook niet op het vlak van het huwelijk. Dit impliceert, dat het huwelijk in het geheel niet van invloed dient te zijn op de nationaliteit van de vrouw. ${ }^{764}$ Ook Nani Soewondo wijdt een uitvoerige beschouwing aan de plaats van de Indonesische vrouw in het recht en de maatschappij. ${ }^{765}$ Onder de aandacht kan voorts worden gebracht, dat volgens het Adatrecht en het Islamitisch recht, de vrouw in het algemeen tot het verrichten van rechtshandelingen bevoegd is en sedert 1963 de artikelen 108 en $110 \mathrm{IBW}$, inzake de handelingsonbekwaamheid van de vrouw om rechtshandelingen te verrichten en in rechten te verschijnen ongeldig werden verklaard, opdat niet langer verschil op dit vlak bestaat tussen Indonesische staatsburgers. ${ }^{766}$ Dat niet altijd het recht van de man prevaleert boven dat van de vrouw kan voorts worden aangetoond door artikel 75 van de Huwelijksordonnantie Christen-Indonesiërs, Ind. Stb. 1933-74 waarbij in het geval van een huwelijk tussen een niet-Christenman en een Christenvrouw, het huwelijk in kwestie door het recht van de vrouw wordt beheerst.

762. Zie hiervoor $\$ 5.1$ van dit Hoofdstuk.

763. Op het vlak van het agrarisch recht is het gelijkgerechtigd zijn van mannen en vrouwen vitdrukkelijk in de Agrarische Basiswet no. 5 van 1960 gesteld.

764. Zie Gautama, Warganegara, p. $129-140$.

765. Nani Soewondo, Kedudukan Wanita.

766. De basis hiervan vormt het Rondschrijven van de "Mahkamah Agung" no. 3 van 5 september 1963, waarbij het IBW niet langer van kracht werd verklaard. Betwijfeld kan echter worden of met een rondschrijven van de "Mahkamah Agung" het IBW ongeldig kan worden verklaard. Wellicht met het oog hierop is voorgesteld om het IBW niet langer als een wet, doch als een document te beschouwen, waarin een deel van het "ongeschreven recht" is beschreven. Hierdoor zjn rechters vrij om bepaalde artikelen, die niet langer in overeenstemming zijn met het huidige Indonesische rechtsbestel te negeren. In de praktijk maken rechtbanken echter nog gebruik van de bepalingen van bet IBW en kan worden aangenomen, dat dit Wetboek nog altijd rechtskracht heeft. 
Samenvattend ben ik van mening, dat toepassing van het gelijkgerechtigdheidsbeginsel zeker aan te bevelen is. Genoemd beginsel kan bovendien meer in overeenstemming met de moderne opvattingen worden geacht te zijn - gezien de emancipatie van de vrouw een opvatting die ook tot uiting komt in andere gebieden van het Indonesische recht. ${ }^{767}$

Wordt een vergelijking gemaakt met Nederland, dan kan worden opgemerkt dat uit hoofde van het gelijkgerechtigdheidsbeginsel, het huwelijk van een Nederlandse vrouw met een buitenlander van geen invloed op de status van eerstgenoemde is en zij haar Nederlandse nationaliteit blijft behouden. Voor het ongekeerde geval geldt, dat de buitenlandse vrouw die met een Nederlander trouwt zich tot Nederlandse dient te naturaliseren, wil zij deze nationaliteit bezitten. De nationaliteit van de vrouw is evengoed van invloed op dat van het kind als de nationaliteit van de man, ook al zou dit tot bipatridie leiden. Het is wellicht van nut om hierop aansluitend de geschiedenis van de Nederlandse wetgeving inzake deze aangelegenheid aan te halen. Krachtens het Nederlands BW van 1838, volgden zowel een buitenlandse vrouw met een Nederlander getrouwd als een Nederlandse vrouw met een vreemdeling gehuwd de staat van de man. De Wet van 1850 die het politieke Nederlanderschap regelde, hield geen bepalingen in omtrent het verkrijgen of het verlies van de Nederlandse nationaliteit door de gehuwde vrouw. ${ }^{768}$ In de loop der jaren kwam herhaaldelijk het standpunt van de voorstanders van het beginsel "eenheid van nationaliteit" naar voren en werd het wenselijk geacht dat de vrouw de staat van haar man volgde. Strijd leverde echter de vraag op of dit ook opging, indien de man tjjdens het huwelijk - bijvoorbeeld door naturalisatie - een andere nationaliteit verkreeg. Zo werd onder meer naar voren gebracht, dat genoemd beginsel wél kon worden aangenomen bij de huwelijkssluiting, aangezien de vrouw dan op de hoogte was van de nationaliteit van de man waarmede zij trouwde, doch dit niet op zijn plaats werd geacht bij nationaliteitswisseling tijdens het huwelijk, aangezien dit de vrouw voor onaanvaardbare situaties zou kunnen plaatsen. Hiervan kan worden genoemd, dat het huwelijk niet kon worden ontbonden volgens het oorspronkelijke recht, doch wél onder het nieuwe recht. Tot een wijziging van de nationaliteitswetgeving leidde dit echter niet. ${ }^{769}$ Ook de Wet van 1892 huldigde oorspronkelijk het beginsel van algehele cenheid van nationaliteit; de vrouw zou zowel bij als tijdens het huwelijk de staat van de man volgen. Eerst als gevolg van de ratificatie van het Haagse Verdrag

767. Ter illustratie kan de Rijkswet van 1985 op het Nederlanderschap worden genoemd. Het buwelijk is van geen invloed op de nationaliteit, in die zin dat een Nederlandse vrouw die met een buitenlander trouwt, baar eigen nationaliteit blijft behouden. Omgekeerd verkrijgt een buitenlandse vrouw die met een Nederlander trouwt, niet van rechtswege de Nederlandse nationaliteit. Het Nederlandse nationaliteitsrecht heeft op dit punt een hele evolutie doornakak. Zie hiervoor Brouwer, De Nationaliteit, p.203-204.

768. Dit leidde in de literatuur tot interpretatieverschillen; zo waren enkele auteurs van mening dat, gelet op het feit dat de Wet van 1850 omtrent deze aangelegenheid niets bepaalde, de Nederlandse vrouw noch door huwelijk met een vreemdeling, noch in het geval haar man tijdens het huwelijk zijn Nederlandse nationaliteit verloor, haar Nederlandse nationaliteit krachtens deze Wet kon verliezen. Zie Brouwer, De Nationaliteit, p.203. Zie voor een uittreksel wan het Ned. BW en de tekst van de Wet van 1850, Chalanton, La Nationalité, p. 115-118 en p. 119-124.

769. Brouwer, De Nationaliteit, p.204-205. 
van 1930 werd bij Wet van 21 December 1936, N. Stb. 209 een wijziging in de Wet van 1892 doorgevoerd, voornamelijk met het doel om staatloosleid te voorkomen. Bepaald werd dat de vrouw indien zij met een vreemdeling huwde of in het geval haar man door naturalisatie in een vreemd land een andere nationaliteit verwierf en de vreemde nationaliteit van de man niet deelachtig werd of kon worden, zij Nederlandse zou blijven. Alhoewel bij die gelegenheid vurig werd gepleit voor een algehele herziening van de nationaliteitsbepalingen voor de gehuwde vrouw, waarbij mede in aanmerking werd genomen, dat veel landen die het eenheidsprincipe gehuldigd hadden waren teruggekeerd tot het stelsel van de onafhankelijke nationaliteit van de vrouw, mocht dit niet baten. ${ }^{70}$ Ook in de Wet van 1910 inzake het Nederlands onderdaanschap van niet-Nederlanders kwam het eenheidsbeginsel tot uiting; naderhand werd in deze Wet een soortgelijke wijziging doorgevoerd als in de Wet van 1892 als hiervoor genoemd. Laatstgenoemde Wet werd echter in 1964 krachtens de Rijkswet van 14 november 1963 , N. Stb. 467 gewijzigd in die zin dat het "système unitaire" voorgoed werd verlaten; een met een Nederlander gehuwde vrouw verkreeg sindsdien niet meer automatisch de nationaliteit van haar man, doch kon deze op eenvoudige wijze verkrijgen middels optie. Ook een Nederlandse vrouw die met een vreemdeling trouwde, kon sedertdien in alle gevallen haar Nederlandse nationaliteit behouden. ${ }^{n_{1}}$ In de thans geldende Rijkswet van 1985 inzake het Nederlanderschap heeft deze aangelegenheid haar hoogtepunt bereikt, aangezien gelijke behandeling van man en vrouw die ook op andere rechtsgebieden steeds meer terrein wint, thans consequent in het nationaliteitsrecht is doorgevoerd. Ik ben op deze aangelegenheid aan de hand van de Nederlandse wetgeving ingegaan, omdat Indonesië hierin wellicht een voorbeeld kan vinden om ook volledig het gelijkgerechtigdheidbeginsel van man en vrouw toe te passen.

\section{$\$ 8$ Verkrijging door het volgen van de staat van de vader c.q. moeder}

In $\S 2$ werd opgemerkt, dat het Indonesisch staatsburgerschap in eerste instantie op grond van het "ius sanguinis" wordt verkregen; toepassing van het "ius soli" vindt eerst in die gevallen plaats, waarin staatloosheid zou kunnen optreden.

In aansluiting hierop kan op artikel 13 van de Wet no. 62 van 1958 worden gewezen, waarin ten aanzien van een kind dat de leeftijd van 18 jaar nog niet heeft bereikt of niet op een eerder tijdstip is gehuwd is bepaald, dat het mede verkrijgen van het Indonesisch staatsburgerschap van de vader door het kind in kwestie, afhankelijk is van het voldoen aan de navolgende criteria:

a. de familierechtelijke betrekking met de vader moet zijn ontstaan, vó́rdat de vader het Indonesisch staatsburgerschap verkrijgt;

b. het kind dient in Indonesië woonplaats te hebben en zich aldaar de facto te bevinden.

770. Brouwer, De Nationaliteit, p. 209-210.

771. De Groot en Tratnik, Nationaliteitsrecht, p.51. 
Met betrekking tot het hierboven onder a. genoemde criterium kan ter verduidelijking naar voren worden gebracht, dat in het geval de familierechtelijke betrekking tussen vader en kind ontstaat, nadat eerstgenoemde het Indonesisch staatsburgerschap heeft verkregen, het kind in kwestie 6ók de status van de vader verkrijgt en wel krachtens het beginsel van de afgeleide nationaliteit. In dit verband kan het in artikel 1 sub b. van de Wet bepaalde in herinnering worden gebracht, in $\$ 2$ reeds behandeld. Toegelicht met een voorbeeld: heeft de vader een buitenlandse nationaliteit en wordt hij vervolgens tot Indonesisch staatsburger genaturaliseerd, dan delen de vóor het tijdstip der naturalisatie geboren kinderen in de verkrijging van het Indonesisch staatsburgerschap door de vader krachtens het hierboven aangehaald artikel. Betreft het daarentegen kinderen ná bedoeld tijdstip geboren, dan zijn deze kinderen Indonesisch staatsburger krachtens artikel 1 sub b. der Wet. Immers, krachtens genoemd artikel is Indonesisch staatsburger, een persoon minderjarig in de zin van de Wet die op het tijdstip van zijn geboorte een familierechtelijke betrekking met zijn vader, een Indonesisch staatsburger heeft, welk staatsburgerschap een aanvang neemt vanaf het ontstaan van die familierechtelijke betrekking.

Afgaande op het hierboven onder b. genoemde criterium, kan voorts worden opgemerkt, dat het kind niet alleen aan het juridisch criterium van "in Indonesië woonplaats hebben" dient te voldoen, doch het zich bovendien feitelijk in Indonesië dient te bevinden, wil het in de verkrijging van het Indonesisch staatsburgerschap door de vader delen. De mogelijkheid bestaat met name, dat een persoon die een verzoek tot naturalisatie ex artikel 5 van de Wet indient nog in het buitenland woonplaats heeft en dit ook hel geval is wat betreft zijn vrouw en kinderen. Zoals reeds opgemerkt, verkrijgt de vrouw van rechtswege mede het Indonesisch staatsburgerschap krachtens het in artikel 9 lid I van de Wet bepaalde - voor zover zij niet de status van bipatride krijgl - of zij nu in het buitenland of in Indonesië verblijft. Minderjarige kinderen van de betrokken persoon verkrijgen eerst het Indonesisch staatsburgerschap indien zij in Indonesië woonplaats hebben en aldaar de facto verblijven. ${ }^{m 2}$ Ingevolge het Rondschrijven van de Minister van Justitie van 19 februari 1972 dient nauwkeurig te worden nagegaan of de desbetreffende kinderen inderdaad in Indonesië woonplaats hebben en aldaar feitelijk verblijven.

Buitenlands verblijvende kinderen verkrijgen niet mede het door de vader verkregen Indonesisch staatsburgerschap. Hierbij is echter het voorbehoud gemaakt, dat de voorwaarde die betrekking heeft op het in Indonesië woonplaats hebben en het zich feitelijk aldaar bevinden, niet geldt voor kinderen die apatride zouden worden vanwege het verkrijgen van het Indonesisch staatsburgerschap door de vader. Dit houdt in, dat ook een buitenlands verblijvend kind, dat zijn (buitenlandse) nationaliteit zou verliezen omdat zijn vader het Indonesisch staatsburgerschap verkrijgt en als zodanig dreigt staatloos te worden, de status van Indonesisch staatsburger wordt toegekend. Dit betekent in feite een versoepeling ten aanzien van de gestelde voorwaarde als hierboven genoemd. Ook Bujung Datuk Intan Sati wijst op deze uitzondering; hij brengt onder de

772. Zie Bujung Datuk Intan Sati, Beberapa Hal, Himpunan, p.367. 
aandacht dat het staatloos worden van de onderhavige kinderen bijvoorbeeld een gevolg kan zijn van een in het land van orsprong geldende regeling, die inhoudt dat het verlies van een nationaliteit door een vader ook geldt voor de minderjarige kinderen. ${ }^{73}$ Zou een als hierbedoelde uitzondering niet worden gemaakt, dan zou dit kunnen betekenen dat buitenlands verblijvende kinderen hun oorspronkelijke nationaliteit zouden verliezen vanwege het verkrijgen van het Indonesisch staatsburgerschap door de vader. Indien deze kinderen niet mede het Indonesisch staatsburgerschap verkrijgen, dan zouden zij apatride worden. Met het reeds aangehaalde schrijven van de Minister van Justitie van 18 september 1969 is echter benadrukt, dat kinderen die buitenlands woonplaats hebben en aldaar verblijven, die hun oorspronkelijke nationaliteit niet verliezen op het tijdstip dat de vader het Indonesisch staatsburgerschap verkrijgt, niet mede in de verkrijging van het staatsburgerschap door de vader delen. Komen zij naderhand in Indonesiê nadat zij de leeftijd van 18 jaar of hoger hebben bereikt, dan blijven zij de status van buitenlander behouden. ${ }^{774}$ Gaat de oorspronkelijke nationaliteit van het kind wél verloren, dan dient dit door het kind te worden bewezen met een verklaring van de competente autoriteit van het land van oorsprong, onder vermelding van de artikelen van de desbetreffende wettelijke regeling. ${ }^{\text {ns }}$ Deze bepaling dient te worden gezien in het licht om het optreden van bipatridie te voorkomen.

In de Memorie van Toelichting van de Wet is met betrekking tot het zich de facto in Indonesië bevinden van bedoelde kinderen gesteld, dat het verkrijgen van een nieuw staatsburgerschap, eerst reële betekenis heeft, indien de persoon in kwestie zich in het land bevindt, waarvan deze persoon het staatsburgerschap verkrijgt. De wetgever gaat er derhalve vanuit, dat eerst in het geval betrokkene zich ook de facto in Indonesië bevindt, de band tussen de Staat en de desbetreffende persoon hecht is te noemen.

Met betrekking tot het - juridisch - woonplaats hebben in Indonesië, eveneens in artikel 13 der Wet genoemd, kan worden verwezen naar artikel III van de Slotbepalingen van deze Wet. Dit artikel houdt in, dat een kind dat de leeftijd van 18 jaar nog niet heeft bereikt en nog niet gehuwd is, geacht wordt mede met de vader of moeder woonplaats te hebben, volgens de specificatie, als opgenomen in artikel 1 sub b, c. en d. der Wet. Wanneer nu kan worden gezegd, dat een persoon, in juridische zin geacht kan worden in Indonesië woonplaats te hebben? De Wet geeft hieromtrent geen nadere uitleg, zodat andere wetten dienen te worden geraadpleegd.

Bepalingen inzake deze aangelegenheid waren aanvankelijk vastgesteld met de Noodwet no. 9 van het jaar 1955, Stb. 1955-33 betreffende het Ingezetenschap van Buitenlanders. ${ }^{76}$ Krachtens het in artikel 3 van deze Noodwet bepaalde, wordt een buitenlander aangemerkt in Indonesiē gevestigd te zijn, indien hij in het bezit van een vergunning

773. Zie hiervoor Bujung Datuk Intan Sati, Beberapa hal, Himpunan, p.367.

774. Zie het Rondschrijven van de Minister van Justitie no. JHB 3/4/17 van 19 februari 1972, gericht aan de Voorzitters van de "Pengadilan Negeri's" in geheel Indonesié.

775. Het betreft hier het schrijven van de Minister van Justitie no. DTC/14/17 van 18 september 1969 , gericht aan het Hoofd van de te Jakarta gevestigde Centrale "Pengadilan Negeri".

776. Zie voor de tekst van deze Noodwet, Engelbrecht p.336. 
tot het hebben van woonplaats in Indonesiē is gesteld, nadat de geldigheid van zijn toelatingskaart is verstreken, onder aantekening dat bedoelde vergunning voorts "vestigingsvergunning" ("izin menetap") wordt genoemd. ${ }^{m 7}$ Bedoelde vestigingsvergunning wordt slechts aan buitenlanders, die reeds gedurende een periode van vijftien jaar ononderbroken in Indonesië woonplaats hebben, verstrekt. De echtgenote van bedoelde buitenlander wordt - zolang gehuwd - geacht in Indonesië gevestigd te zijn, nadat zij in Indonesië woonplaats heeft (artikel 3 lid 2). Een hiermede overeenkomende bepaling geldt krachtens artikel 3 lid 3 van deze Noodwet voor de kinderen, in de betekenis van wettige, gewettigde, erkende of op wettige wijze geadopteerde kinderen, waarvan de leeftijd beneden de 18 jaar ligt en die nog ongehuwd zijn. Hebben deze kinderen geen vader (meer), dan wordt afgegaan op het in Indonesië gevestigd zijn van de moeder. Ook deze kinderen worden beschouwd in Indonesië gevestigd te zijn, nadat zij aldaar woonplaats hebben. Met de afkondiging van de Wet no. 9 van het jaar 1992 betreffende Immigratie, is de Noodwet no. 9 van het jaar 1955 echter niet langer van kracht. Als overgangsbepaling is in artikel 63 van eerstgenoemde Wet echter bepaald, dat vestigingsvergunningen krachtens de onderhavige Noodwet verstrekt, van kracht blijven gedurende een termijn van drie jaar gerekend vanaf het van kracht worden van de Wet no. 9 van 1992 (31 maart 1992).

Terugkerend naar de Wet no. 62 van het jaar 1958 kan naar voren worden gebracht, dat krachtens het tweede lid van artikel 13, het door een moeder verkregen Indonesisch staatsburgerschap, mede geldt voor haar kinderen, die géen familierechtelijke betrekking met de vader hebben. ${ }^{78}$ Bujung Datuk Intan Sati haalt in dit verband als voorbeeld buiten huwelijk geboren kinderen aan, waarvan de moeder vervolgens met een Indonesisch staatsburger trouwt en voor het Indonesisch staatsburgerschap ex artikel 7 lid 1 opteert en als zodanig dit staatsburgerschap verkrijgt; ook haar kinderen verkrijgen dan deze status, al zijn zij niet de kinderen van de echtgenoot van hun moeder c.q. zijn zij niet door deze persoon erkend c.q. gewettigd. ${ }^{79}$ Ook hier is het voorbehoud gemaakt, dat deze kinderen de leeftijd van 18 jaar nog niet dienen te hebben bereikt c.q. te zijn gehuwd en zij eerst Indonesisch staatsburger worden, nadat zij in Indonesië woonplaats hebben en zich aldaar de facto bevinden. Voorts geldt ook in dit geval, dat laatstgenoemde voorwaarde niet geldt voor kinderen, die vanwege het verkrijgen van het Indonesisch staatsburgerschap door de moeder, staatloos zouden worden.

Ik acht het tenslotte van belang te wijzen op het door Ko Swan Sik en Teuku Moh. Rhadie gehuldigde standpunt, als zouden de kinderen als bedoeld in artikel 13 de status van bipatride hebben, een standpunt dat mij onwaarschijnlijk voorkomt. ${ }^{780}$ Immers, ook al is in artikel 13 niet met zoveel woorden bepaald, dat het verkrijgen van het

777. Krachtens artikel 1 sub a. van het in deze Noodwet bepaalde, dient onder de omschrijving "het hebben van woonplaats" ("bertempat tinggal") te worden verstaan, het in Indonesiẽ verblijven krachtens een toelatingskaart, volgens de geldende wettelijke bepalingen.

778. Het betreft hier buiten huwelijk geboren kinderen, die worden beschouwd slechts een burgerlijke betrekking met de moeder te hebben.

779. Bujung Daruk Intan Sati, Beberapa hal, Himpunan p. 368.

780. Ko Swan Sik en Teuku Moh. Rhadie, Nationality, p. 167. 
Indonesisch staatsburgerschap door de kinderen afhankelijk is van het niet bezitten van een andere nationaliteit, in het hiervoor reeds aangehaalde schrijven van de Minister van Justitie van 18 september 1969 is uitdrukkelijk gesteld, dat kinderen als in artikel 13 bedoeld, die buitenlands woonplaats hebben en aldaar verblijven en niet hun oorspronkelijke nationaliteit verliezen op het tijdstip hun vader Indonesisch staatsburger wordt, niet mede het Indonesisch staatsburgerschap van de vader verkrijgen. Deze bepaling dient, zoals reeds opgemerkt, te worden gezien in het licht om het ontstaan van bipatridie te voorkomen! ${ }^{781}$ Gaat de oorspronkelijke nationaliteit van de kinderen in de zin van dit artikel wél verloren, dan dient dit aan de hand van een verklaring van het land van oorsprong te worden gestaafd. In dit licht gezien is het onwaarschijnlijk te achten, dat kinderen die in Indonesië woonplaats te hebben en aldaar feitelijk te verblijven, de status van bipatridie zouden kunnen hebben.

\section{$\$ 9$ verkrijging door aflegging van een verklaring (optie)}

In $\S 7$ werd aangegeven, dat het Indonesisch staatsburgerschap in enkele gevallen op eenvoudige wijze kan worden verkregen, met name door het afleggen van een daarop gerichte optieverklaring, die - anders dan het in het kader van geprivilegieerde of gewone naturalisatie op de verkrijging van dit staatsburgerschap gericht verzoek - niet kan worden afgewezen, indien aan de gestelde voorwaarden is voldaan. Ik doel hier op de, aan de met een Indonesisch staatsburger gehuwde buitenlandse vrouw geboden gelegenheid om door optie dit staatsburgerschap te verkrijgen. ${ }^{782}$ Volledigheidshalve zij nog opgemerkt, dat ook een persoon - vrouw of man - die door of als gevolg van huwelijk het Indonesisch staatsburgerschap heeft verloren, dit door optie herknjgen kan, zoals in $\$ 7.1 .2$ behandeld. ${ }^{783}$

Voorts staat ook voor kinderen die vanwege het volgen van de staat van de respectieve ouder het Indonesische staatsburgerschap hebben verloren de mogelijkheid open, om door optie genoemd staatsburgerschap te herkrijgen. Artikel 16 van de Wet no. 62 van 1958 opent namelijk de mogelijkheid, om in geval van het krachtens artikel 15 van de Wet verloren gaan van het Indonesisch staatsburgerschap vanwege het volgen van de staat van de vader of moeder - hierop zal in Hoofdstuk 6 worden teruggekomen genoemd staatsburgerschap te herkrijgen middels een daartoe strekkende verklaring, derhalve door optie. Genoemde optieverklaring dient te worden afgelegd binnen de termijn van één jaar na het bereikt hebben van de leeftijd van 18 jaar bij de "Pengadilan Negeri" of de Diplomatieke Vertegenwoordiging van de Republiek Indonesië van de

781. Zie het aan de Voorzitter van de te Jakarta gevestigde Centrale "Pengadilan Negeri" gerichte schrijven van de Minister van Justitie no. DTC/14/17 van 18 september 1969.

782. Zie hiervoor artikel 7 lid 1 en artikel II van de Overgangshepalingen van de onderhavige Wet.

783. Zie hiervoor artikel 11 van de Wet en het in artikel III van de Overgangshepalingen bepaalde. Het verschil tussen deze artikelen ligt mede hierin, dat in het in artikel 11 omschreven geval, het personen - vrouwen of mannen - betreft die coit Indonesisch staatsburger zijn geweest, terwijl het in artikel III der Overgangsbepalingen van de Wet gaat om vrouwen, die door of als gevolg van huwelijk een buitenlandse status bezitten, doch Indonesisch staatsburger zouden zijn, indien zij niet gehuwd waren geweest. Zie Bujung Datuk Intan Sati, Beberapa hal, Himpunan p.361. 
woonplaats van betrokkene. Algemeen geldt nieltemin het voorbehoud, dat met de herkrijging van het Indonesisch staatsburgerschap betrokkene geen andere nationaliteit mag bezitten. (artikel 16 lid 2). Het betreft ook hier een bepaling, gericht op het voorkomen van het optreden van bipatridie.

Algemeen gesteld, is in de Wet no. 62 van het jaar 1958 verkrijging van het Indonesisch staatsburgerschap middels optie slechts in enkele gevallen mogelijk. Samenvattend kan worden gesteld, dat krachtens de hieronder volgende artikelen het Indonesisch staatsburgerschap middels een optieverklaring kan worden verkregen/herkregen:

artikel 7 lid 1, voor een buitenlandse vrouw met een Indonesisch staatsburger gehuwd;

artikel 11, voor een Indonesisch staatsburger die door of als gevolg van huwelijk, haar/zijn Indonesisch staatsburgerschap heeft verloren;

artikel 16, voor een persoon, wiens Indonesisch staatsburgerschap verloren is gegaan, als gevolg van het verloren gaan van dit staatsburgerschap door de vader c.q. moeder;

artikel 18, voor een persoon wiens Indonesisch staatsburgerschap verloren is gegaan op grond van artikel 17 sub $k$ dat de verplichting oplegt tot het te kennen geven van de wens Indonesisch staatsburger te willen blijven bij verblijf buitenlands, wil het staatsburgerschap niet verloren gaan; ${ }^{784}$

artikel II van de Overgangsbepalingen, voor een buitenlandse vrouw die zich bevindt in de positie als in artikel 7 omschreven, op het tijdstip dat de Wet no. 62 van 1958 van kracht is geworden;

artikel III van de Overgangsbepalingen, voor een vrouw, wiens huwelijk is ontbonden en die indien zij niet gehuwd ware, Indonesisch staatsburger zou zijn vóor het van kracht worden van de onderhavige Wet. ${ }^{785}$

Het afleggen van een optieverklaring is gericht op de verkrijging/herkrijging van het Indonesisch staatsburgerschap. Het kan echter ook het omgekeerde geval betreffen, in casu om dit staatsburgerschap prijs te geven - door mij negatieve optie genoemd - met het doel de oorspronkelijke nationaliteit te herkrijgen dan wel een andere nationaliteit te verkrijgen. Op deze negatieve optie zal in Hoofdstuk 6 worden teruggekomen. Aangezien bedoelde wijze van verkrijging/herkrijging van het Indonesisch staatsburgerschap door optie reeds werd behandeld bij die gelegenheden waar hiervan sprake was, moge kortheidshalve naar het viteengezette in de hierboven aangehaalde paragrafen worden verwezen.

784. Deze bepaling is nog niet aan de orde gekomen, aangezien ik mij tot dusverre heb beperkt tot de behandeling van de verschillende mogelijkheden tol verkrijging van het Indonesisch staatsburgerschap.

785. Zie het Rondschrijven van de Minister van Justitie no. J.B.3/166/22 van 30 september 1958, aan aile Voorzitters van de "Pengadilan Negeri's" in Indonesiē gericht. 


\subsection{Gevallen waarin niet van zuivere optie kan worden gesproken}

In het kader van de implementatie van de Wet no. 62 van het jaar 1958 komen niettemin ook enkele gevallen voor, waarin niet van verkrijging van het Indonesisch staatsburgerschap middels het afleggen van een optieverklaring in de zuivere betekenis daarvan kan worden gesproken. Op deze aangelegenheid zal hieronder worden ingegaan.

9.1.1. Artikel 18 van de Wet no. 62 van 1958, zoals gewijzigd en aangevuld bij de Wet no. 3 van 1976

In artikel 18 van de Wet no. 62 van het jaar 1958 is de mogelijkheid opgenomen voor personen, die het Indonesische staatsburgerschap hebben verloren vanwege langdurig verblijf in het buitenland anders dan in dienst van de Indonesische staat en het niet hebben doen blijken van de wens om hun staatsburgerschap te behouden, dit staatsburgerschap terug te krijgen middels het afleggen van een daartoe strekkende optieverklaring. ${ }^{786}$

Vooruitlopend op de nog te behandelen gronden, die verlies van het Indonesisch staatsburgerschap opleveren zoals opgenomen in artikel 17 van de Wet no. 62 van het jaar 1958, acht ik het van nut om in aansluiting op het bovenstaande, de mogelijkheid tot herkrijging van het Indonesisch staatsburgerschap in het hierbedoelde geval, nader in beschouwing te nemen.

De reden daartoe is hierin gelegen, dat het op deze aangelegenheid betrekking hebbende artikel 18 van de Wet, met de Wet no. 3 van het jaar 1976, Stb. 1976-20 wijziging heeft ondergaan.

Krachtens de oorspronkelijke redactie van artikel 18, kan een persoon het Indonesisch staatsburgerschap herkrijgen, indien hij wederom in Indonesië op basis van een toelatingskaart woonplaats heeft. Hij dient een daartoe strekkende optieverklaring af te leggen bij de "Pengadilan Negeri" van zijn woonplaats, binnen de periode van een jaar, gerekend vanaf het tijdstip hij weer in Indonesiê woonachtig is. ${ }^{787}$

Dit artikel werd echter met de hiervoor genoemde Wet no. 3 van het jaar 1976 aangevuld, op basis van het aanwezig zijn van personen in het buitenland, die hun staatsburgerschap hebben verloren vanwege het niet kenbaar maken van de wens dit te willen behouden, evenwel te wijten aan omstandigheden, buiten hun schuld gelegen, zoals in de Wet gesteld.

786. Zie hiervoor ook Wantjik Saleh, Peraturan baru tentang kewarganegaraan Republik Indonesia, Jakarta, 1980.

787. Zie ook Soedarman Ganda Soebrata, Pengadilan Negeri, Himpunan, p.124. 
De in de onderhavige Wet no. 3 van 1976 opgenomen bepalingen stelden zich in het buitenland bevindende personen - met name uit Indonesië afkomstige personen die op het tijdstip van inwerkingtreding van deze Wet in Nederland, Suriname en de Nederlandse Antillen woonachtig waren - in de gelegenheid om hun Indonesisch staatsburgerschap terug te krijgen. Het betreft hier derhalve een wijze van herkrijging van het Indonesisch staatsburgerschap.

De betrokken persoon kon zich voor genoemd doel melden c.q. een op de herkrijging van het Indonesisch staatsburgerschap gerichte verklaring afleggen bij de Diplomatieke Vertegenwoordiging van de Republiek Indonesië in het land van zijn woonplaats of bij de Diplomatieke Vertegenwoordiging in het dichtsbij gelegen land. Dit diende te geschieden binnen de termijn van respectievelijk éen jaar of twee jaar, gerekend vanaf 5 april 1976, de datum van inwerkingtreding van de Wet no. 3 van 1976.

De hierboven genoemde situatie heeft betrekking op het niet c.q. maar gedeeltelijk kunnen functioneren van de Diplomatieke Vertegenwoordiging van de Republiek Indonesie in Nederland, vanwege het in de jaren 1958 tot 1963 lopende conflict tussen Indonesië en Nederland inzake de kwestie Irian Jaya. ${ }^{788}$

Personen, gerechtigd tot het gebruik maken van de door het gewijzigde artikel 18 geboden gelegenheid waren personen, die op het tijdstip van inwerkingtreding van de Wet no. 62 van 1958 Indonesisch staatsburger waren en steeds van hun trouw aan de Indonesische staat hebben blijk gegeven. ${ }^{7 \times 9}$ Deze gelegenheid stond derhalve niet open voor personen met een buitenlandse nationaliteit, apatriden of voor personen die reeds hadden verkozen de nationaliteit van een ander land aan te nemen. Volgens Gautama, betrof het hier - uit het oogpunt van de geschiedenis gezien - grotendeels personen uit de Molukken afkomstig, voorheen werkzaam bij de Overheid of bij particuliere instanties in Nederland. De hierbedoelde wettelijke Regeling werd, naar het zich laat aanzien, uitgegeven in verband met de beweging van de zogenaamde Republiek der Zuid-Molukken ("Republik Maluku Selatan", afgekort RMS) ${ }^{790}$, waardoor duidelijkheid kon worden verkregen door de Indonesische regering, welke personen nog als trouw aan de Indonesische staat konden worden aangemerkt. ${ }^{791}$ Hecker wijst erop, dat de RMS die zich op 25 april 1950 onafhankelijk had verklaard en op 20 juli 1950 een eigen Grondwet invoerde door geen enkel land, ook niet door Nederland is erkend en dit gebied heden ten dage een autonome Provincie van Indonesië is. ${ }^{792}$ Onder de aandacht kan worden gebracht, dat de RMS de Regeringsverordening van 30 mei 1950 betreffende de Zuidmolukse nationaliteit had vastgesteld, die bepaalde dat Zuidmolukker zijn, zij die geboren zijn uit in de Zuid-Molukken woonachtige ouders of uit ouders van

788. Zie hiervoor $\S 2.1$ van Hoofdstuk 1 .

789. Het oorspronkelijke artikel 18 werd door de met de Wet no. 3 van 1976 doorgevoerde wijziging, artikel 18 lid 1; de met deze Wet bedoelde aanvulling werd opgenomen in de leden 2 tot en met 8 van dit artikel.

790. Zie ook hiervoor $\$ 2.1$ van Hoofdstuk 1 .

791. Gautama, Tafsiran, p.217.

792. Hecker, Das Staatsangehōrigkeitsrecht, p.39. 
Zuidmolukse afkomst; deze Regeling is echter in de praktijk van geen enkele betekenis gebleken. Ook Ko Swan Sik en Teuku Moh. Rhadie brengen deze aangelegenheid ter sprake en wijzen er onder meer op, dat personen van Molukse oorsprong deel uitmaken van de autochtone Indonesiërs en als zodanig volgens de in \$ 5.3.2 van Hoofdstuk 3 aan de orde gekomen Toescheidingsovereenkomst het Indonesische staatsburgerschap hebben verkregen. De meeste, zo niet alle van deze personen die in 1951 naar Nederland werden overgebracht en hun alhier geboren kinderen zijn uiteraard niet geregistreerd bij de Indonesische Diplomatieke Vertegenwoordiging in Nederland en hebben niet van hun wens te kennen gegeven om de Indonesische nationaliteit te behouden en derhalve dit staatsburgerschap verloren krachtens artikel 17 sub k. van de Wet no. 62 van 1958. Genoemde auteurs zeggen voorts dat "facilitation for both recovery of Indonesian nationality and eventual resettlement in Indonesia was offered legally in a rather disguised manner by way of the insertion of additional provisions of a temporary character in Article 18. All possible care appears to have been taken not to show openly the actual purpose of the measure, and consequently the case of the Moluccans in the Netherlands is nowhere mentioned with a single word in the Modification Act". ${ }^{793}$ Met betrekking tot het niet kunnen voldoen aan de door de Wet vereiste verplichtingen buiten de schuld van betrokkenen zeggen genoemde auteurs het volgende: "Even if this conforms with the facts, however, it would still not cover those adult persons who had already been in the Netherlands since 1951 or 1952 and for whom the five year-period of Article 17 item (k) would have already expired in 1956 or 1957. Yet the whole legislative exercise was primarily intended to accomodate precisely the "first generation" Moluccans. And the provision has been applied accordingly, despite the fact that the loss of Indonesian nationality was undoubtedly the result of the persons own "fault" and in no way the result of circumstances prevailing in the Netherlands preventing them from fulfilling the statutory requirements. $\mathrm{Zij}$ voegen hieraan toe, dat "we are faced with a case of a political solution for a political and humanitarian problem, which has been moulded in a completely inadequate legal form", een standpunt ook door mij gedeeld. ${ }^{794}$

De door de Wet no. 3 van het jaar 1976 geboden gelegenheid, was niettemin beperkt. Het betrof hier een regeling, die slechts eenmalig geldig was.

Met betrekking tot de mogelijkheid tot het afleggen van bedoelde verklaring, dienden deze personen van de wens te doen blijken, daadwerkelijk - wederom - Indonesisch staatsburger te worden en van hun trouw aan de Indonesische staat te hebben blijk gegeven. Voldeden zij aan deze voorwaarden, dan herkregen zij het Indonesisch staatsburgerschap binnen een jaar na zich bij de Indonesische Diplomatieke Vertegen-

793. Ko Swan Sik en Teuku Moh. Rhadie, Nationality, p. 152.

794. Ko Swan Sik en Teuku Moh. Rhadie, Nationality, p. 152-153. Hierbij komt nog, dat gedurende de periode van bevriezing van de diplomatieke betrekkingen tussen Indonesië en Nederland, dit feit personen niet belette om aan de desbetreffende vereisten te voldoen, aangezien de belangen en consulaire diensten van Indonesië in Nederland indertijd werden waargenomen door de Verenigde Arabische Republiek, terwijl paspoort- en nationaliteitsaangelegenheden werden behartigd door de Indonesische ambassade in Brussel. 
woordiging te hebben gemeld c.q. de daartoe strekkende verklaring te hebben afgelegd en het besluit van de Minister van Justitie dat op deze aangelegenheid betrekking heeft, te hebben verkregen. Opvallend is, dat ook hier het afleggen van de eed c.q. het uitspreken van de belofte van trouw aan de Indonesische staat - af te leggen ten overstaan van de Diplomatieke Vertegenwoordiging van de Republiek Indonesië verplicht was gesteld. Het aldus herkregen staatsburgerschap werd van kracht op de dag van bedoelde eedsaflegging c.q. het uitspreken van de belofte van trouw en wel met terugwerkende kracht tot de datum van het desbetreffende besluit van de Minister van Justitie.

De door genoemde personen te volgen procedure is bijzonder te noemen. Wellicht is de reden daarvan gelegen in de toen geldende omstandigheden, hetgeen niet alleen blijkt uil de gestelde voorwaarden, wilde een persoon van deze gelegenheid gebruik kunnen maken, maar ook uit het feit dat de Minister van Justitie, de "verklaring" gericht op de verkrijging van het Indonesisch staatsburgerschap kon inwilligen dan wel afwijzen! Dit blijkt uit artikel 6 van de, ter uitvoering van de Wet no. 3 van het jaar 1976 vastgestelde Regeringsverordening no. 13 van het jaar 1976, Stb. 1976-22.795. In artikel 2 van deze Regeringsverordening wordt bovendien van een "verzoek tot het afleggen van een verklaring" gesproken. Het betreft hier derhalve geen geval van zuivere optie, doch eerder een "oneigenlijke optie". Wordt echter ervan uitgegaan dat hier sprake is van een verzoek ter herkrijging van het Indonesisch staatsburgerschap en naast de gestelde voorwaarden, ook nog de eedsaflegging c.q. belofte van trouw diende te worden uitgesproken ${ }^{796}$, dan kan worden geconstateerd, dat het hier in feite handelt om een vorm van vereenvoudigde naturalisatie. Het niet afleggen van de eed c.q. het uitspreken van de belofte van trouw in de daartoe vastgestelde termijn, had het van rechtswege nietig worden van het ministerieel besluit ten gevolge. Voorts kon een persoon slechts het staalsburgerschap terugkrijgen, indien hij na verkrijging van bedoeld staatsburgerschap geen andere nationaliteit bezat. Het aldus herkregen Indonesisch staatsburgerschap gold mede voor de echtgenote van de persoon in kwestie - tenzij deze daarnaast nog een andere nationaliteit bezat - en voor de kinderen, die nog geen 18 jaar en nog ongehuwd waren.

Ik maak van deze gelegenheid nog gebruik om te wijzen op maatregelen van Nederlandse zijde getroffen ter regeling van de positie van Molukkers in Nederland. Met de Wet van 9 september 1976 betreffende de positie van Molukkers, N. Stb. 468 - de zogenaamde Faciliteitenwet - is bepaald, dat Molukkers die door de zorg van de Neder-

795. Zie voor deze Verordening, Engelbrecht p.299.

796. Opmerkelijk is dat de tekst van de eed c.q. belofte van trouw verschilt van die in het kader van de toepassing van artikel 5 af te leggen c.q. uit te spreken. Zo was in het hierbedoelde geval onder meer het zweren/beloven van trouw aan de Republiek Indonesië als gebaseerd op de Pancasila en het hoog houden van de Grondwet van 1945 voorgeschreven. Dit heeft wellicht te maken met het feit, dat het hier handelde om personen, die wegens de toenmalige omstandigheden uit de Molukken naar Nederland zijn overgebracht. 
landse overheid in 1951 of 1952 in groepsverband naar Nederland zijn overgebracht ${ }^{797}$ en op het tijdstip van de inwerkingtreding van deze Wet op 1 januari 1977 krachtens Koninklijk Besluit van 14 oktober 1976, N. Stb. 554 - in Nederland woonplaats of werkelijk verblijf hebben en niet het Nederlanderschap bezitten, bij de toepassing van de Nederlandse wetgeving behandeld worden als Nederlander; zij verkrijgen daardoor echter niet de staat van Nederlander (artikel 1). ${ }^{798}$ Krachtens artikel 2 van deze Wet komt de behandeling als Nederlander ook toe aan het niet-Nederlandse kind van een vader of, indien deze wettelijk onbekend is, van een moeder, die deze behandeling geniet dan wel, indien nog in leven, zou hebben genoten, mits dat kind op het tijdstip van inwerkingtreding van deze Wet in Nederland woonplaats of werkelijk verblijf heeft. Dit artikel heeft betrekking op die kinderen van Molukkers die in de jaren 1951-1952 naar Nederland zijn overbracht, die echter niet zélf zijn overgebracht doch later naar Nederland zijn gekomen of hier te lande vóor de inwerkingtreding van de Faciliteitenwet zijn geboren, waarbij het geen verschil maakt of deze kinderen meerderjarig of minderjarig zijn. Kinderen die destijds wél tegelijk met hun ouders naar Nederland zijn overgebracht, vallen niet onder de toepassing van artikel 2, doch onder artikel 1. Personen die op 1 januari 1977 nog minderjarig waren, hebben woonplaats bij hun vader, moeder of voogd. ${ }^{799}$

De Minister van Justitie kan, op een daartoe gedaan schriftelijk verzoek, door een aan de verzoeker af te geven verklaring de toepassing van de onderhavige Wet uitoreiden tot andere dan de in de artikelen 1 en 2 bedoelde Molukkers, die met deze nauwe maatschappelijke banden hebben en zich vór 1 oktober 1965 in Nederland hebben gevestigd en aldaar tijdens het verzoek woonplaats of werkelijk verblijf hebben. Bij het criterium "nauwe maatschappelijke banden" is gedacht aan het volgende: in Nederland verblijven behalve de Molukkers die destijds in groepsverband naar Nederland zijn overgebracht, ook zij die later tot Nederland zijn toegelaten in het kader van gezinshereniging. Ook zijn er Molukkers die naar het voormalige Nederlands Nieuw-Guinea zijn uitgeweken en later van daanuit naar Nederland zijn gekomen. Voorts zijn er Molukkers, die vóor de soevereiniteitsoverdracht in het voormalige Nederlands Nieuw-Guinea woonachtig waren en tot 1 oktober 1962 als Nederlands onderdaan niet-Nederlander waren aan te merken. Ingevolge artikel 4 van de Rijkswet van 14 september 1962, N. Stb. 358 - deze Rijkswet zal in $\$ 10$ ter sprake komen - zijn deze personen, indien zij zich naar Nederland hebben begeven, tot 1 oktober 1965 behandeld als Nederlander. Tot genoemde datum werden zij dan ook in beginsel tot Nederland toegelaten. Al deze Molukkers mogen gerekend worden tot de groep voor wie de faciliteit van het behan-

797. Dit geschiedde up een collectieve laissez-passer, bij beschikking van de Minister van Buitenlandse Zaken 24 december 1975 ingetrokken.

798. In dit opzicht kan een vergelijking worden gemuakt met de krachtens de voormalige Verordeningen van het Militaire Gezag c.4. Oorlogsgezag ná 27 december 1949 met Indonesische staatsburgers gehuwde buitenlandse vrouwen, die eveneens werden "behandeld als" Indonesisch staatsburger, warbij in het midden werd gelaten, of deze vrouwen nu al dan niet genoemde status bezaten. Zie hiervoor $\S 6.2$ van Hoofdstuk 3.

799. Zie hiervoor de Circulaire van de Staatssecretaris van Justitie aan de Burgemeasters van 23 november 1976, Hœofdafdeling Privastrecht, no. 557/176. 
delings-Nederlanderschap zinvol is. ${ }^{800}$ Ook kinderen van Molukkers aan wie bedoelde verklaring is afgegeven komen voor een zodanige behandeling in aanmerking, op dezelfde wijze als de kinderen als bedoeld in artikel 2 , indien zij op het tijdstip van de indiening van het verzoek in Nederland woonplaats of werkelijk verblijf hebben (artikel 3).

Artikel 8 van de Faciliteitenwet bepaalt vervolgens dat de niet-Nederlandse vrouw of man die bij de inwerkingtreding van deze Wet is gehuwd met een persoon als bedoeld in artikel 1 of artikel 2 - indien zij of hij de behandeling als Nederlander niet reeds uit eigen hoofde bezit - die behandeling verkrijgt door haar of zijn wil daartoe te kennen te geven aan de burgemeester van haar of zijn woonplaats in Nederland, mits op het tijdstip van kennisgeving het huwelijk voortduurt. Een soortgelijke bepaling is vastgesteld voor de niet-Nederlandse vrouw of man, die de echtgenote of echtgenoot is van een persoon aan wie de behandeling als Nederlander wordt verleend krachtens artikel 3. De gelijkheid van man en vrouw is echter niet volkomen. De vrouw die ná 31 december 1976 huwt met een man die de behandeling als Nederlander geniet, kan deze behandeling ook verkrijgen door naar analogie van artikel 8 van de toen nog geldende Wet van 1892 haar wil daartoe te verklaren. Huwt daarentegen een man ná 31 december 1976 met een vrouw die de behandeling als Nederlander geniet, dan kan hij niet voor die behandeling opteren, aangezien genoemd artikel 8 van de Wet van 1892 niet van toepassing is op de gehuwde man. ${ }^{801}$

Krachtens artikel 5 verliezen personen die de behandeling als Nederlander genieten deze behandeling, door hetzij zich met het doel van repatriëring naar Indonesië te begeven, hetzij langer dan drie jaar onafgebroken woonplaats en werkelijk verblijf elders buiten Nederland te hebben. Een als hierbedoelde persoon kan echter deze behandeling herknjgen indien hij daarna gedurende een jaar onafgebroken woonplaats of werkelijk verblijf in Nederland heeft en staatloos is.

Molukkers die ingevolge de onderhavige Wet als Nederlander worden behandeld - de alsof-Nederlanders - zijn niettemin uitgesloten van kiesrecht en verkiesbaarheid voor krachtens wettelijk voorschrift uitgeschreven verkiezingen. $\mathrm{Zij}$ worden bovendien niet toegelaten tot de dienst bij de krijgsmacht, behoudens op grond van een verbintenis als bedoeld in artikel 3, lid 4 van de Dienstplichtwet. De in dit artikel opgenomen uitzondering beoogt - zoals ook ten aanzien van andere niet-Nederlanders het geval is - uitsluitend de mogelijkheid open te laten tot het aangaan van een verbintenis voor hen die, in afwachting van de beslissing op een door hen ingediend verzoek om naturalisatie, vrijwillig in dienst van de krijgsmacht willen treden op voet van gewoon dienstplichtige. ${ }^{* 02}$

800. Zie hiervoor de Tcelichting op de Wet vin 1976 betreffende de positie van Molukkers.

801. Zie ook hiervoor de Circulaire van de Staatssecretaris van Justitie van 23 november 1976, Hoofd afdeling Privaatrecht, no. 557/176. De Wet van 1892 is in $\$ 1.4$ van Hoofdstuk 3 aan de orde gekomen.

802. Zie de Toelichting op de Faciliteitenwet. 
De Groot is van mening, dat met betrekking tot deze alsof-Nederlanders verdedigd kan worden, dat zij een Nederlandse "Schutzangehörigkeit" bezitten. ${ }^{803}$ Ik deel die mening echter niet, aangezien in dit geval moeilijk gezegd kan worden dat deze personen een "nationaliteit" bezitten. Zou toch van een nationaliteit dienen te worden gesproken, dan dient mijns inziens eerder van een "sachlich beschränkte" nationaliteit te worden gesproken, aangezien deze personen uitgesloten zijn van politieke rechten en niet tot de krijgsmacht kunnen toetreden. ${ }^{804}$

Alhoewel de Faciliteitenwet geen bepaling bevat omtrent de uitgifte van paspoorten, is bij de voorbereidingen voor de totstandkoming van deze Wet overeengekomen, dat onder de behandeling als Nederlander ook zal vallen de verstrekking van paspoorten. Op grond hiervan kunnen aan de Molukkers op wie genoemde Wet van toepassing is, na de inwerkingtreding daarvan Nederlandse nationale paspoorten worden verstrekt, waarin als "nationaliteit" dient te worden vermeld: "Wordt als Nederlander behandeld op grond van de Wet van...., Stb....". ${ }^{805}$ Het betreft hier de zogenaamde faciliteitenpaspoorten. Niettegenstaande verwacht werd dat de houders van zodanige paspoorten zonder visum in een aantal andere landen zouden worden toegelaten, waar dit ook ten aanzien van Nederlanders het geval is, bleek dit in de praktijk niet op te gaan. Bepaalde landen concludeerden dat de paspoorthouder kennelijk geen echte Nederlander was. Molukkers met zo'n paspoort werden dan ook regelmatig teruggestuurd. ${ }^{806}$ Krachtens de in N. Stb. 1991-672 opgenomen Wijzigingswet van de Faciliteitenwet kunnen Molukkers sedert 1 april 1992 een keuze maken tussen verschillende soorten van paspoorten, waaronder een Nederlands nationaal paspoort, waardoor zij in het buitenland dezelfde rechten krijgen als Nederlandse staatsburgers. ${ }^{\text {"M }}$ Benadrukt dient echter te worden, dat het bezit van genoemd Nederlands paspoort van geen invloed is op hun status; zij blijven derhalve de status van "als Nederlander te worden behandeld" behouden. Een eerder voorstel in 1986 gedaan om staatloze Molukkers een als hierboven bedoeld Nederlands paspoort te verstrekken haalde het niet, omdat de Indonesische regering met maatregelen dreigde waardoor alle Molukkers en eventueel ook Nederlanders moeilijkheden konden krijgen bij toelating tot Indonesië. ${ }^{80 \%}$

803. De Groot, Personen- en familierecht, p. 8 (Nat.).

804. Zie voor deze begrippen, $\$ 1.1$ van Hoofdstuk 2 .

805. Zie het schrijven van de Minister van Buitenlandse Zaken van 2 juni 1976, Directie Algemene Zaken, DAZ/PP-127151, aan de Commissaris der Koningin in de provincie Overijssel. Deze aangelegenheid is cok ter sprake gekomen in het schrijven van de Minister van Buitenlandse Zaken van 21 april 1977, Directie Algemene Zaken, DAZ/PP-94147.

806. Zie het Algemeen Dagblad van 7 juli 1978. Dit blad meldt, dat Molukkers voorheen bij buitenlandse reizen een zogenaamde staatlozenpas kregen, die het reizen nas het buitenland echter erg moeilijk maakte. Ook gebruikmaking van een faciliteitenpaspoort bleek in de praktijk niettemin nog minder doelmatig dan de vorige.

807. Zie Nota van Wijziging van 18 oktober 1991. Tweede Kamer, vẹgaderjaar 1991-1992, 20524, no. 11

808. Over het huidige voorstel zijn contacten geweest met Indonesië, zoals door het NRC Handelsblad $\operatorname{van} 18$ oktober 1991 is bekendgemaakt. 
Krachtens artikel VI van de Overgangsbepalingen van de Wet no. 62 van het jaar 1958 , verkreeg een vreemdeling die voór 1 augustus 1958 ooit in het leger van de Republiek Indonesië heeft gediend en aan de door de Minister van Defensie vast te stellen voorwaarden voldeed, het Indonesisch staatsburgerschap, indien hij een daartoe strekkende verklaring aflegde ten overstaan van genoemde Minister of een door deze autoriteit aan te wijzen functionaris. Voor de eerste en enige keer werd aan de Minister van Defensie een taak toebedeeld op het vlak van aangelegenheden die met het Indonesisch staatsburgerschap verband houden.

De hierbedoelde voorwaarden zijn vastgesteld met het Besluit van de Onderminister van Defensie van 12 september 1959, no. MP/E/0179/59. Met betrekking tot de hierbedoelde personen, dient onder de omschrijving "ooit in het leger van de Republiek Indonesië te hebben gediend" de periode vanaf 17 augustus 1945 tot 27 december 1949 te worden verstaan en wel in de betekenis van tenminste gedurende twee jaar ononderbroken deel te hebben genomen aan de verdediging van de Indonesische staat. Betrokkenen konden daartoe deel hebben uitgemaakt van het officiele leger van de Republiek of van het volksleger - de Indonesische term luidt "kelaskaran", welke term een troep van gewone personen, die geen echte soldaten zijn inhoudt - in die periode van strijd door de Regering erkend. Van regeringswege werd op vragen van leden van de Volksvertegenwoordiging bij de behandeling van het ontwerp betreffende het Indonesisch Staatsburgerschap naar voren gebracht, dat het hier om circa 82 personen gaat. ${ }^{8(1)}$

Van de daartoe gestelde voorwaarden kan eerst worden genoemd, het in de vastgestelde termijn - drie maanden voor personen op Java en zes maanden voor personen, die buiten Java woonplaats hebben, gerekend vanaf de inwerkingtreding van het desbetreffende Besluit, in casu 12 september 1959 - een verzoek bij de Minister c.q. daartoe aangewezen functionaris te hebben ingediend teneinde Indonesisch staatsburger te worden. ${ }^{810}$ Voorts dienden de onderhavige personen aan de navolgende voorwaarden te voldoen:

a. nooit oneervol uit hun eenheid te zijn ontslagen;

b. nooit te zijn veroordeeld wegens een misdrijf dat de Republiek Indonesië nadeel heeft berokkend;

c. afstand te hebben gedaan van hun nationaliteit op het moment van verkrijging van het Indonesisch staatsburgerschap, volgens de wettelijke bepalingen van het desbetreffende land of volgens de bepalingen van de overeenkomst tussen de Republiek Indonesië en het land in kwestie gesloten;

d. indien gehuwd, diende de echtgenote geen bezwaar te hebben tegen het verzoek tot verkrijging van het staatsburgerschap door de echtgenoot;

809. Zie het Regeringsantwoord in het kader van de Algemene Beschouwingen Hoofdstuk II, no. 18, bij de behandeling van bet onderhavige ontwerp in de Volksvertegenwoordiging.

810. De hierbedoelde termijnen zjnn nogmaals benadrukt met de Instructie van de Onderminister van Defensie van 12 september 1959 no.III/E/017/59. 
e. in het gebied van de Republiek Indonesiē gedurende de laatste vijf jaar ononderbroken of, over het geheel genomen, gedurende tien jaar onderbroken te zijn gevestigd;

f. voldoende de Indonesische taal te beheersen;

g. de eed c.q. de beloften van trouw aan de Indonesische staat af te leggen c.q. uit te spreken ten overstaan van de "Pengadilan Negeri", wiens rechtgebied de woonplaats van de betrokken personen omvat.

De hiervoor genoemde voorwaarden dienden aan de hand van bewijzen te worden gestaafd. Hierbij zij aangetekend, dat de betrokken Minister het verzoek tot verkrijging van het Indonesisch staatsburgerschap kon inwilligen of afwijzen krachtens het in artikel 5 van het onderhavige Besluit bepaalde. In het eerstgenoemde geval, trad het daarop gericht ministerieel besluit in werking op de dag dat de aanvrager de eed/belofte van trouw ten overstaan van de "Pengadilan Negeri" aflegde c.q. uitsprak. Het Indonesisch staatsburgerschap ging met terugwerkende kracht in tot het tijdstip waarop de betrokken persoon in dienst van de Republiek Indonesië was getreden. Vond de eedsaflegging of het uitspreken van de belofte van trouw niet in de daartoe gestelde termijn plaats, dan kwam het desbetreffende ministerieel besluit van rechtswege te vervallen.

Het van kracht worden van het op de verkrijging van het Indonesische staatsburgerschap gericht besluit, heeft niettemin geen andere rechtsgevolgen dan alleen in die zin, dat bedoelde personen een gelijke behandeling verkrijgen als andere Indonesische staatsburgers voor wat betreft de voorwaarden, rechten en verplichtingen, die voor veteranen/strijders voor de vrijheid van de Republiek Indonesië gelden. ${ }^{811}$ Het onderhavige ministerieel besluit geldt zowel in eerste als in laatste instantie, hetgeen impliceert dat hiertegen niet in beroep kon worden gegaan.

Werd het verzoek van een als hierbedoelde persoon afgewezen, dan staat voor hem nog de gelegenheid open om een verzoek ter verkrijging van hel Indonesisch staatsburgerschap in te dienen, volgens de procedure zoals vastgesteld in artikel 5 van de Wet no. 62 van het jaar 1958, derhalve middels gewone naturalisatie, aan de orde gekomen in $\$ 6$.

In aansluiting op het voorgaande, kan worden opgemerkt dat het hier personen betrof, die voorheen deel uitmaakten van buitenlandse strijdkrachten die tijdens de Indonesische vrijheidsstrijd hun respectieve eenheden verlaten hebben om deel te nemen aan de vrijheidsstrijd. Ten tijde van de uitgifte van voornoemd Besluit van de Onderminister van Defensie, was een deel van bedoelde personen reeds uit het Indonesische leger getreden, terwijl een ander deel nog hiervan deel uitmaakte, een situatie die juridisch niet aanvaardbaar kon worden geacht, omdat het dienen in het Indonesische leger aan

811. De status van veteranen is geregeld in de Wet no. 7 van het jaar 1967, Stb. 1967-17. Voor de status van veteranen, strijders voor de vrijheid van de Republiek Indonesië kan worden gewezen op de Wet no. 75 van het jaar 1967, Stb. 1957-162. 
de voorwaarde is gebonden, dat betrokkenen het Indonesisch staatsburgerschap dienen te bezitten.

Alhoewel in artikel VI der Overgangsbepalingen van de Wet no. 62 van 1958 van het afleggen van een verklaring ter verkrijging van het staatsburgerschap (optie) wordt gesproken, blijkt uit het onderhavige Ministerieel besluit dat hier in feite van een wijze van "naturalisatie" sprake is. In dit Besluit is gesteld, dat de hierbedoelde verklaring is "ingesloten" in het verzoek ter verkrijging van het staatsburgerschap, waarbij de bepalingen die betrekking hebben op de naturalisatieprocedure als leidraad zijn genomen. Wil men van optie spreken, dan kan hoogstens worden gezegd dat hier sprake is van "oneigenlijke optie"; aangezien de nationaliteitsverkrijging ook hier afhankelijk is gesteld van een daartoe strekkend verzoek dat van overheidswege kan worden ingewilligd of afgewezen, is in feite sprake van vereenvoudigde naturalisatie. Dit blijkt ook uit de voorwaarden, die voor het indienen van het desbetreffende verzoek zijn komen te gelden.

De gestelde voorwaarden om krachtens het onderhavige Besluit het Indonesisch staatsburgerschap te verkrijgen, zijn in enkele opzichten versoepeld. Dit blijkt hieruit dat in het hierbedoelde geval géén naturalisatiesom verschuldigd was, de verzoeker niet over een vaste bron van inkomsten behoefde te beschikken en hij van de verplichting was ontheven om voldoende kennis van de Indonesische geschiedenis te hebben. Het verzoek ter verkrijging van het Indonesisch staatsburgerschap kon voorts vrij van zegelrechten worden ingediend. Dat het echter niet in de bedoeling heeft gelegen, om de daartoe gestelde voorwaarden te "licht" te maken, blijkt uit de voorwaarden, die ten doel strekken, de houding van de desbetreffende buitenlander ten aanzien van de Indonesische staat en het Indonesische volk te kunnen evalueren, zoals het voldoende beheersen van de Indonesische taal, het in Indonesië gevestigd zijn en het zich nooit hebben schuldig gemaakt aan een misdrijf, dat de Indonesische staat schade heeft berokkend. Voorts blijkt dit ook uit de verplichting tot het afleggen c.q. uitspreken van de eed c.q. belofte van trouw aan de Indonesische staat.

Voorts gelden de beginselen, die ten grondslag liggen aan de Wet no. 62 van het jaar 1958, zoals het vermijden van het optreden van bipatridie, terwijl de echtgenote van de gehuwden onder deze personen niet automatisch het Indonesisch staatsburgerschap verkreeg. ${ }^{812}$

Het met terugwerkende kracht verlenen van het staatsburgerschap aan de hierbedoelde personen - uiteraard indien het daartoe ingediende verzoek werd ingewilligd - tot het tijdstip dat zij in dienst van het Indonesische leger zijn getreden, houdt echter niet in dat zij reeds over rechten beschikken, die qua uitgebreidheid overeenkomen met die van de gewone staatsburgers. Aan deze gedachtengang ligt de overweging ten grondslag, dat het niet in de bedoeling ligt aan de rechten c.q. het gezag van de desbetreffende Staten met betrekking tot hun burgers te tomen, zolang deze personen nog de positie

812. Dit is conform het in de Wet no. 62 van 1958 bepaalde. 
innemen van burger van bedoelde Staten. Dit strekt ten doel, mogelijke internationale conflicten te vermijden. Kortom, het met terugwerkende kracht komen te gelden van het Indonesisch staatsburgerschap, heeft geen ander rechtsgevolg, dan dat de personen in kwestie dezelfde behandeling als andere staatsburgers verkrijgen met betrekking tot de voorwaarden inzake de voor veteranen/ exstrijders van de Indonesische vrijheidsstrijd geldende rechten en verplichtingen.

Hoe dient deze aangelegenheid, gezien vanuit het gezichtspunt van Staten, wier burgers aan de Indonesische vrijheidsstrijd hebben deelgenomen, te worden opgevat? Mannoury is van mening, dat indien wordt uitgegaan van het in "vreemde" krijgsdienst treden, een organisatie van opstandelingen eerst het karakter van een vreemde Staat verkrijgt, wanneer de grenzen worden gewijzigd, zoals bij de soevereiniteitsoverdracht aan Indonesië als gevolg van de RTC-conferentie plaatsvond. Het in dienst treden van de Republiek Indonesië van de Yogya-regering deed volgens deze auteur om deze reden, het Nederlanderschap niet verliezen. Daarentegen was de Republiek der Verenigde Staten van Indonesië (later de Republiek Indonesië) wél een staat; het treden in dienst daarvan had volgens de indertijd geldende bepalingen verlies van het Nederlanderschap ten gevolge. Hierop aansluitend moge echter worden gewezen op het Koninklijk Besluit van 28 december 1951, N. Stb. 603, dat een algemeen verlof inhield om in krijgs- of staatsdienst van de Republiek der Verenigde Staten van Indonesië c.q. van de Republiek Indonesië te treden. Dit Besluit was als zodanig als een regeling van nationaliteitsrecht te beschouwen. ${ }^{813}$

Voorts moge de aandacht worden gevestigd op de mening van Boelens, die onder meer ernstige vormen van ontrouw aan de Nederlandse staat en van hulpverlening aan de vijand behandelt, die leiden tot de strafbaarstelling daarvan krachtens het Nederlands Wetboek van Strafrecht en bovendien tot het verloren gaan van het Nederlanderschap. Volgens deze auteur is het onbevredigend te achten om in deze gevallen, naast een zware bestraffing, verlies van nationaliteit te doen optreden. Hij is van mening, dat potentiële ontrouw aan de Staat en gevaar voor doorkruising van diens buitenlandse beleid aanmerkelijk rechtvaardiger en effectiever door een algemene strafbaarstelling van het zonder verlof in vreemde krijgsdienst treden zou zijn tegen te gaan, dan een door de administratie te constateren verval van nationaliteit. ${ }^{814}$

\section{$\$ 10$ Regeling van de nationaliteit van de ingezerenen van Irian Joya}

Met betrekking tot de nationaliteit van de ingezetenen van Irian Jaya, dient onderscheid te worden gemaakt tussen de periode, aan de overdracht van dit gebiedsdeel aan Indonesië voorafgaande en de periode nadat bedoelde overdracht had plaatsgevonden.

813. Mannoury, Het Nederlandse Nationaliteitsrecht, p.69.

814. Boelens, G.J., Vreende Krijgsdienst, Rechtsgeleerd magazijn Themis, 1950, p.298-299. 
10.1. Status van de ingezetenen van Irian Jaya vór de overdracht van dit gebiedsdeel aan Indonesië

Bij de soevereiniteitsoverdracht aan Indonesië bleef op de voet van het tweede artikel van het Charter van Soevereiniteitsoverdracht uitgezonderd, het gebied van NieuwGuinea (het huidige Irian Jaya). In het Slot van de Toescheidingsovereenkomst - het onderwerp van $\S 5.3$ van Hoofdstuk 3 - werd een bepaling opgenomen, dat omtrent de nationaliteit van de inwoners van genoemd gebied niets is beslist. Voor bedoelde personen bleef ingevolge artikel 2 van genoemd Charter de status quo gehandhaafd en bleven zij derhalve, voor zover zij Nederlands onderdaan waren die hoedanigheid behouden, hetzij op de voet van de Wet van 1892, hetzij op de voet van de Wet van 1910. ${ }^{815}$ Dit was het gevolg van de afkondiging van de Wet van 21 december 1951, N. Stb. 1951-593, waarbij ná de onafhankelijksverklaring van Indonesië, het zijn van Nederlands onderdaan niet-Nederlander werd beperkt tot de inwoners van NieuwGuinea.

Na de onafhankelijksproclamatie van Indonesië, lag het in de bedoeling van de Nederlandse overheid om één enkelvoudig nationaliteitsrecht in het leven te roepen voor Nederland in Europa, Suriname en de Nederlandse Antillen en werd aan de hele bevolking van Suriname en de Nederlandse Antillen, het Nederlanderschap verleend. Krachtens de reeds genoemde Wet van 1951 werd met terugwerkende kracht tot het tijdstip der soevereiniteitsoverdracht (artikel 5) bepaald, dat allen die volgens de Toescheidingsovereenkomst de Nederlandse nationaliteit bezitten of zullen bezitten, Nederlander zijn of worden - ook indien zij tevoren Nederlands onderdaan niet-Nederlander waren ${ }^{816}$ - in de zin van de Wet van 1892; krachtens artikel 3 van deze Wet werd de toepasselijkheid van de Wet van 1910 beperkt tot de inwoners van NieuwGuinea.

In de literatuur is genoemd artikel 3 van de Wet van 1951 niet ongemoeid gelaten. Zo is Logemann van mening, dat dit artikel ondeugdelijk was en de Wet van 1910 diende te worden aangepast. Wat betekende het, dat artikel 3 van de Wet van 1951 de toepasselijkheid van de Wet van 1910 aan het inwonerschap koppelde? Hield dit in, dat indien dit inwonerschap verloren ging, deze personen apatride werden? ${ }^{817}$ De wetgever had uit het $00 \mathrm{~g}$ verloren, dat de Toescheidingsovereenkomst niet meer dan een momentopname was, aangezien men niet meer met een groep "inwoners van Nieuw-Guinea" te doen had, maar met een groep personen die Nederlandse onderdanen niet-Nederlanders waren gebleven. Kon nu worden volstaan met het schrappen van het ondeugdelijke artikel 3 ?

815. Zie voor deze Wetten $\S 1.4$ en $\$ 3$ van Hoofdstuk 3.

816. Adriaanse en van der Weg, Nationaliteitswetgeving, p. IA-3 en 4. Derhalve zijn alle Nederlandse onderdanen die krachtens de Toescheidingsovereenkomst, opgenomen in de Wet Souvereiniteitoverdracht Indonesiē (Wet van 21 december 1949, N. Stb. 1949-J.570, Stb. 1950-2, Engelbrecht-oude stijl, p. 2967) die de Nederlandse nationaliteit hebben behouden of deze hoedanigheid door optie bebben verkregen, Nederlanders in de zin van de Wet van 1892.

817. Logemann, J.H.A., De Nationaliteitsregeling voor de inwoners van Nederlands Nieuw-Guinea, Nederlands Juristenblad, 1957, p. 129. 
Volgens Logemann bleek dit niet het geval te zijn. De Wet van 1910 ging voomamelijk uit van het "ius soli". Wordt ervan uitgegaan dat men dit "ius soli" uiteraard niet heeft kunnen en willen uitstrekken tot het gebied van de soevereine staat Indonesië, dan had dit tot consequentie dat waar de Wet naar territoir verwees, van Nederlands NieuwGuinea had moeten worden gesproken, in plaats van op de criteria van deze Wet het additionele criterium van het inwonerschap te planten. Alhoewel met het inwonerschap van Nieuw-Guinea dat ook aan territoir hechtte, vaak ook tot de gewenste resultaten werd gekomen, ging dit niet altijd op. ${ }^{818}$ Een voorbeeld: artikel 1 sub ten vierde van de Wet van 1910 stelde dat onderdaan zijn, de buiten Nederlandsch-Indië (Suriname of Curaçao) geboren ongehuwde kinderen van een onderdaan, als bedoeld in dit artikel, zolang die nog geen 18 jaar oud zijn. Hier ging het criterium van inwonerschap niet op. Prins wijst voorts erop, dat de inwoners van Nieuw-Guinea, de enige Nederlandse onderdanen waren, die niet in de Toescheidingsovereenkomst begrepen waren. Naar de mening van deze auteur was de persoon die daar op 27 december 1949 woonde en toen Nederlands onderdaan was, dit - behoudens verlies uit andere hoofde - gebleven. Het was echter niet zo dat degene, die ingevolge de Toescheidingsovereenkomst de Nederlandse nationaliteit heeft verloren, in Nieuw-Guinea als Nederlands onderdaan zou worden beschouwd, wanneer hij dat onmiddellijk voór de soevereiniteitsoverdracht was, een visie die mijns inziens voor de hand ligt. De kinderen die sedert 27 december 1949 in Nieuw-Guinea uit aldaar gevestigde ouders geboren, waren Nederlands onderdaan, ook al hebben hun ouders de Indonesische of een andere, vreemde nationaliteit. ${ }^{819}$ Deze opvatting was conform het in de Wet van 1910 bepaalde.

Op 1 oktober 1962 werd het bestuur over het voormalige Nederlands Nieuw-Guinea overgedragen aan een orgaan van de Verenigde Naties, als overgang naar de overdracht van het bestuur over het gebied aan Indonesië, die op 1 mei 1963 plaatsvond. In verband met deze overdracht werd bij Rijkswet van 14 september 1962, N. Stb. 1962 358 de voor Nieuw-Guinea nog van kracht zijnde Wet van 1910 met ingang van 1 oktober 1962 ingetrokken en werd in artikel 2 van deze Wet bepaald dat degenen, die onmiddellijk vóór het tijdstip van de overdracht de staat van Nederlands onderdaan nietNederlander bezaten, die staat verloren. ${ }^{820}$

In de praktijk zijn naar aanleiding van het in artikel 4 van genoemde Rijkswet bepaalde, een aantal vragen naar voren gekomen. Genoemd artikel 4 hield in, dat degenen die op grond van artikel 2 de staat van Nederlands onderdaan niet-Nederlander hebben verloren en in het Koninkrijk woonplaats of hoofdverblijf hebben, tot uiterlijk drie jaren na het in artikel 1 bedoelde tijdstip, worden behandeld als ware zij Nederlanders. De bewoordingen "als Nederlander te worden behandeld" konden betrekking hebben op vreemdelingen zonder nationaliteit, in Nederland toegelaten, die uit het voormalige Nieuw-Guinea kwamen. Bakker vraagt zich af, of de onderhavige Rijkswet geen enkele

818. Ibid., p.129-130.

819. Prins, De gevolgen, p.71. Volgens deze auteur werd deze reconstructie van het Nederlandse nationaliteitsrecht zo ingrijpend geacht, dat naar de opvatting van de Nederlandse regering een geheel nieuwe regeling in werking was getreden.

820. Adrianse en van der Weg, Nationaliteitswetgeving, p.IA-4. 
beperking inhield inzake de behandeling als Nederlander. ${ }^{821}$ Het betreft hier de vraag, of alle rechten en verplichtingen die Nederlanders bezitten op deze personen waren overgegaan. Hij is van mening dat, gezien de Intrekkingswet Nederlands onderdaanschap geen enkele beperking inhield betreffende de behandeling als Nederlander, deze conclusie inderdaad kan worden getrokken; deze auteur voegt niettemin hieraan toe, dat wellicht de bedoeling van artikel 4 is geweest, dat de rechten en plichten die de voormalige Nederlands onderdanen in Nieuw Guinea hadden, voorshands in Nederland onverkort gehandhaafd waren gebleven, doch uit de wettekst hiervan niets blijkt. Volgens deze auteur zou dus aangenomen kunnen worden, dat de personen die onder artikel 4 vielen, in Nederland actief en passief kiesrecht bezaten en eventueel dienstplichtig waren. ${ }^{822}$. Ik ben het met deze opvatting niet eens, gelet op de voormalige status van deze personen als Nederlands onderdaan niet-Nederlander; in dit licht gezien, lijkt uitbreiding van de rechten en plichten van bedoelde personen, die deze rechten en plichten krachtens hun voormalige status niet bezaten, mijns inziens onwaarschijnlijk. Bovendien kan de aandacht worden gevestigd op de in $\S 9.1 .1$ aan de orde gekomen status van alsof-Nederlander van in Nederland verblijvende Molukkers die, zoals opgemerkt, van de hierbedoelde categorie van personen konden deel uitmaken en die van deze rechten en plichten uitgezonderd zijn.

Hoe nu was de status van de inwoners van Irian Jaya in de periode vanaf de onafhankelijksproclamatie van Indonesië op 17 augustus 1945 tot de intrekking van de Wet van 1910 met ingang van 1 oktober 1962 ? Hecker is van mening, dat genoemde personen bipatride waren, omdat volgens de wettelijke bepalingen van Nederland, deze personen hun status van Nederlands onderdaan bleven behouden; aan de andere kant beschouwde Indonesië deze personen als zijn staatsburgers. ${ }^{823}$ Ook ik ben van mening, dat in bovengenoemde periode de inwoners van Irian Jaya een dubbele nationaliteit bezaten.

Met de overdracht van Irian Jaya aan Indonesië, rees de vraag hoe de nationaliteit van de ingezetenen van dit gebiedsdeel diende te worden geregeld, in aanmerking genomen dat tussen de betrokken landen hieromtrent niets was geregeld. Op deze aangelegenheid zal in het onderstaande worden teruggekomen.

10.2. Status van de ingezetenen van Irian Jaya ná de overdracht van dit gebiedsdeel aan Indonesië

In $\S 5.2$ van Hoofdstuk 3 werd de Wet no. 3 van het jaar 1946, zoals naderhand gewijzigd en aangevuld, van de toenmalige Yogyaregering genoemd. De behandeling van deze Wet vond hierin haar rechtvaardiging, dat in artikel 144 van de voorheen

821. Opvallend is dat de constructie "behandeld als Nederlander" verschillende keren in de Nederlandse wetgeving voorkomt. Zie hiervoor ook $\$ 9.1 .1$. Ook in de Indonesische wetgeving is van een dergelijke constructie gebruik gemaakt, zoals blijkt uit hetgeen in $\S 6.2$ van Hoofdstuk 3 is uiteengezet.

822. Bakker, P., Intrekking van de Wet op het Nederlands onderdaanschap, Het Persontel Statuut, 1963/1964, p. 10.

823. Hecker, Das Staatsangehörigkeitsrecht, p.46. 
geldende Voorlopige Grondwet van 1950 naar deze Wet is verwezen, ter erkenning c.q. bekrachtiging van het Indonesisch staatsburgerschap van personen, die reeds vór de afkondiging van de Wet no. 62 van het jaar 1958 als staatsburger dienden te worden aangemerkt. Dit is naderhand bevestigd door het in artikel 1 sub a, van genoemde Wet bepaalde, in $\S 1.1$ van Hoofdstuk 4 aan de orde gekomen.

De aandacht moge thans worden gevestigd op het Presidentieel Besluit no. 7 van het jaar 1971. Bij dit Besluit is verklaard, dat van de in de Wet no. 3 van het jaar 1946 opgenomen bepalingen gebruik zal worden gemaakt ter vaststelling van het Indonesisch staatsburgerschap van de ingezetenen van Irian Jaya als gevolg van de overdracht van genoemd gebiedsdeel aan de Republiek Indonesiê. ${ }^{824}$ Ook in de Considerans van dit Presidentiële Besluit is naar artikel 1 sub a. van de Wet no. 62 van 1958 verwezen.

Dat gebruik is gemaakt van de Wet no. 3 van 1946 - en niet van de Wet no. 62 van 1958 - ter vaststelling van het staatsburgerschap van de ingezetenen van Irian Jaya vindt, zoals reeds opgemerkt, hierin zijn oorzaak, dat naar de mening van de Indonesische overheid, Irian Jaya altijd deel heeft uitgemaakt van het grondgebied van Indonesië, of beter gezegd, van het voormalige Nederlandsch-Indië. De onafhankelijkheidsproclamatie van 17 augustus 1945 is voor hel gehele grondgebied van Indonesië komen te gelden, derhalve met inbegrip van Irian Jaya. Aangezien Wet no. 3 van 1946 op 17 augustus 1945 van kracht is geworden, werd het mogelijk om middels gebruikmaking van deze Wet de status van de ingezetenen van Irian Jaya te bepalen met ingang van 17 augustus 1945. Dat de Wet no. 62 van 1958 daarvoor niet in aanmerking kwam, is mijns inziens hieraan te wijten dat deze Wet eerst op l augustus 1958 van kracht is geworden en derhalve niet als grondslag kon dienen voor genoemd doel. ${ }^{825}$ Bovendien sluit het hiervoor uiteengezette aan op artikel 1 sub a van de Wet no. 62 van 1958, dat bepaalt dat Indonesisch staatsburger reeds waren, personen die deze status hadden verkregen krachtens onder meer de Wet no. 3 van 1946. Dit neemt echter niet weg, dat de gebruikmaking van de Wet no. 3 van 1946 als een "kunstmatige" constructie is aan te merken, aangezien deze Wet reeds korte tijd na haar totstandkoming buiten werking is gesteld, doch voor het hierbedoelde doel opnieuw hiervan gebruik is gemaakt!

In het belang van de rechtszekerheid werd het noodzakelijk geacht om de gebruikmaking van de in de Wet no. 3 van het jaar 1946 - zoals later gewijzigd en aangevuld met de Wetten no. 6 en 8 van het jaar 1947 en de Wet no. 11 van het jaar 1948 - opgenomen bepalingen, ter vaststelling van het Indonesisch staatsburgerschap van de ingezetenen van Irian Jaya uitdrukkelijk met het onderhavige Presidentiële Besluit te stellen.

824. Ter verduidelijking zij opgemerkt, dat op 15 augustus 1962 onder Amerikaanse bemiddeling een accoord tot stand werd gebracht, krachtens welk accoord Nederland op 1 oktober 1962 Irian Jaya aan de Verenigde Naties overdroeg, die dit gebied op 1 mei 1963 aan Indonesiē overdroegen. In 1969 werd een volkraadspleging gehouden volgens het "musyawarah"-systeem, waarbij 1025 atgevaardigden voor de Papoea's beslisten dat het gebied bij Indonesiē zou blijven.

825. Wel is het zo, dat enkele bepalingen van deze Wet met terugwerkende kracht tot 27 december 1949 in werking zijn getreden, zoals bij de behandeling van deze Wet is gebleken. 
Krachtens het in artikel 1 sub a. en b. van de Wet no. 3 van het jaar 1946 bepaalde zijn Indonesisch staatsburger, alle personen die deel uitmaken van de autochtone bevolking die zich in het gebied van de Indonesische staat bevinden. Voorts zijn Indonesisch staatsburger, personen die niet tot genoemde categorie behoren doch van iemand uit die categorie afstammen en personen die niet afstammen van iemand uit bedoelde categorie, laatstgenoemden voor zover zij aan de in genoemd artikel vastgestelde criteria voldeden. Op grond van de toelichting op voomoemd Presidentieel Besluit zoals gegeven met het Rondschrijven van de Minister van Justitië van 22 februari 1971, wordt met de categorie van personen die tot de autochtone bevolking behoren, niet alleen de oorspronkelijke inwoners van Irian Jaya bedoeld, doch ook andere Indonesiërs van onder meer Java, Bali en Ambon afkomstig, die zich aldaar hebben gevestigd. ${ }^{826}$

Met personen, die niet tot voomoemde categorie behoren, doch van iemand uit die categorie afstammen, werden voorts bedoeld:

a. wettige kinderen van een man die onder de categorie van autochtone Indonesiërs valt en een vrouw die niet tot deze categorie behoort zoals onder meer Nederlandse, Chinese, en Indiase vrouwen;

b. buiten huwelijk geboren kinderen van een vrouw, die deel uitmaakt van de categorie van autochtone Indonesiërs en een man, die niet onder genoemde categorie valt.

Ook buitenlanders, die in Irian Jaya geboren en aldaar ononderbroken woonplaats hebben gedurende tenminste de laatste vijf jaar, werden als Indonesisch staatsburger aangemerkt. Met deze categorie van personen werden krachtens de Wet no. 3 van het jaar 1946 bedoeld:

c. personen, die niet van iemand uit voomoemde categorie van autochtone Indonesiërs afstammen, die geboren zijn in het gebied van de Indonesische staat en aldaar woonplaats hebben gedurende tenminste de laatste vijf achtereenvolgende jaren, de leeftijd van 21 jaar hebben bereikt of reeds gehuwd zijn. Onder deze categorie vallen onder meer Nederlanders, Chinezen en Arabieren, die in Irian Jaya woonplaats hebben.

De Wet no. 3 van het jaar 1946 gaf aan de hierboven onder a. tot en met c. genoemde personen, die ook een andere nationaliteit bezitten, niettemin de gelegenheid om middels een daarop gerichte verklaring - in casu door negatieve optie - het Indonesisch staatsburgerschap prijs te geven. Met het afleggen van de hierbedoelde verklaring werden deze personen buitenlander. Ook aan de kinderen en hun afstammelingen van de onder a. tot en met c. genoemde personen, kwam het recht toe om het Indonesisch staatsburgerschap prijs te geven.

Aangezien de Wet no. 3 van het jaar 1946, middels de op wijziging van deze Wet gerichte Wet no. 6 van het jaar 1947 met ingang van 17 augustus 1945 van kracht is

826. Bedoeld is hier het Ministeriële Rondschrijven no. DTB/4/12 van 22 februari 1971. 
verklaard, impliceert dit dat genoemde leeftijd van 21 jaar en de periode van vijf jaar ononderbroken als hierboven genoemd, diende te worden gerekend vanaf deze datum. Dit had tot consequentie, dat de onder c. bedoelde personen Indonesisch staatsburger worden, indien zij vór 17 augustus 1924 in Irian Jaya geboren zijn - teneinde aan de gestelde voorwaarde van 21 jaar te voldoen - en aldaar sedert 17 augustus 1940 tol tenminste 17 augustus 1945 gevestigd dienden te zijn, gezien de gestelde eis met betrekking tot de vestigingsduur. Dat hier wordt uitgegaan van de datum van 17 augustus 1945 vindt zijn oorzaak in het op deze datum van kracht worden van de Wet no. 3 van het jaar 1946, in feite de datum van de inluiding van de Indonesische onafhankelijkheid.

In herinnering zij gebracht, dat de Wet no. 3 van het jaar 1946 nog uitgaat van het beginsel, dat de vrouw staande huwelijk de staat van de man volgt. Dit houdt in, dat de echtgenote van autochtone Indonesiërs en van de personen als genoemd onder a. tot en met c. waarvan de voltrekking van het huwelijk heeft plaatsgevonden vóor 17 februari 1971 - de datum van inwerkingtreding van het Presidentieel Besluit no. 7 van het jaar 1971 - Indonesisch staatsburger is, vanwege het volgen van de staat van haar echtgenoot. Betreft het daarentegen huwelijken ná 17 februari 1971 gesloten, dan zijn deze huwelijken onderworpen aan de bepalingen van de Wet no. 62 van het jaar 1958, in $\$ 7$ aan de orde gekomen.

Voorts zij naar voren gebracht, dat met de in de artikelen 9 en 10 van de Wet no. 3 van het jaar 1946 genoemde huwelijken c.q. de ontbinding daarvan zijn bedoeld, gemengde huwelijken voltrokken c.q. ontbonden vóór 17 februari 1971. De daarin genoemde verklaringen, die betrekking hebben op het terugkrijgen van het door huwelijk verloren gegaan Indonesisch staatsburgerschap c.q. het niet langer willen bezitten van dit door huwelijk verkregen staatsburgerschap dienden te worden afgelegd binnen de periode van é̂n jaar gerekend vanaf 17 februari 1971. Huwelijken, ontbonden ná 17 februari 1971 zijn daarentegen onderworpen aan de bepalingen van de Wet no. 62 van het jaar 1958.

In de uitvoering van het Presidentieel Besluit no. 7 van het jaar 1971 werd artikel 8 lid 2 van de Wet no. 3 van 1946 dat inhoudt, dat het zonder vooraf gegeven toestemming van de President van de Republiek Indonesië worden van soldaat of van ambtenaar in dienst van een ander land, verlies van het Indonesisch staatsburgerschap oplevert, niet toegepast op Indonesische staatsburgers, die gedurende de Nederlandse periode als zodanig in dienst waren van het Koninkrijk der Nederlanden. Betrof het derhalve personen als soldaat of ambtenaar in dienst van de Nederlandse staat vór 1 mei 1963 het tijdstip van teruggave van Irian Jaya aan de Republiek Indonesië - dan verloren deze personen hun Indonesisch staatsburgerschap niet c.q. bleven staatsburger van de Republiek. Zijn genoemde personen daarentegen ná 1 mei 1963 nog in genoemde functies in dienst van Nederland zonder toestemming van de President, dan verliezen zij hun staatsburgerschap krachtens de in artikel 17 sub g. van de Wet no. 62 van het 1958 opgenomen bepaling, die in $\$ 2.6$ van Hoofdstuk 6 aan de orde zal komen. De vraag kan echter worden gesteld, of laatstbedoelde situatie zich in de praktijk wel heeft voorgedaan. Dit wordt door mij betwijfeld, al is het niet uitgesloten dat dit gedurende korte tijd - een overgangsperiode - heeft plaatsgevonden. 
Heeft de uitvoering van het Presidentiēle Besluit no. 7 van 1971 zijn voltooiing bereikt, dan is de Wet no. 62 van het jaar 1958 ten volle van toepassing in Irian Jaya. In het voorafgaande werd reeds onder de aandacht gebracht, dat de Wet no. 3 van het jaar 1946 van andere beginselen uitgaat dan de Wet no. 62 van het jaar 1958, gezien het feit, dat eerstgenoemde Wet in eerste instantie het "ius soli" en voor gemengde huwelijken, het "vrouw volgt man" beginsel hanteert. Aangezien het gebruikmaken van de bepalingen van de Wet no. 3 van het jaar 1946 ter vaststelling van het Indonesisch staatsburgerschap van de ingezetenen van Irian Jaya bij Presidentieel Besluit - niet bij wet - is vastgelegd en bij voltooiing van de uitvoering van dit Besluit, de Wet no. 62 van het jaar 1958 ten volle van toepassing zal zijn in Irian Jaya, kan de conclusie worden getrokken, dat het hier een overgangsfase betrof. 



\section{HOOFDSTUK 6 WIJZE VAN VERLOREN GAAN VAN HET INDONESISCH STAATSBURGERSCHAP VOLGENS DE WET No. 62 VAN HET JAAR 1958}

\section{$\S 1$ Inleiding}

Ook ten aanzien van het verloren gaan van het Indonesisch staatsburgerschap, kunnen verschillende manieren worden onderscheiden. Op grond van het "vrouw volgt man" beginsel geldt het verloren gaan van het Indonesisch staatsburgerschap door de man, van rechtswege voor zijn vrouw, tenzij zij daardoor staatsloos zou worden. Dat ook het omgekeerde geval zich voor kan doen, met name het verloren gaan van het staatsburgerschap door een vrouw, ook voor haar man komt te gelden, eveneens onder voorbehoud dat hij daardoor niet staatloos mag worden, zal worden aangetoond. Ook kinderen kunnen het Indonesisch staatsburgerschap verliezen, als gevolg van het volgen van de staat van de vader of moeder, tenzij zij daardoor de status van apatride zouden verkrijgen.

Vindt in de hiervoor genoemde gevallen het verloren gaan van het staatsburgerschap van rechtswege plaats, verlies van het Indonesisch staatsburgerschap kan ook het gevolg zijn van negatieve optie, in casu door het afleggen van een verklaring teneinde het Indonesisch staatsburgerschap prijs te geven, met het doel een andere nationaliteit te kunnen verkrijgen of - eveneens middels een daarop gerichte verklaring - het verworven Indonesisch staatsburgerschap wederom te verliezen, teneinde de oorspronkelijk status terug te krijgen.

Het voorgaande zal hieronder aan een nadere beschouwing worden onderworpen.

\subsection{Verlies van rechtswege krachtens het "vrouw volgt man" beginsel}

In het voorgaande is reeds tot uiting gekomen, dat de Wet no. 62 van 1958 in principe het beginsel van eenheid van nationaliteit in het gezin hanteert, middels toepassing van het "vrouw volgt man" beginsel. Het is de man, die de eenheid van nationaliteit van beide huwelijkspartners bepaalt, in die zin dat zijn staatsburgerschap doorslaggevend is. Dit beginsel blijkt niet alleen uit de bepalingen die betrekking hebben op het verkrijgen van het Indonesisch staatsburgerschap, zoals reeds naar voren gebracht ${ }^{827}$, doch ook bij net verloren gaan van dit staatsburgerschap krachtens artikel 9 lid 2 van de Wet, waar het "vrouw volgt man" beginsel duidelijk naar voren komt. Het door de man verloren gaan van het Indonesisch staatsburgerschap geldt van rechtswege ook voor diens echtgenote. De Wet maakt echter ter zake een voorbehoud, met name dat dit geen apatridie voor de vrouw mag veroorzaken.

Gesteld kan derhalve worden dat het principe van eenheid van nationaliteit door de Wet wordt vooropgesteld en het, in het algemeen, de status van de man is die ter zake 
doorslaggevend is. Het beginsel van eenheid van nationaliteit wordt echter losgelaten, indien:

- door het verloren gaan van genoemd staatsburgerschap, apatridie optreedt.

Uit het voorgaande blijkt, dat aan het streven apatridie (en bipatridie) te voorkomen voorrang wordt gegeven boven het hanteren van het beginsel van de eenheid van nationaliteit krachtens het "vrouw volgt man" beginsel. Hieruit kan worden afgeleid, dat laatstgenoemd beginsel dient te wijken voor het beginsel dat geen apatridie (of bipatridie) mag optreden en in dit geval het beginsel van eenheid van nationaliteit als gevolg van het "vrouw volgt man" beginsel doorbroken wordt. ${ }^{828}$

Is het nu altijd zo dat de status van de man ter zake doorslaggevend is? Dit blijkt niet het geval te zijn, zoals uit artikel 10 lid 2 blijkt. Dit artikel houdt in, dat het verloren gaan van het Indonesisch staatsburgerschap door de vrouw, van rechtswege komt te gelden voor haar man, tenzij laatstgenoemde daardoor staatloos zou worden! ${ }^{829}$ Deze in artikel 10 lid 2 opgenomen bepaling is merkwaardig te noemen, aangezien in dit geval de status van de vrouw doorslaggevend is. Bij de behandeling van het ontwerp betreffende het Indonesisch staatsburgerschap in de Volksvertegenwoordiging, werd op vragen van enkele leden daarvan naar aanleiding van het in artikel 10 lid 2 bepaalde van regeringswege naar voren gebracht, dat het hier de echtgenoot betreft van een vrouw, die het Indonesisch staatsburgerschap verliest op basis van én van de in artikel 17 der Wet aangegeven gronden. ${ }^{\mathbf{8 3 0}}$ Dit artikel - waarop hieronder zal worden teruggekomen - dat aangeeft in welke gevallen het Indonesisch staatsburgerschap verloren gaat, geldt voor iedere staatsburger, mannen zowel als vrouwen. Ik ben echter van mening, dat het nut van het opnemen van artikel 10 lid 2 kan worden betwijfeld, aangezien dit artikel inbreuk maakt op de in de Wet no. 62 van 1958 gehanteerde systematiek. Hierbij wordt ervan uitgegaan dat het de man is, wiens staatsburgerschap de nationaliteit van beide partijen bepaalt. Zijdens de Regering werd ter toelichting naar voren gebracht, dat in het onderhavige geval verlies van het Indonesisch staatsburgerschap kan samengaan met de verkrijging van een andere nationaliteit, die mogelijkerwijze ook voor de echtgenoot geldt. Ook is het mogelijk dat man en vrouw reeds een andere nationaliteit hebben, naast hun Indonesisch staatsburgerschap. In de hierbedoelde gevallen geldt het verloren gaan van het staatsburgerschap door de vrouw ook voor haar echtgenoot. ${ }^{831}$

828. Met het doel dit beleid duidelijk te stellen, is ook de verkrijging van het Indonesisch staatsburgerschap en de mogelijkheid van het optreden van bipatridie - in $\$ 7$ reeds aan de orde gekomen - hier aangehaald.

829. Een ander geval waarin de status van de vrouw doorslaggevend is, kan zich voordoen krachtens artikel 7 lid 2 van de Wet, dat de mogelijkheid regelt tot prijsgeving van het Indonesische staatsburgerschap door de man, waarop nader zal worden teruggekomen.

830. Gautama, Tafsiran, p.183. Dit gaat uiteraard niet op in het geval van het verforen gaan van het Indonesisch staatsburgerschap bij adoptie door een buitenlander gezien de gestelde leeftijdsgrens en ook niet bij het verloren gaan van dit staatsburgerschap door erkenning van een persoon door een buitenlander, gezien de in de Wet gestelde voorwaarde, dat de desbetreffende persoon nog geen 18 jaar en niet gehuwd dient te zijn.

831. Regeringsantwoord op het Gemeenschappelijk Verslag van de fracties, p.6. 
Dit neemt niet weg, dat dit artikellid niet bepaald op duidelijkheid kan buigen! Het in genoemd artikel 10 lid 2 bepaalde, waarbij de status van de vrouw doorslaggevend is, beperkt zich niettemin tot het verloren gaan van het Indonesisch staatsburgerschap door de vrouw. Dit impliceert, dat niet analoog kan worden geredeneerd, dat verkrijging van het Indonesisch staatsburgerschap door een gehuwde vrouw in bepaalde gevallen mede geldt voor haar echtgenoot.

\subsection{Verlies van rechtswege door het volgen van de staat van de vader of moeder}

Het van rechtswege verloren gaan van het Indonesisch staatsburgerschap vindt ook plaats in het geval een kind deelt in het verloren gaan van het staatsburgerschap van de desbetreffende ouder.

Krachtens artikel 15 lid 1 en 2 van de Wet, geldt het verloren gaan van het staatsburgerschap door een vader ook voor de kinderen, die in familierechtelijke betrekking tot hem staan, voor zover zij de leeftijd van 18 jaar nog niet hebben bereikt c.q. nog niet gehuwd zijn. Ook hier is het voorbehoud gemaakt, dat deze kinderen met het verloren gaan van het staatsburgerschap niet staatloos mogen worden. Evenzo is bepaald, dat het verlies van het Indonesisch staatsburgerschap door een moeder, ook voor haar kinderen die geen familierechtelijke betrekking met hun vader hebben geldt, tenzij deze kinderen met het verloren gaan van het staatsburgerschap staatloos zouden worden. ${ }^{832}$

Ingevolge het derde lid van artikel 15 van de Wet geldt het verloren gaan van het Indonesisch staatsburgerschap door een moeder met de status van weduwe door naturalisatie in het buitenland, van rechtswege mede voor haar kinderen, die in familierechtelijke betrekking stonden met de - overleden - echtgenoot. Dit gaat eerst op, wanneer die kinderen in het buitenland woonplaats hebben en zich de facto aldaar bevinden. Hierbij is echter het voorbehoud gemaakt, dat die kinderen met het verloren gaan van het staatsburgerschap geen apatride mogen worden. Dat het verloren gaan van het staatsburgerschap door de vrouw zich mede uitstrekt tot haar minderjarige, ongehuwde kinderen is mijns inziens hieraan te wijten, dat het huwelijk door overlijden van de echtgenoot ontbonden is en de weduwe zelfstandig kan optreden, mede voor haar kinderen.

\subsection{Verlies door negatieve optie in gevallen van gemengde huwelijken}

Bij de behandeling van het gemengde huwelijk in de zin van een huwelijk tussen een buitenlandse vrouw en een Indonesisch staatsburger werd reeds gewezen op de mogelijkheid van een als hierbedoelde man om zijn Indonesisch staatsburgerschap prijs te geven. ${ }^{833}$ De mogelijkheid aan mannelijke staatsburgers met buitenlandse vrouwen gehuwd geboden, om een verklaring tot prijsgeving van hun Indonesisch staatsburger-

832. Dat de Indonesische wetgever bedoelde kinderen bij het hereiken van de leeftijd van 18 jaar - of op een eerder tijdstip gehuwd - de mogelijkheid biedt, om het verloren gegaan staatsburgerschap te herkrijgen op de daartoe in de Wet gestipuleerde wijze, werd in $\S 9$ van Hoofdstuk 5 reeds toegelicht.

833. Krachtens artikel 7 lid 2 van de onderhavige Wet. Zie hiervoor $\$ 7.1 .1$ van Hoofdstuk 5. 
schap af te leggen - negatieve optie - is krachtens artikel 7 lid 2, tweede alinea van de Wet aan een voorbehoud onderworpen. Deze verklaring mag met name slechts worden afgelegd en heeft eerst dan verlies van het Indonesisch staatsburgerschap ten gevolge, indien betrokkene daardoor niet staatloos wordt. Wil een als hierbedoelde persoon van deze gelegenheid gebruik maken, dan zal hij derhalve moeten kunnen aantonen, dat hij de door hem gewenste nationaliteit inderdaad kan verkrijgen. ${ }^{834}$ Het beginsel, dat het staatsburgerschap van de man in principe doorslaggevend is ter bepaling van de nationaliteit van beide huwelijkspartners wordt hier losgelaten. Hierbij wordt rekening gehouden met de mogelijkheid, dat slechts op deze wijze eenheid van nationaliteit van beide huwelijkspartners bereikt kan worden. Het ligt voor de hand aan te nemen, dat de man in kwestie zijn staatsburgerschap prijsgeeft met het oogmerk, de nationaliteit van zijn - buitenlandse - echtgenote te verkrijgen. In het hierbedoelde geval speelt derhalve de nationaliteit van de echtgenote een belangrijke rol! ${ }^{835}$ Hierop aansluitend dient nog te worden gewezen op het in artikel II van de Overgangsbepalingen van de Wet bepaalde, dat aan op 1 augustus 1958 - de datum van inwerkingtreding van de Wet - reeds met buitenlandse vrouwen gehuwde Indonesische staatsburgers de gelegenheid bood om hun Indonesisch staatsburgerschap alsnog middels negatieve optie prijs te geven. De desbetreffende verklaring diende te worden afgelegd binnen de termijn van een jaar gerekend vanaf 1 augustus 1958.

Uit artikel 12 van de Wet no. 62 van 1958 blijkt voorts, dat aan van oorsprong buitenlandse vrouwen de gelegenheid wordt geboden, om het door of als gevolg van het huwelijk verkregen Indonesisch staatsburgerschap, bij ontbinding van het huwelijk wederom te verliezen middels negatieve optie. ${ }^{836}$ De daarop gerichte verklaring dient te worden afgelegd binnen de termijn van een jaar na ontbinding van het huwelijk voor de "Pengadilan Negeri" van de woonplaats van de betrokken vrouw of de Diplomatieke Vertegenwoordiging van de Republiek Indonesië in het buitenland. Aan dit artikel ligt de overweging ten grondslag, om deze vrouwen de gelegenheid te geven hun oorspronkelijke nationaliteit terug te krijgen, indien zij niet langer de staat van hun - gewezen echtgenoot volgen. Ook in dit geval is de voorwaarde gesteld, dat prijsgeving van het Indonesisch staatsburgerschap niet tot apatridie mag leiden. ${ }^{837}$ Voor een goed begrip dient hieraan nog te worden toegevoegd, dat vanwege de in het onderhavige artikel 12 gehanteerde terminologie, dit artikel niet alleen betrekking heeft op vrouwen, die vanwege sluiting van een huwelijk met een Indonesisch staatsburger op de in artikel 7 der Wet bedoelde wijze het Indonesisch staatsburgerschap hebben verkregen. Blijkens

834. Dit dient te worden aangetoond door middel van een verklaring van de Diplomatieke Vertegenwoordiging van het desbetreffende land.

835. In herinnering zij gebracht, dat ik hier van negatieve optie spreek, omdat de hierbedoelde verklaring niet is gericht op de verkrijging van een nationaliteit doch juist het tegenovergestelde doel beoogt, met name om de eigen nationaliteit prijs te geven.

836. Ontbinding van het huwelijk kan het gevolg zijn van overlijden van de echtgenoot of van echtscheiding. Zie Bujung Datuk Intan Sati, Beberapa hal, Himpunan, p.360.

837. In dit geval dienen bewijsstukken te worden overgelegd inzake het bestaan van een wettig huwelijk, de ontbinding daarvan voordat een jaar verstreken is en het niet staatloos worden, te staven met een verklaring van de Diplomatieke Vertegenwoordiging van het land van oorsprong. Zie Soedarman Ganda Soebrata, Pengadilan Negeri, Himpunan, p.123. 
de omschrijving "door of als gevolg van het huwelijk" moet dit artikel in ruime zin worden opgevat. Hierdoor wordt aan buitenlandse vrouwen, die als gevolg van een bepaalde gebeurtenis tijdens het huwelijk voorgevallen - bijvoorbeeld doordat hun echtgenoot door naturalisatie Indonesisch staatsburger is geworden - genoemd staatsburgerschap hebben verkregen ${ }^{838}$, de gelegenheid geboden om hun oorspronkelijke nationaliteit terug te krijgen, op de wijze vastgesteld in artikel 12 van de Wet.

Betreft het echter een gemengd huwelijk tussen een vrouw die het Indonesisch staatsburgerschap bezit en een buitenlander, dan verliest de vrouw krachtens artikel 8 lid 1 van de Wet haar staatsburgerschap eerst, indien zij binnen de termijn van een jaar na voltrekking van het huwelijk, een daartoe strekkende verklaring bij de "Pengadilan Negeri" van haar woonplaats of de Diplomatieke Vertegenwoordiging van de Republiek Indonesië in het buitenland aflegt, derhalve middels negatieve optie. Ook in dit geval is het voorbehoud gemaakt, dat de vrouw niet staatloos worden mag. Aan dit artikel ligt de overweging ten grondslag, dat het bezwaarlijk wordt geacht, om een als hierbedoelde, met een buitenlander gehuwde vrouw zonder meer buiten te sluiten, door haar het Indonesisch staatsburgerschap te ontnemen. Dit kan zich voordoen, indien de vrouw in kwestie door huwelijk een buitenlandse status verkrijgt, terwijl zij dit in feite niet wenst. ${ }^{839}$ Om de hiervoor uiteengezette reden is in de Wet bepaald, dat de hierbedoelde vrouw die met een buitenlander trouwt, haar staatsburgerschap niet door of als gevolg van het huwelijk verliest, tenzij zij zélf besluit dit door negatieve optie prijs te geven. Voor dit doel is een verklaring van de Diplomatieke Vertegenwoordiging van het land van haar echtgenoot nodig, die inhoudt dat betrokkene de nationaliteit van haar echtgenoot kan krijgen; deze verklaring is noodzakelijk om aan te tonen, dat met het prijsgeven van het Indonesisch staatsburgerschap de vrouw geen apatride wordt. ${ }^{840}$ De Wet houdt voorts rekening met op 1 augustus 1958 reeds met buitenlanders gehuwde vrouwelijke Indonesische staatsburgers, door deze vrouw alsnog de gelegenheid te geven middels negatieve optie hun Indonesisch staatsburgerschap prijs te geven op grond van artikel II van de Overgangsbepalingen van de wet. Dit diende te geschieden binnen de periode van een jaar gerekend vanaf 1 augustus 1958.

838. In dit verband kan het beginsel van eenheid van nationaliteit onder de aandacht worden gebracht, zoals neergelegd in artikel 9 van de Wet, dat inhoudt dat het door de man verkregen Indonesisch staatsburgerschap van rechtswege mede geldt voor zijn echtgenote - tenzij zij hierdoor bipatride wordt - en omgekeerd, verlies van het staatsburgerschap door de man van recheswege mede geldt voor zijn vrouw, tenzij zij stastloos zou worden.

839. Deze toelichting werd door de Regering bij de behandeling van het ontwerp betreffende het Indonesisch staatsburgerschap in de Volksvertegenwoordiging naar voren gebracht. Door enkele leden daarvan werd de mogelijkheid onder de aandacht gebracht, dat in het hierbedoelde geval verschil in nationaliteit tussen beide partijen kan optreden, hetgeen als een ongewenste situatie werd beschouwd. Van overheidswege werd opgemerkt, dat dit in principe geen civielrechtelijke gevolgen heeft, doch deze aangelegenheid slechts het personeel statuut betreft. Mijns inziens kan deze uitspraak als minder juist worden beschouwd, aangezien het personeel statuut als in artikel $16 \mathrm{AB}$ geregeld, onderdeel van het familierecht vormt en als zodanig onder het civiele recht valt. Zie hiervoor de Algemene Beschouwingen, Hoofdstuk I van 4-6-1958, inzake deze aangelegenheid.

840. Welke consequenties dit kan hebben met betrekking tot het eventueel kunnen optreden van bipatridie, werd reeds in $\$ 7.1 .2$ van Hoofdstuk 5 onder de aandacht gebracht. 
1.4. Verlies door negatieve optie in gevallen van het volgen van de staat van de vader of moeder

In $\S 8$ is de verkrijging van het Indonesisch staatsburgerschap vanwege het volgen van de staat van de vader c.q. moeder ex artikel 13 van de Wet uitgebreid aan de orde gekomen. Krachtens artikel 14 van de Wet wordt het kind in kwestie in de gelegenheid gesteld om het verkregen Indonesisch staatsburgerschap weer te verliezen middels negatieve optie. De hierop gerichte verklaring dient binnen de termijn van een jaar, na het bereiken van de leeftijd van 21 jaar bij de daartoe aangewezen instanties te worden. In dit verband zij naar voren gebracht, dat een op een eerder tijdstip gesloten huwelijk niet van invloed is. ${ }^{841}$

Dezelfde mogelijkheid als hiervoor genoemd staat krachtens artikel 14 van de Wet open voor kinderen die door adoptie door Indonesische staatsburgers dit staatsburgerschap hebben verkregen; ook deze kinderen kunnen middels negatieve optie hun staatsburgerschap prijsgeven.

Aan het hanteren van een hogere leeftijdsgrens voor het wederom verliezen van het Indonesisch staatsburgerschap dan bij verkrijgen daarvan het geval is - op 18 jaar gesteld - ligt de overweging ten grondslag, dat het kind in kwestie op de leeftijd van 21 jaar beter in staat wordt geacht de consequenties van zijn beslissing onder ogen te zien. Aldus volgens de officiële toelichting van regeringswege bij de behandeling van het desbetreffende ontwerp in de Volksvertegenwoordiging. ${ }^{842}$ Hieraan kan worden toegevoegd, dat de leeftijdsgrens van 21 jaar in de onderhavige Wet algemeen wordt gehanteerd voor handelingen, die tot doel hebben het Indonesisch staatsburgerschap te verliezen. Het bieden van genoemde mogelijkheden aan het kind in kwestie dient te worden gezien als een uitvloeisel van de overweging, dat aan dit kind de mogelijkheid dient te worden gegeven zijn oorspronkelijke nationaliteit terug te krijgen bij het bereiken van de gestelde leeftijd.

Algemeen geldt echter het voorbehoud, dat het kind in kwestie met het verloren gaan van het Indonesisch staatsburgerschap niet staatloos mag worden en dat kind derhalve bij het afleggen van voornoemde verklaring dient aan te tonen, een andere nationaliteit te kunnen verkrijgen.

\subsection{Samenvatting}

In het bovenstaande werd aangegeven in welke gevallen verlies van het Indonesisch staatsburgerschap kan optreden, waarbij onderscheid werd gemaakt tussen verlies van rechtswege en verlies door negatieve optie.

841. Dit impliceert, dat ook een persoon die voór het bereiken van de leeftijd van 21 jaar in het huwelijk is getreden, voor het gebruikmaken van deze mogelijkheid dient te wachten tot het tijdstip van het bereiken van genoemde leeftijd.

842. Volgens het Regeringsantwoord op het Gemeenschappelijke Verslag van de fracties, p.6. 
Wat betreft vrouwen kan verlies van rechtswege optreden als gevolg van het "vrouw volgt man" beginsel als omschreven in artikel 9 lid 2 van de Wet, waarbij het voorbehoud is gemaakt dat de vrouw in kwestie niet staatloos mag worden. Treedt apatridie op, dan gaat genoemd beginsel niet op, hetgeen betekent dat in dit geval het beginsel van eenheid van nationaliteit wordt doorbroken, aangezien de echtgenoten dan van nationaliteit verschillen. ${ }^{843}$

Met betrekking tot minderjarige, nog ongehuwde kinderen levert krachtens het in artikel 15 van de Wet bepaalde, het verlies van het Indonesisch staatsburgerschap door de desbetreffende ouder - vader of moeder - mede van rechtswege het verloren gaan van het staatsburgerschap der kinderen op, tenzij zij hierdoor staatloos worden. Hetzelfde effect heeft krachtens artikel 15 lid 3 het verloren gaan van het Indonesisch staatsburgerschap van een moeder met de status van weduwe door naturalisatie in een vreemd land op haar kinderen, vooropgesteld dat deze aan de in dit artikellid gestelde voorwaarden voldoen.

Gaat het om verlies van het Indonesisch staatsburgerschap door negatieve optie, dan kan dit plaatsvinden krachtens de hieronder volgende artikelen van de Wet no. 62 van 1958:

- artikel 7 lid 2 voor een Indonesisch staatsburger, gehuwd met een buitenlandse vrouw;

- artikel 8 voor een vrouw die Indonesisch staatsburger is en met een buitenlander is gehuwd;

- artikel 12 voor een buitenlandse vrouw die door of als gevolg van huwelijk het Indonesisch staatsburgerschap heeft verkregen;

- artikel 14 voor:

a. kinderen die door adoptie op grond van artikel 2 het Indonesisch staatsburgerschap hebben verkregen;

b. kinderen die Indonesisch staatsburger zijn geworden door het volgen van de staal van de vader c.q. moeder ingevolge artikel 13 van de Wet;

artikel II van de Overgangsbepalingen voor vrouwelijke staatsburgers die zich op 1 augustus 1958 in de omstandigheden bevinden als omschreven in artikel 8 van de Wet ${ }^{844}$ dan wel Indonesische staatsburgers op genoemde datum reeds met buitenlandse vrouwen gehuwd.

843. Toegelicht met een voorbee I: Wordt de man door naturalisatie Nederlander krachtens de Rijkswet op het Nederlanderschap van 1985, dan komt deze status niet van rechtswege ook voor de vrouw te gelden doch dient ook zij zich tot Nederlandse te naturaliseren, warbij eventueel gebnik kan worden gemaakt van de verlichte naturalisatieprocedure krachtens artikel 8 lid 2 van de Rijkswet. Doet zij dit niet en zou zij op grond van bet in artikel 9 lid 2 van de Wet no. 62 van 1958 bepaalde het Indonesisch staatsburgerschap verliezen, dan word' zij staatloos. Om dit te voorkomen, is in genoemd artikellid de mogelijkheid tot behoud van het Indonesisch staatsburgerschap door de vrouw opgenomen.

844. Het betreft vrouwen die Indonesisch staatsburger zijn en op de datum van inwerkingtreding van de Wet no. 62 van 1958 reeds met buitenlanders zijn gehuwd. Deze bepaling is opgenomen om in een vacuüm te voorzien. 
Afgezien van hetgeen in het voorgaande werd uiteengezet, geeft de Wet uitdrukkelijk de gronden aan die tot verlies van het Indonesisch staatsburgerschap leiden, met name in artikel 17 van de Wet, die hieronder nader aan de orde zullen komen.

\subsection{Het vrijwillig verkrijgen van een andere nationaliteit}

Verlies van het Indonesisch staatsburgerschap treedt op door het vrijwillig verkrijgen van een andere nationaliteit, krachtens het in artikel 17 sub a. van de Wet bepaalde. Opgemerkt dient echter te worden, dat in het geval betrokkene zich op het tijdstip van verkrijging van die andere nationaliteit in het gebied van de Republiek Indonesië bevindt, zijn Indonesisch staatsburgerschap eerst geacht wordt te zijn verloren gegaan, indien de Minister van Justitie op eigen initiatief of op verzoek van de betrokken persoon, dit verloren te zijn gegaan heeft verklaard. De op deze aangelegenheid betrekking hebbende bepaling gaat met terugwerkende kracht tot 27 december 1949 in.

In het hierbedoelde geval spelen twee criteria een rol; in eerste instantie is als zodanig aan te merken, dat de andere nationaliteit vrijwillig dient te zijn verkregen, dus middels naturalisatie en optie. Dat een nationaliteit verloren gaat door het vrijwillig verkrijgen van een andere nationaliteit is een vrij gebruikelijk beginsel in het nationaliteitsrecht. ${ }^{845}$ In de Memorie van Toelichting van de Wet no. 62 van het jaar 1958 is gesteld, dat het verloren gaan van het Indonesisch staatsburgerschap door een persoon algemeen gesteld - kan worden veroorzaakt door het vrijwillig verkrijgen van een andere nationaliteit, of omdat betrokkene slechts érn nationaliteit wenst te bezitten of vanwege het verrichten van handelingen die aantonen, dat de betrokken persoon het Indonesisch staatsburgerschap niet of minder op prijs stelt.

De vrijwilligheid waardoor een andere nationaliteit wordt verkregen, duidt op een ter verkrijging daarvan verrichte handeling, een positieve daad, derhalve niet op het automatisch verkrijgen daarvan. Dit laatste kan zich bijvoorbeeld voordoen door toepassing van het "ius soli" zoals het geval was bij het voormalig Nederlands onderdaanschap, of door het automatisch verkrijgen - in het geval van een gemengd huwelijk - van de nationaliteit van de echtgenoot op grond van het "vrouw volgt man" beginsel. ${ }^{846}$ In laatstgenoemd geval is geen sprake van een vrijwillig verkregen andere nationaliteit. De vrouw heeft immers geen op verkrijging van die andere nationaliteit gerichte handeling verricht. Anders ligt de zaak, indien de hiervoor genoemde vrouw, die Indonesisch staatsburger is, de nationaliteit van haar echtgenoot niet automatisch verkrijgt, doch zij zich bijvoorbeeld heeft doen naturaliseren om bedoelde nationaliteit

845. Ter illustratie: krachtens artikel 15 van de Rijkswet op het Nederlanderschap van 1985 gaat het Nederlanderschap voor een meerderjarige onder meer verloren door bet vrijwillig verkrijgen van een andere nationaliteit.

846. Zie het in artikel 9 lid 1 van de Wet no.62 van 1958 bepaalde. 
te verkrijgen; in dit geval is wél sprake van een vrijwillig verkregen andere nationaliteit. ${ }^{847}$

Het tweede criterium, dat in het hierbedoelde geval van wezenlijk belang is te achten, is gelegen in het zich nog in Indonesië bevinden van betrokkene. Het vrijwillig verkrijgen van een andere nationaliteit heeft in dit geval niet automatisch verlies van het Indonesisch staatsburgerschap ten gevolge, aangezien in artikel 17 sub a. ter zake een voorbehoud is gemaakt, zoals hiervoor reeds aan de orde gekomen.

In de Memorie van Toelichting van de Wet is met betrekking tot deze aangelegenheid gesteld, dat het verlies van het staatsburgerschap betrokkene vrijwaart van zijn verplichtingen als Indonesisch staatsburger. Omgekeerd kan bedoelde persoon, indien zijn staatsburgerschap niet verloren gaat, niet als buitenlander worden behandeld. Bovendien blijkt uit de Memorie van Toelichting, dat het soms in het belang van de Staat kan zijn, dat een persoon die reeds een andere nationaliteit heeft verkregen als buitenlander kan worden behandeld, bijvoorbeeld om hem te kunnen uitwijzen of op zodanige wijze te behandelen als niet mogelijk is ten aanzien van de eigen staatsburgers.

Samenvattend kan worden gesteld, dat in het geval een als hierbedoelde persoon zich nog in het gebied van de Republiek Indonesië bevindt, het vrijwillig verkrijgen van een andere nationaliteit niet automatisch verlies van het Indonesisch staatsburgerschap ten gevolge heeft, doch dit afhankelijk wordt gesteld van een daartoe van regeringswege uitgegeven verklaring, hetzij op verzoek van betrokkene hetzij op initiatief van de Minister. Hier is sprake van overheidsbemoeienis, in die zin dat van overheidswege dient te worden ingestemd met het verloren gaan van het Indonesisch staatsburgerschap van betrokkene. ${ }^{848}$ De vraag kan worden gesteld, waarom het verloren gaan van het Indonesisch staatsburgerschap in het hierbedoelde geval van een daartoe strekkende verklaring van de Minister van Justitie afhankelijk is gesteld. Mijns inziens dient dit te worden gezien tegen de achtergrond dat de betrokken persoon die vrijwillig een andere nationaliteit heeft verkregen nog in Indonesië vertoeft en de mogelijkheid tot het maken van misbruik niet is uitgesloten, doordat deze persoon door zich te beroepen op zijn nieuwe nationaliteit tracht zich aan bepaalde, voor Indonesische staatsburgers geldende verplichtingen - zoals bijvoorbeeld het verrichten van dienstplicht - te onttrekken.

Zou kunnen worden gesteld, dat ook het verkrijgen van een andere nationaliteit door betrokkene aan toestemming van de Overheid c.q. de Minister van Justitie gebonden is? Ter beantwoording van deze vraag, kan in herinnering worden gebracht, dat het verkrijgen van een andere nationaliteit, de uitsluitende bevoegdheid van de desbetreffende Staat uitmaakt krachtens de aan deze Staat toekomende nationale autonomie om de nationaliteit van zijn burgers te regelen en derhalve niet de competentie vormt van de

847. Ik bracht reeds het voorbeeld naar voren, dat een vrouwelijke Indonesisch staatsburger die met een Nederlander is gebuwd, zich dient te laten naturaliseren om het Nederlanderschap deelachtig te worden.

848. Zie hetgeen omtrent het expatriatierecht werd opgemerkt in $\S 1$ 3.3.3 van Hoofdstuk 2 . 
Indonesische overheid. ${ }^{849}$ Dit neemt echter niet weg, dat het kan voorkomen dat de Overheid het feit van het hebben verkregen van een andere nationaliteit door betrokkene niet erkent en de betrokken persoon nog steeds als zijn staatsburger beschouwt, waardoor bipatridie kan optreden. ${ }^{850} \mathrm{Het}$ in artikel 17 sub a bepaalde laat in casu de mogelijkheid tot het optreden van bipatridie open zolang de desbetreffende personen nog niet in het bezit van een van overheidswege afgegeven verklaring betreffende het verlies van het Indonesische staatsburgerschap zijn gesteld.

Volgens Adriaanse en van der Weg kan uit artikel 17 sub a. worden afgeleid, dat in het geval Indonesische staatsburgers op eigen verzoek een vreemde nationaliteit verkrijgen en zich buiten Indonesië bevinden, het staatsburgerschap van rechtswege verloren gaat. ${ }^{851}$ Deze mening wordt door Ko Swan Sik en Teuku Moh. Rhadie gedeeld. ${ }^{852}$ Ook ik onderschrijf dit standpunt, gezien de in dit artikel opgenomen bepaling: "Het vrijwillig verkrijgen van een andere nationaliteit..." ${ }^{853}$, op welke algemene bepaling een voorbehoud is gemaakt voor het geval de betrokken persoon zich nog in Indonesië bevindt, in welk geval het verloren gaan van het Indonesisch staatsburgerschap niet van rechtswege is. Niettemin zou het aan te bevelen zijn, om het van rechtswege verloren gaan van het Indonesisch staatsburgerschap bij verblijf buitenlands van de betrokken persoon vanwege de vrijwillige verkrijging van een andere nationaliteit uitdrukkelijk in de Wet op te nemen, ter voorkoming van misverstand. Wordt hiervan uitgegaan, dan is de in artikel 17 sub e. opgenomen bepaling - hieronder nader toe te lichten - merkwaardig te noemen, aangezien in dit geval waarbij betrokkene buitenlands verblijft, hij de Minister van Justitie om vervallenverklaring van zijn staatsburgerschap moet verzoeken, ook al zou het hier niet om het "vrijwillig verkrijgen van een andere nationaliteit" gaan. Op het in artikel 17 sub e. bepaalde zal hieronder worden teruggekomen.

2.2. Het niet verwerpen c.q. prijsgeven van een andere nationaliteit, terwijl de betrokken persoon daartoe de gelegenheid krijgt

Het behoeft geen nadere toelichting, dat de in artikel 17 sub b. opgenomen, tot verlies van het staatsburgerschap leidende rechtsgrond - het niet verwerpen of prijsgeven van een andere nationaliteit terwijl betrokkene daartoe de gelegenheid krijgt - dient te worden gezien als een bepaling die voortkomt uit het door de Indonesische overheid gevolgde beleid om bipatridie zoveel mogelijk te voorkomen. In de Memorie van Toelichting van de Wet is naar voren gebracht, dat een als hierbedoelde persoon aantoont het bezit van het Indonesisch staatsburgerschap niet langer op prijs te stellen.

849. Zie hetgeen inzake de nationale autonomie van Staten in $\$ 1.4$ van Hoofdstuk 2 naar voren werd gebracht.

850. Dit is in het kader van mijn beschouwing verschillende keren nasr voren gekomen, onder meer bij de behandeling van de nationaliteit van de inwoners van Irian Jaya in $\$ 10$ van Hoofdstuk 5.

851. Adriaanse en van der Weg, Nationaliteitswetgeving, Indonesiē, p.Ib-17.

852. Ko Swan Sik en Teuku Moh. Rhadie, Nationality, p. 154.

853. In het Indonesisch luidt deze bepaling, dat het Indonesisch stagtsburgenschap verloren gaat vanwege het "memperoleh kewarga-negaraan lain karena kemauannja sendiri...." 
Het klassieke voorbeeld van het beleid om bipatridie te voorkomen c.q. aan deze status een einde te maken, was de door de Indonesische Regering en die van de Chinese Volksrepubliek gesloten Overeenkomst ter afwikkeling van het probleem van de bipatridie. Hierbij was - aanvankelijk - overeengekomen, dat personen, die onder vigeur van deze Overeenkomst vallen, een keuze dienden te maken tussen de twee nationaliteiten die zij bezaten. Met het door Indonesië opzeggen van de ter uitvoering daarvan vastgestelde bepalingen, staat deze mogelijkheid niet langer open, werd in casu een "stop" ingevoerd. Tijdens het debat over het desbetreffende ontwerp in de Volksvertegenwoordiging, is van regeringswege echter naar voren gebracht, dat artikel 17 sub b. geheel los van de Wet no. 2 van 1958 dient te worden gezien. ${ }^{854}$

Ik bracht reeds onder de aandacht, dat door Ko Swan Sik en Teuku Moh. Rhadie wordt aangenomen dat in drie gevallen het Indonesische staatsburgerschap kan worden behouden c.q. verkregen, in weerwil van het optreden van bipatridie. Het betreft hier de verkrijging krachtens het "ius sanguinis" ex artikel 1 sub b., c. en d., krachtens adoptie (artikel 2) en vanwege het delen in de verkrijging van het Indonesisch staatsburgerschap door de desbetreffende ouder (artikel 13). ${ }^{855}$ Wat betreft de verkrijging van het Indonesisch staatsburgerschap door adoptie, wordt ook door Adriaanse en van der Weg erop gewezen, dat de Wet no. 62 van 1958 niet de voorwaarde stelt, dat het kind door de verkrijging van de Indonesische nationaliteit de vreemde nationaliteit, die het mogelijk bezit, moet verliezen. ${ }^{856}$ Toegegeven moet worden, dat niet alleen in artikel 2, doch ook in artikel 1 sub b., c. en d. en in artikel 13, de gebruikelijke clausule van "het niet bezitten van een andere nationaliteit" niet is opgenomen; in het kader van mijn beschouwing inzake deze aangelegenheid, vroeg ik mij reeds af, of hieruit kan worden afgeleid, dat de Indonesische overheid in deze gevallen van het beleid om bipatridie te voorkomen, afwijkt. ${ }^{857}$ In het geval van vrouwen die Indonesisch staatsburger zijn en met buitenlanders zijn gehuwd - als omschreven in artikel 8 van de Wet - dient te worden opgemerkt, dat de redactie van dit artikel de mogelijkheid tot het optreden van bipatridie openlaat. Ook in dit geval is het echter de vraag, of dit overeenkomt met het van overheidswege ingenomen standpunt om het optreden van bipatridie zoveel mogelijk te voorkomen. ${ }^{858}$ Volledigheidshalve dient voorts op het in artikel 17 sub a. bedoelde geval te worden gewezen, waarin een nog in Indonesië verblijvende persoon mogelijkerwijze de staat van bipatride kan bezitten zolang van regeringswege geen verklaring is gegeven, waarbij het Indonesisch staatsburgerschap verloren gegaan wordt verklaard.

854. Regeringsantwoord op het Gemeenschappelijk Verslag van de fracties, p.6. De Wet no. 2 van 1958 is aan de orde gekomen bij de behandeling van het dubhele staatsburgerschap der Chinezen in $\$ 3$ van Hoofdstuk 4.

855. Ko Swan Sik en Teuku Moh. Rhadie, Nationality, p. 167.

856. Adriaanse en van der Weg, Nationaliteitswetgeving, Indonesië, p. Ib-13.

857. Zie voor de verkijging van het Indonesisch staatsburgerschap krachtens genoemde artikelen, hetgeen naar voren is gebracht in resp. $\$ 2, \S 4$ en $\$ 8$ van Hoofdstuk 5 . In $\$ 8$ werd op de van overheidswege gegeven toelichting op artikel 13 van de Wet gewezen, als gevolg warrvan het optreden van bipatridie in het geval in dit artikel omschreven, praktisch is uitgesloten.

858. Op deze aangelegenheid werd reeds uitvoerig ingegaan in \$ 7.1.2 van Hoofdstuk 5. 
Ik zie de betekenis van het in artikel 17 sub b. bepaalde hierin, dat indien zich toch onverhoopt gevallen van bipatridie zouden mogen voordoen, deze bepaling fungeert als "stok achter de deur", teneinde aan de mogelijke status van bipatride van een persoon een einde te maken. In dit artikel is immers bepaald, dat het niet verwerpen of prijsgeven van een andere nationaliteit - terwijl betrokkene daartoe de gelegenheid krijgt - het verloren gaan van het Indonesisch staatsburgerschap ten gevolge heeft. Bovendien is het zo, dat het in het bezit zijn van een buitenlands, nog geldig paspoort of ander reisdocument op naam van de betrokken persoon, eveneens het verloren gaan van het Indonesisch staatsburgerschap ten gevolge heeft - zoals nader zal worden aangetoond - een tweede "stok achter de deur"!

\subsection{Erkenning door een buitenlander}

Wordt een Indonesisch staatsburger door een buitenlander als zijn kind erkend, dan heeft deze rechtshandeling krachtens artikel 17 sub c. der Wet verlies van het Indonesisch staatsburgerschap ten gevolge. Hierbij is echter het voorbehoud gemaakt, dat het kind in kwestie de leeftijd van 18 jaar nog niet bereikt mag hebben c.q. niet op een eerder tijdstip mag zijn gehuwd.

Een buiten huwelijk uit een vrouw, die het Indonesisch staatsburgerschap bezit geboren kind, volgt de staat van zijn moeder en is dus Indonesisch staatsburger. ${ }^{859}$ Wordt het kind echter door de vader, een buitenlander, erkend, dan wordt het kind vanwege de familierechtelijke betrekking die door de erkenning ontstaat, buitenlander. Door auteurs en in de jurisprudentie wordt algemeen aangenomen, dat de erkenning dient te geschieden volgens het recht van de erkennende partij. ${ }^{800}$

De Wet no. 62 van het jaar 1958 houdt zich in het algemeen aan de leeftijd van 18 jaar - of op een eerder tijdstip zijn gehuwd - als de leeftijd, waarop een persoon als volwassen wordt aangemerkt. Het kind dient de nationaliteit van zijn vader te verkrijgen, hij mag met andere woorden, door het verloren gaan van het Indonesisch staatsburgerschap niet staatloos worden. Deze bepaling gaat met terugwerkende kracht tot 27 december 1949 in. Dit impliceert, dat ook erkenningen tussen 1 augustus 1958 en 27 december 1949 verricht, onder vigeur van artikel 17 sub c. vallen.

In de Wet no. 62 van het jaar 1958 wordt niet gesproken van verlies van het Indonesisch staatsburgerschap door wettiging door een buitenlander, waarvoor algemeen wordt vereist, dat het kind wordt erkend en tussen de erkenner en de moeder van het kind, een huwelijk wordt gesloten. De erkenning van het kind in kwestie kind kan hetzij vóor de voltrekking van het huwelijk, hetzij bij de voltrekking daarvan plaatsvinden. Hierbij is het niet noodzakelijk, dat de man die het kind erkent, de naturlijke vader is van het

859. De Wet volgt het beginsel van "moeder maakt geen bastaard"; dit komt overeen met het in de Huwelijkswet van 1974 bepaalde, dat tussen een buiten huwelijk geboren kind en zijn moeder en haar familie een burgerlijke betrekking bestaat.

860. Zie Gautama, Hukum Perdata, p.78. 
kind in kwestie. De erkenning is de enige voorwaarde, waaruit volgt dat elk kind dat erkend kan worden, ook gewettigd kan worden. ${ }^{861}$

Alhoewel "wettiging" niet als rechtsgrond in de Wet is opgenomen, is uit kringen van advocaten vemomen dat in de jurispnudentie ervan wordt uitgegaan, dat de wettiging van een kind in het verlengde kan worden gezien van de erkenning van een kind en levert ook wettiging grond op voor verlies van het Indonesisch staatsburgerschap.

Dit neemt niet weg, dat dit in het belang van de rechtszekerheid, in de Wet had dienen te zijn gestipuleerd.

\subsection{Adoptie door een buitenlander}

Op grond van artikel 17 sub d. van de Wet, treedt verlies van het Indonesisch staatsburgerschap op, indien een kind dat het Indonesisch staatsburgerschap bezit, op wettige wijze door een buitenlander wordt geadopteerd.

Als voorwaarde is hierbij gesteld, dat het kind in kwestie niet ouder mag zijn dan 5 jaar. Deze bepaling is gesteld naar analogie van artikel 2 van de Wet, dat de verkrijging van het Indonesisch staatsburgerschap door een buitenlands kind middels adoptie door een Indonesisch staatsburger regelt; hierbij wordt dezelfde leeftijdsgrens gehanteerd.

In het Rondschrijven van de Voorzitter van de "Mahkamah Agung" (MA) no. 6 van het jaar 1983 inzake de vervolmaking van het Rondschrijven no. 2 van het jaar 1979, is in het bijzonder wat betreft de adoptie van kinderen op de wijze van "inter-country" gesteld, dat de adoptie van een kind eerst wettig is, indien daartoe een besluit van het Gerecht verkregen is. ${ }^{862}$ Dit vormt een essentiële voorwaarde voor de wettigheid van de desbetreffende adoptie. Met de term "inter-country" wordt bedoeld, een adoptie waarbij de adoptanten en het kind niet dezelfde nationaliteit hebben of de gewone verblijfplaats van de adopterende partij en van het kind in kwestie in verschillende landen is gelegen. In dit verband wordt verwezen naar het Haagse Adoptieverdrag van 1965, dat in de praktijk als leidraad wordt genomen, om op het gangbare recht aan te sluiten. ${ }^{863}$

861. Ter illustratie: Ingevolge de Nederlandse nationaliteitswet - de Rijkswet van 1985 - worden minderjarige vreemdelingen, door en Nederlander erkend of zonder erkenning gewettigd, van rechtswege Nederlander.

862. Het Rondscbrijven van de MA no.6 van het jaar 1983 is in $\$ 4$ van Hoofdstuk. 5 reeds aan de orde gekomen.

863. Zie voor een beschouwing van dit Verdrag, de Winter, L.I. het Haagse Adoptieverdrag, WPNR, 1965, p.353-355, 365-367 en 395-397. Deze auteur wijst erop, dat in het geval de adoptanten en het kind hun gewoon verblijf in verschillende landen hebben, aan de autoriteiten van het verblijfplaats van bet kind het recht wordt toegekend zich tegen de adoptie te verzetten, indien deze naar hun oordeel in strijd is met de belangen van het kind. Kwesties betreffende de voor de adoptie vereiste loestemmingen zouden voorts moeten worden onderzocht en beslist door de autoriteiten van het vaderland van het kind. 
Een als hierbedoeld internationaal adoptieverzoek dient krachtens het Rondschrijven van de Minister van Justitie van 24 februari 1978, te worden voorgelegd bij de "Pengadilan Negeri", waar het kind woont. ${ }^{864}$ Ook met genoemd Rondschrijven van de MA no. 6 van het jaar 1983 is bevestigd dat een als hierbedoeld verzoek dient te worden gericht aan de Voorzitter van de "Pengadilan Negeri". waarvan het rechtsgebied de woonplaats/domicilie van het te adopteren kind omvat. Hieruit blijkt dat aangeknoopt dient te worden bij de gewone verblijfplaats van het kind in kwestie, teneinde te bepalen welke rechtbank ter zake bevoegd is. Het welzijn van het te adopteren kind, dient voorop te staan. De verzoeker dient in Indonesië domicilie te hebben en aldaar een vaste werkkring te hebben gedurende tenminste 3 jaar. De adoptie van het kind dient te worden uritgevoerd met inschakeling van een sociale stichting, die in het bezit van een vergunning van het Departement van Sociale Zaken dient te zijn; dit houdt in, dat een als hierbedoelde adoptie niet rechtstreeks tussen de natuurlijke ouders van het kind en de potentiële adoptanten kan worden afgewikkeld. Voorts is de adoptie van een kind dat het Indonesisch staatsburgerschap bezit door een (nog) niet gehuwde buitenlandse partij - één ouder adoptie - niet toegestaan.

In het Rondschrijven van de "Mahkamah Agung" no. 6 van het jaar 1983 is voorts de procedure aangegeven bij de adoptie te volgen, waarbij onder meer het Departement van Buitenlandse Zaken, de Immigratiedienst en de lokaal gevestigde Politie dienen te worden gehoord, aangezien zich publiekrechtelijke factoren en mogelijk ook factoren die op de staatsveiligheid betrekking hebben, daarbij kunnen voordoen. Bewijsstukken dienen voorts te worden overgelegd, die onder meer betrekking hebben op de leeftijd van het te adopteren kind. Het Gerecht onderwerpt voorts de toestemming of de vergunning van de daarvoor in aanmerking komende instantie van het land van oorsprong der kandidaat-adoptiefouders aan een onderzoek.

Het verschil tussen verlies van het Indonesisch staatsburgerschap als gevolg van erkenning en als gevolg van adoptie door een buitenlander, ligt in de als voorwaarde gestelde leeftijd, voor adopties vastgesteld op 5 jaar. Bij door een buitenlander erkende kinderen is deze leeftijd gesteld op het nog niet zijn van 18 jaar c.q. niet op een eerder tijdstip zijn gehuwd.

Gezien de leeftijd van het te adopteren kind een belangrijke rol speelt, kan de aandacht worden gevestigd op een geval dat zich in de Duitse jurisprudentie heeft voorgedaan, dat betrekking heeft op de adoptie van kinderen; het betreft hier Indonesische staatsburgers van Chinese origine door een Duitser geadopteerd. In deze zaak werd ervan uitgegaan dat Indonesische staatsburgers van Chinese afkomst op de leeftijd van 20 jaar in de regel nog minderjarig zijn, aangezien volgens artikel 330 van het IBW de meerderjarigheid aanvangt bij het bereiken van de leeftijd van 21 jaar. Twee van de geadopteerde kinderen waren op respectievelijk 11 oktober 1964 en 4 april 1966 geboren - het derde kind was op 14 oktober 1969 geboren - als kinderen van Indonesische staatsbur-

864. Bedoeld is hier het Ministeriēle Rondschrijven no. JHA 1/1/2 van 24 februari 1978 aan de notarissen gericht. 
gers en hadden het Indonesisch staatsburgerschap "iure sanguinis" verkregen. Het huwelijk van de ouders werd in 1981 door echtscheiding ontbonden, waarbij de zorg voor de kinderen aan de moeder werd toevertrouwd. Op 10 juni 1982 verklaarde de moeder ten overstaan van een notaris dat zij de kinderen voor adoptie aan A - een persoon met de Duitse nationaliteit - overdroeg, terwijl A bevestigde dat hij die kinderen geadopteerd heeft. In mei 1983 traden de moeder van de kinderen en A voor de Burgelijke Stand in Mannheim in het huwelijk. Met het Besluit van 1 november 1984 - van kracht sedert 15 november 1984 - sprak het AG Schöneberg in Berlijn zich voor de adoptie der kinderen uit. Onder overlegging van dit Besluit vroegen de kinderen in 1985 een bewijsstuk inzake de verkrijging van de Duitse nationaliteit aan. Werd de aanvraag van het jongste kind ingewilligd, dit was niet het geval met de aanvraag van de twee andere kinderen, aangezien volgens de desbetreffende autoriteit deze kinderen op het tijdstip van de adoptie - ook naar Indonesisch recht - reeds meerderjarig waren. Wordt uitgegaan van het Adoptiebesluit van AG Schöneberg van 15 november 1984, dan waren de desbetreffende kinderen in november 1984 respectievelijk 20 en 18 jaar oud en waren - naar werd aangenomen - nog minderjarig, aangezien naar Indonesisch recht de meerderjarigheid eerst met 21 jaar aanvangt. ${ }^{865}$ $1 \mathrm{k}$ ben echter van mening, dat de leeftijd van 21 jaar hier niet ter zake doende is; alhoewel volgens het IBW de meerderjarigheid op 21 jaar was gesteld - Indonesische staatsburgers van Chinese origine vallen onder het IBW - dient erop te worden gewezen dat het op de meerderjarigheid betrekking hebbende artikel 330 IBW niet langer van kracht is. Immers, in artikel 66 van de Huwelijkswet van 1974 is met zoveel woorden bepaald, dat voor het huwelijk en alles dat daarmede samenhangt, de bepalingen van het IBW niet langer van kracht zijn, voor zover aangelegenheden betreffende, reeds in de Huwelijkswet geregeld. Wordt afgegaan op het in artikel 47 van deze Wet bepaalde - op grond waarvan de meerderjarigheid op 18 jaar is gesteld - dan kan worden geconcludeerd, dat thans de leeftijd van 18 jaar en niet langer die van 21 jaar geldt. Genoemde leeftijd speelt in adoptiezaken echter geen rol, aangezien de leeftijd van het kind beneden de 5 jaar dient te liggen, wil de adoptie wettig zijn. Bovendien is de gevolgde adoptieprocedure niet in overeenstemming met het Rondschrijven van de "Mahkamah Agung" no. 2 van 1979 - naderhand vervolmaakt met het Rondschrijven no. 6 van 1983 - aangezien voor de wettigheid van een adoptie een besluit van de "Pengadilan Negeri" doorslaggevend is en niet kan worden volstaan met een notariële akte, zelfs al wordt deze gelegaliseerd door het Gerecht. Met het Rondschrijven no. 6 van 1983 werden de voorwaarden van een adoptie teneinde wettig te zijn, nog aangescherpt. In dit Rondschrijven werd niet alleen nogmaals de nadruk gelegd op genoemde leeftijd van 5 jaar, doch ook bepaald, dat éen ouder adopties niet toegestaan zijn; de adoptant was in casu op het moment van de adoptie nog niet met de moeder der kinderen gehuwd.

865. Meegedeeld door Dr. von Bargen, rechter in Mannheim. 
Verlies van het Indonesisch staatsburgerschap uit hoofde van adoptie door een buitenlander, mag niet tot staatloosheid van het kind in kwestie mag leiden, hetgeen impliceert dat het kind de nationaliteit van de adopterende personen dient te verkrijgen. ${ }^{866}$

Het valt niettemin te betreuren, dat nog gé́n wet op de adoptie van kinderen voor Indonesië voorhanden is, teneinde mogelijk misbruik op dit vlak te voorkomen. $\mathrm{ZO}$ is uit de praktijk gebleken, dat de "Pengadilan Negeri" zich niet altijd aan de gegeven richtlijnen houdt c.q. niet steeds het vereiste grondige onderzoek instelt. Ook komt het voor, dat het onderzoek voor het Gerecht slechts op summiere wijze geschiedt, alsof de onderhavige aangelegenheid slechts pro forma plaatsvindt, zonder dat beoogd wordt van de motieven en de achtergrond van de desbetreffende adoptie een duidelijk beeld te verkrijgen. Het komt bovendien voor, dat de daartoe te volgen procedure beperkt wordt tot het horen van de twee betrokken partijen, met name de ouders van het kind in kwestie en de personen die het willen adopteren, vergezeld door een notariële akte. Dat dergelijke praktijken dienen te worden voorkomen teneinde misbruik uit te sluiten, spreekt vanzelf. De adoptie van Indonesische kinderen vormt een aktuele aangelegenheid, aangezien de indruk wordt verkregen dat buitenlanders naar Indonesië komen en als "souvenir" een Indonesisch kind meenemen. Ook laat het zich aanzien, dat Indonesische kinderen worden "verkocht" om te worden geadopteerd. Het voorhanden zijn van een Wet, die de adoptie van kinderen regelt, is dan ook dringend noodzakelijk. ${ }^{867}$

In het algemeen kan de vraag worden gesteld, of adoptie altijd invloed heeft op de nationaliteit. ${ }^{868}$ Volgens Ko Swan Sik is in sommige nationaliteitswetten uitdrukkelijk bepaald, dat adoptie van géén invloed is op de nationaliteit. Andere landen bieden aan personen door hun burgers geadopteerd de mogelijkheid tot vereenvoudigde naturalisatie, zoals bijvoorbeeld Japan ${ }^{869}$ of nationaliteitsverkrijging door optie. Andere landen verlenen hun nationaliteit onvoorwaardelijk op grond van adoptie, terwijl weer andere landen die op dezelfde grond ontnemen. ${ }^{870}$

Wat Indonesië betreft, levert de adoptie van een buitenlands kind door zijn burgers grond op ter verkrijging van het Indonesisch staatsburgerschap, zoals in $\S 4$ van Hoofdstuk 5 naar voren gebracht. Het tegengestelde geval zoals in artikel 17 sub d. gestipuleerd, heeft het verloren gaan van genoemd staatsburgerschap ten gevolge. Het kind in kwestie mag geen apatride worden. Dit impliceert, dat het te adopteren kind zijn

866. Ter illustratie: De Nederlandse wet maakt verkrijging van het Nederlanderschap - van rechtswege mogelijk voor kinderen, die in Nederland, de Nederlandse Antillen of Aruba worden geadopteerd, vooropgesteld dat zij aan de gestelde voorwaarden voldoen. Gezien de door de Wet gehanteerde terminologie, hebben buitenlandse adopties, gén verkrijging van het Nederlanderschap ten gevolge.

867. Gautama, Tafsiran, p. 208.

868. Zie voor een wereldomvattend overzicht, Hecker, H., Einfluß der Adoption auf die Staatsangebōingkeit, STAZ 1985, p.153-163.

869. Zie de nationaliteitswet van dit land no. 147 van 1950, gewijzigd bij Wet no. 268 van 1952 en de Wet no. 45 van 1984. Krachtens artikel 8 lid 2 van deze Wet, wordt door adoptie de Japanse nationaliteit niet verkregen, doch is wel vereenvoudigde naturalisatie mogelijk. Zie Adriaanse en van der Weg, Nationaliteitswetgeving.

870. Ko Swan Sik, De Meervoudige, p.99-102. 
Indonesisch staatsburgerschap zal blijven behouden, indien krachtens het nationaliteitsrecht van de adoptant, de adoptie van geen invloed is op de nationaliteit van het kind in kwestie.

\subsection{Verlorenverklaring door de Minister van Justitie}

De Minister van Justitie kan op verzoek van de betrokken persoon, diens Indonesisch staatsburgerschap verloren verklaren, indien betrokkene de leeftijd van 21 jaar heeft bereikt, hij in het buitenland woonplaats heeft en door het verlies van het Indonesisch staatsburgerschap, niet staatloos wordt.

Het hierbedoelde, in artikel 17 sub e. geregelde geval kan zich onder meer voordoen, in het geval van het verkrijgen van een andere nationaliteit. Deze nationaliteit behoeft niet vrijwillig te zijn verkregen, anders dan het in artikel 17 sub a. bedoelde geval, in $\$ 2.1$ behandeld. ${ }^{871}$

Van belang is, dat de betrokken persoon in het buitenland verblijft. Bevindt hij zich in Indonesië, dan kunnen de banden met het land van oorsprong nog hecht worden genoemd c.q. valt betrokkene nog onder de gezagssfeer van de Indonesische overheid. In het in artikel 17 sub e. bedoelde geval kan daarentegen worden aangenomen, dat de banden met het land van oorsprong niet meer sterk zijn te noemen c.q. de persoon in kwestie zich reeds buiten de gezagssfeer van de Indonesische overheid bevindt.

De leeftijd van 21 jaar, is de leeftijd die ook in andere gevallen van prijsgeving van het Indonesisch staatsburgerschap wordt gehanteerd. Hierbij zij aangetekend, dat een op een eerder tijdstip gesloten huwelijk niet van invloed is. ${ }^{872}$

Dient een als hierbedoeld verzoek door de Minister te worden ingewilligd indien aan de gestelde voorwaarden is voldaan? De nadruk dient te worden gelegd op het feit, dat hier van een verzoek van betrokkene sprake is en het derhalve van de Minister afhangt, hoe op dit verzoek zal worden gereageerd. Mijns inziens zal het hierbedoelde verzoek eerder voor inwilliging in aanmerking komen dan het verzoek tot verlorenverklaring van het Indonesisch staatsburgerschap als bedoeld in $\$ 2.1$. In laatstbedoeld geval zijn vanwege het zich nog bevinden van betrokkene in Indonesië de banden met Indonesië nog hecht te noemen en hangt het van de Minister van Justitie af, of het Indonesisch staatsburgerschap van de betrokken persoon - die nog in Indonesië verblijft - verloren kan worden verklaard, om redenen in de desbetreffende paragraaf reeds aangegeven.

Krachtens het in artikel 17 sub e. bepaalde is het verlies van het Indonesisch staatsburgerschap echter niet van rechtswege, doch dient daartoe een verzoek door de betrokken

871. Als voorbeeld van het hierbedoelde geval, zou nationaliteitsverkrijging krachtens het "ius soli" kunnen worden genoemd.

872. Dit impliceert, dat in het geval de betrokken persoon bijvoorheeld op de leeftijd van 19 jasr is gehuwd, hij desondanks de leeftijd van 21 jaar dient te hebben bereikt, wil hij van de hierbedoelde gelegenheid gebruik maken. 
persoon te worden ingediend. Wordt in het in $\$ 2.1$ behandelde geval ervan uitgegaan, dat in het geval de betrokken persoon buitenlands verblijft het verloren gaan van het Indonesisch staatsburgerschap bij vrijwillige verkrijging van een andere nationaliteit van rechtswege plaatsvindt, dan kan het in artikel 17 sub e. bepaalde merkwaardig worden genoemd, aangezien hier het komen te vervallen van het Indonesisch staatsburgerschap van een daartoe strekkend verzoek van de betrokken persoon afhankelijk is gesteld. De vraag rijst, waarom in het hierbedoelde geval verlies van het Indonesisch staatsburgerschap niet van rechtswege geschiedt. Is dit gelegen in het feit, dat de Indonesische overheid een vinger in de pap wenst te hebben, niet alleen met betrekking tot het verkrijgen van het Indonesisch staatsburgerschap doch ook met betrekking tot het verloren gaan daarvan? Of speelt hier een rol, dat het land waarvan betrokkene de nationaliteit verkrijgt de voorwaarde stelt dat het Indonesisch staatsburgerschap van de persoon in kwestie daadwerkelijk verloren is gegaan, hetgeen door een bewijs dient te worden gestaafd? I $\mathrm{k}$ ben van mening, dat beide overwegingen hier een rol spelen.

\subsection{Het verrichten van bepaalde handelingen}

Krachtens het in artikel 17 sub f. tot en met sub j. bepaalde, kan in het geval Indonesische staatsburgers door het verrichten van bepaalde handelingen blijk geven hun staatsburgerschap niet of minder op prijs stellen, dit tot verlies van het staatsburgerschap leiden.

Als zodanig zijn in artikel 17 sub $\mathrm{f}$. en g. van de Wet genoemd, het zonder toestemming van de Minister van Justitie, in vreemde krijgs- of staatsdienst of in dienst van een internationale organisatie - waarvan de Republiek Indonesië geen lid is - treden. Wat betreft het treden in vreemde krijgsdienst, kan worden opgemerkt dat het uitoefenen van militaire dienstplicht in principe aan de eigen staatsburgers is voorbehouden. Het kan derhalve op zijn plaats worden geacht, dat het treden in vreemde krijgsdienst tot verlies van het Indonesisch staatsburgerschap leidt, tenzij vooraf vergunning daartoe van de Minister van Justitie is verkregen. Wat betreft de door een persoon in vreemde staatsdienst uitgeoefende functie, dient het cen functie te betreffen, die naar de regeling van de Republiek Indonesië slechts door een staatsburger kan worden uitgeoefend, wil dil tot verlies van het Indonesisch staatsburgerschap leiden. Uit het hier gemaakte voorbehoud kan worden afgeleid, dat het in vreemde staatsdienst treden niet in alle gevallen tot het verloren gaan van het Indonesisch staatsburgerschap leidt. In dit verband dient erop te worden gewezen dat het feit, of een functie al dan niet door een staatsburger kan worden uitgeoefend, aan de hand van de in Indonesië geldende bepalingen dient te worden bepaald. Het kan in de praktijk wellicht voorkomen, dat verschil van mening optreedt met betrekking tot het feit, of een bepaalde functie uitsluitend voor staatsburgers is gereserveerd c.q. buitenlanders daarvan zijn uitgesloten. Is dit het geval, dat is hetgeen de regeling van Indonesië ter zake bepaait, doorslaggevend. ${ }^{873}$

873. Van de functies die volgens de in Indonesië vigerende bepalingen slechts door Indonesische staatsburgers kunnen worden uitgeoefend, kan ter illustratie worden genoemd, het zijn van Minister, lid van de Volksvertegenwoordiging en rechter. 
Het treden in dienst van een intemationale organisatie, waarvan Indonesië geen lid is, leidt eerst tot verlies van het Indonesisch staatsburgerschap, indien voor het uitoefenen van een daarin te vervullen functie, het afleggen van een eed of het uitspreken van een belofte van trouw noodzakelijk is. Aangezien het afleggen c.q. uitspreken van een eed/belofte van trouw aan een vreemde mogendheid "an sich" in de Wet - artikel 17 sub h. - als grond is genoemd, die tot verlies van het Indonesisch staatsburgerschap leidt, kan hieruit worden geconcludeerd dat deze handeling de desbetreffende persoon zwaar wordt aangerekend. De in het onderhavige artikel 17 sub h. opgenomen bepaling, treedt met terugwerkende kracht tot 27 december 1949 in werking. De hierbedoelde functies worden van zo groot belang geacht, dat deze eerst door Indonesische staatsburgers kunnen worden uitgeofend, indien daartoe toestemming van de Indonesische overheid is verkregen,

Gezien het in artikel VII van de Overgangsbepalingen van de Wet bepaalde, kan het voorkomen dat personen zich reeds in vreemde krijgsdienst, in vreemde staatsdienst of in dienst van een internationale organisatie zoals bedoeld in artikel 17 sub $\mathrm{f}$. en $\mathrm{g}$. bevinden, vóór de inwerkingtreding van de Wet no. 62 van 1958, te weten 1 augustus 1958. Genoemd artikel VII bood aan deze personen de mogelijkheid, om alsnog een vergunning var de Minister van Justitie aan te vragen binnen de termijn van een jaar gerekend vanaf genoemd tijdstip. Dit heeft tot doel, het verloren gaan van het Indonesisch staatsburgerschap te voorkomen.

Het deelnemen aan de verkiezing voor een aangelegenheid van staatsrechtelijke aard ten behoeve van een vreemd land zonder daartoe verplicht te zijn ${ }^{874}$, levert - krachtens artikel 17 sub i. - eveneens grond tot verlies van het Indonesisch staatsburgerschap op. De nadruk dient te worden gelegd op het criterium "zonder daartoe verplicht te zijn", wil de hierbedoelde grond tot het verloren gaan van het staatsburgerschap leiden. Theoretisch zou derhalve kunnen worden gesteld, dat indien het deelnemen aan een verkiezing van boven af wordt opgelegd, dit niet tot verlies van het Indonesisch staatsburgerschap zou leiden. ${ }^{875}$ De hierbedoelde aangelegenheid kon betrekking

874. Het is wellicht interessant in dit verband melding te maken van recente tendenzen in West-Europese landen waar vreemdelingen in West-Europese landen beperkt kiesrecht wordt verleend, waarvan deze vreemdelingen niet zonder meer gebruik moeten maken zonder zich eventuele nationaliteitsrechtelijke gevolgen bewust te zijn. Het lijkt mij van nut in dit verband te wijzen op de mening van Breukelaar, die wat betreft verlening van kiesrecht aan vreemdelingen, gezien de uitcefening van overheidsverantwoordelijkbeid in bet algemeen toch wel een zo grote mate van geworteldheid in de Nederlandse samenleving vraagt, dat de eis van het Nederlanderschap mag worden gesteld. Doet volgens deze auteur op lokaal niveau of voor lagere of adviserende functies bij het centraal bestuur het nationaliteitsvereiste zich niet of minder gelden, anders ligt de zaak bij een ambt als dat van burgemeester dat aan Nederlanders dient te worden voorbehouden, aangezien daaraan tevens de functie van hoofd van de plaatselijke politie, waaronder de vreemdelingendienst, is verbonden. Zie Breukelaar, Onderscheid naar nationaliteit, p. 343.

875. Hecker wijst in dit verband op Indonesische staatsburgers met de status van bipatride en zegt hieromtrent dat "ein Indonesier, der eine fremde StA (Staatsangehōrigkeit) besitzt und der danach Wahlzwang unterliegt, verliert also durch Wahlbeteiligung nicht die indones. StA. Wahlbeteiligung kann aktiv und passiv sein". Zie Hecker, Das Staatsangehōrigkeitsrecht, p.62. 
hebben op personen die voorheen een dubbel staatsburgerschap bezaten, met name die naast het Indonesische staatsburgerschap, dat van de Chinese Volksrepubliek bezaten. Ter toelichting kan naar voren worden gebracht dat in het verleden volgens de toenmalige Chinese wetgeving, bijvoorbeeld van 1912, voor Chinezen in het buitenland gevestigd, afzonderlijke zetels in de Volksvertegenwoordiging werden gereserveerd; in deze situatie is inmiddels wijziging opgetreden. ${ }^{876}$

Het bezitten van een geldig, op naam gesteld buitenlands paspoort dan wel daarmede gelijk te stellen document, levert verlies van het Indonesisch staatsburgerschap op, krachtens het in artikel 17 sub $\mathrm{j}$. van de Wet bepaalde. In herinnering kan worden gebracht, dat in de voorheen geldende Militaire Verordeningen een soortgelijke bepaling was opgenomen, in 1960 echter ingetrokken ${ }^{87}$ Adriaanse en van der Weg zijn van mening, dat gelet op het feit dat de Wet no. 62 van 1958 op 1 augustus 1958 van kracht is geworden, de onderhavige bepaling valt toe te passen van 4 juni 1957 af, te weten de datum van vaststelling van de onderhavige Militaire Verordening. De thans krachtens de Wet no. 62 van het jaar 1958 vigerende bepaling gaat niettemin beduidend verder, aangezien het hier om verlies van het Indonesisch staatsburgerschap gaat, terwijl in de desbetreffende Militaire verordening gesproken werd van "het niet meer als Indonesisch staatsburger beschouwd worden."

Volgens Adriaanse en van der Weg, heeft de hierbedoelde verliesbepaling zowel betrekking op personen die bipatride zijn en gebruik maken van een paspoort van een andere Staat, als op personen die uitsluitend het Indonesisch staatsburgerschap bezitten en in het bezit zijn van een, door een andere mogendheid afgegeven reispapier, zoals een vreemdelingenpaspoort of een "laissez-passer". ${ }^{878}$ Wat betreft laatstgenoemde twee documenten dient het accent te worden gelegd op het "door een andere mogendheid afgegeven reispapier". Ik vraag mij echter af, of verlies van het Indonesisch staatsburgerschap ook plaatsvindt in het geval betrokkene over een laissez-passer beschikt. Ook van officiële Nederlandse zijde is ter zake opgemerkt, dat niet geheel duidelijk is wat de Indonesische wetgever onder de term "bezitten" verstaat, met name of daaronder ook is begrepen het ter beschikking hebben van een "laissez-passer" voor een korte reis. Ten aanzien van de hier bedoelde personen zijn teveel onzekere factoren aanwezig om te kunnen stellen, enerzijds dat zij als staatloos moeten worden aangemerkt, anderzijds dat zij door de Indonesische autoriteiten nog als Indonesiërs worden beschouwd. Zij waren - voor zover zij niet wegens vijfjarig verblijf buiten Indonesiē ex artikel 17 sub $k$ dan wel op grond van het gereisd hebben op een "provisional aliens certificate" als staatloos zijn te beschouwen - aan te merken als zijnde van onbekende nationaliteit, tenzij mocht blijken dat zij een andere nationaliteit bezitten. Ook de echtgenoten en de ongehuwde c.q. nooit gehuwd geweest zijnde kinderen beneden de leeftijd van 18 jaar moeten eveneens geacht worden van onbekende nationaliteit te zijn,

876. Gautama, Tafsiran, p. 213 ..

877. Zie voor deze aangelegenheid \$ 6.2 van Hoofdstuk 3 .

878. Adriaanse en van der Weg, Nationaliteitswetgeving, Indonesië, p.lb-19. 
tenzij zij een andere, bijvoorbeeld de Nederlandse nationaliteit blijken te bezitten. ${ }^{879}$ Een vreemdelingenpaspoort wordt in de regel verstrekt aan personen, die geen nationaliteit bezitten. Ook het aan Molukkers met de status van "alsof-Neder-lander" verstrekte faciliteitenpaspoort kan als een soort vreemdelingenpaspoort worden aangemerkt. ${ }^{880}$

Ook vrouwen met de staat van bipatride, die gebruik maken van een paspoort dat op hun andere nationaliteit betrekking heeft, verliezen hun Indonesisch staatsburgerschap. Deze bepaling kan als een "stok achter de deur" worden gezien voor als hierbedoelde vrouwen om hen te verplichten een keuze te maken tussen hun Indonesisch staatsburgerschap en hun andere, buitenlandse nationaliteit en zo een einde te maken aan hun status van bipatride! ${ }^{881}$ De hierbedoelde verliesgrond geldt uiteraard niet alleen voor vrouwen met de status van bipatride doch voor alle bipatriden, evenals het geval is met de in $\S 2.1$ genoemde bepaling, waarvan het optreden van bipatridie het gevolg kan zijn.

Hierop aansluitend moge de status van Indonesiërs, die na 27 december 1949 op een "provisional aliens certificate" of ander reisdocument - waarin is vermeld dat zij geen onderdaan van de Republiek Indonesië zijn - naar Nederland zijn gekomen, onder de aandacht worden gebracht. Van Nederlandse zijde is opgemerkt ${ }^{882}$, dat de Indonesische autoriteiten het verlies van de Indonesische nationaliteit voor deze personen baseren op artikel 17 sub a. jo artikel II van de Slotbepalingen van de Wet no. 62 van 1958. ${ }^{883}$ Van Indonesische zijde gezien, betekent dit dat de hierbedoelde personen zich door hun vertrek naar Nederland onder bescherming van de Nederlandse staat hebben gesteld. Dit vloeit voort uit de - Indonesische - opvatting, dat degene die zich onder bescherming van een vreemde Staat stelt, bij verlies van de Indonesische nationaliteit niet staatloos wordt. Naar van Nederlandse zijde aangenomen, kunnen bedoelde Indonesiërs echter worden geacht staatloos te zijn geworden met ingang van de dagtekening van het "provisional aliens certificate". Aanknopend bij het in artikel II van de Slotbepalingen van de Wet no. 62 van 1958, lijkt het niet geheel uitgesloten, dat de echtgenote en ongehuwde kinderen beneden de leeftijd van 18 jaar, die op het "provisional aliens certificate" (of ander reisdocument) van de man respectievelijk vader zijn bijgeschreven, wegens hun komst naar Nederland een vorm van bescherming van een andere Staat verkrijgen. Dit impliceert - naar Indonesische begrippen - de verkrijging van een andere nationaliteit; zij zullen de Indonesische nationaliteit hebben verloren, hetzij in samenhang met de man c.q. vader krachtens respectievelijk artikel

879. Zie hiervoor de Circulaire van de Minister van Binnenlandse Zaken van 23 juli 1968, afdeling BB no. B68/1890, aan de gemeentebesturen gericht.

880. Zie hiervoor $\$ 9.1 .1$ van Hoofdstuk 5.

881. Hier is ervan uitgegaan, dat Indonesische staatsburgers van Chinese origine met de staat van bipatride, heden ten dage praktisch niet meer voorkomen.

882. Zie ook hiervoor de Circulaire van de Minister van Binnenlandse Zaken van 23 juli 1968, no. B68/1890.

883. Artikel 17 sub a. is hierboven reeds aan de orde gekomen. Wat betreft artikel II van de Slothepalingen van de Wet, kan worden verwezen naar \$1.3.2 van Hoofdstuk 2. Op grond van laatstgenoemd artikel is in het begrip "staatsburgerschap" iedere soort bescherming door een Staat te verlenen, begrepen. 
9 lid 2 en artikel 15 lid 1 van de Wet ${ }^{884}$, hetzij zelfstandig op grond van artikel 17 sub a., in $\& 2.1$ aan de orde gekomen. Van Nederlandse zijde wordt niettemin de opvatting gehuldigd, dat zekerheid omtrent de vraag of betrokkenen de Indonesische nationaliteit inderdaad op een van bovengenoemde gronden verloren hebben en de jure staatloos zijn geworden, niet bestaat. Om die reden worden deze personen - voor zover zij niet door naturalisatie Nederlander zijn geworden of een andere nationaliteit bezitten - bij inschrijving in het bevolkingsregister aangemerkt als vreemdelingen van onbekende nationaliteit. ${ }^{885} \mathrm{Ik}$ heb op deze aangelegenheid gewezen, vanwege de aan artikel II van de Slotbepalingen gegeven uitleg, die zou kunnen leiden tot het verloren gaan van het Indonesisch staatsburgerschap. Wordt hiervan uitgegaan, dan nog dient te worden gewezen op het in artikel 9 lid 2 en artikel 15 lid 1 gemaakte voorbehoud, dat met het verlies van het Indonesisch staatsburgerschap door de betrokken persoon, zijn vrouw c.q. kinderen hierdoor niet staatloos mogen worden.

Met betrekking tot de hierboven genoemde handelingen c.q. feiten die op de aflegging van een eed c.q. het uitspreken van een belofte van trouw aan een buitenlandse mogendheid, het deelnemen aan de verkiezing voor een vreemd land en het in het bezit zijn van een buitenlands paspoort betrekking hebben, is in de Memorie van Toelichting van de Wet gesteld, dat de desbetreffende personen vanzelfsprekend staatsburger van het vreemde land in kwestie zijn of zullen worden, gezien de door hen verrichte handelingen, die getuigen van de wens als buitenlander op te treden.

\subsection{Het langdurig in het buitenland gevestigd zijn}

De laatste grond, die krachtens het in artikel 17 sub k. van de Wet bepaalde, verlies van het Indonesisch staatsburgerschap oplevert, betreft het gedurende een periode van vijf jaar ononderbroken in het buitenland gevestigd zijn, zonder daarbij de wens, om Indonesisch staatsburger te willen blijven kenbaar te maken. Bedoelde wens dient te worden kenbaar gemaakt bij de plaatselijk gevestigde Diplomatieke Vertegenwoordiging van de Republiek Indonesië vóor verstrijking van voomoemde periode en dient iedere twee jaar te worden herhaald. De termijnen van vijf en twee jaar, die op deze verplichting betrekking hebben, gaan voor ongehuwde staatsburgers die de leeftijd van 18 jaar nog niet hebben bereikt, bij het bereiken van genoemde leeftijd in.

Ook van Nederlandse zijde is op deze aangelegenheid gewezen door te stellen, dat destijds naar Nederland gekomen personen van Indonesische nationaliteit, die na 1 augustus 1958 vijf jaar onafgebroken woonplaats buiten Indonesië hebben gehad, de Indonesische nationaliteit hebben verloren en derhalve staatloos zijn, tenzij zij verklaren tijdig de kennisgeving tot behoud van die nationaliteit te hebben gedaan. De Indonesische echtgenote en ongehuwde kinderen beneden de leeftijd van 18 jaar van betrokkene zullen in het verlies van de nationaliteit van de man respectievelijk vader hebben

884. Artikel 9 lid 2 is aan de orde gekomen in $\$ 1.1$ van dit Honfdstuk, artikel 15 lid 1 in $\$ 1.2$.

885. Zie hiervoor de Circulaire van de Minister van Binnenlaridse Zaken van 9 januari 1970, Directie BB, afdeling BZ no. B 69/2782, gericht aan de gemeentebesturen. 
gedeeld, tenzij zij daardoor staatloos werden. Indien zij krachtens de restrictie van artikel 9 lid 2 en artikel 15 lid 1 van de Wet de Indonesische nationaliteit hebben behouden, valt te bedenken dat artikel 17 sub $\mathrm{k}$ rechtstreeks op hen van toepassing is, mel dien verstande dat de daarin genoemde termijn van vijf jaar voor de ongehuwde minderjarige kinderen begint te lopen bij het bereiken van de leeftijd van 18 jaar. Voor met Indonesische staatsburgers gehuwde vrouwen van vreemde - bijvoorbeeld Nederlandse - nationaliteit gaat deze termijn in op de dag waarop zij door of tengevolge van het huwelijk de Indonesische nationaliteit hebben verkregen. ${ }^{886}$

De vraag rijst of het verlies van het Indonesisch staatsburgerschap krachtens de in artikel 17 opgenomen gronden, van rechtswege is. Met uitzondering van de in $\$ 2.1$ voor zover betrekking hebbende op een nog in Indonesië verblijvende persoon - en het in $\S 2.5$ behandelde geval, is dit inderdaad het geval. Ik ben het derhalve niet eens met Adriaanse en van der Weg die - globaal - stellen, dat de tot verlies van de Indonesische nationaliteit leidende bepalingen van artikel 17 van rechtswege werken en enige uitspraak of beslissing van de rechter of de administratie niet vereist is. ${ }^{887}$ Ter toelichting van het hiervoor in $\S 2.1$ bedoelde geval, kan in herinnering worden gebracht, dat het verloren gaan van het Indonesisch staatsburgerschap door een in Indonesië verblijvende persoon afhankelijk is gesteld van een door de Minister van Justitie uitgegeven verklaring, die daartoe eerst overgaat indien hij dit nodig acht teneinde de betrokken persoon als buitenlander te kunnen behandelen. Kan genoemde Minister daartoe het initiatief nemen, door betrokkene kan ook een verzoek tot het verloren gaan van het staatsburgerschap worden ingediend, nader door de Minister te onderzoeken. Anders dan het in $\S 2.1$ bedoelde geval, warin betrokkene zich nog in Indonesië bevindt en hij derhalve nog onder de gezagssfeer van de Indonesische overheid valt, is dit niet meer het geval in het in $\S 2.5$ omschreven geval, waarin de betrokken persoon zich in het buitenland bevindt, derhalve buiten de gezagssfeer van de Indonesische overheid.

Van belang is voorts, dat de hierboven behandelde verliesgronden én voor mannen én voor (gehuwde) vrouwen geldt.

\subsection{Verlies van het Indonesisch staatsburgerschap door een gehuwde vrouw}

Ter afsluiting van de hiervoor behandelde verliesgronden zij in herinnering gebracht, dat verlies van het Indonesisch staatsburgerschap door een gehuwde vrouw op basis van één der gronden als in artikel 17 van de Wet omschreven - met uitzondering van de in $\$ 2.3$ en $\$ 2.4$ omschreven verliesgronden - zich mede uitstrekt tot haar echtgenoot. Het betreft hier de in artikel 10 lid 2 der Wet opgenomen bepaling, die inhoudt dat het verloren gaan van genoemd staatsburgerschap door een gehuwde vrouw, van rechtswege mede komt te gelden voor haar echtgenoot, uitgezonderd in het geval laatstgenoemde

886. Zie ook hiervoor de Circulaire van de Minister van Binnenlandse Zaken van 23 juli 1968, no. B68/1890.

887. Adrianse en van der Weg, Nationaliteitswetgeving, Indonesiē, p.Ib-17. 
hierdoor staatloos zou worden. Ik wees reeds op het feit, dat dit artikel niet op duidelijkheid kan buigen. Dit strookt immers niet met de door Wet no. 62 van 1958 gevolgde systematiek, waarbij het in principe de man is, die het staatsburgerschap van beide partijen bepaalt! Ko Swan Sik en Teuku Moh. Rhadie schrijven over deze aangelegenheid, dat "...we come across a most inconsistent provision, prescribing that the (autonomous) loss of Indonesian nationality by the wife of an Indonesian couple leads to the same lost for the husband (provided he does not thereby becomes stateless). This provision, although strictly in accordance with the idea of family unity, stands in stark contrast to the mutual position of husband and wife as reflected in other provisions of the Act. The exact purposes of the legislature on this point are not entirely clear, the only guess being an emphasis on the idea of family unity which nowadays appears exaggerated. It is certainly hardly compatible with the quickly increasing recognition of complete independent status of the sexes in the law of many countries, particularly in the law on nationality. No data was available to the authors as to the application of the provision in practice." ${ }^{8 * 8}$

Wordt teruggegrepen op het hierboven behandelde artikel 17 sub b., dat bepaalt dat verlies van het Indonesisch staatsburgerschap optreedt, indien een persoon de andere nationaliteit die hij naast het Indonesisch staatsburgerschap bezit, niet verwerpt c.q. prijsgeeft terwijl hij daartoe de gelegenheid krijgt, dan kan de van overheidswege gegeven verklaring met betrekking tot het in artikel 10 lid 2 bepaalde in herinnering worden gebracht. Gesteld werd in casu, dat het verloren gaan van het staatsburgerschap door de vrouw, gepaard kan gaan met het verwerven van een andere nationaliteit - die mogelijkerwijze ook geldt voor haar man - of dat man en vrouw reeds een andere nationaliteit, naast hun Indonesisch staatsburgerschap kunnen bezitten. Wordt hierop afgegaan, dan komt het verlies van het Indonesisch staatsburgerschap ex artikel 17 sub b. betrokkenen alleen maar goed uit. Dit neemt echter niet weg, dat artikel 10 lid 2 niet past in het door de Wet gevolgde systeem en beter weggelaten had kunnen worden.

Hierbij komt nog, dat indien wordt afgegaan op het in artikel 9 van de Wet bepaalde in $\S 7$ van Hoofdstuk 5 aan de orde gekomen - waarin het "vrouw volgt man" beginsel tot uiting komt, het verloren gaan van het Indonesisch staatsburgerschap door de man van rechtswege mede geldt voor zijn vrouw, tenzij laatstgenoemde daardoor staatloos wordt. Zou de wetgever de eenheid van nationaliteit van beide partijen bij het opnemen van artikel 10 lid 2 voor ogen hebben gehad, dan ligt het meer voor de hand dit te bereiken door toepassing van artikel 9 der Wet en was vanuit dit oogpunt gezien, opneming van artikel 10 lid 2 in feite overbodig!

\section{\$ 3 Mogelijkheid tot intrekking van het Indonesisch staatsburgerschap}

In artikel 19 van de Wet no. 62 van 1958 is uitdrukkelijk gesteld, dat het Indonesisch staatsburgerschap dat werd verleend of verkregen - door naturalisatie dan wel middels een daartoe strekkende verklaring - op grond van gegevens, die niet op waarheid

888. Ko Swan Sik en Teuku Moh. Rhadie, Nationality, p. 146. 
berusten, kan worden ingetrokken door de autoriteit, die het heeft verleend of de instantie die de desbetreffende gegevens heeft ontvangen. Bedoeld zijn hier de Minister van Justitie, de "Pengadilan Negeri" en de Diplomatieke Vertegenwoordiging van de Republiek Indonesië.

Het behoeft geen nadere toelichting dat ten aanzien van personen, die met de bedoeling het Indonesisch staatsburgerschap te verkrijgen valse gegevens hebben verstrekt, maatregelen worden getroffen. Naast het intrekken van hun staatsburgerschap, kunnen zij bovendien strafrechtelijk worden vervolgd.

Ik maak van deze gelegenheid gebruik erop te wijzen, dat de Wet no. 62 van 1958 in de toepassing daarvan niet zover gaat, dat tot ontneming van het Indonesisch staatsburgerschap wordt overgegaan als strafmaatregel, als sanctie. Dit is wél het geval krachtens de nationaliteitswetten van enkele andere landen als bijvoorbeeld Marokko, waarin vervallenverklaring van de Marokkaanse nationaliteit - als strafmaatregel - kan plaatsvinden ten aanzien van personen, die deze nationaliteit niet door geboorte - door afstamming of door geboorte op het grondgebied - bezitten en die zich op enigerlei wijze van bezit van genoemde nationaliteit onwaardig hebben betoond door het verrichten van handelingen zoals in artikel 22 van de Wet gestipuleerd. ${ }^{889}$

Ook een land als Egypte kent de mogelijkheid tot ontneming van de nationaliteit aan een ieder die de Egyptische nationaliteit hebben verkregen door bedrog of op grond van leugenachtige verklaringen - hier kan een vergelijking worden gemaakt met Indonesië maar ook aan personen, die deze nationaliteit hebben verkregen door naturalisatie of door huwelijk, in écn van de in de Egyptische nationaliteitswet gestipuleerde gevallen. Als zodanig kunnen worden genoemd, veroordeling wegens misdaad of tot een vrijheidsstraf wegens een onterende overtreding, overtredingen die afbreuk doen aan de buitenlandse of binnenlandse veiligheid van de Staat, $60 \mathrm{k}$ in het geval van onderbreking van het verblijf in Egypte gedurende twee achtereenvolgende jaren, zonder een door de Minister van Binnenlandse Zaken geaccepteerde verontschuldiging. Hiemaast kent de Egyptische nationaliteitswet de mogelijkheid van vervallenverklaring van de nationaliteit van iedere Egyptenaar, die zich schuldig maakt aan verkrijging van een vreemde nationaliteit, zonder daartoe gemachtigd te zijn bij besluit van de Minister van Binnenlandse Zaken, hij buitenlands verblijft en veroordeeld is wegens én der misdaden die de buitenlandse veiligheid van de Staat raken. Verkrijging van een vreemde nationaliteit zonder daartoe gemachtigd te zijn levert derhalve volgens het Egyptische nationaliteitsrecht vervallenverklaring van de nationaliteit op; hier is sprake van overheidsbemoeienis ten aarzien van de verkrijging van een vreemde nationaliteit! ${ }^{890}$ In de Wet no. 62 van 1958 is het - vrijwillig - verkrijgen van een andere nationaliteit als grond van het verloren gaan van het Indonesisch staatsburgerschap genoemd, hetgeen niet altijd automatisch plaatsvindt, zoals in $\$ 2,1$, reeds ter sprake gekomen.

889. Zie de Marokkaanse nationaliteitswet van 1 oktober 1958. Adriaansen en van der Weg, Nationaliteitswetgeving.

890. Zie voor deze aangelegenheid de artikelen 15 en 16 van de Wet no. 26 van 1975 op de Egyptische nationaliteit. Adriaansen en van der Weg, Nationaliteitswetgeving. 
Ook de Thaise nationaliteitswet van 1965 kent de mogelijkheid tot herroeping van de Thaise nationaliteit ten aanzien van een persoon, die deze nationaliteit door naturalisatie heeft verkregen door verzwijging van feiten of vervalsing van gegevens - vergelijk Indonesië - maar ook onder meer in het geval de persoon in kwestie handelt in strijd met de veiligheid of de belangen van de staat of de goede naam van het volk in discrediet brengt, hij in strijd handelt met de openbare orde of de goede zeden dan wel de nationaliteit bezit van een land waarmede Thailand in oorlog is. ${ }^{891}$

Ik heb de hiervoor genoemde landen in de eerste plaats aangehaald om aan te tonen, dat de Indonesische nationaliteitswet veel minder streng is, aangezien in deze Wet geen onderscheid wordt gemaakt tussen autochtone en niet-autochtone Indonesische staatsburgers, die immers op grond van het Presidentiële Besluit no.240 van 1967 in rechten en plichten overeenkomen. In de tweede plaats, omdat de Wet no. 62 van 1958 wel de gronden aangeeft tot het verloren gaan van het Indonesisch staatsburgerschap, doch geen bepalingen bevat inzake ontneming of vervallenverklaring van het staatsburgerschap als sanctie en om die reden veel minder streng kan worden geacht te zijn dan de hiervoor aangehaalde nationaliteitswetten van andere ontwikkelingslanden. ${ }^{892}$

De Minister van Justitie maakt in het Staatsblad de namen bekend van de personen, die het Indonesisch staatsburgerschap hebben verkregen of verloren; deze bepaling is van belang, vanuit het oogpunt der rechtszekerheid gezien.

\section{$\$ 4$ De praktijk}

Het lijkt mij nuttig om de hierboven behandelde nationaliteitsrechtelijke aangelegenheden aan de hand van enkele rechtelijke uitspraken te illustreren.

In eerste instantie kan het arrest van de "Mahkamah Agung" (MA) no. $156 \mathrm{~K} / \mathrm{Sip} / 1967$ van 1 mei 1968 worden aangehaald in de zaak van Mw.Jadwiga Alexander ZemzarMaun. Het betreft hier een beroep in cassatie ingesteld, ten aanzien van een uitspraak van de "Pengadilan Negeri" te Jakarta betreffende de status van een kind uit een Russische moeder en een Indonesisch staatsburger op 27 september 1964 in Moskou geboren. In afwachting van een uitspraak betreffende een eis tot echtscheiding door de vrouw ingediend, wonen beide echtgenoten niet meer samen. Met betrekking tot het standpunt door de moeder van het kind gehuldigd, als zou het kind Russisch staatsburger zijn, aangezien het is geregistreerd bij de daartoe in aanmerking komende Russische overheidsinstantie en in Moskou is geboren zoals uit haar paspoort blijkt, stelde MA zich op het standpunt - waarbij de uitspraak van de "Pengadilan Negeri" werd bekrachtigd - dat ieder kind uit een wettig huwelijk geboren, volgens het Indonesische recht de staat van zijn vader volgt. ${ }^{893}$

891. Zie artikel 19 van de Thaise nationaliteitswet van 21 juli 1965. Adriaansen en van der Weg, Nationaliteitswetgeving.

892. Het maken van een rechtsvergelijking is niet de opzet van dit boek, dat uitsluitend aan het Indonesisch nationaliteitsrecht is gewijd.

893. Zie Yurisprudensi Indonesia Mahkamah Agung R.I., uitgave I-II-III-JV/69, p.687. 
Het tweede geval betreft het arrest van de MA van 8 januari 1972 no. $556 \mathrm{~K} / \mathrm{Sip} / 1971$ betreffende de zaak van Sumarni tegen Tjong Foen Sen. Partijen zijn gehuwd volgens het Chinese gewoonterecht, gevolgd door een wettige huwelijksvoltrekking voor de Burgerlijke Stand. Het geschil bewoog zich rond de schenking van nader gespecificeerde goederen door de man Tjong Foen Sen aan zijn echtgenote Sumami, op verzoek van laatstgenoemde omdat uit het huwelijk geen kinderen geboren zijn en de man reeds op leettijd is. Gezien daarna opgetreden misdragingen van de vrouw, werd door de man geêist de schenking ongedaan te maken c.q. de goederen aan hem terug te geven. Van belang in deze zaak is, dat door de MA het noodzakelijk werd gevonden om eerst vast te stellen welk recht ter zake dient te worden toegepast, gelet op de nationaliteit van beide partijen. De MA stelde zich op het standpunt, dat op de vrouw het Westers recht van toepassing is, niettegenstaande zij de status van Indonesisch staatsburger bezit. Aan deze uitspraak lag de overweging ten grondslag, dat zij met een buitenlander met de nationaliteit van de Chinese Volksrepubliek is gehuwd, hetgeen met zich brengt dat het voor de echtgenoot geldende recht, het Westers recht is en gesteld kan worden dat de vrouw in de rechtssfeer van haar echtgenoot leeft. ${ }^{894}$

Het arrest van de MA no. $990 \mathrm{~K} / \mathrm{Sip} / 1974$ van 6 mei 1976, heeft betrekking op de zaak van Syechun binti S. Umar Alatas versus Muznah binti S. Umar Alatas. Het betreft hier het voor een Indonesisch staatsburger van Arabische afkomst geldende recht, waarbij de overwegingen van de "Pengadilan Negeri" door de "Pengadilan Tinggi" en de "Mahkamah Agung" werden bekrachtigd. Hierbij werd het standpunt ingenomen, dat in het geval van boedelscheiding van de nalatenschap van S. Umar Alatas, in overeenstemming met de jurisprudentie van de MA betreffende personen van Arabische afkomst, het Islamitisch recht van toepassing is, dit in overeenstemming met de wil van de erflater, zoals uit de desbetreffende notariele akte is op te maken. ${ }^{* 95}$

Niettegenstaande het feit, dat de "Mahkamah Agung" in het eerste arrest de uitspraak heeft gedaan, dat ieder kind uit een wettig huwelijk geboren, volgens het Indonesische recht de staat van zijn vader volgt, lijkt deze zaak mij een typisch voorbeeld van het worden van bipatride door het kind in kwestie. ${ }^{806}$ Alhoewel de laatste twee arresten niet rechtstreeks het nationaliteitsrecht raken, wordt door deze arresten een beeld gegeven van de invloed van het koloniale recht op het huidige recht in Indonesië. Via het instituut van de toepasselijkverklaring - in $\$ 2.1$ van Hoofdstuk 3 aan de orde gekomen - is op de man, een buitenlander met het staatsburgerschap van de Chinese Volksrepubliek, niet zijn eigen recht doch het Westers recht (IBW) van toepassing. Op zijn vrouw, die Indonesisch staatsburger is - het betreft hier een gemengd huwelijk - is niet het Adatrecht van toepassing, maar het Westers recht, omdat wordt aangenomen dat zij zich in de rechtssfeer van de man beweegt. Het huwelijk met een buitenlander speelt hier een rol. Het zijn van Indonesisch staatsburger betekent nog niet dat op

894. Yurisprudensi Indonesia Mahkamah Agung R. I., uitgave I-II-III-IV/72, p.494.

895. Zie Rangkuman Yurisprudensi Mahkamah Agung Indonesia, II, Hukum Perdata dan Acara Perdata, Proyek Yurisprudensi Mahkamah Agung, p.2.

896. Zie hiervoor hetgeen in $\$ 2$ van Hoofdstuk 5 met betrekking tot de mogelijkheid van het optreden van bipatridie is opgemerkt. 
staatsburgers hetzelfde recht van toepassing is. $\mathrm{Zo}$ is in het laatste hiervoor aangehaalde geval, op de Indonesische staatsburger van Arabische afkomst, het Islamitisch recht van toepassing. Op Indonesische staatsburgers van vreemde origine kan verschillend recht van toepassing zijn, afhankelijk van hun oorspronkelijke status, zoals door laatstgenoemd geval aangetoond. Van deze twee arresten is melding gemaakt ter illustratie van het in Indonesië vooralsnog heersende rechtspluralisme, een erfenis van het koloniale verleden.

Andere rechterlijke uitspraken staan mij helaas niet ter beschikking. 


\section{$\$ 1$ Inleiding}

Gezien de in Indonesië heersende omstandigheden, is het vaak noodzakelijk een bewijsstuk inzake het bezitten van het Indonesisch staatsburgerschap te kunnen overleggen, vanwege de voor staatsburgers geldende rechten en verplichtingen. Hiernaast is het in voorkomende gevallen zaak aan te kunnen tonen, dat men niet de status van buitenlander bezit, gezien de bepalingen, die in het bijzonder voor deze categorie van personen gelden.

In dit kader is de bepaling, die in artikel IV van de Slotbepalingen van de Wet no. 62 van 1958 is opgenomen - waarin de wijze van verkrijging van een bewijsstuk op het bezit van het Indonesisch staatsburgerschap is aangegeven - van wezenlijk belang te achten. Vooraf moge worden opgemerkt, dat in het geval het Indonesisch staatsburgerschap wordt verleend als gevolg van naturalisatie - geprivilegieerde, vereenvoudigde of gewone - dan wel door optie, de persoon in kwestie over een bewijsstuk beschikt, dat eventueel ook voor zijn echtgenote en nog niet volwassen kinderen geldt.

In andere dan de hierboven aangegeven gevallen, met name indien het Indonesisch staatsburgerschap van rechtswege is verkregen, beschikt de desbetreffende persoon vaak niet over een bewijsstuk, dat aantoont dat hij het Indonesisch staatsburgerschap bezit of heeft verkregen c.q. deelt in het bezit of in de verkrijging daarvan. De hierbedoelde aangelegenheid is voornamelijk van belang voor Indonesische staatsburgers van buitenlandse afkomst. ${ }^{897}$

Welke documenten kunnen als bewijs van het bezit van het Indonesisch staatsburgerschap worden aangemerkt? Gezien de verschillende manieren waarop dit staatsburgerschap kan worden verkregen, waarbij vaak de voorheen, vóór de inwerkingtreding van de Wet no. 62 van het jaar 1958 heersende situatie mede in beschouwing dient te worden genomen, kunnen onder meer de navolgende documenten als bewijs van het bezit van het Indonesisch staatsburgerschap dienst doen:

de verklaring waarbij voor het Indonesisch staatsburgerschap werd geopteerd door (afstammelingen) van Nederlanders ${ }^{898}$ of door personen die vóór 27 december 1949 de status van Nederlander hadden door gelijkstelling voor de datum 1 juli 1893 of die tot Nederlander waren genaturaliseerd; ${ }^{899}$

897. Het bezit van een "kartu tanda penduduk" (persoonsbewijs) een soort identiteitsbewijs dat door de Regionale overheid wordt uitgegeven, kan geen dienst doen als een bewijs dat op het bezit van het Indonesisch staatsburgerschap betrekking heeft.

898. In het kader van de toepassing van de Toescheidingsovereenkomst, behancleld in $\$ 5.3 .2$ van Hoofdstuk 3 .

899. Zie voor de gelijkstelling $\$ 2.2$ van Hoofdstuk 3. Van naturalisatie tot Nederlander is melding gemaakt in $\S 1.4$ en $\$ 7.2$ van dit Hoofdstuk. 
- de wet waarbij tot naturalisatie van een bepaalde persoon werd overgegaan krachtens de Wet no. 3 van het jaar 1946, zoals naderhand gewijzigd en aangevuld; ${ }^{900}$

- documenten inzake de vaststelling van het Indonesisch staatsburgerschap door de "Pengadilan Negeri" krachtens artikel I van de Verordening van het Militaire Gezag no. Prt/PM/09/1957 van 4 juni 1957, naderhand vervangen door de Regeling van het Centraal Oorlogsgezag van 16 april 1958 no. Prt/Peperpu/014/ $1958 ;$; 91

- wettige huwelijksakten van vrouwen, vór 27 december 1949 gehuwd met personen die krachtens de Toescheidingsovereenkomst het Indonesisch staatsburgerschap bezitten of hebben verkregen ${ }^{902}$ en wettige geboorte-akten van kinderen uit zodanige huwelijken geboren dan wel in het geval van buiten huwelijk geboren kinderen, akten van erkenning door de vader; ${ }^{903}$

- $\quad$ besluiten van vaststelling van de Minister van Justitie, die betrekking hebben op het als Indonesisch staatsburger behandeld worden van buitenlandse vrouwen, ná 27 december met Indonesische staatsburgers gehuwd. ${ }^{904}$

Met betrekking tot de hierbedoelde aangelegenheid dient ook rekening te worden gehouden met de tussen Indonesië en de Chinese Volksrepubliek gesloten Overeenkomst inzake de afwikkeling van het probleem van de bipatridie, alhoewel naderhand eenzijdig door Indonesië beëindigd. Personen, die zich voor het Indonesisch staatsburgerschap hadden uitgesproken, werden in het bezit gesteld van de formulieren I tot en met VI die betrekking hebben op de gezinssamenstelling van betrokkenen - en de formulieren $C$. en $D$, die respectievelijk betrekking hebben op personen die werden beschouwd als enkel het Indonesisch staatsburgerschap te bezitten en zodanige personen die deel hadden genomen aan de algemene verkiezingen van 1955 ten behoeve van de Volksvertegenwoordiging en de lokale vertegenwoordigingsraden. ${ }^{\text {vis }}$

Sedert het voorhanden zijn van de Wet no. 62 van 1958 dient voorts als bewijsstuk van het bezit van het Indonesisch staatsburgerschap te worden aangemerkt:

- $\quad$ het besluit van de Minister van Justie c.q. het presidentiële besluit waarbij een verzoek tot naturalisatie ex artikel 3, 4 en 5 werd ingewilligd; 906

- het presidentiële besluit, waarbij de voordracht van een persoon teneinde te worden genaturaliseerd tot Indonesisch staatsburger ex artikel 6 werd goedgekeurd; ${ }^{907}$

900. Zie hiervoor $\$ 5.2$ van Hoofdstuk 3, waarin een specificatie is opgenomen van personen die bij wet zijn genaturaliseerd, krachtens de Wet no. 3 van 1946 van de zogenaamde Yogya-regering.

901. Deze Regelingen van het Militaire Gezag c.q. Oorlogsgezag zijn aan de orde gekomen in $\$ 6.1$ van Hoofdstuk 3.

902. Krachtens artikel 10 van de Toescheidingsovereenkomst, behandeld in $\$ 5.3 .2$ van Hoofdstuk 3 .

903. Op grond van de artikelen 8 en 9 van de Toescheidingsovereenkomst, behandeld in $\$ 5.3 .2$ van Hoofdstuk 3.

904. Op deze aangelegenheid is in $\$ 6.2$ van Hoofdstuk 3 ingegaan.

905. De hierbedoelde personen zijn aan de orde gekomen in $\$ 3.3$ van Hoofdstuk 4.

906. Zie hiervoor $\$ 5$ en $\$ 6$ van Hoofdstuk 5.

907. Deze uitzonderingsnaturalisatie is behandeld in $\$ 6.13$ van Hoofdstuk 5 . 
het besluit van de "Pengadilan Negeri" waarbij de adoptie van een kind als bedoeld in artikel 2 van de Wet no. 62 van 1958 wettig werd verklaard; 908

- optieverklaringen als bedoeld in artikel 7 lid 1 van de Wet op het Indonesische staatsburgerschap jo. artikel II van de Overgangsbepalingen der Wet ${ }^{909}$, artikel 11 van deze Wet ${ }^{910}$, artikel 16 van de onderhavige Wet ${ }^{91 \%}$ en artikel III van de Overgangsbepalingen van de Wet; ${ }^{912}$

het besluit van respectievelijk de Minister van Justitie en de Onderminister van Defensie inzake de inwilliging van een verzoek tot - vereenvoudigde - naturalisatie krachtens respectievelijk artikel 18 en artikel VI van de Overgangsbepalingen jo. het Besluit van de Onderminister van Defensie no. MP/E/0179/59 van 12 september 1959 , waarbij de voorwaarden waren vastgesteld waaraan de betrokken personen dienden te voldoen. ${ }^{913}$

Ter vaststelling van het feit, wie op 1 augustus 1958 - de datum van inwerkingtreding van de Wet no. 62 van 1958 - reeds Indonesisch staatsburger waren, dient af te worden gegaan op het bepaalde in artikel 1 sub a. van de Wet, op grond waarvan het staatsburgerschap was verkregen krachtens de Toescheidingsovereenkomst of de Wet no. 3 van $1946 .^{914}$

Bezitten de desbetreffende personen geen bewijsstuk op het bezit van het Indonesisch staatsburgerschap betrekking hebbende, dan ligt de zaak gecompliceerder, aangezien dan een onderzoek dient te worden ingesteld naar alle factoren die het bezit van dit staatsburgerschap zouden hebben kunnen bewerkstelligd, zoals tot welke bevolkingsgroep

908. Zie hiervoor $\$ 4.2$ van Hoofdstuk 5 .

909. Het betreft hier een met een Indonesisch staatsburger gehuwde buitenlandse vrouw die voor het staatsburgerschap opteen, welke gelegenheid ook werd opengesteld voor zodanige vrouwen op 1 augustus 1958 reeds met Indonesische statsburgers gehuwd. Zie hiervoor \$ 7.1.1 van Hoofdstuk 5.

910. Dit artikel heeft betrekking op personen, die door of als gevolg van huwelijk het Indonesisch staatsburgerschap verloren hadden en dit middels aflegging van een optieverklaring hebben herkregen. Toegelicht in $\$ 7.1 .2$ van Hoofdstuk 5 .

911. Dit artikel geeft aan een persoon, die wegens het volgen van de staat van zijn vader of moeder het Indonesisch staatsburgerschap heeft verloren de gelegenheid dit staatsburgerschap middels aflegging van een optieverklaring te berkrijgen. Zie hiervoor $\$ 9$ van Hoofdstuk 5 .

912. Het betreft hier vrouwen die door huwelijk een buitenlandse status hebhen verkregen, die waren zij niet gehuwd Indonesisch statsburger zouden zijn. Aan als hierbedoelde vrouwen, werd na ontbinding van het huwelijk de gelegengegeven door middel van een optieverklaring Indonesisch staatsburger te worden, zoals toegelicht in $\$ 7.1 .2$ van Hoofdstuk 5 .

913. Dit artikel geeft aan personen die door het niet voldoen aan de verplichting een verklaring af te leggen tot behoud van het Indonesische staatsburgerschap in het geval van langdurig verblijf buitenlands dit staatsburgerschap hadden verloren, de gelegenheid dit door aflegging van een optieverklaring terug te krijgen. Ook personen die ingevolge de Wet no. 3 van 1976 waarbij artikel 18 van de Wet no. 62 van 1958 werd aangevuld het Indonesisch staatsburgerschap hadden verloren, te wijten aan omstandigheden "buiten bun schuld" konden dit staatsburgerschap terugkrijgen door vereenvoudigde aturalisatie. Zie hiervoor $\$ 9.1 .1$ van Hoofdstuk 5 . Een soortgelijke mogelijkheid was opengesteld voor personen, die ooit aan de Indonesische vrijheidsstrijd hadden deel genomen, als toegelicht in $\$ 9.1 .2$ van Hoofustuk 5 .

914. Zie mijo toelichting in $\$ 1.1$ van Hoofdstuk 4. 
betrokkene behoort ${ }^{915}$, de geboorte- en/of woonplaats vór 27 december 1949 van betrokkene ${ }^{916}$, of de betrokken persoon, indien hem de gelegenheid was geboden tot verwerping van het Indonesisch staatsburgerschap van deze mogelijkheid inderdaad geen gebruik had gemaakt. ${ }^{917}$ Met betrekking tot de uitvoering van de bepalingen van de Toescheidingsovereenkomst kan onder de aandacht worden gebracht, dat exemplaren van de verklaringen tot het opteren of verwerpen van het Indonesisch staatsburgerschap bij het Departement van Justitie worden bewaard en ter staving van het feit of een persoon nooit dit staatsburgerschap heeft verloren, een verklaring van dit Departement dient te worden opgevraagd. Met betrekking tot de toepassing van de Overeenkomst tussen Indonesië en de Chinese Volksrepubliek betreffende de afwikkeling van de bipatridie, dient niet uitsluitend te worden afgegaan op de formulieren I tot en met VI dan wel de formulieren C of D zoals hierboven reeds aan de orde gekomen. Ook de wettigheid van deze formulieren dient te worden onderzocht teneinde na te gaan of de persoon in kwestie wel gerechtigd was een als hierbedoeld formulier te bezitten. ${ }^{918}$

Was reeds aan de hand van de hiervoor genoemde bewijsstukken het zijn van Indonesisch staatsburger vastgesteld, dan dient te worden nagegaan of de desbetreffende personen achteraf dit staatsburgerschap niet hebben verloren aan de hand van de bepalingen in de Wet no. 62 van 1958 opgenomen, zoals in Hoofdstuk 6 behandeld. Hierbij dient niettemin rekening te worden gehouden met de mogelijkheid, een persoon achteraf toch weer het Indonesisch staatsburgerschap was komen te bezitten, bijvoorbeeld krachtens artikel 11, artikel 16 of artikel 18 van de Wet no. 62 van 1958 jo. de Wet no. 3 van 1976, hiervoor reeds aan de orde gekomen.

Aan deze aangelegenheid zijn derhalve meer facetten te onderscheiden dan op het eerste gezicht lijkt!

\section{$\S 2$ De oude en de nieuwe situatie}

Met betrekking tot het verkrijgen van een bewijsstuk inzake het bezit van het Indonesisch staatsburgerschap, kan onderscheid worden gemaakt tussen de oude en de nieuwe situatie. Onder de oude situatie was het niet $z 0$ eenvoudig om bedoeld bewijsstuk te verkrijgen, vanwege het feit, dat ook toen - net als op basis van de bepalingen van het Militair c.q. Oorlogsgezag, die indertijd golden - betrokkene in het bezit diende te zijn

915. De onderverdeling van de bevolking van Indoneste is aan de orde gekomen in $\S 2$ van Hoofdstuk 3.

916. Dit kon van wezenlijk belang zijn ter vaststelling van het feit, of betrokkene Nederlands onderdaan was geweest, agngezien de Toescheidingsovereenkomst slechts voor - voormalige - Nederlandse onderdanen gold. Zie hiervoor $\$ 3$ en $\$ 5.3 .2$ van Horfdstuk 3 .

917. Het was in dit geval niet voldoende slechts af te gaan op eun verklaring van de "Pengadilan Negeri" van de woonplaats van betrokkene, aangezien de mogelijkheid bestond dat verwerping van het staatsburgerschap voor een andere "Pengadilan Negeri" dan die van de woonplaats van de desbetreffende persoon had platsgevonden.

918. Bujung Datuk Intan Sati, Beberapa hal, Himpunan p.372. 
van een urgentiebewijs van een daartoe competente instantie, zoals toegelicht in $\$ 6$ van Hoofdstuk 3 . $^{919}$

Naderhand werden echter nieuwe bepalingen vastgesteld inzake de wijze van verkrijging van een bewijsstuk, dat het bezit van het Indonesisch staatsburgerschap aantoont. Onder deze nieuwe situatie wordt het bezit van een urgentiebewijs niet langer verplicht gesteld. Betrokkene kan voor genoemd doel zélf stappen ondernemen.

\subsection{De oude situatie}

In het hierboven aangehaalde artikel IV van de Slotbepalingen van de Wet no. 62 van 1958 is bepaald, dat de persoon die dient te bewijzen dat hij Indonesisch staatsburger is en geen bewijsstuk dat daarop betrekking heeft bezit, de "Pengadilan Negeri" van zijn woonplaats volgens de gewone burgerrechtelijke procedure kan verzoeken, vast te stellen of hij al dan niet Indonesisch staatsburger is. In de Memorie van Toelichting van de Wet is echter uitdrukkelijk gesteld, dat de noodzaak tot het bezit van bedoeld bewijsstuk zich eerst voordoet, indien om dit bewijs wordt verzocht, dit om te voorkomen, dat het Gerecht met aanvragen wordt overspoeld.

In de praktijk kwam dit hierop neer, dat een persoon niet op eigen initiatief vanwege een gerezen belang, een aanvraag ter vaststelling van zijn status bij de "Pengadilan Negeri" kon indienen. Evenals dit in het kader van de bepalingen van het Militair c.q. Oorlogsgezag die voorheen op dit vlak golden het geval was, diende belanghebbende over een urgentiebewijs van een officiële instantie te beschikken, die hem vanwege twijfel aan zijn status, verplichtte te bewijzen, dat hij Indonesisch staatsburger is. Het vaststellen van de status van een persoon diende derhalve te zijn verplicht gesteld door een officiële instantie in de uitvoering van haar taak, die slechts in uiterst dringende gevallen tot de afgifte van een urgentiebewijs overging. Dit bracht met zich dat de afgifte van een urgentiebewijs, enkel en alleen in het belang van de betrokken persoon afgegeven, niet was toegestaan c.q. door het Gerecht diende te worden afgewezen. ${ }^{920}$

Voor de vaststelling van de status van een persoon, was een uitspraak van het Gerecht nodig. Bevond betrokkene zich in het buitenland, dan is de "Pengadilan Negeri Jakarta Pusat" (het in Centraal-Jakarta gevestigde Gerecht) bevoegd vast te stellen, of een persoon al dan niet Indonesisch staatsburger is; in dit geval speelde de in het buitenland gevestigde Diplomatieke Vertegenwoordiging van de Republiek Indonesië een bemiddelende rol.

Het in artikel IV van de Slotbepalingen van de Wet bepaalde sluit niettemin de mogelijkheid niet uit, dat op grond van een andere wet, een andere instantie dan de "Peng-

919. Zie hiervoor ook het Rondschriven van de Minister van Justitie no. J.B.3/92/16 van 28 juni 1958 , gericht aan alle Voorzitters van de "Pengadilan Negeri's" in Indonesiê.

920. Zie het Rondschrijven van de Minister van Justitie no. J.B.3/2/25 van 5 januari 1959 aan de Voorzitters van de "Pengadilan Negeri's" gericht. Ook door Soedarman Ganda Soebrata, Pengadilan Negeri, Himpunan p. 129 is op deze aangelegenheid gewezen. 
adilan Negeri" wordt aangewezen om de hierbedoelde taak te verrichten. Ter illustratie kan in dit verband worden gewezen op de Noodwet no. 9 van het jaar 1953, Stb. 195364 inzake het Toezicht op Buitenlanders. ${ }^{\text {91 }}$ Op basis van deze Wet is de "Pengadilan Tinggi" de bevoegde instantie om een uitspraak te doen met betrekking tot de nationaliteit van een persoon. Dit kan zich voordoen, wanneer buitenlanders, die worden beschouwd een gevaar op te leveren voor de veiligheid, de moraal, het publieke welzijn of die de regelingen voor buitenlanders opgesteld niet in acht nemen en als gevolg daarvan zich blootstellen aan maatregelen als in artikel 5 lid 1 van deze Noodwet omschreven, zoals onder meer uitwijzing uit Indonesië, claimen het Indonesisch staatsburgerschap te bezitten. Voor de goede orde dient te worden opgemerkt, dat de hierboven genoemde Noodwet met de inwerkingtreding op 31 maart 1992 van de Wet no. 9 van het jaar 1992 inzake Immigratie niet langer van kracht is verklaard. Hierbij zij echter aangetekend, dat regeringsverordeningen en andere uitvoeringsregelingen op het vlak der immigratie voorshands nog van kracht zijn, voor zover niet in strijd met de Wet no. 9 van 1992 en nog niet vervangen door nieuwe uitvoeringsregelingen krachtens deze Wet.

\subsection{De nieuwe situatie}

Met de Regeling van de Minister van Justitie van 14 maart 1978, werd echter tot de vaststelling van nieuwe bepalingen inzake het Bewijsstuk betreffende het Staatsburgerschap van de Republiek Indonesië overgegaan. ${ }^{92}$ Hierbij werd mede in aanmerking genomen, dat de noodzaak inzake het bezit daarvan zich in het dagelijks verkeer maar al te vaak voordoet, met name indien met betrekking tot een bepaalde persoon het vervullen van verplichtingen wordt gevorderd, die in het bijzonder voor buitenlanders gelden. Het heeft derhalve zeker zin te kunnen bewijzen dat men geen buitenlander is.

Krachtens artikel 1 van deze Ministeriële Regeling kan iedere persoon die het bezitten van het Indonesisch staatsburgerschap dient te bewijzen, een daartoe strekkend verzoek aan de Minister van Justitie richten, door tussenkomst van de "Pengadilan Negeri" van de woonplaats van betrokkene of de Diplomatieke Vertegenwoordiging van de Republiek Indonesië, bij verblijf van de betrokken persoon buitenlands.

Wordt een persoon geacht aan alle voorwaarden te voldoen, dan wordt aan betrokkene een bewijsstuk inzake het bezit van het Indonesisch staatsburgerschap ("Surat Bukti Kewarganegaraan Republik Indonesia", afgekort SBKRI) verstrekt. Bedoeld bewijsstuk doet krachtens artikel 7 van bedoelde Ministeriële Regeling, gén afbreuk aan de bewijskracht van voorheen uitgegeven bewijsstukken inzake het bezit van genoemd staatsburgerschap van personen, die Indonesisch staatsburger zijn op grond van de in het voorafgaande behandelde wettelijke regelingen. ${ }^{923}$

921. Zie Engelbrecht p.338.

922. Bedoeld is hier de Ministeriele Regeling Do. JB.3/4/12 van 14 maart 1978.

923. Zie $\$ 1$ van dit Hoofdstuk. 
Met het afkomen van de onderhavige Regeling van de Minister van Justitie, zijn de voorheen vastgestelde bepalingen die deze materie regelen, niet langer van kracht. Dit impliceert mede, dat belanghebbende personen niet langer in het bexit van een urgentieverklaring van een offciële instantie dienen te zijn, teneinde een uitspraak inzake hun staatsburgerschap te verkrijgen. ${ }^{924}$

Stuiten de ter zake bevoegde instanties bij het onderzoeken van aanvragen ter verkrijging van een SBKRI echter op moeilijkheden of wordt aan de status van betrokkenen getwijfeld, dan dient deze aangelegenheid aan het Departement van Justitie te worden voorgelegd. De Minister van Justitie kan, indien dit nodig wordt geacht, de desbetreffende verzoeker gelasten meer bewijsstukken te overleggen of de "Pengadilan Negeri" c.q. Diplomatieke Vertegenwoordiging van de Republiek Indonesië opdragen, een heronderzoek naar de status van de betrokken persoon in te stellen. De afgifte van genoemd bewijsstuk omvat in het hierbedoelde geval, mede het instellen van een heronderzoek naar reeds uitgegeven bewijsstukken, die op het Indonesisch staatsburgerschap betrekking hebben. Een verzoek ter verkrijging van een SBKRI zou in het geval als hier omschreven, het komen te vervallen van zodanige verklaringen en andere bescheiden ten gevolge kunnen hebben.

Met de Instructie van de President no. 2 van het jaar 1980, werden de bij het verlenen van het SBKRI betrokken instanties opgedragen deze aangelegenheid zo snel mogelijk af te wikkelen. ${ }^{925}$ Voor dit doel werd bepaald, dat de afgifte van genoemde bewijsstukken zal geschieden door de Regent ("Bupati") c.q. het Hoofd van de Regio van het tweede Niveau;deze bevoegdheid wordt aan het Onderdistricthoofd ("Camat") overgedragen, die de onderhavige bewijsstukken ondertekent namens de Minister van Justitie. ${ }^{926}$ Het verlenen van een SBKRI diende op uiterlijk 17 augustus 1980 te zijn voltooid.

In aansluiting op genoemde Presidentiële Instructie werden met Gezamenlijk Besluit van de Minister van Justitie en de Minister van Binnenlandse Zaken no. M.01-UM.09.03-80 en no. 42 van het jaar 1980 nadere bepalingen inzake deze aangelegenheid vastgesteld. ${ }^{97}$ In het kader daarvan werd bepaald, dat voor een SBKRI in aanmerking komen, afstammelingen van buitenlanders die reeds Indonesisch staatsburger zijn geworden en volwassen zijn, doch nog niet in het bezit zijn van bedoeld bewijsstuk. Het betreft hier personen, die aan de navolgende voorwaarden voldoen;

a. in Indonesië zijn geboren en grootgebracht;

b. dagelijks leven als lid van de Indonesische samenleving;

c. de Indonesische of regionale taal beheersen;

924. Zie het Rondschrijven van de Minister van Justitie no. DTC/9/11 van 1 juli 1969 sub 6 ad a. jo. het Rondschrijven van voornoemde Minister no. J.B.3/2/25 van 5 januari 1969 sub 11, gericht wan de Voorzitters van de in geheel Indonesiē gevestigde "Pengadilan Negeri's".

925. Zie voor deze Presidentiële Instructie, Engelbrecht p. 322.

926. Zie voor de stątsstructuur van Indonesiē, $\$ 2.2$ van Hoofdstuk 1 .

927. Opgenomen in Engelbrecht p.323. 
d. nooit de Indonesische nationaliteit in de optie/repudiatieperiode tussen 27 december 1949 en 27 december 1951 hebben verworpen;

e. geen tekenen aanwezig zijn dat de betrokken personen buitenlander zijn en nooit in het bezit van enkel een exitpermit zijn gesteld;

f. op het tijdstip van inwerkingtreding van de Presidentiële Instructie no. 2 van het jaar 1980 - 31 januari 1980 - woonplaats hebben in de regio's van de Provincies Noord-Sumatra, Riau, West-Kalimantan, het Speciale District van de Hoofdstad Jakarta, de Regentschappen Bangka, Belitung, de Stadsgemeente Pangkal Pinang en de Regentschappen Tangerang, Bekasi en Karawang.

Een SBKRI kan voorts ook worden verstrekt aan personen die ooit hebben deelgenomen aan de algemene verkiezingen voor de (regionale) Volksvertegenwoordiging. Ingevolge de door de Minister van Justitie aan de Voorzitters van de lokaal gevestigde "Pengadilan Negeri" en de "Pengadilan Tinggi" gegeven toelichting vallen onder vigeur van genoemd Gezamenlijk Besluit, mede Indonesische staatsburgers van buitenlandse afkomst, die Indonesië zijn binnengekomen - alhoewel buiten Indonesië geboren - en zich vór 27 december 1949 hebben "opgelost" in de plaatselijke bevolking. De hierbedoelde "oplossing" - het onderwerp van $\$ 2.3$ van Hoofdstuk 3 - wordt als wettig aangemerkt, voor zover hieraan geen juridische gebreken kleven.

Bij het nader in beschouwing nemen van de hierboven genoemde voorwaarden - als hierboven onder d. en e. genoemd - zou de conclusie kunnen worden getrokken, dat de onderhavige bepalingen in eerste instantie betrekking hebben op Indonesische staatsburgers van Chinese afkomst. Dit blijkt ook uit de onder f. gegeven opsomming van gebieden, met name gebieden waar als hierbedoelde personen activiteiten op verschillend vlak ontplooien. Inmiddels is echter benadrukt, dat de Presidentiële Instructie no. 2 van het jaar 1980 in feite voor geheel Indonesië is bedoeld, zodat de verstrekking van bewijsstukken die op het Indonesisch staatsburgerschap betrekking hebben, ook in andere gebieden dient te geschieden. ${ }^{928}$

Het verstrekken van binnen het kader van genoemde Instructie bedoelde bewijstukken diende uiterlijk op 17 augustus 1980 te zijn voltooid. Niettemin werd overgegaan tot de vaststelling van het Besluit van de Minister van Justitie no. M.01.HL.04.02 van het jaar 1983 , als rechtsbasis bedoeld voor de verstrekking van bewijsstukken aan personen, die een als hierbedoeld bewijsstuk nog niet hebben verkregen op basis van de Presidentiële Instructie no. 2 van het jaar 1980. In genoemd Besluit van de Minister van Justitie is benadrukt dat personen die voor een SBKRI in aanmerking komen, personen zijn die het Indonesisch staatsburgerschap reeds bezitten.

Met het van kracht worden van dit Besluit, kan een als hierbedoeld bewijsstuk slechts worden verzocht aan c.q. verkregen van de Minister van Justitie door tussenkomst van

928. Zie hiervoor het Rondschrijven van de Minister van Justitie no. JHB.3/8/12 van 30 januari 1982 aan de Voorzitters van de in geheel Indonesië gevestigde "Pengadilan Tinggi's" en van de "Pengadilan Negeri's" gericht en het Rondschrijven van voomoemde autoriteit, gericht aan de Voorzitters van de "Pengadilan Negeri's" in geheel Indonesiē no. C.UM.01.05-10 van 7 juli 1983. 
de "Pengadilan Negeri" of de Diplomatieke Vertegenwoordiging van de Republiek Indonesië in het buitenland. Aangezien het bezitten van het Indonesisch staatsburgerschap in beginsel uitgebreide gevolgen heeft, met name de rechten van een staatsburger en diens verplichtingen ten aanzien van de Indonesische overheid en staat raken, is dit Ministerieel Besluit bedoeld ter waarborging van de rechtszekerheid.

De hiervoor omschreven aangelegenheid heeft tevens tot doel, om twijfel aan de wettigheid van een bewijs van staatsburgerschap, in het bijzonder van formulieren, voorheen in het kader van de toepassing van de Overeenkomst tussen Indonesië en de Chinese Volksrepubliek ter afwikkeling van het probleem der bipatridie verstrekt, te voorkomen. Indien een als hierbedoeld bewijs niet wettig, vervalst of op onwaarheid berust, kan het door de Minister van Justitie vervallen worden verklaard. Zoals uit het onderhavige Besluit van de Minister van Justitie no. M.01-HL.04.02 van het jaar 1983 valt op te maken, kunnen in het afgeven van formulieren als hiervoor bedoeld, administratieve vergissingen of juridische misinterpretaties zijn opgetreden, waardoor deze bewijzen als te zijn vervallen zouden kunnen worden verklaard.

Van regeringswege heeft men niettemin open oog voor het feit, dat het vervallen verklaren van bedoelde formulieren complexe sociaal-juridische gevolgen kan hebben voor de belanghebbende personen, die zich reeds lange tijd Indonesisch staatsburger voelen. Om die reden is in het onderhavige Ministerieel Besluit gesteld, dat iedere verklaring tot prijsgeving van het staatsburgerschap van de Chinese Volksrepublick, afgelegd op grond van de voorheen tussen de Republiek Indonesië en de Volksrepubliek gesloten Overeenkomst ter afwikkeling van het probleem van de bipatridie, die reeds door de bevoegde beambten is uitgegeven c.q. wettig verklaard volgens de geldende bepalingen, rechtens wettig is. Hierbij is uitdrukkelijk gesteld, dat eventueel opgetreden administratieve vergissingen, evenzo mogelijke juridische misinterpretaties gén afbreuk doen aan de wettigheid van een als hierbedoeld formulier, die op het afleggen van bedoelde verklaring betrekking heeft. ${ }^{929}$

Een nadere toelichting op de implementatie van het onderhavige Besluit van de Minister van Justitie van het jaar 1983, werd gegeven met het Rondschrijven van deze Minister van 7 juli 1983 no. C.HL.03.10-1. Benadrukt werd, dat de bevoegdheid om een verklaring als vervat in de onderhavige formulieren - het betreft hier formulieren, afgestemd op de gezinssamenstelling van de betrokken personen - krachtens de Overeenkomst ter afwikkeling van het dubbel staatsburgerschap tussen de Republiek Indonesië en de Chinese Volksrepubliek afgelegd, al dan niet wettig te verklaren, is voorbehouden aan de Minister van Justitie c.q. de Directeur-Generaal van Recht en Wetgeving namens genoemde Minister. Alleen deze autoriteiten kunnen derhalve een bewijs van staatsburgerschap vervallen verklaren.

Met betrekking tot personen van Chinese afkomst is voorts gesteld, dat personen geboren op 27 december 1949 of daama de staat van hun ouders volgen en de voor-

929. De hierbedoelde formulieren zijn in $\$ 1$ van dit Hoofdstuk reeds ter sprake gekomen. 
waarde van het nooit hebben verworpen c.q. het voor hen verwerpen of het delen in de verwerping van het Indonesisch staatsburgerschap gedurende de periode 27 december 1949 en 27 december 1951 - als hiervoor onder d. genoemd - slechts is bedoeld voor personen vó́r 27 december 1949 geboren.

Aansluitend op het voorgaande kan de aandacht worden gevestigd op het Besluit van de Minister van Justitie no. M.02-HL.04.10 van het jaar 1992 betreffende het bewijs van het bezit van het Indonesisch staatsburgerschap door kinderen van Indonesische staatsburgers van buitenlandse origine, houders van een SBKRI. ${ }^{930}$ Uit dit besluit valt op te maken, dat het niet zo is dat iedere Indonesische statsburger in het bezit van een SBKRI dient te zijn. Zo geldt voor de hierbedoelde kinderen niet de verplichting tot het bezitten van dit bewijsstuk, doch kan bezit van het Indonesisch staatsburgerschap worden aangetoond middels een geboorte-akte en een "Kartu Tanda Penduduk" (KTP $=$ persoonsbewijs), uitgegeven door de daartoe competente instantie. Een geboorte-akte wordt als een zeer belangrijk bewijsstuk aangemerkt, zowel voor alle Indonesische staatsburgers in het algemeen als voor Indonesische staatsburgers van buitenlandse afkomst in het bijzonder, teneinde te worden gebruikt als indicatie betreffende de status van het zijn van Indonesisch staatsburger.

Afsluitend kan worden gesteld, dat de SBKRI als rechtstreeks bewijs voor de betrokken persoon van groot belang kan worden geacht, in de eerste plaats voor Indonesische staatsburgers van buitenlandse origine. Hieraan kan echter de vraag worden vastgeknoopt of aan dit bewijs een even grote rechtskracht kan worden gehecht als het geval is met het paspoort. Uit hetgeen in Hoofdstuk 6 is behandeld is reeds naar voren gekomen, dat het bezitten van een buitenlands paspoort emstige gevolgen voor de betrokken persoon kan hebben, in casu kan leiden tot verlies van het Indonesisch staatsburgerschap. ${ }^{931}$ Het paspoort geeft de nationale status van de houder daarvan aan; uit dien hoofde geldt de algemene regel dat het slechts aan personen wordt uitgereikt die de daartoe bevoegde functionaris ervan kan overtuigen, dat hij/zij de nationaliteit van het land waarom het gaat bezit. ${ }^{932}$ Alhoewel de SBKRI binnenlands van grote waarde kan zijn, is niet duidelijk wat de rechtskracht daarvan is in het internationale verkeer. Hierop aansluitend kan de mening van Paulus naar voren worden gebracht; alhoewel deze auteur, mijns inziens ten onrechte, het Indonesisch staatsburgerschap als een nationaliteit in sociologische zin typeert - het gaat hier in feite om een nationaliteit in juridische zin - ben ik het met hem eens, dat de kwestie van Indonesische staatsburgers van vreemde origine met betrekking tot het deel uitmaken van het Indonesische volk, niet uitsluitend een kwestie van schriftelijk bewijs is, doch het ook om andere factoren gaat die aanduiden dat een bepaalde persoon Indonesisch staatsbur-

930. Dit Ministeriële besluit is opgenomen in het tijdschrift Varia Peradilan van september 1992, p.111.

931. Zie hiervoor hetgeen in $\$ 2.6$ van Hoofdstuk 6 is uiteengezet.

932. Het paspoort speelt onder meer een rol bij het geven van diplomatieke bescherming door een Staat, waarop de houder daarvan krachtens zijn nationaal recht op heeft. Zie Weis, Nationality, p.205. Deze auteur wijdt een uitvoerige beschouwing an bewijzen van nationaliteit als onder meer het paspoort, zie p. 222-236. 
ger is. ${ }^{933}$ Alhoewel volledige oplossing in de Indonesische bevolking te ver zou voeren, aangezien dit zou betekenen dat de betrokken personen afstand dienen te doen van hun culturele identitieit, dient wel sprake te zijn van een daadwerkelijk proces van integratie in de Indonesische samenleving.

933. Paulus, Kewarganegaraan RI, p.490-491. 



\section{\$ Algemeen}

In erste instantie kan worden geconcludeerd, dat het door artikel 15 van de Universele Verklaring van de Rechten van de Mens gegarandeerde recht op een nationaliteit, evenzeer de waarborging van een mensenrecht betreft, als andere mensenrechten die rechtstreeks het persoonlijk bestaan van de individu raken. Ik onderschrijf derhalve niet het in de literatur vaak gehuldigde standpunt, als zou het begrip "nationaliteit" een dubieus mensenrecht zijn, dat in feite niets garandeert, doch slechts het karakter van een technisch koppelbegrip zou hebben, dat eerst waarde krijgt door de rechtsgevolgen die nationale of intemationale rechtssystemen eraan koppelen.

Mijns inziens kan met betrekking tot het nationaliteitsbegrip onderscheid worden gemaakt tussen de nationaliteit als koppelbegrip en als inhoudelijk begrip. Van laatstgenoemd begrip kan worden gesproken omdat er belangrijke fundamentele rechten met het begrip "nationaliteit" nauw verweven zijn, hetgeen ook van belang is voor de typering van het recht op een nationaliteit als een mensenrecht. Hierbij komt nog, dat het recht op een nationaliteit niet alleen in de Universele Verklaring op de Rechten van de Mens als zodanig is omschreven, doch ook in andere verdragen hiervan melding is gemaakt. Het recht op een nationaliteit is een fundamenteel menselijk recht, een mensenrecht. Dit houdt in dat het zeker niet enkel de functie van koppelbegrip kan hebben. Nietternin kunnen ook bij de door mij gehuldigde visie, naast de fundamentele rechten die begripsmatig uit het bezitten van een nationaliteit voortvloeien, andere rechten - en plichten - als minder fundamenteel aan te merken, worden onderscheiden. Deze zijn niet met de nationaliteit nauw verweven, doch in dit geval dient de nationaliteit als aanknopingspunt, als koppelbegrip. Laatstbedoelde rechten en verplichtingen kunnen van land tot land verschillen.

Samenvattend kan worden gesteld, dat fundamentele rechten zoals het recht op toelating tot de Staat waarvan men de nationaliteit bezit en op niet-uitwijzing, het recht op diplomatieke bescherming door die Staat en politieke rechten als het actieve en passieve kiesrecht nauw met de nationaliteit zijn verweven en de nationaliteit om die reden een inhoudelijk begrip is. Hiernaast kan het bezitten van een nationaliteit als aanknopingspunt, als koppelbegrip dienen voor andere dan de hiervoor genoemde rechten en voor plichten. Het karakteriseren van het recht op een nationaliteit als mensenrecht heeft tot consequentie, dat (willekeurige) ontneming van de nationaliteit een schending van dit recht oplevert, dat een ieder het recht heeft om van nationaliteit te veranderen. Is discriminatie, algemeen gesteld, ontoelaatbaar, ook discriminatie naar nationaliteit is niet c.q. zou niet mogen worden toegestaan. Betreft het onderscheid tussen koppelbegrip en inhoudelijk begrip slechts een gedachtenconstructie, het recht op een nationaliteit als mensenrecht ligt op een hoger niveau. Het gaat dan immers om een existentieel recht, dat het individu evenals andere mensenrechten niet kan worden ontnomen. Anders ligt de zaak bij de nationaliteit als koppelbegrip, in welk geval willekeurige rechten en 
plichten aan de nationaliteit gekoppeld worden, die aan het individu zouden kunnen worden ontnomen. ${ }^{934}$

De uit het Nederlands-Indische tijdperk daterende bepalingen zijn zeker niet zonder invloed op het huidige Indonesisch nationaliteitsrecht geweest. De koloniale nationaliteitswetgeving was in het verleden niet van discriminatoire trekken ontbloot. Het vóor de inwerkingtreding van de Wet van 1892 op het Nederlander- en Ingezetenschap op 1 juli 1893 voorhanden zijn van twee soorten van Nederlanderschap, met name de regeling van het Burgerlijk Wetboek van 1838 voor privaatrechtelijke en de Wet van 1850 voor publiekrechtelijke aangelegenheden had voor Nederlandsch-Indië onder meer tot gevolg, dat autochtone Indonesiërs en daarmede gelijkgestelden zoals Chinezen en Arabieren in Nederlandsch-Indië geboren, "Nederlander" waren, doch slechts voor privaatrechtelijke doeleinden. Dit bracht met zich dat aan deze civiele Nederlanders gén politiek-staatkundige rechten en verplichtingen toekwamen, die normaliter aan de status van staatsburger zijn verbonden.

Met de inwerkingtreding van de Wet van $1892 \mathrm{kwam}$ een einde aan het bestaan van twee soorten van Nederlanderschap. Autochtone Indonesiërs en daarmede gelijkgestelden werden van het Nederlanderschap als in deze Wet geregeld uitgesloten. In feite trad een rechtsvacuüm op met betrekking tot de regeling van de nationaliteit van deze groepen van ingezetenen van Nederlandsch-Indië, die "vreemdeling" werden.

Eerst in 1910 werd voor deze groepen van personen een "nationaliteitswet" afgekondigd, waarbij echter genoegen moest worden genomen met de in deze Wet geregelde tweederangse status van Nederlands onderdaan niet-Nederlander. Gaf de juridische nationaliteit zoals geregeld in de Wet van 1892 aanleiding tot het bezit van alle, aan een nationaliteit verbonden rechten en verplichtingen, wat betreft de nationaliteit zoals geregeld in de Wet van 1910 was dit niet het geval. Nederlandse onderdanen nietNederlanders waren in casu uitgesloten van politieke rechten in het moederland. Het Nederlands onderdaanschap van niet-Nederlanders kon derhalve niet als een "volwaardige" nationaliteit worden aangemerkt.

Met de afkondiging van de Wet no. 62 van 1958 inzake het Indonesische staatsburgerschap werd gepoogd van het in het koloniale tijdperk gehanteerde systeem af te stappen. De ontwikkelingen laten sedertdien een geheel ander beeld zien met betrekking tot de uit het bezit van dit staatsburgerschap voortvloeiende rechten en verplichtingen. In dit verband is van belang, dat het voorheen gemaakte onderscheid tussen autochtone en niet-autochtone Indonesiërs - althans in juridische zin - is komen te vervallen, zoals

934. Eén van de meest betekenisvolle veranderingen in de internationale betrekkingen is de toenemende bezorgdheid met betrekking tot de mensenrechten, wasrvan de snel groeiende omvang van het recht inzake mensenrechten in de internationale arena getuigt. Het op de voorgrond treden van dit recht en de snelle dekolonialisatie sedert de Tweede Wereldoorlog vereist een herwaardering van de positie van de nationaliteit in de nieuwe internationale rechtsorde. Zie hiervoor Chan, The right to a Nationality, p.2-5 en 9-11. 
door de Minister van Justitie is benadrukt. ${ }^{935}$ Thans wordt slechts één begrip gebruikt, met name het begrip "Indonesisch staatsburger" voor alle burgers van de Republiek Indonesië, zowel autochtone als niet-autochtone. Hierop aansluitend kan het Presidentiële Besluit no. 240 van 1967 in herinnering worden gebracht, waarin onder meer is bepaald dat Indonesische staatsburgers van vreemde origine een gelijkwaardige positie in het staatsrecht innemen als andere Indonesische staatsburgers, en deze niet in rechten en verplichtingen verschillen van laatstbedoelde personen.

Indonesië heeft sedert het uitroepen van zijn onafhankelijkheid diverse territoirwisselingen ondergaan, die nationaliteitsrechtelijke vragen hebben opgeroepen. Werd de Republiek Indonesië gegrondvest krachtens de onafhankelijkheidsverklaring van 17 augustus 1945, de formele soevereiniteitsoverdracht door Nederland aan Indonesië vond eerst op 27 december 1949 plaats. In 1963 werd Irian Jaya aan Indonesië overgedragen. Moeilijk ligt de kwestie van de inlijving van Oost-Timor door Indonesië als de 27 ste provincie van laatstgenoemd land, die internationaal niet wordt erkend.

Aan gebiedsovergang zijn nationaliteitsrechtelijke consequenties verbonden. Zo heeft de soevereiniteitsoverdracht aan Indonesië op 27 december 1949 in het kader van de overeenkomsten bij de RTC aangegaan, geleid tot de totstandkoming van de Overeenkomst op de Toescheiding van Staatsburgers. Op grond van deze Overeenkomst werden voormalige Nederlandse onderdanen, hetzij aan Nederland, hetzij aan Indonesië toegescheiden. Werd de toegescheiden nationaliteit door betrokkenen als onaanvaardbaar gevoeld, dan kon onder bepaalde voorwaarden wijziging in de verkregen status worden gebracht, door gebruikmaking van het recht van optie of het recht van repudiatie.

Bij de soevereiniteitsoverdracht door Nederland aan Indonesië bleef op de voet van het tweede artikel van het Charter van Soevereiniteitsoverdracht, het gebied van het voormalige Nieuw-Guinea (Irian Jaya) uitgezonderd. In het slot van de Toescheidingsovereenkomst werd een bepaling opgenomen waarin was gesteld, dat omtrent de nationaliteit van de inwoners van dit gebied niets was beslist. Voor genoemde inwoners bleef ingevolge artikel 2 van het Charter van Soevereiniteitsoverdracht de status quo gehandhaafd en bleven zij, voor zover zij Nederlandse onderdanen waren, die hoedanigheid behouden, hetzij op de voet van de Wet van 1892, hetzij op de voet van de Wet van 1910. Naar aanleiding van de overdracht van Irian Jaya aan Indonesië werden geen afspraken inzake de nationaliteit van de inwoners van dit gebied door de daarbij betrokken landen gemaakt. Door de Indonesische overheid werd nadat Irian Jaya aan dit land was overgedragen, met terugwerkende kracht tot 17 augustus 1945 een regeling getroffen ter vaststelling van de nationaliteit van de inwoners van dit gebied. Dit vond in een overgangsfase eerst plaats op grond van de Wet no. 3 van 1946 zoals later gewijzigd en aangevuld en vervolgens krachtens de Wet no. 62 van 1958. Dit had tot gevolg, dat de inwoners van Irian Jaya in de periode vanaf 17 augustus 1945 tot 1 oktober 1962 toen de Wet van 1910 bij Rijkswet van 14 september 1962 - op 21

935. Zie het Ministeriële Rondschrijven no. D.T.C./14/15 van 28 augustus 1965, aan alle Vocrzitters van de "Pengadilan Negeri's" in geheel Indonesiē gericht. 
september 1962 in werking getreden ${ }^{936}$ - met ingang van 1 oktober 1962 werd ingetrokken, een dubbele nationaliteit hadden. Volkenrechtelijk kunnen hierbij vraagtekens worden gezet, wat betreft de daaruit voortvloeiende consequenties.

Heeft de inlijving van Oost-Timor door Indonesië nu ook nationaliteitsrechtelijke gevolgen voor dit gebied? Volgens Hecker waren de inwoners van de Portugese kolonie Oost-Timor Portugees staatsburger; verschil tussen inheemsen en staatsburgers zoals in de Afrikaanse koloniën bestond voor Oost-Timor niet. Toen Indonesië Oost-Timor in 1976 inlijfde, rees de vraag welk staatsburgerschap de inwoners bezitten. Aangezien Portugal en ook andere landen de inlijving niet erkend hebben, zijn de Portugese staatsburgers van Oost-Timor Portugees gebleven. De Wet no. 7 van 15 juli 1976 betreffende de inlijving bevat in zijn vier artikelen, noch direct noch indirect iets over het staatsburgerschap. ${ }^{937}$ Voor Indonesië zijn de bij de inlijving in Oost-Timor gevestigde Portugese staatsburgers Indonesiër geworden. Ofschoon Oost-Timor in de Portugese Grondwet van 1976 niet als Portugees gebied is genoemd, wordt het ten opzichte van het staatsburgerschap van de inwoners daarvan als zodanig behandeld. Ook de ná de inlijving in Oost-Timor geboren kinderen, beschouwt Portugal als zijn staatsburgers. Vluchtelingen uit Oost-Timor verkrijgen van Portugal onder versoepelde voorwaarden Portugese paspoorten en akten betreffende geboorte, huwelijk of overlijden. Andere Staten, die de inlijving vanwege schending van het verbod tot het gebruiken van geweld niet erkennen, behoeven ook het nieuwe Indonesisch staatsburgerschap niet te erkennen. ${ }^{938}$ Inmiddels is gebleken, dat de Wet no. 62 van 1958 ook in Oost-Timor is komen te gelden. ${ }^{939}$ Dit zou tot gevolg kunnen hebben dat Oost-Timorezen de status van bipatride bezitten.

\section{$\S 2$ Het "ius sanguinis" tegenover het "ius soli"}

Bij het nader in beschouwing nemen van de Wet no. 62 van het jaar 1958 zélf, vallen enkele belangrijke, daarin opgenomen beginselen in het oog waarvan kan worden genoemd, het uitgaan van het "ius sanguinis", het vermijden van apatridie en van bipatridie en de positie van de gehuwde vrouw. In tegenstelling tot de Wet van 1910 waarin werd uitgegaan van het "ius soli", hetgeen ook het geval was met de Wet no. 3 van 1946, de eerste nationaliteitswet van Indonesië, wordt thans in eerste instantie

936. In artikel 5 van deze Rijkswet is bepaald, dat deze Wet op de zevende dag ná afkondiging (14 september 1962) in werking zal treden.

937. In de Memorie van Toelichting van de Wet no. 7 van het jaar 1976 is echter gesteld, dat met de "unificatie" van Oost-Timor met de Republiek Indonesië, het grondgebied van Oost-Timor tot grondgebied van Indonesiē wordt. Dit heeft tot gevolg, dat het volk van Oost-Timor volk en staatsburger van de Republiek Indonesië wordt en alle wettelijke regelingen van de Republiek Indonesiê tevens voor het grondgebied van Oost-Timor gelden. Zie hiervoor $\$ 1.5 .4$ van Hoofdstuk 2. Of met deze toelichting kan worden volstaan, is de vraag.

938. Hecker, Das Staatsangehörigkeitsrecht, p. 47.

939. Uit de Considerans van de Regeringsverordening no. 18 van het jaar 1991, waarbij conversiebepalingen zijn vastgesteld in verband met het van toepassing worden van de Agrarische Basiswet van 1960 in Oost-Timor - waarvoor het nationaliteitscriterium van cruciaal belang is - blijkt, dat aan de hand van de Wet no. 62 van 1958 wordt vastgesteld wie al dan niet Indonesisch staatsburger is. 
vitgegaan van het "ius sanguinis" en vindt het "ius soli" eerst toepassing ter vermijding van het optreden van apatridie.

Een uitzondering hierop vormt niettemin de in artikel 4 van de Wet geregelde mogelijkheid tot verkrijging van het Indonesisch staatsburgerschap door kleinkinderen van immigranten, waarbij wordt uitgegaan van het "ius soli". Bij het in artikel 4 van de Wet bepaalde, kunnen echter de nodige vraagtekens worden gezet. In herinnering kan worden gebracht, dat bij de behandeling van het ontwerp - welke geleid heeft tot de vaststelling van de Nationaliteitswet no. 62 van het jaar 1958 - in de Volksvertegenwoordiging, door verschillende leden daarvan bezwaren werd gemaakt tegen het in dit artikel bepaalde. ${ }^{40} \mathrm{Zo}$ werd door enkele leden voorgesteld om het onderhavige artikel 4 maar te doen vervallen, gezien de reeds in artikel 5 van de Wet opgenomen mogelijkheid tot - gewone - naturalisatie. Door weer andere leden werd voorgesteld, om het in artikel 4 bepaalde in artikel 5 van de Wet op te nemen. Het doen vervallen van dit artikel, zoals door enkele leden van de Volksvertegenwoordiging voorgesteld, zou mijns inziens te ver voeren. Ook het opnemen van de in artikel 4 opgenomen nationaliteitsverkrijging in artikel 5 zou afbreuk doen aan de systematiek van de Wet. Ik kan mij voorstellen, dat het bieden van de mogelijkheid aan bepaalde buitenlanders om door middel van geprivilegieerde naturalisatie Indonesisch staatsburger te worden billijk kan worden geacht. Dat in dit geval zwaardere vereisten zijn gesteld inzake geboorte en woonplaats in Indonesië, in vergelijking met hetgeen hieromtrent in artikel 5 is bepaald, is mijns inziens niet onrechtvaardig te achten. In herinnering kan worden gebracht, dat artikel 4 betrekking heeft op de derde generatie buitenlanders, die in Indonesië geboren is en woonplaats heeft, dus om de kleinkinderen van buitenlanders in Indonesië, met de status van ingezetene. De andere voorwaarden om een verzoek tot geprivilegieerde naturalisatie te kunnen indienen, dienen dan lichter te zijn dan het geval is bij gewone naturalisatie als in artikel 5 omschreven, door vrijstelling te geven van bepaalde vereisten.

\section{§ 3 Apatridie en bipatridie}

Het voorkomen van apatridie en bipatridie vormt een belangrijk beginsel, dat aan de Wet no. 62 van het jaar 1958 ten grondslag ligt, gezien de vele op voorkoming van het ontstaan daarvan gerichte artikelen.

Samengevat komen bedoelde bepalingen, voor zover die het vermijden van apatridie betreffen hierop neer, dat aan personen waarvan de ouders onbekend zijn, die ten vondeling zijn gelegd, waarvan het staatsburgerschap van de ouders onbekend is of deze ouders geen staatsburgerschap bezitten dan wel die het staatsburgerschap van de ouders niet kunnen verkrijgen, op grond van het "ius soli" gelegenheid wordt geboden Indonesisch staatsburger te worden (artikel 1 sub f., g., h. en i). Het "vrouw volgt man"

940. Deze bezwaren hebben betrekking op de veel zwaardere eisen op geboorte- en woonplaats betrekking hebbende van artikel 4 , in vergelijking met artikel 5 van de Wet en bet feit, dat ter verkrijging van bet Indonesisch staatsburgerschap ex artikel 4 een verzoek dient te worden ingediend - het betreft hier geprivilegieerde naturalisatie - en niet met een optieverklaring kan worden volstaan. 
beginsel gaat niet op voor de vrouw, indien met het verliezen van het Indonesisch staatsburgerschap door de man zij staatloos zou worden (artikel 9 lid 2). Ook in het kader van de bepalingen die het gemengd huwelijk betreffen, zijn voorzieningen getroffen om apatridie te voorkomen. Zo mag een met een buitenlandse vrouw getrouwde Indonesische staatsburger zijn staatsburgerschap niet prijsgeven, als hij hierdoor staatloos zou worden (artikel 7 lid 2 tweede alinea). Het door een buitenlandse vrouw verkregen Indonesisch staatsburgerschap kan na ontbinding van het huwelijk niet worden prijsgegeven met het doel de oorspronkelijke nationaliteit terug te krijgen, indien zij hierdoor staatloos zou worden (artikel 12 lid 2). Betreft het een vrouw die Indonesisch staatsburger is en met een buitenlander is gehuwd, dan kan zij haar staatsburgerschap niet prijsgeven, indien zij hierdoor staatloos zou worden (artikel 8 lid 1). Verlies van het Indonesisch staatsburgerschap door een vrouw geldt krachtens artikel 10 lid 2 van rechtswege voor haar man, tenzij hij hierdoor staatloos zou worden. Kinderen die de staat van de vader c.q. moeder volgen, delen niet in het verloren gaan van het Indonesische staatsburgerschap van de ouder, indien zij hierdoor staatloos zouden worden (artikel 15 lid 1 en 2). Het door deze kinderen verkregen Indonesisch staatsburgerschap wegens het volgen van de staat van de desbetreffende ouder kan niet worden prijsgegeven, indien dit tot staatloosheid zou leiden (artikel 14 lid 2). Hetzelfde geldt voor door Indonesische staatsburgers geadopteerde buitenlandse kinderen, die eveneens het verkregen Indonesisch staatsburgerschap niet kunnen prijsgeven, indien apatridie hiervan het gevolg zou zijn (artikel 14 lid 2).

Met betrekking tot het voorkomen van bipatridie is gesteld, dat het "vrouw volgt man" beginsel bij het worden van Indonesisch staatsburger van de man, niet geldt voor de vrouw, indien zij daardoor bipatride zou worden (artikel 9 lid 1). In het kader van gemengde huwelijken is de voorwaarde gesteld, dat de met een Indonesisch staatsburger gehuwde buitenlandse vrouw dit staatburgerschap niet verkrijgt, ingeval dit tot bipatridie zou leiden (artikel 7 lid 1). Voor minderjarige kinderen buiten huwelijk geboren en door de vader, een buitenlander, erkend, evenzo voor kinderen, geboren uit een huwelijk tussen een vrouw die Indonesisch staatsburger is en een buitenlander geldt, dat zij het Indonesisch staatsburgerschap niet kunnen verkrijgen, indien zij daarnaast nog een andere nationaliteit bezitten (artikel 3 lid 1). Ook kleinkinderen van buitenlandse immigranten kunnen het Indonesisch staatsburgerschap slechts krijgen, indien zij hierdoor geen bipatride worden (artikel 4 lid 1). Personen die door of als gevolg van huwelijk het Indonesisch staatsburgerschap hebben verloren, kunnen dit staatsburgerschap slechts terugkrijgen, indien zij geen bipatride worden (artikel 11). Aan kinderen die wegens het volgen van de staat van respectievelijk de vader of de moeder het Indonesisch staatburgerschap hebben verloren wordt de gelegenheid geboden om dit te herkrijgen, mits zij daarnaast geen andere nationaliteit bezitten (artikel 16 lid 2). Aan in het buitenland verblijvende personen die het Indonesisch staatsburgerschap "buiten hun schuld" hebben verloren wordt de gelegenheid geboden dit te herkrijgen, mits zij daardoor geen bipatride worden, hetgeen ook geldt voor hun echtgenote (artikel 18 lid 5 en 6). Ook in het kader van de naturalisatieprocedure is bepaald, dat het mede bezitten van een andere nationaliteit een beletsel vormt voor het worden van Indonesisch staatsburger (artikel 5 lid 1 sub h). 
Aldus in grote lijnen het door de Indonesische wetgever gevolgde beleid om apatridie en bipatridie te voorkomen. Welke conclusie kan uit het voorgaande worden getrokken? Verlies van het Indonesisch staatsburgerschap mag niet tot apatridie leiden, aan welke voorwaarde dient te zijn voldaan, wil verlies van genoemd staatsburgerschap daadwerkelijk plaatsvinden. Indonesië gaat in de toepassing van dit beginsel zó ver, dat zelfs een van oorsprong buitenlandse vrouw die door huwelijk het Indonesisch staatsburgerschap heeft verkregen, dit bij ontbinding van het huwelijk niet mag prijsgeven, indien dit leidt tot apatridie. Hetzelfde principe wordt aangehangen voor wat betreft andere personen met van oorsprong een buitenlandse status, zoals personen die het Indonesisch staatsburgerschap hebben verkregen door adoptie en kinderen die vanwege het volgen van de staat van de respectieve ouder, Indonesisch staatsburger zijn geworden. Al deze personen met van oorsprong een buitenlandse status, kunnen hun Indonesisch staatsburgerschap alleen prijsgeven, indien daardoor geen apatridie optreedt. Wat betreft kinderen die buitenlands verblijven en krachtens artikel 13 lid 1 in Indonesië woonplaats dienen te hebben en aldaar de facto dienen te verblijven om het Indonesisch staatsburgerschap van de desbetreffende ouder te verkrijgen kan van deze voorwaarde worden afgeweken, indien de verkrijging van het Indonesisch staatsburgerschap door die ouder, staatloosheid voor hen ten gevolge zou hebben. Staatloosheid is ook één van de alternatieve voorwaarden, om een verzoek ter verkrijging van het Indonesisch staatsburgerschap middels naturalisatie te kunnen indienen. Alhoewel Indonesië zeer ver gaat in zijn beleid om staatloosheid te voorkomen, heeft het land niettemin generlei overeenkomst met andere landen aangegaan - bilateraal of multilateraal - om het ontstaan van apatridie te vermijden.

Het stereotype voorbeeld om tot afwikkeling van het probleem der bipatridie te komen, vormde de tussen Indonesië en de Chinese Volksrepubliek over deze aangelegenheid gesloten overeenkomst, die door Indonesië echter werd opgezegd. Algemeen gesteld, mag verkrijging van het Indonesisch staatsburgerschap niet tot bipatridie leiden. Dit impliceert, dat bij verkrijging van het Indonesisch staatsburgerschap, de oorspronkelijke nationaliteit dient verloren te gaan of hiervan afstand dient te worden gedaan.

Wél zijn de hierop gerichte voorwaarden voor personen met de nationaliteit van de Chinese Volksrepubliek in zoverre versoepeld, dat zij in het kader van de naturalisatieprocedure - hetzelfde gold voor de hierbedoelde vrouwen met Indonesische staatsburgers gehuwd - konden volstaan met een door hen ondertekende verklaring van hun oorspronkelijke nationaliteit afstand te doen. Deze aangelegenheid is echter niet meer opportuun. Ter staving hiervan kan erop worden gewezen, dat de Chinese Volksrepubliek in 1980 een nieuwe nationaliteitswet heeft afgekondigd, welke tot doel heeft het optreden van bipatridie niet langer te tolereren. Dit blijkt ook uit de door Indonesië en de Chinese Volksrepubliek ondertekende "Memorandum of Understanding", ter gelegenheid van het herstel van de diplomatieke betrekkingen tussen beide landen in augustus 1990 . Beide regeringen stellen zich derhalve op het standpunt van het niet erkennen van een dubbel staatsburgerschap voor hun burgers. ${ }^{941}$

941. Zie hiervoor $\$ 3$ van Hoofdstuk 4, $\$ 6.8$ en $\$ 7.1 .1$ van Hoofdstuk 5 , 
De Wet no. 62 van 1958 is echter niet dermate nauwgezet geredigeerd, dat het optreden van bipatridie geheel is uitgesloten. Met Ko Swan Sik en Teuku Moh. Rhadie ${ }^{942}$ ben ik van mening, dat dit het geval is bij verkrijging van het Indonesisch staatsburgerschap krachtens het "ius sanguinis" ex artikel 1 sub b., c. en d. en artikel 2 inzake verkrijging van het staatsburgerschap door adoptie alsmede artikel 13 inzake verkrijging van dit staatsburgerschap door het volgen van de staat van de vader of moeder. ${ }^{943}$ In al deze gevallen is in de Wet niet uitdrukkelijk bepaald, dat de betrokken persoon het Indonesisch staatsburgerschap niet kan bezitten c.q. verkrijgen, indien hij/zij daarnaast nog een andere nationaliteit bezit. Kan dit in de gevallen als in artikel 2 en artikel 13 van de Wet omschreven als een verzuim worden aangemerkt aangezien het hier van oorsprong buitenlandse kinderen betreft, anders ligt dit in het geval van artikel 1 sub b., c. en d. In de hierin omschreven gevallen komt de gebruikelijke clausule, dat de persoon in kwestie bij verkrijging van het Indonesisch staatsburgerschap geen andere nationaliteit mag bezitten, niet voor, waaruit sommige auteurs ${ }^{24}$ de mogelijkheid tot het ontstaan van bipatridie concluderen. Het gaat hier voornamelijk om kinderen, die in familierechtelijke betrekking staan tot de vader, een Indonesisch staatsburger, en krachtens het "ius sanguinis" het Indonesisch staatsburgerschap hebben verkregen. Hierbij bestaat echter de mogelijkheid, dat de moeder van deze kinderen een buitenlandse nationaliteit heeft. Bedoeld is hier het in artikel 7 van de Wet omschreven geval van een gemengd huwe$\mathrm{lijk}^{245}$, waarbij de buitenlandse vrouw niet voor het Indonesisch staatsburgerschap van haar man opteert en krachtens de nationaliteitswetgeving van haar land van oorsprong haar - buitenlandse - nationaliteit blijft behouden c.q. hiervan geen afstand doet en dientengevolge buitenlandse blijft. Hierdoor is de mogelijkheid niet uitgesloten, dat de uit dit huwelijk geboren kinderen de status van bipatride bezitten, indien de nationaliteitswetgeving van hun moeder het mogelijk maakt, dat zij naast het Indonesisch staatsburgerschap van hun vader tevens de nationaliteit van hun moeder bezitten. Zou in het hierbedoelde geval de clausule worden opgenomen, dat de kinderen naast hun Indonesisch staatsburgerschap geen andere nationaliteit mogen bezitten, dan zou dit inhouden dat deze kinderen van hun Indonesisch staatsburgerschap worden beroofd, hetgeen mijns inziens als onbillijk zou moeten worden aangemerkt! Ik ben dan ook van mening, dat het optreden van bipatridie niet altijd kan worden voorkomen c.q. dit niet steeds als een onaanvaardbare situatie kan worden aangegemerkt. Het optreden van bipatridie in het hier geschetste geval is zeker niet onwaarschijnlijk te achten, gezien de heterogeniteit waardoor de bevolking van Indonesië zich kenmerkt, hetgeen de mogelijkheid tot het aangaan van gemengde huwelijken tussen Indonesische staatsburgers en buitenlanders in zich sluit. ${ }^{946}$ Wordt bovendien afgegaan op het door Indonesië in 1984 geratificeerde Verdrag inzake de uitbanning van alle vormen van discriminatie van vrouwen van 1979, dan kan worden gewezen op het daarin opgenomen artikel

942. Ko Swan Sik en Teuku Moh. Rhadie, Nationality, p.167.

943. Wat betreft het in artikel 13 omschreven geval dient erop te worden gewezen, dat in de praktijk aan de hand van het voor dit doel uitgegeven schrijven van de Minister van Justitie emaar wordt gestreefd om het optreden van bipatridie te voorkomen. Zie $\$ 8$ van Hoofdstuk 5 .

944. Zie Ko Swan Sik en Teuku Moh. Rhadie, Nationality, p:167.

945. Zie hiervoor $\S 7.1 .1$ van Hoofdstuk 5.

946. Zie hetgeen in $\$ 2$ van Hoofdstuk 3 naar voren is gebracht. 
9 lid 2, dat inhoudt dat vrouwen gelijke rechten als mannen hebben met betrekking tot de nationaliteit van hun kinderen. Hierin kan een nadere bevestiging worden gezien van hetgeen in het voorgaande onder de aandacht is gebracht. Immers, de in bedoeld Verdrag voorkomende bepaling op deze aangelegenheid betrekking hebbende, is niet aan de voorwaarde gebonden, dat hierdoor geen bipatridie mag ontstaan. Aangezien dit Verdrag door Indonesië is geratificeerd mag worden aangenomen, dat Indonesië de daarin opgenomen bepalingen zal naleven.

Vooral artikel 8 van de Wet - dat betrekking heeft op een vrouw die Indonesisch staatsburger is en met een buitenlander is gehuwd, die in principe haar staatsburgerschap blijft behouden - is zodanig geredigeerd, dat dit het verkrijgen van de staat van bipatride openlaat, een mening door Gautama gedeeld. ${ }^{947}$ Het beleid dat door de Indonesische overheid wordt gevolgd, is niettemin erop gericht het optreden van bipatridie zoveel mogelijk te voorkomen. Dit heeft geleid tot het opnemen van een "stok achter de deur" in artikel 17 sub b, krachtens welk artikel het niet prijsgeven of opgeven van een andere nationaliteit die betrokkene naast het Indonesisch staatsburgerschap bezit, terwijl hij/zij er de gelegenheid voor krijgt, tot verlies van het Indonesisch staatsburgerschap leidt. Dit zal derhalve ook een rol gaan spelen voor de uit gemengde huwelijken geboren kinderen bij het bereiken van de meerderjarigheid. ${ }^{948}$ Bovendien leidt het bezitten van een geldig, op eigen naam luidend buitenlands paspoort of hiermede overeenkomend document ex artikel 17 sub j. eveneens tot het verloren gaan van het Indonesisch staatsburgerschap, een tweede "stok achter de deur"! Dit komt in de praktijk hierop neer, dat personen met de status van bipatride een keuze dienen te maken tussen de twee nationaliteiten die zij bezitten, wil dit niet leiden tot verlies van het Indonesisch staatsburgerschap. ${ }^{949}$ Voorts moge nog worden gewezen op artikel I van de Slotbepalingen van de Wet no. 62 van 1958, dat bepaalt dat een Indonesisch staatsburger die zich in het gebied van de Republiek Indonesie bevindt, wordt geacht geen andere nationaliteit te bezitten. Men zou dit als een uitvloeisel van het exclusiviteitsbeginsel - het beginsel, dat iedere Staat het recht heeft om personen met een meervoudige nationaliteit die tevens zijn nationaliteit bezitten, uitsluitend als zijn eigen onderdanen te behandelen - kunnen beschouwen. ${ }^{950}$ Indonesië gaat in de toepassing van dit beginsel $z 6$ ver, dat ervan wordt uitgegaan, dat de onder zijn nationaliteitswet vallende staatsburgers worden geacht geen andere nationaliteit te bezitten. ${ }^{951}$

Hoeveel waarde Indonesië hecht aan het beginsel apatridie en bipatridie te voorkomen, blijkt ook uit het feit, dat een ander door dit land aangehangen beginsel, met name het "vrouw volgt man" beginsel, moet wijken voor eerstgenoemd beginsel - zoals uit artikel

947. Gautama, Tafsiran, p.175.

948. In de in artikel 17 van de Wet opgenomen verliesgronden is de eis van meerderjarigheid niet uitdrukkelijk gestipuleerd, maar is er wel uit af te leiden.

949. Zie hiervoor $\$ 2.2$ en $\$ 2.6$ van Hoofdstuk 6 .

950. Tratnik, Het Nationaliteitsrecht, p. 37 .

951. Aan deze bepaling is niet altijd strikt de hand gehouden. Zo werd in het kader van de agrarische wetgeving, het bezitten van "hak milik" - een specifiek Indonesisch eigendomsrecht - slechts aan personen, die enkel het Indonesisch staatsburgerschap bezitten, voorbehouden. 
9 der Wet blijkt - waardoor de eenheid van nationaliteit van beide partijen wordt doorbroken.

In het internationale licht gezien, houdt het hanteren van het beginsel het optreden van apatridie te voorkomen in, dat Indonesië recht doet aan de in artikel 15 van de Universele Verklaring van de Rechten van de Mens voorkomende bepaling, dat een ieder recht heeft op een nationaliteit. Hierbij wordt het standpunt ingenomen, dat het zijn van apatride voor betrokkene een ongewenste situatie is; hij kan zich immers tot geen enkel land voor diplomatieke bescherming wenden. Omgekeerd houdt dit voor het land, waarvan hij ingezetene is in, dat hij naar geen enkel land kan worden uitgewezen. Het vermijden van apatridie is een modem verschijnsel, dat overeenkomt met de standpunten betreffende nationaliteit die heden ten dage in de internationale wereld gelden. Om het optreden van apatridie te vermijden c.q. te beperken is tot het sluiten van verdragen overgegaan, waarvan het Verdrag tot beperking der staatloosheid van 1961 kan worden genoemd ${ }^{952}$; Indonesië is echter niet tot dit Verdrag toegetreden.

\section{$\S 4$ Posinie van de gehuwde vrouw}

Met betrekking tot de positie van de gehuwde vrouw kan worden opgemerkt, dat de thans vigerende Indonesische nationaliteitswet in principe nog uitgaal van het "vrouw volgt man" beginsel. Voor een Wet die uit het jaar 1958 dateert, is dit normaal te achten. Onder de aandacht dient echter te worden gebracht, dat genoemd principe tot op de dag van heden nog altijd geldt, hetgeen mijns inziens als onaanvaardbaar is te beschouwen, gezien de ontwikkelingen die zich op het vlak van de emancipicatie van de vrouw voordoen en het gelijkgerechtigdheidbeginsel reeds toepassing vindt op verschillende gebieden van het recht! Ik ben van mening, dat de tijd is aangebroken om het "vrouw volgt man" beginsel te vervangen door het gelijkgerechtigdheidsbeginsel! Ter staving hiervan kan in eerste instantie worden gewezen op de bepalingen inzake het gemengde huwelijk, waarbij van het "vrouw volgt man" beginsel wordt afgeweken. Voorts zie ik in de door artikel 3 van de Wet geboden gelegenheid aan kinderen, uit een gemengd huwelijk geboren of buitenechtelijke kinderen die door de vader, een buitenlander zijn erkend, om bij het bereiken van de daartoe gestelde leeftijd, het staatsburgerschap van de moeder te verkrijgen een verder argument ter staving van mijn standpunt. Hierbij komt nog, het door Indonesië geratificeerde Verdrag inzake de uitbanning van alle vormen van discriminatie van vrouwen van 10 december 1979, alhoewel dit Verdrag niet geheel door Indonesië wordt nageleefd. Dit geldt met name voor de in artikel 9 van dit Verdrag voorkomende bepaling, dat noch een huwelijk met een buitenlander, noch een wijziging van nationaliteit van de echtgenoot staande huwelijk, automatisch de nationaliteit van de echtgenote verandert, haar staatloos maakt of haar dwingt de nationaliteit van haar echtgenoot aan te nemen. Krachtens artikel 9 van de Wet no. 62 van 1958 geldt namelijk het door de echtgenoot verkregen Indonesisch staatsburgerschap en het verloren gaan van dit staatsburgerschap door de echtgenoot, van rechtswege ook voor diens echtgenote! Opvallend is voorts, dat Indonesië wél 
bovengenoemd Verdrag van 1979 heeft geratificeerd, doch dit niet heeft gedaan wat betreft het Verdrag inzake de nationaliteit van de gehuwde vrouw van 20 februari 1957, ofschoon dit toch meer voor de hand ligt, aangezien Indonesië in principe nog uitgaat van het "vrouw volgt man" beginsel! 953 Ook hierin zie ik een reden, om dit beginsel te doen vervangen door het gelijkgerechtigdheidsbeginsel. Gesteld kan worden, dat de positie van de vrouw in het nationaliteitsrecht, nationaal en internationaal gezien, drie stadia doormaakt. Het eerste wordt gekenmerkt door een volstrekt afhankelijke nationaliteitsrechtelijke rechtspositie, waarbij de vrouw van rechtswege de nationaliteit verwerft en verliest die haar echtgenoot verkrijgt c.q. verliest. Tijdens het tweede stadium ontstaat onder invloed van de emancipatie van de vrouw een stelsel, waarbij het automatisme geblokkeerd wordt en de vrouw de keus krijgt om zich "vrijwillig" aan te passen aan de nationaliteit van de man en de mutaties daarin. ${ }^{954}$ Volgens Jessurun d'Oliveira is het Verdrag van 1957 een duidelijke exponent hiervan. Het laatste stadium is dat van zelfstandigheid en symmetrie: mannen en vrouwen nemen nationaliteitsrechtelijk dezelfde positie in ten opzichte van elkaar en hun kinderen. ${ }^{955}$ Wordt teruggegrepen op het Vrouwendiscriminatieverdrag van 1979, dan kan worden opgemerkt dat de eerste volzin van het daarin opgenomen artikel 9 , formele gelijkheid tussen mannen en vrouwen eist als het gaat om het verkrijgen, veranderen en behouden van nationaliteit. Van het Verdrag van 1957 kan worden gezegd dat het vooral de eenheid van het gezin wil bevorderen. Het Verdrag van 1979 is derhalve van verder strekkende aard dan het Verdrag van 1957; om met de woorden van Jessurun d' Oliveira te spreken, vormt laatstgenoemd verdrag een station op de weg tussen de volstrekte nationaliteitsrechtelijke afhankelijkheid van de vrouw naar volledige gelijkgerechtigdheid. ${ }^{956}$ In welke fase bevindt Indonesië zich wat betreft de nationaliteit van de gehuwde vrouw? Dit land heeft mijns inziens een aarzelend stapje gezet in de richting van het derde stadium, gezien hetgeen hiervoor werd uiteengezet. $\mathrm{Er}$ is dan ook veel voor te zeggen om het "vrouw volgt man" beginsel te vervangen door het gelijkgerechtigdheidsbeginsel!

Ik neem het standpunt in, dat het huwelijk van geen invloed behoort te zijn op de nationaliteit der vrouw. Ter staving hiervan zij opgemerkt, dat het "vrouw volgt man" beginsel niet strookt met het emancipatiestreven van Indonesische vrouwen en door deze vrouwen wordt afgewezen. De vrouw dient immers niet als een "willoos object" te worden aangemerkt; dit zou het geval zijn indien haar slechts wordt toegestaan om niet alleen als gevolg van de huwelijkssluiting de nationaliteit van de man te verkrijgen, maar hem ook te volgen bij eventuele verandering van de nationaliteit tijdens het huwelijk. Toepassing van het beginsel van gelijkgerechtigdheid van man en vrouw vindt

953. Zie voor het Verdrag van 1957, Trb. 1965, 218.

954. Zie hetgeen in artikel 3 van dit Verdrag is bepiald.

955. Jessurun d'Oliveira, Internationaal Recht en Vrouwen, De betekenis van het internationale recht voor vrouwen in Nederland, Zwolle, 1987, p. 281.

956. Zie Jessurun d'Oliveira, Moet het Verdrag van New York van 20 februari 1957 betreffende de nationaliteit van de gehuwde vrouw nu wel of niet worden opgezegd?, Nederlands Juristenblad, 1985, p.53. Uit dit artikel blijkt dat het Verdrag van 1957 ook in de Nederlandse literatuur niet ongemoeid is gelaten. 
bovendien reeds plaats op andere gebieden van het recht. ${ }^{957}$ Dit geeft mij aanleiding om het standpunt te huldigen, dat een artikel als artikel 9 van de Wet no. 62 van 1958 beter weggelaten kan worden en voorts geen beperkingen aan de handelingsbevoegdheid van de vrouw zoals in artikel 5 lid 2 sub h., tweede alinea en artikel 10 lid 1 bepaald, dienen te worden opgelegd. ${ }^{958}$ Wel dient acht te worden geslagen op het feit, dat als gevolg van de toepassing van het gelijkgerechtigdheidbeginsel, de gevallen van bipatridie mogelijkerwijze kunnen toenemen. Gezien het beleid van de Indonesische overheid om bipatridie tegen te gaan, zouden met het oog hierop voorzieningen dienen te worden getroffen met betrekking tot de status van uit gemengde huwelijken geboren kinderen. Wordt in dit geval bepaald, dat deze kinderen de status van de vader volgen, dan wordt hierdoor afbreuk gedaan aan het gelijkgerechtigdheidbeginsel. ${ }^{959}$ Door de Groot is een mogelijkheid aangegeven om de gelijkheid van man en vrouw met betrekking tot de nationaliteit der wettige kinderen gestalte te geven, met name door het combineren van het "ius sanguinis"-beginsel met het "ius soli"-beginsel; door deze oplossing te kiezen, zou het aantal mensen met een meervoudige nationaliteit aanzienlijk gereduceerd worden. ${ }^{960}$ Deze auteur noemt als voorbeeld het geval, dat beide ouders de Nederlandse nationaliteit bezitten waardoor hun kinderen deze nationaliteit verkrijgen, waar zij ook geboren worden. Bezit slechts één ouder het Nederlanderschap, dan dient het kind door geboorte de Nederlandse nationaliteit te verkrijgen, indien het in Nederland geboren wordt. Wordt het kind van ouders, die in nationaliteit verschillen echter in het buitenland geboren, dan dient het slechts de Nederlandse nationaliteit te verwerven, indien het anders staatloos zou zijn, of én der ouders een dienstverband met Nederland heeft. ${ }^{961}$ Een soortgelijke oplossing zou mijns inziens ook door Indonesië kunnen worden gevolgd, teneinde het aantal gevallen van bipatridie zoveel mogelijk te verminderen.

957. Dit is bijvoorbeeld het geval in het kader van de toepassing van de Agrarische Basiswet van 1960. Het gelijkgerechtigd zijn van mannen en vrouwen vormt een onderdeel van het door de Indonesische overheid gevolgde beleid, dat op diverse gebieden van het recht tot uiting komt.

958. Artikel 5 lid 2 sub $h$ tweede alinea bepaalt, dat de gehuwde vrouw geen verzoek tot naturalisatie mag indienen. Een soortgelijk verbod is opgenomen in artikel 10 lid 1 , dat bepaalt dat het de gehuwde vrouw niet is toegestasn om een verzoek ter verknijging van het Indonesisch staatsburgerschap als bedoeld in de artikelen 3 en 4 van de Wet in te dienen. Vergelijk de Rijkswet op het Nederlanderschap, dat uitgaat van de gelijkgerechtigdheid van man en vrouw en geen beperkingen ten aanzien van de handelingen van de vrouw inhoudt.

959. In dit verband kan de aandacht worden gevestigd op het in $\$ 4$ van Hoofdstuk 6 aan de orde gekomen arrest van de MA no. $156 \mathrm{~K} / \mathrm{Sip} / 1967$ van 1 mei 1968 inzake de status van een kind uit een Russische moeder en een Indonesische staatsburger in Moskou geboren. Hierbij werd door de MA de uitspraak gedaan, dat ieder kind uit een wettig huwelijk geboren, volgens Indonesisch recht de staat van zijn vader volgt.

960. De Groot, G.R., Gelijkheid van man en vrouw in het nationaliteitsrecht, preadvies uitgebracht voor de Nederlandse Vereniging voor Rechtsvergelijking, 1977, p.87.

961. Ibid. 
In de voorgaande Hoofdstukken werd een uitvoerige beschouwing gegeven over het Indonesisch nationaliteitsrecht, waarbij de verschillende aspecten daarvan werden belicht. In dit kader werd gewezen op enkele zwakke punten in de door mij behandelde Wet no. 62 van het jaar 1958 betreffende het Staatsburgerschap van Indonesië. Ik meen hierin aanleiding te mogen vinden om enkele voorstellen tot wijziging c.q. aanvulling van deze Wet te doen, die wellicht aan de verbetering daarvan zouden kunnen bijdragen.

Een eerste conclusie die uit de behandelde materie kan worden getrokken is, dat sedert de afkondiging van deze Wet een "overall"-regeling aanwezig is inzake het Indonesisch staatsburgerschap. Dit kan als een verbetering worden aangemerkt ten aanzien van de voorheen door rechtsverscheidenheid gekenmerkte regelingen inzake dit staatsburgerschap op grond waarvan het vaak niet zo eenvoudig was vast te stellen, wie Indonesisch staatsburger is, waar nog bij komt dat enkele regelingen als minder volmaakt konden worden getypeerd.

Het bovenstaande neemt echter niet weg, dat de systematiek waarvan de Wet no. 62 van 1958 uitgaat, in bepaalde opzichten voor verbetering vatbaar is. Het betreft hier in eerste instantie, de wijze van verkrijging van het Indonesisch staatsburgerschap in de Wet omschreven als "verkrijging door inwilliging van een verzoek", terwijl het hier in feite gaat om het indienen van een verzoek, als onderdeel van de geprivilegieerde naturalisatieprocedure, waarvan in de artikelen 3 en 4 van de Wet sprake is.

Verschil dient voorts te worden gemaakt tussen het indienen van een verzoek ter verkrijging van het Indonesisch staatsburgerschap door middel van (gewone, geprivilegieerde of vereenvoudigde) naturalisatie, dat afhankelijk van het regeringsbeleid kan worden ingewilligd of afgewezen enerzijds en het afleggen van een optieverklaring anderzijds. Wat betreft laatstgenoemde mogelijkheid zij onderstreept, dat het slechts zinvol is om een optieconstructie te hanteren, indien de Overheid geen vrijheid heeft om de afgelegde optieverklaring te weigeren, indien aan de objectieve optievereisten is voldaan. Met Tratnik ben ik van mening, dat een eventuele "acceptatieverklaring" slechts een declaratoir karakter dient te hebben; in alle andere gevallen wordt de nationaliteit door de Overheid verleend en is derhalve sprake van (geprivilegieerde, vereenvoudigde of gewone) naturalisatie. ${ }^{962}$ In de Wet no. 62 van 1958 is echter niet altijd duidelijk onderscheid gemaakt tussen de verkrijging van het Indonesisch staatsburgerschap middels het afleggen van een optieverklaring en het indienen van een verzoek in het kader van de naturalisatieprocedure. Dit is met name het geval in de Wet no. 3 van 1976 jo. de Regeringsverordening no. 13 van hetzelfde jaar, gericht op wijziging van artikel 18 van de Wet no. 62 van het jaar 1958. Het gaat hier om personen, die wegens langdurig verblijf in het buitenland en het gedurende die tijd niet kenbaar maken van de wens om bedoeld staatsburgerschap te behouden het Indonesisch staatsburger-

962. Tratnik, Het nationaliteitsrecht, p.29. 
schap hadden verloren, volgens de Indonesische wetgever te wijten aan omstandigheden, buiten hun schuld gelegen. Aan deze personen werd de mogelijkheid geboden genoemd staatsburgerschap te herkrijgen. Een soortgelijk geval doet zich voor met betrekking tot artikel VI van de Overgangsbepalingen van de Wet no. 62 van het jaar 1958 jo. het Besluit van de Onderminister van Defensie van 12 september 1959, waarbij aan vreemdelingen die ooit in het Indonesische leger hebben gediend, de mogelijkheid werd geboden om het Indonesisch staatsburgerschap te verkrijgen. ${ }^{963}$ Uit beide gevallen blijkt, dat niettegenstaande in de Wet van een optieverklaring wordt gesproken, in feite sprake is van vereenvoudigde naturalisatie. Het op een dergelijke manier door elkaar halen van twee manieren om het Indonesisch staatsburgerschap te verkrijgen dient mijns inziens te worden vermeden. Anders dan in de gevallen als omschreven in de artikelen 3 en 4 van de Wet, betreft het in laatstgenoemde twee gevallen echter een eenmalige mogelijkheid en hoeven de desbetreffende categorieën niet structureel in de Nationaliteitswet te worden opgenomen.

Afgezien van het voorgaande kan echter worden geconcludeerd, dat de mogelijkheid tot verkrijging van het Indonesisch staatsburgerschap door aflegging van een optieverklaring volgens de Wet no. 62 van 1958 slechts op beperkte schaal mogelijk is. Wellicht ligt hieraan de overweging ten grondslag, dat het geven van voorrang aan het doen van een verzoek tot de verkrijging van het Indonesische staatsburgerschap in het kader van de naturalisatieprocedure boven de aflegging van een hierop gerichte optieverklaring beter past in het door de Indonesische overheid gevoerde beleid, om zelf te kunnen bepalen, wie tot de kring van haar staatsburgers wordt toegelaten.

Niettegenstaande de Wet no. 62 van het jaar 1958 enkele strenge verliesbepalingen bevat, gaat deze Wet niet zover, dat zij het mogelijk maakt om als strafmaatregel het Indonesisch staatsburgerschap aan een persoon te ontnemen. Intrekking van het Indonesisch staatsburgerschap wordt beperkt tot het geval dat dit staatsburgerschap door het verstrekken van valse gegevens is verkregen. Dit ligt voor de hand; daarnaast bestaat de mogelijkheid dat de persoon in kwestie strafrechtelijk vervolgd kan worden. Interessant is dat, indien een vergelijking wordt gemaakt met de Nederlandse nationaliteitswet van 1985, deze aangelegenheid in de Indonesische nationaliteitswet beter is geregeld.

Naast de hierboven gemaakte algemene opmerkingen, geeft de Wet no. 62 van 1958 in verschillende gevallen aanleiding tot het doen van suggesties tot het wijzigen van details. Deze voorstellen zijn de volgende:

het redigeren van die bepalingen, welke de mogelijkheid tot het optreden van bipatridie openlaten op zodanige wijze, dat deze mogelijkheid wordt uitgesloten. Zo kan verschil van interpretatie ontstaan, doordat in artikel 2 en artikel 13 de gebruikelijke clausule ontbreekt, dat de persoon in kwestie bij verkrijging van het Indonesisch staatsburgerschap geen andere nationaliteit mag bezitten, waaruit

963. Het betreft hier het Besluit no. MP/E/0179/59 van 12 september 1959. 
sommige auteurs de mogelijkheid van het ontstaan van bipatridie concluderen. $\$$ In deze gevallen verdient het aanbeveling om alsnog bedoelde clausule op te nemen, teneinde het optreden van rechtsonzekerheid te voorkomen. Ter staving van de noodzaak tot opneming van bedoelde clausule diene, dat het hier om personen gaat met een van oorsprong buitenlandse nationaliteit. ${ }^{965}$ Betreft het echter gevallen, waarin het optreden van bipatridie kan worden gerechtvaardigd, dan dient in deze situatie geen wijziging te worden gebracht;

teneinde het optreden van staatloosheid te voorkomen, is het aan te bevelen om artikel 1 sub e. zodanig te wijzigen, dat niet alleen een kind het Indonesisch staatsburgerschap van de moeder volgt, indien het staatsburgerschap van de vader onbekend is, doch ook indien de vader dit niet op het kind kan overdragen. Deze aangelegenheid dient echter te worden beperkt tot kinderen, buiten Indonesië geboren;

- het op grond van artikel 1 sub f., g., h. en i. van de Wet gehanteerde beginsel van het "ius soli", ter verkrijging van het Indonesisch staatsburgerschap heeft tot doel om het optreden van apatridie zoveel mogelijk te voorkomen. In genoemde bepalingen is niettemin gén termijn gesteld betreffende het behoud van het Indonesisch staatsburgerschap, gezien de ter zake gehanteerde clausule:"....zolang de ouders niet bekend zijn/ het staatsburgerschap der ouders niet bekend is of zolang betrokkene het staatsburgerschap van zijn vader of moeder niet verkrijgt". Door het opnemen van genoemd voorbehoud, wordt de desbetreffende staatsburgers geen garantie geboden met betrekking tot het behouden van hun staatsburgerschap dat hun elk moment - ook na lange tijd - kan komen te ontvallen. Dit moet mijns inziens als een onbillijkheid worden aangemerkt. Het is dan ook aan te bevelen, om deze clausulering aan een termijn te binden. Hierbij zou de Rijkswet op het Nederland als voorbeeld kunnen worden genomen, waarin ter zake een termijn van vijf jaar wordt gehanteerd. ${ }^{966}$;

- bij de behandeling van de adoptiemogelijkheden die tot verkrijging of het verloren gaan van het Indonesisch staatsburgerschap kunnen leiden, werd gewezen op het Rondschrijven van de "Mahkamah Agung" (MA) no. 6 van het jaar 1983, dat nadere bepalingen inzake deze aangelegenheid bevat. Met dit Rondschrijven is wijziging gebracht in de bepalingen inzake een verzoek tot wettigverklaring van

964. Zie Ko Swan Sik en Teuku Moh. Rhadie, Nationality, p. 167.

965. Het streven van de Overheid om bipatridie tegen te gaan, blijkt niet alleen uit de vele, in de Wet opgenomen bepalingen om deze situatie te voorkomen, doch ook uit de artikelen 17 sub b. en j. van de Wet, die als "stok achter de deur" fungeren, om het ontstaan daarvan tegen te gaan. Artikel 17 sub b. bepaalt, dat het niet prijsgeven of opgeven van een andere nationaliteit, die de betrokken persoon naast het Indonesisch staatsburgerschap bezit, leidt tot het verloren gaan van het Indonesisch staatsburgerschap. Dit is ook het geval in het in artikel 17 sub j. omschreven geval, waartoe het bezitten op eigen naam van een nog geldig buitenlands pasponort c.q. hiermede overeenkomend document aanleiding geeft.

966. Zie artikel 3 lid 2 van deze Rijkswet. 
een adoptie van een kind, die betrekking hebben op de relatieve competentie van de "Pengadilan Negeri" zoals geregeld in artikel 2 lid 1 en artikel 17 sub d. van de onderhavige Wet. Het in het Rondschrijven bepaalde komt hierop neer, dat thans dient te worden afgegaan op de gewone verblijfplaats van het kind in kwestie, hetgeen een afwijking vormt van het in de Wet bepaalde. Ik ben echter van mening, dat een wijziging van de Wet niet kan worden doorgevoerd met een Rondschrijven van de MA, doch dit bij wet dient te geschieden;

- sommige auteurs zijn van mening, dat uit het in de slotzin van artikel 17 sub a. bepaalde a contrario kan worden geconcludeerd, dat bij vrijwillige verkrijging van een andere nationaliteit het Indonesisch staatsburgerschap van rechtswege verloren gaat, indien betrokkene buitenlands verblijft. ${ }^{967}$ Deze opvatting wordt ook door mij gedeeld. In herinnering kan worden gebracht, dat het verlies van het Indonesisch staatsburgerschap ex artikel 17 sub a. indien de betrokken persoon nog in Indonesië verblijft, niet van rechtswege optreedt, doch dit afhankelijk wordt gesteld van een daarop betrekking hebbende verklaring van de Minister van Justitie. Om wille van de rechtszekerheid verdient het aanbeveling om het van rechtswege verloren gaan van het Indonesisch staatsburgerschap bij verblijf van de betrokken persoon buitenlands uitdrukkelijk in de Wet te stipuleren. Hierbij wordt ervan uitgegaan, dat dit conform de bedoeling van de Indonesische wetgever is;

wordt ervan uitgegaan, dat verlies van het Indonesisch staatsburgerschap door vrijwillige verkrijging van een andere nationaliteit bij verblijf van de betrokken persoon buitenlands van rechtswege plaatsvindt, dan is het in artikel 17 sub e. bepaalde merkwaardig te noemen. Immers, ook in het in dit artikellid omschreven geval bevindt betrokkene zich in het buitenland en valt als zodanig buiten de gezagssfeer van de Indonesische overheid. Het opnemen van deze bepaling heeft slechts zin, indien het de betrokken persoon erom te doen is, van zijn Indonesisch staatsburgerschap te worden "bevrijd", indien ter verkrijging van een andere nationaliteit uitdrukkelijk de voorwaarde wordt gesteld, dat bedoelde persoon zijn Indonesisch staatsburgerschap dient te verliezen, hetgeen met een bewijs dient te worden gestaafd. Dient artikel 17 sub e. op deze manier worden uitgelegd, dan dient dit duidelijk uit de redactie daarvan te blijken. Het verschil met het in artikel 17 sub a. bedoelde geval - waarbij de persoon in kwestie nog in Indonesië verblijft - is hierin gelegen, dat betrokkene zich in het buitenland bevindt en derhalve buiten de gezagssfeer van de Indonesische overheid valt. De voorwaarden inzake de leeftijd en het niet staatloos worden van de betrokken persoon, kunnen worden gehandhaafd;

- in artikel 17 sub c. is slechts melding gemaakt van het verloren gaan van het Indonesisch staatsburgerschap door erkenning van een kind door een buitenlander.

967. Het betreft hier de beginzin van artikel $17 \mathrm{sub}$ a., die als volgt luidt: "het verknijgen van een andere nationaliteit door de eigen wil..." Zie Adriaanse en van der Weg, Nationaliteitswetgeving, Indonesië, p.Ib-17. Zie voorts Ko Swan Sik en Teuku Moh. Rhadie, Nationality, p.154. 
Niet bepaald is dat ook wettiging van een kind door een buitenlander tot verlies van het staatsburgerschap leidt. Omwille van de rechtszekerheid, dient dit in de Wet worden gestipuleerd.

Een "eigenaardigheid" vormt artikel 10 lid 2 van de Wet no. 62 van 1958, dat inhoudt dat verlies van het Indonesisch staatsburgerschap door een vrouw van rechtswege voor haar man komt te gelden, tenzij laatstgenoemde daardoor staatloos wordt. Deze bepaling strookt in het geheel niet met het door de wetgever gevolgde beleid, waarbij het in principe de man is, die de nationaliteit van de huwelijkspartners bepaalt. In dit verband kan de van overheidswege naar voren gebrachte verklaring bij de behandeling van het ontwerp betreffende het Indonesisch staatsburgerschap in de Volksvertegenwoordiging naar aanleiding van het in artikel 10 lid 2 bepaalde worden aangehaald. Hierbij werd de mogelijkheid geopperd, dat de hierbedoelde vrouw wellicht reeds een andere nationaliteit heeft, die mogelijkerwijze ook voor haar man geldt of dat beide partners op het moment van het verloren gaan van hun Indonesisch staatsburgerschap reeds een andere nationaliteit bezitten. Mocht dit zo zijn, dan zou dit betrokkenen - gelet op het in artikel 17 sub b. bepaalde - alleen maar goed uitkomen en is het verloren gaan van het Indonesisch staatsburgerschap slechts welkom! Dit neemt echter niet weg, dat artikel 10 lid 2 niet in de systematiek van de Wet no. 62 van 1958 past. Samenvattend meen ik dan ook te mogen stellen, dat het in artikel 10 lid 2 bepaalde, beter weggelaten kan worden.

\section{$\S 6$ Maatregelen door Indonesië buiten de nationaliteitswetgeving om op juridisch gebied te nemen}

Bij de behandeling van de Wet no. 62 van 1958 betreffende het Indonesisch staatsburgerschap is de noodzaak gebleken tot het nemen van maatregelen op juridisch gebied buiten de nationaliteitswetgeving om. Dit heeft tot doel om in leemten te voorzien en als zodanig rechtsonzekerheid weg te nemen. Het ligt niet in mijn bedoeling om diepgaand op deze aangelegenheid in te gaan, doch slechts enkele onderwerpen aan te stippen, waarop ik bij de behandeling van het Indonesisch nationaliteitsrecht ben gestoten.

Bij de behandeling van het Indonesisch staatsburgerschap werd gewezen op de noodzaak van het bestaan van een wettelijke regeling betreffende adoptie. Dat deze noodzaak wordt gevoeld, blijkt uit het oorspronkelijke ontwerp van de Indonesische Huwelijkswet, dat enkele artikelen inzake de adoptie van kinderen bevatte, waarbij de voorwaarden, wijze en gevolgen daarvan waren geregeld. Bedoelde artikelen werden uiteindelijk niet opgenomen, omdat het Islamitisch recht dit instituut niet kent c.q. daaraan geen rechtsgevolgen verbindt. Dat de behoefte aan dit instituut zich in de samenleving echter steeds meer doet gevoelen, blijkt uit het Rondschrijven van de "Mahkamah Agung" no. 6 van 1983 waarbij regels werden aangegeven, die zowel binnenlandse als internationale adoptie van kinderen betreffen. Voorts is in de Wet no. 4 van het jaar 1979 inzake het Welzijn van kinderen onder meer bepaald, dat adoptie van kinderen in het belang van het welzijn van het kind, die buiten de "adat" en het gebruik plaatsvindt, op basis van een wettelijke regeling geschiedt. Deze regeling heeft, voor zover ik heb kunnen 
nagaan, haar beslag nog niet gevonden, terwijl de behoefte daaraan zich steeds meer doet gevoelen. Zo is bijvoorbeeld voor Indonesische staatsburgers van Europese origine geen wettelijke regeling voor deze mogelijkheid voorhanden. Het verdient derhalve aanbeveling om in de behoefte aan dit instituut te voldoen, mede om wantoestanden op dit vlak te voorkomen.

Een ander geval betreft de noodzaak van het treffen van een nationale wettelijke regeling van de Burgerlijke Stand, een regeling die, alhoewel in het vooruitzicht gesteld, nog niet is afgekomen. Tot dusverre is geen uniforme regeling inzake deze aangelegenheid voorhanden; de thans geldende bepalingen zijn nog gebaseerd op de onderverdeling van de bevolking van Indonesië in bevolkingsgroepen ex artikel 163 IS en variëren onderling. ${ }^{968}$ Ook de Instructie van de Voorzitter van het Presidium van het Kabinet no. 31/U/IN/12/1966 van 27 december 1966 - aan de orde gekomen in $\S 2.1$ van Hoofdstuk 3 - heeft in feite geen wijziging in de bestaande situatie gebracht. In deze Instructie is bepaald dat in afwachting van een nationale wettelijke regeling inzake de Burgerlijke Stand, niet langer zal worden afgegaan op de onderverdeling van de bevolking van Indonesië ex de artikelen 131 en 163 IS, doch slechts onderscheid zal worden gemaakt tussen Indonesische staatsburgers en buitenlanders. In de praktijk word echter nog gebruik gemaakt van reeds bestaande akten van de Burgerlijke Stand, alhoewel niet langer melding wordt gemaakt van de desbetreffende bevolkingsgroepen. Thans wordt onderscheid gemaakt tussen Indonesische staatsburgers, buitenlanders en apatriden, evenwel onder vermelding van het staatsblad dat voor de desbetreffende bevolkingsgroep geldt. ${ }^{969}$ Ook de Huwelijkswet no. 1 van het jaar 1974 en de ter uitvoering daarvan afgekondigde Regeringsverordening no. 9 van het jaar 1975 geven geen algemene regeling voor de registratie van huwelijken en echtscheidingen, aangezien ter zake onderscheid wordt gemaakt tussen Moslims en niet-Mosiims. ${ }^{970}$ In

968. Bedoeld is hier het Reglement op het houden van registers van de Burgerlijke Stand voor Europeanen alsmede voor Indonesiërs en met hen gelijkgestelden die geheel zijn of zich vrijwillig hebben onderworpen aan het voor Europeanen yastgestelde burgerlijk en handelsrecht, Ind. Stb. 1849-25, Engelbrecht-oude stijl p.457. Voor Chinezen kan worden gewezen op het Reglement op het houden van registers van de Burgerlijke Stand, Ind. Stb. 1917-130 jo. 1919-81, Engelbrecht-oude stijl p.477. Wat betreft bepaalde groepen van de Indonesische bevolking van Java en Madoera geldt het Reglement op het houden van registers van de Burgerlijke Stand, Ind. Stb. 1920-751 jo. Ind. Stb. 1927-564, Engelbrecht-oude stijl p.497. Genoemd reglement geldt niet voor alle Indonesiêrs op Jawa en Madoera, doch is slechts van toepassing op personen van adel, ambtenaren met een daartoe vastgestelde bezoldiging, officieren van het leger en personen, die krachtens Ind. Stb. 1917-12 gedeeltelijk zijn of zich hebben onderworpen an het privaatrecht der Europeanen en afstammelingen van genoemde categorieën van personen. Voor de Registers van de Burgerlijke Stand voor gemengde huwelijken kan worden gewezen op Ind. Stb. 1904-279, Engelbrecht-oude stijl p.507 en voor Christen-Indonesiêrs op het Reglement Burgerlijke Stand, Ind. Stb. 1933-75 jo. 1936-607, Engelbrecht-oude stijl p.522. Zie voor de wettelijke onderverdeling van de bevolking van Indonesië \& 2 van Hoofdstuk 3.

969. Zie Nyoman Budijaya, Catatan Sipil di Indonesia, suatu tinjauan yuridis, Surabaya, 1987, p.56-57.

970. Zie Nyoman Budijaya, Catatan Sipil, p.4-5, waarin wordt ingegaan op de situatie ná de afkondiging van de Huwelijkswet van 1974. Zie voor deze Huwelijkswet \$ 7.1.3 van Hoofdstuk 5. Voor een overzicht van de wettelijke regelingen inzake de Burgerlijke Stand kan worden verwezen naar 
afwachting van een nationale wettelijke regeling inzake de Burgerlijke Stand, geschiedt de registratie van huwelijken en echtscheidingen voor niet-Moslims bij de kantoren van de Burgerlijke Stand volgens de bepalingen van de Wet no. 1 van 1947 jo. de Regeringsverordening no. 9 van $1975 .{ }^{971}$ Bedoeld zijn hier personen, waarvan de registratie van hun huwelijk plaatsvindt volgens de hiervoor reeds aan de orde gekomen staatsbladen inzake de Burgerlijke Stand zoals die respectievelijk voor Europeanen, Chinezen, Christen-Indonesiërs en voor gemengde huwelijken gelden. Hiernaast zijn personen genoemd, die niet aan bedoelde staatsbladen zijn onderworpen en personen, die niet onder vigeur van de voor Moslims geldende Wet no. 32 van het jaar 1954 vallen. ${ }^{972}$ Hierbij dient rekening te worden gehouden met hetgeen in artikel 47 van de Regeringsverordening no. 9 van het jaar 1975 is bepaald, met name dat met het van kracht worden van deze Regeringsverordening, de bepalingen van de in deze staatsbladen opgenomen Ordonnanties inzake het huwelijk die reeds regeling hebben gevonden in deze Verordening, niet meer van kracht zijn. In het voorgaande werd reeds gewezen op de essentiële betekenis van akten zoals geboorte- en huwelijksakten, van belang voor alle Indonesische staatsburgers, in het bijzonder voor de hiervan deel uitmakende personen van buitenlandse origine, met name om als bewijs te dienen van het zijn van Indonesisch staatsburger. De afkondiging van een nationale wettelijke regeling inzake de Burgerlijke Stand dient derhalve binnen afzienbare tijd plaats te vinden. ${ }^{973}$

In het kader van de nationaliteitsrechtelijke gevolgen van een (wettige) huwelijksvoltrekking acht ik het van nut om naar voren te brengen, dat de elementen "nationaliteit" en "godsdienst" niet altijd gescheiden kunnen worden. Betreft het bijvoorbeeld een internationaal huwelijk tussen een Indonesisch staatsburger die tevens Moslim is en een persoon van een andere nationaliteit en godsdienst, dan is voor wat betreft de nationaliteitsrechtelijke gevolgen, de nationaliteit en niet de godsdienst doorslaggevend. Wordt in dit verband de Wet no. 7 van het jaar 1989 betreffende de Godsdienstige Rechtspraak ter sprake gebracht, dan blijkt daaruit dat slechts rekening is gehouden met de godsdienst van de betrokken personen, gezien het ter zake gehanteerde criterium "personen, die de Islamitische godsdienst belijden ". Geen rekening is gehouden met de mogelijkheid, dat beide huwelijkspartners wél in godsdienst kunnen overeenkomen, doch van nationaliteit kunnen verschillen. Het betreft hier een aangelegenheid die in een land als. Indonesië met de diversiteit waardoor de bevolking gekenmerkt wordt, niet over het

970. $\rightarrow$

Sukamo, H., Himpunan lengkap Peraturan Perundang-Undangan Cakatan Sipil di Indonesia, Jakarta, 1985.

971. Voor Moslims geldt de Wet no. 32 van het jaar 1954 betreffende Registratie van Huwelijken; Verstotingen en herroeping van Verstotingen. Aan de orde gekomen in $\$ 7.1 .3$ van Hoofdstuk 5 .

972. Zie het Besluit van de Minister van Binnenlandse Zaken no. 221a van het jaar 1975 betreffende de registratie van huwelijken en echtscheidingeu bij kantoren van de Burgerlijke Stand in verband met. bet van kracht worden van de Huwelijkswet en de uitvoeringsbepalingen daarvan. Hiervoor kan worden verwezen naar Sukamo, Himpunan Lengkap, p. 180.

973. Ook de vaststelling van het Presidentiële Besluit no. 12 van het jaar 1983 inzake de Organisatie en. de Verhoging van de Bevordering van de Uitvoering van de Burgerlijke Stand en de ter uitvoering darvan vastgestelde Besluiten van de Minister van Binnenlandse Zaken hebben in de praktijk niet tot de gewenste resultaten geleid. Zie Marbun, Fungsi dan Makna, p. 148 en 150. 
hoofd mag worden gezien. Aangezien met een eventueel verschil van nationaliteit tussen personen die wél in godsdienst overeenkomen - indien bijvoorbeeld beide partners Moslim zijn - geen rekening in de onderhavige Wet is gehouden rijst de vraag, naar welk recht in dit geval bijvoorbeeld de geldigheid van een huwelijk, het wettig zijn van de daaruit geboren kinderen, echtscheiding en dergelijke dient te worden beoordeeld. Dient een als hierbedoelde aangelegenheid naar Islamitisch recht te worden beoordeeld? Kunnen zich hierbij jurisdictiegeschillen voordoen tussen Islamitisch recht en bijvoorbeeld Westers recht, indien de man onder laatstgenoemd recht valt? In Islamitische landen is het Islamitisch recht ter zake doorslaggevend. Wat Indonesië betreft, een rechtsstaat gebaseerd op de Pancasila, ligt deze aangelegenheid evenwel anders. In verband met de rechtszekerheid, is een uitspraak betreffende bedoelde aangelegenheid noodzakelijk. Voorgesteld kan derhalve worden, om dit te verwezenlijken door middel van wijziging c.q. aanvulling van de Wet no. 7 van het jaar 1989.

\section{$\S 7$ Een enkel woord tot besluit}

Alhoewel moet worden toegegeven, dat de Indonesische nationaliteitswet in bepaalde opzichten leemten vertoont en andere, daarin opgenomen bepalingen voor wijziging c.q. weglating in aanmerking komen, kan worden gesteld dat Indonesië, gezien het hanteren van enkele belangrijke, internationaal aanvaarde beginselen, nog niet zo'n gek figuur slaat. Het belang van de Wet no. 62 van 1958 ligt bovendien hierin, dat met de inwerkingtreding van deze Wet in de behoefte aan een algemeen geldende nationaliteitswet is voorzien. Dit heeft mede hiertoe geleid, dat duidelijkheid is verkregen met betrekking tot het feit, wie als Indonesisch staatsburger kan worden aangemerkt en wie als buitenlander, aangezien een ieder die het Indonesisch staatsburgerschap niet bezit, buitenlander is. Het betreft hier een belangrijk beginsel, gezien de rechten en plichten, die aan Indonesische staatsburgers toekomen, waarvan buitenlanders in principe zijn uitgesloten. 


De beweegreden om het Indonesisch nationaliteitsrecht als onderwerp voor een proefschrift te kiezen ligt hierin, dat een monografie hierover in Nederland, ondanks de langdurige banden tussen Indonesië en Nederland, ontbreekt. De invloed van deze langdurige banden manifesteert zich op diverse vlakken van de samenleving, ook op het vlak van het (nationaliteits)recht. Mijn opzet is om na te gaan hoe het Indonesische nationaliteitsrecht zich vanuit het koloniale tijdperk tot op heden heeft ontwikkeld en om voorts geruime aandacht te besteden aan het huidige Indonesisch nationaliteitsrecht, zoals uit Hoofdstuk 1 blijkt.

In Hoofdstuk 2 van deze beschouwing worden eerst enige algemene opmerkingen geplaatst. Allereerst wordt ingegaan op diverse betekenissen van het begrip "nationaliteit". Vervolgens wordt nagegaan, waarin de functie van de nationaliteit ligt. Interessant is de vraag, hoe het begrip "nationaliteit" moet worden opgevat. Hierbij zal in eerste instantie worden uitgegaan van artikel 15 van de Universele Verklaring van de Rechten van de Mens, op 10 december 1948 geproclameerd door de Algemene Vergadering der Verenigde Naties. Genoemd artikel houdt in, dat een ieder recht heeft op een nationaliteit en aan niemand willekeurig zijn nationaliteit mag worden ontnomen, noch het recht mag worden ontzegd van nationaliteit te veranderen. Het recht op een nationaliteit is voorts ook in verschillende verdragen uitdrukkelijk genoemd. Alhoewel de meningen omtrent het begrip "nationaliteit" in de literatuur variëren, ben ik van mening dat hier sprake is van een mensenrecht. Ik deel derhalve niet het in de literatuur door sommige auteurs gehuldigde standpunt, als zou het recht op een nationaliteit een "dubieus" mensenrecht zijn, dat slechts het karakter van een technisch koppelbegrip heeft, dat eerst waarde krijgt door de rechtsgevolgen die nationale of internationale rechtssystemen eraan koppelen. Dit zou inhouden, dat er geen enkel recht en geen enkele plicht is die voor het individu begripsmatig uit de nationaliteit voortvloeien. Zou dit zo zijn, dan zou men zich aan het bezit daarvan weinig gelegen hoeven laten liggen. Ik ga daarentegen uit van een staatsburgerschapsbegrip waarmede een pakket rechten en plichten op vanzelfsprekende manier samenhangt, een mening ook door andere auteurs gedeeld. Het betreft hier fundamentele rechten als het recht van toelating tot en het recht op nietuitwijzing uit het land waarvan men de nationaliteit bezit, het recht op diplomatieke bescherming door dat land en politieke rechten. In dit licht gezien, gaat het hier om de nationaliteit als inhoudelijk begrip. Wat betreft andere, niet-fundamentele rechten, fungeert de nationaliteit als aanknopingspunt, als koppelbegrip; het betreft hier rechten en plichten - die van land tot land kunnen verschillen. Dan kunnen willekeurige rechten en plichten aan de nationaliteit gekoppeld worden, die een individu zouden kunnen worden ontnomen. Wordt echter uitgegaan van het recht op een nationaliteit als mensenrecht, dan speelt de nationaliteit als inhoudelijk begrip een belangrijke rol. In dit geval kan de nationaliteit niet enkel en alleen als koppelbegrip worden getypeerd.

Voorts wordt de vraag worden besproken, of zich met betrekking tot de nationale autonomie van Staten om bepalingen vast te stellen ter regeling van de nationaliteit van hun burgers volkenrechtelijke beperkingen kunnen voordoen. Tenslotte is het van belang 
te onderzoeken wat in het algemeen de nationaliteitsrechtelijke gevolgen van gebiedsovergang kunnen zijn, een onderwerp, dat gezien de geschiedenis van Indonesië, uiterst relevant is.

De inhoud van een nationaliteit is niet aan een nationaliteitswet af te lezen; daarvoor moeten andere wetten worden geraadpleegd. Dit geldt ook voor de inhoud van het Indonesisch staatsburgerschap, waarvoor dient te worden afgegaan op het in de Grondwet van 1945 en in andere wetten bepaalde. Naast fundamentele rechten nauw met het Indonesisch staatsburgerschap verweven, zijn er ook andere rechten - en plichten waarbij dit staatsburgerschap als aanknopingspunt dient.

Hoofdstuk 3 behandelt de voorgeschiedenis van de Wet no. 62 van 1958 betreffende het Indonesisch Staatsburgerschap. Hierbij is eerst ingegaan op hetgeen voorafging aan de afkondiging van twee belangrijke wetten uit het koloniale tijdperk, met name de Wet van 1892 op het Nederlander- en Ingezetenschap en de Wet van 1910 op het Nederlandsch Onderdaanschap van niet-Nederlanders. Voór de afkondiging van de Wet van 1892 bestond een dubbele regeling inzake het nationaliteitsrecht, in casu de bepalingen opgenomen in de tweede titel van Boek 1 van het Burgerlijk Wetboek van 1838 (de artikelen 5 tot en met 12) die golden voor een ieder. Hiernaast kwam de Wet van 1850 te gelden, die het politieke Nederlanderschap regelde, waarvan de geldingssfeer echter beperkt bleef tot het Rijk in Europa en als zodanig als discriminatoir was aan te merken. Autochtone Indonesiërs en daarmede gelijkgestelden waren wel "Nederlander" doch slechts voor privaatrechtelijke doeleinden; aan deze personen kwamen namelijk geen politieke rechten toe, normaliter aan het bezit van een nationaliteit verbonden. Met de afkondiging van de Wet van 1892 kwam niet alleen een einde aan het bestaan van een dubbele regeling het Nederlanderschap betreffende; dit had voor de categorie der autochtone Indonesiërs en daarmede gelijkgestelden tot gevolg dat deze van hun "Nederlanderschap" werden beroofd en in feite een vacuüm optrad wat betreft de status van genoemde personen. Met het doel in dit vacuüm te voorzien werd de Wet van 1910 afgekondigd. De afkondiging van deze Wet had echter niet tot gevolg dat deze personen in hun "Nederlanderschap" werden hersteld; zij moesten genoegen nemen met de tweederangse status van Nederlands onderdaan niet-Nederlander. Ook deze Wet was niet van discriminatoire trekken ontbloot; zo kwamen aan autochtone Indonesiërs en daarmede gelijkgestelden geen politieke rechten in het moederland toe. Het betrof hier een opgelegde "nationaliteit", verwerping daarvan was niet mogelijk. Dit had tot gevolg, dat op basis van het "ius soli" waar deze Wet van uitging, niet alleen autochtone Indonesiërs Nederlands onderdaan waren, doch ook personen reeds in het bezit van een nationaliteit, met name Chinezen die op deze wijze bipatride werden.

Voor een goed begrip van de ontwikkelingen die uiteindelijk geleid hebben tot de afkondiging van de Wet van 1910, dient te worden gewezen op de wettelijke onderverdeling van de bevolking van Indonesiê in de bevolkingsgroepen: Europeanen, autochtone Indonesiërs en Vreemde Oosterlingen ex artikel 163 van de Indische Staatsregeling (IS). Deze onderverdeling was noodzakelijk gezien de complexiteit en heterogeniteit waardoor de bevolking van Indonesië zich kenmerkt door het naast elkaar bestaan van de verschillende etnische groeperingen, maar ook door de immigratie van Europeanen 
zoals onder meer Nederlanders, Duitsers, Fransen en Aziaten - met de term "Vreemde Oosterlingen" aangeduid - waarvan Chinezen en Arabieren deel uitmaken. Genoemde onderverdeling geschiedde ter vaststelling van het voor de respectieve groepen geldende recht. De koloniale overheid poogde voorts de geldingssfeer van het Europese recht uit te breiden, door de introductie van instituten als de toepasselijkverklaring van het voor Europeanen geldende recht op andere dan deze, de vrijwillige onderwerping aan het voor Europeanen geldende recht en het instituut van de gelijkstelling aan Europeanen. Hiemaast kon nog het instituut van de oplossing in de autochtone bevolking worden onderscheiden en dat van de gemengde huwelijken ex Ind. Stb. 1898, waaraan nationaliteitsrechtelijke consequenties waren verbonden.

Ook Indonesië werd verwikkeld in de tweede Wereldoorlog, gevolgd door de Japanse bezetting gedurende de jaren 1942-1945. Enige dagen ná de Japanse capitulatie werd op 17 augusutus 1945 de Republiek Indonesië uitgeroepen. In dit verband verdient de afkondiging van de Wet no. 3 van 1946 op het Staatsburgerschap en Ingezetenschap van Indonesië, zoals naderhand gewijzigd en aangevuld, vermelding. Deze Wet vormde de eerste nationaliteitswet van Indonesië, afgekondigd door de toenmalige Republikeinse regering, de zogenaamde Yogya-regering, doch heeft slechts kort en beperkt gegolden. Het belang van de Wet no. 3 van $1946 \mathrm{lag}$ onder meer hierin, dat burgers met de Republikeinse nationaliteit onder de geldingssfeer van de Toescheidingsovereenkomst werden gebracht. Bovendien is van deze Wet op een later tijdstip gebruik gemaakt ter vaststeling van de nationaliteit van de ingezetenen van Irian-Jaya, nadat dit gebiedsdeel aan de Republiek Indonesië was overgedragen. Ter gelegenheid van de soevereiniteitsoverdracht door Nederland aan Indonesië werd in het kader van de overeenkomsten bij de Ronde Tafel Conferentie aangegaan, de reeds genoemde Overeenkomst betreffende de Toescheiding van Staatsburgers - de Toescheidingsovereenkomst - gesloten. De Toescheidingsovereenkomst was van wezenlijk belang, omdat deze Overeenkomst enerzijds aanknoopte bij de voorheen geldende wettelijke regelingen zoals de onderverdeling van de bevolking ex artikel 163 I.S., de Wetten van 1892 en van 1910 en anderzjjds het vertrekpunt vormde van de huidige Nationaliteitswet, de Wet no. 62 van 1958 betreffende het Staatsburgerschap van Indonesië. Ook de Wet van 1910 was op bedoelde onderdeling gebaseerd, maakte met name onderscheid tussen Nederlanders, inheemse Nederlandse onderdanen niet-Nederlanders - de autochtone Indonesiërs - en uitheemse Nederlandse onderdanen niet-Nederlanders, met name Vreemde Oosterlingen en Europeanen andere dan Nederlanders. De systematiek van de Toescheidingsovereenkomst kwam, algemeen gesteld, hierop neer dat Nederlanders hun nationaliteit bleven behouden, echter het recht hadden voor het Indonesisch staatsburgerschap te opteren. Uitheemse Nederlandse onderdanen niet-Nederlanders verkregen daarentegen automatisch het Indonesisch staatsburgerschap met het recht dit te repudiëren. De Toescheidingsovereenkomst beoogde enkel een regeling te treffen voor Nederlandse onderdanen. Het feit, dat volgens de Indonesische overheid ná 27 december 1949 - de datum van de formele soevereiniteitsoverdracht - niet langer van "Nederlands onderdanen" kon worden gesproken, heeft bij de vaststelling van de nationaliteit van personen met de status van niet-Nederlands onderdaan in de praktijk tot interpretatiemoeilijkheden geleid. 
Ook door het Militaire Gezag/Oorlogsgezag waren enkele bepalingen vastgesteld, die het Indonesisch staatsburgerschap betroffen, onder meer aangaande de verknijging van een bewijsstuk inzake het bezit van dit staatsburgerschap. De door genoemd Militair Gezag c.q. Oorlogsgezag afgekondigde bepalingen inzake de positie van buitenlandse vrouwen, die ná 27 december 1949 met een Indonesisch staatsburger zijn gehuwd kwamen hierop neer, dat deze vrouwen slechts "werden behandeld" als Indonesisch staatsburger, voor zover zij in het bezit van een daarop betrekking hebbend besluit van de Minister van Justitie waren gesteld.

In Hoofdstuk 4 is op de Wet no. 62 van 1958 op het Staaatsburgerschap zélf ingegaan. Met deze Wet werden reeds verkregen rechten geëerbiedigd in die zin, dat aan de status van Indonesisch staatsburger van personen die dit reeds waren sedert de proclamatie van de onafhankelijkheid van Indonesië, niet werd getornd. Voorts is aan onzekerheden met betrekking tot het al dan niet bezitten van het Indonesisch staatsburgerschap een einde gekomen; in deze Wet zijn met name voorzieningen getroffen teneinde aan twijfelgevallen een einde te maken c.q. het bezit van het staatsburgerschap door personen als hier bedoeld, te bevestigen.

Vervolgens is ingegaan op enige belangrijke, algemene aspecten van de Wet no. 62 van 1958 , zoals het in eerste instantie uitgaan van het "ius sanguinis" en het vermijden van apatridie en bipatridie. Hierop aansluitend dient te worden opgemerkt, dat de Wet niet dermate nauwkeurig is geredigeerd, dat het optreden van bipatridie geheel is uitgesloten. Dit is met name het geval wat betreft artikel 1 sub b., c., en d., artikel 2 en artikel 13, respectievelijk betrekking hebbende op de verkrijging van het Indonesisch staatsburgerschap "iure sanguinis", door adoptie en vanwege het volgen van de staat van de vader c.q. de moeder. Het in artikel 17 sub b. en sub j. bepaalde fungeert echter als "stok achter de deur" om bipatridie tegen te gaan! In deze artikelen is in casu bepaald, dat het niet prijsgeven van een andere nationaliteit die men bezit terwijl men daartoe de gelegenheid krijgt en het bezitten van een nog geldig, op naam staand buitenlands paspoort, verlies van het Indonesisch staatsburgerschap ten gevolge heeft.

Aangezien de Indonesische overheid zich op het standpunt stelt dat bipatridie zoveel mogelijk dient te worden voorkomen, heeft dit geleid tot het sluiten van de Overeenkomst ter afwikkeling van de bipatridie tussen de Republiek Indonesië en de Volksrepubliek China. In deze Overeenkomst waren bepalingen opgenomen om aan bestaande bipatridie een einde te maken door de desbetreffende personen te verplichten een keuze tussen het staatsburgerschap van Indonesië en dat van de Volksrepubliek te maken. Op het niet maken van een keuze waren sancties gesteld in de vorm van het opleggen van één van beide nationaliteiten. In de onderhavige Overeenkomst waren bovendien bepalingen opgenomen om in de toekomst het optreden van bipatridie te voorkomen. Deze Overeenkomst - waarvan de inwerkingtreding daarvan lang op zich heeft laten wachten - is echter in 1969 unilateraal door Indonesië beëindigd. Sedert de Volksrepubliek in 1980 met een nieuwe nationaliteitswet is gekomen, waarin geen dubbel staatsburgerschap meer voor haar burgers wordt erkend - een principe met zoveel woorden bovendien vastgelegd in het ter gelegenheid van het herstel van de diplomatieke betrekkingen tussen Indonesië en de Chinese.Volksrepubliek opgestelde "Memorandum 
of Understanding" - behoren problemen rond het dubbel staatsburgerschap van personen als hier bedoeld tot het verleden. Moeilijkheden kunnen zich echter voordon wat betreft de positie van burgers van de Republiek China, het huidige Taiwan.

Hoofdstuk 5 wijdt een beschouwing aan de verschillende wijzen van verkrijging van het Indonesisch staatsburgerschap, met name krachtens het "ius sanguinis" en het "ius soli", door adoptie, door (geprivilegieerde, vereenvoudigde of gewone) naturalisatie, door of als gevolg van huwelijk, door het volgen van de staat van respectievelijk de vader of moeder en door aflegging van een daartoe strekkende verklaring (optie).

Bij verkrijging door geboorte wordt het "ius sanguinis"-beginsel vooropgesteld en vindt het "ius soli" eerst toepassing om apatridie te voorkomen. Adoptie fungeert onder bepaalde voorwaarden als rechtsgrond om het Indonesische staatsburgerschap te verkrijgen.

Verkrijging van het staatsburgerschap door geprivilegieerde naturalisatie staat open voor buiten huwelijk geboren kinderen van een vrouw die Indonesisch staatsburger is en door hun vader, een buitenlander zijn erkend en voor kinderen, geboren uit een gemengd huwelijk tussen een als hierbedoelde vrouw en een buitenlander. Aan deze kinderen, die de status van hun vader bezitten wordt de mogelijkheid geboden om het Indonesisch statsburgerschap te verwerven. Dezelfde mogelijkheid staat open voor kleinkinderen van buitenlandse immigranten; de voor deze personen geldende geboorte- en woonplaatsvereisten - gebaseerd op het "ius soli" zijn als zwaarder aan te merken dan die in het kader van de gewone naturalisatie zijn gesteld. De nadruk dient te worden gelegd op het feit, dat in beide gevallen van nationaliteitsverkrijging middels een daartoe strekkend verzoek sprake is, hetgeen impliceert dat de daartoe competente autoriteit het verzoek in kwestie al dan niet kan afwijzen!

Wat betreft de verkrijging van het Indonesisch staatsburgerschap middels (gewone) naturalisatie zijn voorwaarden gesteld om een verzoek daartoe te kunnen indienen. Wordt een als hierbedoeld verzoek ingewilligd dan dient betrokkene over te gaan tot het afleggen van de eed c.q. het uitspreken van de belofte van trouw aan de Indonesische staat c.q. te verklaren alle trouw aan een buitenlandse mogendheid prijs te geven. Hierdoor geeft de persoon in kwestie te kennen, het nieuw verworven staatsburgerschap niet alleen in juridische zin maar ook in sociologische zin te waarderen. Ook hier dient te worden benadrukt, dat verkrijging van het Indonesisch staatsburgerschap middels naturalisatie niet als een recht kan worden aangemerkt, maar het hier om een gunst gaat en het derhalve afhankelijk is van de daartoe competente autoriteit of het desbetreffende verzoek zal worden ingewilligd dan wel afgewezen. Sedert het jaar 1980 ligt de beslissing inzake het al dan niet inwilligen van naturalisatieverzoeken in de handen van de President - voorheen was dit de competentie van de Minister van Justitie - en is als zodanig op een hoger niveau getrokken.

Wat betreft de verkrijging van het Indonesisch staatsburgerschap door of als gevolg van huwelijk kan erop worden gewezen, dat Indonesië in principe nog het "vrouw volgt man" beginsel volgt. Dit wil zeggen dat de verkrijging - dan wel verlies - van dit 
staatsburgerschap door de man, van rechtswege ook voor de vrouw geldt, tenzij zij daardoor bipatride dan wel apatride zou worden. Hieruit blijkt, dat aan het beginsel om apatridie en bipatridie te voorkomen voorrang wordt gegeven boven het "vrouw volgt man" beginsel. Laatstgenoemd beginsel vindt echter geen toepassing, indien het gemengde huwelijken betreft. Een buitenlandse vrouw met een Indonesisch staatsburger gehuwd, verkrijgt niet automatisch het staatsburgerschap van de man; zij dient daarvoor te opteren. Automatische verkrijging van het Indonesisch staatsburgerschap is in het hierbedoelde geval slechts mogelijk indien aan twee voorwaarden is voldaan, met name de vrouw geen bipatride wordt en haar echtgenoot zijn Indonesisch staatsburgerschap niet prijsgeeft. Dat hier aan de man de mogelijkheid word geboden zijn staatsburgerschap middels "negatieve optie" prijs te geven, dient te worden gezien in het licht van de gedachtengang, dat wellicht slechts op deze wijze de eenheid van nationaliteit van man en vrouw behouden blijft. Hij mag hierdoor echter niet staatloos worden; het ligt voor de hand aan te nemen dat de man zijn staatsburgerschap prijsgeeft om de buitenlandse - nationaliteit van zijn vrouw te verkrijgen. Omgekeerd geldt dat een vrouw die Indonesisch staatsburger is en met een buitenlander trouwt in principe haar staatsburgerschap blijft behouden, ook al zou zij hierdoor bipatride worden.

Ook de Huwelijkswet van 1974 bevat bepalingen inzake het gemengde huwelijk, waarmede in deze Wet is bedoeld, een huwelijk tussen personen, die van nationaliteil verschillen. Ter vergelijking diene, dat in de Regeling op de Gemengde Huwelijken (RGH) ex Ind. Stb. 1898, van een veel ruimer begrip "gemengd huwelijk" wordt uitgegaan; krachtens de RGH kan van een gemengd huwelijk sprake zijn op grond van verschil in bevolkingsgroep, godsdienst, plaats en regio van de huwelijkspartners. Vór de afkondiging van de Huwelijkswet vielen gemengde huwelijken in de zin van verschil in nationaliteit ook onder de RGH. Het verschil zit hierin, dat de RGH van het "vrouw volgt man" beginsel uitgaat, anders dan de Huwelijkswel, die ter zake de Wet no. 62 van 1958 volgt.

Met betrekking tot de verkrijging van het Indonesisch staatsburgerschap wegens het volgen van de staat van de vader c.q. moeder door een kind zijn bepaalde voorwaarden gesteld, waarvan moge worden genoemd dat het kind in kwestie in Indonesië woonplaats dient te hebben en zich aldaar de facto dient te bevinden. Van deze voorwaarde kan echter worden afgeweken, indien het kind vanwege het verkrijgen van het Indonesisch staatsburgerschap door de desbetreffende ouder staatloos zou worden. Dit impliceert, dat een buitenlands verblijvend kind dat zijn (buitenlandse) nationaliteit zou verliezen vanwege het feit dat zijn vader/moeder het Indonesisch staatsburgerschap verwerft, in het hierbedoelde geval de status van Indonesisch staatsburger wordt toegekend.

Met betrekking tot de verkrijging van het Indonesisch staalsburgerschap door aflegging van een verklaring - optie - kan worden opgemerkt, dat deze mogelijkheid in de Wet slechts summier is geregeld. Hiernaast komt het voor, dat in enkele gevallen niet van optie in de zuivere betekenis kan worden gesproken, doch het in feite om vereenvoudigde naturalisatie gaat. Het gaat hier om personen, die vanwege langdurig verblijf in het buitenland en het niet te kennen hebben gegeven van de wens Indonesisch staatsburger 
te willen blijven, dit staatsburgerschap hebben verloren, volgens de Indonesische wetgever echter te wijten aan omstandigheden "buiten hun schuld". Ingevolge de Wet no. 3 van 1976, afgekondigd ter aanvulling van artikel 18 van de Wet no. 62 van 1958 ligt de oorzaak hiervan in het indertijd lopende geschil tussen Nederland en Indonesië naar aanleiding van de kwestie Irian Jaya en het daardoor niet optimaal kunnen functioneren van de Diplomatieke Vertegenwoordiging van Indonesië in Nederland. Ook voor buitenlanders in de Indonesische krijgsmacht, die deel hebben genomen aan de vrijheidsstrijd van Indonesië ter verkrijging van de onafhankelijkheid is een soortgelijke mogelijkheid opengesteld. Anders dan in het eerste geval - waarin in feite sprake was van de herkrijging van het Indonesisch staatsburgerschap - gaat het in het tweede geval om buitenlanders. Wil men toch van optie spreken, dan dient te worden benadrukt, dat het hier gevallen van "oneigenlijke" optie betreft. Waar het in feite om gaat, is nationaliteitsverkrijging door vereenvoudigde naturalisatie.

Hoofdstuk 6 handelt over de wijze van verloren gaan van het Indonesisch staatsburgerschap. Algemeen gesteld kan dit staatsburgerschap verloren gaan indien een verklaring wordt afgelegd teneinde dit prijs te geven met het doel een andere nationaliteit te verkrijgen of - eveneens middels een daarop gerichte verklaring - het verworven Indonesisch staatsburgerschap te verliezen met het doel om de oorspronkelijke status terug te krijgen. In de hier omschreven gevallen treedt verlies van het staatsburgerschap vrijwillig op, door een opzettelijk daarop gerichte handeling met een vooropgezet doel.

Hiernaast vindt verlies van staatsburgerschap ook plaats in het geval dat een kind van rechtswege deelt in het verloren gaan van het staatsburgerschap van de desbetreffende ouder en in het geval een vrouw, eveneens van rechtswege, deelt in het verloren gaan van het staatsburgerschap door haar man, onafhankelijk van de wil van de desbetreffende personen.

De Wet no. 62 van 1958 geeft nochtans ook uitdrukkelijk de gronden aan die tot verlies van het Indonesisch staatsburgerschap leiden. Hiervan kan worden genoemd, het verloren gaan van het staatsburgerschap als gevolg van het vrijwillig verkrijgen van een andere nationaliteit. Bevindt betrokkene zich echter nog in Indonesië, dan gaat zijn staatsburgerschap eerst verloren indien dit door de Minister van Justitie verloren gegaan wordt verklaard.

Ook het niet verwerpen c.q. prijsgeven van een andere nationaliteit, terwijl betrokkene daartoe de gelegenheid krijgt vormt een verliesgrond, die tot doel heeft aan de status van bipatride van de betrokken personen een einde te maken. Het betreft hier de in artikel 17 sub b. omschreven verliesgrond, in het voorgaande reeds aan de orde gekomen. Erkenning en adoptie door een buitenlander leidt voorts tot het verloren gaan van het staatsburgerschap.

Een andere verliesgrond is gelegen in de vervallenverklaring van het Indonesisch staatsburgerschap door de Minister van Justitie op verzoek van betrokkene. Alhoewel in het hierbedoelde geval de persoon in kwestie zich in hel buitenland bevindt, neemt 
dit niet weg dat hij een verzoek dient te doen om het Indonesisch staatsburgerschap te kunnen verliezen en dit derhalve niet van rechtswege plaatsvindt.

Het verrichten van bepaalde handelingen zoals het zonder toestemming van de Minister van Justie treden in vreemde krijgs- of staatsdienst dan wel in dienst van een internationale organisatie waarvan Indonesië geen lid is, leidt tot verlies van het staatsburgerschap. Andere verliesgronden zijn gelegen in het deelnemen aan de verkiezing voor een aangelegenheid van staatsrechtelijke aard ten behoeve van een vreemd land zonder daartoe verplicht te zijn, het afleggen van een eed/belofte van trouw aan een vreemde mogendheid en het in het bezit zijn van een geldig, op naam gesteld buitenlands paspoort. Laatstgenoemde verliesgrond - in artikel 17 sub j. opgenomen - heeft tevens tot doel om aan de status van bipatride van personen die deze status mogelijk bezitten, een einde te maken. Ook het langdurig in het buitenland gevestigd zijn, zonder van de wens te doen blijken het Indonesisch staatsburgerschap te willen behouden, leidt tot het verloren gaan van dit staatsburgerschap.

In Hoofdstuk 7 is ingegaan op de mogelijkheid om in het bezit van een bewijsstuk inzake het Indonesisch staatsburgerschap (de Indonesische afkorting luidt SBKRI) te komen. De desbetreffende bepalingen waren eerst streng te noemen, omdat de betrokken personen zich niet op eigen initiatief tot het Gerecht konden wenden, doch daartoe een urgentiebewijs van een instantie, die aan de status van betrokkene twijfelde, diende te worden overgelegd. Met het afkomen van de Presidentiële Instructie no. 2 van 1980 en een hierop aansluitend Gezamenlijk Besluit van de Ministers van Justitie en van Binnenlandse Zaken werd in deze situatie wijziging gebracht. Voorwaarden werden gesteld, waaruit kan worden afgeleid dat het hier voornamelijk om Indonesische staatsburgers van Chinese origine ging. Het behoeft geen nadere toelichting, dat het bezit van een SBKRI van groot belang is voor Indonesische staatsburgers van buitenlandse origine, die deze status anders dan door (geprivilegieerde, vereenvoudigde of gewone) naturalisatie of door optie hadden verkregen en derhalve niet op een bewijsstuk betreffende het bezit van het Indonesisch staatsburgerschap kunnen buigen. Dit dient te worden gezien tegen de achtergrond van de verschillende verplichtingen die voor buitenlanders gelden, waaronder het voorgeschreven bezit van een werk- of bedrijfsvergunning, registratieplicht, betalen van vreemdelingenbelasting. Door de Overheid wordt evenwel de nodige soepelheid betracht, waarbij rekening wordt gehouden met het feit dat het hier om staatsburgers gaat die deze status reeds lange tijd bezitten.

In Hoofdstuk 8 worden eerst enkele algemene conclusies uit de behandelde materie getrokken. In het kader daarvan wordt teruggekomen op het recht op een nationaliteit als mensenrecht. Voorts wordt ingegaan op de invloed van de uit het NederlandsIndische tijdperk daterende bepalingen op het huidige Indonesische nationaliteitsrecht; met de afkondiging van de Wet no. 62 van 1958 werd gepoogd van het in het koloniale tijdperk gehanteerde systeem af te stappen. Een ander onderwerp betreft het feit, dat Indonesië sedert het uitroepen van zijn onafhankelijkheid gekenmerkt is door territoirwisseling, die nationaliteitsrechtelijke vragen heeft opgeroepen. Dit heeft betrekking op de ter gelegenheid van de formele soevereiniteitsoverdracht in 1949 door Nederland aan Indonesië gesloten Toescheidingsovereenkomst, de overdracht van Irian Jaya in 1963 
aan Indonesië en het worden in 1976 van Oost-Timor tot een provincie van Indonesië. Bijzondere aandacht is geschonken aan enkele belangrijke aangelegenheden in de Wet no. 62 van 1958 geregeld, zoals het "ius sanguinis" tegenover het "ius soli", apatridie en bipatridie en de positie van de gehuwde vrouw.

Geconcludeerd kan worden, dat sedert de afkondiging van deze Wet een "overall" . regeling aanwezig is inzake het Indonesisch staatsburgerschap, hetgeen als een verbetering kan worden aangemerkt ten aanzien van de voorheen door rechtsverscheidenheid gekenmerkte regelingen, waarvan enkele als minder volmaakt kunnen worden getypeerd. Dit neemt echter niet weg, dat de systematiek waarvan de Wet no. 62 van 1958 van uitgaat, in bepaalde opzichten voor verbetering vatbaar is. Dit geldt in de eerste plaats voor de wijze van verkrijging van het Indonesisch staatsburgerschap in de Wet omschreven als "verkrijging door inwilliging van een verzoek", terwijl het in feit gaat om het indienen van een verzoek als onderdeel van de geprivilegieerde naturalisatieprocedure. Verschil dient voorts te worden gemaakt tussen het indienen van een verzoek ter verkrijging van het Indonesisch staatsburgerschap door middel van (gewone, geprivilegieerde of vereenvoudigde) naturalisatie, dat afhankelijk van het regeringsbeleid kan worden ingewilligd of afgewezen enerzijds en het afleggen van een optieverklaring anderzijds. Dit onderscheid is in de Wet no. 62 van 1958 niet altijd duidelijk gemaakt. Ook het in artikel 10 lid 2 van de Wet bepaalde strookt in het geheel niet met het door de wetgever gevolgde beleid, waarvan het in principe de man is, die de nationaliteit van de huwelijkspartners bepaalt. Dit artikel houdt in, dat verlies van het Indonesisch staatsburgerschap door een vrouw van rechtswege voor haar man geldt, tenzij laatstgenoemde daardoor staatloos wordt.

Naast de hiervoor gemaakte algemene opmerkingen, geeft de Wet no. 62 van 1958 in verschillende gevalien aanleiding tot het doen van suggesties tot wijziging van details. Deze voorstellen zijn de volgende:

het opnemen van een tijdsbepaling teneinde te garanderen, dat aan kinderen die krachtens het "ius soli" het Indonesisch staatsburgerschap hebben verkregen ter vermijding van het optreden van apatridie, dit staatsburgerschap ná de daartoe vastgestelde termijn niet meer kunnen verliezen;

het redigeren van die bepalingen, die de mogelijkheid tot het optreden van bipatridie openlaten op zodanige wijze, dat deze mogelijkheid wordt uitgesloten, uitgezonderd in die gevallen dat het optreden van bipatridie kan worden gerechtvaardigd; het opnemen van een bepaling, dat een kind het Indonesisch staatsburgerschap van de moeder niet alleen volgt als het staatsburgerschap van de vader onbekend is, doch ook indien de vader dit niet op het kind kan overdragen en het kind in kwestie buiten Indonesië geboren is;

het uitdrukkelijk stellen, dat het verloren gaan van het Indonesisch staatsburgerschap bij vrijwillige verkrijging van een andere nationaliteit en betrokkene buitenlands verblijft van rechtwege plaatsvindt;

- gelet op laatstgenoemd voorstel, zou het binden van de vervallenverklaring van het Indonesisch staatsburgerschap door de Minister van Justitie aan een daartoe strekkend verzoek van betrokkene die buitenlands verblijft slechts zin hebben, 
indien betrokkene het verloren gaan van zijn staatsburgerschap middels een daarop betrekking hebbend bewijs dient te staven. Dient het desbetreffende artikel 17 sub e. zodanig te worden uitgelegd, dan dient dit uit de redactie te blijken;

- het opnemen van een bepaling, dat ook wettiging van een kind door een buitenlander het verloren gaan van het Indonesisch staatsburgerschap ten gevolge heeft;

- de in het kader van de adoptiemogelijkheden met het Rondschrijven van de "Mahkamah Agung" van 1983 doorgevoerde wijziging met betrekking tot de relatieve competentie van de "Pengadilan Negeri" - waarbij thans wordt afgegaan op de gewone verblijfsplaats van het te adopteren kind - dient bij wet te geschieden.

Wat de status van de gehuwde vrouw betreft, ben ik van mening dat het huwelijk van generlei invloed dient te zijn op de nationaliteit van de vrouw. Ter staving hiervan kan worden opgemerkt, dat het "vrouw voigt man" beginsel niet consequent in de Wet no. 62 van 1958 is doorgevoerd en Indonesië bovendien het Verdrag inzake de uitbanning van alle vormen van discriminatie van vrouwen van 10 december 1979 heeft geratificeerd. Er is derhalve alle reden om het "vrouw volgt man" beginsel te vervangen door het gelijkgerechtigdheidsbeginsel. Zou als gevolg van de toepassing van laatstgenoemd beginsel, de mogelijkheden dat uit een gemengd huwelijk geboren kinderen de status van bipatride komen te bezitten toenemen, dan dienen in de Wet voorzieningen worden getroffen om de gelijkheid van man en vrouw met betrekking tot de nationaliteit der wettige kinderen gestalte te geven. Dit kan geschieden door het combineren van het "ius sanguinis"-beginsel met het "ius soli"-beginsel, waardoor het aantal personen met een dubbele nationaliteit gereduceerd wordt.

Afsluitend zijn enkele voorstellen gedaan tot het treffen van wettelijke maatregelen buiten de nationaliteitswetgeving om. Deze voorstellen betreffen het afkondigen van een regeling inzake de adoptie van kinderen, het treffen van een nationale regeling inzake de Burgerlijke Stand en het wijzigen van de Wet no. 7 van het jaar 1989 betreffende de Godsdienstige Rechtspraak in die zin, dat ook met een eventueel verschil in nationaliteit van personen die wél in godsdienst overeenkomen, rekening wordt gehouden.

De Wet no. 62 van 1958 kan als een soort basiswet worden gezien, omdat kennis inzake het Indonesische nationaliteitsrecht onontbeerlijk is wil men een beter begrip hebben van andere wetten, waarin van Indonesische staatsburgers en buitenlanders wordt gesproken. De Wet gaat er met name vanuit, dat een ieder die het Indonesisch staatsburgerschap niet bezit, buitenlander is. 
The motive to choose the Indonesian nationality law as the theme of a thesis is that in the Netherlands there is no monograph on this matter, in spite of the ties lasting since long between Indonesia and the Netherlands. The influence of these ties manifests itself in various fields of the society, also in the field of (nationality) law.It is my intention to investigate as to how the Indonesian nationality law has developed as of the colonial era until now and furthermore to pay considerable attention to the present Indonesian nationality law, as appears from Chapter 1.

In Chapter 2 of this contemplation first of all some general remarks are made. Initially the various meanings of the concept "nationality" are considered. Then a survey is made of what the function of nationality is. An interesting question is how the concept of nationality should be understood. Thereby in the first instance article 15 of the Universal Declaration of Human Rights proclaimed on December 10, 1948 by the United Nations General Assembly will be the starting-point. Said article implies that everybody is entitled to a nationality and nobody may arbitrarily be deprived of his nationality nor of the right to change his nationality. Although in literature the opinions as to the concept of "nationality" vary, in my opinion the right to a nationality is a human right. I therefore do not share the opinion as adopted in literature by some authors that the right to a nationality would be a "doubtful" human right that only has the character of a a technical link-concept, the value of which only comes into being through the legal effects linked up with it by national or intemational systems of law. This would imply that there is not a single right nor a single duty which for the individual arise intrinsically from nationality. Would this be the case then there would be not much need for a person to be worried as to whether or not possessing a nationality. On the contrary, I depart from a concept of nationality with which a package of rights and duties is self-evidently bound up, an opinion also shared by other authors. Here fundamental rights are referred to, such as the right of admittance to the country, the nationality of which one possesses and the right of not being expelled from such country, the right to diplomatic protection by that country, and political rights. Seen in this light, it is the nationality as a concept concerning contents that is involved here. As to other, non-fundamental rights the nationality serves as point of linkage, as linkconcept; it concers here rights - and duties - which can differ from one country to another. Any rights and duties are concerned then, which can be linked up with the nationality and which an individual could be beprived of. When, however, the right to a nationality as a human right is taken as starting-point, then the nationality as a concept concerning contents plays an important role. In this case the nationality cannot merely be typified as a link-concept.

Furthermore, the question is dealt with whether limitations of international law could occur with regard to the national autonomy of States to lay down stipulations regulating the nationality of their citizens. Finally it is of importance to investigate what in general are the consequences in the field of nationality law of transfer of territory; it concems here a subject which, in view of Indonesia's history, is a highly relevant matter. 
The contents of a nationality cannot be derived from a nationality act; for that purpose other acts should be consulted. This applies also for the contents of the Indonesian citizenship for which the stipulations laid down in the 1945 Constitution and other acts should be taken in consideration. Besides fundamental rights closely tied up with the Indonesian citizenship, there are also other rights - and duties - whereby this citizenship serves as point of linkage.

Chapter 3 deals with the previous history of Act no. 62 of the year 1958 concerming the Indonesian citizenship. In this context first of all a survey is given of the previous history of two important acts dating from the colonial era, viz. Act of the year 1892 on Dutch Nationality and Residence and the Act of the year 1910 on Dutch subjects of non-Dutchmen. Before the promulgation of Act of the year 1892 there was a dual regulation on nationality law, i.c. the stipulations inserted in the second title of Book 1 of the 1838 Civil Code (the articles 5 up to and including 12) which applied to everybody. Besides, Act of the year 1850 came into being regulating the political Dutch nationality. The sphere of validity of this Act, however, was limited to the Realm in Europe and could as such be considered discriminatory. Autochthonous Indonesians and those placed on the same footing were, indeed, "Dutchman" but only for private law purposes; notably, they were not entitled to political rights which normally are related with the possession of a nationality. The promulgation of the Act of the year 1892 did not only put an end to the existence of a double regulation conceming the Dutch nationality; for the group of autochthonous Indonesians and those placed on the same footing this had the result that they were robbed of their "Dutch nationality" and that in fact a vacuum arose as to the status of these persons. With the purpose of meeting this vacuum Act of the year 1910 was promulgated. The promulgation of this Act, however, did not result in the restoration of the "Dutchmanship" of these persons; they had to content themselves with the second-rate status of Dutch subject of non-Dutchman. This Act, too, was not devoid of discriminative traits; autochthonous Indonesian and those placed on the same footing, for instance, were not entitled to political rights in the mother country. It concerned here an imposed "nationality", repudiation of which was not possible. As a result of the promulgation of this Act, which departed from the "ius soli" principle, not only autochthonous Indonesians were Dutch subjects, but also persons who had already a nationality, namely Chinamen who in this way became persons with a dual nationality.

For a good understanding of the developments which ultimately have led to the promulgation of Act of the year 1910, reference should be made to the legal division of the population of Indonesia into the groups: Europeans, autochthonous Indonesians and Foreign Orientals ex article 163 IS (IS = Indische Staatsregeling, the Netherlands East Indies State Regulation). This division was necessary in view of the complexity and heterogeneousness which is a distinctive characteristic of the population of Indonesia, because of the coexistence of different ethnical groups, but also as a result of the immigration of Europeans such as Dutchmen, Germans, Frenchmen and the like and Asians - indicated as Foreign Orientals - such as Chinamen and Arabs. This division was made in order to determine the law applying to the respective groups. Furthermore the colonial government tried to extend the sphere of validity of European law by 
introducing institutes such as the declaration of applying the law on Europeans to others than these, the voluntary submission to the law applying to Europeans and the institute of placing on the same footing with Europeans. Besides this, the institute of the solution in the autochthonous population and the institute of mixed marriages ex State Gazette 1898 to which consequences in the field of nationality law were related, could be distinquished.

Indonesia, too, was involved in World War II, followed by the Japanese occupation during the period 1942-1945. A couple of days after Japan's capitulation the Republic of Indonesia was proclaimed on August 17, 1945. In this connection, mention should be made of the Act No. 3 of the year 1946, subsequently altered and supplemented, concerning Citizens and Residents of the Republic of Indonesia. This Act was Indonesia's first nationality act promulgated by the Republican government at that time, the socalled Yogya-government, but it was only valid during a short period of time and in a limited way. The importance of this Act laid in the fact that citizens with the Republic nationality were brought under the sphere of validity of the Assignment Agreement. Besides, at a later time this Act was used to determine the nationality of the residents of Irian Jaya, after the transfer of this territory to Indonesia. On the occasion of the formal transfer of sovereignty by the Netherlands to Indonesia, within the framework of the agreements made at the Round Table Conference, the already mentioned Agreement on the Assignment of Citizens - the Assignment Agreement - was concluded. The Assignment Agreement was of essential importance because on the one hand this Agreement linked up with the legal regulations valid previously, such as the division of the population ex article 163 IS and the Acts of the years 1892 and 1910, while on the other hand it formed the point of departure of the present Nationality act, viz. Act No. 62 of the year 1958 on the Indonesian Citizenship. Act of the year 1910, 100 , was based on the aforementioned division; distinction was made between Dutchmen, native Dutch subjects non-Dutchmen - the autochthonous Indonesians - and foreign Dutch subjects non-Dutchmen, namely Foreign Orientals and Europeans other than Dutchmen. In general, the systematics of the Assignment Agreement came to the fact, that Dutchmen retained their nationality, however, with the right to opt for the Indonesian citizenship. Foreign Dutch subjects non-Dutchmen, namely Foreign Orientals and Europeans other than Dutchmen, on the contrary, automatically acquired the Indonesian citizenship with the right to repudiate this citizenship. The Assignment Agreement, merely aimed at making a regulation for Dutch subjects. The fact, that according to the Indonesian government after December 27, 1949 - the date of the transfer of sovereignty - no longer mention could be made of "Dutch subjects", in practice gave rise to difficulties regarding the interpretation of this Agreement as to determining the nationality of persons with the status of non-Dutch subjects.

The Military/War Authority, too, laid down some stipulations concerning the Indonesian citizenship, int. al. regarding the acquisition of a certificate of evidence as to being an Indonesian citizen. The stipulations promulgated by said Military/War Authority concerning the position of foreign women married to an Indonesian citizen after December 27, 1949, came to this that these women were only "treated" as Indonesian 
citizens in so far that they had been given a decree on this matter by the Minister of Justice.

Chapter 4 deals with the Act No. 62 of the year 1958 on the Indonesian citizenship itself. With this Act rights already obtained were respected in the sense, that the status of persons who since the proclamation of independence by Indonesia already had been Indonesian citizens was maintained. Furthermore, uncertainties with regard to the question whether or not a person possesses the Indonesian citizenship have come to an end; in this Act, namely, provisions have been made with the purpose to put an end to cases of doubt c.q. to confirm the citizenship of the persons meant here.

Moreover this chapter goes into some general aspects of Act No. 62 of the year 1958, such as the fact that in the first instance the "ius sanguinis" principle is taken as point of departure and that occurrence of statelessness and dual citizenship should be avoided. Linking up with this, however, it should be noted that the Act is not formulated accurately to such an extent that dual citizenship is entirely excluded, This namely is the case as to article 1 sub b., c. and d., article 2 and article 13 , respectively referring to acquiring the Indonesian citizenship "iure sanguinis", through adoption and by way of following the father's c.q. the mother's status. The stipulations laid down in article 17 sub b. and j., however, function as "safeguard" to prevent the occurrence of dual citizenship! In these stipulations the provisions are made that not releasing another nationality a person possesses whilst the person concerned gets the opportunity to do so, and possessing a valid foreign passport in one's own name result in the loss of the Indonesian citizenship.

Since the Indonesian government takes the position, that dual citizenship should be avoided as much as possible, this led to the conclusion of the Agreement for the settlement of dual citizenship between the Republic of Indonesia and the People's Republic of China. In this Agreement stipulations were inserted in order to end dual citizenship by obliging the persons concerned to make a choice between the citizenship of the Republic of Indonesia and that of the People's Republic of China. In case of not having made a choice, sanctions were applied in the form of imposing one of both nationalities. In addition, said Agreement contained stipulations to avoid the occurrence of dual citizenship in the future. However, this Agreement - which came into force only after a long time - was terminated unilaterally by Indonesia in 1969. Since the People's Republic of China introduced a new nationality act in 1980 which includes non-recognition of dual citizenship for her citizens - a principle that, moreover, was laid down explicitly in the Memorandum of Understanding, drawn up on the occasion of the restoration of the diplomatic relations between Indonesia and the People's Republic of China - the problems around the dual citizenship of persons referred to above belong to the past now. However, dificulties may arise as to the position of citizens of the Republic of China, the present Taiwan.

Chapter 5 is dedicated to a contemplation on the different ways of acquiring the Indonesian citizenship, viz.: by virtue of "ius sanguinis" and "ius soli", through adoption, through (privileged, simplified or. common) naturalization, by way of or as 
a result of marriage, by way of following the status of respectively the father or the mother, and by making a statement as to that effect (option).

In case of acquiring the Indonesian citizenship by birth the "ius sanguinis" principle is put first, while the "ius soli" principle is only applied in order to avoid the occurrence of statelessness. Subject to specific conditions adoption functions as legal ground to acquire the Indonesian citizenship.

Acquiring the Indonesian citizenship through privileged naturalization is open to a child bom out of wedlock whose mother is an Indonesian citizen and whose father, who is a foreigner, has acknowledged him and to a child born of a mixed marriage of a woman as meant here with a foreigner. To these children who have their fathers' status, the possibily is offered to acquire the Indonesian citizenship. A similar possibility is open to grandchildren of foreign immigrants; the requirements applying to these persons as to birth and residence - based on the "ius soli" principle - are heavier than those within the framework of common naturalization. As to both aforementioned cases the fact should be emphasized that here it concerns the acquisition of nationality by means of a request submitted for that purpose, which implies that the competent authority may or may not grant it!

As to acquiring the Indonesian citizenship by means of (common) naturalization, conditions have been fixed in order to be able to submit a request to that effect. When such a request is granted, the person concerned has to take an oath or pronounce a promise of allegiance to the Indonesian state c.q. has to declare to release all loyalty to a foreign power. By doing so the person concerned intimates that he does not only appreciate the newly acquired citizenship in juridical sense but also in sociological sense. Here, too, the fact should be stressed that acquiring the Indonesian citizenship through naturalization cannot be regarded as a right since here it concerns a favour and it depends as such on the competent authority whether the relevant request will be granted or refused. Since 1980 the decision on granting or refusing a request for naturalization rests with the President - formerly the Minister of Justice - and has thus been levelled up.

As to acquiring the Indonesian citizenship by way of or as a result of marriage it should be pointed out that in principle Indonesia still follows the "woman follows husband" rule, which means that the acquiring - or losing - of this citizenship by a man ipso iure also apply to his wife, unless as a result thereof she would obtain a dual citizenship or become stateless. This shows that the principle of preventing statelessness and dual citizenship is given precedence over the "woman follows husband" principle. However, the last mentioned principle does not hold in as far as mixed marriages are concerned. A foreign woman married to an Indonesian citizen does not automatically acquire her husband's citizenship; she has to opt for that purpose. The automatic acquisition of the Indonesian citizenship is in this case only possible if two conditions have been fulfilled, viz. the woman does not obtain a dual citizenship and her husband does not release his Indonesian citizenship. The fact that the man here is given the possibility to release his citizenship by means of "negative option" should be seen in the light of the line of 
thought that only in this way the unity of nationality of husband and wife can be retained. But as a result of this the husband may not become stateless; it is only natural to presume that the man releases his citizenship in order to acquire the - foreign nationality of his wife. Contrariwise, a woman who is an Indonesian citizen and marries a foreigner in principle retains her citizenship even though as a consequence of her marriage she would acquire a dual citizenship.

The Marriage Act of the year 1974, too, includes stipulations concerning the mixed marriage, by which in this Act is meant a marriage between persons who nationalities differ one from the other. For the purpose of comparison it may be brought forward that in the "Regeling op de Gemengde Huwelijken" (RGH = Regulation on Mixed Marriages) ex State Gazette 1898 a much wider concept of "mixed mariage" is taken as starting-point; according to the RGH of a mixed marriage can be spoken when the partners concerned differ as to population group, religion, place or region. Before the promulgation of the Marriage Act mixed marriages between persons who differ in nationality also fell under the RGH. In the case meant here the difference lies in the fact that the RGH departs from the "woman follows husband" principle whereas the Marriage Act follows Act No. 62 of the year 1958.

As to acquiring the Indonesian citizenship by a child because of following the status of respectively his father or mother, certain conditions have been fixed, among which may be mentioned that the relevant child should be resided in Indonesia and should de facto be in said country. It is, however, possible to deviate from this condition in case the child, as a consequence of the fact that the relevant parent has acquired the Indonesian citizenship, would become stateless. This implies that a child staying abroad who would lose his (foreign) nationality as a result of the fact that his father/mother acquires the Indonesian citizenship, in the case meant here, too, is granted the Indonesian citizenship.

In the event of acquiring the Indonesian citizenship by making a statement - option - it may be brought forward that this possibility is regulated in the Act only summarily. Besides this it occurs, that in some cases there is no question of option in the real sense, but that in fact it concems here a simplified naturalization. It here concerns persons who as a result of residing abroad during a long period of time and not having expressed the wish to remain Indonesian citizen have lost said citizenship which, however, according to the Indonesian legislator is due to circumstances "outside their fault". On the basis of Act No. 3 of the year 1976, promulgated to supplement article 18 of Act No. 62 of the year 1958, the reason for said situation laid in the conflict going on at that time between the Netherlands and Indonesia conceming the question of Irian Jaya, for which reason the Diplomatic Representation of Indonesia in the Netherlands could not function in a proper way. A similar possibility has also been rendered to foreigners in the Indonesian armed forces who participated in Indonesia's struggle for freedom towards independence. Unlike the first case - which in fact concems the regaining of the Indonesian citizenship - in the second case it concems foreigners. If yet one likes to speak of option, than it has to be emphasized that it 
concerns here cases of option in the metaphorical meaning of the word. In fact it concerns here acquisition of nationality through simplified naturalization.

Chapter 6 deals with the way of losing the Indonesian citizenship. In general, the Indonesian citizenship can get lost when a statement is made to release this citizenship with the purpose of acquiring another nationality or - likewise by making a statement to that effect - to lose again the Indonesian citizenship acquired in order to regain the original status. In the cases described here the loss of the citizenship in question is the result of a voluntary act done on purpose with a presupposed aim.

Besides, the loss of citizenship ipso iure also takes place in case a child shares in the loss of the Indonesian citizenship of the relevant parent and in case a woman automatically shares in the loss of her husband's Indonesian citizenship, whether or not these persons do want it.

Yet, Act No. 62 of the year 1958 also explicitly indicates the grounds which lead to the loss of the Indonesian citizenship. Among those may be mentioned the loss of the citizenship as a result of voluntarily acquiring another nationality. But in case the person concerned is still in Indonesia, then his Indonesian citizenship only gets lost when the Minister of Justice has declared it lost.

Not repudiating c.q. releasing another nationality, whereas the person concerned gets the opportunity to do so, is also a ground for losing the Indonesian citizenship. This has the aim to make an end at the status of persons, having a dual citizenship. It concerns here the ground for losing the Indonesian citizenship described in article 17 sub b., already mentioned before. Also acknowledgement and adoption of a child by a foreigner result in the loss of citizenship.

Another ground for losing the Indonesian citizenship lies in the declaration, upon request of the person involved, by the Minister of Justice that the citizenship is lost. Although in this case the person concemed is staying abroad, it is none the less a fact that he has to submit a request to lose the Indonesian citizenship. This implies that this does not take place ipso iure.

There are some acts, too, which result in the loss of the Indonesian citizenship, such as without previous consent of the Minister of Justice entering foreign military or state service or the service of an international organization of which Indonesia is not a member. Other grounds for losing the Indonesian citizenship are the sharing in the election for an affair of constitutional law for the benefit of a foreign country without being obliged to do so, the taking of an oath or the pronouncing of a promise of allegiance to a foreign power, and the possession of a valid foreign passport in one's own name. The lastmentioned ground - inserted in article $17 \mathrm{sub} \mathrm{j}$. - at the same time aims at making an end to the possible occurrence of the status of persons, having a dual citizenship. Likewise, a protracted residence abroad without having expressed the wish to retain the Indonesian citizenship will lead to the loss of the Indonesian citizenship. 
In Chapter 7 the possibility of obtaining a certificate of evidence conceming the Indonesian citizenship (the Indonesian abbreviation is SBKRI) is entered into. At first, the stipulations concerned could be called stringent, because the persons involved could not apply to the Court on their own initiative, but for that purpose had to submit a declaration of urgency from an authority, who was in doubt as to the status of the relevant persons. With the issuance of Presidential Instruction no. 2 of the year 1980 followed up by a Joint Decree of the Minister of Justice and the Minister of Home Affairs this situation was altered. Conditions were fixed, from which could be derived that mainly Indonesian citizens of Chinese origin were involved here. Needless to say that the possession of a SBKRI is a matter of great importance to Indonesian citizens of foreign origin, who have acquired this status in another way than through (privileged, simplified or common) naturalization or option, and therefore cannot produce any certificate as to their being an Indonesian citizen. This should be seen in view of the various obligations imposed upon foreigners, such as the obligatory possession of a work permit or a business licence, the registration duty, the payment of foreign tax and the like. However, the Government shows proper flexibility taking account of the fact that here Indonesian citizens are involved who have had this status already during a long time.

In Chapter 8 first of all some general conclusions are drawn from the matters dealt with. Within that framework once again reference is made to the right to a nationality as a human right. Furthermore the influence of the regulations dating back to the Netherlands Indies era on the present Indonesian nationality law is referred to. With the promulgation of Act No. 62 of the year 1958 was attempted to drop the system used in the colonial era. Another subject concerns the fact that since the proclamation of her independence, Indonesia has been marked by changes of territory which raised questions in the field of nationality law, such as those in connection with the Assignment Agreement concluded on the occasion of the formal transfer of sovereignty by the Netherlands to Indonesia in 1949, the transfer of Irian Jaya to Indonesia in 1963, and the becoming a province of Indonesia of East Timor in 1969. Particular attention is given to some important matters regulated in Act No. 62 of the year 1958, such as the "ius sanguinis" principle against the "ius soli" principle, statelessness and dual citizenship, and the position of the married woman.

The conclusion may be drawn that as of the promulgation of the aforementioned Act there exists now an overall regulation as to the Indonesian citizenship, which may be considered an improvement compared with the former regulations characterized by legal diversity, a number of which may be typified as less perfect. This does not alter the fact, however, that in the systematics from which Act No. 62 of 1958 departs in certain respects there is still room for improvement. In the first place this is true for the way of acquiring the Indonesian citizenship, which in the Act is defined as "acquiring by being granted a request", whereas, in fact, it concerns the submission of a request as a part of the procedure of privileged naturalization. Furthermore, difference should be made at the one hand between the submission of a request to acquire the Indonesian citizenship by way of (common, privileged or simplified) naturalization which depending on the Government policy can be granted or refused, and on the other hand the 
making of a statement of option. In Act No. 62 of the year 1958 this distinction is not always made clear. The stipulation laid down in article 10 section 2 of the Act, too, does not at all coincide with the legislator's policy that in principle the man's status determines the nationality of the marriage couple. This article contains the provision that the loss of the Indonesian citizenship by a woman ipso iure applies to her husband, unless the latter as a result of that become stateless.

Besides the general remarks made before, Act No. 62 of the year 1958 gives in several cases reason to suggestions to alter details. These suggestions are as follows:

the insertion of a limitation of time in order to guarantee that children who have acquired the Indonesian citizenship on the basis of the "ius soli" principle so as to avoid statelessness, can no longer be deprived of this citizenship after the period of time fixed for that purpose;

the formulation of such stipulations which leave the possibility open to the occurrence of dual citizenship in such a way as to exclude this possibility, which the exception of those cases in which the occurrence of dual citizenship may be justified;

the insertion of a stipulation that a child does not only follows his mother's citizenship in case the citizenship of the father is unknown but also in case the father can not transfer his citizenship to the child and that child is born outside Indonesia;

lay down in explicit wording that voluntary acquisition of another nationality and the person concerned stays abroad ipso iure results in the loss of the Indonesian citizens;

taking into consideration the latter suggestion, the declaring lost of the Indonesian citizenship by the Minister of Justice to a request to that effect by the person concerned who stays abroad, would only be significant if said person would have to prove the loss of his citizenship by evidence. If the relevant article 17 sub e has to be interpreted in such a way, then this should clearly appear from the formulation thereof;

the insertion of a stipulation that also the legitimation of a child by a foreigner results in the loss of the Indonesian citizenship;

The alteration carried out by Circular Letter of the "Mahkamah Agung" of the year 1983 within the framework of possibilities of adoption concerning the relative competence of the "Pengadilan Negeri"- in which case now the habituel residence of the child to be adopted is taken as basis - should take place by act.

As to the status of a married woman I am of the opinion that a marriage should not, in whatever way, influence her nationality. In support of this it may be pointed out that the "woman follows husband" principle is not carried out consistently in Act No. 62 of the year 1958. Moreover Indonesia ratified the Convention on the Elimination of all forms of Discrimination against Women. Therefore, there is every reason to replace the "woman follows husband" principle by the principle of equal rights. If as a result of the application of the latter principle the possibilities would increase that children born of mixed marriages would get the status of having a dual citizenship, then in the Act 
provisions should be made which would put the equality of man and woman as to the nationality of their legal children into shape. This can be done by combining the "ius sanguinis" principle and the "ius soli" principle in such a way that the number of persons with a dual citizenship would be reduced.

In conclusion, a number of suggestions are made to take legislative measures outside the scope of the nationality legislation. These suggestions concern the promulgation of a regulation on the adoption of children, of a national regulation on the Registry Office and the alteration of Act No. 7 of the year 1989 on the Religieus Judicature, to such an extent that also a possible difference in nationality of persons who do have the same religion is taken into due account.

The Act No. 62 of the year 1958 may be seen as a kind of basic act, because knowledge of the Indonesian nationality law is indispensable if one intends to have a better understanding of other acts which deal with Indonesian citizens and foreigners. This Act, namely, departs from the principle that everyone who does not possess the Indonesian citizenship is a foreigner. 
Alasan untuk memilih hukum kebangsaan Indonesia sebagai pokok disertasi ini adalah bahwa suatu monografi tentang soal tersebut tidak terdapat di Negeri Belanda namun adanya ikatan antara Indonesia dan Negeri Belanda yang sudah berlangsung begitu lama sekalipun. Pengaruh ikatan yang sudah berlangsung lama itu tampak di berbagai-bagai bidang masyarakat, juga di bidang hukum (kebangsaan). Tujuan saya ialah hendak menyelidiki bagaimana hukum kebangsaan Indonesia berkembang sejak jaman kolonial hingga kini, lagipula untuk menaruh perhatian luas pada hukum kebangsaan Indonesia yang berlaku sekarang ini, sebagaimana ternyata dari Bab 1 .

Dalam Bab 2 tinjauan ini mula-mula diadakan beberapa perkataan umum. Satu dan lain dimulai dengan membentangkan pelbagai pengertian tentang faham "kebangsaan". Selanjutnya diselidiki apa yang menjadi pokok fungsi kebangsaan. Yang menarik perhatian ialah bagaimana faham "kebangsaan" itu harus ditafsirkan. Dalam pada itu maka yang diambil sebagai titik tolak ialah pasal 15 Pernyataan Universal Hak-Hak Manusia yang diproklamir pada tanggal 10 Desember 1948 oleh Rapat Umum Perserikatan Bangsa-Bangsa. Pasal tersebut berarti bahwa setiap orang berhak atas suatu kebangsaan dan tak seorang pun boleh dicabut kebangsaannya dengan sewenangwenang, sedangkan tak seorang pun boleh ditiadakan haknya akan mengubah kebangsaannya. Hak atas kebangsaan itu pun secara ekplisit pula disebut dalam berbagai-bagai perjanjian. Walaupun pendapat-pendapat mengenai pengertian "kebangsaan" berbedabeda dalam kepustakaan, namun saya berpendapat bahwa di sini pun yang dimaksud ialah suatu hak manusia. Maka itu saya tidak sependapat dengan pendirian yang dikemukakan oleh beberapa pengarang dalam kepustakaan ialah seolah-olah hak atas suatu kebangsaan itu adalah suatu hak manusia yang meragukan dan hanya bersifat suatu pengertian kaitan ("koppelbegrip") secara teknis belaka yang nilainya baru timbul karena akibat-akibat hukum yang dikaitkan padanya oleh sistem hukum nasional ataupun intemasional. Jalan pikiran sedemikjan itu kiranya berarti bahwa untuk seseorang tidak sekali-kali terdapat suatu hak ataupun suatu kewajiban yang dapat dipandang intrinsik pada pengertian "kebangsaan". Andaikata memang demikian adanya maka, orang pun tidak perlu menghiraukan punya tidaknya suatu kebangsaan. Sebaliknya saya berpangkal pada suatu pengertian kebangsaan dengan mana secara nyata terjalin suatu paket hak dan kewajiban. Pendirian tersebut terakhir itu dianut pula oleh pengarang-pengarang lain. Yang dimaksud di sini ialah hak-hak fundamental, yaitu hak seseorang yang berkebangsaan sesuatu negara untuk masuk negara itu dan tidak dikeluarkan dari negara tersebut, hak atas perlindungan diplomatik oleh negara itu dan hak-hak politik. Dilihat dari sudut ini, di sini kebangsaan sebagai pengertian menurut isinya itulah yang menjadi pokok. Sepanjang mengenai hak-hak lain yang bukan fundamental, maka kebangsaan berfungsi sebagai titik pertalian, sebagai pengertian kaitan; yang dimaksud di sini ialah hak-hak dan kewajiban-kewajiban - yang dapat berbedaan di masing-masing negara. Maka yang dimaksud ialah sembarang hak-hak dan kewajiban-kewajiban yang dapat dikaitkan pada kebangsaan dan yang dapat dicabut dari seorang. Akan tetapi apabila hak atas kebangsan sebagai hak manusia itu yang diambil sebagai titik tolak, maka kebangsaan sebagai 
pengertian menurut isinya itulah yang memegang peranan penting. Dalam hal ini kebangsaan tidaklah dapat dicirikan sebagai pengertian kaitan semata-mata.

Selanjutnya dibicarakan pertanyaan apakah bertalian dengan otonomi nasional negaranegara untuk menetapkan ketentuan-ketentuan untuk mengatur kebangsaan warga mereka dapat terjadi pembatasan menurut hukum antarbangsa. Pada akhirnya penting pula untuk menyelidiki secara umum konsekuensi-konsekuensi menurut hukum kebangsaan yang dapat timbul sebagai akibat peralihan wilajah; mengingat sejarah Indonesia hal tersebut sangat relevan.

Isi kebangsaan tidak nampak dari sesuatu undang-undang kebangsaan; untuk itu perlu diperiksa berbagai undang-undang lain. Ini pun berlaku pula bagi isi kewarganegaraan Indonesia; dalam hal ini harus diperiksa ketentuan-ketentuan dalam Undang-undang Dasar 1945 dan undang-undang lain-lainnya. Di samping hak-hak fundamental yang erat bersangkutan dengan kewarganegaraan Indonesia itu terdapat pula hak-hak - dan kewajiban-kewajiban - lain dimana kewarganegaraan tersebut berfungsi sebagai titik pertalian.

Dalam Bab 3 diperbincangkan segala sesuatu yang mendahului diundangkannya Undangundang No. 62 tahun 1958 tentang Kewarganegaraan Republik Indonesia. Dalam pada itu mula-mula dibahas hal-hal yang mendahului pengundangan dua undang-undang penting dari jaman kolonial, yakni "Wet van 1892 op het Nederlander- en Ingezetenschap" (Undang-undang tahun 1892 tentang Kebangsaan dan Kependudukan Belanda) dan "Wet van 1910 op het Nederlandsch Onderdaanschap van niet-Nederlanders" (Undang-undang tahun 1910 tentang Kekaulanegaraan Belanda orang-orang bukanBelanda). Sebelum pengundangan Undang-undang tahun 1892 terdapat aturan ganda mengenai hukum kebangsaan, yakni ketentuan-ketentuan titel kedua Buku I Kitab Undang-undang Hukum Perdata tahun 1838 (pasal 5 sampai dengan 12) yang berlaku terhadap setiap orang. Di samping itu terdapat Undang-undang tahun 1850 yang mengatur kebangsaan Belanda politik, tapi yang lingkungan berlakunya terbatas pada "het Rijk in Europa" (Negara di Eropa) dan dengan demikian dapat dianggap diskriminatif. Orang Indonesia pribumi dan orang yang dipersamakan dengan mereka memang berstatus "Nederlander" (orang Belanda), tetapi hanya untuk tujuan-tujuan berkenaan dengan hukum perdata; orang-orang tersebut tidak mempunyai hak-hak politik, yang biasanya bersangkut-paut dengan memiliki suatu kebangsaan. Dengan pengundangan Undang-undang tahun 1892 bukan saja berakhirlah keadaan adanya aturan ganda mengenai kebangsaan Belanda, melainkan sebagai akibat diundangkannya Undangundang tersebut golongan Indonesia pribumi dan orang yang dipersamakan dengan mereka dirampas "kebangsaan Belanda" mereka dan akibatnya adalah bahwa sebenamya terjadi sutu vakum sepanjang mengenai status orang-orang tersebut. Dengan tujuan untuk mengisi vakum tersebut diundangkanlah Undang-undang tahun 1910. Akan tetapi pengundangan Undang-undang tersebut belum juga berakibat dipulihkannya kebangsaan Belanda orang tersebut; mereka terpaksa memuaskan diri dengan status kwalitas rendahan sebagai "Nederlands onderdaan niet-Nederlander" (kaulanegara Belanda bukan Belanda). Undang-undang ini pun tidak terlepas dari ciri-ciri diskriminasi; dengan demikian orang Indonesia pribumi dan orang yang dipersamakan dengan mereka tidak 
memperoleh hak-hak politik di negara induk. Yang dimaksud disini ialah suatu "kebangsaan" yang dibebankan dan tak dapat ditolak. Akibatnya ialah bahwa berdasarkan prinsip "ius soli" yang merupakan titik tolak Undang-undang ini, maka bukan orang Indonesia pribumi saja yang menjadi kaulanegara Belanda, melainkan juga orang-orang yang sudah mempunyai sesuatu kebangsaan, yaitu orang Cina, sehingga dengan demikian mereka itu menjadi orang berdwikewarganegaraan.

Demi untuk dapat memahami perkembangan yang akhirnya menghasilkan pengundangan Undang-undang tahun 1910, perlu ditunjuk pada pembagian menurut hukum para penduduk Indonesia dalam golongan: Eropa, Indonesia pribumi dan "Vreemde Oosterlingen (orang Timur Asing) ex pasal 163 IS (Indische Staatsregeling = Peraturan Tatanegara Hindia Belanda). Pembagian tersebut perlu mengingat kompleksitas dan heterogenitas yang merupakan ciri para penduduk Indonesia sebagai akibat dari adanya berbagai-bagai suku bangsa yang hidup berdampingan, tetapi juga sebagai akibat dari adanya imigrasi orang-orang Eropa seperti orang Belanda, orang Jerman, orang Perancis dsb. dan orang-orang Asia - yang disebut dengan istilah "Vreemde Oosterlingen" itu - termasuk antara lain orang Cina dan orang Arab. Pembagian itu terjadi untuk dapat menetapkan hukum yang berlaku terhadap masing-masing golongan tersebut. Selanjutnya Pemerintah kolonial berusaha memperluas lingkungan berlakunya hukum Eropah dengan mengadakan lembaga-lembaga seperti misalnya pernyataan berlakunya hukum yang berlaku terhadap orang Eropa menjadi berlaku pula terhadap orang lain daripada orang Eropa itu, penundukan secara sukarela pada hukum yang berlaku terhadap orang Eropa dan lembaga penyamaan dengan orang Eropa. Di samping itu pun masih terdapat lembaga peleburan ke dalam masyarakat penduduk pribumi dan lembaga perkawinan campuran ex Lembara Negara tahun 1898. Dengan lembaga-lembaga tersebut terachir tersangkutlah akibat-akibat hukum kebangsaan.

Indonesia pun tersangkut pada Perang Dunia Kedua, diikuti oleh pendudukan Jepang selama tahun 1942-1945. Beberapa hari sesudah kapitulasi Jepang, maka Republik Indonesia diproklamasikan pada tanggal 17 Agustus 1945. Dalam hubungan ini perlu disebut pengundangan Undang-undang No. 3 tahun 1946 tentang Warga Negara dan Penduduk Negara Indonesia, sebagaimana kemudian diubah dan ditambah. Undangundang ini merupakan undang-undang kebangsaan Indonesia yang pertama, yang diundangkan oleh Pemerintah Republik yang lalu, yang dapat disebut PemerintahYogya. Akan tetapi Undang-undang tersebut hanya berlaku selama waktu pendek dan secara terbatas saja. Pentingnya Undang-undang tersebut antara lain terletak dalam kenyataan bahwa warga yang berkebangsaan Republik itu dibawa ke dalam lingkungan berlakunya Persetujuan perihal Pembagian Warganegara. Lagipula Undang-undang tersebut kelak kemudian digunakan untuk menetapkan kebangsaan para penduduk Irian Jaya setelah daerah tersebut diserahkan kepada Republik Indonesia. Berhubung dengan penyerahan kedaulatan secara formil oleh Negeri Belanda kepada Indonesia maka dalam rangka persetujuan-persetujuan yang diadakan pada Konperensi Meja Bundar diadakan Persetujuan perihal Pembagian Warganegara - Persetujuan Pembagian - yang telah disebut tadi. Persetujuan Pembagian tersebut banyak sekali pentingnya oleh karena pada satu pihak Persetujuan tersebut menjalin pada peraturan-peraturan hukum yang berlaku sebelumnya, antara lain pada pembagian para penduduk ex pasat 163 IS dan Undang- 
undang tahun 1892 dan 1910, sedangkan pada pihak lain Persetujuan itu merupakan titik tolak untuk undang-undang kebangsaan yang sekarang ini, yaitu Undang-undang no. 62 tahun 1958 tentang Kewarganegaraan Indonesia. Undang-undang tahun 1910 pun berdasarkan pembagian yang dimaksud itu, yaitu membeda-bedakan antara golongan Belanda, golongan kaulanegara Belanda bukan-Belanda pribumi - ialah orang Indonesia pribumi - dan golongan kaulanegara Belanda bukan-Belanda asing, yakni orang Timur Asing dan orang Eropah lain daripada orang Belanda. Dipandang secara umum maka sistematik Persetujuan Pembagian mengandung arti bahwa orang Belanda tetap berkebangsaan Belanda, tetapi berhak memilih kewarganegaraan Indonesia. Sebaliknya kaulanegara Belanda bukan-Belanda asing secara otomatis memperoleh kewarganegaraan Indonesia dengan berhak menolaknya. Persetujuan Pembagian hanya bermaksud akan mengadakan peraturan untuk kaulanegara Belanda belaka. Kenyataan bahwa sesudah tanggal 27 Desember 1949 - ialah tanggal penyerahan kedaulatan - tidak terdapat kaulanegara Belanda lagi, dalam penetapan kebangsaan orang yang berstatus bukan kaulanegara Belanda dalam praktek menimbulkan kesukaran-kesukaran interpretasi.

Oleh Penguasa Militer/Perang pun ditetapkan pula beberapa ketentuan mengenai kewarganegaraan Indonesia, yang antara lain berhubungan dengan diperolehnya suatu surat bukti kewarganegaraan Indonesia. Ketentuan-ketentuan yang diadakan oleh Penguasa Militer/Perang tersebut mengenai kedudukan wanita asing yang sesudah tanggal 27 Desember 1949 kawin dengan warganegara Indonesia mengandung arti bahwa wanita tersebut hanya "diperlakukan" sebagai warganegara Indonesia, sepanjang mereka diberi surat keputusan Menteri Kehakiman mengenai hal tersebut.

Dalam Bab 4 maka yang menjadi pokok pembicaraan ialah Undang-uridang No. 62 tahun 1958 tentang Kewarganegaraan Indonesia itu sendiri. Dengan Undang-undang ini hak-hak yang telah diperoleh lebih dahulu dihormati, dengan pengertian bahwa orang yang telah berstatus warganegara Indonesia semenjak proklamasi kemerdekaan Indonesia, status itu tetap dipertahankan. Selain itu pun berakhirlah pula segala ketidaktentuan mengenai punya tidaknya kewarganegaraan Indonesia, oleh karena dalam Undangundang ini diadakan beberapa ketentuan agar ditiadakan hal-hal yang meragukan c.q. dari orang yang dimaksud di sini ditegaskan kewarganegaraannya.

Selanjutnya dibahas beberapa segi umum dari Undang-undang No. 62 tahun 1958, antara lain bahwa dalam instansi pertama prinsip "ius sanguinis" diambil sebagai titik tolak dan selanjutnya dicegah terjadinya keadaan orang tak berkewarganegaraan atau berdwikewarganegaraan. Akan tetapi perlu diperhatikan, bahwa Undang-undang tersebut perumusannya tidaklah disusun sedemikjan telitinya sehingga terjadinya dwikewarganegaraan terkecuali sama sekali. Hal tersebut terjadi sepanjang mengenai pasal 1 sub $b$., c. dan d., pasal 2 dan pasal 13, masing-masing mengenai diperolehnya kewarganegaraan Indonesia "iure sanguinis", karena pengangkatan dan karena mengikuti status ayah c.q. ibu. Akan tetapi, ketentuan-ketentuan yang terdapat dalam pasal 17 sub b. dan sub j. berfungsi sebagai "pencegahan" untuk mencegah timbulnya dwikewarganegaraan! Dalam pasal-pasal tersebut ditentukan, bahwa apabila orang yang berkewarganegaraan lain tidak melepaskan kewarganegaraan tersebut sedangkan ia mendapat kesempatan 
untuk berbuat demikian, dan apabila orang memiliki paspor asing yang masih berlaku atas namanya, maka hilanglah kewarganegaraan Indonesia.

Karena Pemerintah Indonesia berpendirian bahwa terjadinya dwikewarganegaraan harus dicegah sebanyak mungkin maka antara Republik Indonesia dan Republik Rakyat Cina diadakan Persetujuan untuk menyelesaikan soal dwikewarganegaraan. Dalam Persetujuan tersebut diadakan ketentuan-ketentuan untuk mengakhiri adanya dwikewarganegaraan dengan cara mewajibkan orang yang bersangkutan memilih antara kewarganegaraan Republik Indonesia dan kewarganegaraan Republik Rakyat Cina. Bila orang-orang yang bersangkutan tidak melakukan pilihan maka diadakan sanksi dalam bentuk dibebankannya salah satu dari kewarganegaraan-kewarganegaraan itu kepada orang tersebut. Selain itu dalam Persetujuan tersebut diadakan ketentuan-ketentuan untuk mencegah timbulnya dwikewarganegaraan dalam masa yang akan datang. Akan tetapi Persetujuan tersebut yang mulai berlakunya memakan masa yang agak panjang - dalam tahun 1969 oleh Indonesia secara unilateral dinyatakan tidak berlaku lagi. Sementara itu dalam tahun 1980 Republik Rakyat Cina mengundangkan suatu uandang-undang kebangsaan baru yang tidak lagi mengakui dwikewarganegaraan untuk warganya. Prinsip itu pun diletakkan pula dengan jelasnya dalam "Memorandum of Understanding" yang dibuat pada kesempatan pemulihan kembali hubungan diplomatik antara Republik Indonesia dan Republik Rakyat Cina. Dengan demikian maka segala masalah sekitar dwikewarganegaraan kini sudahlah lampau. Akan tetapi mungkin timbul kesukaran sepanjang mengenai status warga Republik Cina, yang kini disebut Taiwan.

Bab 5 membahas bermacam-macam cara akan memperoleh kewarganegaraan Indonesia, ialah berdasarkan asas "ius sanguinis" dan asas "ius soli", karena pengangkatan, karena pewarganegaraan (teristimewa, yang dipermudah atau biasa), karena atau sebagai akibat dari perkawinan, karena turut ayah/ibunya dan karena pernyataan (opsi).

Dalam hal kewarganegaraan diperoleh karena kelahiran maka yang didahulukan ialah asas "ius sanguinis", sedangkan asas "ius soli" baru diterapkan demi untuk menghindarkan terjadinya tanpa kewarganegaraan. Dengan syarat-syarat tertentu pengangkatan merupakan dasar hukum untuk memperoleh kewarganegaraan Indonesia.

Diperolehnya kewarganegaraan Indonesia karena pewarganegaraan teristimewa ("geprivilegieerde") terbuka bagi anak yang lahir di luar perkawinan seorang ibu yang berstatus warganegara Indonesia dan yang diakui oleh ayahnya yang berstatus asing dan bagi anak yang lahir dari perkawinan campuran antara seorang sebagaimana dimaksud diatas dan seorang asing. Anak-anak tersebut itu yang ikut status ayahnya diberi kesempatan untuk memperoleh kewarganegaraan Indonesia. Kesempatan yang sama terbuka bagi cucu imigran asing; syarat-syarat kelahiran dan tempat kediaman berdasarkan "ius soli" dapat dianggap lebih berat daripada syarat-syarat yang diadakan dalam rangka pewarganegaraan biasa. Perlu ditekankan bahwa dalam kedua hal tersebut harus diajukan suatu permohonan untuk memperoleh kewarganegaraan Indonesia; ini berarti bahwa petugas yang berwenang dapat mengabulkan permohonan itu atau tidak!‘ 
Sepanjang mengenai diperolehnya kewarganegaraan Indonesia karena pewarganegaraan biasa ditetapkan syrat-syarat untuk dapat mengajukan permohonan untuk tudjuan tersebut. Jika permohonan sebagaimana dimaksud di sini dikabulkan, maka orang yang bersangkutan harus mengucapkan sumpah atau janji setia kepada Negara Indonesia serta menyatakan melepaskan seluruhnya segala kesetiaan kepada kekuasaan asing. Dengan demikian maka orang yang bersangkutan memberitahukan menghargai kewarganegaraan yang baru diperoleh itu bukan saja dalam arti yuridis melainkan pun dalam arti sosiologis pula. Di sini pun perlu ditekankan bahwa diperolehnya kewarganegaraan Indonesia melalui pewarganegaraan tidaklah dapat dipandang sebagai sesuatu hak tetapi merupakan suatu anugerah, jadi bergantunglah pada pihak yang berwenang apakah permohonan yang bersangkutan dikabulkan atau tidak. Sejak tahun 1980 diambilnya keputusan atas dikabulkan tidaknya permohonan pewarganegaraan berada pada Presiden - dahulu Menteri Kehakiman - jadi dengan demikian kini terletak pada tingkatan lebih tinggi.

Sepanjang mengenai diperolehnya kewarganegaraan Indonesia karena atau sebagai akibat perkawinan dapat diperhatikan bahwa Indonesia pada prinsipnya masih menganut asas "isteri ikut suami", artinya bahwa diperolehnya - atau pun hilangnya - kewarganegaraan tersebut oleh si suami karena hukum turut berlaku terhadap si isteri, kecuali jika si isteri itu oleh karenanya akan menjadi tidak berkewarganegaraan atau berdwikewarganegaraan. Maka nyatalah bahwa asas menghindarkan timbulnya status tidak berkewarganegaraan dan status berdwikewarganegaraan diutamakan daripada asas "isteri ikut suami". Akan tetapi asas tersebut terakhir tidak berlaku terhadap perkawinan campuran. Seorang wanita asing yang kawin dengan seorang warganegara Indonesia tidak secara otomatis memperoleh kewarganegaraan suaminya; wanita tersebut harus menyatakan memilih kewarganegaraan Indonesia. Memperoleh kewarganegaraan Indonesia secara otomatis dalam hal tersebut hanya mungkin bila dua syarat terpenuhi, yakni si isteri itu tidak menjadi berdwikewarganegaraan dan suaminya tidak melepaskan kewarganegaraan Indonesianya. Bahwa dalam hal ini kepada si suami diberi kesempatan untuk melepaskan kewarganegaraannya melalui "opsi negatif" ("negatieve optie") berdasarkan jalan pikiran bahwa kiranya hanya dengan cara demikianlah maka kesatuan kebangsaan suami dan isteri tetap dipertahankan. Akan tetapi dengan cara tersebut si suami tidak boleh menjadi tidak berkewarganegaraan. Sudah barang tentu dapat masuk akal bahwa si suami itu melepaskan kewarganegaraannya dengan maksud hendak memperoleh kewarganegaraan (asing) isterinya. Sebaliknya seorang wanita yang berkewarganegaraan Indonesia pada prinsipnya tetap berkewarganegaraan Indonesia apabila ia kawin dengan seorang asing, sekalipun sebagai akibat perkawinannya ia menjadi berdwikewarganegaraan.

Undang-Undang Perkawinan tahun 1974 pun bermuat ketentuan-ketentuan tentang perkawinan campuran; dalam Undang-undang ini dengan "perkawinan campuran" dimaksud perkawinan antara orang yang kebangsaannya berbedaan. Dalam RGH ("Regeling op de Gemengde Huwelijken" = Peraturan Perkawinan Campuran) ex Lembaran Negara tahun 1898 pengertian "perkawinan campuran" itu dipandang jauh lebih luas; atas dasar RGH itu maka sesuatu perkawinan dapat disebut "perkawinan campuran" berdasarkan perbedaan golongan penduduk, agama, tempat dan regio kedua teman hidup. Sebelum Undang-undang Perkawinan diundangkan, perkawinan campuran 
dalam arti perbedaan kebangsaan juga termasuk RGH itu. Dalam hal yang dimaksud di sini perbedaannya terletak dalam hal bahwa RGH berpangkal dari asas "isteri turut suami", sedangkan Undang-undang Perkawinan mengikuti Undang-undang No. 62 tahun 1958.

Sepanjang mengenai diperolehnya kewarganegaraan Indonesia karena ikut status ayah atau ibu oleh seorang anak maka ditetapkan syarat-syarat tertentu, ialah antara lain bahwa anak itu harus bertempat tinggal di Indonesia dan harus de fakto berada di Indonesia pula. Akan tetapi, ada kemungkinan untuk menyimpang dari syarat ini, ialah jika si anak itu menjadi lidak berkewarganegaraan sebagai akibat orang-tuanya memperoleh kewarganegaraan Indonesia. Ini berarti bahwa seorang anak yang berada di luar negeri dan akan kehilangan kewarganegaraannya (yang asing) akibat ayahnya/ibunya memperoleh kewarganegaraan Indonesia, maka dalam hal itu anak tersebut diberikan status kewarganegaraan Indonesia pula.

Sepanjang mengenai diperolehnya kewarganegaraan Indonesia dengan menyatakan keterangan - melalui opsi - dapat dikatakan bahwa kemungkinan ini dalam Undangundang No. 62 tahun 1958 hanya diatur secara sumir saja. Di samping itu dapat terjadi bahwa dalam beberapa hal tidak dapat dibicara dari opsi dalam arti muminya karena yang dimaksud sebenamya ialah pewarganegaraan yang dipermudah. Yang dimaksud di sini ialah orang-orang yang kehilangan kewarganegaraan Indonesianya oleh sebab mereka lama tinggal di luar negeri dan tidak memberitahukan keinginan hendak mempertahankan kewarganegaraan Indonesia sedangkan hal tersebut menurut pembuat undang-undang Indonesia terjadi di luar kesalahan orang-orang yang bersangkutan itu. Menurut Undang-undang No. 3 tahun 1976 yang diundangkan dengan tujuan menambah pasal 18 Undang-undang No. 62 tahun 1958, keadaan tersebut disebabkan oleh sengketa antara Indonesia dan Negeri Belanda mengenai soal Irian Jaya pada masa lampau yang mengakibatkan bahwa Perwakilan Diplomatik Indonesia dalam Negeri Belanda tidak dapat menjalankan tugasnya secara optimal. Kesempatan yang sedemikian itu diadakan pula terhadap orang asing dalam Angkatan Bersenjata Indonesia yang turut berjuang untuk kemerdekaan Indonesia. Lain daripada dalam hal yang disebut pertama - yang sebenarnya mengenai memperoleh kembali kewarganegaraan Indonesia - maka hal yang disebut terakhir mengenai orang asing. Bila istilah "opsi" masih hendak dipertahankan juga, maka harus ditekankan bahwa yang dimaksud di sini ialah opsi yang bukan menurut arti yang sebenarnya. Maksud yang sebenamya ialah memperoleh kebangsaan karena pewarganegaraan yang dipermudah.

Bab 6 membahas cara hilangnya kewarganegaraan Indonesia. Pada umumnya kewarganegaraan Indonesia dapat hilang dalam hal orang menyatakan keterangan untuk melepaskan kewarganegaraan tersebut dengan tujuan akan memperoleh kewarganegaraan lain atau pun - demikian pula dengan cara menyatakan keterangan untuk tujuan itu - untuk melepaskan lagi kewarganegaraan Indonesia yang diperoleh dengan maksud untuk memperoleh kembali status semula. Dalam hal-hal tersebut hilangnya kewarganegaraan itu terjadi secara sukarela karena perbuatan yang diadakan sengaja dengan tujuan yang dipertimbangkan terlebih dahulu. 
Di samping itu hilangnya kewarganegaraan dapat juga terjadi dalam hal seorang anak karena hukum turut serta dalam hilangnya kewarganegaraan orang tuanya dan dalam hal seorang isteri karena hukum turut serta dalam hilangnya kewarganegaraan suaminya terlepas dari kehendak orang-orang yang bersangkutan itu.

Akan tetapi, Undang-undang No. 62 tahun 1958 dengan tegas menunjukan pula dasardasar hukum yang mengakibatkan hilangnya kewarganegaraan. Diantaranya dapat disebut hilangnya kewarganegaraan sebagai akibat diperolehnya kebangsaan lain atas kehendak sendiri. Akan tetapi bila orang yang bersangkutan masih berada di Indonesia, maka kewarganegaraannya baru hilang bila Menteri Kehakiman menyatakan kewarganegaraan itu hilang.

Pun tidak ditolaknya c.q. tidak dilepaskannya sesuatu kebangsaan lain, sedangkan orang yang bersangkutan mendapat kesempatan untuk itu, merupakan dasar untuk hilangnya kewarganegaraan Indonesia, hal mana bertujuan hendak mengakhiri status berdwikewarganegaraan orang yang bersangkutan. Yang dimaksud di sini ialah dasar untuk hilangnya kewarganegaraan Indonesia sebagaimana dimuat dalam pasal 17 sub b. yang telah disebut tersebut di atas. Pengakuan dan pengangkatan seorang anak oleh orang asing pun mengakibatkan hilangnya kewarganegaraan.

Dasar lain untuk hilangnya kewarganegaraan Indonesia terdapat dalam hal oleh Menteri Kehakiman kewarganegaraan itu dinyatakan hilang atas permintaan orang yang bersangkutan. Walaupun dalam hal yang dikemukakan di sini orang yang bersangkutan berada di luar negeri, namun ia pun harus mengajukan juga permohonan untuk kehilangan kewarganegaraan Indonesia, sehingga hal tersebut tidak tejadi karena hukum.

Perbuatan-perbuatan tertentu, seperti misalnya tanpa izin Menteri Kehakiman masuk dinas tentara asing atau memangku jabatan dalam dinas negara asing atau dinas suatu organisasi antar-negara yang tidak dimasuki oleh Republik Indonesia sebagai anggota mengakibatkan hilangnya kewarganegaraan Indonesia. Dasar-dasar hukum lain untuk kehilangan kewarganegaraan Indonesia ialah: dengan tidak diwajibkan turut serta dalam pemilihan sesuatu yang bersifat ketatanegaraan untuk sesuatu negara asing; mengangkat sumpah atau menyatakan janji setia kepada negara asing dan mempunyai paspor dari negara asing atas namanya yang masih berlaku. Dasar hukum yang tersebut terakhir yang dimuat dalam pasal 17 sub j. - juga bertujuan hendak mengakhiri status berdwikewarganegaraan orang yang mungkin berstatus demikian. Pun dalam hal seorang lama sekali bertempat tinggal di luar negeri tanpa menyatakan keinginan hendak mempertahankan kewarganegaraan Indonesia, maka akibatnya kewarganegaraan Indonesia hilang juga.

Dalam Bab 7 dibentangkan kemungkinan untuk memperoleh suatu Surat Bukti Kewarganegaraan Republik Indonesia (SBKRI). Mula-mula ketentuan-ketentuan yang bersangkutan dapat disebut ketat, karena orang yang berkepentingan tidak dapat menghadap Peradilan atas inisiatif sendiri, melainkan harus mempunjai surat bukti urgensi dari sesuatu instansi yang meragukan akan status orang yang bersangkutan itu. Dengan ditetapkannya Instruksi Presiden No. 2 tahun 1980 yang disusul oleh suatu Surat 
Keputusan Bersama Menteri Kehakiman dan Menteri Dalam Negeri maka diadakan perubahan dalam keadaan tersebut. Diadakanlah syarat-syarat tertentu dan dari syaratsyarat tersebut dapat ditarik kesimpulan bahwa dalam hal ini yang terutama tersangkut ialah warganegara Indonesia keturunan Cina. Sudah jelaslah bahwa mempunjai SBKRI penting sekali bagi warganegara Indonesia keturunan asing yang memperoleh status tersebut dengan cara lain daripada karena pewarganegaraan (teristimewa, yang dipermudah atau biasa) atau melalui opsi dan karena itu tidak dapat menunjukkan suatu bukti mengenai status kewarganegaran Indonesia. Hal tersebut perlu dilihat dengan mengingat adanya berbagai-bagai kewajiban yang berlaku terhadap orang asing, seperti kewajiban memiliki izin kerja atau izin berusaha, kewajiban mendaftarkan diri, kewajiban membajar pajak orang asing dsb. Akan tetapi, Pemerintah dalam hal ini bertindak cukup luwes dengan memperhatikan kenyataan bahwa yang tersangkut adalah warganegara Indonesia yang sudah lama berstatus demikian.

Dalam Bab 8 terlebih dahulu ditarik beberapa kesimpulan umum dari bahan pembicaraan yang dikemukakan dalam tinjauan ini. Dalam rangka itu kembalilah dikemukakan bahwa hak atas sesuatu kebangsaan adalam hak manusia.

Selanjutnya dibentangnya pengaruh ketentuan-ketentuan yang berasal dari zaman Hindia Belanda atas hukum kebangsaan Indonesia sekarang ini; dengan diundangkannya Undang-undang no.62 tahun 1958 maka diusahakan akan meninggalkan sistem yang dianut dalam zaman kolonial. Suatu pokok lain ialah kenyataan bahwa Indonesia sejak proklamasi kemerdekaannya mengalami perubahan wilajah yang menimbulkan pertanjaan-pertanjaan hukum kebangsaan. Hal tersebut bersangkut paut dengan Persetujuan Pembagian yang diadakan berhubungan dengan penyerahan kedaulatan secara formil dalan tahun 1949 oleh Negeri Belanda kepada Indonesia, penyerahan Irian Jaya kepada Indonesia dalam tahun 1963 dan terbentuknya Timor Timur sebagai provinsi Indonesia. Perhatian khusus diberi kepada beberapa hal penting yang diatur dalam Undang-undang no. 62 tahun 1958, seperti asas "ius sanguinis" berhadapan asas "ius soli", status tidak berkewarganegaraan dan status berdwikewarganegaraan dan kedudukan wanita yang bersuami.

Dapat menarik kesimpulan bahwa sejak diundangkannya Undang-undang tersebut maka terdapat suatu aturan "overall." mengenai kewarganegaraan Indonesia, hal mana dapat dianggap sebagai kemajuan terhadap aturan-aturan dahulu yang bercirikan keanekawarnaan hukum, sedangkan beberapa di antara peraturan tersebut dapat dianggap kurang sempurna. Namun hal tersebut belumlah berarti bahwa sistematik yang menjadi titik tolak Undang-undang No. 62 tahun 1958 pada beberapa sudut tidak dapat diperbaiki. Hal ini pertama-tama berlaku terhadap cara memperoleh kewarganegaraan Indonesia seperti diuraikan dalam Undang-undang tersebut sebagai" "diperolehnya karena dikabulkannya permohonan", sedangkan yang sebenamya menjadi pokok ialah mengajukan permohonan sebagai bagian daripada prosedur pewarganegaraan teristimewa. Perlu pula dibedakan antara pada satu pihak menajukan permohonan untuk memperoleh kewarganegaraan Indonesia dengan cara pewarganegaraan (biasa, teristimewa atau yang dipermudah) yang, bergantung dari kebijaksanaan Pemerintah dapat dikabulkan atau ditolak, dan pada pihak lain dengan cara pernyataan opsi. Pembedaan tersebut tidak selalu tercantum 
dengan jelas dalam Undang-undang No. 62 tahun 1958. Pun hal yang termuat dalam pasal 10 ayat 2 dari Undang-undang tersebut sama sekali tidak cocok dengan kebijaksanaan yang dianut oleh pembuat undang-undang; menurut kebijaksanaan tersebut maka pada prinsipnya suamilah yang menentukan kebangsaan kedua teman hidup. Berdasarkan pasal tersebut hilangnya kewarganegaraan Indonesia oleh seorang wanita berlaku pula terhadap suaminya karena hukum, kecuali bila si suami itu menjadi tidak berkewarganegaraan karena itu.

Di samping catatan-catatan umum tersebut, maka Undang-undang No. 62 tahun 1958 dalam pelbagai hal memberi alasan untuk mengajukan saran untuk mengubah beberapa detail. Saran tersebut adalah sebagai berikut:

- diadakannya penentuan batas waktu demi untuk menjamin bahwa anak yang berdasarkan asas "ius soli" telah memperoleh kewarganegaraan Indonesia untuk mencegah terjadinya status tidak berkewarganegaraan, tidak dapat kehilangan kewarganegaraan tersebut sesudah jangka waktu yang ditetapkan untuk tujuan itu;

- merumuskan ketentuan-ketentuan yang memberi kesempatan untuk timbulnya dwikewarganegaraan secara demikian sehingga kesempatan tersebut ditiadakan, kecuali dalam hal-hal adanya dwikewarganegaraan dapat dibenarkan;

- diadakannya ketentuan bahwa seorang anak bukan saja ikut serta ibunya dalam status kewarganegaraan Indonesia apabila ayahnya tidak dikenal, melainkan juga apabila ayahnya tidak dapat mengalihkan kewarganegaraannya kepada anak tersebut dan anak itu lahir di luar Indonesia;

- dinyatakan dengan tegas bahwa apabila orang atas kehendak sendiri memperoleh kebangsaan lain dan orang tersebut berada di luar negeri, maka kewarganegaraan Indonesia hilang karena hukum;

- mengingat saran tersebut terakhir maka hanyalah bila orang yang berada di Juar negeri diharuskan menguatkan hilangnya kewarganegaraan Indonesianya dengan bukti tentang hal tersebut, maka ada gunanya pernyataan Menteri Kehakiman tentang kehilangan kewarganegaraan Indonesia dijalinkan pada permohonan orang yang bersangkutan itu untuk tujuan tersebut. Apabila pasal 17 sub e. harus ditafsirkan secara demikian, maka hal itu harus nampak dari numusan pasal tersebut;

- diadakannya ketentuan bahwa legalisasi anak oleh orang asing pun mengakibatkan hilangnya kewarganegaraan Indonesia pula;

- perubahan yang diadakan dengan Surat Edaran Mahkamah Agung tahun 1983 dalam rangka kemungkinan-kemungkinan pengangkatan berhubung dengan kompetensi relatif Pengadilan Negeri - dalam hal mana kini tempat tinggal biasa anak yang hendak diangkat itu diambil sebagai titik tolak - seharusnya dilaksanakan dengan undang-undang.

Sepanjang mengenai status wanita yang bersuami, maka saya berpendapat bahwa perkawinan tidak sekali-kali boleh mempengaruhi kebangsaan wanita tersebut. Untuk membuktikan hal tersebut dapat dikemukakan bahwa asas "isteri ikut suami" tidak dilaksanakan secara konsekwen dalam Undang-undang No. 62 tahun 1958, sedangkan lagipula Indonesia telah meratifikasikan Perjanjian perihal penyisian segala bentuk diskriminasi terhadap wanita ("Convention of the Elimination of all forms of Discrimi- 
nation against Women") tertanggal 10 Desember 1979. Maka cukup banyaklah alasannya agar asas "istri ikut suami" itu diganti dengan asas persamaan hak. Seandainya pelaksanaan asas tersebut terakhir menyebabkan kemungkinan akan pertambahnya anakanak yang lahir dari perkawinan campuran berstatus berdwikewarganegaraan, maka dalam Undang-undang haruslah diadakan ketentuan-ketentuan untuk mewujudkan kesamaan suami dan istri berkenaan dengan kebangsaan anak-anak yang sah. $\mathrm{Hal}$ tersebut dapat dilaksanakan dengan menggabungkan asas "ius sanguinis" dengan asas "ius soli"; dengan penggabungan tersebut maka dikurangilah jumlah orang yang berdwikewarganegaraan.

Sebagai penutup maka diajukan beberapa usul untuk mengambil tindakan-tindakan hukum di luar pengundang-undangan kebangsaan. Usul-usul tersebut mengenai pengundangan peraturan tentang pengangkatan anak, diadakannya peraturan nasional tentang Cacatan Sipil dan diubahnya Undang-undang no.7 tahun 1989 tentang Peradilan Agama sedemikian rupa sehingga diperhatikan pula perbedaan kebangsaan orang-orang yang agamanya sama.

Undang-undang No. 62 tahun 1958 dapat dipandang sebagai semacam undang-undang pokok, karena pengetahuan tentang hukum kebangsaan Indonesia itu sangat dibutuhkan untuk mempunjai pengertian lebih mendalam terhadap undang-undang lain-lainnya yang menyangkut orang warganegara Indonesia dan orang asing. Titik tolak Undang-undang tersebut ialah bahwa setiap orang yang tidak berkewarganegaraan Indonesia adalah orang asing. 



\section{NEDERLANDSCH ONDERDAANSCHAP VAN NIET-NEDERLANDERS}

Wet van den 10den Februari 1910, houdende regeling van het Nederlandsch onderdaanschap van niet-Nederlanders. ${ }^{974}$

N.S. 1910-55 jo. 27-175;

Ind. S. $1910-296$ jo. $27-418$

N.B. Bij de wet van 10 Juni 1927, N.S. 1927-175, Ind.S. 27-418, is de toepasselijkheid dezer wet uitgebreid tot de bevolking van Suriname en Curaçao.

Bij de wet nadere regelen omtrent nationaliteit en ingezetenschap, N.S. 51-593, is met terugwerking tot 27 Dec. 1949, de datum van de souvereiniteitsoverdracht, de werking van onderstaande wet beperkt tot de inwoners van Nieuw-Guinea.

Consid. Alzoo Wij in overweging genomen hebben, dat het wenschenlijk is, de kenmerken vast te stellen van het Nederlandsch Onderdaanschap van niet-Nederlanders; enz.

Artikel 1. (Gew. S. 27-418; 37-389 jo. 392). Van degenen, die de staat van Nederlander niet bezitten ingevolge de wet op het Nederlanderschap en het ingezetenschap, zijn Nederlandsche onderdanen:

le. zij, die in Ned.-Indië, Suriname of Curaçao zijn geboren uit ouders aldaar gevestigd, of is de vader niet bekend, uit eene aldaar gevestigde moeder, met dien verstande, dat deze bepaling niet geldt voor kinderen van beroepsconsuls van vreemde mogendheden of van ambtenaren van vreemde staten, door hun regeering met een officieele opdracht belast, indien die kinderen krachtens geboorte een vreemde nationaliteit bezitten;

2e. de in Ned.-Indië, in Suriname of in Curaçao geborenen:

a. wier ouders niet bekend zijn;

b. wier ouders aldaar niet gevestigd en zonder nationaliteit zijn;

c. wier ouders aldaar niet gevestigd zijn en van onbekende nationaliteit zijn, zoolang die onbekendheid duurt;

d. wier vader - hoewel niet in Ned.-Indië, Suriname of in Curaçao gevestigd onderdaan is, als in dit art. bedoeld;

e. wier moeder - hoewel niet in Ned.-Indië, Suriname of in Curaçao gevestigd onderdaan is, als in dit art. bedoeld:

1. wanneer de vader zonder nationaliteit is;

2. wanneer de vader onbekend is of van onbekende nationaliteit, zolang die onbekendheid duurt.

974. Opschrift aldus gelezen krachtens art. VIl van S. 37-389 jo. 392 . 
Een in Ned.-Indië, in Suriname of in Curaçao te vondeling gelegd kind wordt, totdat het bewijs van het tegendeel is geleverd, verondersteld te zijn geboren op het grondgebied waar het is gevonden.

3e. de echtgenoote van een onderdaan als bedoeld onder le of 2e; de vrouw, die door of ten gevolge van haar huwelijk haar nationaliteit verloren en het Nederlandsch onderdaanschap verkregen heeft, verliest dit laatste ná de ontbinding des huwelijks, indien zij op haar verzoek voorgeschreven nationaliteit terugkrijgt.

4e. de buiten Ned.-Indië, Suriname of Curaçao geboren ongehuwde kinderen van een onderdaan als bedoeld in dit artikel, zoolang die nog geen achttien jaar oud zijn;

5e. de buiten Ned.-Indië, Suriname of Curaçao uit ouders, die onderdanen zijn volgens dit artikel, geboren kinderen, wanneer zij na hun huwelijk of na het bereiken van hun achttiende jaar in het Koninkrijk gevestigd zijn of zich aldaar vestigen, benevens hunne vrouw en hunne ongehuwde kinderen, die nog geen achttien jaar oud zijn, indien zij zich mede in het Koninkrijk vestigen.

Artikel 2. (Gew. S. 37-389 jo. 392) Het in art. 1 bedoelde Nederlandsch onderdaanschap wordt verloren:

1e. door naturalisatie van een man of ongehuwde vrouw in een vreemd land.

Dat verlies strekt zich uit:

a. tot de met den genaturaliseerde gehuwde vrouw, tenzij zij door naturalisatie van haren man een vreemde nationaliteit niet deelachtig wordt noch kan worden;

b. tot de ongehuwde kinderen, die nog geen 18 jaar oud zijn, indien deze door de naturalisatie van den vader, of - is deze onbekend of overleden - van de moeder, in een vreemd land een vreemde nationaliteit deelachtig worden.

2e. door te huwen met een man, die niet valt in de termen van art. 1 onder le, 2e of $5 \mathrm{e}$, tenzij de vrouw bij het aangaan van het huwelijk met een vreemdeling diens vreemde nationaliteit niet deelachtig wordt noch kan worden;

3e. (Gew. S. 27-418) door zonder verlof van den Koning of in Ned.-Indië, Suriname of Curaçao van hem, die aldaar in 's Konings naam het algemeen bestuur uitoefent, zich te begeven in vreemde krijgs- of Staatsdienst; (Cf. K.B. 28 Dec. '51, N.S. 51-603 onder Nedsch.)

4e. (Gew. S. 29-294) voor zover het betreft personen, niet behoorende tot de inheemsche bevolking van Ned.-Indië, door in geval van verblijf in een vreemd land, na te laten zich binnen drie maanden na aankomst aan te geven bij een Nederlandschen consulairen ambtenaar in dat land en door bij voortgezet verblijf na te laten die aangifte binnen de eerste drie maanden van elk kalenderjaar te herhalen; (Voor Chineezen zie Bb. 7489)) 
5e. (Toeg. S. 37-389 jo. 392) door de vrouw, die in de gevallen bedoeld onder le en 2e van dit art. het Nederlandsch onderdaanschap heeft behouden, zoodra zij alsnog de vreemde nationaliteit van haar man verkrijgt;

6e. (Toeg. S. 37-389 jo. 392) door vervallenverklaring, welke naar gelang de betrokkene buiten Ned.-Indië, Suriname en Curaçao, dan wel binnen een dezer gebiedsdeelen van het Koninkrijk der Nederlanden geboren is, wordt uitgesproken door Ons dan wel Onzen Gouverneur-Generaal, onderscheidenlijk Onzen Gouverneur, ten verzoeke van den meerderjarige man of ongehuwde vrouw, die naast het Nederlandsch onderdaanschap een vreemde nationaliteit bezit, beide heeft verkregen zonder den wil daartoe kenbaar te hebben gemaakt en gedurende de laatste vijf jaren gewoon- en hoofdverblijf buitenlands heeft.

(Gew. S. 37-389 jo. 392) De onder 4e bedoelde aangifte door den man of vader voor zijne vrouw of kinderen en door de weduwe voor hare kinderen geldt voor eigen aangifte van dezen.

(Ing. S 37-389 jo. 392) De vrouw, die door of tengevolge van haar huwelijk het Nederlandsch onderdaanschap verloren heeft, bekomt dat door de ontbinding van haar huwelijk terug, mits zij binnen het jaar daarna haren wil om dat onderdaanschap terug te bekomen aan den Burgemeester harer woonplaats in het Rijk of aan den voor het ressort harer woonplaats in Ned.-Indië, in Suriname of in Curaçao door Onzen Gouverneur-Generaal, onderscheidenlijk Onzen Gouverneur aangewezen ambtenaar of aan den Nederlandschen gezant of een Nederlandschen consulairen ambtenaar in het Land, waar zij woont, te kennen geeft.

(Gew. S. 27-418; 37-389, 392) Wie volgens het onder 4e bepaalde het Nederlandsch onderdaanschap heeft verloren en daarna niet in omstandigheden is komen te verkeeren als bedoeld onder le, $2 \mathrm{e}$ of $3 \mathrm{e}$, herkrijgt het door vestiging in het Koninkrijk.

Artikel 3. (Gew. S. 27-418) Deze wet is ook verbindend voor Ned.-Indië, Suriname en Curaçao. (Zie aant. onder opschrift) 



\section{THE PRESIDENT OF THE REPUBLIC OF INDONESIA}

Considering: that for the sake of consolidating the position of the State of the Republic of Indonesia it is of the greatest importance to lay down a regulation which provides for the citizenship and the legal position of residents of the State of the Republic of Indonesia;

With a view to: article 26 , article 20 section 1 , in relation to article IV of the Transitional Regulation of the Constitution and the Proclamation of the Vice-President of 16-10-1945 No. X;

With the approval of the Working Committee of the Central National Commission;

$$
\text { H A S D E C I D E D; }
$$

To enact the following regulation:

\section{THE ACT CONCERNING THE CITIZENS AND RESIDENTS OF THE STATE OF THE REPUBLIC OF INDONESIA}

\section{Article 1.}

Indonesia citizen is:

a. an autochthon residing within the territory of the Indonesian State;

b. a person who does not fall under the abovementioned group, but is a descedant of a person out of that group, born and resided within the territory of the Indonesian State as well as a person who is no descedant of a person of the meant group, bom and resided within the territory of the Indonesian State for the last 5 consecutive years, already 21 years of age or already married, unless he declares to have objections against becoming an Indonesian citizen due to the fact that he is a citizen of another country;

c. a person who acquires the Indonesian citizenship by way of naturalization;

d. a legal or legitimated child or a child legally acknowledged by his father who at the moment of its birth, that father had the Indonesian citizenship;

e. the child born within 300 days after his father, who had the Indonesian citizenship, died; 
f. the child legally acknowledged only by his mother, who at the moment of its birth, had the Indonesian citizenship;

g. a child legally adopted by an Indonesian citizen;

h. a child born within the territory of the Indonesian State, who has not been legally acknowledged by his father nor by his mother;

i. a child born within the territory of the Indonesian State, of whom the parents are unknown or of whom the parents' citizenship is unknown.

\section{Article 2.}

(1) A woman during matrimony follows the citizenship of her husband;

(2) A request or statement in order to change the citizenship may not be submitted by a wife.

\section{Article 3.}

(1) The Indonesian citizenship granted to a father automatically also applies to his legal and legitimated children or children legally acknowledged by him, as well as to his adopted children, who are under the age of 21 years and are not married yet.

(2) The Indonesian citizenship granted to a widow by way of naturalization applies automatically also to her legal or legitimated children, who are under the age of 21 years and are not married yet.

(3) The Indonesian citizenship acquired by a mother applies automatically also to her children who are legally acknowledged only by her, who are under the age of 21 years and are not married yet.

(4) The loss of the Indonesian citizenship of a father or a mother as specified above, also applied to his/her children as specified above and to his/her adopted children, only if those children join in acquiring the citizenship of another country.

(5) The loss of the Indonesian citizenship by a mother because or as a result of her marriage or because of a statement as meant in article 10 does not apply to her children.

\section{Article 4.}

(1) The statement mentioned in article 1 paragraph b. should be extended in writing to the Minister of Justice within 1 year after the regulation in said article is applicable to the person concerned. 
(2) Together with the written statement, the person who makes the statement should extend or be ready to give proofs about:

a. his birth and the birth of his children according to the specification in article 3 , who are under the age of 21 years and are not married yet, with the full names of them and of his wives;

b. his marriages;

c. the dissolution of his marriages;

d. their being citizens of another country.

(3) Within the shortest time possible after having received that written statement, the Minister of Justice should register and announce that statement in the State Gazette, when the statement is legalized and to whom it applies, and inform the person having made the statement of the decision concerning that statement.

\section{Article 5.}

(1) The Indonesian citizenship by way of naturalization is acquired with the coming into force of the act, by which said naturalization is granted.

(2) Who can acquire the Indonesian citizenship by way of naturalization are persons, who have reached the age of 21 years or are already married, already resided within the territory of the Indonesian State for the last 5 consecutive years and are able to speak the Indonesian language.

(3) For each naturalization an amount of Rp. 500 ,- is due to the State Treasury.

(4) Requests to acquire the Indonesian citizenship bij way of naturalization should be extended in writing on stamped paper to the Minister of Justice through the District Court of the region where the applicant resides.

(5) Together with the request for naturalization, the applicant should extent or be ready to give proofs about:

a. his birth and the birth of his children according to the specification in article 3 , who are under the age of 21 age and are not married yet, with the full names of them and of his wives;

b. his marriages;

c. the dissolution of his marriages; 
d. the fact that he has been resided within the territory of the Indonesian State for the last 5 consecutive years;

e. his ability to speak the Indonesian language;

f. the fact of having paid for the naturalization the amount of money as fixed above to the Indonesian State Treasury;

g. the fact that in case the applicant originates from a foreign country, the legislation of that foreign country does not become an impediment for said naturalization.

(6) After having received that written request, the District Court is obliged to examine it within the shortest time possible in order to ascertain whether the conditions fixed by this act have been fulfilled. Within the shortest possible time after taking a decision concerning that request, the District Court is obliged to send a copy of that decision, accompanied by the request and its appendices to the Minister of Justice.

(7) If the request is complied with, the Minister of Justice should inform the applicant within the shortest time possible through the President of the District Court concerned.

(8) The act that complies with the request for naturalization, shall come into force on the day the applicant before the District Court of his residence takes an oath or promises allegiance to the Indonesian State as follows:

I swear (promise) that I recognize and accept the highest authority of the Indonesian State and will remain loyal to her, that I will respect the law of the Indonesian State and that I take this obligation voluntary and will not diminish it whatsoever.

(9) The clerk of the District Court must drawn up a report of the oath or promise made.

(10) To the person who has made said oath or promise and to all persons who join in being involved in that naturalization, the District Court should instantly give a piece of evidence of Indonesian citizenship according to the model fixed by the Minister of Justice.

(11) Within the shortest time possible, the District Court should inform the Minister of Justice about the issue of the aforementioned piece of evidence.

(12) Within the shortest time possible after having received the aforementioned notice, the Minister of Justice should register and announce said matter in the State Gazette. 
(13) In case the request for naturalization is rejected, the amount of money paid to the Indonesian State Treasury must be refunded.

\section{Article 6.}

(1) When a child who has acquired the Indonesian citizenship by way of being involved in the naturalization of his father or mother has reached the age of 21 years or is married before reaching that age, he may state in the following year that he does not want to be involved in the naturalization any more.

(2) That statement should be extended to the Minister of Justice in writing. Together with the written statement, the person making the statement should give or be ready to give proofs about:

a. his birth and the births of his children according to the specification in article 3 , with the full names of them and of his wives;

b. the fact that he was born before his father or mother obtained the Indonesion citizenship by way of naturalization;

c. his marriages;

d. the dissolution of his marriages;

e. the fact that through this statement, the children mentioned above obtain the citizenship of another country.

(3) Within the shortest time possible after having received that written statement, the Minister of Justice should register and announce that statement in the State Gazette, when that statement is legalized and to whom it applies, and inform the person who has made the statement of the decision concerning that statement.

\section{Article 7.}

Naturalization can also be granted for reasons of the interest of the State. In this case the regulations mentioned in article 5 section 2 up to and including section 7 and section 13 are not applicable. The acts granting such naturalization should each time stipulate the conditions for this naturalization.

Article 8.

The Indonesian citizenship is lost:

1. bij acquiring the citizenship of another country; 
2. by entering the military service or public service of another country without previous permission of the President of the Republic of Indonesia.

\section{Article 9.}

(1) A woman who has lost her Indonesian citizenship caused by or as the result of her marriage may regain this citizenship if within 1 year after her marriage has been dissolved she conveys her wish to the Minister of Justice in writing. Together with the written statement, the person making the statement should give or be ready to give proofs about:

\section{a. her marriage;}

b. the dissolution of her marriage;

c. the fact that she was an Indonesian citizen before her marriage;

d. the birth and full names of her child, born outside matrimony after the aforementioned marriage has been dissolved and legally acknowledged only by her.

(2) Within the shortest time possible after having received that written statement, the Minister of Justice should register and announce this statement in the State Gazelte, when the statement is legalized and to whom it applies, and inform the person who has made the statement of the decision concerning that statement.

\section{Article 10.}

(1) A woman who has acquired the Indonesian citizenship caused by or as result of her marriage remains an Indonesian citizen, unless within one year after her marriage has been dissolved she conveys a statement in writing to the Minister of Justice that she does not like to be an Indonesian citizen any more. Together with this statement, the person making the statement should give or be ready to give proofs about:
a. her marriage;
b. the dissolution of her marriage;
c. the fact that before that marriage, she was no Indonesian citizen.

(2) Within the shortest time possible after having received that statement, the Minister of Justice should register and announce this statement in the State Gazette, when the statement is legalized and to whom it applies and inform the person who has made the statement of the decision concerning that statement. 
(1) A child of an Indonesian citizen who has lost his Indonesian citizenship because he was involved in the acquiring of the citizenship of another country by his father or mother by way of naturalization, may regain the Indonesian citizenship if within 1 year after he has reached the age of 21 years or is married before reaching that age, he states his wish to the Minister of Justice in writing. Together with this written statement, the person making the statement should give or be ready to give proofs about:

a. his birth and the birth of his children according to the specification in article 3, with the full names of them and of his wives;

b. the fact that he was born before his father or mother obtained the citizenship of another country by way of naturalization;

c. his marriage;

d. the dissolution of his marriage.

(2) Within the shortest time possible after having received that written statement, the Minister of Justice should register and announce that statement in the State Gazette, when that statement is legalized and to whom it applies, and inform the person who has made the statement of the decision concerning that statement.

Article 12.

The Miniser of Justice should have and take care of a list in his department for the registrations mentioned above.

Article 13.

He who is no Indonesian citizen, is a foreigner.

Article 14.

(1) Resident of the Indonesian State is every person who has resided in the territory of the Indonesian State for one consecutive year.

(2) The legal position of resident of the Indonesian State of a person is automatically lost in case that person is resided outside the territory of the Indonesian State.

(3) A woman during matrimony follows the legal position of resident of the country of her husband. 
(4) A child under the age of 21 years and not married yet is considered a resident of the Indonesian State, if his father or guardian has the legal position of resident of the Indonesian State.

When that child reaches the age of 21 years or is married before that age, he remains a resident of the Indonesian State, if he resides within the territory of the Indonesian State.

\section{Article 15}

This act comes into force on the date of his promulgation.

\section{TRANSITIONAL PROVISIONS}

1. Persons who at the moment this act comes into force have no father any more and at that moment are under the age of 21 years and are not married yet, are Indonesian citizen if their father at the moment of his death fulfilled the conditions mentioned in article 1 paragraph $b$.

The person who may make a statement as mentioned at the end of article 1 paragraph b. for the persons mentioned above, is the guardian of those persions.

2. A woman who at the moment this act comes into force has no husband any more because her last husband has died, while that husband at the moment of his death fulfilled the conditions mentioned in article 1 paragraph b., is Indonesian citizen, unless within 1 year after this act comes into force she declares that she does not like to become Indonesian citizen, because she herself does not fulfill the conditions concerned.

In this case the regulations in article 10 are applicable, with the difference that the second sentence of paragraph $\mathrm{c}$. of section 1 becomes:

the fact that she does not fulfill the conditions mentioned in article 1 paragraph a. or article 1 paragraph b.

Till the moment to be fixed with Government Regulation, the statement as mentioned in article 4 section 1, article 6 section 2, article 9 section 1, article 10 section 1 and article 11 section 1 should be extended to the Minister of Justice through the District Court of the place of residence of the person who makes the statement.

After having received the statement mentioned in section 1, the District Court should within the shortest time possible forward it to the Minister of Justice.

In order to have this act publicly known, it is ordered to have it announced in the usual way.

Promulgated

on April 10, 1946

the State's Secretary

A.G. PRINGGODIGDO
Sanctioned at Jokjakarta

on April 10, 1946

THE PRESIDENT OF THE REPUBLIC OF INDONESIA

SOEKARNO

THE MINISTER OF JUSTICE SOEWAND 
ALTERATION OF ACT NO. 3 YEAR 1946 CONCERNING

CITIZENS AND RESIDENTS OF THE

STATE OF THE REPUBLIC OF INDONESIA

THE PRESIDENT OF THE REPUBLIC OF INDONESIA

Considering: that is necessary to make some alterations in Act No. 3 year 1946 concerning Citizens and Residents of the State of the Republic of Indonesia;

With a view to: Article 20 section (1) of the Constitution in connection with article IV of the Transitional Regulation of the Constitution and the Proclamation of the Vice-President of 16-10-1945 no. X;

With the approval of the Working Committee of the Central National Commission;

\section{H A S DE C I D E D;}

To enact the following regulation:

THE ACT REGARDING THE ALTERATION OF ACT NO. 3 YEAR 1946 CONCERNING CITIZENS AND RESIDENTS OF THE STATE OF THE REPUBLIC OF INDONESIA

Article 1.

Act No. 3 year 1946 concerning Citizens and Residents of the State of the Republic of Indonesia is altered and supplemented as follows:

a. Article I paragraph b. should be read as follows:

b. a person, who does not fall under the abovementioned group, but is a descendant of a person out of that group, born and resided within the territory of the Indonesian State as well as a person who is no descendant of a person of the meant group, bom and resided within the territory of the Indonesian State for the last 5 consecutive years, already 21 years of age or already married;

b. The full stop at the end of the sentence of article 1 paragraph $i$. should be replaced by a semicolon;

c. Article 1 is supplemented by: 
j. a legal body established according to the law prevailing in the Indonesian State and domiciled within the territory of the Indonesian State;

d. Between article 3 and article 4 is inserted:

\section{Article 3a.}

An Indonesian citizen as mentioned in article 1 paragraph b., who possesses the citizenship of another country may release his Indonesian citizenship by declaring that he has objections against becoming an Indonesian citizen.

\section{Article 3b.}

If an Indonesian citizen as mentioned in article 1 paragraph $b$. deceases at a time he still declares to have objections against becoming an Indonesian citizen, in view of the regulation in article $3 a$ the right to state these objections is continued, for his legal, legitimated, legally acknowledged or adopted children by their respective guardians and for his widow by herself, unless in case that widow falls under the group mentioned in article 1 paragraph a., who in that case remains becoming Indonesian citizen.

e. Article 4 section (1) should be read as follows:

(1) The statement of objection mentioned in article 3 a should be extended in writing to the Minister of Justice within one year after the regulation in article 1 paragraph b. is applicable tot the person concemed;

f. Article 5 section (3) should be read as follows;

(3) For each naturalization an amount of Rp. 200,- is due to the State Treasury;

g. Between article 11 and article 12 is inserted:

Article 1la.

(1) The written statement mentioned in article 4 section (1), article 6 section (2), article 9 section (1), article 10 section (1) and article 11 section (1) should be extended to the Minister of Justice through the District Court whose legal district covers the place of residence of the person who makes the statement.

(2) After having received that written statement, the District Court is obliged to examine it within the shortest time possible to ascertain whether the conditions determined by this act have been fulfilled.

Within the shortest possible time after having taken a decision conceming that statement, the District Court must send a copy of that decision accompanied by the written statement and its appendices to the Minister of Justice. 
h. Between article 14 and article 15 is inserted:

Article $14 a$.

All that is necessary to carry out the regulations in this act is regulated by Government Regulation.

i. Article 15 should be read as follows:

This act comes into force on August 17, 1945.

j. The Transitional Provisions should be read as follows:

I. Persons who at the moment this act comes into force have no father any more and at that time are under the age of 21 years and are not married yet, are Indonesian citizen if their father at the moment of his death fulfilled the conditions mentioned in article 1 paragraph $b$.

As long as the persons who are entitled to declare their objections as mentioned in article $3 \mathrm{a}$ have not yet reached the age of 21 years or are not married yet, the person who may make the statement as mentioned in article 3a for those persons, is their guardian.

II. A woman who at the moment this act comes into force has no husband any more because her last husband has died while that husband at the moment of his death fulfilled the conditions mentioned in article 1 paragraph a. or article 1 paragraph b. and she herself does not, is Indonesian citizen. Within 1 year after April 10, 1946 she may released her citizenship of the Indonesian State. In this case the regulations in article $3 \mathrm{a}$, article 10 and article $11 \mathrm{a}$ are applicable with the difference, that the second sentence of paragraph $\mathrm{c}$. of section (1) of article 10 becomes:

the fact that she does not fulfill the conditions mentioned in article 1 paragraph a. or article 1 paragraph $b$.

III. Persons who on April 10, 1946 fulfill the conditions mentioned in article 1 paragraph b. or are in a position as described in article 9 section (1), article 10 section (1) or article 11 section (1) may make use of the right to make a statement respectively within 1 year after said date.

Likewise, persons, who lost their father or husband as meant in article $3 \mathrm{~b}$ between August 17, 1945 and April 10, 1946 may make use of the right to make a statement respectively within said period of time. 
Article 2.

This act comes into force on August 17, 1945 .

Promulgated

on March 3, 1947

Sanctioned at Jokjakarta on February 27, 1947

the State's Secretary

THE PRESIDENT OF THE

A.G. PRINGGODIGDO REPUBLIC OF INDONESIA

SOEKARNO

THE MINISTER OF JUSTICE

SOESANTO TIRTOPRODJO 

A STATEMENT AS TO THE INDONESIAN CITIZENSHIP

\section{THE PRESIDENT OF THE REPUBLIC OF INDONESIA}

Considering: that for this initial stage it is necessary to prolong the period of time to submit a statement as to the Indonesian citizenship;

With a view to: article 20 section (1) of the Constitution in connection with article IV of the Transitional Regulation of the Constitution and the Proclamation of the Vice-President of 16-10-1945 no. X.

With the approval of the Working Committee of the Central National Commission:

HAS DECI D E D:

To enact the following regulation:

THE ACT CONCERNING THE PROLONGATION OF THE PERIOD

TO SUBMIT A STATEMENT AS TO THE

INDONESIAN CITIZENSHIP

Article 1.

Act No. 3 year 1946 concerning Indonesian Citizens and Residents as altered and supplemented by Act No. 6 year 1947 is altered as followed:

a. Transitional Provision I is supplemented by a third sentence, reading:

"That statement may be submitted until April 10, 1948".

b. In Transitional Provision II second sentence, the words:

"Within 1 year after April 10, 1946"

are replaced by:

"Until April 10, 1948".

c. In Transitional Provision III first and second sentence, the words:

"April 10, 1946"

are replaced by:

"April 10, 1947". 
This act comes into force on April 10, 1947.

Promulgated

on May 2, 1947

The State's Secretary

A.G. PRINGGODIGDO
Sanctioned at Jokjakarta on May 1, 1947

THE PRESIDENT OF THE REPUBLIC OF INDONESIA SOEKARNO

THE MINISTER OF JUSTICE SOESANTO TIRTOPRODJO 


\section{THE PRESIDENT OF THE REPUBLIC OF INDONESIA}

Considering: that in connection with the armed conflict it is difficult to make a statement as mentioned in Act No. 8 year 1947, so that it is necessary to prolong the period of time to submit that statement;

With a view to: article 20 section (1) of the Constitution in connection with article IV of the Transitional Regulation of the Constitution and the Proclamation of the Vice-President of 16-10-1945 no. X.

With the approval of the Working Committee of the Central National Commission:

To enact the following regulation:

\section{THE ACT CONCERNING THE FURTHER PROLONGATION \\ OF THE PERIOD TO SUBMIT A STATEMENT \\ AS TO THE INDONESIAN CITIZENSHIP}

\section{Article 1.}

All statements in connection with the Indonesian Citizenship which according to Act No. 3 year 1946 as altered and supplemented with Act No. 6 year 1947 and Act No. 8 year 1947 must be submitted before August 17, 1948, may be submitted until said date.

Article 2.

This act comes into force on April 10, 1948.

Promulgated

on April 15, 1948

the State's Secretary

A.G. PRINGGODIGDO
Sanctioned at Yogyakarta on April 15, 1948

THE PRESIDENT OF THE REPUBLIC OF INDONESIA

SOEKARNO

THE MINISTER OF JUSTICE SOESANTO TIRTOPRODJO 
Het Koninkrijk der Nederlanden en de Republiek der Verenigde Staten van Indonesië, overwegende, dat, op het tijdstip van de souvereiniteitsoverdracht, ten aanzien van de personen, die tot op dat ogenblik onderdanen van het Koninkrijk der Nederlanden waren, voor de Republiek der Verenigde Staten van Indonesië daaronder begrepen de personen, die volgens de wetgeving van de Republiek Indonesië burgers waren van deze Republiek, dient te worden bepaald of zij de Nederlandse dan wel de Indonesische nationaliteit zullen bezitten, komen overeen, dat te dien aanzien op dat ogenblik de navolgende bepalingen in werking treden.

Artikel 1. Meerderjarig in de zin van deze overeenkomst zijn zij, die de volle leeftijd van achttien hebben bereikt of vroeger in het huwelijk zijn getreden.

Wanneer het huwelijk is ontbonden, voordat zij de volle leeftijd van achttien jaar hebben bereikt, blijven zij meerderjarig.

Artikel 2. Voor de RVSI zal bij toepassing van deze overeenkomst op personen, die naar de nationaliteitswetgeving van de Republiek Indonesië onmiddellijk voor de souvereiniteitsoverdracht burgers zijn van deze Republiek, waar gesproken wordt van het "verkrijgen" of "verkiezen" van de Indonesische nationaliteit, de Republikeinse worden omgezet in de Indonesische, en, waar gesproken wordt van het "behouden" van de Nederlandse of het "verwerpen" van de Indonesische nationaliteit, de Republikeinse nationaliteit verloren gaan.

Artikel 3. Meerderjarige Nederlanders behouden de Nederlandse nationaliteit, doch zijn bevoegd, indien zij in Indonesië geboren of aldaar tenminste zes maanden woonachtig zijn, binnen de gestelde termijn, te verklaren, dat zij de Indonesische nationaliteit verkiezen.

Artikel 4. (1) Behoudens het tweede lid van dit art. verkrijgen de onmiddellijk vóór de souvereiniteitsoverdracht tot de inheemse bevolking (orang2 jang asli) van Indonesië behorende meerderjarige Nederlandse onderdanen-niet-Nederlanders de Indonesische nationaliteit, doch zijn, indien zij buiten Indonesië geboren en in Nederland of buiten de gebieden der deelgenoten van de Unie woonachtig zijn, bevoegd binnen de gestelde termijn te verklaren, dat zij de Nederlandse nationaliteit verkiezen.

(2) De in de aanhef van het vorige lid omschreven Nederlandse onderdanen, die in Suriname of in de Nederlandse Antillen woonachtig zijn:

a. verkrijgen, indien zij buiten het Koninkrijk geboren zijn, de Indonesische nationaliteit, doch zijn bevoegd binnen de gestelde termijn te verklaren, dat zij de Nederlandse nationaliteit verkiezen;

b. behouden, indien zij in het Koninkrijk geboren zijn, de Nederlandse nationaliteit, doch zijn bevoegd binnen de gestelde termijn te verklaren, dat zij de Indonesische nationaliteil verkiezen. 
Artikel 5. De onmiddellijk vóór de souvereiniteitsoverdracht meerderjarige uitheemse Nederlandse onderdanen-niet-Nederlanders, die in Indonesië geboren of in de RVSI woonachtig zijn, verkrijgen de Indonesische nationaliteit, doch zijn bevoegd deze binnen de gestelde termijn te verwerpen;

bezaten zij in dit geval onmiddellijk voór de souvereiniteitsoverdracht geen andere dan de Nederlandse nationaliteit, dan zullen zij deze herkrijgen;

bezaten zij op gemeld tijdstip mede een vreemde nationaliteit, dan zullen zij, bij verwerping van de Indonesische nationaliteit, de Nederlandse slechts dan herkrijgen, indien zij tegelijkertijd een daartoe strekkende verklaring afleggen.

Artikel 6. De onmiddellijk vór de souvereiniteitsoverdracht meerderjarige uitheemse Nederlandse onderdanen-niet-Nederlanders, die niet in Indonesië geboren zijn en in het Koninkrijk woonachtig, behouden de Nederlandse nationaliteit, doch zijn bevoegd binnen de gestelde termijn met verwerping van deze, de Indonesische nationaliteit te verkiezen;

bezaten zij op gemeld tijdstip mede een vreemde nationaliteit, dan zijn zij bevogd de Nederlandse zonder meer te verwerpen.

Deze bevoegdheid tot verwerping van de Nederlandse nationaliteit al dan niet verbonden met die tot verkiezing van de Indonesische nationaliteit komt niet toe aan de uit India of Pakistan afkomstige bewoners van Suriname.

Artikel 7. De onmiddellijk vóor de souvereiniteitsoverdracht meerderjarige uitheemse Nederlandse onderdanen-niet-Nederlanders, die buiten de gebieden der deelgenoten van de Unie woonachtig en in Nederland, Suriname of de Nederlandse Antillen geboren zijn, behouden de Nederlandse nationaliteit, doch zijn, indien zij geboren zijn uit ouders, die door geboorte in Indonesië Nederlands onderdaan waren, bevoegd binnen de gestelde termijn met verwerping van deze de Indonesische nationaliteit te verkiezen;

bezaten zij op gemeld tijdstip mede een vreemde nationaliteit, dan zijn zij bevoegd de Nederlandse zonder meer te verwerpen.

Zijn zij buiten de gebieden der deelgenoten van de Unie geboren dan is naar gelang van de geboorteplaats van hun vader of van hun moeder, naar de in art. 1 van de Wet van 1892 op het Nederlanderschap en het Ingezetenschap gemaakte onderscheidingen, dit art. of art. 5 toepasselijk; indien deze ouder ook buiten de gebieden der deelgenoten van de Unie geboren is, zal de geboorteplaats van diens vader of moeder beslissend zijn.

Artikel 8. Minderjarigen volgen de nationaliteit van hun vader of van hun moeder, naar de in art. 1 van de bovengenoemde Wet van 1892 gemaakte onderscheidingen, indien deze onmiddellijk vór de souvereiniteitsoverdracht Nederlands onderdaan en in leven is. 
Artikel 9. Op minderjarigen van wie de vader of de moeder, naar de in art. 1 van genoemde Wet van 1892 gemaakte onderscheidingen, onmiddellijk vór de souvereiniteilsoverdracht geen Nederlands onderdaan of niet meer in leven is, worden bovenstaande regels rechtstreeks toegepast met dien verstande, dat in het laatste geval als hun woonplaats zal gelden de feitelijke plaats van hun vestiging en dat in beide gevallen, waar sprake is van een verklaring, deze zal kunnen worden gedaan door hun rechtmatige vertegenwoordiger.

Is er geen rechtmatige vertegenwoordiger, dan zullen de gestelde termijnen eerst beginnen te lopen vanaf het ogenblik, dat een vertegenwoordiger is benoemd.

Artikel 10. De gehuwde vrouw volgt de staat van haar man.

Na ontbinding van het huwelijk is zij gedurende een jaar daama bevoegd alsnog door een verklaring de nationaliteit te verkrijgen of te verwerpen, die zij, ware zij op het ogenblik van de souvereiniteitsoverdracht niet gehuwd geweest, verkregen had of door het afleggen van een verklaring had kunnen verkrijgen of verwerpen.

Artikel 11. De uitoefening van het recht van verkiezing of verwerping van een nationaliteit maakt geen tevoren verrichte handeling ongeldig, die geldig zou zijn, indien dit recht niet ware uitgeoefend.

\section{UITVOERINGSBEPALINGEN.}

Artikel 12. De verklaringen van verkiezing of verwerping van nationaliteit kunnen door de daartoe bevoegde personen worden afgelegd voor of toegezonden aan hetzij de Hoge Commissarissen van Partijen, hetzij de gewone dagelijkse rechter van de betreffende persoon, hetzij de ambtenaren, die daartoe door de bevoegde autoriteiten in beide staten alsnog zullen worden aangewezen. In den vreemde zullen deze verklaringen kunnen worden afgelegd voor of toegezonden aan de diplomatieke of consulaire ambtenaren van een van beide Partijen, binnen wier ressort de woonplaats van de betreffende persoon is gelegen.

De onder een schriftelijke verklaring gestelde handtekening of vingertopafdruk moet worden gelegaliseerd.

Aan hem, die een verklaring aflegt of indient, wordt aanstonds een bewijs daarvan uitgereikt of toegezonden.

De gedurende een kalendermaand afgelegde verklaringen worden in de daarop volgende maand in de staatscourant van de staat, wiens ambtenaren daarvan kennis hebben genomen, gepubliceerd, terwijl duplicaten of gewaarmerkte afschriften dier verklaringen maandelijks aan de Regering van de andere staat worden toegezonden. 
Beide Partijen verbinden zich om aan de mogelijkheid tot het afleggen der bedoelde verklaringen ruime bekendheid te geven. De verklaringen en de daarvan af te geven bewijsstukken zijn vrij van zegel en kosten.

Artikel 13. Deze overeenkomst verstaat onder "de gestelde termijn": een tijdvak van twee jaar na de overdracht van de souvereiniteit.

Artikel 14. Beslissingen over de uitoefening of verhindering van uitoefening van het optierecht kunnen worden gevraagd aan de gewone dagelijkse rechter van de woonplaats van de betrokken persoon. Indien deze in den vreemde woont, zullen de Arondissements-Rechtbank te Amsterdam en de gewone dagelijkse rechter te Batavia (Djakarta) bevoegd zijn. Hoger beroep en andere rechtsmiddelen staan daartegen open als in burgerlijke zaken. De in kracht van gewijsde gegane beslissing wordt door de Regering van de Partij, in wier rechtsgebied de beslissing gevallen is, aan de Regering van de andere Partij medegedeeld en door deze als zodanig erkend.

\section{AANTEKENING.}

Omtrent de nationaliteit van de inwoners van Nieuw-Guinea is, indien de souvereiniteit over dit gebied niet op de RVSI. overgaat, in de bovenstaande bepalingen niets beslist. 
SOME MATTERS REGARDING CITIZENSHIP

\section{THE HEAD OF THE STAFF OF THE ARMY FORCE IN HIS CAPACITY OF THE CENTRAL WAR AUTHORITY FOR THE REGION OF THE ARMY FORCE}

Considering: that the Regulation of the Military Authority, Head of the Staff of the Army Force No. Prt/09/1957 concerning some matters regarding citizenship based on the "Regeling op den Staat van Oorlog en van Beleg" (Regulation on the State of War and of Siege), State Gazette 1939 No. 582 as further altered and supplemented, according to article 60 of the Act on the State of Danger of 1957 will automatically no longer be valid according to the law as of April 17, 1958, whereas considering the present situation it is still necessary to maintain the stipulations inserted in said Regulation of the Military Authority;

With a view to: (1) Decree of the President of the Republic of Indonesia No. 225 year 1957 in relation with Act No. 79 year 1957 (State Gazette 1957/170; Supplementary State Gazette 1957/1491) concerning the declaration of the state of war on the entire territory of the Republic of Indonesia;

(2) Act No. 74 year 1957 (State Gazette 1957/160; Supplementary State Gazette 1957/1485) concerning the State of Danger, article 43 section (2) in relation with article 7 section (2);

(3) The Provisional Constitution of the Republic of Indonesia, article 144;

(4) Act No. 3 year 1946 of the Republic of Indonesia concerning Citizens and Residents of the State of Indonesia jo. the Agreement as to the assignment of citizens as enclosed with the Agreement of Transition of the Round Table Conference.

After having acquired the authority of the Council of Ministers in its 97th session of April 15, 1958;

\section{H AS DEC I D E D;}

to lay down: Regulation of the Central War Authority/Army Force concerning some matters regarding citizenship as follows:

\section{Article 1.}

(1) Anyone who by order of an official authority has to give proof of being a citizen of the Republic of Indonesia or a foreigner should request the District Court of 
his/her residence to confirm whether or not he/she is a citizen of the Republic of Indonesia according to the normal civil procedure.

The District Court decides in first and last instance. Before taking a decision the District Court hears officials of the Immigration Service and in the absence of such officials, the Public Prosecutor.

(2). The stipulation mentioned in section (1) does not diminish special stipulations in other regulations, when the latter demand the decision of a higher court than the District Court.

Article 2.

A citizen of the Republic of Indonesia in the possession of a passport or a certificate having the character of a passport of a foreign country in the name of the person concerned and still valid, is considered no longer a citizen of the Republic of Indonesia.

Article 3.

A foreign woman married to a citizen of the Republic of Indonesia after Decermber 27, 1949 is treated as a citizen of the Republic of Indonesia after she has received a decree from the Minister of Justice.

Article 4.

This Regulation of the Central War Authority comes into force on April 17, 1958.

In order that everybody may know same, the publication of this Regulation of the Central War Authority is ordered by insertion thereof in the State Gazette, in newspapers and through announcement in the Governmental Broadcast of Radio of the Republic of Indonesia.

Promulgated on

Sanctioned at Jakarta

April 16, 1958. on April 16, 1958.

HEAD OF THE STAFF OF THE ARMY FORCE IN HIS CAPACITY OF CENTRAL WAR AUTHORTY

A. H. NASUTION 
Considering: that it is necessary that the agreement between the Republic of Indonesia and the People's Republic of China concerning the problem of dual citizenship is approved by law;

With a view to: a. Article XIV of the aforementioned agreement;

b. The articles 89 and 120 of the Provisional Constitution of the Republic of Indonesia;

c. Act no.29 of the year 1957 (State Gazette year 1957, No.101)

With the approval of the House of Representatives:

\section{H AS DECI D E D;}

To enact:

ACT CONCERNING THE APPROVAL OF THE AGREEMENT BETWEEN THE REPUBLIC OF INDONESIA AND THE PEOPLE'S REPUBLIC OF CHINA CONCERNING THE PROBLEM OF DUAL CITIZENSHIP.

\section{Article 1.}

The Agreement between the Republic of Indonesia and the Republic of China conceming the problem of dual citizenship dated April 22, 1955, including the exchange of notes between Prime Minister Ali Sastroatmidjojo and Prime Minister Chou En-Lai dated June 3, 1955, Peking, copies of which are attached to the act are herewith approved.

Article 2.

The Agreement mentioned above comes into force as of the date of the exchange of the letters of ratification that will take place in Peking. 


\section{Article 3.}

This Act comes into force on the date of its promulgation.

In order that everybody may known this Act, the promulgation of said Act is ordered by insertion thereof in the State Gazette of the Republic of Indonesia.

Promulgated

on January 27, 1958

THE MINISTER OF JUSTICE

G.A. MAENGKOM
Sanctioned at Jakarta on January 11, 1958

ACTING PRESIDENT OF THE REPUBLIC OF INDONESIA

SARTONO

THE MINISTER OF FOREIGN AFFAIRS SUBANDRI0

STATE GAZETTE NO.5 YEAR 1958 


\section{AGREEMENT BETWEEN THE REPUBLIC OF INDONESIA AND THE PEOPLE'S REPUBLIC OF CHINA concerning \\ THE PROBLEM OF DUAL CITIZENSHIP}

The Government of the Republic of Indonesia and the Government of the People's Republic of China, on the basis of:

the principle of equality;

the principle of mutual benefit; and

the principle of non interference in the domestic policy of the respective States:

having the desire to solve in the best possible way in friendly cooperation the question of the citizenship of persons, who simultaneously possess the citizenship of the Republic of Indonesia and the citizenship of the People's Republic of China, have decided to enter into this Agreement and for that purpose have appointed their plenipotentiary representatives:

for the Government of the Republic of Indonesia:

His Excellency SUNARIO

Minister of Foreign Affairs, and

for the Government of the People's Republic of China:

His Excellency CHOU EN-LAI

Minister of Foreign Affairs

who, after the examination of the respective letters of attomey, which appeared to be correct and just, have agreed to the following articles:

\section{Article I.}

Both Distinguished Agreeing Parties agree, that anyone who simultaneously possesses the citizenship of the Republic of Indonesia and the citizenship of the People's Republic of China must choose either the citizenship of the Republic of Indonesia or the citizenship of the People's Republic of China, on the basis of the interested person's own free will.

A woman in matrimony, who possesses the two aforementioned citizenships, must also choose one of those two citizenships mentioned above, out of her own free will.

Article II.

Anyone who possesses the two citizenships mentioned in article I, who is an adult at the moment this Agreement comes into force, must choose one of the two citizenships within two years after this Agreement has come into force.

In this Agreement by an adult is understood, a person who has reached the age of 18 years or a person who has not yet reached the age of 18 years but is already married. 
Anyone who possesses the two citizenships mentioned in article I who wants to retain the citizenship of the Republic of Indonesia, should make a statement in order to release the citizenship of the People's Republic of China to the authority of the Republic of Indonesia in charge. After having made that statement the person concerned is considered having chosen the citizenship of the Republic of Indonesia out of own free will.

Anyone who possesses the two citizenships mentioned in article I who wants to retain the citizenship of the People's Republic of China, should make a statement in order to release the citizenship of the Republic of Indonesia to the authority of the People's Republic of China in charge. After having made that statement the person concerned is considered having chosen the citizenship of the People's Republic of China out of own free will.

The authority of the Republic of Indonesia in charge mentioned above is:

In the Republic of Indonesia: the authorities appointed by the Government of the Republic of Indonesia;

In the People's Republic of China: the Embassy of the Republic of Indonesia and the Consulates of the Republic of Indonesia in the People's Republic of China - if existing and the provisional offices, which according to the needs will be established by the Embassy or the Consulates concerned and which will be served by their officials. For the establishment of those priovisional offices the approval of the Government of the People's Republic of China is required.

The authority of the People's Republic of China in charge mentioned above is:

In the People's Republic of China: the authorities appointed by the Government of the People's Republic of China;

In the Republic of Indonesia: the Embassy of the People's Republic of China and the Consulates of the People's Republic of China in the Republic of Indonesia and the provisional offices, which according to the needs will be established bij the Embassy or the Consulates concerned and which will be served by their officials. For the establishment of those provisional offices the approval of the Government of the Republic of Indonesia is required.

In order to facilitate persons who possess two citizenships as mentioned in Article I in choosing a citizenship, Both Distinguished Agreeing Parties agree to make use of a simple procedure for making a statement.

The stipulations concerning the way of choosing a citizenship in this article in principle also apply to persons who possess the two citizenships as mentioned in article I, who reside outside the territory of the Republic of Indonesia and outside the territory of the People's Republic of China. 
Both Distinguished Agreeing Parties agree that anyone who possesses the two citizenships as mentioned in article I and chooses the citizenship of the Republic Indonesia in accordance with the stipulations of this Agreement shall automatically lose the citizenship of the People's Republic of China and that anyone, who possesses the two citizenships as mentioned in article I and chooses the citizenship of the People's Republic of China in accordance with the stipulations of this Agreement shall automatically lose the citizenship of the Republic of Indonesia.

\section{Article V.}

Both Distinguished Agreeing Parties agree, that anyone who possesses the two citizenships as mentioned in article I and does not make a statement in order to choose a citizenship within the period of two years as stipulated in article II, shall be considered as having chosen the citizenship of the Republic of Indonesia, in case he/she from the side of his/her father is of Indonesian descent and is considered as having chosen the citizenship of the People's Republic of China in case he/she is from the side of his/her father of Chinese descent.

In case the person concerned has no legal relationship with his/her father or if his/her father's citizenship is unknown, he/she is considered as having chosen the citizenship of the Republic of Indonesia, if his/her mother is from father's side of Indonesian descent and is considered as having chosen the citizenship of the People's Republic of China, if his/her mother from father's side is of Chinese descent.

\section{Article VI.}

Anyone who possesses the two citizenships mentioned in article I, who has not yet reached adulthood at the moment this Agreement comes into force, must choose one of the citizenships within the period of one year after having reached adulthood.

Before having reached adulthood the aforementioned person shall be considered as only possessing the citizenship chosen by his/her parents or his/her father in accordance with the stipulations of this Agreement.

If the aforementioned person has no legal relationship with his/her father, or in case his/her father has deceased before having made a statement in order to choose one of the citizenships within the period of time fixed, or in case his/her father's citizenship is unknown, the person concerned is considered as to only having the citizenship chosen by his/her mother in accordance with the stipulations of this Agreement.

If the aforementioned person after having reached adulthood does not choose one of the citizenships within the period of time fixed in this article, he/she shall be considered as having chosen the citizenship that he/she has followed during the time prior to adulthood, out of own free will. 
Anyone who possesses the two citizenships mentioned in article I, who has acquired the citizenship of the Republic of Indonesia and has lost the citizenship of the People's Republic of China shall automatically lose the citizenship of the Republic of Indonesia if he/she after having left the territory of the State of the Republic of Indonesia and is residing permanently outside the territory of the State of the Republic of Indonesia regains the citizenship of the Republic of China out of own free will.

Anyone who possesses the two citizenships mentioned in article I, who has acquired the citizenship of the People's Republic of China and has lost the citizenship of the Republic of Indonesia shall automatically lose the citizenship of the People's Republic of China if he/she after having left the territory of the People's Republic of China and is residing permanently outside the territory of the State of the People's Republic of China regains the citizenship of the Republic of Indonesia out of own free will.

\section{Article VIII.}

Children born within the territory of the State of the People's Republic of China possess the citizenship of the Republic of Indonesia as of the date of their birth if their parents or only their fathers possess the citizenship of the Republic of Indonesia.

Children born within the territory of the State of the Republic of Indonesia possess the citizenship of the People's Republic of China as of the date of their birth if their parents or only their fathers possess the citizenship of the People's Republic of China.

\section{Article IX.}

A child who possesses the citizenship of the People's Republic of China, in case he/she before reaching the age of five years is legally adopted by a citizen of the Republic of Indonesia acquires for that reason the citizenship of the Republic of Indonesia and automatically loses the citizenship of the People's Republic of China.

A child who possesses the citizenship of the Republic of Indonesia, in case he/she before reaching the age of five years is legally adopted by a citizen of the People's Republic of China acquires for that reason the citizenship of the People's Republic of China and automatically loses the citizenship of the People's Republic of China.

Article X.

In case a citizen of the Republic of Indonesia marries a citizen of the People's Republic of China, each of them remains to possess the citizenship they possess before being married, unless one of them out of free will applies for and acquires the citizenship of the other. In case of acquiring that other citizenship, the original citizenship is automatically lost. 
An application as mentioned above should be submitted to the authority in charge of the relevant State.

Article XI.

Both Distinguished Agreeing Parties agree for the sake of the improvement of the living conditions of their respective citizens residing in the State of the other party, i.e. the citizens of the Republic of Indonesia residing in the People's Republic of China and the citizens of the People's Republic of China residing in the Republic of Indonesia, to comply with the law and traditional customs of the State where they reside and to refrain from interfering in political activities in the State where they reside.

Both Distinguished Agreeing Parties agree to mutually secure protection according to the law of the respective legal rights and interests of the citizens of the other party, residing within the territory of their State.

\section{Article XII.}

Both Distinguished Agreeing Parties agree that concerning matters of implementation not regulated in this Agreement, exchange of thoughts shall take place between the two parties.

Article XIII.

In case between Both Distinguished Agreeing Parties a dispute emerges on the interpretation or the implementation of this Agreement, that dispute shall be settled through deliberations between both parties.

\section{Article XIV.}

This Agreement shall be ratified bij Both Distinguished Agreeing Parties in accordance with the procedure fixed in the respective Constitutions and shall come into force as of the date of exchange of the letters of ratification taking place in Peking.

This Agreement is valid for twenty years and shall after that time remain valid, unless one of the partijs wants to cancel it. Notice of that wish should be given in writing to the other party and this Agreement shall then terminate one year after the notice has been submitted.

To give witness the Plenipotentiary Representatives have signed this Agreement and also affixed their seals.

Made in duplicate at Bandung on the twenty second day of April nineteen hundred fiftyfive in the Indonesian and Chinese language.

The text has the same force in both languages.

For the Republic of Indonesa

For the People's Republic

of China

SUNARIO

Minister of Foreign Affairs

CHOU EN-LAI

Minister of Foreign Affairs 
His Excellency Dr. Ali Sastroamidjojo

Prime Minister of the Republic of Indonesia

PEKING

Peking, June 3, 1955

\section{Your Excellency,}

On April 22, 1955 the People's Republic of China and the Republic of Indonesia signed the Agreement concerning the problem of Dual Citizenship. During the time of Your Excellency's visit to the People's Republic of China further exchange of thoughts in full took place in Peking between our Governments conceming the aim and the way of implementing of this Agreement and consensus of opinion was achieved which I shall herewith set forth as follows:

1. The aim of the aforementioned Agreement concerning the problem of Dual Citizenship is to settle the problem of Dual Citizenship between the People's Republic of China and the Republic of Indonesia, a matter inherited by us from the past and the settlement of which is in the interest of the People of both countries. In order to achieve the aim mentioned above, both Governments have agreed in the implementation of the aforementioned Agreement, to take all necessary measures and to give all opportunities so that everybody who possesses a dual citizenship be able to choose his/her citizenship out of own free will.

2. The Government of the People's Republic of China and the Government of the Republic of Indonesia have agreed that among those who simultaneously possess the citizenship of the Republic of Indonesia and of the People's Republic of China, there is a group of persons who may be considered having only one citizenship and not having a dual citizenship, because in the opinion of the Government of the Republic of Indonesia, their social and political position gives proof of the fact that they automatically (implicitly) have released their citizenship of the People's Republic of China.

Persons who fall under the aforementioned group are due to the fact that they have only one citizenship, not obliged to choose a citizenship in accordance with the stipulations of the Agreement concerning Dual Citizenship.

Upon their wish, an identification paper concerning that matter may be given such persons.

3. In order to avoid misunderstanding as to the stipulation regarding the period of validity of 20 years in article XIV of the aforementioned Agreement concerning Dual Citizenship, both Governments have agreed on the following interpretation, viz. that persons who have once chosen their citizenship in accordance with the Agreement mentioned above, will not be obliged to choose again after the expiration of the period of 20 years.

4. In order that the aforementioned Agreement shall be implemented satisfactorily both Governments have agreed to establish in Jakarta a Joint Committee existing of represen- 
tatives of the Government of the Republic of Indonesia and of the Government of the People's Republic of China. The task of said Joint Committee is to discuss and plan the way of implementing the Agreement concerning Dual Citizenship mentioned above.

5. Before the expiration of the period of two years fixed to choose a citizenship, the present position of persons who possess a dual citizenship will not change until and after they have chosen their citizenship in accordance with the stipulations of the Agreement mentioned above.

If the aforementioned matters acquire Your Excellency's approval, this note and Your Excellency's reply will constitute a concensus of opinion achieved between the Government of the Republic of Indonesia and the Government of the People's Republic of China regarding the implementation of the Agreement concerning the question of Dual Citizenship, coming into force at a moment coinciding with the moment of the coming into force of the Agreement mentioned above.

We avail ourselves of this opportunity to express our highest respect to Your Excellency.

CHOU EN-LAI Prime Minister of the State's Council of the People's Republic of China 
His Excellency Chou En-Lai

Prime Minister of the State's Council of the

People's Republic of China

PEKING

Peking, June 3, 1955.

\section{Your Excellency,}

We herewith acknowledge receipt of Your Excellency's note dated June 3, 1955, which reads as follows:

"On April 22, 1955 the People's Republic of China and the Republic of Indonesia signed the Agreement concerning the problem of Dual Citizenship. During the time of Your Excellency's visit to the People's Republic of China, further exchange of thoughts in full took place in Peking between our Governments concerning the aim and the way of implementing of this Agreement and consensus of opinion was achieved which I shall herewith set forth as follows:

1. The aim of the aforementioned Agreement concerning the problem of Dual Citizenship is to settle the problem of Dual Citizenship between the People's Republic of China and the Republic of Indonesia, a matter inherited by us from the past and the settlement of that matter is in the interest of the People of both countries. In order to achieve the aim mentioned above, both Governments have agreed in the implementation of the aforementioned Agreement, to take all necessary measures and to give all opportunities so that everybody who possesses a dual citizenship be able to choose his/her citizenship out of own free will.

2. The Government of the People's Republic of China and the Govemment of the Republic of Indonesia have agreed that among those who simultaneously possess the citizenship of the Republic of Indonesia and of the People's Republic of China, there is a group of persons who may be considered having only one citizenship and not having a dual citizenship, because in the opinion of the Government of the Republic of Indonesia, their social and political position gives proof of the fact that they automatically (implicitly) have released their citizenship of the People's Republic of China. Persons who fall under the aforementioned group are due to the fact that they have only one citizenship, not obliged to choose a citizenship in accordance with the stipulations of the Agreement concerning Dual Citizenship.

Upon their wish, an identification paper concerning that matter may be given to such persons.

3. In order to avoid misunderstanding as to the stipulation regarding the period of validity of 20 years in article XIV of the aforementioned Agreement concerning Dual Citizenship, both Governments have agreed on the following interpretation, viz. that persons who have chosen their citizenship in accordance with the Agreement mentioned above, will not be obliged to choose again after the expiration of the period of 20 years. 
4. In order that the aforementioned Agreement shall be implemented satisfactory, both Governments have agreed to establish in Jakarta a Joint Committee existing of representatives of the Government of the Republic of Indonesia and of the Government of the People's Republic of China. The task of said Joint Committee is to discuss and plan the way of implementing the Agreement concerning Dual Citizenship mentioned above.

5. Before the expiration of the period of two years fixed to choose a citizenship, the present position of persons who possess a dual citizenship will not change until and after they have chosen their citizenship in accordance with the stipulations of the Agreement mentioned above.

If the aforementioned matters acquire Your Excellency's approval, this note and Your Excellency's reply will constitute a consensus of opinion achieved between the Govemment of the Republic of Indonesia and the Government of the People's Republic of China regarding the implementation of the Agreement concerning the question of Dual Citizenship, coming into force at a moment coinciding with the moment of the coming into force of the Agreement mentioned above".

On behalf of the Government of the Republic of Indonesia we confirm all matters laid down in Your Excellency's note. Your Excellency's note and our reply to that note will constitute a consensus of opinion achieved between the Government of the Republic of Indonesia and the Government of the People's Republic of China regarding the implementation of the Agreement concerning the question of Dual Citizenship, coming into force at a moment coinciding with the moment of the coming into force of the aforementioned Agreement.

We avail ourselves of this opportuny to express our highest respect to Your Excellency.

ALI SASTROAMIDJOJO
Prime Minister




\section{DE PRESIDENT VAN DE REPUBLIEK INDONESIE}

Overwegende: dat het nodig is een Wet op het Staatsburgerschap van de Republiek Indonesië uit te vaardigen;

Gezien: $\quad$ a. de artikelen 5 en 144 van de Voorlopige Grondwet van de Republiek Indonesië;

b. artikel 89 van de Voorlopige Grondwet van de Republiek Indonesië;

In overeenstemming mel de Volksvertegenwoordiging;

\section{HEEFT BES L O T E N}

Vast te stellen:

\section{WET BETREFFENDE HET STAATSBURGERSCHAP VAN DE REPUBLIEK INDONESIE}

\section{Artikel 1}

Staatsburgers van de Republiek Indonesië zijn:

a. personen, die op grond van wetgeving en/of overeenkomsten en/of regelingen welke sedert de proclamatie van 17 augusuts 1945 hebben gegoiden, reeds staatsburgers van de Republiek Indonesië zijn;

b. personen, die op het tijdstip van hun geboorte in familierechtelijke betrekkingen staan tot de vader, die staatsburger van de Republiek Indonesië is, met dien verstande, dat het staatsburgerschap van de Republiek Indonesië aanvangt bij het ontstaan van de familierechtelijke betrekkingen en dat deze familiebetrekkingen zijn ontstaan voordat deze personen de leeftijd van 18 jaar hebben bereikt of voordat zij huwden op een leeftijd beneden 18 jaar;

c. kinderen, die geboren zijn binnen 300 dagen na het overlijden van hun vader, indien deze vader op het tijdstip van het overlijden staatsburger van de Republiek Indonesië was;

d. personen, wier moeder op het tijdstip van hun geboorte staatsburger van de Republiek Indonesië is, indien zij op dit tijdstip niet in familierechtelijke betrekkingen tot hun vader staan; 
e. personen, wier moeder op het tijdstip van hun geboorte staatsburger van de Republiek Indonesië is, indien hun vader geen nationaliteit bezit of zolang de nationaliteit van hun vader niet bekend is;

f. personen, die geboren zijn op het grondgebied van de Republiek Indonesië, zolang beide ouders niet bekend zijn;

g. een kind, dat is aangetroffen op het grondgebied van de Republiek Indonesiē, zolang beide ouders niet bekend zijn;

h. personen, die geboren zijn op het grondgebied van de Republiek Indonesië, indien beide ouders geen nationaliteit bezitten of zolang de nationaliteit van beide ouders niet bekend is;

i. personen, die geboren zijn op het grondgebied van de Republiek Indonesië en die op het tijdstip van hun geboorte de nationaliteit van de vader of de moeder niet hebben verkregen en zolang zij de nationaliteit van de vader of de moeder niet krijgen;

j. personen, die het staatsburgerschap van de Republiek Indonesië verkrijgen volgens de bepalingen van deze Wet.

\section{Artikel 2}

1. Buitenlandse kinderen, die de leeftijd van 5 jaar nog niet hebben bereikt en die zijn geadopteerd door een staatsburger van de Republiek Indonesië verkrijgen het staatsburgerschap van de Republiek Indonesië, indien de adoptie wettig is verklaard door het Landgerecht van de woonplaats van degene, die het kind adopteerde.

2. De wettigverklaring door het Landgerecht moet binnen 1 jaar na de adoptie of binnen 1 jaar nadat deze Wet in werking is getreden worden gevraagd door degene, die het kind adopteerde.

\section{Artikel 3}

1. Buitenechtelijke kinderen wier moeder staatsburger van de Republiek Indonesië is, of kinderen uit een wettig huwelijk, die bij een echtscheiding door de rechter aan de zorg van hun Indonesische moeder zijn toevertrouwd doch die dezelfde nationaliteitsrechtelijke staat hebben als hun buitenlandse vader kunnen bij de Minister van Justitie het verzoek indienen om hel staatsburgerschap van de Republiek Indonesië te verkrijgen, indien zij na het verkrijgen van het staatsburgerschap van de Republiek Indonesië geen andere nationaliteit bezitten of een verklaring tot verwerping van de andere nationaliteit overleggen, hetzij op de wijze vastgesteld door rechisregels van hun land van oorsprong, hetzij op de wijze vastgesteld door een overeenkomst tot afwikkeling van dubbele nationaliteil tussen de Republiek Indonesiē en de betrokken staat. 
2. Het bovenbedoelde verzoek moet binnen 1 jaar nadat de betrokkene de leeftijd van 18 jaar heeft bereikt, worden ingediend bij de Minister van Justitie door tussenkomst van het Landgerecht of de Vertegenwoordiging van de Republiek Indonesië van de woonplaats.

3. De Minister van Justitie willigt het verzoek in of wijst het af in overeenstemming met de Ministerraad.

4. Het staatsburgerschap van de Republiek Indonesië, dat op dit verzoek wordt verkregen, wordt van kracht met ingang van de datum van het besluit van de Minister van Justitie.

\section{Artikel 4}

1. Buitenlanders, die geboren zijn en woonplaats hebben op het grondgebied van de Republiek Indonesië en wier vader of, wanneer zij niet in familierechtelijke betrekkingen staan tot de vader, wier moeder, eveneens is geboren op het grondgebied van de Republiek Indonesië en ingezetene is van de Republiek Indonesië, kunnen bij de Minister van Justitie een verzoek indienen om het staatsburgerschap van de Republiek Indonesië te verkrijgen, indien zij na het verkrijgen van het staatsburgerschap van de Republiek Indonesië niet een andere nationaliteit bezitten of bij het indienen van het verzoek tevens overleggen een verklaring tot verwerping van de andere nationaliteit die zij mogelijk bezitten, in overeenstemming met de in hun land van oorsprong geldende bepalingen of met bepalingen van een overeenkomst tot afwikkeling van dubbele nationaliteit tussen de Republiek Indonesië en de betrokken staat.

2. Het bovenbedoelde verzoek moet binnen 1 jaar nadat de betrokkene de leeftijd van 18 jaar heeft bereikt, worden ingediend bij de Minister van Justitie door tussenkomst van het Landgerecht van zijn woonplaats.

3. De Minister van Justitie willigt het verzoek in of wijst het af in overeenstemming met de Ministerraad.

4. Het staatsburgerschap van de Republiek Indonesië, dat op dit verzoek wordt verkregen, wordt van kracht met ingang van de datum van het besluit van de Minister van Justitie.

\section{Artikel 5}

I. Het staatsburgerschap van de Republiek Indonesië door naturalisatie wordt verkregen door het van kracht worden van het besluit van de Minister van Justitie, die de naturalisatie verleent. 
2. Voor het indienen van een verzoek om naturalisatie moet de verzoeker:

a. de leeftijd van 21 jaar hebben bereikt;

b. geboren zijn op het grondgebied van de Republiek Indonesië of op het tijdstip van het indienen van het verzoek gedurende tenminste de laatste 5 achtereenvolgende jaren of in het geheel gedurende 10 niet achtereenvolgende jaren woonplaats hebben gehad op dit grondgebied;

c. wanneer hij een gehuwde man is, de toestemming hebben verkregen van zijn echtgenote (echtgenoten);

d. de Indonesische taal voldoende kunnen spreken en een redelijke kennis bezitten van de geschiedenis van Indonesië, alsmede nimmer veroordeeld zijn wegens het begaan van een misdrijf, dat de Republiek Indonesië schade heeft berokkend;

e. in geestelijke en lichamelijke welstand verkeren;

f. aan 's Lands Kas een som gelds betalen van tussen Rp. 500,- en Rp. 10.000,-, waarvan de grootte wordt vastgesteld door de Belastingdienst van zijn woonplaats, op grond van het zuiver maandelijks inkomen, met de bepaling, dat het bedrag het zuiver maandelijks inkomen niet te boven mag gaan;

g. vaste middelen van bestaan hebben;

h. zonder nationaliteit zijn, dan wel zijn nationaliteit verliezen wanneer hij het staatsburgerschap van de Republiek Indonesië verkrijgt of een verklaring tot verwerping van de andere nationaliteit overleggen volgens de bepalingen van het land van oorsprong of volgens de bepalingen van een overeenkomst tot afwikkeling van dubbele nationaliteit tussen de Republiek Indonesië en de betrokken staat.

Een vrouw mag staande huwelijk geen verzoek om naturalisatie indienen.

3. Het verzoek om naturalisatie moet schriftelijk en op gezegeld papier worden ingediend bij de Minister van Justitie door tussenkomst van het Landgerecht of de Vertegenwoordiging van de Republiek Indonesië van de woonplaats van de verzoeker.

Het verzoek moet zijn gesteld in de Indonesische taal en tegelijk met het verzoek moeten worden overgelegd de bewijsstukken betreffende de punten, genoemd in lid 2 , uitgezonderd dat, genoemd onder letter $d$.

Het Landgerecht of de Vertegenwoordiging van de Republiek Indonesië onderzoekt de bewijsstukken op hun juistheid en hoort de verzoeker omtrent zijn kennis van de Indonesische taal en de geschiedenis van Indonesië.

4. De Minister van Justitie willigt het verzoek om naturalisatie in of wijst het af in overeenstemming met de Ministerraad. 
5. Het besluit van de Minister van Justitie, waarbij de naturalisatie wordt verleend, wordt van kracht met ingang van de dag waarop de verzoeker ten overstaan van het Landgerecht of de Vertegenwoordiging van de Republiek Indonesië van zijn woonplaats een eed of belofte van trouw aflegt en werkt terug tot de datum van genoemd besluit van de Minister van Justitie.

De eed of belofte van trouw luidt als volgt:

"Ik zweer (beloof):

dat ik geheel en al afstand doe van alle loyaliteit aan een vreemde macht;

dat ik de hoogste macht van de Republiek Indonesië erken en aanvaard en aan haar loyaal zal zijn;

dat ik de Grondwet en de wetten van de Republiek Indonesië hoog zal houden en ze waarachtig zal verdedigen;

dat ik deze plichten vrijwillig zal dragen en er niets aan te kort zal doen."

6. Nadat de verzoeker de bovenbedoelde eed of belofte van trouw heeft afgelegd, maakt de Minister van Justitie de naturalisatie bekend door plaatsing van zijn besluit in het Staatsblad.

7. Wanneer de eed of belofte van trouw niet is afgelegd binnen drie maanden na de datum van het besluit van de Minister van Justitie, wordt dit besluit van rechtswege nietig.

8. De som gelds, genoemd in lid 2, wordt terugbetaald, wanneer het verzoek om naturalisatie niet wordt ingewilligd.

9. Indien het verzoek om naturalisatie is afgewezen, kan de verzoeker nogmaals een verzoek indienen.

\section{Artikel 6}

Naturalisatie kan ook door de Regering, in overeenstemming met de Volksvertegenwoordiging, worden verleend om redenen van Staatsbelang of wegens het zich hebben verdienstelijk gemaakt jegens de Staat.

Hierbij zijn van de bepalingen van artikel 5 slechts van toepassing de bepalingen van lid 1 , lid 5 , lid 6 en lid 7.

\section{Artikel 7}

1. Een buitenlandse vrouw, die huwt met een staatsburger van de Republiek Indonesië, verkrijgt het staatsburgerschap van de Republiek Indonesië, indien en op het tijdstip dat zij binnen I jaar na de voltrekking van haar huwelijk een daartoe strekkende verklaring aflegt, uitgezonderd indien $\mathrm{zij}$, wanneer $\mathrm{zij}$ het staatsburgerschap van de Republiek Indonesië verkrijgt, nog een andere nationaliteit heeft, in welk geval die verklaring niet mag worden afgelegd. 
2. Met behoud van de uitzondering in lid 1, verkrijgt de buitenlandse vrouw, die met een staatsburger van de Republiek Indonesië huwt, eveneens het staatsburgerschap van de Republiek Indonesië een jaar na de huwelijksvoltrekking tenzij haar echtgenoot in dat jaar een verklaring aflegt tot prijsgeving van zijn staatsburgerschap van de Republiek Indonesië.

Deze verklaring mag slechts worden afgelegd en heeft slechts het verlies van het staatsburgerschap van de Republiek Indonesië tot gevolg, wanneer de genoemde echtgenoot door dit verlies niet staatloos wordt.

3. Indien een van de verklaringen, genoemd in lid 1 en 2 , is afgelegd, mag de andere verklaring niet worden afgelegd.

4. De bovengenoemde verklaringen moeten worden afgelegd bij het Landgerecht of de Vertegenwoordiging van de Republiek Indonesië van de woonplaats van degene, die de verklaring aflegt.

\section{Artikel 8}

1. Een staatsburgeres van de Republiek Indonesië, die huwt met een buitenlander, verliest haar staatsburgerschap van de Republiek Indonesiē, indien en op het tijdstip dat zij binnen 1 jaar na de voltrekking van haar huwelijk een daartoe strekkende verklaring aflegt, uitgezonderd indien zij door het verlies van het staatsburgerschap van de Republiek Indonesië staatloos wordt.

2. De verklaring, genoemd in lid 1, moet worden afgelegd bij het Landgerecht of de Vertegenwoordiging van de Republiek Indonesië van de woonplaats van degene, die de verklaring aflegt.

\section{Artikel 9}

1. Het staatsburgerschap van de Republiek Indonesië, dat verkregen wordt door een gehuwde man, is van rechtswege van kracht jegens zijn echtgenote, tenzij de echtgenote na de verkrijging van het staatsburgerschap van de Republiek Indonesië nog een andere nationaliteit bezit.

2. Het verlies van het staatsburgerschap van de Republiek Indonesië door een gehuwde man is van rechtswege van kracht jegens zijn echtgenote, tenzij de echtgenote staatloos zal worden.

Artikel 10

1. Een vrouw mag staande huwelijk geen verzoek indienen als bedoeld in de artikelen 3 en 4. 
2. Het verlies van het staatsburgerschap van de Republiek Indonesië door een gehuwde vrouw is van rechtswege van kracht jegens haar echtgenoot, tenzij de echtgenoot staatloos zal worden.

\section{Artikel 11}

1. Iemand, die door of tengevolge van huwelijk het staatsburgerschap van de Republiek Indonesië heeft verloren, herkrijgt dit staatsburgerschap, indien en op het tijdstip dat betrokkene na de ontbinding van het huwelijk een daartoe strekkende verklaring aflegt.

De verklaring moet binnen een jaar na de ontbinding van het huwelijk worden afgelegd bij het Landgerecht of bij de Vertegenwoordiging van de Republiek Indonesië van de woonplaats.

2. Het bepaalde in lid 1 geldt niet in het geval, dat de betrokkene na het terugkrijgen van het staatsburgerschap van de Republiek Indonesië nog een andere nationaliteit bezil.

\section{Artikel 12}

1. Een vrouw, die door of tengevolge van haar huwelijk het staatsburgerschap van de Republiek Indonesië heeft verkregen, verliest dit staatsburgerschap, indien en op het tijdstip dat zij, na de ontbinding van haar huwelijk, een daartoe strekkende verklaring aflegt.

Deze verklaring moet binnen 1 jaar na de ontbinding van het huwelijk worden afgelegd bij het Landgerecht of de Vertegenwoordiging van de Republiek Indonesië van haar woonplaats.

2. Het bepaalde in lid 1 geldt niet, wanneer de vrouw door het verlies van het staatsburgerschap van de Republiek Indonesië staatloos wordt.

\section{Artikel 13}

1. Kinderen, die de leeftijd van 18 jaar nog niet hebben bereikt en nog niet zijn gehuwd en die in familierechtelijke betrekkingen staan tot hun vader voordat deze het staatsburgerschap van de Republiek Indonesië verkreeg, verkrijgen eveneens het staatsburgerschap van de Republiek Indonesië nadat zij woonplaats hebben en verblijven in Indonesië.

Het bepaalde betreffende de woonplaats en het verblijven in Indonesië geldt niet ten opzichte van kinderen, die, doordat hun vader het staatsburgerschap van de Republiek Indonesië verkreeg, staatloos zijn geworden.

2. Het staatsburgerschap van de Republiek Indonesië, dat verkregen wordt door een moeder, is eveneens van kracht jegens haar kinderen, die niet in familierechtelijke betrekkingen staan tot hun vader en die de leeftijd van 18 jaar nog niet hebben 
bereikt en nog niet gehuwd zijn, nadat zij woonplaats hebben en verblijven in Indonesië.

Indien het staatsburgerschap van de Republiek Indonesië wordt verkregen door middel van naturalisatie door een moeder wier huwelijk is ontbonden door het overlijden van haar echtgenoot, verkrijgen de kinderen, die in familierechtelijke betrekkingen tot die echtgenote stonden en die de leeftijd van 18 jaar nog niet hebben bereikt en nog niet gehuwd zijn, eveneens het staatsburgerschap van de Republiek Indonesië nadat zij woonplaats hebben en verblijven in Indonesië.

Het bepaalde betreffende de woonplaats en het verblijven in Indonesië geldt niet ten opzichte van kinderen, die, doordat hun moeder het staatsburgerschap van de Republiek Indonesië verkreeg, staatloos zijn geworden.

Artikel 14.

1. Wanneer de kinderen, bedoeld in artikel 2 en artikel 13 , de leeftijd van 21 jaar bereiken, verliezen zij het staatsburgerschap van de Republiek Indonesië weer, indien en op het tijdstip dat zij een daartoe strekkende verklaring afleggen.

De verklaring moet binnen 1 jaar nadat de kinderen de leeftijd van 21 jaar hebben bereikt, worden afgelegd bij het Landgerecht of de Vertegenwoordiging van de Republiek Indonesië van hun woonplaats.

2. Het bepaalde in lid 1 geldt niet wanneer de kinderen door het verlies van het staatsburgerschap van de Republiek Indonesië staatloos worden.

\section{Artikel 15}

1. Het verlies van het staatsburgerschap van de Republiek Indonesië door een vader is eveneens van kracht jegens zijn kinderen, die in familierechtelijke betrekkingen tot die vader staan en die de leeftijd van 18 jaar nog niet hebben bereikt en nog niet gehuwd zijn, tenzij die kinderen door het verlies van het staatsburgerschap van de Republiek Indonesië staatloos worden.

2. Het verlies van het staatsburgerschap van de Republiek Indonesië door een moeder is eveneens van kracht jegens haar kinderen, die niet in familierechtelijke betrekkingen staan tot hun vader, tenzij die kinderen door het verlies van het staatsburgerschap van de Republiek Indonesië staatloos worden.

3. Indien de moeder het staatsburgerschap van de Republiek Indonesië verliest door naturalisatie in het buitenland en het huwelijk van die moeder is ontbonden door het overlijden van haar echtgenoot, zijn de bepalingen van lid 2 eveneens van kracht jegens haar kinderen, die in familierechtelijke betrekkingen stonden tot die echtgenoot, nadat de kinderen in het buitenland woonplaats hebben en verblijven. 
1. Het kind, dat het staatsburgerschap van de Republiek Indonesië heeft verloren tengevolge van het verlies van dit staatsburgerschap door zijn vader of moeder, herkrijgt het staatsburgerschap van de Republiek Indonesië nadat het kind de leeftijd van 18 jaar heeft bereikt, indien en op het tijdstip dat het een daartoe strekkende verklaring aflegt.

De bedoelde verklaring moet binnen 1 jaar nadat het kind de leeftijd van 18 jaar heeft bereikt worden afgelegd bij het Landgerecht of de Vertegenwoordiging van de Republiek Indonesië van zijn woonplaats.

2. Het bepaalde in lid 1 geldt niet in het geval, dat het kind - na het verkrijgen van het staatsburgerschap van de Republiek Indonesië - nog een andere nationaliteit bezit.

\section{Artikel 17}

Het staatsburgerschap van de Republiek Indonesië wordt verloren door:

a. het verkrijgen van een andere nationaliteit door de eigen wil, met dien verstande dat, indien de betrokkene op het tijdstip van het verkrijgen van de andere nationaliteit verblijft op het grondgebied van de Republiek Indonesië, zijn staatsburgerschap van de Republiek Indonesië eerst wordt geacht verloren te zijn gegaan indien de Minister van Justitie in overeenstemming met de Ministerraad uit eigen beweging of op verzoek van de betrokkene het verlies uitspreekt;

b. het niet verwerpen of prijsgeven van een andere nationaliteit, terwijl de betrokkene daartoe de gelegenheid krijgt;

c. de erkenning als zijn kind door een buitenlander, indien de betrokkene de leeftijd van 18 jaar nog niet heeft bereikt en nog niet is gehuwd en door het verlies van het staatsburgerschap van de Republiek Indonesië niet staatloos wordt;

d. kinderen, die door buitenlanders rechtsgeldig als hun kind zijn geadopteerd, indien de betrokken kinderen de leeftijd van 5 jaar nog niet hebben bereikt en door het verlies van het staatsburgerschap van de Republiek Indonesië niet staatloos worden;

e. het uitspreken van het verlies door de Minister van Justitie in overeenstemming met de Ministerraad op verzoek van de betrokkene, indien deze de leeftijd van 21 jaar heeft bereikt, woonplaats heeft in het buitenland en door het verlies van het staatsburgerschap van de Republiek Indonesië niet staatloos wordt;

f. het treden in vreemde krijgsdienst zonder voorafgaand verlof van de Minister van Justitie; 
g. het zonder voorafgaand verlof van de Minister van Juslitie treden in dienst van een vreemde staat of in dienst van een internationale organisatie, waartoe de Republiek Indonesië niet als lid is toegetreden, indien het staatsambt, dat wordt bekleed, volgens de voorschriften van de Republiek Indonesië slechts kan worden bekleed door staatsburgers of indien het ambt in dienst van de bedoelde internationale organisatie verplicht tot een ambtseed of belofte;

h. het afleggen van een eed of het doen van een belofte van trouw jegens een vreemde staat of deel daarvan;

i. het zonder daartoe verplicht te zijn deelnemen aan een verkiezing, die een staatsrechtelijk karakter heeft, voor een vreemde staat;

j. het bezitten op eigen naam van een nog geldig paspoort of van een geschrift, dat het karakter heeft van een paspoort, van een vreemde staal;

k. het anders dan voor 's lands dienst gedurende 5 achtereenvolgende jaren woonplaats hebben in het buitenland, zonder, voordat deze termijn is verstreken en vervolgens elke twee jaar, het verlangen kenbaar te maken om staatsburger te blijven;

dit verlangen moet worden kenbaar gemaakt bij de Vertegenwoordiging van de Republiek Indonesië van de woonplaats.

Voor een staatsburger van de Republiek Indonesië, die een leeftijd heeft beneden 18 jaar, uitgezonderd wanneer hij voordien is gehuwd of gehuwd is geweest, beginnen de bovengenoemde termijnen van vijf en twee jaar te lopen op de datum, waarop hij de leeftijd van 18 jaar bereikt.

\section{Artikel 18}

1. Hij die het staatsburgerschap van de Republiek Indonesië heeft verloren, zoals bedoeld in artikel 17 letter k., herkrijgt het staalsburgerschap van de Republiek Indonesië indien hij woonplaats heeft in Indonesië krachtens een toelatingskaart en daartoe een verklaring aflegt.

Deze verklaring dient te worden gericht tot het Landgerecht van zijn woonplaats binnen 1 jaar nadat de persoon woonplaats heeft in Indonesië.

2. Hij die in het buitenland woonplaats heeft en het staatsburgerschap van de Republiek Indonesië heeft verloren, zoals bedoeld in artikel 17 letter k., om redenen buiten zijn schuld als gevolg van de situatie in het land van zijn woonplaats waardoor hij zijn verplichting niet heeft kunnen vervullen zoals geregeld in bedoelde bepaling, kan het staatsburgerschap van de Republiek Indonesië herknjgen:

a. indien hij zich meldt en de daartoe strekkende verklaring aflegt bij de Vertegenwoordiging van de Republiek Indonesië in het land van zijn woonplaats binnen 1 jaar, gerekend van de afkondiging van deze Wet; 
b. indien hij zich meldt en de daartoe strekkende verklaring aflegt bij de Vertegenwoordiging van de Republiek Indonesië in een land, het dichtst gelegen bij zijn woonplaats binnen 2 jaar na de inwerkingtreding van deze Wet;

Naast de indiening van de verklaring voor de herkrijging van het Indonesisch staatsburgerschap zoals bedoeld in lid 2 dient betrokkene:

a. werkelijk de wens te hebben laten blijken om staatsburger van de Republiek Indonesië te worden;

b. zich trouw te hebben getoond jegens de Republiek Indonesiē.

4. Hij die de verklaring heeft afgelegd overeenkomstig het bepaalde in lid 2, herkrijgt het staatsburgerschap van de Republiek Indonesië binnen 1 jaar na aanmelding en aflegging van de verklaring en nadat gebleken is dat hij voldaan heeft aan de vereisten bedoeld in lid 3 en nadat hij het desbetreffende besluit heeft ontvangen van de Minister van Justitie.

Het besluit van de Minister van Justitie betreffende de wedertoekenning van het staatsburgerschap van de Republiek Indonesië is pas geldig op de dag dat verzoeker de eed of belofte van trouw heeft afgelegd tegenover de Vertegenwoordiging van de Republiek Indonesië en heeft terugwerkende kracht tot de datum van het besluit van de Minister van Justitie.

De eed of belofte van trouw Juidt als volgt:

"Ik zweer (beloof) dat ik om het staatsburgerschap van de Republiek Indonesië te herkrijgen trouw zal zijn aan de Republiek Indonesië, die gebaseerd is op de Pancasila;

dat ik de Grondwet van 1945 hoog zal houden benevens de wetten van de Republiek Indonesië;

dat ik deze waarachtig zal verdedigen;

dat ik eerlijk, oprecht en vrijwillig deze plicht zal vervullen."

5. Een persoon kan slechts het staatsburgerschap van de Republiek Indonesië herkrijgen volgens bovenbedoelde bepaling, indien hij op dat moment geen andere nationaliteit bezit of indien hij na het verkrijgen van het Indonesisch staatsburgerschap geen andere nationaliteit heeft.

5. Het op de wijze zoals bedoeld in lid 4 door de man verkregen staatsburgerschap van de Republiek Indonesië geldt ook voor zijn vrouw, tenzij zij na het verkrijgen van het Indonesisch staatsburgerschap nog een andere nationaliteit bezit.

1. Het op deze wijze zoals bedoeld in lid 4 door de vader verkregen staatsburgerschap van de Republiek Indonesië geldt ook voor zijn kinderen, die nog geen 18 jaar en nog niet getrouwd zijn.

Alles wat nodig is voor de uitvoering van de bepalingen in lid 1 tot en met lid 7 $\mathrm{zal}$ verder worden geregeld bij Regeringsverordening. 
Het staatsburgerschap van de Republiek Indonesië, dat wordt verleend of verkregen op verklaringen, die niet op waarheid berusten, kan worden ingetrokken door de instantie, die het heeft verleend of door de instanties die de verklaringen hebben ontvangen.

Artikel 20

Een ieder, die geen staatsburger van de Republiek Indonesië is, is vreemdeling.

\section{OVERGANGSBEPALINGEN}

\section{Artikel I}

Een vrouw, die op grond van artikel 3 van de Verordening van het Militaire Gezag No. Prt/PM/09/1957 en artikel 3 van de Verordening van het Centrale Oorlogsgezag no. Prt/Peperpu/014/1958 wordt behandeld als staatsburger van de Republiek Indonesië, wordt staatsburger van de Republiek Indonesië, indien zij geen andere nationaliteit bezit.

\section{Artikel II}

Degene, die op het tijdstip, waarop deze Wet in werking treedt, verkeert in de omstandigheden van artikel 7 of artikel 8, kan de in deze artikelen bedoelde verklaringen afleggen binnen 1 jaar na het in werking treden van deze Wet, met dien verstande, dat de echtgenoot van de vrouw, die staatsburger van de Republiek Indonesië is geworden, bedoeld in artikel I van de overgangsbepalingen, niet meer de verklaring kan afleggen, bedoeld in artikel 7 , lid 2 .

Artikel III

Een vrouw, die volgens de voorschriften, die van kracht waren voordat deze Wet in werking is getreden, van rechtswege, aangenomen, dat zij niet gehuwd was, staatsburger van de Republiek Indonesië zou zijn, verkrijgt het staatsburgerschap van de Republiek Indonesië, indien en op het tijdstip dat zij binnen 1 jaar na de ontbinding van haar huwelijk of binnen 1 jaar nadat deze Wet in werking is getreden een daartoe strekkende verklaring aflegt bij het Landgerecht of bij de Vertegenwoordiging van de Republiek Indonesië van haar woonplaats.

\section{Artikel IV}

Degene, die zijn vader of zijn moeder niet volgde in het verkrijgen van het staatsburgerschap van de Republiek Indonesië door het afleggen van een verklaring volgens de wetgeving, die van kracht was voordat deze. Wet in werking is getreden, omdat de betrokkene op het tijdstip, waarop zijn vader of zijn moeder deze verklaring aflegde, reeds volwassen was, terwijl hijzelf geen verklaring tot verkiezing van het staatsburger- 
schap van de Republiek Indonesië mocht afleggen, is staatsburger van de Republiek Indonesië, tenzij hij na het verkrijgen van dit staatsburgerschap nog een andere nationaliteit bezit.

Het staatsburgerschap van de Republiek Indonesië, dat de bedoelde persoon verkrijgt, werkt terug tot het tijdstip, waarop zijn vader/moeder dat staatsburgerschap verkreeg.

\section{Artikel V}

In afwijking van de bepalingen van artikel 4 , lid 1 en 2 , kunnen kinderen, wier ouders tussen de 27ste December 1949 en de 27ste December 1951 hun staatsburgerschap van de Republiek Indonesië hebben verworpen, gedurende een jaar nadat deze Wet in werking is getreden een verzoek indienen bij de Minister van Justitie door tussenkomst van het Landgerecht van hun woonplaats om het staatsburgerschap van de Republiek Indonesië te verkrijgen, wanneer zij de leeftijd van 28 jaar nog niet hebben bereikt; vervolgens geldt artikel 4 , lid 3 en 4 .

\section{Artikel VI}

Een vreemdeling, die voordat deze wet in werking is getreden te eniger tijd is toegetreden tot de krijgsmacht van de Republiek Indonesië en voldoet aan de voorwaarden, die zullen worden vastgesteld door de Minister van Defensie, verkrijgt het staatsburgerschap van de Republiek Indonesië, indien hij een daartoe strekkende verklaring aflegt bij de Minister van Defensie of bij de ambtsdrager daartoe door deze aangewezen. Het staatsburgerschap van de Republiek Indonesië, dat door bovengenoemde persoon wordt verkregen, werkt terug tot het tijdstip, waarop de betrokkene tot de krijgsmacht is toegetreden.

\section{Artikel VII}

Degene, die voordat deze wet in werking treedt, in dienst was van een vreemde krijgsmacht, bedoeld in artikel 17 , letter $\mathrm{f}$., of in dienst van een intemationale organisatie, bedoeld in artikel 17 , letter g., kan binnen een jaar na het in werking treden van deze Wet daartoe alsnog verlof vragen aan de Minister van Justitie.

\section{SLOTBEPALINGEN}

\section{Artikel I}

Een staatsburger van de Republiek Indonesië, die verblijft op het grondgebied van de Republiek Indonesië, wordt geacht geen andere nationaliteit te bezitten.

\section{Artikel II}

Onder het begrip nationaliteit valt elke soort bescherming door een of andere staat. 
Voor de toepassing van deze Wet worden kinderen die de leeftijd van 18 jaar nog niet hebben bereikt en nog niet zijn gehuwd, geacht de woonplaats te volgen van hun vader of moeder naar de onderscheidingen van artikel 1 , letter b., c. of $d$.

\section{Artikel IV}

Een ieder, die moet bewijzen, dat hij staatsburger van de Republiek Indonesië is en geen bewijsstukken bezit, die aantonen, dat hij dit statsburgerschap bezit of heeft verkregen of is gevolgd in het bezit of de verkrijging ervan, kan aan het Landgerecht van zijn woonplaats vragen om volgens het gewone burgerlijk procesrecht vast te stellen of hij al dan niet staatsburger van de Republiek Indonesië is. Deze bepaling doet niet af aan bijzondere voorschriften in of krachtens andere Wetten.

\section{Artikel V}

Van de afgelegde verklaringen, die de verkrijging of het verlies van het staatsburgerschap van de Republiek Indonesië tot gevolg hebben, wordt door de betrokken ambtsdrager afschrift gezonden aan de Minister van Justitie.

\section{Artikel VI}

De Minister van Justitie publiceert in de Staatscourant de namen van degenen, die het staatsburgerschap van de Republiek Indonesië hebben verkregen of verloren.

\section{Artikel VII}

Al hetgeen nodig is voor het ten uitvoer leggen van de bepalingen van deze Wet wordt geregeld bij Regeringsverordening.

Artikel VIII

Deze Wet treedt in werking op de dag van haar afkondiging, met de bepaling, dat de bepalingen van artikel 1 , letter $b$. tot letter j., artikel 2 , artikel 17, letter a., c. en h. terugwerken tot de 27ste December 1949. 
Opdat een ieder op de hoogte is van de Wet, wordt de afkondiging van deze Wet verordend door plaatsing in het Staatsblad van de Republiek Indonesië.

Afgekondigd

op 1 augustus 1958

DE MINISTER VAN JUSTITIE

G.A. MAENGKOM goedgekeurd te Jakarta

op 29 juli 1958

THE PRESIDENT VAN DE

REPUBLIEK INDONESIE

SOEKARNO

DE MINISTER VAN JUSTITIE

G.A. MAENGKOM

STAATSBLAD NO.113 VAN HET JAAR 1958 

Achterberg, C.E.

Adriaanse, J.C. en S. van der Weg, oorspronkelijke bewerkers, thans onder redactie van C.J. Brinkman, met medewerking van F.Th.

Zilverentant en R.M. Pruimers.

Algra, N.E. en H.R.W. Gokkel

Ali, H. Mohammad Daud

American Society of International Law

Asser, C., bewerkt door W.C.L. van der Grinten

Association of South East Asian Nations

Australian Council for Overseas Aid (ACFOA)

Avoort, A.S. van der en G.R. de Groot
Nederlanders, Vreemdelingen en Ingezetenen, Groningen, 1895.

Nationaliteitswetgeving, 's-Gravenhage.

Fockema Andrea's Juridisch Woordenboek, Alphen aan den Rijn, 1985.

Sikap Negara dalam mewujudkan Perlindungan Hukum bagi Warganegara dan pelaksanaan Undang-Undang Perkawinan yang berlaku, Hukum dan Pembangunan, 1992, p. 128-243.

Vienna Convention on Succession of States in Respect of Treaties, American Journal of International Law, Vol. 72, 1978.

Handleiding tot de beoefening van het Nederlands Burgerlijk Recht, vertegenwoordiging en rechtspersoon, Zwolle, 1986.

10 Years ASEAN, Jakarta, 1978.

Transmigration in Indonesia, ACFOA Briefing, mei 1985.

De Rijkswet op het Nederlanderschap, De jurisprudentie naar aanleiding van art. 8, 9 en 10 van de Rijkswet op het Nederlanderschap nader onderzocht, Migrantenrecht, 1992, p.27-36. 
Bagley, Ch.

Bakker, P.

Bakker, P.

Bank Indonesia

Bardjo, Imam

Barentsen, W.A.

Basuki, Z. Djoko

Beets, N.

Blume, H.A.
The Dutch Plural Society: A Comparative Study in Race Relations, London/New York/Toronto, Oxford University Press, 1973.

De nationaliteit van de Nederlandse vrouw na huwelijk met een Indonesiêr, Het Personeel Statuut, 1954, p.64-67.

Intrekking Wet Nederlands Onderdaanschap, Het Personeel Statuut, 1963, p.9-11 en 1964, p.88-91.

Report for the Financial Year 1986/87, Jakarta.

Masaalah Kewargaan Negara Republik Indonesia, Semarang, 1958.

Overzicht van de huidige interpretatie van de Overeenkomst betreffende de Toescheiding van Staatsburgers, Het Personeel Statuut, 1961, p.51-60 en 1962, p.61-62.

Perkawinan Antar Agama dewasa ini di Indonesia, ditinjau dari segi Hukum Antar Tata Hukum, Hukum dan Pembangunan, 1987, p.235-243.

Het Ingezetenschap en het Nederlandsch Onderdaanschap der Inheemsche Bevolking van Nederlandsch-Indië, Indisch Tijdschrift van het Recht, 1933, p.525-528.

De toekenning van Regt op Verblijf in Nederlandsch-Indië en de Hoofdonderscheidingen in zijn Bevolking naar aanleiding van artikel 105, 106, 107 en 109 van het R.R. van Nederlandsch-Indië, Leyden, 1858. 
Boelens, G.J.

Borchard, E.M.

Breukelaar, W.

Brinkman, C.J.

Brinkman, C.J.

Brouwer, J.

Brownlie, I.

Budiarto, M.

Budijaya, Nyoman

Campbell, D.

Chalanton, $\mathrm{P}$.

Chan, J.M.M.
Vreemde Krijgsdienst, Rechtsgeleerd Magazijn Themis, 1950, p.276-299.

The Diplomatic Protection of Citizens Abroad, New York, 1915.

Onderscheid naar Nationaliteit:

Discriminatie, NJCM, 1984, p. 339-347.

De Nederlandse nationaliteitswetgeving, Zwolle, 1985.

Het Nederlandse nationaliteitsrecht in de praktijk, Alphen aan den Rijn, 1985.

De Nationaliteit van de Gehuwde Vrouw in België en in Nederland, Assen/Amsterdam, 1955.

Principles of Public International Law, Oxford, 1990.

Pengangkatan Anak ditinjau dari segi Hukum, Jakarta, 1984.

Catatan Sipil di Indonesia, suatu tinjauan yuridis, Surabaya, 1987.

Legal Aspects of Doing Business in Asia and the Pacific, Intemational Business Series (Indonesië samengesteld door Gautama, S.).

La Nationalité Néerlandaise, (Pays-Bas et Colonies), 's-Gravenhage, 1928.

The Right to a Nationality as a Human Right, The current Trend towards Recognition, Human Rights Law Joumal, 1991, p.1-14. 
Commercial Advisory Foundation in Indonesia

Commissie Ontwikkeling Bedrijven (COB/SER)

Damian, E. en R.N. Hornick

Darjanto, Rom en D. Muljadi

Duynstee, F.J.M.

Ende, W. en U. Steinbach

Engelbrecht, W.A.

Fromberg, P.H.

Gautama, S.

Gautama, S.

Gautama, S.
Warta-Cafi, jaargang 33, no. 136 van 14 nov. 1991 en jaargang 34 , nummers 63 van 26 mei 1992, 64 van 27 mei 1992, 66 van 2 juni 1992 en 116 van 26 sept. 1992.

Ervaringen van Nederlandse bedrijven in Ontwikkelingslanden; Dagelijkse praktijk van management en investeren in Afrika en Azië.

Indonesia's Formal Legal System, The American Joumal of Comparative Law, 1972, p.492-530.

Kewargaan Negara Indonesia, Jogjakarta, 1968.

Nieuw-Guinea als schakel tussen Nederland en Indonesië, Amsterdam, 1961.

Der Islam in der Gegenwart, München, 1984.

De Wetboeken, Wetten en Verordeningen benevens de Voorlopige Grondwet van de Republiek Indonesië, Leiden, 1954.

Verspreide Geschriften verzameld door Chung Hwa Hui, Chineesche vereeniging in Nederland, Leiden, 1926.

Aneka Masalah Hukum Perdata Internasional, Bandung, 1985.

De rechtsontwikkeling in Indonesië na de Souvereiniteitsoverdracht, WPNR, 1969, p.61-63, 89-91 en 101-104.

Hukum Perdata Internasional Indonesia, vol. III, deel 1, Bandung, 1981. 
Gautama, S.

Gautama, S.

Gautama, S.

Gautama, S.

Gautama, S. en R.N. Homick

Gondokusumo, Djody

Gouw Giok Siong (Gautama, S.)

Gouw Giok Siong

Groot, G.R. de

Groot, G.R. de

Groot, G.R. de

Groot, L.J.A. de
Komentar Keputusan Hakim: Adopsi Internasional dalam Praktek Peradilan di Indonesia, Hukum dan

Pembangunan, 1991, p.83-90.

Mahkamah Agung dan

Keanekaragaman Hukum Perdata, Hukum dan Pembangunan, 1987, p. 163-169.

Tafsiran Undang-Undang Kewarganegaraan Republik Indonesia, Bandung, 1973.

Warganegara dan Orang Asing, Bandung, 1987.

The Employment of Foreigners in Indonesia, Malaya Law Review no. $29,1987$.

Siapa termasuk Warganegara Indonesia, Voorlichtingsdienst van de Centrale Baperki, Jakarta.

Hukum Antargolongan, Jakarta, 1956.

Soal-Soal Aktuil tentang

Kewarganegaraan, Jakarta, 1959.

Gelijkheid van man en vrouw in het nationaliteitsrecht, preadvies uitgebracht voor de Nederlandse Vereniging voor Rechtsvergelijking no. 25, Deventer 1977.

Personen- en familierecht, Nationaliteitswetgeving, Deventer (losbladig).

Staatsangehörigsrecht im Wandel, 's-Gravenhage, 1988.

De Nationaliteit van Gehuwde Vrouwen, Het Personeel Statuut, 1952, p.89-92. 
Groot, G.R. de en M. Tratnik.

Gunn, G.C.

Haar, B. ter

Haar, B. ter

Haarmans, P.D.

Haas-Engel, R.H. de

Haas-Engel, R.H. de

Hamid, A.T.

Hasselt, van

Hecker, $\mathrm{H}$.

Hecker, $\mathrm{H}$.

Hecker, $\mathrm{H}$.
Nationaliteitsrecht, Zwolle, 1986.

The Garuda and the Dragon; Indonesian-Chinese relations, Asian Pacific Review, 1987, p.17-34.

Adat Law in Indonesia, New York, 1948.

Beginselen en Stelsel van het Adatrecht, Batavia, 1939.

De Toescheidingsovereenkomst in de praktijk, De nationaliteitswetgeving bij de Souvereiniteitsoverdracht aan de Republiek Suriname, Paramaribo, 1988.

De Indonesische Huwelijkswet en Echtscheidingen, Orion, 1988, no.3, p. $46-47$.

Het Staatsburgerschap van de Republiek Indonesië, Jakarta, 1958.

Kamus Yurisprudensi dan beberapa Pengertian tentang Hukum (acara) Perdata, Bandung, 1984.

Verzameling van Nederlandse Staatsregelingen en Grondwetten, Alphen aan den Rijn, 1964.

Das Staatsangehörigkeitsrecht von Brunei, Indonesien, Malaysia, Singapur und den Philippinen, Frankfurt am Main, 1978.

Die Staatsangehörigkeitsregelungen in den vier überseeischen Kontinenten, Hamburg, 1970.

Einfluß der Adoption auf die Staatsangehörigkeitsrecht, StAZ 1985, p. 153-163. 
Heijs, E.

Heinsius, A.J.R.

Heyden, E.J.J. van der, bewerkt door W.C.L. van der Grinten

Himawan, Ch.

Ichtiar Baru-van Hoeve

Ichtiar Baru-van Hoeve

Ichtiyanto, $\mathrm{H}$.

Indon. Departement van Binnenlandse Zaken

Indon. Departement van Justitie, Directoraat-Generaal Recht en Wetgeving
Nederlanderschap in de Nederlandse Koloniën: Regulering van immigratie vanuit de koloniën door nationaliteitsbeleid in Nederland, Recht der Werkelijkheid, 1991, p.21-42.

Zijn zy, die behooren tot de inheemsche bevolking van Nederlandsch-Indië, ingezetenen van Nederlandsch-Indië en Nederlandse onderdanen? Indisch Tijdschrift van het Recht, 1933, p.9-14.

Handboek voor de Naamloze Vennootschap en de Besloten Vennootschap, Zwolle, 1984.

The Foreign Investment Process in Indonesia, Singapore, 1980.

De Wetboeken, Wetten en

Verordeningen, benevens de Grondwet van de Republiek Indonesië, $d / h$ Engelbrecht, Jakarta, 1989.

Himpunan Peraturan

Perundang-Undangan, disusun menurut sistem Engelbrecht, Jakarta, 1989.

Perkawinan Campuran menurut Undang-Undang Perkawinan, Hukum dan Pembangunan, 1989, p.123-148.

Himpunan peraturan perundang-undangan tentang Kewarganegaraan, Assimilasi, dan Orang Asing, Jakarta, 1978.

Himpunan Peraturan-Peraturan Kewarganegaraan R.I. 
Indon. Departement van Voorlichting, speciale editie no. 56 .

Indon. Departement van Voorlichting

Indon. Departement van Voorlichting

Institute of South East Asian Studies

International Law Association

Jessurun d'Oliveira, H.U.

Jessurun d'Oliveira, H.U.

Jessurun d'Oliveira, H.U.

Juynboll, Th.W.

Kähler, K.

Kansil, C.S.T.
Het Regeringsantwoord op de Algemene Beschouwingen van de Constituante betreffende de opdracht van de President van 22 april 1959 en de aanbeveling van de Regering om naar de Grondwet van 1945 terug te keren.

Indonesia 1988, an official handbook.

Wie zijn de Staatsburgers van de Republiek? Jakarta, 1946.

ASEAN, a bibliography, Singapore, 1984.

Report of the 33rd Conference (1924)

Internationaal recht en Vrouwen. De betekenis van het Internationale recht voor Vrouwen in Nederland, deel 1, Commentaren, Zwolle, 1987.

Moet het Verdrag van New York van 20 februari 1957 betreffende de Nationaliteil van de Gehuwde Vrouw nu wel of niet worden opgezegd? Nederlands Juristenblad, 1985, p.50-54.

Onderscheid naar Nationaliteit:

Discriminatie, NJCM-bulletin, 1984, 327-338.

Handleiding tot de Kennis van de Mohammedaanse Wet, Leiden, 1930.

Wirtschafsverfassung und Kapitalinvestation in Indonesien, Hamburg, 1974.

Hukum Kewarganegaraan Republik Indonesia, Jakarta, 1992. 
Kansil, C.S.T.

Kansil, C.S.T.

Kansil, C.S.T.

Kantoor ter Regeling van Ingezetenen van het Speciale District van de Hoofdstad Jakarta

Keller, J.E. en W.E.A. van Beek

Knapp, V.

Koch, D.M.G. en J.W.E. Riemers

Koessler, M.

Kollewijn, R.D.

Kollewijn, R.D.

Kollewijn, R.D.
Hukum Tata Negara Republik Indonesia, boek 1 (1945-1985), Jakarta, 1986.

Hukum Tata Negara Republik Indonesia, boek 2 (1985 tot heden), Jakarta, 1987.

Sistem Pemerintahan Indonesia, Jakarta, 1985.

Himpunan undang-undang dan peraturan-peraturan tentang Orang Asing di Indonesia, Jakarta, 1972.

Anthropologische Nomenclatuur, Heerlen, Open Universiteit

International Encyclopedia of Comparative Law, volume 1, National Reports.

Het geschilpunt West Nieuw Guinea eist een oplossing, gecommentarieerde bloemlezing, 1955.

Subject, Citizen, National and Permanent Allegiance, The Yale Law Journal, 1946-1947, p.58-76.

Het Wetsontwerp tot nadere vaststelling van art. 2 der Wet op het Nederlanderschap en de Toescheidingsregeling met Indonesiē, Nederlands Juristenblad, 1952, p.378-379.

Intergentiel Recht, Verzamelde Opstellen over Intergentiel Privaatrecht, 's-Gravenhage, 1955.

Nationaliteit en Burgerschap in het Koninkrijk der Nederlanden en in de Nederlands-Indonesische Unie, Indonesië, 1947, p.98-116. 
Ko Swan Sik

Ko Swan Sik

Ko Swan Sik

Lauterpacht, $\mathrm{H}$.

Lemaire, W.L.G.

Lev, D.S.

Logemann, J.H.A.

Logemann, J.H.A.

Mackie, J.A.C.

Mahkamah Agung R.I.

Mahkamah Agung R.I.

Mahkamah Agung R.I.
De Meervoudige Nationaliteit, Leiden, 1957.

Nationality and International Law in Asian Perspective, 's-Gravenhage, 1990.

Preadvies "Nationaliteit en

Volkenrecht", Ned. VVIR, Deventer, 1981.

International Law and Human Rights, Londen. 1950.

Het Recht in Indonesië, 's-Gravenhage, 1952.

The Lady and the Banyan Tree: Civil Law Change in Indonesia, The American Joumal of Comparative Law, 1965, p.282-307.

De Nationaliteitsregeling voor de inwoners van Nederlands Nieuw Guina, Nederlands Juristenblad, 1957 , p. 127-130.

Nederlandsch onderdaanschap en het Hooggerechtshof (in

Nederlandsch-Indië), Indisch

Tijdschrift voor het Recht, 1933, p.500-501.

The Chinese in Indonesia, The University Press of Hawaii, Honolulu, in association with The Australian Institute of International Affairs, 1976.

Himpunan Tanya - Jawab tentang Hukum Perdata.

Putusan-Putusan yang menyangkut masalah Perkawinan.

Rangkuman Yurisprudensi. 
Mahkamah Agung R.I.

Makarov, A.N.

Makarov, A.N.

Mangoldt, $H$. von

Mannoury, J.

Mannoury, J.

Marbun, D.C.

Marsono

Martosoewignjo, Sri Soemantri

Mastenbroek, W.E. van

McNair, H.F.
Yurisprudensi Indonesia.

Allgemeine Lehren des

Staatsangehörigkeitsrechts, Stuttgart, 1962.

Staatsangehörigkeit in: Strupp, K. en H.J. Schlochauer, Wörterbuch des Völkerrechts, Berlijn, 1962, derde band, p.323-329.

Anerkennung der Staatsangehörigkeit und effektive Staatsangehörigkeit natürlicher Personen im Völkerrecht und im Internationalen Privatrecht, Heidelberg, 1988.

De herziening van onze

Nationaliteitswetgeving en de status van Indonesische staatsburgers in Nederland, Bestuurswetenschappen, 1953, p. 125-141.

Het Nederlandse Nationaliteitsrecht, Alphen aan den Rijn, 1954.

Fungsi dan Makna Pencacatan dalam Undang-Undang Perkawinan, Varia Peradilan, januari 1992, p.144-150.

Almanak Negara Republik Indonesia, Jakarta, 1987.

Tentang Lembaga-Lembaga Negara menurut UUD 1945, Bandung, 1983.

De Historische ontwikkeling van de Staatsrechtelijke Indeeling der Bevolking van Nederlandsch-Indië, Amsterdam, 1934.

The Chinese Abroad, Shanghai, 1924. 
Molengraaff, W.L.P.A.

Muralt, R.W.G. de

Nationale Bibliotheek, Indon. Departement van Opvoeding en Cultuur

Ndraha, Taliziduhu

Ned. Ministerie van Buitenlandse Zaken

Ned. Ministerie van Buitenlandse Zaken

Ned. Ministerie van Buitenlandse Zaken

Ned. Ministerie van Buitenlandse Zaken

Nederburgh, I.A.

Nederburgh, I.A.

Otten, $\mathbf{M}$.

Palte, J.G.L. en G.J. Tempelman
Praeadvies: Moet aan private rechtspersonen een nationaliteit toegekend worden en $z 0 \mathrm{ja}$, verlangt deze nationaliteit bijzondere wettelijke regeling, NJV, 1920.

The Problem of State Succession with regards to Treaties, Utrecht, 1954.

Bibliografi Hukum di Indonesia, 1945-1981, Jakarta, 1982.

Dimensi-Dimensi Pemerintahan Desa, Jakarta, 1991.

Directoraat-Generaal Internationale Samenwerking, Beleidsplan voor de Ontwikkelingssamenwerking met Indonesië voor de periode 1989-1992.

Internationale Samenwerking, no. 6, juni 1987, Indonesië/Historie IGGI.

Internationale Samenwerking, no. 10, october 1988, Indonesië, Werkgelegenheid.

Internationale Samenwerking no. 8, augustus 1989, Indonesië/IGGI.

Nederlanderschap en Naturalisatie van in Ned.-Indië geborenen, Indisch Tijdschrift van het Recht, 1902, p.69-73.

Nederlandsch Staatsverband en Koloniën, Rechtsgeleerd magazijn Themis, 1928, p.222-230.

Transmigrasi: Myths and Realities Indonesian Resettlement Policy, 1965-1985, Kopenhagen, 1986.

Indonesië, Haarlem, 1981. 
The rôle of Nationality in International law, Leiden, 1959.

Paulus, B.P.

Perhimpunan Ahli-Hukum Indonesia

Pitlo, A. en G. Meijling

Pompe, S.

Pompe, $\mathrm{S}$.

Pompe, S. en C. de Waaij-Vosters

Posthumus, G.A.

Practicus

Praeger Publishers, CBS Educational and Professional Publishing, a

Division of CBS, inc.

Prins, W.F.
Kewarganegaraan RI ditinjau dari

UUD 1945, khususnya

Kewarganegaraan Peranakan

Tionghoa, Jakarta, 1983.

Hukum, 1957, no. 1-2, en 1958, no. 9-10.

Het Personenrecht naar het Nederlands Burgerlijk Wetboek, Haarlem, 1953.

A short note on some Recents Developments with regard to Mixed Marriages in Indonesia, Bijdragen tot de taal-, land- en volkenkunde, 1991, p. 261-272.

Mixed Marriages in Indonesia, Bijdragen tot de taal-, land- en volkenkunde, 1988, 259-275.

The End of Hukum Antargolongan?

Bijdragen tot de taal-, land- en volkenkunde, 1989, p.365-369.

De Intergouvernemental Group on Indonesia (IGGI), Rotterdam, 1971.

Nationaliteitsrecht, Alphen aan den Rijn, 1954.

The Indonesian Economy, New York, 1980.

De Bevolkingsgroepen in het Nederlandsch-Indische recht, Kol. Stud., 1933, p.652-689. 
Prins, W.P.

Prins, W.F.

Prins, W.F.

Prodjohamidjojo, Martiman

Purbopranoto, Kuntjoro

Reksodiputro, Mardjono

Ricklefs, M.C.

Roeder, R.O.G. en J. Willecke

Röling, B.V.A.

Saleh, K. Wantjik

Sande Bakhuyzen, A. van de

Sanger, E.
De gevolgen van de

Souvereiniteitsoverdracht ten aanzien van de nationaliteit van Nederlandse onderdanen, Het Personeel Statuut, 1952, p.49-74.

Een verwaarloosde zuster vraagt aandacht, Het Personeel Statuut, 1962, p. 25-28.

Jurisprudentie inzake de Wet op het Nederlanderschap en de Toescheidingsovereenkomst, Het Personeel Statuut, 1953, p.34-38.

Penerapan atas ketentuan Pasal 284 (1) KUHP, Varia Peradilan, oktober 1991, p.151-155.

Dasar-dasar hubungan Warganegara dengan Pemerintah, Malang, 1960.

Pemantauan Pelaksanaan Hukum tentang Hak-Hak Asasi Manusia, Hukum dan Pembangunan, 1991, p.545-559.

A History of Modern Indonesia, part c.: 1300 to the present, Monash University, Londen, 1981.

Wirtschafspartner Indonesien, Hamburg, 1979.

Nieuw-Guinea als Wereldprobleem, Assen.

Peraturan baru tentang kewarganegaraan Republik Indonesia, Jakarta, 1980.

Nederlandsch Onderdaanschap, Leiden, 1900.

Die indonesische Staatsangehörigkeit, Bonn, 1958. 
Sasmojo

Sastrayudha, S.

Sati, Bujung Datuk Intan

Sati, Bujung Datuk Intan

Schreuder, L.F.G.P.

Schwarzerberger, G.

Scolt, G.L.

Sieghart, P.

Siregar, Bismar

Siregar, Bismar
Menjelesaikan masalah

dwikewarganegaraan R.I.-R.R.T., Jakarta, 1959.

Het Nederlandsche onderdaanenschap en de Indonesische Candidaten voor de 2de kamer, Weekblad van het Recht, 1933, no. 12590 . p.8.

Beberapa Hal mengenai cara memperoleh Kewarganegaraan R.I., Himpunan Peraturan-Peraturan Kewarganegaraan R.I.

Beberapa Pokok-Pokok dalam memecahkan Masalah

Kewarganegaraan R.I., Himpunan

Peraturan-Peraturan Kewarganegaraan R.I.

Wet van 12 December 1892 op het Nederlanderschap en het Ingezetenschap, Zutphen.

International Law, deel I, 1957.

Indonesian Women and Development, Leiden.

The Lawful Rights of Mankind, Oxford, 1986.

Catatan atas putusan Mahkamah Agung R.I. no. $1400 \mathrm{~K} / \mathrm{Pdt} / 1986$, Benarkah Perkawinan Beda Agama, rechtsvacuum?, Varia Peradilan, november 1989 , p. $150-152$.

Hubungan Kitab Undang-Undang Hukum Perdata dengan Undang-Undang No. 1 tahun 1974 tentang Perkawinan dan Penerapannya dalam Praktek Notaris, Varia Peradilan, augustus 1988, p.127-139. 
Siregar, Bismar

Soebrata, Soedarman Ganda

Soenario

Soewondo, Nani

Sukamo, H.

Suntjaja

Suraputra, D. Sidik

Suriawinata, D.D.

Suryadinata, L.

Swasono, S. en M. Singarimbun
Kawin Campur antar Agama, bagaimana Penyelesaiannya, Varia

Peradilan, december 1991, p.145-147.

Pengadilan Negeri dalam penyelenggaraan Undang-Undang Kewarganegaraan Republik Indonesia no. 62 tahun 1958 jo. Peraturan Pemerintah no.67 tahun 1958, Himpunan Peraturan-Peraturan Kewarganegaraan R.I.

Masalah-Masalah disekitar soal Warganegara dan Orang Asing.

Kedudukan Wanita Indonesia dalam Hukum dan Masyarakat, Jakarta, 1984.

Himpunan lengkap Peraturan

Perundang-Undangan Catatan Sipil di Indonesia, Jakarta, 1985.

Himpunan peraturan perundang-undangan tentang masalah Orang Asing, Jakarta, 1976.

Sikap Indonesia terhadap Perjanjian Intemasional yang dibuat Pemerintah Belanda, Hukum dan Pembangunan, 1980, p.227-238.

"Kawin Agama" merupakan unsur "Kawin lagi" yang diminta oleh pasal 9 Undang-Undang no. 1 tahun 1974 jo. pasal 279 KUU Pidana, Varia Peradilan, juni 1989, p.135-137.

Military Ascendance and Political Culture, a Study of Indonesia's Golkar, Ohio, 1989.

Sepuluh Windhu Transmigrasi di Indonesia, 1905-1985, Jakarta, 1985. 
Syahmin, A.K.

The Indonesia Spectator, the magazine on Indonesian affairs,

Tirtawidjaja, Tubagus Pranata

Tirtoprodjo, Susanto

Tratnik, M.

Tribe, L.H.

Utrecht, E. en Moh. Saleh Djindang

Vollenhoven, C. van

Vollenhoven, C. van

Weg, S. van der

Weg, S. van der
Penyelundupan Hukum lewat Lembaga Perkawinan Campuran, Padjadjaran, 1986, p.56-66.

Chinese Dual Nationality, 1958.

Jus sanguinis dan dwi-kewarganegaraan di Indonesia, Mimbar Departemen Kehakiman, Jakarta, 1969.

Hasil kerdja panitya-bersama tjara pelaksanaan Perdjandjian Dwikewarganegaraan Republik Indonesia-Republik Rakjat Tiongkok, Jakarta, 1961.

Het Nationaliteitsrecht in de Oosteuropese landen, Deventer, 1989.

American Constitutional Law, New York, 1978.

Pengantar dalam Hukum Indonesia, Jakarta, 1982.

Het Adatrecht van Nederlandsch-Indië, deel I, Leiden, 1918.

Het Adatrecht van Nederlandsch-Indië, deel II, Leiden, 1926.

Artikel 10 der Wet op het Nederlanderschap en het Ingezetenschap geldt niet voor kinderen van spijtoptanten, Het Personeel Statuut, 1959, p.36-37.

De artikelen 8 en 9 van de Overeenkomst betreffende de Toescheiding van Staatsburgers, Het Personeel Statuut, 1955, p.63-66 en 1956, p.111-112. 
Weg, S. van der

Weg, S. van der

Weg, S. van der

Weg, S. van der

Weis, $\mathbf{P}$.

Wengler, W.

Wertheim, W.F.

Wertheim, W.F.

Wertheim, W.F.

Wiessner, S.

Winter, L.I. de
De Indonesische nationaliteitswet, Het Personeel Statuut, 1959, p.1-9.

Hoe bewijzen Indische Nederlanders hun Nederlanderschap, Het Personeel Statuut, 1950, p.31-32.

Is een met Europeanen gelijkgestelde een inheemse in de zin van de Toescheidingsovereenkomst? Het Personeel Statuut, 1952, p.44-48 en 74.

Terugwerkende kracht van opties tot verkiezing of verwerping van nationaliteit ingevolge de souvereiniteitsoverdracht, Het Personeel Statuut, 1952, p.43-44.

Nationality and Statelessness in International Law Alphen aan de Rijn/Germantown 1979.

Betrachtungen zum Begriff der Staatsangehörigkeit, in internationalrechtliche und staatsrechtliche Abhandlungen, Festschrift für Walter Schätzel, 1960.

Herrijzend Azië, Opstellen over de Oosterse samenleving, Amhem, 1950.

Het Rassenprobleem, De ondergang van een mythe, 's-Gravenhage, 1948.

Indonesian Society in Transition, a study of Social Change, 's-Gravenhage, 1956.

Die Funktion der Staatsangehörigkeit, Tübingen, 1989.

Het Haagse Adoptieverdrag, WPNR, 1965, p.353-355, 365-367 en 395-397. 
Yamin, H.M.

Yayasan Lima
Naskah Persiapan Undang-Undang Dasar 1945, deel 1, 1959.

Himpunan undang-undang \& peraturan mengenai masalah Cina di Indonesia, Jakarta, 1976. 

A. Vindplaatsen jurisprudentie

1. Rangkuman Yurisprudensi Mahkamah Agung Indonesia, Hukum Perdata dan Acara Perdata, Proyek Yurisprudensi Mahkamah Agung.

(Code RY)

2. Yurisprudensi Indonesia, uitgegeven door de Mahkamah Agung R.I. (Code YI)

3. Hukum, tijdschrift van de Perhimpunan Ahli-Hukum Indonesia, no. 1-2, jaar 1957 en no. 9-10, jaar 1958.

(Code Huk.)

4. Kamus Yurisprudensi dan beberapa Pengertian tentang Hukum (acara) Perdata, uitgegeven door A.T. Hamid, Surabaya, 1984.

(Code KY)

5. Literatuur.

(Code Lit.)

B. Aangehaalde arresten van de "Mahkamah Agung" en vonnissen van lagere rechtbanken betreffende Nationaliteitsrecht, adoptie en het van toepassing zijnde recht in Indonesië.

\section{Datum Nummer Vindplaats}

1. I september 1954

2. 10 october 1956

3. 15 november 1957

4. 1 mei 1968

5. 8 januari 1972

6. 5 december 1975

7. 14 december 1975

8. 29 december 1975

9. -

10. 6 mei 1976

11. 13 april 1978

12. 3 juli 1980 no. $269 / 1954 \mathrm{G}$.

Reg.no. 2

no. $308 / 1957 /$ Pdt. R

no. $156 \mathrm{~K} / \mathrm{Sip} / 1967$

กо. $556 \mathrm{~K} / \mathrm{Sip} / 1971$

no. $261 \mathrm{~K} / \mathrm{Sip} / 1973$

no. $942 \mathrm{~K} / \mathrm{Sip} / 1972$

no. $281 \mathrm{~K} / \mathrm{Sip} / 1973$

no. $349 \mathrm{~K} / \mathrm{Sip} / 1967$

no. $990 \mathrm{~K} / \mathrm{Sip} / 1974$

no. $1002 \mathrm{~K} / \mathrm{Sip} / 1976$

no. $849 \mathrm{~K} / \mathrm{Sip} / 1977$
Lit. ${ }^{975}$

K/Rup/1956 Huk. p. 134. ${ }^{976}$

Huk. p. $130 .{ }^{977}$

YI I-II-III-IV/69 p.687

YI I-II-III-IV/72 p.494

RY II p.1

KY p.22.

KY p.22.

RY II p.7. ${ }^{978}$

RY II p.2

YI 1980-II p. 160

YI 1980 -I p. 179

975. Het betreft hier het vonnis van de "Pengadilan Negeri" te Jakarta, aangehaaid door Gautama, S., Tafsiran Undang-Undang Kewarganegaraan Republik Indonesia, Bandung, 1973, p.150. Ik heb niet kunnen nagaan of er een vonnis van een hogere rechtbank aanwezig is.

976. Opgenomen in het tijdschrift Hukum van de Perhimpunan Ahli-Hukum Indonesia, no. 1-2, jaar 1957.

977. Het gaat hier om het vonnis van de "Pengadilan Negeri" te Semarang. Niet kon worden nagegaan, of er een vonnis van een hogere rechtbank voorhanden is. Dit vonnis is opgenomen in het tijdschrift Hukum van de Perhimpunan Ahli-Hukum Indonesia, no. 9-10, jaar 1958.

978. De datum van dit arrest is niet bekend. 

Actieve stelsel 117

Adatrecht 18, 19, 28, 92, 94, 98, 105, $118,151,184,185,192-194$, $196,214,242,248,301$

Adoptie 61, 94, 131, 168, 181, 189-198, 202, 276, 280, 281, $285,287-291,305,321,322$, 330,331

Adoptio minus plena 196

Adoptio plena 196

Afgeleide nationaliteit 251

Algemene rechtbanken 15

Algemene verkiezingen $11-13,42,172$, 304,310

Allégeance perpétuelle 53,54, 145, 205,210

Alsof-Nederlanders 261, 262

Apatride 142, 187, 188, 235, 247, 251, $252,267,275,277,279,290$, 324

Apatridie $70,163,164,187,188,221$, $245,247,275,276,278,281$, $318-321,323,324,329$

Assimilatieproces 56

Autochtone Indonesiërs $19,56,79-82$, $84,86,90,92-94,101,109$. $114,117,121,128,151,152$, $153,185,212,258,271,272$, 316

Autochtone Indonesiërs en dasrmede gelijkgestelden $79,80,82,84$, $86,109,152,316$

Behandeld als $147,236,260,268,269$ Bescherming 1, 16, 34, 37-41, 43, 50, $64-67,72,74,81,82,101$, $145,147,152,221,295,312$, 315,324

Bevolkingsgroep $89,90,92,98-100$, $127,139,183,194,242,245$, 305,332

Bipatride $31,54,73,114,144,153$, $165,167-169,173,178,186$, $191,201,204,205,213,216$, $222,237-239,244,247,251$, $253,269,279,285,286$, $293-295,301,318,320,322$, 323
Bipatridie 3, 31, 102, 112, 143, 145, $146,162-166,168,170,173$, $176-178,186,187,189,190$, $191,203,205,208,221,222$, $227,231-234,237,238,245$, $247,249,252,254,255,265$, $276,279,284-286,295,301$, $304,306,311,318-323,326$, 328,329

Buitenlander 33, 34, 42, 78, 87, 133, $173,177-179,190,191,199$, $200,202,206,207,212,213$, $226,232,237,238,241-243$, $246-249,252,253,265,271$, $276,279,281,283,286-288$, 290, 296, 297, 301, 303, 308, $310,320,323,324,330,331$, 334

Buitenlands paspoort 143, 187, 213, $238,294,296,312,323,329$

Buitenlandse vrouwen $141,146,163$, $232,236,237,260,277-279$, 281,304

BUPO-verdrag $38,45,46$

Burgerlijke betrekking $118,182,184$, $242,253,286$

Burgerlijke Stand $86,96,105,163$, 241-244, 301, 332, 333

Chinese Volksrepubliek 3, 22, 31, 65, $99,143-146,165,166$, $168-170,172-1.74,176-179$, 189, 193, 203, 205, 209, $221-223,234,241,285,294$, $301,304,306,311,321$

Chinezen $19,23,31,56,65,81,85$, $87,88,93-95,101,110,128$, $143-145,153,158,165,166$, $183,185,195,205,271,285$, $294,316,332,333$

Civiele Nederlander 82

Concordantiebeginsel 93

Constitutie van de RVSI $114,115,146$, 153

Culturele identiteit 213,217

De facto-apatriden 143

Dekolonisatie 71

Diplomatieke bescherming $1,37,39$, $40,43,64-67,74,81,101$, $152,221,312,315,324$ 
Diplomatieke betrekkingen $7,22,144$, $176,223,234,258,321$

Discriminatie $33,52,55-57,64,90$, $246,315,322,324$

Dubbel staatsburgerschap 65, 164-167, $170,174,176,201,202,205$, $208,211,222,223,234,294$, 311,321

Dubbele nationaliteitsrechtelijke regeling 80,81

Eed c.q. belofte van trouw 211,229 , 259,265

Eenheid van nationaliteit $108,206,216$, $229,231,232,235,236,247$, $249,275,276,278,279,281$, 298,324

Eenmalige mogelijkheid 328

Effectieve nationaliteit $31,32,63$

Erkenning 61, 63, 65, 68, 69, 93, 112, $118,131,145,151,182,184$, $190,191,270,276,286,287$, $288,304,330$

Etnische nationaliteit 28-30

Europeanen 19, 23, 84, 85, 87-90, $92-98,109,117,121,125-128$, $150,152,158,183-185,195$, 332,333

Exclusiviteitsheginsel 58, 323

Expatriatierecht 52-54, 57, 210, 283

Faciliteitenpaspoorten 262

Faciliteitenwet 259-262

Familienaam 33, 46, 57

Familierecht 18, 28, 29, 92-95, 108, $243,262,279$

Familierechtelijke betrekking 161, 167, 181-184, 186, 190, 202, 216. $250,251,253,277,286,322$

Functionele nationaliteit 27, 30

Fundamentele rechten $34,36,38$, $43-45,48,50,57,73,74,315$

Gebiedsovergang 2, 27,63, 65, 68, $70-72,317$

Gecontroleerde optie 198, 231

Gehuwde vrouw 101, 108, 110, 119. $132,206,238,247,249,250$. $277,279,297,318,324,325$, 326

Gelijkgerechtigdheidsbeginsel 120, 246, $248,249,324,325$

Gelijkstelling aan Europeanen 97, 150

Gelijkwardige positie 56, 317
Gemengd huwelijk 99, 100, 199-201, $232,237,238,243,244,247$, $248,279,282,301,320,322$, 324

Genuine link 58, 65-67

Geprivilegieerde naturalisatie 181,198 , 199, 201, 202, 206, 207, 210, $214,226,227,231,247,319$

Gewone naturalisatie 181, 199-201, $203,210,226,228,254,264$, 319

Gewone verblijfplaats 61, 196, 197 , $287,288,330$

Godsdienst $15,72,88,89,98,100$, $101,105,154,183-185,193$, 240-246, 333, 334

Grondwet van 1945 4, 6, 10-12, 56, $95,114,140,155,203,225$, 259

Gunst $97,200,225,228,231$

Haagse Verdrag van $193040,50,53$, $59,61,62,65,110,113,249$

Handelingsonbekwaamheid 248

Huwelijk 18, 19, 28, 47, 61, 91, $94-97,99-102,105-109,118$, $119,132-136,141,142,146$, $147,150,151,161,163,168$, 181-186, 194, 196, 199-201, $213,214,216,217,230$, 232-249, 253-255, 261, 271, 272, 277-282, 286, 289, 291, $297,299,300,301,304,305$, $318,320-322,324-326,333$, 334

Huwelijksrecht 15, 18, 19, 91, 96, 245 Immigratiewet 34, 74, 142, 206, 215 , 221

Indische Nederlanders 129, 157

Indonesiscb staatsburger $28,30,39,56$, $67,73,91,99-101,115-118$, $120,122,127,128,130,133$, $137,139-143,146,147,150$, 151, 153-165, 168-170, 173, 175-178, 181, 182, 186-189, $191,192,200,206,212$, 216-218, 221, 227, 228, 230, $232,233,235-244,246-248$, $251,253-255,257,258,260$, 263. 270, 271, 272, 277-279, 281-283, 285-287, 294, 296, $300,301,304-309,311,312$, $317-323,327,333,334$

Indonesische namen 56 
Informele gelijkstelling 97

Ingezetenschap 1, 75-78, 83, 103, 109, $115,118,120,125,134,137$, $150,160,202,203,206,252$. 316

Inheemse bevolking $71,77,90,98,99$, $101,107,121,125-127,133$, 156

Inhoudelijk begrip $34,36,44,45,47$, $55,57,315$

Inlanders en mel deze gelijkgestelden 83, 129

Inter-American Convention on Human Rights 49, 57, 64, 67

Intergentiel recht 91 Intergentiele rechtskeuze 95

Internationaal gewoonterecht 57,60,61 Irian Jaya 3, 7, 23, 24, 71, 113, 139, $257,266,267,269-273,284$, 317

Islamitisch recht $18,105,185,193$, $214,241,246,248,301,302$, 331,334

Islamitische godsdienst $15,98,101$, $105,185,193,241,243,245$, 246,333

Ius sanguinis $61,78,79,105,106$, $117,144,145,163,165,168$, $171,181,186,188,250,285$, $318,319,322,326$

Ius soli $61,67,72,78,79,85,86$, $104,105,117,139,144,145$, $163-165,181,187-189,204$, $250,267,273,282,291,318$, $319,326,329$

Japannerwet 93

Juridische nationaliteit $27,29,30,32$, 316

Jurisprudentie $19,97,99,100,124$, $127,154,184,215,286-288$, 301

Kleinkind 205, 208, 226

Koloniale nationaliteitswetgeving 316

Koppelbegrip $34-36,44,45,47,55$, 57,315

Lokale Overheid 17

Mahkamah Agung 11, 14, 15, 19, 91, 149-151, 184, 191-193, $195-197,241,242,245,248$, $287,288,289,300,301,329$, 331
Meerderjarig $61,128,131,134,149$, $157-159,162,175,191,207$. $214,260,289$

Memorandum of Understanding 22, $176,223,234,321$

Mensenrecht 2, 27, 34, 41, 44-49, 52, $55,57,68,315$

Militair Gezag 236

Militaire dienstplicht 54, 61, 292

Minderheden 166

Minderjarig 136-138, 148, 162, 167 , $170,175,179,191,214,230$, $251,260,288,289$

Moeder maakt geen bastaard 182, 286

Morele nationaliteit 27, 28, 30

Moslim 242-244, 246, 333, 334

MPR 11, 12

Naam 4, 13, 17, 33, 46, 52, 56, 57, $75,89,97,99,107,143,173$, $187,238,286,294,300,323$, 329

Nationale autonomie 2, 27, 49, 57-60, $66,67,187,283,284$

Nationalistisch China 143, 144

Naturalisatie $52,61,65,67,85,101$, $106-108,114-119,138,141$, $144,145,153,157,164,170$, $176,181,198-203,206,207$, 209-217, 219-231, 238, 247, $249-251,254,259,261,264$, $265,277,279,281,282,290$, 296, 298-300, 303-305, 319, $321,326-328$

Natuurlijk kind 118, 125

Nederlands onderdaan $1,30,31,81$, $91,102-110,122,125-127$, $132-134,136,138,146,150$, $152,153,157,159,177-179$, $260,267-269,306,316$

Nederlandse nationaliteit $1,31,85$, $100,102,121,123,124$, $127-131,133,147,148,150$, $156,157,158,159,162,201$, $215,237,249,250,267,268$. 295,326

Negatieve optie 230-232, 234, 237. $255,271,275,277-281$

Newcomers 176, 204, 208

Niet-fundamentele rechten 44

Niet-Nederlandse onderdanen 139, 140 , 161,178

Nieuw-Guinea 4-7, 106, 129, 130, 260, $267,268,317$ 
Onafhankelijksverklaring 4, 121, 267

Onderdaanschap $1,2,30,31,75-78$, $81,82,86,87,91,96$, $101-107,109,114,117,120$, $123,128,139,144,153,163$, $165,212,250,269,282,316$

Onderwerping voor een bepaalde rechtshandeling 95

Oneigenlijke optie 231,259, 265

Ontbinding van het huwelijk 106, 107 , $119,133,134,185,239,240$, $278,305,320,321$

Ontneming van nationaliteit $45,50-52$, 55

Oorlogsgezsg $2,123,140,141,143$, $149,163,236,260,304,306$, 307

Oorspronkelijke status 184,302

Oost-Timor 3, 8, 9, 21, 72, 73, 317, 318

Oplossing 5, 7-9, 29, 76, 95, 98, 99, $129,151,165,176,212,213$, $310,313,326$

Optie $63,71,122,124,130-136,155$, $157,159,167,169,178,181$. $198,201,210,224,227,228$, $230-232,234,236,237,239$, $240,250,254-256,259,265$, $267,271,275,277-282,290$, $303,310,317$

Overgangsovereenkomst $111,115,120$, 123,124

Overheidsbemoeienis 283,299

Overname 114

Pacta sunt servanda 112, 176

Pancasila 10, 218, 246, 259, 334

Paspoort 133, 143, 187, 213, 221, 234, $238,258,262,286,294-296$, $300,312,323,329$

Passieve stelsel 116,117

Pengadilan Agama 15, 242, 243, 245, 246

Pengadilan Negeri $15,56,101,117$, $140,142,149,150,189$, $191-193,195,197,198$, 200-203, 205, 207-209, $218-220,222,224,226,229$. 233, 234, 239, 241, 242, 243, 245, 246, 252, 254-256, 264, 278, 279, 288-290, 299-301, $304,305,306-311,317,330$

Pengadilan Negeri Jakarta Pusat 307
Pengadilan Tinggi 15, 16, 117, 142, $245,301,308,310$

Personeel statuut $33,90,124,126$, $129,131,134,135,147,214$, $215,243,269,279$

Personen van Molukse oorsprong 258

Politieke betrouwbararheid 201, 206, 226

Politieke Nederlander 82

Politieke rechten $1,31,37,38,41-43$, $47,74,79,80,82,104,152$, $262,315,316$

Positie van de gehuwde vrouw 108 , 318,324

President $4,6,8,9,11-14,16,19,56$, $114,120,140,166,226,229$. 272,309

Presidentiële systeem 12

Pure apatriden 188, 221

Rassendiscriminatie $38,46,55$

Ratificatiedocumenten 166, 175

Rebus sic stantibus 112

Recht van expatriatie 210,234

Recht van optie $122,159,317$

Recht van repudiatie $31,103,122,137$, $145,158,165,317$

Rechtsconstructie 142

Rechtskeuze 95, 99, 100

Rechtspluralisme 18,91, 96, 302

Rechtsstaat 10,246, 334

Rechtsverhouding 32

Rechtsverscheidenheid 18, 91, 154, $183,185,216,327$

Regeling op de Gemengde Huwelijken $19,99,132,147,244$

Registratieplicht $34,74,141$

Religieuze rechtbanken 15

Ronde Tafel Conferentie (RTC) 5, 111. 120

Sanctie $50,170,171,299,300$

SBKRI 308-310, 312

Schutzangebōrigkeit 31, 104, 262

Sociologische nationaliteit 28-30

Soevereiniteitsoverdracht $1,2,5,31$, $71,87,113,114,121$, $123-126,128,130-136,138$, $146,147,148,153,156$, $158-160,162,166,179,260$, $266-268,317$

Staat van Gevasr 2, 6, 13, 140

Staat van Oorlog en Beleg 2, 6, 7, 140

Suriname en de Nederlandse Antillen $84,127,257,267$ 
Systematiek $276,298,319,327,331$

Taiwan 143, 144, 188, 221

Terugwerking van opties 130

Toelatingskaart 215, 221, 253, 256

Toepasselijkverklaring 94, 95, 97, 195, 301

Uitbanning van alle vormen van Discriminatie van vrouwen 246,322 , 324

Uitzonderingsasturalisatie 181, 210, 228, 304

Unificatiestreven 18,91

Universele Verklaring van de Rechten van de Mens 38, 45-48, 50, $57,210,315,324$

Urgentiebewijs 141, 307

Urgentieverklaring 309

Vacuūm 122, 152, 161, 239, 281

Verblijfsvergunning 215

Verdrag inzake de Rechten van het kind 46,56

Verdragsbeperkingen 65

Vereenvoudige naturalisatie 199, 202

Verklaring van trouw 226

Verlichte naturalisatie 198

Verschil in nationaliteit $19,240,246$, 279

Verwerping $61,64,104,127,128$, $131,138,148-150,153,158$, 159, 170, 177-179, 187, 207, 306,312

Verzoek 20,85, 106, 107, 117-119, $133,138,144,145,150,164$, $168-170,176,191,198-203$, 205-219, 221, 222, 224-231, $236,247,251,254,259-261$, $263,264,265,282-284,288$, $291,292,297,301,304,305$. $308,309,319,321,326$, $327-329$

Volkenrechtelijke beperkingen 2, 27, 57-59

Volksrepubliek China 174, 223

Voorlopige Grondwet van 19506,114 , $115,121,146,149,153,155$, $160,166,225,270$

Vreemde krijgsdienst $30,51,266,292$, 293

Vreemde Oosterlingen $19,30,71,82$, $86-89,92-95,97,109,121$, $128,158,205,208$

Vreemde stagtsdienst 292,293
Vreemdeling $39,55,86,101,106$, $108,123,124,129,132,139$. $152,171,217,238,249,250$, 263,316

Vreemdelingenbelasting 74,141

Vrijwillige verkrijging van een andere nationaliteit 53, 284, 292, 330

Vrouwendiscriminatieverdrag 325

Weduwe 108, 116, 118, 125, 135, 195, $197,204,216,217,229,230$. 277,281

Werkvergunning 141

Wettig huwelijk 182, 184, 199-201, $233,278,300,301,326$

Wettiging $61,182,190,286,287,331$ 

Renata Henriëtte de Haas-Engel werd op 25 januari 1925 in Balige, Indonesië geboren. Na het behalen van het einddiploma van de vijfjarige H.B.S. te Surabaia in 1947, welke studie werd onderbroken door de oorlogsjaren, de Japanse bezetting en de daarop volgende politieke verwikkelingen in verband met de onafhankelijkheidsproclamatie van de Republiek Indonesië, studeerde zij rechten aan de Universiteit van Indonesië te Jakarta, waar zij afstudeerde in 1953. Gedurende de jaren 1947 tot 1951 bekleedde zij diverse functies, voomamelijk in dienst van de Overheid, ter bekostiging van haar rechtenstudie. Met ingang van 1 augustus 1952 kwam zij te werken bij een belangenorganisatie, de "Vereniging van Importeurs-Groothandelaren in Indonesië" (VIGI), aanvankelijk als Hoofd van de Economische afdeling, daama als Hoofd van de afdeling Arbeidsaangelegenheden. Vervolgens werd zij met ingang van 1 januari 1958 tot Directrice van deze organisatie benoemd. Bij de oprichting van de "Commercial Advisory Foundation in Indonesia" (CAFI), een voorlichtings- en advieslichaam, belast met het geven van juridische en economische adviezen aan zowel nationale als aan buitenlandse, in Indonesië gevestigde bedrijven en ambassades op 1 januari 1958 , werd zij tevens tot Directrice van laatstgenoemd lichaam benoemd. In deze hoedanigheid verschenen talrijke artikelen op verschillend gebied van het Indonesische recht van haar hand. Gedurende deze periode legde zij zich tevens toe op de studie van het notariaat en slaagde in 1955 voor het tweede gedeelte hiervan en is candidaat-notaris. De hierboven genoemde twee functies heeft zij uitgeoefend tot haar vertrek naar Nederland op 1 augustus 1969. Sedert haar aankomst in Nederland, brachten persoonlijke omstandigheden haar ertoe haar interesse naar ander gebied te verleggen. Gedurende de jaren 1971 tot 1978 studeerde zij aan de Muziekschool te Maastricht en legde zich toe op de talenstudie, hetgeen leidde tot het behalen van diverse certificaten, met name de Duitse taal en letterkunde, de Franse taal en letterkunde en de Spaanse taal en letterkunde in de jaren 1983 tot 1988. Zij studeerde voorts geruime tijd - als intermezzo - aan de Open Universiteit te Heerlen, richting Cultuurwetenschappen en wist in de periode 1985 tot 1988, zeven certificaten in diverse vakken te behalen. Deze activiteiten deden echter haar interesse voor het Indonesische recht niet verflauwen. Zij bleef dan ook geïnteresseerd in haar geboorteland en heeft de ontwikkelingen op juridisch gebied in dit land steeds met veel belangstelling gevolgd, hetgeen ertoe heeft geleid om een op Indonesië gericht onderwerp voor haar proefschrift te kiezen. 